Florida International University FIU Digital Commons

\title{
Geopolitical Account of Iran's Ties with Non-State Actors under the Shah: 1958-1979
}

\author{
Arash Reisinezhad \\ arash.reisinezhad@gmail.com
}

DOI: $10.25148 /$ etd.FIDC001777

Follow this and additional works at: https://digitalcommons.fiu.edu/etd

Part of the International Relations Commons

\section{Recommended Citation}

Reisinezhad, Arash, "Geopolitical Account of Iran's Ties with Non-State Actors under the Shah: 1958-1979" (2017). FIU Electronic Theses and Dissertations. 3196.

https://digitalcommons.fiu.edu/etd/3196

This work is brought to you for free and open access by the University Graduate School at FIU Digital Commons. It has been accepted for inclusion in FIU Electronic Theses and Dissertations by an authorized administrator of FIU Digital Commons. For more information, please contact dcc@fiu.edu. 


\title{
FLORIDA INTERNATIONAL UNIVERSITY
}

Miami, Florida

GEOPOLITICAL ACCOUNT OF IRAN'S TIES WITH NON-STATE ACTORS

UNDER THE SHAH: 1958-1979

\author{
A dissertation submitted in partial fulfillment of the \\ requirements for the degree of \\ DOCTOR OF PHILOSOPHY \\ in \\ POLITICAL SCIENCE \\ By \\ Arash Reisinezhad
}

2017 
To: Dean John F. Stack, Jr.

Green School of International and Public Affairs

This dissertation, written by Arash Reisinezhad, and entitled Geopolitical Account of Iran's Ties with Non-State Actors under the Shah: 1958-1979, having been approved in respect to style and intellectual content, is referred to you for judgment.

We have read this dissertation and recommend that it be approved.

Thomas Breslin

Ronald Cox

Iqbal Akhtar

Mohiaddin Mesbahi, Major Professor

Date of Defense: March 30, 2017

The dissertation of Arash Reisinezhad is approved.

Dean John F. Stack, Jr. Green School of International and Public Affairs

Andrés G. Gil

Vice President for Research and Economic Development and Dean of the University Graduate School

Florida International University, 2017 


\section{DEDICATION}

I dedicate this thesis to my parents, Ebrahim and Sadigheh. Without their patience, understanding, support, and most of all love, the completion of this work would not have been possible.

I also dedicate this thesis to my advisor and hero, Dr. Mohiaddin Mesbahi whose intellectual and cordial supports helped me to receive my Ph.D. degree. 


\section{ACKNOWLEDGMENT}

There is not enough room here to thank everyone who deserves credit for this dissertation. First and foremost, I am forever indebted to Dr. Mohiaddin Messbahi whose intellectual brilliance and generous mentorship have guided the present work throughout. I have been fortunate and honored in receiving his advice and assistance, and I hope to be able to continue my study of politics and Iranian foreign policy in his tradition and to uphold the standard he has set. I also wish to thank other members of my committee for patiently and smoothly guiding me throughout the research. I would like to thank Dr. Thomas Breslin for providing thoughtful criticism and archival research advice. Furthermore, the methodological advice of Dr. Ronald Cox has been immensely helpful. I have also benefitted from Dr. Iqbal Akhtar's words.

Also, I owe much gratitude to Florida International University and Department of Politics and International Relations for giving me the opportunity to investigate in-depth this important issue. Above all, I must thank my family: my father, Ebrahim, my mother, Sadigheh, my brother, Arsham, and my sister, Raha, without whose love, friendship, and endless patience I could not accomplish my doctorate. I am to them eternally grateful.

I must also thank my dear friends, Dr. Mohammad Homayounvash, Dr. Nika Esitashvili, Dr. Hamid Serri, Dr. Kaveh Mirazie, Dr. Mirsad Krijestorac, Nima Baghdadi, Dr. Peyman Karvani, Ehsan Darvishi, Saeed Mousavi, and Hasan Vaezi, whose supports have been crucial and constant for the accomplishment of my Doctorate degree. 


\begin{abstract}
OF THE DISSERTATION
GEOPOLITICAL ACCOUNT OF IRAN'S TIES WITH NON-STATE ACTORS
\end{abstract}

UNDER THE SHAH: 1958-1979

by

Arash Reisinezhad

Florida International University, 2017

Miami, Florida

Professor Mohiaddin Mesbahi, Major Professor

Late in 2004, King Abdullah of Jordan coined a controversial phrase that still dominates the heart of the geopolitics of the Middle East: The Shia Crescent. "If pro-Iran parties or politicians dominate the new Iraqi government, a new 'crescent' of dominant Shia movements or governments stretching from Iran into Iraq, Syria, and Lebanon could emerge to alter the traditional balance of power between the two main Islamic sects and pose new challenges to U.S. interests and allies. What the King of Jordan saw as a threat, Iran saw as the bedrock of its newfound regional power. However, what the King of Jordan and his Arab-Sunni aides downplayed was Iran's ties with non-Shia groups, ranging from Sunni parties to secular and even non-Muslim groups. More importantly, they neglected Iran's presence in the Middle East before the 1979 Islamic Revolution. In fact, the seeming omnipresence of Iran's proxies in the Middle East is not a recent, nuanced phenomenon; rather, it dated back to the Shah's foreign policy in making connections with both the Iraqi Kurds and Shia Lebanese. While much ink has been spilled on Iran's foreign policy under the Islamic Republic, there has been a void in analysis of Iran's ties with Non-State Actors (NSAs) in the pre-1979 Revolution Era. 
From this point of view, the present study is an attempt to set forth a new understanding of the emergence and fluctuation of Iran's ties with NSAs at the heart of the Middle East during the Shah's era. I will accomplish this by identifying the Iran-NSA relationships within an examination of the larger historical context of state-NSA relationships in the region. Here, the story of the evolution of Iran's ties with NSAs can be narrated as the unfolding of constant interaction between states and non-state forces in the Middle East. Analyzed from this perspective, my research examines the actors, processes, and mechanisms that Iran has used to construct ties with NSAs from 1961 until 1979. "What actors and processes at what levels of analysis and through what mechanisms have constructed Iran's ties with NSAs?" This is the central question that guides the analytical narrative in the present survey. Therefore, the dependent variable for this research is the evolution of Iran's ties with NSAs, while the intervening variable is a set of actors and processes that has brought about such sub-state ties. In this framework, the proposed work will undertake these main tasks:

A) Tracing the history of the ebbs and flows within Iran's ties with non-state actors through a geopolitical lens.

B) Explaining how Iran's ties with non-state actors unfolded and understanding why Iran's proxies evolved in the way they did.

C) Assessing the broad contours of the evolutionary trajectory of Iran's ties with NSAs and its possible future path(s) for the geopolitics of the Middle East and its regional balance of power. 


\section{TABLE OF CONTENTS}

CHAPTER

PAGE

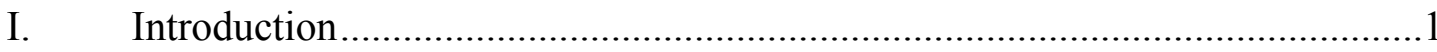

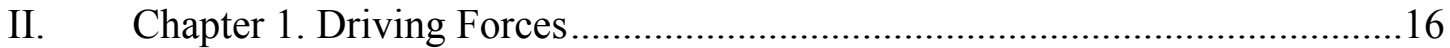

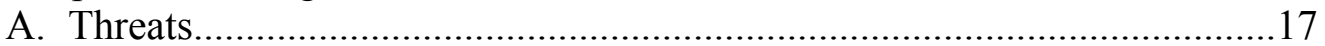

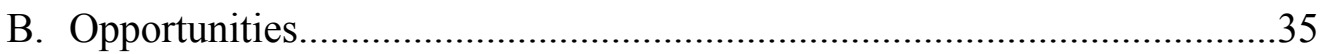

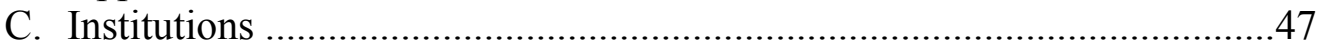

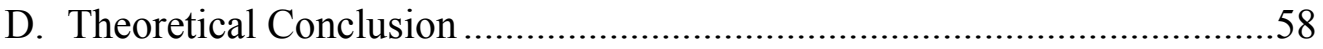

III. Chapter 2. Inception: Iran's Non-State Foreign Policy in Pre-1958_...............59

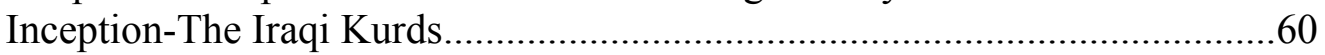

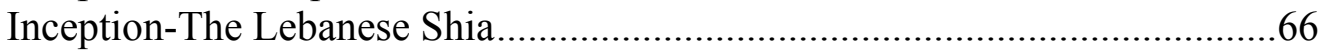

IV. Chapter 3. Creation: Iran's Non-State Foreign Policy 1958-1963 …..............72

Creation-The Iraqi Kurds...........................................................................73

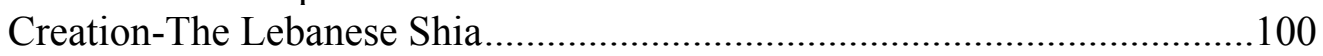

V. Chapter 4. Ascension: Iran's Non-State Foreign Policy in 1963-1968 ….....111

Ascension-The Iraqi Kurds .....................................................................112

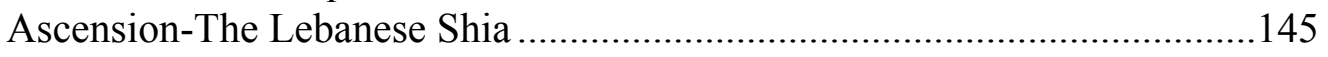

VI. Chapter 5. Limbo: Iran's Non-State Foreign Policy in 1968-1973 …............152

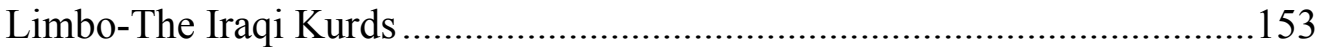

Limbo-The Lebanese Shia ............................................................................192

VII. Chapter 6. Downfall: Iran's Non-State Foreign Policy in 1973-1977 ...........229

Downfall-The Iraqi Kurds …………………………...........................230

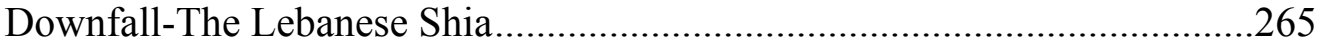

VIII. Chapter 7. Resurrection: Iran's Non-State Foreign Policy in 1977-1979......311

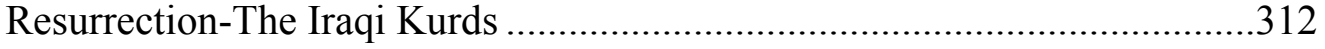

Resurrection-The Lebanese Shia ................................................................322

IX. Conclusion: Iran's Non-State Foreign Policy and the Shah's Legacy...........349

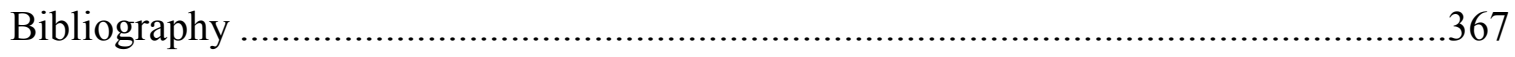

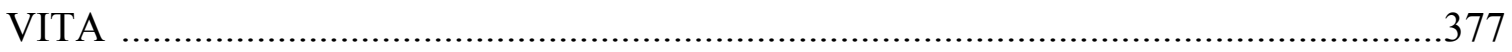


Abbreviations and Acronyms

\begin{tabular}{|c|c|}
\hline AAD & Access to Archive Database \\
\hline CENTO & Central Treaty Organization \\
\hline CFPF & Central Foreign Policy \\
\hline CIA & Central Intelligence Agency \\
\hline $\mathrm{DCI}$ & Director of Central Intelligence \\
\hline DNSA & Digital National Security Archive \\
\hline FRUS & Foreign Relations of the United States \\
\hline HSF & Harold Saunders Files \\
\hline $\mathrm{ICP}$ & Iraqi Communist Party \\
\hline IDF & Israeli Defense Force \\
\hline INR & Bureau of Intelligence and Research \\
\hline IPC & Iraq Petroleum Company \\
\hline JPL & Johnson Presidential Library \\
\hline KDP & Kurdistan Democratic Party \\
\hline KPL & Kennedy Presidential Library \\
\hline KSF & Kissinger-Scowcroft West Wing Office Files \\
\hline KT & Kissinger Transcripts \\
\hline NARA & U.S. National Archives and Records Administration \\
\hline NCRC & National Council of the Revolutionary Command \\
\hline NDP & National Democratic Party \\
\hline NEA & Bureau of Near Eastern Affairs \\
\hline NIE & National Intelligence Estimate \\
\hline
\end{tabular}




\begin{tabular}{|c|c|}
\hline NPL & Nixon Presidential Library \\
\hline NSC & The National Security Council \\
\hline NSF & National Security File \\
\hline OPEC & Organization of Petroleum Exporting Countries \\
\hline PFLP & Popular Front for the Liberation of Palestine \\
\hline PLO & Palestinian Liberation Organization \\
\hline PRF & People's Resistance Force \\
\hline $\mathrm{RCC}$ & Revolutionary Command Council \\
\hline RKF & Robert Komer Files \\
\hline SAVAK & National Intelligence and Security Organization \\
\hline SICS & Supreme Islamic Shia Council \\
\hline SCOR & Security Council Official Records \\
\hline SSNP & Syrian Social Nationalist Party \\
\hline UAR & United Arab Republic \\
\hline UN & United Nations \\
\hline UNARMS & United Nations Archives Records Management Section \\
\hline UNGA & United Nations General Assembly \\
\hline USSR & Union of Soviet Socialist Republics \\
\hline USUN & United States Mission to the United Nations \\
\hline
\end{tabular}




\section{Introduction}

"We should combat to and contain the threat in the East coast of the Mediterranean to prevent shedding blood on Iranian soil." These words were uttered by Colonel Pashaie, head of the Middle East Directorate of SAVAK, Iran's National Intelligence and Security Organization, to weaken the rising Pan-Arabism in the Middle East in the aftermath of the Iraqi coup of 1958. It was the beginning of the Green Plan strategy in Southern Lebanon. Iran's Green Plan planted the seed of Iran's connections with a marginalized Shia community in Lebanon. With charismatic, Iranian-born Seyyed Musa Sadr's departure to the south of Lebanon, Tehran's relations with the Lebanese Shia hit the new course.

Pahlavi Iran also sided with the Iraqi Kurds against Iraq. The Iraqi coup of 1958 toppled the pro-Western monarchy and established a Pan-Arab, pro-Moscow republic on Iran's western borders. Within this context, SAVAK was instructed by the Shah to build a strategic connection with the Kurds in Northern Iraq. Led by Mullah Mustafa Barzani, the Kurdish guerrillas tied down the Iraqi Army and turned Baghdad away from posing a threat to Iran's western provinces and the Persian Gulf.

Contrary to popular opinion regarding the Shah's foreign policy, the U.S. did not initially side with Iran's strategy towards the Kurds in the period between 1961-1972. Despite maintaining close ties with the Shah, the White House did not share his threat assessment towards Iraq. It was only after the Tehran summit of 1972 that President Richard Nixon instructed CIA covert cooperation with SAVAK in Iraqi Kurdistan.

Iran's strategic connections with the Iraqi Kurds and the Lebanese Shia ushered in a strategy towards non-state entities in the Middle East. It was the beginning of 'Iran's nonstate foreign policy'—a specific foreign policy intended to build connections with political 
and militant groups and movements. Non-state foreign policy refers to connections between a state and a political-militant non-state actor. This policy relates to how a state builds and manages ties with a non-state actor(s) through mechanisms beyond the common foreign policy. Since the Islamic Revolution of 1979, Iran has heavily relied on its nonstate foreign policy. In addition to revolutionary Iran, the non-state foreign policy has been implemented by the Soviet Union in support for communist parties, leftist movements, and liberation militias during the Cold War. Other countries, like China, Cuba, and more importantly, the U.S. have followed the same policy.

Almost a half-century later, Iran's non-state foreign policy expanded to an unprecedented level. Late in 2004, King Abdullah of Jordan popularized a controversial phrase that still dominates the heart of the geopolitics of the Middle East: The Shia Crescent. "If pro-Iran parties or politicians dominate the new Iraqi government, a new 'crescent' of dominant Shia movements or governments stretching from Iran into Iraq, Syria, and Lebanon could emerge to alter the traditional balance of power between the two main Islamic sects and pose new challenges to U.S. interests and allies." In Sunni Arab leaders' eyes, the Shia Crescent has been shaped around the armature of strategic connections between Iran and Shia non-state entities. However, this outlook failed to recognize the significance of the roots of Iran's non-state foreign policy in the Middle East before the Islamic Revolution of 1979. In reality, Iran's non-state foreign policy emerged in the midst of the Cold War. After the Iraqi coup of 1958, Mohammad-Reza Shah Pahlavi tried to preserve Iran's national integrity by making connections with regional non-state entities. 


\section{Significance of the Study}

Pre-revolutionary Iran's support for non-state entities was not limited to the support for the Iraqi Kurds and the Lebanese Shia. The Shah backed the royalist Mutawakkilite forces against the Soviet-backed, pro-Nasser Republicans in North Yemen in the 60s. In the last months of his reign, he began siding with Afghan Mujahedin against communist Kabul and the Red Army in Afghanistan. The Shah financially and logistically supported a remote western-backed UNITA in fighting with the Soviet-backed MPLA in Angola. He also supported the Polisario Front in Western Sahara. Despite their significance, the Iraqi Kurds and the Lebanese Shia played major parts in Iran's non-state foreign policy. First, connections with the Iraqi Kurds and the Lebanese Shia are still significant. Since the Islamic Revolution, Iran has sided with the Lebanese Shia and the Iraqi Kurds against its regional foes Israel and Baath Iraq. Second, the Iraqi Kurds and the Lebanese Shia were geographically and culturally closer to Iran. Shia Islam has been the predominant religion in Iran since the early $16^{\text {th }}$ century. The Kurds are an Iranian ethnic group whose culture and language are much closer to the people living in modern Iran than to Turks or Arabs. Third, both the Iraqi Kurds and the Lebanese Shia have affected Iranian society and domestic politics. The Kurdish separatism in Iraqi Kurdistan could have spillover effects on Iran's Kurdistan since Iran has been prone to Kurdish irredentism. Iranian leaders have suppressed Kurdish separatism in Iran while at the same time siding with the Iraqi Kurds. In the pre-revolutionary era, several Iranian revolutionaries were trained on military bases in the south of Lebanon. On top of that, religious networks between Seyyed Musa Sadr, the leader of the Lebanese Shia, with the Shia Marja, including Ayatollah Khomeini, had tremendous effects on the dynamics of the Islamic Revolution of 1979. 
Iran's connections with political-militant non-state entities in the Middle East has been at the heart of international and regional security policy for more than three decades. Interestingly, while the Islamic Republic's support for non-state entities in the Middle East, like Hezbollah, has framed the country as an allegedly top state 'sponsor of terrorism', the Shah's support for the Iraqi Kurds and the Lebanese Shia was never framed as a significant threat to international peace and security. The breadth and depth of these ties, along with Iran's geostrategic location and its antagonistic relationship with the United States over the last three decades, have given rise to a body of literature on various aspects of Iran's foreign policy. While much ink has been spilled on Iran's foreign policy, there has been a void in the analysis of the country's ties with non-states entities. Despite their profound impact on the power arrangement of the region and on U.S. national security, these connections have been partially unknown to Western audiences. In fact, the sensitivity and complexity of the issue, as well as the lack of access to Iranian sources and officials, have caused most experts to avoid dedicating extensive efforts to the matter.

\section{Background}

The current literature on Iran's ties with non-state actors could be classified in four categories. The first category focuses on regional political-militant groups and only indirectly and superficially addresses their ties with Iran. The main goal is to unravel the hidden black box of the socio-political context, internal power struggles, decision-making processes, and institutional arrangements of each non-state entity. ${ }^{1}$ The second category

\footnotetext{
1 "Hezbollah: The Story of the Party of God, From Revolution to Institutionalization" by Eitan Azani; "Hezbollah" by Naim Qassem; "Hezbullah's Documents: From the 1985 open letter to the 2009 Manifesto" by Joseph Alagha; "Hezbollah: The Global Footprint of Lebanon's Party of God" by Matthew Levitt; "Hamas" by Beveley Milton-Edwards and Stephen Farrell, and "The Brotherhood: America's Next Great Enemy" by Erick Stakelbeck.
} 
includes literature on Iranian foreign policy in general, and on Iran's regional or relations with great powers and the U.S. in particular. ${ }^{2}$ However, this specific literature has downplayed Iran's non-state foreign policy by reducing Iran-U.S. relations to accounts of the coup in 1953 and the turmoil of the Iranian Revolution of 1979 and framing IranianAmerican 'special relations' as a direct path from the coup to the revolution. Such an overly simplistic narrative neglects the crucial period between those two momentous events. The third category looks at terrorism and terrorist networks, considering Iran's ties with these groups highly suspect. Blinded by the condemnatory rhetoric, these textbooks frame Iran's non-state connections as the source of instability in the Middle East. ${ }^{3}$ The last category focuses on Shiism and Shia groups and communities as well as Kurdish communities. These books are notable for taking a longer view of the history of Shias and the Kurds. ${ }^{4}$ Similarly, relations with Iran are merely secondary topics in this category.

\section{Goals and Contributions}

This work sheds new light on the emergence and fluctuation of Iran's connections with non-state entities in Iraq and Lebanon during the Shah's era. The dissertation is not

\footnotetext{
2 "After Khomeini" by Anoushirvan Ehteshami; "Reading in Iran Foreign Policy After September11" by Abbas Maleki and Kaveh Afrasiabi; "Iran in World Politics: The Question of the Islamic Republic" by Arshin Adib-Moghaddam; "Reflections on Iran's Foreign Policy and Ideology and Pragmatism in Iran's Foreign Policy" both by Rouhollah Ramazani; "The Treacherous Alliance" by Trita Parsi; "The Eagle and Lion" by James Bill; "Iran" by Brzezinski et.al; "The Great Satan vs. the Mad Mullahs" by William Beeman; and "The Persian Puzzle" by Kenneth Pollack.

3 "Jihad Ultimatum" by J. D. Randall; "The Axis of the Evil" by Shaul Shay, and "Iran, Hezbollah, Hamas, and Global Jihadi: A New Conflict Paradigm for the West" by Dore Gold and Daniel Diker

4 "The Shia Revival: How Conflicts within Islam Will Shape the Future" by Vali Nasr; "The Shi'a Worlds and Iran" edited by Sabrina Marvin; "Shiism and Politics in the Middle East" by Laurence Louer; "A Modern History of the Kurds" by David McDowall, "Invisible Nation: How the Kurds' Quest for Statehood Is Shaping Iraq and the Middle East" by Quil Lawrence; "The Kurds: A People in Search of Their Homeland" by Kevin Mckiernan; "No Friends But the Mountains: The Tragic History of the Kurds" by John Bulloch.
} 
intended to cover different aspects of Iran's foreign policy under the Shah's reign; rather, it examines institutions within the Pahlavi regime that implemented Iran's non-state foreign policy. The present dissertation also narrates the story of Iran's non-state foreign policy by focusing on specific geopolitical and geocultural threats and opportunities that pushed Tehran to build strategic ties with the Iraqi Kurds and the Lebanese Shia in the period between 1958 and 1979. This is the central task that guides the analytical narrative in the dissertation.

The present dissertation contributes to the literature in multiple ways. First, it traces the ebbs and flows within Iran's non-state foreign policy under the Shah's reign. The primary focus is on the relations between a state, Iran, with non-state actors, the Iraqi Kurds and the Lebanese Shia. Therefore, it is not about internal politics during pre-revolutionary Iran. Second, this dissertation challenges the widespread view of Iran's non-state allies as only allied after the Islamic Revolution of 1979 by highlighting Pahlavi Iran's role in shaping Iran's non-state foreign policy. It illustrates how the expansion of Iran's connections with non-state actors was established for the first time by the Pahlavi regime. Third, the dissertation provides yet another example of how the course of the Cold War and the Middle East politics were forged by one of the super-powers' allies in the Third World, i.e., Iran. The Shah, as a Third World leader, actively contained threats by manipulating the superpowers. With its detailed investigation of Iran's non-state foreign policy, the dissertation shows that Iran and the U.S. had significant tensions over the Kurdish War in a period between 1961-72. Therefore, the present dissertation fleshes out our understanding of Iran-America relations and recasts the question of U.S.-Iranian relations at its zenith in the $60 \mathrm{~s}$ and $70 \mathrm{~s}$. Fourth, this dissertation puts emphasis on the 
significance of militant-political non-state entities in the world, in general, and in the Middle East, in particular. The proliferation of these entities in the Middle East has challenged pivotal assumptions of realism and eroded the state-centric international politics and traditional Westphalian nation-state claim on sovereignty. Ranging from social movements and guerrillas to semi-state actors, non-state actors acted within and upon the international system. Therefore, the present study will be a step towards a better understanding of the relation between states and non-state entities. Fifth, the dissertation challenges the dominant view of Iran's foreign policy decision-making processes. The dominant view on pre-revolutionary Iran has framed Iran's foreign policy as the Shah's foreign policy. Conversely, the present dissertation shows that other institutions, especially SAVAK, played a key role in shaping the trajectory of Iran's non-state foreign policy in Iraqi Kurdistan and Southern Lebanon. Sixth, the present dissertation assesses the trajectory of Iran's non-state foreign policy by highlighting geopolitical/geo-cultural threats and opportunities, rather than focusing on ideology, in the evolution of Iran's nonstate foreign policy. Seventh, this dissertation does not focus just on politics and political issues. Rather, it is a multi-disciplinary study, tackling different domains of social science. Along with politics, it demonstrates the significance of culture and religion to investigate how connections with Iran affected the solidarity of non-state entities' communities. Lastly, the dissertation is a historiography. It provides a theoretical plot to narrate a story, a story of the history of Iran's non-state foreign policy under the Shah's reign.

\section{Theoretical Framework}

It is tempting to capture Iran's non-state foreign policy in terms of Iranian leaders' power ambitions. It could be also explained as some mere ethnic or religious formula. 
According to this narrative, Iran's support for the Iraqi Kurds against Iraq could be considered as another course of a long-standing rivalry between the Iranian and the Arab. As a constitutive ethnic group of the Iranian people, the Kurds have been culturally and linguistically affiliated with the Iranian civilization. Iran's assistance to the Shia in the south of Lebanon could be also explicated as an example of long-running tension between the Shia and Sunni variants of Islam. With its overwhelmingly Shia population, Iran has been the Shia hub in the Islamic world. From this point of view, Iran's culture and religion could be introduced as determinant drives in shaping ties with the Iraqi Kurds and the Lebanese Shia. One could also emphasize on Baghdad-Tehran and Cairo-Tehran competition for regional hegemony as driving forces in prompting Iran to side with the Iraqi Kurds and the Lebanese Shia. Since both Iran and Iraq possessed vast oil reservoirs and were seeking to influence oil policy in their favor, an economic-energy competition could be considered as a final source of Iran's non-state foreign policy. At the same time, Pahlavi Iran was the U.S. major ally in the Cold War era while Baghdad, on the whole, oscillated between the Soviet camp and neutrality.

Though significant, a cursory survey reveals that there have been a number of factors, rather than a single one which influenced the formation of Iran's non-state foreign policy. Like other states of the region, Pahlavi Iran encountered major 'threats' and 'opportunities' that had decisive ramifications for the formation of Iran's ties with nonstate entities in the Middle East. Such a coherent system of threat-opportunity interplayed on three 'levels' of international, regional, and domestic. Iran's domestic institutional arrangement under the Shah's reign was added to the crosscutting complexities of domestic, regional, and international levels of threats-opportunities. From this perspective, 
the present theoretical framework is at the same time based on a geopolitical and an institutional narrative of Iran's non-state foreign policy.

Pahlavi Iran's internal institutions underscored the complexity of continuity and change of the evolution of Iran's non-state foreign policy. Institutions are recognizable patterns of rules and practices. Each institution includes "the formal and informal procedures, routines, norms and conventions embedded in the organizational structure of the polity" that generates the socio-political changes. ${ }^{5}$ New Institutionalism highlights the key role of institutions in sociopolitical changes. The present study utilizes Historical New Institutionalism which focuses on interactions among institutions in a polity as ultimate reasons behind specific historical junctures. Therefore, major transformations in the trajectory of Iran's non-state foreign policy occurred within institutional arrangements in different historical stages.

Geopolitics deals with relationships among geography, power, and world order, stressing the role of geographical constraints and opportunities in the conduct of politics. A set of threats and opportunities convinced Iran to build its connections in Northern Mesopotamia and the eastern coast of the Mediterranean. This set of threats and opportunities had political, cultural, and economic aspects. From this perspective, Mohiaddin Mesbahi's theory provides a robust framework for the evolution and dynamics of Iran's non-state foreign policy. This framework offers a 'tripartite' view of the international system "with three interrelated yet distinct structures, namely the coercive-

\footnotetext{
${ }^{5}$ Hall, Peter and Rosemary C. R. T Taylor, Political Science and the Three New Institutionalism. (1996), XLIV, p. 938.
} 
military, the normative-social, and the economic." Along with geographical factors, each state experiences the symbiotic impact from interactions with tripartite domains and forces. Lastly, the nature and scope of each domain is different. As Mesbahi asserts, "each structure deals with the state in a manner most conducive to its own elemental attributes, extracting and re-prevailing identity. Thus, for example, within the coercive structure, it is the unitary state which is being dealt with and taken into consideration, while in the social/normative and economic/developmental structures, the state, no matter how resistant and how insistent on its unitary nature and sovereignty, will be dealt with and interacted with in its composite form, displaying and exposing its inner components including sociocultural and economic groupings and associations." ${ }^{, 7}$ In short, three domains of geopolitics, geoculture, and geoeconomics are embedded in three levels of international, regional, and domestic.

From this perspective, the Middle East during the Cold War possessed three clearly interrelated, yet distinct, domains of geopolitics, geoculture, and geoeconomy. It had been riven with powerful premodern religious-cultural-ethnic divisions. It also contained distinctive ideological features that caused the emergence of potent geocultural forces in the region. With its enormous oil fields, the disputes over oil prices, and oil pipeline routes, the region had become an integral part of the global economy and shaped the geoeconomic forces. Lastly, the geostrategic location of the Middle East and its vicinity to one of the two

\footnotetext{
${ }^{6}$ Mesbahi, Mohiaddin, Free and Confined: Iran and the International System. (Spring 2011). Iranian Review of Foreign Affairs, 5 (2): 9-34.

${ }^{7}$ Mesbahi, Mohiaddin, Free and Confined: Iran and the International System. (Spring 2011). Iranian Review of Foreign Affairs, 5 (2): 9-34.
} 
super-powers, internal territorial disputes, and power and status rivalries among the regional states had constituted major geopolitical forces in the Middle East.

The Middle East during the Cold War can be described with this tripartite arrangement. As a perfect example of a conflict formation in the Cold War era, the Middle East had autonomous regional and domestic levels of security. The insecurity of ruling elites domestically played a significant role in shaping the dynamics of (in)security in the region. ${ }^{8}$ Crafted out of the Sykes-Picot Agreement of 1916, the Middle Eastern countries(except for Iran) were postcolonial insecure regimes, lacking simultaneously state identity, national identity, and regime identity. The lack of a strong state in the region spilled over into regional security politics that had emerged since the collapse of the Ottoman Empire. It was driven by a complex agenda of ideological competitions, longstanding religious-ethnic division, oil rival policies, border disputes, and power status. The Middle East had been subject to continuous and heavy impact of the international Cold War rivalry. Before then, its regional state system had been shaped through the British and French interventions. In the aftermath of the World War II, the Middle East soon became the third battleground in the Cold War, after Europe and Asia. Heavily manifested in intense patterns of 'enmity-amity,'9 like Iranian-Arab and Shia-Sunni enmities, the regional dynamics were so vigorous and durable that neither the U.S. nor the USSR had effective control over the region.

\footnotetext{
${ }^{8}$ Buzan, Barry and Ole Waver Regions and Powers: The Structure of International Security. (Cambridge University Press, 4 Dec 2003). p. 187.

${ }^{9}$ Buzan, Barry and Ole Waver Regions and Powers: The Structure of International Security, (Cambridge University Press, 4 Dec 2003).
} 
Consequently, this theoretical framework demonstrates critical historical junctures, forces (internal/ external), and actors (decision-makers/elites/institutions) that played key role in the trajectory of Iran's non-state foreign policy. The present theoretical template also demonstrates that the roots and effects of Iran's non-state foreign policy could be traced to three 'domains' of geopolitical, geocultural and geoeconomic, and at the same time, on three 'levels' of international, regional, and domestic.

\section{Methodology and Sources}

The present dissertation employs a 'historical analysis' approach to Iran's connections with non-state entities. In the part of this work aimed at tracing the evolution of Iran's non-state foreign policy in the Pahlavi era, I have used three types of sources. The most important types of data are declassified documents related to Iran's engagement in Iraqi Kurdistan and the south of Lebanon. Most of these materials were gathered from major archival collections in both the U.S. and Iran.

On the Iranian side of the story, the dissertation is heavily based on major documents obtained from the Ministry of Foreign Affairs and SAVAK, gathered from Markaz-e Amouzesh va Pajooheshhay-e Beynolmelali-e Vezarat-e Omour-e Kharejeh (Center of International Research and Education of the Ministry of Foreign Affairs), Markaz-e Asnad- Enghelab-e Eslami (Islamic Revolution Document Center), and Sazman-

e asnad va Ketabkhane Melli-e Jomouhori Eslami (National Library and Archives of Islamic Republic of Iran). Additionally, the dissertation relied on published government documents, including Imam Musa Sadr be Ravayat-e Asnad-e SAVAK (Musa Sadr according to SAVAK Documents, 3 volumes), Hezb-e Democrat-e Kurdestan-e Araq be 
Ravayet-e SAVAK (Iraqi Kurdistan Democratic Party according to SAVAK) and Ravabete Iran va Araq be Ravayat-e SAVAK (Iran-Iraq Relations According to SAVAK).

Other than these Persian documents, the biographical interview accounts collected by Harvard University's Iranian Oral History Project and The Foundation for Iranian Studies contained significant insights into the Shah's threat assessment and decisionmaking processes. For media accounts of the post-Revolution era, I have used Iranian government-affiliated websites, newspaper archives, and news websites. Besides, there have been several Persian sources which show the Shah's view towards non-state foreign policy. These include the diaries of Assadollah Alam, the Shah's closest advisor, former prime minister, and Minister of the Imperial Court, which shed light on the Shah's day-today ruling over the country. Other memoirs include Colonel Isa Pejman, head of the section of 'Kurdistan' in SAVAK, and Major General Mansour Qadar, former ambassador to Beirut. Other important sources are memories of Iranian revolutionaries, including Sadegh Tabatabaie, Seyyed Musa Sadr's nephew and first deputy of prime minister after the Revolution.

In the U.S., I gathered documents from the National Archives in College Park, Maryland. I have also used documents from the Richard Nixon Presidential Library's online website ${ }^{10}$ and the Gerald Ford Presidential Library's online website. ${ }^{11}$ The dissertation benefited from published government documents, including Foreign Relations of the United States-Historical Documents (FRUS), CIA: The Pike Report, Public Papers of the Presidents: Dwight D. Eisenhower 1953 and Gerald R. Ford 1976-77, the Cold War

\footnotetext{
${ }^{10}$ Available at https://www.nixonlibrary.gov.

${ }^{11}$ Available at https://www.fordlibrarymuseum.gov/collections-digital.aspx.
} 
International History Project (CWIHP) at the Woodrow Wilson International Center for Scholars, Israel State Archives Online Collection, and Special Collection: A Life in Intelligence-The Richard Helms Collections (CIA-Helms). I also collected the National Security Archive documents from George Washington University (GWU), ${ }^{12}$ the CIA Records Search Tool (CREST) at the National Archives in College Park, the FOIA (Freedom of Information Act) Electronic Reading Room, ${ }^{13}$ and the history collection of the Office of Central Interlligence Agency. ${ }^{14}$

The dissertation addresses Iran's non-state foreign policy in a period between the Iraqi coup of 1958 and the collapse of the Pahlavi regime in 1979. In order to analyze the evolution and dynamics of Iran's non-state foreign policy under the Shah's reign, the dissertation adopts a chronological structure. This is done in seven separate chapters. Chapter 1 examines driving forces behind the evolution of Iran's connections with the Iraqi Kurds and the Lebanese Shia. This chapter contains three sections. The first section assesses geopolitical and geo-cultural threats that convinced the Shah to build connections with non-state entities in Iraq and Lebanon. The second section tackles regional and international opportunities that urged the Shah to implement Iran's non-state foreign policy. The third section demonstrates the vital role institutions played in the evolution and dynamics of Iran's non-state foreign policy. The rest of the chapters, from the second chapter to the seventh, trace historical fluctuations of Iran's ties with non-state actors in different epochs, each containing two sections: one focused on Iran's relations with the

\footnotetext{
${ }^{12}$ Also available at http://nsarchive.gwu.edu.

${ }^{13}$ Available at http://www.foia.cia.gov.

${ }^{14}$ Available at https://www.cia.gov/offices-of-cia/intelligence-analysis/history.
} 
Iraqi Kurds and the other focused on Iran's relations with the Lebanese Shia. The second chapter begins with the historical background of Iranian-Iraqi Kurdish and IranianLebanese Shia connections before the Iraqi coup of 1958. The third chapter provides a detailed account of how Iran constructed networks with the Iraqi Kurds and the Lebanese Shia between 1958 and 1963. The fourth chapter focuses on Iran's massive support of the Kurds in fighting with the Pan-Arab regime of Baghdad as well as the Shia in challenging Nasserism in the Levant in the years between 1963 and 1968. The fifth chapter details another course in Iran's non-state foreign policy when the Shah began to scale back his support of Iran's non-state allies in a period between 1968 and 1974. The sixth chapter shows how Tehran terminated its ties with the Iraqi Kurds and the Lebanese Shia between 1975 and 1977. Finally, the last chapter relates to Iran's unsuccessful efforts to revive its connections. The conclusion wraps up the account of Iran's ties with the Iraqi Kurds and the Lebanese Shia. Systematically and methodically constructed, these chapters trace the first-hand history of Iran's connections with the Iraqi Kurds and the Lebanese Shia in the pre-revolutionary era. 


\section{Chapter 1}

\section{Driving Forces}

The evolution and trajectory of Iran's non-state foreign policy under the Shah's reign were mainly shaped by a set of geopolitical and geocultural threats and opportunities in international, regional, and domestic areas. The strategic connections between Pahlavi Iran with the Iraqi Kurds and the Lebanese Shia were forged to contain Iran's enemies. At the same time, specific opportunities facilitated the formation of Iran's non-state foreign policy. Furthermore, a constellation of institutional arrangements within Pahlavi Iran was responsible for shaping the dynamics of Iran's non-state foreign policy.

The present chapter comprises three parts. The first part focuses on international, regional, and domestic threats--both geopolitical and geocultural threats- that convinced Iran to forge its non-state foreign policy in Iraqi Kurdistan and Southern Lebanon. The second part highlights specific regional and international opportunities that provided a fertile ground for Iran to shape its strategic connections in Iraqi Kurdistan and the south of Lebanon. The last part puts emphasis on the major political institutions of the Pahlavi regime that were responsible in crafting Iran's ties with the Iraqi Kurds and the Lebanese Shia. Systematically intertwined, these three parts constitute a complex of driving factors that determined the formation of Iran's non-state foreign policy. 


\section{A. Threats}

"Well, this greater freedom has rekindled the unholy alliance of the red and the black in Iran and abroad. But we will continue our policy because the pillars that hold this country, propped by the Shah-People Revolution and the Rastakhiz Party of the nation, are strong and will not be harmed by the last gasps of this moribund unholy alliance. This caravan shall never come to a stop. Let the dog bark; the moon shall beam on," The Shah said in a speech to the Iranian women. ${ }^{15}$

"I know I am spending money on the army a lot. But what should I do? Is it acceptable to be beaten by Iraq?" the Shah told Assadollah Alam in January 1971. ${ }^{16}$

Threats are about state survival and security. Threat-construction processes are at the core of the national security. When an issue is framed as posing an existential threat to a state, it justifies the use of extraordinary measures to deter or handle it. ${ }^{17}$ Located at a geostrategic position, Iran had been historically subject to regional threats. The Shah's authoritarian style of government, Iran's oil rentier state, and Iran's multi-ethnic-religiouslinguistic society had nurtured domestic threats. On top of that, the Cold War and neighboring with one of the two superpowers, the USSR, added an international level of threats to Pahlavi Iran's national security. These threats interplayed in a tripartite domain with geopolitical, geocultural and geoeconomic effects, putting Iran's national integrity, identity, and economy in danger. Brought up or intensified by geography, geopolitical threats are political-military threats that endanger the survival and physicality of the state. They are traditional threats that push the state's securitization. The main referent object in the domain of geopolitics has traditionally been the state. Caused or intensified by geography, geocultural threats are ideological-cultural-normative threats that endanger

\footnotetext{
${ }^{15}$ The Rastakhiz Party was established by the Shah in 1975. Kongereh-ye bozorg-e zanan-e Iran [The Grand Congress of Iranian Women] (Tehran: Women's Organization of Iran, 2536 [1978]), 3-5.

16 Alam, Assadollah. Yad'dashtha-ye 'Alam: Virayesh va Muqaddamah az Alinaqi Alikhani [The Alam Diaries: Edited by Alinaqi Alikhani], Vol. II: 1973-1974 (Bethesda, MD: Iranbook, 1995), p. 148.

${ }^{17}$ Buzan, Barry, Ole Wæver and Jaap deWilde. Security: A New Framework for Analysis, (Boulder: Lynne Rienner, 1998). p. 36.
} 
state identity. The primary referent object in this field has been the nation and to some degree the ruling ideology, culture, and norms. Geo-economic threats are economic threats caused or intensified by geography. Iran's vast oil reservoirs in its southwestern province of Khuzestan, as well as an abundance of oil in the southern shore of the Persian Gulf, were targets of these threats. Though significant for its foreign policy, Iran's non-state foreign policy under the Shah's reign was not shaped by geo-economic threats. ${ }^{18}$ Indeed, there were geopolitical-geocultural threats that shaped Iran's non-state foreign policy, including the Red Threat, the Arab Threat, the Kurd Threat, the Black Threat, and the Palestinian Threat.

\section{The Red Threat}

Since Peter the Great's invasion of the Northern Iran in 1722-3, the Russian danger had permanently featured in Iranian kings' threat assessments. The treaties of Golestan, 24 October 1813, and Torkamanchay, 10 February 1828, forced Qajar Iran to cede to Russia control of its historical territories in the South Caucasus. ${ }^{19}$ These treaties limited Iran's full independence and then transformed the country to a major battlefront for the RussianBritish competition in Asia. With this historical background in mind, Iranians considered the geopolitical manifestation of the Red Threat, the Russian Expansionism, as a dangerous threat to Iran's national integrity and independence. The historical Russian threat was intensified with the establishment of the communist empire of the Soviet, posing

\footnotetext{
${ }^{18}$ The Middle East Oil was a strong motive for both superpowers' policies. Iran was a golden gate for the unlimited Middle East oil sources that could play a decisive role in the event of a war with the Soviet Union. For the U.S. policy makers, losing Baghdad and Riyadh oil reservoirs would bring up an oil war with the Soviet Union and vice versa. Besides, regional disputes over the price of oil, a general fear of the hegemonic ambitions of Saddam Hussein, prompted the Shah to contain the Iraqi threat by the support for Barzani's Peshmerga.

${ }^{19}$ These territories in the north of Aras River comprise modern-day Republic of Azerbaijan, Dagestan, Armenia, and Georgia.
} 
Communism as a strong geocultural threat to Iran. In the wake of the Cold War, the Red Threat symbiotically interplayed in both geopolitical and geocultural domains and endangered Iran's state and regime survival.

After defeating the Nazi military machinery in World War II, Russian expansionism was fueled with the Cold War contest with the U.S. and thus was promoted from a regional threat to Iran to an international one. Born in the late years of World War I and intensified by the Soviet victory in the World War II, Communism became a dominant discourse of anti-government forces in the third world. From the Shah's perspective, communism was Moscow's ideological tool to achieve its longstanding goal of reaching the warm water of the Persian Gulf. Consequently, Iran had been directly connected to the international level due to its geographical proximity to the USSR by the end of the World War II.

In the Shah's view, the Red Threat was not solely acting on the international level; rather, it had amplified regional threats to Iran. First, he considered Pan-Arab regimes as Moscow's potential allies in the region. Egypt in the mid-50s and then Iraq in the late-50s shifted from pro-West monarchies to a leftist government with an arms-supply relation with Moscow. With the formation of the second Baath regime in the late 60s, Iraq became the Soviet major ally in the region. In mid-June 1969, Assadollah Alam warned the U.S. ambassador to Tehran that "Iraq has become the Soviet colony." ${ }^{20}$ The Iraqi-Russian Treaty of Friendship of April 1972 fueled the Shah's suspicion of a Moscow-Baghdad

\footnotetext{
${ }^{20}$ Alam, Assadollah. Yad'dashtha-ye 'Alam: Virayesh va Muqaddamah az Alinaqi Alikhani [The Alam Diaries: Edited by Alinaqi Alikhani], Vol. I: 1968-1970 (Bethesda, MD: Iranbook, 1995). p. 71.
} 
alignment. ${ }^{21}$ Indeed, he remained deeply concerned with Moscow's political-military links with both the Arab regimes and militant non-state entities, like the Palestinian and Dhofar rebels in Oman. ${ }^{22} \mathrm{He}$ considered the Soviet potential and intention in transforming the regional power arrangement at the expense of Iran through "a continuing use of state proxies against Tehran" and raising the military capability of Iran's regional foes. ${ }^{23}$ Massive influxes of Russian armament and financial aid to the Pan-Arab regimes and Moscow's occasional threat of bringing their forces into play against Iran made the Red Threat an imminent danger to Iran. "Brezhnev begrudgingly warned me that conflicts in the Persian Gulf might lead to [the outbreak of] another world war," the Shah explained his concern to Alam over Moscow's siding with Baghdad against Iran. ${ }^{24}$ Second, in the Shah's view, the Arab countries of the region were prone to the communist coups or revolutions. For the Shah, communism had contagious effects in the region. "Once you have a legal Communist government they penetrate everywhere," the Shah told President Ford. ${ }^{25}$ In the Shah's view, the Arab states were fake and weak; therefore, they would be toppled, sooner or later, and replaced with communist regimes. The formation of a communist regime in South Yemen in June 1969 reaffirmed his concerns. ${ }^{26}$

${ }^{21}$ Alam, Assadollah. Yad'dashtha-ye 'Alam: Virayesh va Muqaddamah az Alinaqi Alikhani [The Alam Diaries: Edited by Alinaqi Alikhani], Vol. II: 1970-1971 (Bethesda, MD: Iranbook, 1995). p. 270.

${ }^{22}$ A secret U.S. State Department document, April 1974, Documents of the United States Embassy in Tehran, Volume 8, 1979, 65.

${ }^{23}$ A secret U.S. State Department document, April 1974, Documents of the United States Embassy in Tehran, Volume 8, 1979, 65.

${ }^{24}$ The Shah visited Moscow in June 1965. Alam, Assadollah. Yad'dashtha-ye 'Alam: Virayesh va Muqaddamah az Alinaqi Alikhani [The Alam Diaries: Edited by Alinaqi Alikhani], Vol. IV: 1974-1975 (Bethesda, MD: Iranbook, 1995). p. 253.

${ }^{25}$ Memorandum of Conversation, May 15, 1975. (FRUS 1969-1974, XXVII, 377).

${ }^{26}$ Southern Yemen gained its independent initially under the name of the People's Republic of Southern Yemen on 30 November 1967 under the control of the National Liberation Front (NLF). Two years later, 
The Red Threat also endangered both state and regime survival in Iran. Iran's historical multi-ethnic, multi-lingual society was a target for Russian communism. Since the dawn of the 1917 Bolshevik Revolution, Moscow had built its ties with non-Persian communities, particularly the Azaris and the Kurds. Both Azari and Kurdish elites had joined the communist, pro-Soviet parties of the Tudeh Party, Kurdistan Democratic Party, and Azarbaijan Democratic Party. Although the Soviet-fabricated republics of Azarbaijan and Mahabad did not last more than a year (December 1945-December 1946), the Shah never forgot the potential of communism in nurturing ethnic separatist groups against the Iranian state. Additionally, a deeply uneven distribution of wealth, extensive corruption, and the authoritarian political system of Pahlavi Iran produced a fertile ground for communist movements to target the Pahlavi regime. Founded in 1941, the Tudeh (People in Persian) Party was the most popular party in Iran's modern history. Considering its broad support base and close affinity to Moscow, the Shah saw the Tudeh Party as the Russian fifth column with a questionable loyalty to Iran's constitution. The Party had notoriously supported the Soviet demand for Iran's oil in the Caspian Sea and sided with the separatist republics. Finally, after the coup pf 1953 the government cracked down the Party. By the late 50s, Communism revived under the banner of militant groups, the Marxist Sazman-e Cherik' ha-ye Fada'i-ye Khalq (Organization of the Iranian People's Sacrificing Guerrillas) and Islamist-Marxist Sazman-e Mojahedin-e Khalq-e Iran (Organization of the Iranian People's Islamic Warriors). These groups took violent strategies in challenging the Shah's regime. Until the end of the Shah's reign, Communism remained as a robust domestic threat.

however, a radical Marxist wing of the NLF transformed the country into a communist one and reorganized it as the People's Democratic Republic of Yemen. 


\section{The Arab Threat}

Since the Arab Muslim conquest of Iran during 633-654 BC, Iran had been subject to the Arab Threat. Despite the Islamization of Iran, the country was never Arabized. By sticking to their strong civilization and the revival of the Persian language, Iranians remained Iranians. After two centuries of unstoppable riots and insurrection, Iran reemerged. With the establishment of the Safavid Empire in the early $16^{\text {th }}$ century, SunniShia division was added to Iranian-Arab rivalry. Despite this historical background, Iran initially built friendly relations with newly-founded Arab states of the region. Nevertheless, the Arab Threat came to the scene with its geopolitical manifestation, Arab Unity, and its geocultural aspect, Pan-Arabism, in the early 50s.

In the middle of the Cold War, Pan-Arabism was a major de-territorializing force, promising the unity of the Arab-speaking territories, stretching from the Atlantic Ocean to the Persian Gulf. Pan-Arabism was first coined by Jurji Zaydan and his Nahda movement in the late $19^{\text {th }}$ century. Though popular since the collapse of the Ottoman Empire, ${ }^{27}$ it was under Gamal Abdel Nasser that Pan-Arabism swept the region. With the coup of 23 July 1952, Nasser took power in Cairo and soon challenged the Western powers and their regional allies, particularly Iran. ${ }^{28}$ The Suez Crisis of 1956 immeasurably cemented his position in the Arab World. On 22 February 1958, the United Arab Republic (UAR) was founded out of Egypt and Syria. Nasser's UAR was a catalyst for a series of destabilizing

\footnotetext{
${ }^{27}$ Pan-Arabism was first followed by Sharif Hussein ibn Ali, the Sharif of Mecca. Promised a support for the establishment of a unified Arab state, constituted of the Arab lands of the Ottoman Empire, he sided with the British military against Turks in the First World War. The idea of the unified Arab territories was then followed by his son, Abdullah I of Jordan who dreamed of Greater Syria of Syria, Jordan, and Palestine.

${ }^{28}$ The coup plotters initially appointed General Muhammad Naguib as the Egypt's first president. However, it was soon revealed that the real leader of the revolution was Nasser. Conflict with Naguib over strategies soon resulted in his removal in October, 1954.
} 
events in the region, like the first Lebanese Civil War of 1958 and the Iraqi coup of 14 July 1958. Despite a growing tension between Baghdad and Nasser on the Arab leadership, the Arab Threat challenged Iran in the 60 s and 70 s.

In the Shah's view, Pan-Arabism was a naturally anti-Iranian ideology. First, the Shah considered the Pan-Arab regimes as the Soviet's natural allies. In his view, Nasser and Pan-Arab leaders with their socialist background were Moscow's surrogate to penetrate the Persian Gulf. After the Iraqi coup of 1958, the Shah faced the rise of Communism in Iraq. ${ }^{29}$ Second, Pan-Arabism was based on framing external threats to solidify the heterogeneity of Arab identities. ${ }^{30}$ For Pan Arab leaders, the enemy was Zionism and Western Imperialism. Arab historical suspicion of the West's role in the creation of Israel and breaking-up of the Arab Unity had nurtured the anti-Western tone of Pan-Arabism. ${ }^{31}$ Within this context, Israel and pro-Western regimes, notably Iran, became targets for the Pan-Arab propaganda, denouncing Iran's secret cooperation with Tel-Aviv as "a treacherous plot to divide the Arab World between themselves." 32 Third, PanArabism soon fell on an ethnic fault line of the Arab-Iranian and Shia-Sunni divisions.

\footnotetext{
${ }^{29}$ The headquarters of the Iranian Tudeh Party was in Sulaymaniya and Basra. Mosul hosted Turkish and Syrian communist parties, and the Jordanian Communist Party set it bases in Najaf and Karbala. SAVAK Documents, No. f-b2b2/15607, 6 February, 1960; SAVAK Documents, No. 7b4/8200, 13 December, 1958; SAVAK Documents, No Number.

${ }^{30}$ For more detailed discussions see Laclau, Ernesto. New Reflections on the Revolution of Our Time, Cambridge: Cambridge University Press, 1990; Laclau, Ernesto. The Making of Political Identities, Cambridge: Cambridge University Press, 1993; Laclau, Ernesto, and Chantal Mouffe, Hegemony and Socialist Strategy: towards a Radical Democratic politics, Verso, 1985; Melucci, Alberto, Challenging Codes: Collective action in the information age, Cambridge University Press, 1996; Torfing, Jacob. Poststructuralist Discourse Theory: Foucault, Laclau, Mouffe, and Zizek, Cambridge: Cambridge University Press, 2005.

${ }^{31}$ Barnett, Michael N. Dialogues in Arab Politics. (Columbia University Press, October 15, 1998). pp.10829 .

${ }^{32}$ Neda al-Watan, 22 March 1969.
} 
Therefore, Iran's border dispute with Iraq risked becoming a fiery conflict with all Arab states. According to the Iraqi leaders, war with Iran was a war with the enemy of the Arab. "Iraq is not fighting with Iran over one of the Iraqi issues; rather, its goal is to prevent Iran's ambitions and to preserve the Arabness of the [Persian] Gulf and Arabs' right in the Shatt al-Arab (Arvand Rud) waterway. Iraq is not fighting with Iran over an oil barrel; rather, it is doing to defend the Arab nations' wealth of the [Persian Gulf]. ${ }^{33}$ Highlighting "the old alliance pact between Cyrus the Great and the Jews," 34 the Pan-Arab leaders of Baghdad had tried to legitimize Iraqi position within the Arab World by framing themselves as "the Guardian of the Eastern Gate of the Arab World." 35

The Arab Threat also posed domestic dangers to Iran. Indeed, the Pan-Arab leaders were concerned about Arab-speaking people in non-Arab states of the region. Amidst the growing Iranian-Arab rivalry, Nasser, Iraqis, and other Pan-Arab leaders claimed the oilrich Iranian province of Khuzestan. With considerable Arab-speaking inhabitants, less than half of its population, Khuzestan soon became the primary target for Iraqi expansionist ambitions. Qasim called Khuzestan 'Arabistan' and Nasser named the Persian Gulf 'the Arabian Gulf'. Iraqi leaders had also claimed that "Iraq is not fighting with Iran to liberate just an Iraqi territory from Iran's occupation; rather, it is doing to preserve the [Persian] Gulf area from Iran's occupation.."36 They stressed Iran's "occupation of oil reserved, Arab-speaking province of Khuzestan and Mohammarah [Khoramshahr] and stealing our

\footnotetext{
${ }^{33}$ Kuwait 3511 to Ministry of Foreign Affairs, 13 February 1975.

${ }^{34}$ Beirut 3506 to Ministry of Foreign Affairs, 2 December 1971.

${ }^{35}$ Kuwait 9939-12352 to Ministry of Foreign Affairs, 10 February 1975.

${ }^{36}$ Kuwait 3511 to Ministry of Foreign Affairs, 13 February 1975.
} 
[the Arab] oil.". ${ }^{37}$ Saddam Hussein clearly stated that "Iraq has not had a serious dispute with Iran over Shatt al-Arab (Arvand Rud) since this is part of Iraq's soil. Iraq's dispute with Iran is over Khuzestan that is part of Iraq's soil and was annexed to Iran during foreign rule!" ${ }^{38}$ The alleged 'Iranian Occupation' aimed at painting Israel and Iran with the same brush--a claim that was frequently used by Pan-Arab leaders in the 60s and 70s.

Iraq also supported several separatist and anti-Shah organizations. There were several, yet weak, Arab separatist groups, including Arabistan Liberation Front (ALF), the National Front for the Liberation of Arabistan, the Arab Gulf, and the Al-Ahwaz Liberation Front, all fabricated by Iraq. ${ }^{39}$ The Pan-Arab leaders of the region also conspired to raise trouble within other non-Persian communities in Iranian Kurdistan, Azarbaijan, and Baluchistan. ${ }^{40}$ Led by Panhah-Ali Khan Javanshir, the Sunni Baluchi tribes living in the south-east of Iran were among Iraqi targets. In the aftermath of the debacle of the Sovietfabricated Republic of Azarbaijan, a few of its leaders fled into exile to Iraq, particularly Mahmoud Panhaian. ${ }^{41}$ In the late 60 s, Baghdad helped him to establish Jebhe-e Melli Khalq-ha (the National Front of People), a multi-ethnic party aiming to urge non-Persian elites to separate from Iran. Mohammad-Taghi Zehtabi and pro-Ayatollah Khomeini

\footnotetext{
${ }^{37}$ Neda al-Watan, 22 March 1969.

${ }^{38}$ Rajaiee, Farhang, The Iran-Iraq War: The Politics of Aggression. (University Press of Florida, April 20, 1993), p. 12.

${ }^{39}$ Iraqi had also penetrated in the Arab-speaking community of Khuzestan. In the mid-60s, Iranian Arabspeaking teachers, including Zariya Al-Mohiaddin, in Iraqi schools in Khorramshahr were in full connection with Iraqi Istikhbarat, aiming to urge anti-Iran sentiments among the Arab-speaking people. With Mossad direct intervention, SAVAK thwarted their plot. Interview with Major General Mansour Qadar, Oral History, Foundations for Iranian History.

${ }^{40}$ Abdulghani, Jasim, Iraq and Iran: The Years of Crisis. (The Johns Hopkins University Press, October 1, 1984). p. 52.

${ }^{41}$ Panahian was Minister of War in the Soviet-fabricated republic of Azarbaijan.
} 
Mahmoud Doaie also cooperated with Panahian in Radio Baghdad. ${ }^{42}$ Both Nasser and Iraqi leaders unsuccessfully tried to urge the Iranian Kurds, particularly the Jawanrodi, against Tehran. ${ }^{43}$ In addition to supporting separatist groups, Iraqi regimes had backed Iranian dissidents, like anti-Shah Teymour Bakhtiar, former Director of SAVAK. Nasser also backed Sazeman-e Makhsus-e Eettehad va Amal (Special Organization for Unity and Action or SAMA), founded by religious elements of the Iran's National Front. Although the Arab Threat was damaged after the Six Day War of 1967, it was revived with the formation of the Baath regimes in Baghdad and remained a significant threat to Iran's security and interest until the debacle of the Pahlavi dynasty.

\section{The Kurdish Threat}

Since the formation of the Soviet-backed Mahabad Republic (1945-6), the Shah had been considerably worried about the Kurdish Threat. Despite the execution of its separatist leader--Qazi Mohammad-- ${ }^{44}$ the Republic of Mahabad had provided a master frame for the Kurdish separatist groups in Iran and in turn, intensified the Shah's suspicion of the Kurdish movements in the region. The outbreak of the Kurdish War in the north of Iraq in 1961 was a double-edged sword for Iran. Indeed, Iran sided with the Iraqi Kurds in order to contain Pan-Arab Iraq. On the other hand, the Shah was worried about the spillover of the Iraqi Kurdish insurgency into Iranian Kurdistan. ${ }^{45}$ Indeed, the Shah never supported

\footnotetext{
${ }^{42}$ Zehtabi was the main ideologue of Pan-Turkism in Iran. Doaie has been a reformist clergy and editor-inchief of Ettelaat Newspaper since 1994.

${ }^{43}$ SAVAK Documents, No. A/316/23010, 1 September 1964, and SAVAK Documents, No. 2399, 10 September 1966.

${ }^{44}$ There were some strong documents stating that the Shah did not agree with Qazi's execution. It was general Haj-Ali Razmara, then-prime minister, who oredered the execution of Qazi.

${ }^{45}$ SAVAK Documents, 311/185-2-d, 6 May, 1962; SAVAK Documents, 331/21715, 28 August, 1963.
} 
the idea of an independent Kurdistan in the region. The Iranian Kurds soon expressed their support for Barzani and his Peshmerga ${ }^{46}$ Several Iranian Kurds in Mahabad and Sanandaj, as well as the Javanroudis tribe, joined a pro-Barzani party, Kurd Population (Jamiat-e Kurd), in Iranian Kurdistan. ${ }^{47}$ Seyed Abdullah Es'haghi (known as Ahmad Tawfiq), the leader of the Democratic Party of Iranian Kurdistan (KDPI), had pressed Barzani to support the Iranian Kurds while at the same time urged Iranian Kurds in Mahabad to launch a riot against Tehran. Besides, the outbreak of the war in the north of Iraq endangered Iran's national security with a massive influx of the Kurdish refugees crossing the border with Iran. According to SAVAK, Barzani had asked the Kurdish refugees to stay in Iran since they could function for his propaganda against $\operatorname{Iran} .{ }^{48}$ Despite such a broad base of support among the Iranian Kurds, the Iraqi Kurd leaders were divided on the support for other Kurdish communities. With increasing dependency on Iran's support in their conflict with Baghdad, Barzani gradually abandoned supporting the Iranian Kurds. In the late-60s, he killed members of the anti-Iran Revolutionary Committee, aka the KAK, and handed their bodies to SAVAK. ${ }^{49}$

The Shah was also worried about Kurdish-Russian connections. It was Stalin and his agent Mir Ja'far Baghirov, the communist leader of Azerbaijan SSR (1932-1953), who

\footnotetext{
${ }^{46}$ SAVAK Documents, No. 312/54991, 21 April, 1961; SAVAK Documents, No. 2b/1729, 18 May, 1961.

${ }^{47}$ SAVAK Documents, No. a1/43476, No Date.

${ }^{48}$ SAVAK Documents, 234/0245, 13 May, 1963.

${ }^{49}$ In 1967, several members of the KDPI, including Ismail Sharifzadeh, Qadir Sharif, and Sulaiman Moini, left Tawfiq's KDPI. They stressed on military struggles against Tehran. They have connections with the Tudeh Party. See also SAVAK Documents, No. 232/49824, 2 August, 1967.
} 
really fabricated the republics of Azarbaijan and Mahabad. ${ }^{50}$ With this historical background in mind, the Shah considered the Kurdish Threat naturally interwoven with the Red Threat. In addition to Ja'far Pishevari and Qazi Muhammad, leaders of ethnic republics in Iran, Barzani had an extensive tie with Moscow. Barzani believed that an independent, united Kurdistan compared of Kurdish parts of Turkey, Iraq and Iran could be established only by the Russians' support. ${ }^{51}$ During his exile in Moscow for more than thirteen years under the surname Mamedov, Barzani had been connected with the Russian Red Army and the KGB and gained a certificate from the Higher Party School. ${ }^{52}$ Even after the rise of the Kurdish insurgency, Tehran had been suspicious of Moscow's support for Barzani. ${ }^{53}$

\footnotetext{
${ }^{50}$ In the late months of the World War II, Stalin planned to annex several provinces in northern Iran. His territorial aspirations included Iranian provinces of Azarbaijan, Kurdistan, Gilan, Mazandaran and Khorasan. See Secret Soviet Instructions on Measures to Carry out Special Assignments throughout Southern Azerbaijan and the Northern Provinces of Iran in an attempt to set a separatist movement in Northern Iran," Dated 07/14/1945, Available through Cold War International History Project:

www.wilsoncenter.org/index.cfm?topic_id $=1409 \&$ fuseaction=va2.browse\&sort $=$ Collection\&item $=1945 \% 2$ D46\%20Iranian\%20Crisis; According to Nosratollah Jahanshahloo, former Deputy Premier and Health Minister of the Pishevari government of Iranian Azerbaijan Democratic Republic, explained the Soviet's humiliating behavior with Pishevari and said, "Mr. Gholiev [the Soviet Consul in Tabriz] met us in a small room. Angered by the Russian behavior, raggedly protested Col. Gholiev and said, "You [Russians] brought us to this place. Now, you left us since it [supporting the Azarnaijan Republic in Iran] would not be in your favor anymore ... Tell me now who is responsible for this disturbance?" Shocked and angered by Pishevari's bold protest, Col. Gholiev told him, "He who brought you here, now tells you to go." Jahanshahloo, Nosratollah, We and the Foreign: Political Memoirs of Dr Nosratollah Jahanshahloo, Samarghand Publicatio, 1385, p. 190; For more discussion, See Joseph V. Stalin to Ja'far Pishevari, Leader of the Democratic Republic of Azerbaijan, 8 May 1946. AVP RF, f. 06, op. 7, p. 34, d. 544, II. 8-9 Available: http://digitalarchive.wilsoncenter.org/document/117827); Archive of the Ministry of Foreign Affairs of the Russian Federation, АВПРФ، ф. 094، оп. 38، п. 364 А، д. 49، л. 1-7 Федерации Архив внешней политики Российской; Archive of Political Parties and Social Movements of the Azerbaijan Republic, AR SPIHMDA، f. 1، s. 89، i. 114، v. 218-2.

${ }^{51}$ Tafreshian, Aboulhasan, Qiam-e Afsaran-e Khorasan (The Revolt of Khorasan Officers). (Atlas, Tehran, 1988). p. 112-5.

${ }^{52}$ Research Study RNAS-10 prepared by the Department of State, May 31, 1972, FRUS 1969-1976, E4, 310 ; Memcon, April 12, 1962, FRUS 1961-1963, XVII, 243; Gallman to Department of the State, 14 Oct. 1958, in U.S. Department of State, Foreign Relations of the United States, 1958-1960, Vol. XII (Washington, DC: Government Printing Office, 1993), pp. 344-46; Barzani's alleged ties to the KGB are discussed in Pavel Sudolatov and Anatoli Sudoplatov with Jerrold. L. Schecter and Leona P. Schecter, Special Tasks: The Memories of an Unknown Witness - A Soviet Spymaster (Boston: Little, and Co., 1994), pp. 259-64.

${ }^{53}$ SAVAK Documents, No. 311/185, 6 May, 1962.
} 
Although Barzani never became a communist, ${ }^{54}$ and Moscow never fully backed the Kurds, ${ }^{55}$ the Shah was permanently worried about the creation of a Soviet-backed Kurdistan.

Tehran was also already disturbed by the secret ties between Iraqi Kurds and Cairo. Indeed, a possible independent Kurdistan could provide an opportunity for Egypt to infiltrate Iran's western borders. Months before the outbreak of the Kurdish War of 1961, the UAR officials had tried to side with the Iraqi Kurds. General Hakim Amer, the chief of Syrian Army, met both the Russians and Barzani to express his support for the creation of an independent Kurdistan in Iraq. ${ }^{56}$ This was a manifestation of a tripartite alliance of the Red/the Arab/the Kurd threats to Iran's national security. In the middle of fighting with Qasim, Barzani had dispatched Hahzhar Mukriani to the Egyptian embassy in Baghdad in spring 1962. "I went to Baghdad to talk to Egypt ambassador to Baghdad. I initially offered them to make a coup in Iran or at least to begin a war with Iran in Iranian Kurdistan. I also added that Egypt should give us some tanks and planes along with weapons to launch an effective military operation in Iran and weaken the pivot of the CENTO Pact." ${ }^{47}$ Despite

\footnotetext{
${ }^{54}$ O’balance, Edgar. The Kurdish Revolt, 1961 ---1970 (London: Faber and Faber Ltd., 1973). pp.63-64.

${ }^{55}$ During 1961-1979, the Soviets took ambivalent strategies towards the Kurds. On the one hand, Moscow's historical support for the Third World liberation movements, Barzani's long-term connection with Russians KGB and pro-socialism Kurd leaders, like Talabani and Ahmad, solidified the Russian-Kurdish connections. On the other hand, apart from ebbs and flows within the central government, all Iraqi leaders had enjoyed good relations with Moscow. This paradoxical situation recalled the Horn of Africa crisis in the $60 \mathrm{~s}$ and $70 \mathrm{~s}$ for the Soviets. As Khaled Bakdash, the officer of Syria Baath Party, once aptly argued, "The problem of the Kurds is that they are too close to Russian borders, and Russia does not intend to make Iran, Turkey, and Syria upset. However, had Kurds been in Africa, Russians would have established a state for them. The Russian policy toward Kurds always has the policy of Expedient."

${ }^{56}$ SAVAK Documents, No. 13808, 12 February, 1961.

${ }^{57}$ Qaneifard, Erfan, Pas az Shast Sal: Zendegi va Khaterat-e Jalal Talabani (After Sixty Years: The Life and Memories of Jalal Talabani). (Elm Publication, Tehran, October, 2012). p. 677; Qaneifard, Tonbad-e Havades: Goftogooi ba Isa Pejman (Hurricane of Events: A Dialogue with Isa Pejman), (Elm Publication, Tehran, October, 2012). p. 139.
} 
Iran's heavy support for the Iraqi Kurds, Barzani maintained "friendly but unhelpful" 58 contacts with Cairo in the mid-60s. Indeed, SAVAK had been well aware of Nasser's promise of support for "an autonomous, even independent, Kurdistan." ${ }^{, 59}$ Egypt's on-andoff support for Barzani finally ended with Nasser's fiasco in the Six-Day War of $1967 .^{60}$

The Shah was also perturbed by Barzani's unreliable personality. Considering his increasing "popularity" among other Kurds after the outbreak of the movement, ${ }^{61}$ the fate of the Kurdish uprising lay in his hands. Despite the Kurdish-Iranian alliance against Baghdad, Barzani never showed his total loyalty to the Shah. His drastic shift towards Baghdad on several occasions, like the ceasefire of 1964 , reaffirmed that he was not a reliable ally for Iran. Indeed, Barzani was a pragmatist leader seeking a balance between Iran and other powers, like the Soviet and Egypt, to gain more concessions. ${ }^{62}$ As SAVAK rightly argued, "Mullah is an ambitious man" who was "neither Communist nor Pro-West; rather, he is a Barzani Kurd. ${ }^{\prime 63}$ In the Shah's view, Barzani was an opportunist leader who prioritized his personal interest over the Kurds and Iran. Thus, Tehran supported antiBarzani's figures, like Ahmad and Talabani, to counter-balance Barzani's position in Iraqi Kurdistan. ${ }^{64}$ Despite Iran's support for the Iraqi Kurds, the spillover of an independent

\footnotetext{
${ }^{58}$ Baghdad 150 to State; September 20, 1962 (NARA/RG59/R2/787.00/9-2062), PP. 1-2.

${ }^{59}$ SAVAK Documents, No. 231/45008, 12 February 1965, and SAVAK Documents, No. 2/13998, 3 October 1965.

${ }^{60}$ SAVAK Documents, No. 6218, 11 January, 1968.

${ }^{61}$ SAVAK Documents, No. j5/18801, 13 June, 1961; SAVAK Documents, No. 5541, 5 January, 1961.

${ }^{62}$ SAVAK Documents, No. p.348, 16 March, 1966.

${ }^{63}$ Kuwait 1904 to Ministry of Foreign Affairs, 6 July 1963.

${ }^{64}$ Qaneifard, Erfan, Pas az Shast Sal: Zendegi va Khaterat-e Jalal Talabani (After Sixty Years: The Life and Memories of Jalal Talabani), (Elm Publication, Tehran, 2009). p. 787.
} 
Kurdistan in the north of Iraq into Iranian Kurdistan, Mullah Mustafa Barzani's connection with Moscow and Cairo, and his unreliability intensified the Kurdish Threat to Iran's national security.

\section{The Black Threat}

Islamism, the Black Threat, challenged the Pahlavi regime after the mid-60s. Along with Egypt and Turkey, Iran had been a pivotal center for the Islamic Movement in the late $19^{\text {th }}$ century. Sharing common issues with Islamic Revivalism, Islamism gradually gained ascendence after World War II. As Pan-Arabism declined after the fiasco of 1967, the Islamic revivalism gradually emerged as an alternative mobilizing ideology in the region with a potential to unite the Islamic World around the nodal point of 'Islam'. ${ }^{65}$ In the aftermath of the Shah's proclaimed White Revolution in January 1963, Ayatollah Ruhollah Khomeini lashed out at the regime for its westernization program. In June 1963, Ayatollah Khomeini was finally arrested after a fiery anti-Shah speech, leading to bloody riots. The Islamic uprising was violently cracked down, though. The Shah then tightened the political atmosphere, banned moderate opposition groups, and limited Shia Ayatollahs' political activities. Nevertheless, the Iranian dissidents became more radicalized. Despite the growing emergence of Left-oriented militant groups in the world, Islamist groups gradually and successfully spreaded their ideology in Iran. As a pro-Mossadegh party, the Freedom Movement of Iran (FMI) became a major national-religious force in Iran. Influenced by Ali Shariati, the main ideologue of the Islamic Revolution, the 1slamist Sazman-e Mojahedin-e Khalq-e Iran (the People's Mojahedin Organization of Iran or MEK) was established as one of the most influential militant groups throughout the 70s. It was within

\footnotetext{
${ }^{65}$ Sayyid, Bobby S. A Fundamental Fear: Eurocentrism and the Emergence of Islamism. (Zed Books; Revised edition, February 7, 2004).
} 
this context that the Shah coined an 'Unholy Alliance of Erteja'a-e Sorkh va Siah' (the Red and the Black Backwardness). The Red and the Black, according to the Shah, referred to the guerrilla oppositions' eclectic ideology of Revolutionary Islam with Marxism. Despite the rising popularity of the FMI and the Mojahedin, it was Ayatollah Khomeini and his followers who successfully announced a politicized interpretation of Shia Islam. By the mid-70s, Islamism had been the strongest anti-Shah ideology in Iran.

The main bridgeheads of the FMI, the Mojahedin, and pro-Ayatollah Khomeini elements were in the Arab countries of the region, including Iraq, Syria, Egypt, and particularly Lebanon. In the Shah's threat assessment, Baghdad's hosting of Iranian Islamist elements was an ominous alliance of Pan-Arabism and Islamism. These groups also found Lebanon a heaven for waging their anti-Tehran struggle that in turn, damaged Iran's ties with the Lebanese Shia. Besides, Sadr's strong streak of ecumenist messages was based on the revival of Islam and the unity among the Islamic World. With his on-andoff connections with the Iranian Islamist opposition, Pahlavi Tehran ultimately transformed its policy towards the Lebanese Shia. Sadr's support for the Palestinians was also framed as an example of rising Islamism backed by radical left groups. It was another manifestation of an unholy alliance of the Red and the Black. The Black Threat ultimately overthrew the Pahlavi regime in the Islamic Revolution of 1979.

\section{The Palestine Threat}

Contrary to popular perception, the Shah was not against the idea of Palestine. The Shah had rightly predicted that the creation of a Jewish state in the Middle East "would lead to decades, if not centuries, of violence." ${ }^{66}$ Since the dawn of the crisis, he had put

\footnotetext{
${ }^{66}$ UN Special Committee on Palestine, Recommendations to the General Assembly, September 3, 1947.
} 
emphasis on the formation of a 'single federal state' including both the Arab and the Jews. Tehran, in fact, voted in UN against the partition of Palestine, ${ }^{67}$ and refused to formally recognize Israel. Nevertheless, the unstable power equation of the region fed the Shah's controversial view towards the conflict.

Though remote, the durability of Israeli-Palestinian conflict provided a geocultural threat to Iran. The Palestine Cause fueled the three threats of the Arab, the Black, and the Red to Iran. First, Tehran's informal alignment with Israel had damaged Iran's image among the Arabs. ${ }^{68}$ In July 1960, the Shah stated that "Iran has recognized Israel long ago," pointing to Tehran's de facto recognition of Israel in $1951 .{ }^{69}$ His reckless interview gave Nasser a pretext to cut off diplomatic relations with Tehran. Framing the Shah as a proIsraeli puppet of the Western Imperialism, Nasser pushed the Arab regimes to change their relations with Iran. The Iraqi leaders had also taken the same language against Iran and criticized Iran's economic relations with Israel. ${ }^{70}$ Second, the Shah was concerned about the Palestinians connections with the Soviets. In December 1974, the Shah expressed his sympathy with the Palestinian in an interview with the Lebanese newspaper, al-Hawadis, while warning "What I fear is that the Palestinians may allow international circumstances to make their cause a tool of Soviet or some other international strategy."

\footnotetext{
${ }^{67}$ The formation of two independent states in Palestine was finally adopted by the General Assembly as Resolution 181 on November 29, 1947.

${ }^{68}$ Interview with Major General Mansour Qadar, Oral History, Foundations for Iranian History.

${ }^{69}$ R. K. Ramazani, Iran's Foreign Policy 1941-1973 (Charlottesville: University Press of Virginia, 1975). p. 404.

${ }^{70}$ Baghdad 2243 to Iran's Ministry of Foreign Affairs, 1 September 1969.

${ }^{71}$ R. K. Ramazani, Iran's Foreign Policy 1941-1973 (Charlottesville: University Press of Virginia, 1975). p. 427.
} 
the Palestinian cause had been a source of regional instability that provided Moscow with an opportunity to infiltrate the Middle East. Third, the Islamist leaders had considered the Palestine cause a symbol of the oppression of the Muslim. Sadr's Islamic message for the support of the Palestinians had tremendous ramifications for Iran's non-state foreign policy in Lebanon. More substantially, the Palestine had urged the Iranian Islamist groups, like pro-Ayatollah Khomeini's elements, the FMI, and the Mujahedin, to challenge Tehran.

Furthermore, the Palestinian militancy struggle had inspired anti-Shah dissidents, both Marxist and Islamist, in choosing violent strategies against the Pahlavi regime. The Shah had warned of dangerous connections between the Palestinian groups and LeftistIslamist Iranians, stating that “... some of the groups of the resistance trained Iranian saboteurs to infiltrate our territory, kill our people, and blow up various installations..." 72 Within this context, controlling and monitoring relations between Iranian dissidents with the Palestinian was among Tehran's goals in the region.

Consequently, Iran's non-state foreign policy under the Shah's reign was heavily shaped by both geopolitical and geocultural threats, interplaying on three levels international, regional, and domestic. Iran's non-state foreign policy was, in fact, forged to limit threats to Iran. Interplaying in geopolitical and geocultural domains, international threat of the Red had the spillover effects on both regional and domestic levels. The regional threats by the Arabs, the Kurds, and Palestinian issue had spillover effects on the domestic level. This complex of geopolitical-geocultural threats shaped the trajectory of Iran's non-state foreign policy under the Shah's reign (Table 1).

\footnotetext{
${ }^{72}$ R. K. Ramazani, Iran's Foreign Policy 1941-1973 (Charlottesville: University Press of Virginia, 1975). p. 427.
} 
Table 1: Threats in a tripartite domain and level

\begin{tabular}{|l|l|l|l|}
\hline Levels $\backslash \backslash$ & Geopolitics & Geoculture & Geoeconomics \\
\hline International & Russian & Communism & $\ldots \ldots$ \\
\hline Regional & Arab Unity & Pan-Arabism & $\ldots \ldots$ \\
& Greater Kurdistan & Kurdish & \\
& The Palestine & Nationalism & \\
\hline Domestic & $\ldots \ldots . .$. & $\ldots \ldots$ & $\ldots$ \\
\hline
\end{tabular}

\section{B. Opportunities}

"The White House should push the regional powers that had the ability to uphold stability to take on a greater role in security matters. It is better for [the] U.S. to have Iran able to defend [it]self than to have... another Vietnam," the Shah advised Richard Nixon. ${ }^{73}$

I like him [the Shah], I like him, and I like the country[Iran]. And some of those other bastards out there I don't like," President Nixon told his advisers. ${ }^{74}$

In addition to threats, there were international and regional opportunities that facilitated Iran's non-state foreign policy. These opportunities included major strategies and policies taken by Iran's allies during the Cold War, i.e., the U.S., Israel, and the UK. They created fertile ground for Iran to build and expand its networks with the Lebanese Shia and particularly the Iraqi Kurds.

\footnotetext{
${ }^{73}$ Afkhami, Ghoma Reza, The Life and Times of the Shah (Berkeley, CA, 2009). pp. 302-03.

${ }^{74}$ Conversation among President Nixon, MacArthur, and Haig, Washington, April 8, 1971, FRUS 19691976, E-4, 122.
} 


\section{The U.S., Zero-Sum Nature of the Cold War, and the Nixon Doctrine}

The trajectory of Iran's non-state foreign policy under the Shah's reign was affected by U.S. Cold War strategies. Although the U.S. initially had no interest in the Middle Eastern conflicts, it was gradually dragged into the regional crises by the all-encompassing zero-sum nature of the Cold War. The U.S. central goals were designed to counter the Soviet incursion and domination of the oil sources through the support for anti-leftist autocrats in the region. Therefore, the U.S. was not strictly scrupulous about the ideology of its allies as long as they stayed non-communist.

Interestingly, the Iran Crisis of 1946 and the formation of the Soviet-backed republics of Azarbaijan and Mahabad in the north-western of Iran was the dawn of the Cold War. Israel's defeat of the Arab armies in 1948 and then Iran's Nationalization Oil Movement in 1951-53 accelerated the U.S. intervention in the region. Fueled by the Suez Canal crisis of 1956, the Eisenhower Doctrine institutionalized Secretary Dulles's term for the 'Northern Tier' states through the establishment of the Baghdad Pact to contain the Soviets. Nevertheless, the Pact collapsed with the Iraqi coup of 1958. The new Iraqi regime adopted a pro-Soviet policy. Indeed, Iraq's geostrategic position at the heart of the region made it a target of Moscow hoping to leapfrog over the West's containment shield in the Levant and the Persian Gulf. Within the zero-sum nature of the Cold War, Iraq's warming relation with Moscow was considered as Iraqi drift into the orbit of Russian influence. ${ }^{75}$ It was within this context that the Shah crafted ties with the Iraqi Kurds. Although the U.S. did not welcome the Kurdish War in the early 60s, the Cold War context provided Iran

\footnotetext{
${ }^{75}$ National Security Council 5820/1 in Keefer, E.C. and G.W. LaFantasie ed., Foreign Relations of the United States, 1958-1960, Volume XII, Near East Region; Iraq; Iran; Arabian Peninsula (Washington 1992), p. 191.
} 
with an ample opportunity to justify its support for the Iraqi Kurds to block the Soviet infiltration.

In the mid-60s, the U.S. refused to join Iran in its support of the Iraqi Kurds against Baghdad. Under the anticommunist Baath-Arif regime in Baghdad, the Kurdish War was framed as "strictly an internal manner" by U.S. officials. ${ }^{76}$ Nevertheless, this policy was gradually abandoned in the late-60s. On 25 July 1969, President Nixon announced that the U.S. "must avoid the kind of policy that will make countries in Asia so dependent upon us that we are dragged into conflicts such as the one we have in Vietnam... except for the threat of a major power involving nuclear weapons ... the United States is going to encourage and has a right to expect that this problem will be handled by, and responsibility for it taken by, the Asian nations themselves." ${ }^{, 77}$ According to the Nixon Doctrine, the U.S. regional allies, including Iran, would be provided with military and financial aid to contain the Soviet and its satellites in the Third World without U.S. direct intervention. As Nixon clearly outlined, "what happens in those parts of the world is not, in the final analysis, going to have any significant effect on the success of our foreign policy in the foreseeable future." ${ }^{78}$ Interestingly, it seems that Nixon's visits to Tehran, December 1953 and April 1967, planted the seeds of the Nixon Doctrine. ${ }^{79}$

\footnotetext{
${ }^{76}$ McKesson to Baundy, August 6, 1963, (FRUS 1961-1963, XVIII, 307).

${ }^{77}$ Editorial Note, (FRUS 1969-1976, I, 29); Richard Nixon, “Asia after Vietnam,” Foreign Affairs 46, no. 1 (1967): 113-25.

${ }^{78}$ Memorandum from President Nixon to Haldeman, Ehrlichmann, and Kissinger, March 2, 1970, (FRUS 1969-1976, I, 61).

${ }^{79}$ Alvandi, Roham, "Nixon, Kissinger, and the Shah: the origins of Iranian primacy in the Persian Gulf," Diplomatic History, 36; Whether the Shah's advice to Nixon was a determining factor in the decisions he later made as president is debatable. The idea of "regional influentials" was well established in Washington foreign policy circles at the time. See Parsi, Trita. Treacherous Alliance: The Secret Dealings of Israel, Iran, and the U.S. (Yale University Press, 2007). p. 36.
} 
The Nixon Doctrine was, in fact, intertwined with both Nixon-Kissinger plans for the superpower détente and a rapprochement with China. The Moscow Summit of 1972 transformed superpower relations from containment to détente and recognized a peaceful, yet competitive, superpower coexistence. The Shah initially considered détente as a fertile ground for growing the Soviet threat. "The Shah takes a close interest in our détente with the USSR and the possibility that it might free Soviet resources for the Middle East....The Shah remains concerned by the potential for instability — and Soviet Exploitation of it—in neighboring countries. ${ }^{\Perp 80}$ As time wore on, he perceived an opportunity with détente. During Tehran Summit of 1972, Nixon told the Shah, “Don't look at détente as something that weakens you but as a way for the United States to gain influence." ${ }^{\prime 11}$ Astutely employing the Nixon Doctrine language, the Shah replied that the U.S. should "have the right allies ... If they are self-reliant they will welcome it. If they have the principle of fighting until the last American they will not welcome it ... Iran, like Israel, must be able to stand alone. ${ }^{\$ 2}$ Détente ultimately recognized Iran's ambitions and facilitated the Shah to adopt a more independent path in Iran's regional policy.

Besides, President Nixon had built a special relation with the Shah. Nixon had found his personal characteristics in the Shah: brutally pragmatist and harshly anticommunist. Both men were fond of realpolitik and saw themselves as geopolitical mastermind leaders. "I like him [the Shah], I like him, and I like the country[Iran]. And

\footnotetext{
${ }^{80}$ U.S. State Department document, April 1974, Documents of the United States Embassy in Tehran, Volume $8,1979,65$.

${ }^{81}$ White House, Memorandum of Conversation, May 30, 1972 - 5:35 to 6:35 p.m. (FRUS/196468/XXI/doc.200), pp.1-2; and Memorandum of Conversation, May 31, 1972 - 10:30 a.m. to 12:00 p.m. (FRUS/1964-68/XXI/doc.201), pp.1-3.

${ }^{82}$ Memorandum of Conversation, Tehran, May 30, 1972, (FRUS 1969-1976, E-4, 200).
} 
some of those other bastards out there I don't like," Nixon told his advisers. ${ }^{83}$ No foreign leader praised his relation with an Iranian leader in the way President Nixon did. Indeed, Nixon saw Iraq and the Persian Gulf through the Shah's eyes. "As you know, your thoughts and mine coincide at many points on this subject, and a number of the positions I expressed during my Asian trip last summer--as you have noted--would apply to the problems in your region as well." ${ }^{84}$ The Shah had also pointed that Kissinger's "geopolitical ideas coincided perfectly with mine. ${ }^{185}$ Such deep thoughts-and-minds-coincidence ultimately led to the approval of the National Security Decision Memorandum (NSDM) 92 on 7 November 1970 that recognized "the preponderance of Iranian power" in the Persian Gulf. ${ }^{86}$ Given the fact that Iran was "the most powerful and most stable state in the area," ${ }^{, 87}$ NSDM 92 approved Iran as "the preponderant power in the [Persian] Gulf." ${ }^{\prime 8}$ Although Nixon rhetorically stressed Saudi-Iranian cooperation, "the Saudi pillar" was "a nominal pillar there for obvious necessary regional political reasons. ${ }^{\prime 89}$ The core assumption of the Nixon Doctrine in the area lay "in marrying what is already, in fact, extensive support for Iran as the unquestioned power in the area with the logic of cooperation between a strong Iran and

\footnotetext{
${ }^{83}$ Conversation among President Nixon, MacArthur, and Haig, Washington, April 8, 1971, FRUS 19691976, E-4, 122.

${ }^{84}$ Letter from President Nixon to the Shah of Iran, February 23, 1970, (FRUS 1969-1976, E-4, 48).

${ }^{85}$ Pahlavi, Mohammad-Reza Shah, The Shah's Story, Published by Michael Joseph. (London, September 29, 1980). p. 144.

${ }^{86}$ Letter from Laird to Rogers, October 27, 1970, (FRUS 1969-1976, E-4, 93); National Security Decision Memorandum 92, November 7, 1970, (FRUS 1969-1976, E-4, 97).

${ }^{87}$ Memorandum from Saunders and Kennedy to Kissinger, June 3, 1970, (FRUS 1969- 1976, E-4, 70).

${ }^{88}$ Memorandum from Kissinger to President Nixon, October 22, 1970, (FRUS 1969- 1976, E-4, 91).

${ }^{89}$ Harold Saunders in an interview with William Burr, February 24, 1987, Washington, DC, tape 2B, FISOHC.
} 
a weak Saudi Arabia."90 The Nixon Doctrine abandoned the Twin Pillars policy and acknowledged Iran as the sole pillar in the Persian Gulf.

The Nixon Doctrine also gave Iran a fertile ground to act as the U.S. major Cold War partner in the region. Nixon had told the Shah that "I see the world and the part Iran plays pretty much as you do." ${ }^{91}$ His recognition of Iran's regional preponderance brought up the necessity of providing Iran with massive military aid. Subtly taking the language of the Nixon Doctrine, the Shah believed that Iran "must have an 'over-kill' capability so that should anyone be tempted to attack Iran they would think twice or even three times."92 Nixon finally gave Iran a blank card on the purchase of almost all non-nuclear U.S. arms during Tehran Summit of May $1972 .{ }^{93}$

More substantially, the implementation of the Nixon Doctrine entailed backing Iran's non-state foreign policy. At the Tehran Summit, Nixon finally authorized a covert CIA cooperation with SAVAK to support the Iraqi Kurds in order to paralyze Baghdad and decelerate Moscow's rising influence in Iraq. SAVAK-CIA-Mossad cooperation successfully tied down $80 \%$ of the Iraqi army and disabled Iraqi power projection in the Persian Gulf. ${ }^{94}$ Indeed, the cooperation soon became the major manifestation of the Nixon

\footnotetext{
${ }^{90}$ Memorandum from Saunders and Kennedy to Kissinger, June 3, 1970, (FRUS 1969- 1976, E-4, 70).

${ }^{91}$ Memorandum from Kissinger for the President's File, undated, (FRUS 1969-1976, XXVII, 28).

${ }^{92}$ Memorandum of Conversation, Washington, October 22, 1969, (FRUS 1969-1976, E-4, 33).

${ }^{93}$ Although Pentagon strongly objected to this move- since giving Iran unlimited credit for military sales would spark a regional arms race and deepen the Persian-Arab enmity--Kissinger backed the Shah and wrote a memo that "In general, decisions on the acquisition of military equipment should be left primarily to the government of Iran. If the Government of Iran has decided to buy certain equipment, the purchase of U.S. equipment should be encouraged tactfully where appropriate, and technical advice on the capabilities of the equipment in question should be provided." Available at the National Security Archive, http://www.gwu.edu/ nsarchiv/NSAEBB/ NSAEBB21/03-01.htm.

${ }^{94}$ Tehran 10954 to U.S. Department of State, "U.S. Policy on Iraqi/Iranian Conflict," December 30, 1974 (NARA/AAD/RG59/CFPF/ET/1974), pp.1-2.
} 
Doctrine in recognition of Iran's non-state foreign policy. In contrast to Johnson's “policy of detached friendliness" towards Baghdad, ${ }^{95}$ President Nixon drew the U.S. into the Kurdish War "primarily as a favor" to the Shah. ${ }^{96}$ Indeed, CIA cooperation with SAVAK in Iraqi Kurdistan was, according to the Pike Committee, explained by the fact that the U.S. "national interest had thus become effectively meshed with his [the Shah's]."

In the aftermath of the Tehran Summit of 1972, the U.S. considered the Kurdish War as a new front in the Cold War struggle with the Kremlin, rather than a regional competition between Tehran and Baghdad or local fighting between Baghdad and the Kurds. Framed within the context of the Cold War logic of the zero-sum game, Kissinger intended to make the Kurdish War a "bottomless pit" and an "open wound" for the Soviets. He wanted pro-Soviet Arab regimes to understand that "they cannot get a free ride by linking up with the Soviet Union." "If "If we could get the Soviets to suffer a misadventure in Iraq it would curb the Soviet appetite in the Middle East", Kissinger argued. ${ }^{99}$ It was a pure logical extension of the broader Cold War politics over crises in the Middle East that in return, facilitated Iran's non-state foreign policy.

\section{Israel and the Doctrine of Periphery}

The origin of the Doctrine of Periphery or Peripheral Strategy dated back to the late 30s. As a lonely Jewish state in a sea of hostile arab countries, Israel needed to develop

\footnotetext{
${ }^{95}$ Hahn, Peter, Missions Accomplished? The United States and Iraq Since World War I (Oxford University Press, 2011). pp. 51-53.

${ }^{96}$ Memconn, July 23, 1973, (FRUS 1969-1976, XXVII, 24.)

${ }^{97}$ United States Congress, House Select Committee on Intelligence, CIA: The Pike Report. (Nottingham, England: Spokesman Books, 1977). p. 198.

${ }^{98}$ Memcon, July 23, 1973, (FRUS 1969-1976, XXVII, 24).

${ }^{99}$ Minutes of Senior Review Group Meeting, July 20, 1973, (FRUS 1969-1976, XXVII, 23).
} 
strategic partnership with the non-Arab states of encircling the Arab world, i.e., Iran, Turkey, and Ethiopia, as well as non-Arab minorities within the Arab World, including the Lebanese Maronites, the Kurds, and even the Coptic community in Egypt. Before the rise of Seyyed Musa Sadr, the Lebanese Shia minority had been among Israeli targets. Iran needed Israel, though Israel was not equally important to Iran. In the mid-50s, the Shah was seeking Israeli technology as well as the Jewish lobby in the U.S. to contain the Soviet.

As time wore on, Pan-Arab regimes of the region came to play a greater role in Iran-Israel relations. The Iraqi coup of 1958 led Israel to formalize the Doctrine of Periphery through the establishment of formal trilateral intelligence sharing - the Trident-with Ankara and Tehran in 1958. Trident involved semi-annual meetings of the three countries' intelligence Directors of SAVAK, Mossad, and MIT to constantly monitor Soviet-Egyptian-Iraqi military cooperation. ${ }^{100}$ Indeed, the foundation of Iran-Israel entente was predicated less on the non-Arab makeup of the two countries against the Arab regimes rather than their common threat assessment and the logic of the balance of power. On the one hand, a non-Arab, anti-Moscow state in the region could divert Baghdad and Cairo away from Iran's west and the Persian Gulf. On the other hand, a strong Iran would prevent freeing up Baghdad to join Arab armies against Israel. Although Iran never recognized Israel, the Shah considered relation with Israel as a strategic one. "We do not like their [Israeli] policy in occupying Arab territories and we have announced this issue officially several times; however, we are happy of [Israelis] in putting Arab regimes in their places.

\footnotetext{
${ }^{100}$ Military Attaché Report 196-45 from captain Archibald B. Roosevelt, Jr. (Baghdad), “Tribal Revolt in Kurdistan”, August 16, 1945.
} 
[Therefore] It would be nonsense to support [officially] Israel's policies." ${ }^{\text {101 }}$ In addition to Trident, ${ }^{102}$ the Pan-Arab Iraq of the 60 s and the 70s brought up the Iranian-Israeli-Kurdish alliance. The Kurds were the most populous non-Arab, stateless minority and had been fighting with Baghdad since World War I. Furthermore, the geostrategic location of landlocked Kurdish territories in Iraq and Syria provided a strategic base for Israel. ${ }^{103}$ In addition to SAVAK, the Israelis played a partial key role in convincing the Shah to side with the Iraqi Kurds. In the course of the Kurdish War, Iran provided a land corridor to the Israelis "for special subversive and terrorist operations in Iraq." 104 SAVAK worked with Mossad in the establishment of a Kurdish intelligence organization--the Parastin--in order to collect military intelligence on the Iraqi Army. An Iran-Israel-Iraqi Kurds alliance remained until 1975 when Tehran signed the Algiers Accord. Nevertheless, the Shah's swift pullout from northern Iraq did not weaken the continuity of the Iran-Israeli alliance since Iran was the cornerstone of the Israeli Doctrine of Periphery.

\section{The British Withdrawal from East of Suez}

\footnotetext{
${ }^{101}$ Alam, Assadollah. Yad'dashtha-ye 'Alam: Virayesh va Muqaddamah az Alinaqi Alikhani [The Alam Diaries: Edited by Alinaqi Alikhani], Vol. I: 1968-1970 (Bethesda, MD: Iranbook, 1995). p. 196.

${ }^{102}$ The Tehran-Tel-Aviv alliance was also coupled with strategic cooperation in other domains, including the construction of the Eilat-Eshkalon oil pipeline from the Gulf of Aqaba to the Mediterranean that facilitated Israel to import Iran's oil and enabled Iran to export oil to Europe while bypassing the Suez Canal. The Iraqis were also "nervous" about Iran-Israel economic relations and the Eilat-Haifa pipeline. See Baghdad 293 to Iran's Ministry of Foreign Affairs, 8 April 1961.

${ }^{103}$ Furthermore, the Tel-Aviv-Kurdish alliance was intensified by Israeli demographic policy. The small population of the Jewish state pushed the Israeli leaders to encourage remote Jewish communities in Diaspora, especially in the Middle East, to immigrate to 'the Promised Land'. With the outbreak of the ArabIsraeli war in 1948-1949, the Jewish minority in Iraq, about 120,000, began leaving the country. Through SAVAK's direct intervention, Iraqi Jews were smuggled through Iraqi Kurdistan to the northern Iranian city of Urumia and then turned over to Jewish organizations to repatriate Iraqi Jews in Israel. Sobhani, Sohrab, The Pragmatic Entente: Israeli-Iranian Relations, 1948-1988 (New York: Praeger, 1989). p. 86.

${ }^{104}$ For details see Ostrovsky V. By Way of Deception: The Making of a Mossad Officer. (Toronto: Staddart, 1990).
} 
In January 1968, the UK surprisingly announced the withdrawal of its army from 'East of Suez' by the end of 1971. The decision stemmed from Britain's declining power in the post-World War II era. The shocking fall of Singapore to the militant Japanese in the heat of World War II and then Indian (India and Pakistan) Independence in 1947 had weakened awe of the Britain Empire. The Suez Crisis of 1956 hammered the last nail in the coffin of British economic and military power and brought about a financial crisis. In January 1968, Prime Minister Harold Wilson and Defense Secretary Denis Healey announced the withdrawal of the British army from major UK military bases. Despite U.S. heavy lobbying to dissuade London from its announcement, the British withdrawal was an "irreversible decision." 105

Contrary to popular perceptions, Britain's withdrawal weakened the U.S. Twin Pillars policy in the Persian Gulf. ${ }^{106}$ The policy had been rooted in London's strategy in the post-World War II. Earlier, in the late $19^{\text {th }}$ century, the Persian Gulf had become a British Lake. In the wake of the Withdrawal Announcement, London convinced the Arab sheikhdoms of the Persian Gulf to establish a single federation in order to contain the ensuing Soviet influence in the area. ${ }^{107}$ More importantly, the UK fabricated a policy based on a power equilibrium between Tehran and Riyadh to prevent both countries' supremacy

\footnotetext{
${ }^{105}$ In the meeting with British Foreign Secretary George Brown, Secretary Rusk underlined the significance of the UK presence in the Middle East and warned the possible threat of Russian infiltration in the region to fill the power vacuum created by the British departure. Rusk even begged the British officials to "for God's sake, act like Britain!" See Memorandum, Battle to Rusk, "British Plans to Accelerate Withdrawal of Military Presence from the Persian Gulf: Your Meeting with Foreign Secretary Brown, January 11,” January 9, 1968 (FRUS/1964-68/XXI/doc.122).

${ }^{106}$ Commonly used to describe the U.S. Persian Gulf policy before the Islamic Revolution of Iran, the term Twin Pillars was never mentioned in the U.S. documentary records.

107 The United Arab Emirates (UAE) consisted of the emirates of Abu Dhabi, Ajman, Bahrain, Dubai, Fujairah, Ras al-Khaimah and Umm al-Quwain.
} 
in the area. The Johnson Administration inherited the British Twin Pillars policy. Despite the Shah's constant pressure, the U.S. stuck to the Twin Pillars policy and encouraged both states to cooperate in the region. ${ }^{108}$

Nevertheless, the Nixon Doctrine provided Iran with an opportunity to fill the power vacuum in the Persian Gulf. Lobbying from 1969 to 1972, the Shah pressed the U.S. to leave the unnatural power equilibrium in the Persian Gulf. The Shah argued that the best strategy for the U.S. was to provide Iran a context to "stand by itself if necessary." $109 \mathrm{He}$ also warned the U.S. Ambassador MacArthur, "Who else in the area can supply a credible military deterrent in the Persian Gulf? Pakistan, Saudi Arabia, the small weak the [Persian] Gulf States? Of course not." 110 At the same time, however, he was worried about both British secret plans against Iran. "The Shah ordered me to tell the UK ambassador [to Tehran] to wake up their mind. I responded that the British might be worried about us and want to obstruct. He confirmed it. They do not want to see the Persian Gulf in Iran's full control." "111 He also warned that "We will not permit the replacement of the UK navy with the U.S. navy in maintaining [security of] Bahrain...If the Americans do not give us

\footnotetext{
${ }^{108}$ The Johnson Administration's excuse was that "large military expenditures that would adversely affect Iran's economic development" and, more substantially, "Iran's armaments should not be so augmented as to frighten other riparian states and thus endanger prospects for Arab-Iranian cooperation." Memorandum from McClelland to Handley, August 28, 1968, (FRUS 1964-1968, XXI, 155).

${ }^{109}$ Memorandum of Conversation, Washington, October 22, 1969, (FRUS 1969-1976, E-4, 33-35).

${ }^{110}$ Telegram 1019 from the Embassy in Iran to the Department of State, March 19, 1970, (FRUS 1969-1976, E-4, 55).

${ }^{111}$ Alam, Assadollah. Yad'dashtha-ye 'Alam: Virayesh va Muqaddamah az Alinaqi Alikhani [The Alam Diaries: Edited by Alinaqi Alikhani], Vol. I: 1968-1970 (Bethesda, MD: Iranbook, 1995). p. 160.
} 
weapons, we will buy them from the Russians." ${ }^{\prime 12}$ At the end, he successfully convinced Nixon to accept the Persian Gulf as a "Persian Lake.","13

The British withdrawal shifted Iran's non-state foreign policy, particularly towards the Iraqi Kurds, in two directions. First, the British withdrawal meant that the Persian Gulf states had to fend for security on their own. It provided Iran with an opportunity to expand its role in the Persian Gulf. For the Shah, the Persian Gulf was Iran's backyard and, therefore, critical to its national security. With the UK withdrawal from East of Suez, the Shah tried to frame Iran as an independent state that could guard the Persian Gulf shores. In March 1969 in an interview with the New York Times, he self-confidently argued that "the Americans should be thankful that we do not permit external power's entrance to the Persian Gulf. The U.S. should be thankful that there is a country who does not rely on anybody else and will not surrender." The White House ultimately welcomed his decision. According to Kissinger, "the vacuum left by British withdrawal, now menaced by the Soviet intrusion and radical momentum, would be filled by a local power friendly to us [that meant Iran]." ${ }^{\prime 14}$ The power vacuum in the Persian Gulf provided a common threat assessment and deepened cooperation in the region, including in Iraqi Kurdistan. Second, Iran's power projection in the Persian Gulf alerted Baghdad. On 30 November 1971, Iranian troops were deployed on geo-strategically located islands of Abu Musa and the Tunbs in the Persian Gulf. While these islands were historically parts of Iran, the sheikhdoms of Sharjah and Ras al-Khaimah claimed their sovereignty over them. Iraq's

\footnotetext{
112 Ibid. p. 159.

${ }^{113}$ Letter from Laird to Rogers, October 27, 1970, (FRUS 1969-1976, E-4, 93); National Security Decision Memorandum 92, November 7, 1970, (FRUS 1969-1976, E-4, 97).

${ }^{114}$ Kissinger, Henry, The White House Years. (Little Brown \& Co, Boston, Massachusetts, 1979). 1264.
} 
harsh reactions to Iran's move convinced the Shah to intensify his support for the Iraqi Kurds. It was within this context that the Shah framed the Baghdad-Moscow warming relation as an existential threat to the U.S. Cold War policy. The British withdrawal accelerated the U.S. dependence on Iran, rather than the other way around and convinced the White House to side with Iran's non-state foreign policy in Iraqi Kurdistan.

The U.S. Cold War policy to contain the Soviet and its allies in the region, the Nixon Doctrine, the Israeli Doctrine of Periphery, and the UK withdrawal from the East of Suez all provided opportunities for the formation and expansion of Iran's non-state foreign policy, particularly in Iraqi Kurdistan.

\section{Institutions}

"The Shah is a tough, unemotional, and able guy. He has a geopolitical view.",15

-Colonel Isa Pejman: "Your Majesty, please forget it. The zeitgeist and regional context have been completely transformed." 116

"I asked the Shah to build a hospital for the Shia. Then, we can build a university for them, too. The Shah agreed. But Qadar attempted to dissuade the Shah," Seyyed Musa Sadr told Ehsan Naraghi. ${ }^{117}$

The continuity and change in the evolution of the Iran's non-state foreign policy towards the Iraqi Kurds and the Lebanese Shia were shaped by the specific interactions among political institutions in Iran. In contrast to the mainstream literature on Pahlavi

\footnotetext{
${ }^{115}$ Memorandum of Conversation, May 15, 1975, (FRUS 1969-1974, XXVII, 371).

${ }^{116}$ Qaneifard, Tondbad-e Havades: Goftogooi ba Isa Pejman (Hurricane of Events: A Dialogue with Isa Pejman). (Elm Publication, Tehran, 2012). p. 45.

117 Naraghi's interview with Khabar-Online, 2011.
http://www.farsnews.com/newstext.php?nn=8711240772
} 
Iran's foreign policy that overemphasized the Shah's role as Iran's foreign policy custodian, there were major political institutions, including SAVAK, the Ministry of Foreign Affairs, the Iranian Army, and Religious networks, that played key roles in shaping the trajectory of Iran's non-state foreign policy.

\section{The Shah}

Pre-revolutionary Iran's foreign policy has been heavily framed as the Shah's personal foreign policy. Indeed, the Shah's major preoccupation during his reign was the army and foreign policy. He had criticized his father, Reza Shah, for lack of flexibility in foreign policy and "working with the foreigners." 118 Iran's non-state foreign policy was, in fact, a major manifestation of the Shah's flexible foreign policy.

During the 40 s and early $50 \mathrm{~s}$, the Shah stayed out of foreign policy decision-making processes. As time wore on, particularly after the coup of 1953, the Shah became increasingly involved in micromanaging both domestic and foreign affairs. "The Shah rules as well as he reigns. He makes all the important and many unimportant decisions for the government of Iran." ${ }^{119}$ With Iran's rising power and wealth in the early-70s, the Shah became increasingly arrogant. He saw himself as a geopolitical mastermind who forced the Middle Eastern states to recognize Iran as a paramount power in the region in less than three decades. For such a man who single-handedly, as he thought, transformed a backward developing state in the chaotic region into a modern industrial regional power, an appetite for more power rose.

\footnotetext{
118 Alam, Assadollah. Yad'dashtha-ye 'Alam: Virayesh va Muqaddamah az Alinaqi Alikhani [The Alam Diaries: Edited by Alinaqi Alikhani], Vol. III: 1974-75 (Bethesda, MD: Iranbook, 1995), p. 62.

${ }^{119}$ Department of State, Scope Paper, August 15, 1967. Available at the National Security Archive.
} 
In reality, some of the Shah's advisers were aware of dangerous consequences of his decisions. However, nobody dared to challenge his decisions. The Shah was, in fact, suspicious of his experts, calling them as illegible intellectuals. In a meeting with Kissinger, he said that "the intellectuals will destroy the world without knowing how to replace it. They do not have a plan. They would be street cleaners in a Communist regime." ${ }^{120}$ Stressing on a natural interconnection between intellectuals and communists, the Shah claimed that the "intellectuals will win over the world without creating a better one, because when they destroy it the Communists will take it over." ${ }^{, 21}$ Within a highly circumscribed publicly political environment, there was neither public debate over foreign policy issues nor any apparent and credible mechanism to correct errors, beyond the Shah's own perceptions. The failure to consult with Iranian officials fit his autocratic rule. It surprisingly stood in sharp contrast to the Shah's lack of self-confidence in the middle of domestic crises, particularly the Oil Nationalization era and the Islamic Revolution.

By the mid-70s, the Shah had near-absolute free rein in Iran's domestic and foreign policy and had become a one-man government. In January 1973, the U.S. embassy in Tehran assessed that the Shah was "standing astride the Iranian political scene like a colossus, with all the reins of power in his hands and his admitting of no rival.... total success has enhanced his prestige and underlined his multifaceted position as stern ruler, national guide and mentor, remote but omniscient father-figure arid, to some, reactionary

\footnotetext{
${ }^{120}$ Memorandum of Conversation, Washington, May, 15, 1975. Available at: https://www.fordlibrarymuseum.gov/library/guides/findingaid/Memoranda_of_Conversations.asp.

${ }^{121}$ Ibid.
} 
oppressor and destroyer of individual liberties."122 It was within this context that the Shah cut Iran's support for the Iraqi Kurds and the Lebanese Shia.

\section{SAVAK}

Under the Shah's reign, one of the most important institutions that conducted Iran's non-state foreign policy was Sazeman-e Ettela'at Va Amniyat-e Keshvar (the National Intelligence and Security Organization or SAVAK). Officially established in 1957 with the help of the CIA and Mossad, SAVAK successfully suppressed the Shah's opponents, especially the Marxist Tudeh Party and the pro-Mosaddegh National Front. According to General Hossein Fardoust, ${ }^{123}$ "After the coup of 1953, the Americans decided to keep Iran as their major base in the region. Thus, they established Iran Army Counterintelligence and then SAVAK." ${ }^{124}$ Headed first by general Teymour Bakhtiar, military governor of Tehran in December 1953, SAVAK expanded its initial nucleus of a new intelligence organization and conducted training for its members in basic intelligence techniques. The Shah personally controlled SAVAK, though SAVAK directors were nominally under the prime minister's authority. According to Fardoust, "SAVAK had two functions of both 'Intelligence' (related to external issues) and 'Security' (related to internal issues).,'125 Constituted of ten different offices, SAVAK was a combination of the American FBI and

\footnotetext{
${ }^{122}$ Airgram from the U.S. Embassy in Iran to the Department of State, Tehran, January, 1973.

${ }^{123}$ Fardoust was the Shah's childhood friend. He served as deputy of SAVAK (he was, in fact, a real head of SAVAK) for ten years and headed the Special Intelligence Bureau of Iran-described as 'SAVAK within SAVAK' - and the Imperial Inspectorate. He was the Shah's ear.

${ }^{124}$ Fardoust, Hossein, Khaterat-e Arteshbod-e Baznesheshteh Hossein Fardoust: Zohour va Soqout-e Saltanat-e Pahlavi (The Memoirs of Retired General Hossein Fardoust: The Rise and Fall of Pahlavi Dynasty). (Moasese-e Etelaat va Pajouhesh-ha-ye Siasi, Third Edition, 1991). p.382.

125 Fardoust, Hossein, Khaterat-e Arteshbod-e Baznesheshteh Hossein Fardoust: Zohour va Soqout-e Saltanat-e Pahlavi (The Memoirs of Retired General Hossein Fardoust: The Rise and Fall of Pahlavi Dynasty). (Moasese-e Etelaat va Pajouhesh-ha-ye Siasi, Third Edition, 1991). p.382.
} 
the CIA. The Third Office or the Internal Security Office was the most important, yet the most notorious, SAVAK office. Headed by Parviz Sabeti, the Third Office was constituted of six directorates with each focusing on internal threats. ${ }^{126}$ Directed by Manouchehr Hashemi, the Eighth Office or the Counterintelligence Office was established to control the Soviet intelligence networks within Iran. These two offices monitored domestic issues. ${ }^{127}$ The external issues were monitored by the External Intelligence Organization that constituted the Second Office and the Seventh Office. Headed by major general Mansour Qadar--then brigadier general Ali Farazian--the Second Office focused on gathering external intelligence. Headed by brigadier general Kaveh, the Seventh Office focused on analyzing external intelligence. The External Intelligence Organization was also managed by Major General Ali Motazed. The Ministry of Foreign Affairs was supposed to submit its gathered information to this organization. ${ }^{128}$

Although the Shah's role in crafting Iran's foreign policy was untouchable, there were a few SAVAK officials who played significant roles in shaping the trajectory of Iran's non-state foreign policy. Chief among them were major general Mansour Qadar and Colonel Isa Pejman. Qadar had served as the chief of the Middle East directorate in the

\footnotetext{
${ }^{126}$ The first Directorate monitored the Tudeh Party and other communist groups. The second one controlled the National Front and several NGOs, including the Worker and the Women. It was also controlled the parliamentary candidates. The third and fourth directorates monitored separatist parties in Kurdistan, Khuzestan, and Azarbaijan as well as tribes. The fifth directorate traced new parties and anti-Shah activities. The sixth directorate kept information on anti-regime figures.

${ }^{127}$ With rising anti-Shah violent guerrilla activities in Iran and then an internal competition among institutions in curbing guerrillas, Komite-e Moshtarak Zed-e Kharabkari [the Anti-Sabotage Common Committee] was established in late January 1972. Headed by major general Jafar-Gholi Sadri and then brigadier general Zandipour, it consisted of security elements of SAVAK, Gendarmerie, Shahrbani, and the Army.

${ }^{128}$ The rest of SAVAK Offices focused on different issues. The Fourth Office controlled intellectuals, artistic and literature activities and imposed heavy censorship. The Fifth Office and the Sixth Office controlled budget and recruitment. The Ninth Office controlled visa process. The Tenth Office was later established to control public health of SAVAK employees.
} 
Second Office between 1958 and 1961. He was then appointed as the head of SAVAK Station in Lebanon, 1964-67, and later appointed as the Second Secretary in Iran's embassy in Syria and Jordan in 1967-72. In 1972, he was promoted as Iran's ambassador to Jordan. With his diplomatic and security background, Qadar was finally assigned as Iran's Ambassador and the head of SAVAK Station to Beirut where he was until December 1979. By the mid-70s, Qadar had been the strongest Iranian ambassador in the Middle East. As "a sly and sneaky, but very smart, man," ${ }^{129}$ he soon became the Shah's favorite ambassador in the region. When Foreign Minister Khalaatbari explained to the Shah Lebanon's strategic location as the Middle East crossroad and therefore, the necessity of Qadar's appointment as Iran's ambassador to Beirut, the Shah wondered if "Lebanon is that much important that you want to send Qadar there!"130 Qadar's source of power stemmed from his close friendship with Fardoust. Overconfident of these networks, he got promoted fast. According to Qadar himself, “After the Black September, King Hussain of Jordan informed the Shah of my role in helping the Jordanian government. Although I had not been part of the army at the time, the Shah promoted me to a brigadier general. In 1975, I was then promoted as major general." ${ }^{, 131}$ More substantially, Qadar had a key role in transforming

\footnotetext{
${ }^{129}$ According to Ehsan Naraghi, Farah Pahlavi's adviser, Qadar had appointed an agent in his office to listen to all the news related to Iran and especially the Shah. For instance, Your Majesty had asked the officials why they did not use the gasoline in bakeries as a fuel in his travel to Zanjan. Immediately, Qadar reported to the Shah that 'according to my investigation about other countries they all use gasoline as a fuel' to express his belief in the Shah's comprehensive knowledge. Besides, Qadar shared a secret tie with Lebanon's ambassador to Tehran. All members of this family, both the father and the son, were corrupt. The Lebanese ambassador had two pretty sisters. He sent his sisters to Assadollah Alam regularly. Alam was a tasteful, women-lover guy. These women had seduced Alam, providing a fertile ground for Qadar-Alam's friendship and therefore Qadar's ability in attracting the Shah's attention. See Fars News Agency, Interview with Ehsan Naraghi. Available:

http://www.farsnews.com/newstext.php?nn=8711240772

${ }^{130} \quad$ Fars $\quad$ News
http://www.farsnews.com/newstext.php?nn=8711240772.
}


Iran's non-state foreign policy in Lebanon. As a power-hungry, ambitious general, with a Machiavellian mentality, Qadar considered Sadr as his main foe in Lebanon since Sadr rejected entering a master-agent relation with Qadar. Qadar, himself, refused to accept his destructive role. "We tried several times to convince the Shah to revive relations with Sadr but the Shah was against the idea. However, Sadr thought I destroyed the Shia-Iran relation." ${ }^{\prime 132}$ In reality, Qadar played a destructive role in portraying Sadr as the Shah's enemy.

Colonel Isa Pejman was one of the major SAVAK officers in building Iran's ties with the Iraqi Kurds. As an Iranian Kurd, Pejman was among the first officers who joined SAVAK and then was introduced to Major Pashaie, head of SAVAK Middle East directorate, by Colonel Hasan Alavikia, head of the Third Office and then-deputy of SAVAK. Under Pashaie's strict education, Pejman became the main member of the newfounded Kurdistan Desk in SAVAK Middle Eastern Directorate. He was later promoted to the head of SAVAK in Iranian Kurdistan. From 1957 to 1969, Pejman was appointed to different posts, including the head of SAVAK station in Iraq and the head of the section of Kurdistan in the Second Office. Indeed, it was Pejman who persuaded SAVAK Director Bakhtiar and then the Shah to approve the publication of the first Kurdish-language newspaper and Kurdish radio in Iran. Although the Shah initially rejected siding with Barzani, it was Pejman who convinced him to change his attitude towards the Iraqi Kurds. "I was the one who suggested the Shah support a military insurgency in Iraq ... The Shah asked me of the necessity of Iran's support for the Iraqi Kurds and added, 'Barzani killed my Army soldiers (during the Kurdish Republic of Mahabad).' I responded him back,

\footnotetext{
${ }^{132}$ Ibid.
} 
'Your Majesty, please forget it. The zeitgeist and regional context have been completely transformed' ... The Shah ultimately accepted the plan [for Iran to support the Iraqi Kurds] and instructed me to write a letter to general Pakravan, deputy of SAVAK at the time. I asked the Shah to dedicate 1000 Berno $^{133}$ and 1 million bullets, along with 2-3 millions Rial (Iran's national currency) to the Iraqi Kurds. When the Shah wrote on the back of the letter "Accepted" to general Pakravan, I felt I was the true leader of the Kurdish movement. Immediately, I came back to Baghdad and met Talabani in my home. I told him, 'Congratulation!' Jalal was shocked and replied me, 'I have not got married yet!' I told him, 'Who cares about marriage. The Shah has accepted the plan.' Jalal hugged me and said, 'Kak Isa, this is our only way to free Kurdistan."'134

Concisely put, and contrary to popular perceptions of SAVAK as a mere suppression machinery, Iran's non-state foreign policy in Iraqi Kurdistan and Lebanon was mainly monitored by the SAVAK External Intelligence Organization. As Sadr's relation with Tehran worsened, the Lebanese Shia issue was handled in cooperation with the SAVAK Third Office. Indeed, SAVAK's role in non-state foreign policy was much more prominent than other political institutions in Iran.

\section{The Army}

Iran's ties with the Iraqi Kurds in the 60s and early 70 s effectively paralyzed Baghdad's power projection in the Persian Gulf area. Despite this fact, Iran's army generals were always suspicious of Barzani and Kurdish Peshmerga. It partly stemmed from Barzani's participation in the Soviet-fabricated Republic of Mahabad. When the army

\footnotetext{
${ }^{133}$ The vz. 24 rifles were designed and produced in Czechoslovakia from 1924 to 1942.

${ }^{134}$ Qaneifard, Tondbad-e Havades: Goftogooi ba Isa Pejman (Hurricane of Events: A Dialogue with Isa Pejman). (Elm Publication, Tehran, 2012). p. 129.
} 
bloodlessly recaptured Azarbaijan and Mahabad, Barzani had been the only rebel who continued fighting with and killing Iranian troops on his way towards the Soviet Union. The army never forgot this. Furthermore, as the major 'guardian' of Iran's territory, the army considered the Kurdish uprising in Iraq as Soviet master plot targeting Iran's national integrity. In short, Iranian army never trusted the Kurds and it was SAVAK that provided the support for the Iraqi Kurds.

\section{Ministry of Foreign Affairs}

Interestingly, the Ministry of Foreign Affairs did not effectively intervene in shaping the trajectory of Iran's non-state foreign policy. Indeed, the Ministry did not have the final word in the foreign policy decision-making processes; conversely, the Shah gradually became uncomfortable with the Ministry's intervention. The Shah never respected his foreign ministers. When Kissinger had visited the Shah, His Imperial Majesty ordered to see him in private. Foreign Minister Abbas-Ali Khalatbari joined them during the lunch. ${ }^{135}$ In the aftermath of his successful OPEC policy in 1974, the Shah increased his control over the Ministry. "I told Foreign Minister that nobody should interfere in Ministry of Foreign Affairs' issues except me," he told Alam. ${ }^{136}$

The Ministry of Foreign Affairs was generally kept in the dark about Iran's relations with the Lebanese Shia and particularly the Iraqi Kurds. While the Ministry officials were partially aware of Iran's ties with the Iraqi Kurds and the Lebanese Shia, the extent of Iran's involvement was hidden from them. "Often," a former Iranian diplomat explained,

\footnotetext{
${ }^{135}$ Alam, Assadollah. Yad'dashtha-ye 'Alam: Virayesh va Muqaddamah az Alinaqi Alikhani [The Alam Diaries: Edited by Alinaqi Alikhani], Vol. III: 1974-75 (Bethesda, MD: Iranbook, 1995). p. 274.

${ }^{136}$ Ibid. p. 367.
} 
"we didn’t even know what was going on." ${ }^{, 137}$ The Ministry was, in fact, consulted neither in the initiation nor in the termination of the support for both non-state entities. Regarding the Lebanese Shia, it was Ambassador Qadar and SAVAK who controlled Tehran's policy towards Sadr. Major decisions were shaped by Qadar's reports to SAVAK, rather than to the Ministry of Foreign Affairs, and then the Shah ratified them. As Qadar argued, "Iran's Ministry of Foreign Affairs was never strong. They have no comprehensive, detailed knowledge on the regional issues, like when Foreign Minister Khalaatbari convinced the Shah to recognize the PLO but I convinced the Shah later to change his mind." ${ }^{\text {138 }}$ Similarly, the Ministry of Foreign Affairs had also been detached from the Kurdish issue. In contrast to SAVAK that urged the Shah to side with the Iraqi Kurds, the Ministry was unaware of the depth of Iran's support for the Kurdish Peshmerga. Succinctly put, the Shah and SAVAK systematically left the Ministry of Foreign Affairs in the dark on Iran's non-state foreign policy.

\section{Religious institutions}

Although the Shah increasingly tightened the Shia clerics' activities, particularly after the riot of 1964, the development of Iran's ties with non-state entities, especially the Lebanese Shia, was to some degree bound up with Shia Marja'iyya (religious authority) networks. It was mainly because of Seyyed Musa Sadr's undeniable role within the Shia community. Though effectively controlled by SAVAK, connections between religious Marja'iyya and Sadr remained. These networks functioned as double-edged swords for Iran's non-state foreign policy. In the late $50 \mathrm{~s}$ and $60 \mathrm{~s}$, they provided a fertile ground for

\footnotetext{
${ }^{137}$ Parsi, Trita. Treacherous Alliance: The Secret Dealings of Israel, Iran, and the U.S. (Yale University Press, 2007). p. 62.

${ }^{138}$ Interview with Major General Mansour Qadar, Oral History, Foundations for Iranian History.
} 
Tehran to increase its support for the Lebanese Shia. Supported by both Grand Ayatollah Boroujedi in Qom and then Ayatollah Hakim in Najaf, Sadr left Iran to Southern Lebanon wherein he single-handedly constructed a strong sense of a Shia collective identity that acted as a bulwark against the rising tide of Pan-Arabism.

With the emergence of Islamism in the riot of 1964, however, networks between Sadr and Qom were securitized by SAVAK. Sadr's connections with Iranian dissidents, mainly the Islamist ones, framed him as a major problem making actor for Iran's national security. SAVAK became worried about the increasing Iranian Ayatollahs' financial support for the Lebanese Shia. Indeed, Marja'iyya's networks had provided a benchmark for the resource dedication and movement mobilization in the course of the Islamic Revolution. Throughout the 60s and 70s, Sadr's relations with Tehran were partially affected by his ties with Ayatollahs, particularly Ayatollah Khomeini, and their disciples. The significance of these Marja'iyyah networks reaffirms a different nature of culturalreligious domain wherein "the state, no matter how resistant and how insistent on its unitary nature and sovereignty," deals with and interacted with "its composite form.",139

The dynamics of Iran's non-state foreign policy show that other institutions, along with the Shah, played key roles in shaping Iran's ties with the Iraqi Kurds and the Lebanese Shia.

${ }^{139}$ Mesbahi, Mohiaddin, Free and Confined: Iran and the International System. (Spring 2011). Iranian Review of Foreign Affairs, 5 (2): 9-34. 


\section{Theoritecal Conclusion:}

Iran's pre-revolutionary regime established complex networks with the Iraqi Kurds and the Lebanese Shia to contain geopolitical and geocultural threats. Iran also jumped on the geopolitical opportunities. In addition to the Shah's decisive role in shaping Iran's nonstate foreign policy, there were other institutions, particularly SAVAK, that were responsible for the establishment of these connections. (Figure 1) This figure also shows that Iran's non-state foreign policy was a crosscutting policy, interplaying in three levels of international, regional, and domestic. Despite his preoccupation with these tripartite levels, the Shah was heavily engaged with an 'in-between' policy: Iran's non-state foreign policy.

Figure 1: Theoretical Framework for Iran's Non-State Foreign Policy

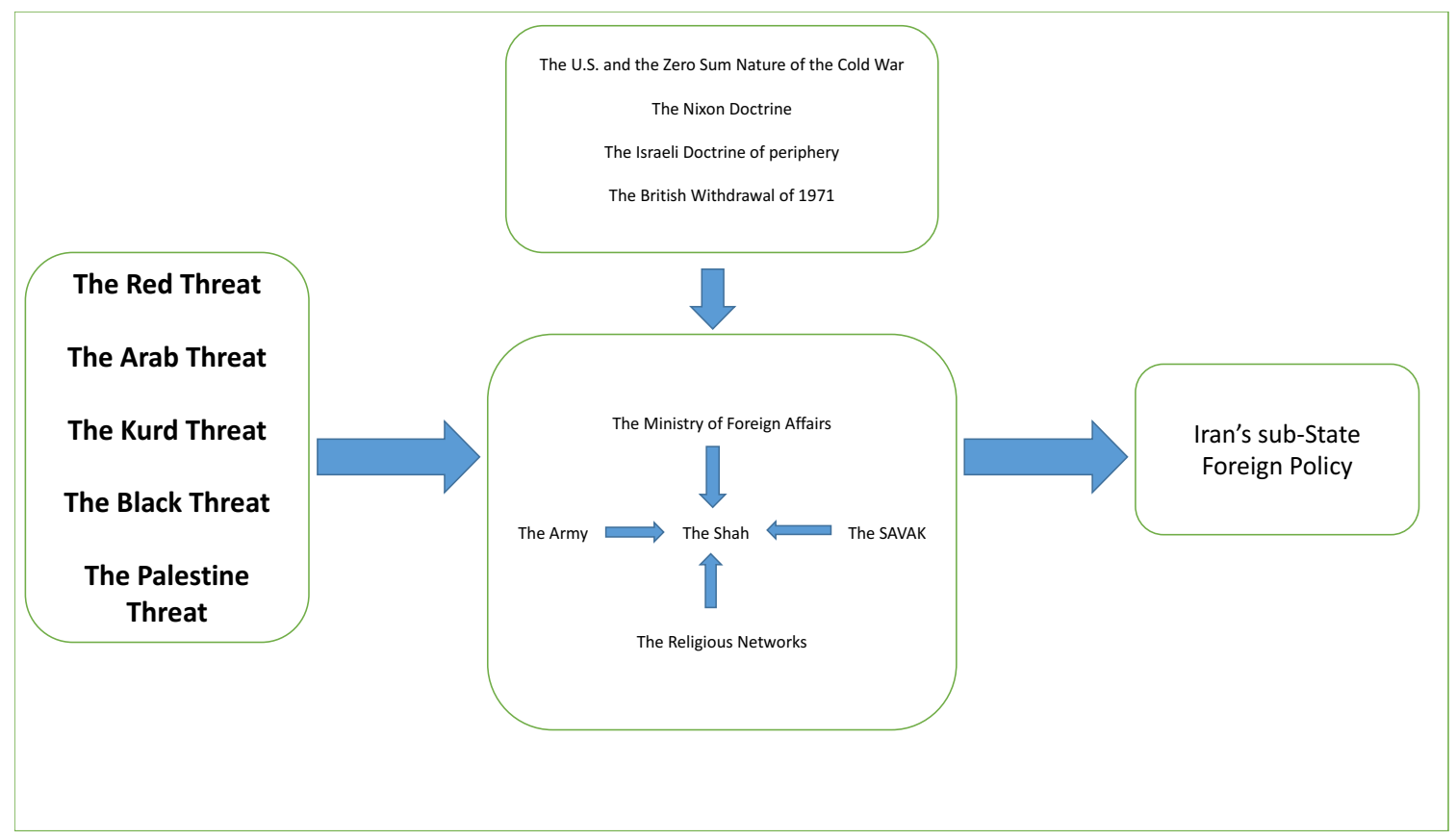




\section{Chapter 2}

\section{Inception: Iran's Non-State Foreign Policy in Pre-1958}

Iran's non-state foreign policy under the Shah's reign was mainly crafted out of Iran's historical relations with the Iraqi Kurds and the Shia Lebanese. The extent and nature of Pahlavi Iran's ties with these two non-state actors were to some degree related to their past connections with Iranian dynasties and society. As an ethnically and culturally Iranian people, the Kurds, particularly the Iraqi Kurds, used to be part of Iranian empires and regimes. As the major Shia country in the region, Iran kept its ties with the Shia communities since the early $16^{\text {th }}$ century. Before the late $50 \mathrm{~s}$, these connections had been mostly cultural and religious. It was only after the Iraqi coup of 1958 that the Iranian regime began crafting its non-state foreign policy towards the Iraqi Kurds and the Lebanese Shia. 


\section{Inception-The Iraqi Kurds}

"The Kurdish fighters, with their Iranian blood, resisted against the well-armed Ottomans to keep their ancient ethnic-cultural Aryan identities just like how Rostam and Esfandiar did," Ihsan Nuri Pasha wrote in his biography. ${ }^{140}$

"As history shows, our grand-grandfather, Kak Ahmad, and family have proved our Iranianness since the Afsharid Dynasty," Sheikh Mahmoud Barzanji wrote a letter to Reza Shah Pahlavi. ${ }^{141}$

\section{The Iranian Medes}

As descendants of the ancient Medes, the true founders of the Iranian Empire (678-

$549 \mathrm{BC})$, the Kurds have inhabited the mountains of the ancient powers of the Mesopotamian plain and the Iranian and Anatolian plateaus. Identified by classical historians, like Xenophon, as 'Karduchoi' or 'Gurti', the Kurds are a distinctive IndoEuropean ethnic group. Traditional 'Kurdistan' has never had a separate political status and was instead part of the Iranian Empire for millennia. In the pre-Arab Muslim conquest of the Middle East, it was an Iranian satrap of the Achaemenian, Parthian, and Sassanid Empires. After the debacle of the Abbasid caliphates, Kurdistan became part of Iranian and then Iranian-Turkic small emirates, until Shah Ismail I (reign 1501-1524), the founder of the Safavid dynasty, conquered it in the early $16^{\text {th }}$ century under his military-political campaign for the revival of Iran. Following the victory of the Ottomans over the Safavid Empire in the Battle of Chaldiran (23 August 1514), Iran lost the western part of Kurdistan, nowadays known as Turkey's Kurdistan, and the Iraqi Kurds became pawns in the destructive Iranians-Turks wars. Iraqi Kurdistan was then ruled back and forth by Persians and Turks until Treaty of Zuhab in 1659 gave its control to Ottomans. Despite the brief

\footnotetext{
${ }^{140}$ Bayat, Kaveh, Vaghayeh-e Ararat: Khaterat-e Ehsan Nuri Pasha (Ararat Events: Ihsan Nuri Pasha's Memories). (Tehran, 1999).

${ }^{141}$ Tehran, The Center of Court and Prime Ministry Documents, No. 17353.
} 
seizure of Iraqi Kurdistan by Shah Abbas in the late $17^{\text {th }}$ century and Nader Shah the Great in the early $18^{\text {th }}$ century, Iranians were never able to reconquer the region. Ruled by three principalities of Baban, Badinan and Soran, the Ottoman rule lasted until World War I. During the War, the Kurdish tribes joined the Ottoman Army. ${ }^{142}$

With the defeat of the Ottoman Empire in 1918, the map of the Middle East was redrawn. Although the foundations of the partitioning of the Ottoman Empire were formed through the secret Sykes-Picot Agreement of May 1916, it was the Treaty of Sevres of August 1920 that temporarily opened an opportunity for an independent Kurdish state. Despite American President Wilson's support of the Kurds, the Turkish War of Independence (1919-1923) and then the Treaty of Lausanne in July 1923 destroyed the Kurds' dream and their territory became part of modern Iraq, Turkey, and Syria. As the leader of the Republic of Turkey, Mustafa Kemal Pasha, later known as Atatürk, claimed, "The state which we have just created is a Turkish state." ${ }^{, 43}$ Turkish leaders called the Kurds 'Mountain Turks' and banned the Kurdish language. Frustrated by the lack of support from foreign powers and persecuted by the Turks' brutal policies, ${ }^{144}$ the Kurds challenged Ankara's authority in the Sheikh Said Rebellion (1925) and the Ararat Rebellion (1927-30), though the Turkey Army crushed them. ${ }^{145}$ In the wake of the emergence of the modern state system in the region, the Kurds were left without a state of

\footnotetext{
${ }^{142}$ There have been major reports that the Kurdish tribes participated under the Turk commanders in the Armenian genocide in the east of Turkey and the north of Syria.

${ }^{143}$ Chaliand, Gerard, A People Without a Country: The Kurds and Kurdistan. (Interlink Pub Group Inc, 1993). p. 48.

144700,000 Kurds were removed from their homes by Turkish Army and 400,000 are believed to have died.

${ }^{145}$ The main figure of the Ararat Rebellion was Ihsan Nuri, Commander-In-Chief of the Kurdish National Army, who died in exile in Tehran in 1976.
} 
their own. Nevertheless, their dream of an independent Kurdistan provided a geo-cultural base for their separatist movements.

The Kurdish question has been historically less crucial in Iran than in Iraq and Turkey where the existence of Kurds was denied for decades. Culturally and linguistically related to the Iranian people, the Kurds never faced the brutality and ethnic cleansing from Tehran as they did from Ankara, Baghdad, and even Damascus. On top of that, a third of Iranian Kurds are Shia Muslim, the predominant sect of Islam in Iran. Conversely, the Iraqi state, like Ankara, has been more prone to Kurdish irredentism. Constituted of the Ottoman principalities of Baghdad, Basra, and Mosul and carved out of three ethnic-religious groups of Shia, Sunni, and Kurd, Iraqi national identity had been vague since its creation.

Still, despite a decisive absence of national identity in Iraq and a historical PersianKurdish affinity, later Qajar kings and then Reza Shah Pahlavi were far from backing Kurdish rebels in Iraqi Kurdistan. Chief among them was the rebelion of Sheikh Mahmud Barzanji between 1919 and 1922. At the height of the revolt, Sheikh Mahmud pleaded Tehran for the support, expressing his loyalty to Iran and Reza Shah. "I am ready to keep our fathers' land, Iran, safe," he wrote a letter to Reza Shah. ${ }^{146}$ Nevertheless, the lack of a strong state in Iran, the Sunni religion of the Kurdish tribes in Iraqi Kurdistan, and Tehran's fear of rising Kurdish separatism within Iran's territory dissuaded Tehran to side with the Kurdish uprisings in Iraq. Conversely, Iranian leaders joined Turks and Iraqis signing the Treaty of Saadabad of July 1937 in order to provide a joint military action against Kurdish uprisings.

\footnotetext{
${ }^{146}$ Documents of Political Studies and Researches Organization [Asnad-e Motaleat va Pajouheshhay-e Siasi], S. 1307, P. 2, p. 28.
} 
Kurdish secessionism was an imminent threat to Iran. In late August 1941, Iran was temporarily conquered by the Allies. The Soviet Red Army did not leave its wartime occupation of northwestern Iran's provinces of Azarbaijan and Kurdestan; rather, it attempted to annex them to the Soviet Union through the establishment of republics of Azarbaijan and Mahabad in mid-December 1945. Qazi Muhammad, the chairman of Komeley Jiyanewey Kurdistan [the Society for the Revival of Kurdistan] and then the leader of the Democratic Party of Iranian Kurdistan, was appointed as the head of the Republic. Organized by Russian officers, the Kurds rallied their support for the newfounded republic. ${ }^{147}$ The Republic quickly collapsed on 17 December 1946 after the Soviet troop withdrawal from Iran and Qazi was hanged on 31 March $1947 .{ }^{148}$

\section{Red Mullah and the Kurdistan Democratic Party (KDP)}

Iran's conections with the Iraqi Kurds was heavily influenced by Mullah Mustafa Barzani. Long before the Iraqi Kurdish Revolt (1961-75), Mullah Mustafa had become a prominent leader of Iraqi Kurds when he fought against the British in 1919 and the 1930s, and then the Iraqi monarchy in the 40s. In the meantime, he founded the Rizgari Kurd Party (the Kurdish Freedom Party) in early $1946 .{ }^{149}$ Right after the establishment of the shortlived Republic of Mahabad, Barzani crossed the Iran-Iraq border with his followers on 7 October 1945, and was then appointed as the Minister of Defense and Commander of the Republic army under Soviet pressure. However, relations between Barzani and Qazi

\footnotetext{
${ }^{147}$ The Republic of Mahabad was constituted of a small territory, including Mahabad and its close cities of Piranshahr and Ushnaviya (Naqadeh).

${ }^{148}$ Qazi was executed by elements of the Iranian Army, especially Major General Haj-Ali Razmara. It seemed the Shah was against the execution of Qazi Muhammad. The Shah later financially supported his family and sent his sons, Mohammad Qazi and Seyf Qazi, to Europe.

${ }^{149}$ The Rizgari was a major foe of the Hiwa [Hope] Kurdish Party, founded by Namik Salim Jaf in 1940.
} 
Muhammad were not easy since Qazi was against Mullah's special dispensation for the Barzanis in Iran in return, for prioritizing the idea of 'One Party'. ${ }^{150}$ In the aftermath of the collapse of the Republic of Mahabad in December 1946, Barzani led his 500 followers in a fifty-day-long running battle with the Iranian Army until they finally fled into the Armenian SSR and then Azerbaijan SSR. Backed by Mir Jafar Baghirov, the Secretary of the Azerbaijan Communist Party, Barzani held a conference on 19 January 1948 in Baku in order to unite the Kurds in Iraq and Iran. The Kurdish Threat was still alive.

Mullah Mustafa was a brave leader whose militiamen worshiped him. According to Abolhasan Tafreshian, ${ }^{151}$ "Mullah was a wise man, though he had not been educated. He knew Persian and Arabic languages well and spoke in Turkish... He told me: "I am neither Pishevari [Leader of the Soviet-made Democratic Republic of Azarbaijan (19456)] nor Panahian [Minister of War in the Soviet-fabricated republic of Azarbaijan 1945-6] who was the head of the army in times of peace but escaped to Baku with the outbreak of the war [When the Soviet withdrew from Northwestern Iran]. I have but my gun, and I am not a servant of any other powers', neither American's, Russian's, nor British's. I am just the Barzani tribe's servant.",152

Although Barzani's exile weakened the Kurdish movement in Iraq and Iran, the new-founded Kurdish Democratic Party (KDP) filled partially the void. The KDP was founded at a Baghdad meeting on 16 August 1946 under Mullah Mustafa's plan to establish

\footnotetext{
${ }^{150}$ McDowall, David. A Modern History of the Kurds. (London: I.B. Tauris, 2007 ed.). p. 242

151 Tafreshian was a pro-Tudeh Party officer who joined the revolt of 'Khorasan Officers' (July 1945) in Turkemen-Sahra, north-east of Iran. He was also the head of the artillery in the Soviet-made republic of Azarbaijan 1945-6.

152 Tafreshian, Aboulhasan, Qiam-e Afsaran-e Khorasan (The Revolt of Khorasan Officers). (Atlas, Tehran, 1988) p. 112-5.
} 
a party independent of Qazi Muhammad and Republic of Mahabad. The Party was constituted of former members of the Rizgari and the Hiwa. During the first meeting, Hamza Abdullah was appointed as secretary-general, Mullah Mustafa as president (in exile), and Shaikh Latif and Ziyad Agha as vice-presidents. The main figure of the KDP was Ibrahim Ahmad. Ahmad was a 'communist and influential'153 intellectual who was also the main editor of the KDP newspapers of Rizgari and Xebat. In the second congress in summer 1951, Ahmad was elected as secretary-general. He changed the party's name from Kurdish Democratic Party to Kurdistan Democratic Party at the third congress in January 1955. On the eve of the bloody regime change in Baghdad, the Kurds had a strong organization to seek their longstanding ambition of independence.

${ }^{153}$ SAVAK Documents, No. 313/29188, 5 May 1963. 


\section{Inception-The Lebanese Shia}

"You are the real king and I am just one of your agents," Shah Tahmasb Safavid told Sheikh Mohaqeq Karaki, senior Shia clergy. ${ }^{154}$

\section{The Shia Jabal Amel}

As one of the oldest Shia communities in the Middle East, ${ }^{155}$ the Lebanese Shia were a marginal people mostly settled in the Beqaa Valley and Jabal Amel, mountainous regions in the south of Lebanon with cities like Nabtiya, Marjayioun, and Bent-Jabil. Harshly persecuted by the Ottomans, and for a while by Egyptians, for more than four centuries, the Shia had been forced to leave the Mediterranean coast and to live in faraway places in the mountain. The Sunni Sultans, Khedives, and ulama had been framing the Shia as 'deviating' from the path of Sunni Islam and put them savagely to the sword. In addition to their different narrative of Islam, the Sunnis, particularly the Turks, suspected the Shia of being "a stalking horse for Persia."156 The Shia oppression in Lebanon was, in fact, a marriage of politics and religion.

From its very inception, the political rise of the Shia had been influenced by Iran. Despite the Iranian Shia dynasties, like the Buyid dynasty of Dailamite origin (934-1055 AC) as well as Zaydi Shia of Alavids (864-928 AC), ${ }^{157}$ Shiism did not come to predominate in Iran before Shah Ismail I. As a champion of Shia aspiration to regional hegemony, the Safavid kings began converting Iran to Shiism by coercion and persuasion. Safavid-led

\footnotetext{
${ }^{154}$ Qaffari Qazvini, Qazi Ahmad, Tarikh-e Jahan-Ara. (Hafez press, 1343). p, 285.

${ }^{155}$ The oldest Shia community in the Islamic World was the Shia community in Hejaz.

${ }^{156}$ Norton, Augustus R. Hezbollah: A Short History. (Princeton University Press, 2007). p. 13.

157 At their peak, Buyids consisted a large portion of modern Iraq and Iran (except North of Iraq as well as East and North of Iran), Alawids consisted of North of Iran.
} 
Shiism, in return, provided Iran its distinct identity and distinguished Iranians from other Muslims, especially the Arabs and the Turks, and established bases for the nation-state of Iran. Interestingly, the Lebanese Shia had a profound role in this process. To compensate for the lack of established Shia Fiqh (Islamic jurisprudence) in Iranian territory, Shah Ismail asked Shia clergies from Jabal Amel in Lebanon and Bahrain and al-Ahsa, Eastern Saudi Arabia, to immigrate to Iran. ${ }^{158}$ Chief among them was Sheikh Mohaqeq Karaki, known as Mohaqeq Sani, ${ }^{159}$ who achieved limitless power during the reign of Shah Tahmasb, Shah Ismail's successor, such that Shah Tahmasb told him that "You are the real king and I am just one of your agents." ${ }^{160}$ In a decree of 1532, Shah Tahmasb honored him by conferring on Karaki the titles of Na'eb al-Imam (Hidden Imam's Deputy) and Khatam al-Mojtahedin (The Last Jurist). ${ }^{161}$ After Kertir, the powerful Zoroastrian chief-priest during the Sassanid, it was only the second time in Iran's history that a jurist became the strongman of the country. Karaki and his successors, like Allameh Majlesi and Sheikh Bahai, were the main jurists for the Safavid Shahs to challenge the Sunni Fiqh backed by the Ottoman Sultans who laid claim to the caliphate in the aftermath of conquering Egypt in 1517. Competing for regional hegemony, the Safavid Iranians and the Ottoman Turks fought several wars. These wars soon took on sectarian overtone between the Shia and the

\footnotetext{
${ }^{158}$ A traditional oasis in the East of the Saudi Arabia and South coast of the Persian Gulf.

${ }^{159}$ His real name was Nur-al-Din Abul-Hasan Ali bin Hussain bin Abdol-Ali. Other than Karaki, Hasan bin Zeinoddin, known as Saheb-e Maalem, and Mohammad bin Ali, known as Saheb-e Madarek, were two of the most famous Lebanese Shia clergies who immigrated to Iran. They are all known as Amelis.

${ }^{160}$ Qaffari Qazvini, Qazi Ahmad, Tarikh-e Jahan-Ara. (Hafez press, 1343). p, 285.

${ }^{161}$ Amir Arjomand, Saeed, tr. And ed., "Two Decrees of Shah Tahmasb Concerning Statecraft and the Authority of Shaykh Ali al-Karki," in Authority and Political Culture in Shi'ism, ed. S.A. Arjomand. (Albany, 1988). pp.255-6; and Amir Arjomand, Saeed, The Shadow of God and the Hidden Imam: Religion, Political Order, and Societal Change in Shi'ite Iran from the Beginning to 1890. (Chicago, 1984). pp. 13334.
} 
Sunni. This was the classic combination of geopolitical and geo-cultural forces that shaped the trajectory of the regional politics for more than four centuries.

Despite the Shia clergy' historical role in the expansion of Shiism in Iran, the Iranian kings were never able to ameliorate their relations with the Lebanese Shia as the Safavids had done. The Weak Zand and Qajar dynasties of Iran were not able to keep Iran's borders safe, let alone expand their power to the Levant. The only exception was Nader Shah, the last great Iranian kings, 'the Napoleon of Persia, ${ }^{, 162}$ who took a distinct religious policy. Nader Shah disagreed with the Safavid policy in the support for the Shia, since he believed that Iran's Shiism had intensified conflicts with the Sunni Ottoman Empire. With Iranian kings' weakness and reluctance in supporting the Shia communities of the region, the faraway Jabal Amel Shia became increasingly distant from Iran's zone of influence.

The Sunni Turks ruled the Lebanese Shia for more than four centuries; however, with the gradual decline of the Ottoman Empire, each ethnic-religious group began seeking external patrons. After all, the fragmented Lebanese society was prone to external-internal ties. During the $19^{\text {th }}$ century, the Maronitess were supported by French, the Druze by the British, the Greek Orthodox by the Russian, and the Sunni by the Ottoman Sultans. In spite of nominal support by the weak Qajar dynasty, the Shia lacked any external state-patron. Indeed, they were the least powerful community in Lebanon. In the meantime, with the Ottomans' agrarian reform in 1858, a new class of Zuama (notables), wealthy feudal patrons who were also politically influential, was formed and gradually dominated ordinary Shia people through extensive patronage networks. ${ }^{163}$

\footnotetext{
${ }^{162}$ Axworthy, Michael, The Sword of Persia: Nader Shah, from Tribal Warrior to Conquering Tyrant. (I.B. Tauris, 2006). p. xvii

${ }^{163}$ Major Zuama family included al-Asad, Hamada, Beizoon, Khalil, Osairan and al-Zayn.
} 
After the collapse of the Ottoman Empire, Lebanon was mandated by the French until 1943 when the country finally won its independence. The first government was established based on the Mithaq al-Watani' (National Pact) that divided political dominance between the Maronites and the Sunni. The Mithaq paved the way for the formation of a unique system of sectarian communities within which religious-ethnic communities pursued their interests as parties. ${ }^{164}$ However, the Mithaq did not change the status of the Shia. The young Shias were attracted to new political forces, mainly leftsecular parties that promised to remove exploitation of minority groups by the ruling elites. ${ }^{165}$ In addition to the leftist groups, the young Shia joined the Palestinian guerrillas and fought for the Palestinian cause to prove their fidelity to the Sunni Arabs. With the Shia Marja Ayatollah Hakim's permission, the Shia began supporting the Palestinian guerrillas. ${ }^{166}$ As the social change occurred in the late $50 \mathrm{~s}$, the growing process of urbanization - the Shia immigration to Beirut and other large cities — and the politicization of the young Shia, the grip of Shia notables and patrons became loosened. Nevertheless, the Shia still did not gain political power. However, an Iranian-born, charismatic Shia leader single-handedly changed their status.

\footnotetext{
${ }^{164}$ According to the Mithaq, Lebanese society recognized political privileges in bureaucracy and parliament for each of the 17 constituent sects. It became 18 communities after the 1975 civil war.

${ }^{165}$ These parties included the Lebanese Communist Party (LCP), two factions of the Arab Socialist Baath Party (a pro-Iraq one led by Sunni Abdul-Majeed Al-Rafei and Greek Christian Nicola Y. Ferzli and a proSyrian one headed by Shia Assem Qanso), the Arab Nationalist Movement, the leftist Lebanese National Movement of the Druze led by Kamal Jumbalat, the Progressive Socialists, and the Parti Populaire Syrien (PPS), especially the Organization for Communist Labor Action and the Syrian Social Nationalist Party (SSNP), which supported the idea of 'Greater Syria' and heavily backed by the Syrian government, attracted the young urbane Shias.

${ }^{166}$ Nasr, Vali, The Shia Revival: How Conflicts within Islam Will Shape the Future. (W. W. Norton \& Company, Apr 17, 2007).p. 111.
} 


\section{A Charismatic Seyyed}

Born in Qum in 1928 into a family with a long-standing tradition of religious education and family networks across Iran, Lebanon, and Iraq, Seyyed Musa Sadr was the main figure in the story of Iran's ties with the Lebanese Shia. Sadr had an ancestry line back to Shia clerics in Jabal Amel. His father, Ayatollah Seyyed Sadr a-Ddin Sadr, and grandfather, Ayatollah Seyyed Ismail Sadr, were both famous Marja in late $19^{\text {th }}$ and early $20^{\text {th }}$. His great-great-grandfather Seyyed Salih bin Muhammad Sharafeddin, a senior cleric in Tyre, had been forced to leave Lebanon and stayed in Najaf. His teachers in Qom were Grand Ayatollah Boroujerdi, Ayatollah Mohaqeq Damad, Allameh Mohammad-Hussein Tabatabaie, Ayatollah Khansari, and Ayatollah Ruhollah Khomeini. Along with his religious study in Fiqh, Sadr earned a degree in political science from the Law School of the new-founded University of Tehran in $1953 .{ }^{167}$ After his father's death in 1953 , he went to Najaf with SAVAK's indirect permission to continue his Fiqh study under Ayatollah Mohsen al-Hakim. ${ }^{168}$

Sadr soon became the most educated student of Ayatollah Hakim and Ayatollah Khoie. He stayed in Najaf four years. In 1955, Sadr took a short trip to Lebanon, his ancestral home, and met the leader of the Lebanese Shia, Ayatollah Seyyed Abd al-Husayn Sharaf al-Din al-Musawi. Impressed with Sadr's personality, Sharaf al-Din asked him to stay in Lebanon and take responsibility for the Shia. But Sadr had other priorities at the

\footnotetext{
${ }^{167}$ Mansour Qadar, Iran's ambassador to Beirut and Sadr's major foe in Lebanon, claimed that Sadr was interested in socialism. For the first time, the SAVAK monitored him during the Left students meeting at the University of Tehran. "He was not turbaned when he came to the university, but in the meetings and official gathering he was turbaned." He also claimed that "Seyyed Musa did not want to go to Najaf. ... Then, his family pressed him to leave Tehran for Najaf and study theology there." See Interview with Major General Mansour Qadar, Oral History, Foundations for Iranian History.

${ }^{168}$ SAVAK Documents, No. 15/s/9880, 24 August 1959.
} 
time. In early 1957, he went back to Qom, Iran's major religious city, and founded a religious journal, Dars ha-i az Maktab-e Eslam [Lessons from the School of Islam], also known as Maktab-e Eslam, with Ayatollah Shariatmadari's support and Grand-Ayatollah Boroujerdi's endorsement. Sadr's journal alarmed SAVAK Director, General Teymour Bakhtiar, who complained to Sadr about his journal and called it "a communist grumble" from Qom. He was, however, convinced by Sadr and permitted Seyyed Musa to continue publishing the journal. ${ }^{169}$ Among the authors of Sadr's journal were then-Shia ayatollahs and Marja, like Seyed Mohammad-Hossein Beheshti, Naser Makarem Shirazi, Ja'far Sobhani, Majd ad-Din Mahalati, Seyed Abdol-Karim Mousavi Ardabili, Seyyed Morteza Jazayeri, Hosein Nouri Hamedani, Mohammad Vaez-zadeh Khorasani, and Ali Davani. Sadr, Beheshti, and Makarem Shirazi planned in devising a new scheme to reform educational system of the Hawza in Qom. Sadr's activities and talent heralded a new school of Shia thought. However, an unpredictable chain of events did not let him continue his religious studies.

${ }^{169}$ SAVAK Documents, No. do.1364/20944, 2 June 1959. 


\section{Chapter 3}

\section{Creation: Iran's Non-State Foreign Policy in 1958-1963}

In summer 1958, the Hashemite dynasty of Iraq was overthrown in a bloody coup led by the Pan-Arab 'Free Officers'. It was a watershed for Iran's non-state foreign policy. Led by Qasim, the new Iraqi regime gradually approached the Soviets. At the same time, Barzani returned to Iraq and initially sided with Qasim. Iraq then became a center of destabilizing threats for Iran, namely, Communism, Pan-Arabism, and Kurdish separatism. It was within this context that Tehran unsuccessfully tried to rally pro-Hashemites and the Iraqi Shia against Baghdad. As a gap between Barzani and Qasim increasingly widened, Iran gradually created its non-state foreign policy towards the Iraqi Kurds to contain Iraq. With the outbreak of the Kurdish War in 1961, Iran effectively backed the Kurdish Peshmerga and tied down the Iraqi Army in Iraqi Kurdistan. Despite the U.S. hands-off policy towards the Kurdish War, Iran kept up its support for the Iraqi Kurds until the debacle of the Qasim's regime in the coup of 1963. In the meantime, and with the formation of the United Arab Republic (UAR) under Nasser's leadership and then of the Iraqi republic, the rising Pan-Arabism convinced Iran to build connections with the Lebanese Shia. In the Shah's view, the Shia community on the east coast of the Mediterranean could function as Iran's natural ally in containing Pan-Arabism. In the meantime, Seyyed Musa Sadr left Iran for the south of Lebanon and led the marginalized Shia community. He began reviving the Shia collective identity by establishing socio-political and religious institutions. Although he did not enter into a Master-Agent relation with Tehran, his messages were in favor of Lebanese unity and independence, counterweighting Nasser's brand of Pan-Arabism. 


\section{Creation-The Iraqi Kurds}

"Alam said Barzani had approached the Shah on a number of occasions to seek assistance against Iraq. He made grand promises of incorporating Iraqi Kurdistan into Iran in return."

\section{The Iraqi Coup of 1958}

On 14 July 1958, the Iraqi Free Officers toppled the Hashemite monarchy in a bloody coup. King Faisal II, the Prince Regent and Crown Prince Abdullah, and Prime Minister Nuri al-Said were brutally assassinated. The leaders of the coup, Brigadier Abd al-Karim Qasim and Abdul-Salam Arif, shared power. ${ }^{171}$ It was the beginning of a new era in Iraq. ${ }^{172}$ The Iraqi coup took Tehran by surprise. The word of the coup reached Istanbul where the Shah, as well as Turkish and Pakistani leaders, expected to see his Iraqi allies for the Baghdad Pact talks. Shocked by the brutality of revolutionaries in killing the royal family, the Shah immediately left Istanbul and put the Iranian Army on red alert along the border with Iraq for several months. The Shah's suspicion of the new Iraqi regime increased when Baghdad approached the Soviets. In the Shah's view, Iran's western neighbor with its considerable oil wealth had turned into a center of the challenging ideologies of Communism and Pan-Arabism. With its deep-rooted local organizations, the Iraq Communist Party (ICP) became the strongest ally of Qasim. ${ }^{173}$ Headed by Abdol Qadir Bostani, the ICP did not strictly adhere to the doctrines of Marxism-Leninism; however,

\footnotetext{
${ }^{170}$ Tehran 136 to the U.S. Department of State, August 2, 1962 (NARA/RG59/R2/787.00/8-162), PP. 1-2.

${ }^{171}$ Qasim became Prime Minister and Minister of Defense and Arif was named as Deputy of Prime Minister, Deputy Commander in Director, and Minister of the Interior.

${ }^{172}$ Most Iraqis considered the instability in Iraq as a vengeance for killing King Faisal II and called it "The King's Curse." See Al-Samarrai, Wafiq, Hottam al-Bawabat al-Sharqi (The Destruction of the Eastern Gate). translated in Farsi. (Markaz Asnad va Tahghighat-e Defa-e Moghaddas). p. 35.

${ }^{173}$ There were other leftist parties, including National Democratic Party (NDP), led by Kamil Chadirchi, that supported Qasim.
} 
the Shah considered it as a major element in the Soviet master plot. He feared Moscow's plot to jump over the Northern Tier containment shield in order to control the Persian Gulf with its vast oil reserves.

Following the Iraqi coup, Tehran expected the U.S. to follow the zero-sum logic of the Cold War and contain the 'Red Threat'. Surprisingly, President Eisenhower took a waitand-see strategy. The White House thought Cairo, not Moscow, had been behind the coup in Baghdad. CIA Director Allen Dulles stated: "The coup ... was executed by pro-Nasser elements of the Iraqi army, and a Republican government has been set up that includes proNasser people." ${ }^{174}$ Even, Qasim’s further radical moves, including closing British military bases, did not change the U.S. strategy. Amidst the rising threats of Pan-Arabism and Communism from Baghdad, Mullah Mustafa Barzani's return to Iraq increased the threat of Kurdish separatism to Iran.

\section{Qasim and the Kurds}

In the aftermath of the coup, Qasim took an inclusive policy towards marginal groups. Article III of the Provisional Constitution stated that "Arabs and Kurds are partners in the Homeland, and their national rights are recognized within the Iraqi entity." $" 175$ Qasim founded a triumvirate 'Sovereignty Council' of a Shia, a Sunni, and a Kurd. It was a temporary move, though. Mohammad-Mehdi Kebbeh, a Shia member of the Supreme Council of the Republic, was soon excluded for his objection to Qasim's lefty policy. ${ }^{176}$

\footnotetext{
${ }^{174}$ CIA, "Some Implications of Iraq's Oil Nationalization," IM 72-92, June 1972 (FRUS/1964-68/XXI/ doc.311), p.2.

175 Jawad, Sa'ad, Iraq and the Kurdish Question: 1958-1970. (London 1981) p. 38; Rubin, Avshalom, Abd al-Karim Qasim and the Kurds of Iraq: Centralization, Resistance, and Revolt: 1958-63. (2007). Middle Eastern Studies. 43 (3): 357; McDowall, David, A Modern History of the Kurds, (London, New York 2004). p. 302; and I.S. Vanly, "Kurdistan in Iraq" in People Without a Country; The Kurds and Kurdistan, edited by G. Chaliand. (London, 1980). p. 165.
} 
The Kurds, however, hailed the revolutionary constitution and sovereignty council. It was a promising era that heralded resolving the Arab-Kurdish tension. Both Barzani and Ibrahim Ahmad pledged the KDP support for Qasim. "We had been surrounded by three countries of Iran, Turkey, and Iraq all were members of Baghdad Pact. We supported Qasim since Baghdad [Hashemite Monarchy] was against the Kurds. We thought no one could be worse than Nouri Saeed. Therefore, we helped Qasim to gain the power", Ahmad recalled explaining his support for Qasim. ${ }^{177}$ On the other side, Qasim needed strong allies, like the KDP, to centralize state power by implementing his Agrarian Reform Law of September 1958 and weakening the Aghas. ${ }^{178}$ The alliance could also appease Kurdish nationalism by binding a major portion of Iraqi Kurds to Baghdad. On top of that, Qasim intended to terminate external interference in Iraq. With a rising tension between Qasim and pro-Nasser Arif, the Kurds became Qasim's assets in defying Nasser in the Arab World. It was in this context that Qasim permitted Barzani and his companies to return from exile in Russia. When Barzani returned via Cairo to a tumultuous welcome in October 1958, Qasim apologized to Barzani on behalf of Iraqi people, named him Chairman of the $\mathrm{KDP}$, and provided him an automobile as well as a handsome monthly stipend of 300 Iraqi Dinars. ${ }^{179} \mathrm{He}$ also promised Barzani a degree of Kurdish autonomy. In return, he asked Mullah Mustafa to oust Ibrahim Ahmad due to Ahmad's building relations with Arif and

\footnotetext{
${ }^{176}$ SAVAK Documents, No. 3-j/1191, 24 August 1959.

${ }^{177}$ Ahmad was a main KDP figure in touch with the Iraqi Free Officers. Qaneifard, Erfan, Pas az Shast Sal: Zendegi va Khaterat-e Jalal Talabani [After Sixty Years: The Life and Memories of Jalal Talabani] (Elm Publication, Tehran, 2009). p. 854.

${ }^{178}$ The Kurdish tribal elites.

${ }^{179}$ SAVAK Documents, No. d/16/16745, 12 March 1960.
} 
Nasser. ${ }^{180}$ Ahmad was then replaced with Hamza Abdullah in January 1959. Pro-socialist Hamza Abdullah eased the Kurdish-Communist front to support Qasim. In October 1958, both parties reached a compromise "the KDP abandoned its claim to an independent Kurdistan in return for the ICP endorsement of administrative autonomy."181

In the Shah's view, Barzani's return and the Kurdish-Communist alliance made Iraq "the center of communists." 182 According to SAVAK, the Iraqi Kurds and the Communists planned to “dispatch several men into Iran's territory for the (anti-regime) propaganda."183 The Shah was also worried about Barzani's efforts to establish an independent Kurdistan along Iran's western borders. According to SAVAK, Barzani had begun to support several former followers of Qazi Mohammad as well as Iranian military officers who had already fled to the Soviet Union. According to SAVAK, Barzani's Peshmerga had been receiving training from Russian officers in Haj-Omran, Sidkan and Baradoust, close to the border with Iran, while at the same time making secret connections with the Iranian Kurds in Mahabad and Sardasht. ${ }^{184}$ In late 1959, Russian officers were instigating the Javanroudis tribe to subvert Iran's national security. ${ }^{185}$ In SAVAK's view, Barzani had been assured of Qasim's support for the establishment of a 'Free Kurdistan' ${ }^{186}$ The Americans were suspicious of Barzani's ties to Moscow. According to the Americans,

\footnotetext{
${ }^{180}$ Despite Arif's suspicion of the Kurds, Ahmad thought Pan-Arabism would be the dominant force in Arab countries of the region, including Iraq.

${ }^{181}$ McDowall, David, A Modern History of the Kurds (London, New York 2004) p. 304.

${ }^{182}$ SAVAK Documents, No.19456, 26 February 1959.

183 SAVAK Documents, No. 40449, 3 March 1959.

${ }^{184}$ SAVAK Documents, No. 8075/19445, 13 July, 1959.

185 Ibid.

${ }^{186}$ SAVAK Documents, No. 7b9/4287, 15 January 1960.
} 
Barzani received a monthly stipend of a thousand Iraqi dinars $(\$ 2,800$ in 1962) from the Soviets in the mid-60s. ${ }^{187}$ It was Moscow's support for Barzani and the short-lived project of the Republic of Kurdistan in the north-west of Iran that convinced the U.S. of the possible Soviet intention to use the Kurds to bypass America's Middle Eastern containment strategy. Within this situation, Tehran began seeking a more reliable strategy of containment.

\section{SAVAK and the 'Rescue Iraq'}

In initial months after the coup, Qasim did not cease alarming Tehran. "Whenever I saw him [Qasim], he implied having a better relation with the Shah and pointed that while he and his followers were anti-royalist forces in Iraq, they were not anti-Shah," Ja'far Raed, Iraq's ambassador to Iran, wrote in his biography. ${ }^{188}$ However, Qasim's fear of Iran's will and potential to mobilize the Iraqi Kurd, the Arab Shia, and anti-Communists groups dissuaded him from having a constructive negotiation with Tehran. Ruptures in IranianIraqi relations widened when Qasim denounced the Shah as a Western puppet in several official conferences and interviews. Qasim then claimed the eastern bank of Arvand Rud (Shatt al-Arab) and the Iranian city of Khorramshahr as indivisible parts of Iraq in March 1959. He also claimed sovereignty over the oil-rich province of Khuzestan in the southwest of Iran and its Arab-speaking inhabitants, stating that his "Arab brother lived under Iranians' yoke for several years." 189 On 18 December 1959, Qasim stated that "We do not

\footnotetext{
${ }^{187}$ Baghdad 150 to the U.S. Department of State; September 20, 1962 (NARA/RG59/R2/787.00/9-2062), PP. 1-2.

${ }^{188}$ Qaneifard, Erfan, Tondbad-e Havades: Goftogooi ba Isa Pejman [Hurricane of Events: A Dialogue with Isa Pejman] (Elm Publication, Tehran, 2011) p. 81.

${ }^{189}$ SAVAK Documents, No. 2b2/10384, 15 March 1959.
} 
wish to refer to the history of Arab tribes residing in al-Ahwaz and Mohammareh (Arabic names for Khuzestan and Khorramshahr, respectively). The Ottomans handed over Mohammareh, which used to be a part of Iraqi territory, to Iran... And the 1937 Treaty was unfairly imposed on Baghdad and Iraq has given $5 \mathrm{~km}$ for free to his neighbor. This generosity was, however, under pressure and Iraq now does not accept it. Iran has no right tn this $5 \mathrm{~km} / \mathrm{sq} 2$ and Iraq will take it back again finally." ${ }^{, 190}$ Qasim also supported Arab separatists of the Arabistan Liberation Front (ALF) and unsuccessfully raised the issue of his territorial claims in the Arab League. The tension between two countries escalated to the brink of war when the Shah harshly rejected Qasim's territorial claim and called him "Crazy."191 Etela'at, the most important daily newspaper in Tehran, stated, "The new regime of Iraq is not aware that if Iran implements his claims, all oil-rich parts of Iraq, especially Kurdistan, should be retaken by Iran.” Arsalan Khalatbari, an influential Parliament representative, stated, "150 years ago, both Baghdad and Basra were parts of Iran. Now, Qasim wants $5 \mathrm{~km} / \mathrm{sq} 2$ of Iran." 192 In the wake of rising instability in Bagdad, this rhetoric was an effective tool for Qasim to rally Iraqis behind himself. According to SAVAK, "The anti-Iran propaganda has been strengthening the unity between the [Iraqi] Army and Qasim. ${ }^{, 193}$ Qasim also tried to connect with Iranian Kurdish groups. Right after the Iraqi coup of 1958, Ahmad Tawfiq had tried to convince Iraqi leaders to support Iranian

\footnotetext{
${ }^{190}$ Karsh, Efraim. The Iran-Iraq War: 1980-1988. (Osprey Publishing, 25 April 2002). pp. 1-8, 12-16, 19 82; Qaneifard, Tondbad-e Havades: Goftogooi ba Isa Pejman [Hurricane of Events: A Dialogue with Isa Pejman] (Elm Publication, Tehran, 2011) p. 78.

${ }^{191}$ Qaneifard, Erfan, Pas az Shast Sal: Zendegi va Khaterat-e Jalal Talabani [After Sixty Years: The Life and Memories of Jalal Talabani] (Elm Publication, Tehran, 2009) p. 620.

${ }^{192}$ Ibid. p. 620.

${ }^{193}$ SAVAK Documents, No. 2b2/12592, 29 December 1959.
} 
Kurds. ${ }^{194}$ SAVAK believed that the plot was made by the ICP since the Iraqi communists did not want "to act directly in Iraqi politics to prevent deterioration of Qasim-Nasser relations. ${ }^{195}$

Beyond threats of Kurdish and Arab separatism, the Iraqi coup convinced antiShah, Marxist opposition groups to opt for violent strategies in challenging the Pahlavi regime of Tehran by providing them military bases. With Nasser's harsh policy towards the communists in Egypt and Syria, a central headquarters of the Middle Eastern communist parties in Sofia, Bulgaria, were replaced by Baghdad. Within this context, the majority of the Iranian Tudeh Party's leaders fled Iraq to revive their activities. ${ }^{196}$ Along with their anti-Shah activities, the Tudeh Party had two missions: training the ICP and making secret connections with pro-Tudeh military officers within the Iranian Army. The Tudeh Party leaders successfully reorganized the ICP.${ }^{197}$ Pro-Tudeh Party military majors, like Pouladdezh and Pezeshkian, joined the Iraqi Army. Pouladdezh became the head of the Iran desk in the Second Office of the Iraqi Army. ${ }^{198}$ Later, pro-Tudeh radio, 'National Voice of Iran', was founded by the Russians in Chamchal, Iraqi Kurdistan. ${ }^{199}$ The Tudeh Party in Iraq also trained Iranian refugees in revolutionary tactics against Tehran. ${ }^{200}$

\footnotetext{
${ }^{194}$ SAVAK Documents, 2b4/531, 4 December, 1958.

195 SAVAK Documents, 2a6/5301, 11 November, 1958.

${ }^{196}$ Reza Radmanesh, Ehsan Tabari, Reza Rousta, Hussein Jodat, Noroddin Kianouri, Rahim Namvar, Bozorg Alavi, Fereydon Keshavarz, Iraj Eskandari, Ahmad Qasemi, and Bozorg Alavi, as well as Majors Parviz Ekteshafi, Mohammad (Qasim) Pouladdezh, Hamid Zargari, and Lotfali Mozafari: See SAVAK Documents, No. 13977, 26 August 1958, and SAVAK Documents, No. 19456, 27 January 1959; SAVAK Documents, No. 19456, 27 January 1959.

${ }^{197}$ Including Ehsan Tabari, Radmanesh, and Fereydoon Keshavarz. SAVAK Documents, No Number.

${ }^{198}$ SAVAK Documents, No. 2b2/3216, 29 May 1959

${ }^{199}$ SAVAK Documents, No. 129, 2 January 1960s
} 
Baghdad's support of Iranian dissidents accelerated the ominous alliance of a Soviet-Baghdad plot against Iran's national security. ${ }^{201}$ According to the SAVAK, "thousands of the Soviet Kurds entered Iraq along with 1500 Tudeh members to cooperate with the ICP." ${ }^{202}$ SAVAK was, in fact, worried about a pro-Soviet coup in Iran; "it is said that several thousands of Iraqi and Iranian communists will enter Iran to sabotage Iran.”203 The zenith of the communism and Pan-Arab threats came at the Baghdad Conference of the Middle Eastern Communist Parties, held on 26 February 1959. The conference supported Qasim's policy in Iraq as well as the rights of the Kurds in Iraq's neighbors. Lastly, it put emphasis on the support for the Iranian Tudeh Party as the main tool to "save Iran from a dictatorship" and "the establishment of a democratic republic." According to SAVAK's report, the conference incited sabotage and demonstration in Iranian provinces of Azarbaijan and Kurdistan with Baghdad and Moscow's support. ${ }^{204}$ By spring 1959, Iraq was the center of destabilizing forces in the Middle East.

In this context, the Shah instructed SAVAK to prepare a plan to contain threats coming from Baghdad. The plan was supposed to overthrow the revolutionary regime and restore the Iraqi monarchy. In doing so, SAVAK built connections with Iraqi feudal, proHashemite, and military generals to form a coup against Qasim. "I was called to SAVAK's headquarter. SAVAK Director, Brigadier General Teymour Bakhtiar, raised an interesting

\footnotetext{
${ }^{200}$ SAVAK Documents, No. 5111-3-2, 26 February 1960

${ }^{201}$ SAVAK Documents, No. 13-1d/3356, 9 December 1959

${ }^{202}$ SAVAK Documents, No. 129, 19 March 1959

${ }^{203}$ SAVAK Documents, No. 2rd1/9431, 23 September 1959.

${ }^{204}$ SAVAK Documents, (p.20)
} 
issue [on planning a coup in Iraq]. Had this plan come successfully through, it would have been SAVAK's masterpiece in the world." ${ }^{205}$ The plan--later known as 'Rescue Iraq'--was based on connections with Iraqi pro-Hashemite elites in Beirut and Baghdad. ${ }^{206}$ Under Colonel Hassan Pakravan, Deputy Director of SAVAK, the plan was conducted from SAVAK station in Baghdad and Colonel Isa Pejman was selected to lead the plan in Iraq. ${ }^{207}$ In the next step, Major Mujtaba Pashaie, Director General Bakhtiar, and Colonel Hassan Alavi-Kia visited Beirut to recruit pro-Hashemite Iraqi elites, particularly Abdel-Hadi Chalabi. ${ }^{208}$ SAVAK invited Chalabi and Colonel Mahdavi, head of Iraqi al-Amn al-'Amm [Directorate of General Security (DGS)], to Iran. ${ }^{209}$ The plan was initially supported by King Husain of Jordan whose reign was under the threat of domestic turmoil after Baghdad labeled him as the puppet of imperialism and urged the Jordanians to overthrow the Hashemite reign. Thus, Bakhtiar, Pashai, and Pejman met King Hussain in Amman to implement the plan. ${ }^{210}$ "During lunch time, Bakhtiar reported a summary of the plan to King Husain. The King promised full support for the plan. Then, he ordered Amir Hasan,

\footnotetext{
${ }^{205}$ Qaneifard, Erfan, Tondbad-e Havades: Goftogooi ba Isa Pejman [Hurricane of Events: A Dialogue with Isa Pejman] (Elm Publication, Tehran, 2011). p. 73.

${ }^{206}$ Ibid. p. 73.

${ }^{207}$ Ibid. p. 95 .

${ }^{208}$ Major among these Iraqi exiles were Abdul Hadi Chalabi (Ahmed Chalabi's father), Abdul Karim Usri, Jawdat Ayyubi, Tawfiq al-Suwaydi, Ahmad Mukhtar Baban, Mahmud Mukhtar Baban, and Major General Abdul Majid Maj. See Samii, Abbas William, The Shah's Lebanon Policy: The Role of SAVAK. (January 1997) Middle Eastern Studies. 33 (1): 68.

${ }^{209}$ Qaneifard, Erfan, Tondbad-e Havades: Goftogooi ba Isa Pejman [Hurricane of Events: A Dialogue with Isa Pejman] (Elm Publication, Tehran, 2011) p. 73.

${ }^{210}$ Summary of communique on the talks between President Shamun and the Shah of Iran, Beirut, 23 Dec. 1957, in M.S. Agwani, The Lebanese Crisis: 1958: A Documentary Study. (Bombay, Asia pub. House. 1965). p.29.
} 
Minister of Royal Court, to facilitate the cooperation. ${ }^{211}$ Later, Colonel Ali Motazed was appointed in Amman as Iran's military attaché, and in return, Colonel Umar Madani was assigned to Iran. ${ }^{212}$ Despite all of these preparations, the plan was terminated. In the middle of the talks, Bakhtiar found out that King Hussain intended to revive the Hashemite throne in Baghdad and to unite Iraq and Jordan. Therefore, Bakhtiar ordered a stop to cooperation with Jordan. ${ }^{213}$ On top of that, SAVAK realized that pro-Hashemite elites had overpromised since they lacked real power on the ground to initiate the plan. The plan of 'Rescue Iraq' came to an end.

In the aftermath of 'Rescue Iraq', SAVAK invested in the Iraqi Shia tribes, like Beni-Laam, which were worried about rising communism in Iraq. ${ }^{214}$ To this end, Isa Pejman met Rashid Kiliddar, an influential Shia figures in Kazemain. Nonetheless, the plan faced the same fate as 'Rescue Iraq'. While the majority of the Iraqi population was Shia, it had been marginalized from the political and economic domains and thus lacked a politically strong organization.

\section{Unstable Iraq}

Shortly after the establishment of the new regime in Baghdad, more acute struggle emerged in Baghdad. Qasim and Arif disagreed on three distinct issues: The Kurdish

\footnotetext{
${ }^{211}$ Qaneifard, Erfan, Tondbad-e Havades: Goftogooi ba Isa Pejman [Hurricane of Events: A Dialogue with Isa Pejman] (Elm Publication, Tehran, 2011). p. 73.

${ }^{212}$ Summary of communique on the talks between President Shamun and the Shah of Iran, Beirut, 23 Dec. 1957, in M.S. Agwani, The Lebanese Crisis: 1958: A Documentary Study. (Bombay, Asia pub. House. 1965). p.29.

${ }^{213}$ Samii, Abbas William, The Shah's Lebanon Policy: The Role of SAVAK. (January 1997) Middle Eastern Studies 33 (1): 68.

${ }^{214}$ SAVAK Documents, No. d/16/14032, 15 January 1960.
} 
question, the role of the ICP in the politics, and unification with the UAR. In contrast to Qasim, Arif endorsed unity with the UAR. Although Qasim had no plan to give the Kurds and the ICP more concessions, he gradually sided with them to deter Arif. In the final course of the struggle, Arif was stripped of his power. ${ }^{215}$ Qasim then pushed the Syrians to quit the alliance with Egypt. ${ }^{216}$ By late 1958, Qasim had consolidated his position as 'Zaiim al-Awwal' [Sole Leader] in Iraq. Nevertheless, Iraq plunged into chaos. ${ }^{217}$ Most of the Arab military officers were against the Kurds, the ICP, and Qasim's policy towards them. ${ }^{218}$ Nasserists in Iraq considered the ICP as a major factor in deepening a gap between the UAR and Baghdad. ${ }^{219}$ The instability of Iraq escalated as a Syrian-backed group of Pan-Arab and Baathist officers, led by general Abdolvahab Al-Shawaf, seized control of Mosul on 6 March 1959. The riot was suppressed by the Iraqi Army, the communist Peace Partisans, and Barzani's Peshmerga. The Mosul riot gave Qasim a pretext to purge Nasserists and Baathists from the Iraqi Army and government. The riot also gave the ICP an unprecedented influence in Iraq and pushed Qasim towards the Soviet bloc. It was within this context that Qasim withdrew from the Baghdad Pact on 24 March 1959. For Tehran, the Iron Curtain was descending over Iraq. ${ }^{220}$

\footnotetext{
${ }^{215}$ Arif was initially appointed as Baghdad ambassador to Bonne, West Germany, on 30 September 1958. Later, he was arrested in November 1958 when he joined aborted Nasser-backed coup plot, led by Rashid Ali Gilani, the anti-British Prime Minister of Iraq during World War II. SAVAK Documents, No. 84, 19 November 1959.

${ }^{216}$ SAVAK Documents, No. d/16/14415, 1 January 1960; SAVAK Documents, No. 3/A/53, 26 March 1960.

${ }^{217}$ SAVAK Documents, No. fb15/5177/38, 10 October 1959; SAVAK Documents, No. fb15/5357/38, 10 October 1959.

${ }^{218}$ SAVAK Documents, No. d/16/16644, 8 March 1960.

${ }^{219}$ Baghdad 1540 to Ministry of Foreign Affairs, 18 March 1961.

${ }^{220}$ Baghdad 2758 to the U.S. Department of State, March 26, 1959, (FRUS/1958-60/XII/doc.166), p.398.
} 
As time wore on, the power of the ICP was limited in Iraq. With quelling Mosul's riot and its potential to rally people, the ICP gradually became a threat to Qasim. On 10 July 1959, serious disorder in Kirkuk occurred as the communist-organized rally 'Popular Resistance Force' [PRF] and Turkmen fought each other. The Kirkuk riot was a watershed for the ICP. ${ }^{221}$ Harshly condemning the violence in Kirkuk, Qasim held the ICP, rather than the Kurds, responsible for the Kirkuk disturbance. ${ }^{222}$ Like the Mosul riot, Qasim used the Kirkuk uprising as a pretext to limit communism in Iraq. By January 1960, Qasim had neutralized the ICP and in March 1960, he allowed the formation of a new communist party to weaken the ICP. ${ }^{223}$ SAVAK reports drew an interesting resemblance between the Iraqi situation with Iran during Mosaddegh's era: "Two years after the July Revolution [of 1958], the Iraqi situation was similar to Iran's situation under Dr. Mosaddegh. This similarity is more vivid in the domestic context than in foreign affairs ... Initially, Qasim supported the ICP and called them the 'most patriot Iraqis' ... due to Moscow's close policy towards Qasim, the ICP newspapers were apparently supporting him. However, they harshly criticized Qasim's conservativeness in their private meetings... Qasim was forced to limit the ICP. Nonetheless, the ICP supported Qasim and warned radical right groups that 'any anti-Qasim action would be harshly reacted upon and Iraq would face a bloody civil war.' It was just like the Tudeh Party activities in the Mosaddegh era."224

\footnotetext{
${ }^{221}$ SAVAK Documents, No. 12/586, 22 April 1960; SAVAK Documents, No. 12/3750, 29 August 1960; SAVAK Documents, No. 281, 11 October 1960.

${ }^{222}$ A disproportionate number of the ICP members and PRF members in the north of Iraq were Kurds.

${ }^{223}$ SAVAK Documents, No. 2/1965, 8 March 1960.

${ }^{224}$ SAVAK Documents, No. 2d1/355, 3 September 1960.
} 
While the Kirkuk riot limited Communism in Iraq, the relationship between Qasim and the KDP was apparently unscathed. By late August 1959, the Iraqi communists had been purged from Iraqi Kurdistan. ${ }^{225}$ Well-aware of Qasim's sense of insecurity, Barzani dismissed some pro-communist KDP members. At the KDP Fourth Congress in October 1959, Barzani replaced pro-communist Hamzah Abdullah with Ibrahim Ahmad as secretary-general and allowed the politburo to re-instate Talabani as a member. Despite his loyalty to Qasim, Barzani's rising power was gradually framed as a threat to Baghdad. Well aware of a deep, long-standing tension between Barzani-KDP forces and Kurdish Aghas, the Iraqi leader tried to incite the Aghas against Barzani. ${ }^{226}$ By fall 1959, Iraqi Kurdistan slowly headed towards a revolt. According to SAVAK, "the people of Sulaymaniyah were ready for the Kurdish uprising. ${ }^{, 227}$ In early 1960, Qasim publicly disparaged the Kurds and sided with anti-Barzani tribes of the Surchis, the Zibari, and the Harkis. By February 1961, Barzani suppressed his foes. His undisputed grip on Kurdistan convinced Qasim to ignore his promise to the Kurds to "separate the Kurdish culture from the rest of Iraq and train Kurds with the Kurdish language."228 By December 1960, the Kurds felt frustrated with Qasim, ${ }^{229}$ mainly because of Qasim's increasing emphasis on Arab nationalism. ${ }^{230}$ The

\footnotetext{
${ }^{225}$ SAVAK Documents, No. 48048, 27 February 1960.

${ }^{227}$ SAVAK Documents, No. 6/16/10659, 20 October 1959.

${ }^{228}$ SAVAK Documents, No. 71, 21 September 1959.

${ }^{229}$ SAVAK Documents, No. f-b-d/16/10272, 20 December 1960.

${ }^{230}$ SAVAK Documents, No. j5/18801, 13 June 1961.
}

${ }^{226}$ Aghas' power had been already weakened down by Qasim's agrarian reform and Barzani's return. In the post-Iraqi coup era, some Agha revolts had been harshly suppressed by Iraqi Army, the Kurdish Peshmerga and the PRF. After the coup, some Aghas fled to Iran and some of them defied the revolutionary regime of Baghdad. In April and May 1959, the Baradust and the Pizhdar were defeated by Barzani Peshmergahs, the PRF, and the Iraqi army. Following up, Barzani killed Ahmad Muhammad Agha, Sheikh Mahmud Barzanji's brother and director of the Zibaris, and attacked the Harkis, Surchis, and Baradustis. 
KDP also accused Baghdad of secret talks with Tehran against the Kurds. ${ }^{231}$ In the meantime, pro-Qasim newspapers called Barzani Mullah al-Ahmar (Red Mullah), calling him as a communist puppet. In June 1961, Qasim ultimately ignored the Kurds' set of demands, ${ }^{232}$ and cut the government stipend and privileges to Barzani. It was within this context that Tehran began building ties with the Kurds.

\section{Planting the Seeds of the Revolt}

As Qasim purged the ICP from his government, a slight détente between Iran and Iraq came to the fore. Baghdad stopped anti-Iran propaganda and attempted to revive diplomatic relations with Tehran in April 1960. Qasim also rejected Iranian political refugees and dissidents to show Tehran his good will. ${ }^{233}$ As a next step, Qasim appointed Abdul-Motalleb Amin as Iraq's ambassador to Tehran, and in return, Azodi was dispatched to Baghdad in May 1960. In the meeting with Azodi, both Qasim and Jawad Hashim, Iraqi Foreign Minister, repeated their request for better relations with Iran. On the Iranian side, however, there was no consensus. While Foreign Minister Gholam-Abbas Aram tried to revive relations between two countries, SAVAK was still suspicious of Qasim's unexpected approach to Tehran. Amidst the tension between Qasim and the ICP, proQasim forces had accused the Soviets of intervening in Iraqi domestic affairs. ${ }^{234}$ However,

\footnotetext{
${ }^{231}$ Baghdad 8457 to Ministry of Foreign Affairs, 13 March 1961.

${ }^{232}$ The removal of "unfriendly Arab officials" and government troops from the region, the return of Kurdish officials back to the north from Arab areas, the introduction of the Kurdish language as an official language, progress on agricultural reform and industrial development, including nationalization of the oil industry, an end to martial law, an abandonment of the so-called 'transitional period', the restoration of democratic liberties and practical implementation of Article III of the Constitution, and the reinstatement of Kurdish newspapers: See Baghdad A-124to U.S. Department of State, August 12, 1961 (NARA/RG59/R2/787.00/81261), PP. 1-2; McDowall, David, A Modern History of the Kurds. (London, New York 2004). p. 308.

${ }^{233}$ SAVAK Documents, No. 13j/7665, 21 December 1961.

${ }^{234}$ Baghdad 1665 to Iran'S Ministry of Foreign Affairs, 12 June 1961.
} 
SAVAK considered this tension as a "deceptive one." "235 Indeed, SAVAK attributed Qasim's new policy to both economic motives, as well as his anti-UAR position. ${ }^{236}$ On the other side, Barzani began seeking support from external powers to counterbalance the Iraqi threat. Iran was his major target since he had considered the Shah as "the key to [side with] the West."237 Other KDP figures, like Ahmad, were against siding with Tehran. "Barzani pleads the U.S. for support. So, he will be with CENTO Pact members [including Iran] and imperialism," Ahmad stated. ${ }^{238}$ However, nobody could challenge Mullah Mustafa.

Although Barzani's policy could be a strategic asset for Iran to contain the Iraqi threat, the Shah was still cautious. The Shah's primary concern was a possible spillover of a Kurdish insurgency in Iraq to the Iranian Kurds. In addition to their close connections with the Iraqi Kurds, the economic underdevelopment of Iran's Kurdistan had fed the separatist groups. The Shah tried to assuage anti-regime sentiments in Iranian Kurdistan. SAVAK officers, particularly Tabrizi, chief of SAVAK Second Office, convinced the Shah to introduce some hasty economic reforms in Iranian Kurdistan to contain the rising Kurdish separatism in Iran. ${ }^{239}$

More significantly, the Shah was rightly worried about Barzani's connections with Moscow. The KDP had sharply criticized the Baghdad Pact as yet another imperialist

\footnotetext{
${ }^{235}$ SAVAK Documents, No. f-b-13d/10823, 4 March 1961.

${ }^{236}$ SAVAK Documents, No. 24 January 1961.

${ }^{237}$ Qaneifard, Erfan, Pas az Shast Sal: Zendegi va Khaterat-e Jalal Talabani [After Sixty Years: The Life and Memories of Jalal Talabani] (Elm Publication, Tehran, 2011) p. 637.

${ }^{238}$ Qaneifard, Erfan, Pas az Shast Sal: Zendegi va Khaterat-e Jalal Talabani [After Sixty Years: The Life and Memories of Jalal Talabani] (Elm Publication, Tehran, 2011) p. 854.

${ }^{239}$ SAVAK Documents, No. 234/5436, 29 May, 1961.
} 
alliance against the Socialist Bloc, in general, and anti-Kurdish in particular. In an article published in Xebat, the official newspaper of the KDP, the Red Army's role in "the liberation of parts of Kurdistan from 'Iranian Oppression'... and the formation of the Democratic Republic of Mahabad" was highly praised. ${ }^{240}$ The Kurdish-Russian threat accelerated with Barzani's trip to Moscow in January 1961. SAVAK reported that his trip was for "the creation of independent Greater Kurdistan, extending from Taurus Mountains of Turkey to the Persian Gulf." The report added that "Barzani stood in front of a fake map of the Greater Kurdistan." Indeed, Tehran considered Barzani's move as a "Moscow's plan to create a corridor to the north coast of the Persian Gulf by promising him the oil-rich Khuzestan."241 According to SAVAK, "the [Kurdish-Russian] negotiations lasted more than 10 days, but it seems the communist Barzani plans to establish an independent Kurdistan out of Kurdish parts of Iraq, Turkey, Iran, Syria, and Southern Armenia. It is said that Khrushchev has promised Barzani to donate part of Southern Armenia to Free Kurdistan. ${ }^{242}$

Although the Shah would be eternally suspicious of Barzani, a rising tension between the Kurds and Qasim gradually convinced him to contain Iraq by siding with Kurdish rebels. Earlier, some of the Kurd leaders, like Sheikh Abdul Qadir, had offered SAVAK to launch an insurgency against Baghdad. While the Sheikh assured SAVAK officers that the Kurd tribes would join his movement, ${ }^{243}$ Tehran did not take it seriously

\footnotetext{
${ }^{240}$ Baghdad 5384 to Iran's Ministry of Foreign Affairs, 10 March 1961.

${ }^{241}$ SAVAK Documents, No. 13j/10177, 15 February, 1961.

${ }^{242}$ SAVAK Documents, No Number.

${ }^{243}$ SAVAK Documents, No. 2/969, 15 January 1960.
} 
mainly due to Sheikh Abdul Qadir's lack of popularity among the Iraqi Kurds. Conversely, Barzani's popularity had made him the only Kurd leader with a capacity to unite several tribes into a formidable paramilitary force. In the aftermath of SAVAK's unsuccessful 'Rescue Iraq', the only option for Iran to destabilize Iraq was to side with Barzani.

Shortly before the Iraqi coup, Director Bakhtiar sent Pejman to Iran's Kurdistan region where he secretly crossed the border with Iraq with the support of Colonel Kamali, the head of the SAVAK office in Saqez. In the midst of apparently calm Baghdad days, he warned SAVAK of an imminent coup in Iraq. The report was, however, mocked by SAVAK personnel, Bakhtiar, and even the Shah. ${ }^{244}$ Pejman visited Turkey Kurdistan and Syrian Kurdistan to gather information on the Kurds' socio-political background. In his second report, Pejman reemphasized the possible role of the Kurds in upcoming drastic changes in Iraq and recommended that Tehran invest in the Kurdish question in order to undermine Iran's western neighbors. Right after Qasim's coup, SAVAK followed his advice to contact Barzani. As head of the SAVAK station in Baghdad, Pejman met Isa Zabihi, head of the KDP in Baghdad, and clarified to him Iran's new strategic turn towards the Iraqi Kurds and asked him to hold a meeting with Barzani. ${ }^{245}$ Before that, though, he went to Sulaymaniyah to meet Jalal Talabani during the Nowruz celebration where he successfully convinced him to join the plan.

In the meantime, Pejman established the first Kurdish-language newspaper in Iran. In doing so, he left Tehran for Paris to meet with Kamran Bedir-Khan. ${ }^{246}$ Pejman explained

\footnotetext{
${ }^{244}$ Qaneifard, Erfan, Tondbad-e Havades: Goftogooi ba Isa Pejman [Hurricane of Events: A Dialogue with Isa Pejman] (Elm Publication, Tehran, 2011) p. 231.

${ }^{245}$ Ibid. p. 97.

${ }^{246}$ He was a Sorbonne professor and the head of Kurdish Association in Europe He was also Bedir Khan's grandson, the last ruler of the principality of Cizre-Botan.
} 
to him Iran's new strategy towards the Kurds. "If the Shah is honest on Iran's new turn, so where is a Kurdish newspaper in Iran then?" Bedir-Khan asked Pejman. ${ }^{247}$ On his return to Tehran, Pejman convinced SAVAK of the advantages of publishing a Kurdish-language newspaper for Iran. With a direct SAVAK budget and supported by Sheikh Othman Naqshbandi and Adab, a newspaper for Kurdistan was published by Abdolhamid Badiozzaman. The Moftizadeh Brothers and Shokrollah Baban managed the newspaper. The Kurdish newspaper alarmed both Iran's Army and Ankara statesmen. Turkey's ambassador to Tehran objected to Iran's use of Kurdish nationalism in the meeting with the Shah. Iranian Army General Jahanbani and General Shahbakhti warned the Shah of uncontrollable consequences of this decision in instigating separatist movements in Iran. The Shah initially gave an order to stop publishing the newspaper; however, Pejman convinced him to republish the newspaper. The Shah then gave an order to restart publishing the newspaper, yet in a more limited way. ${ }^{248}$ Right after publishing the newspaper, Bedir-Khan was invited to Tehran and scheduled a dinner with the Shah. The Pahlavi monarch promised Bedir-Khan to sponsor international conferences of the Kurdish immigrant communities in Europe.

In addition to publishing a Kurdish newspaper, SAVAK implemented new strategies towards the Iraqi Kurds. Colonel Bahrami, director of SAVAK in Kermanshah, the most populated Kurd-inhabited city in Iran, offered Tehran to use a provincial radio to mobilize Iraqi Kurd tribes along the border by highlighting the corruption within the

\footnotetext{
${ }^{247}$ Qaneifard, Erfan, Tondbad-e Havades: Goftogooi ba Isa Pejman [Hurricane of Events: A Dialogue with Isa Pejman] (Elm Publication, Tehran, 2011) p. 50.

248 The newspaper was distributed just in Iran's Kurdistan and to only "trustworthy Kurd figures." See Qaneifard, Erfan, Tondbad-e Havades: Goftogooi ba Isa Pejman [Hurricane of Events: A Dialogue with Isa Pejman] (Elm Publication, Tehran, 2011) p. 92.
} 
communist organization in Iraq. ${ }^{249}$ SAVAK then set a Kurdish radio broadcast channel in motion from Radio va Telvizion-e Melli-e Iran [the National Radio and Television Organization of Iran] in Kermanshah and Mashhad. ${ }^{250}$ SAVAK-orchestrated Kurdish Radio was an effective propaganda campaign to counterweight both Iraqi revolutionary messages and Moscow's new-founded Kurdish-language broadcasts. Managed by Shokrollah Baban, the Kurdish channel cooperated with several Kurdish cultural and intellectual figures, like Abdorahman Sharafkandi (He Zhar) ${ }^{251}$ Indeed, the Newspaper of Kurdistan and the Kurdish Radio both resuscitated Iran's leverage among the Iraqi Kurds.

SAVAK also built a personal tie with Barzani. Despite strict Iraqi-Russian security in Baghdad, Pejman met Barzani for the first time and notified him of the Shah's full readiness in support for the Iraqi Kurds. Barzani immediately welcomed the plan and promised him to be Iran's 'eternal friend and the Shah's servant'. In return, he asked Tehran not to support other Kurd Aghas, like Sheikh Latif Hafidzadeh and Mohammad-Rashid Banehie who were both secretly supported by Iranian border guards. ${ }^{252}$ SAVAK then provided Barzani with a modest amount of ammunition and allowed him to build a radio station to operate from Iranian territory. ${ }^{253}$ SAVAK also thwarted Qasim's plan to assassinate Barzani. "I was informed by Brigadier Fuad Arif, one of few Kurdish generals

${ }^{249}$ SAVAK Documents, No. s/7272, 21 February 1959.

${ }^{250}$ In addition to the West and North-West of Iran, Iranian Kurds have been in the North of Khorasan in the North East of the country. The Kurdish tribes were forced to move to Khorasan region during the reign of Shah Abbas I Safavid in the early $17^{\text {th }}$ century to deter the threat of unstoppable Uzbek invasions.

${ }^{251}$ Abdolhamid Badiozaman, Mohammad-Sadigh Moftizadeh, Abdorahman, Ahmad Moftizadeh, and Abed Serajoddini also cooperated with the Kurdistan radio. See Qaneifard, Erfan, Tondbad-e Havades: Goftogooi ba Isa Pejman [Hurricane of Events: A Dialogue with Isa Pejman] (Elm Publication, Tehran, 2011) p. 93.

${ }^{252}$ SAVAK Documents, No. 213-821-314, 4 April 1962.

${ }^{253}$ O'balance, Edgar, The Kurdish Struggle, 1920-94 (London: Macmillan, 1996), p.61. 
of the Iraqi Army, of Qasim's plan to assassinate Barzani. I informed Barzani through Talabani to leave Baghdad as soon as possible." ${ }^{254}$ At the same time, Colonel Iraj Mansourpour was assigned as SAVAK's military attaché in Iraqi Kurdistan to monitor a strategic supply route running to the Iranian border. With SAVAK's financial support, two strategic military bases were built for Barzani's Peshmerga along the border with Iran. The scene was set for the Kurdish revolt.

\section{Kurdish-Israeli Connections}

In the wake of the formation of the Tehran-Kurdish alliance, Barzani was looking for another external power to undermine Baghdad. Strategically speaking, relying on the Shah would not be a rational decision for the Kurds. Besides, Barzani considered establishing relations with Israel as a key to drag the U.S. into the conflict. On top of that, the geopolitical logic of the region led to the formation of the Israeli-Kurdish alliance. As a major component of the Israeli Doctrine of Periphery, Israel's covert support for the Kurds was a decisive step in containing Baghdad. Indeed, Baghdad had participated in the 1948 Arab fighting with the Jewish state without signing any ceasefire agreements with Israel. Shortly after the establishment of the peripheral 'Trident' pact of 1958, Kamran Bedir-Khan was dispatched by Barzani to Zurich, Switzerland, in 1959, where he was warmly welcomed by Golda Meir, Israeli Foreign Minister. Bedir-Khan was promised unconditional support in fighting against their common foe in Iraq and the creation of a non-Arab state. "We told the Kurds ... [that] whatever they do, we are supporting them -

\footnotetext{
${ }^{254}$ Qaneifard, Erfan, Tondbad-e Havades: Goftogooi ba Isa Pejman [Hurricane of Events: A Dialogue with Isa Pejman] (Elm Publication, Tehran, 2011) p. 122.
} 
in war and peace," Eliezer Tsafrir, the head of the Mossad's operations in Iraqi Kurdistan, stated. $^{255}$

In the middle of 1959, the Shah was still hesitant about siding with the Kurds. According to Tsafrir, the Iranians "did not like Mullah Mustafa Barzani because they thought he was a Red Mullah . . . because he spent twelve years in Russia as a political refugee." 256 Additionally, Tehran was initially quite opposed Israel's presence in Iraqi Kurdistan. Indeed, any support for the Iraqi Kurds without Tehran's permission might have brought up a long-running threat to Iran's national security. No less important, the Shah refrained from exacerbating relations with the Arab states by siding with Israel in support of the Iraqi Kurds. Nevertheless, the formation of a Soviet-backed regime claiming part of Iran's territory, the Iranian-Israeli conflict of interest over support for the Iraqi Kurds was overcome when Iran permitted advanced Israeli weaponry to go to Barzani through Iran. ${ }^{257}$

\section{The Illul Movement of 1961}

On 10 September 1961, an Iraqi Army column was ambushed and massacred by a group of Kurdish forces, led by Barzani-allied Abbas Mamand, near Bazyan. Baghdad faced two alternatives of either "granting the Kurds autonomy" or "dealing with them by force. ${ }^{, 258}$ Qasim went quickly with the Iron Fist strategy. While Barzani had initially stayed

\footnotetext{
${ }^{255}$ Parsi, Trita, Treacherous Alliance: The Secret Dealings of Israel, Iran, and the United States (Yale University Press, 2007) p.53.

${ }^{256}$ Ibid. p.53.

${ }^{257}$ Rubin, Avshalom, Abd al-Karim Qasim and the Kurds of Iraq: Centralization, Resistance, and Revolt, 1958-63 (2007) Middle Eastern Studies, 43 (3): 373.

${ }^{258}$ Tabriz A-26 to the U.S. Department of State, "The Kurdish Movement in Iraq as seen from Mahabad", September 3, 1961 (NARA/RG59/R2/787.00/9-361), pp. 1-4.
} 
out of the conflict, the Iraq Air Force (IAF) bombed Barzan and led him and other Aghas to join the fight. ${ }^{259}$

The war in Iraqi Kurdistan was not only welcomed by Iran and Israel but also by Nasser. Barzani had already turned to Nasser and at the same time stopped supporting Khaled Beyk, the head of the Syrian KDP, to satisfy Cairo. Nasser had also promised to support the Kurdish demands, though verbally, to weaken Qasim's brand of Arab nationalism ${ }^{260}$ Radio Sawt al-Arab [Voice of the Arabs] had been challenging Qasim's regime of Baghdad. ${ }^{261}$ Nevertheless, Qasim denounced the Kurds as "American stooges." 262 The interesting point is that neither Iran nor Israel was aware of Barzani's decision to join the war. Rather, it was the KGB that pressed Barzani to launch the war. ${ }^{263}$ It seemed the logic of geopolitical contest with the U.S., as well as Qasim's anti-ICP campaign, changed its policy. ${ }^{264}$ In a historically unique juncture, the Soviet international

${ }^{259}$ Baghdad 162 to the U.S. Department of State, September 19, 1961 (NARA/RG59/R2/787.00/9-1961), P.1.

${ }^{260}$ SAVAK Documents, No. 2b/1729, 18 May 1961.

${ }^{261}$ Al-Samarrai, Wafiq, Hottam al-Bawabat al-Sharqi [The Destruction of the Eastern Gate], translated in Farsi, (Tehran, Markaz Asnad va Tahghighat-e Defa-e Moghaddas) p. 33-4.

${ }^{262}$ Baghdad A-245, September 27, 1961, "Qasim Accuses British and Americans of complicity in Kurdish Revolt' Exonerates USSR; Dissolve Kurdish Democratic Party", September 27, 1961 (NARA/RG59/R2/787.00/9-2761), P. 2.

${ }^{263}$ Vladislove Zubok, Spy vs. Spy: The KGB vs. the CIA, 1960-62, Cold War International History Project, Woodrow Wilson Center for Scholars, No 4 (1994), pp. 28-29.

${ }^{264}$ In early June 1961, shortly before the Kurdish War, the Berlin Crisis broke out. As the confrontation over Berlin escalated, Russian leaders began planning to turn the U.S. and its allies away from the Berlin crisis and devise a strategy to create crises "in various areas of the world which would favor dispersion of attention and forces by the USA and their satellites, and would tie them down during the settlement of the question of a German peace treaty and West Berlin.” To destabilize Iran and Turkey, along with the U.S. and UK, KGB director Alexander Shelepin recommended employing the Russians' old ties with Barzani "to activate the movement of the Kurdish population of Iraq, Iran, and Turkey for creation of an independent Kurdistan that would include the provinces of aforementioned countries .... [since it] evokes serious concern among Western powers and first of all in England regarding [their access to] oil in Iraq and Iran, and also in the United States regarding its military bases in Turkey." Disappointed by Qasim's unexpected shift and the purge of the ICP, the KGB saw the Kurdish war as a strategic asset to shake Qasim "who [had] begun to 
competition with the U.S. opened a strategic opportunity for both regional powers, Iran and Israel, to side with a local leader like Barzani.

By December 1961, the Iraqi Army had defeated Mamand's disorganized forces, but Barzani's skill in irregular warfare in the Zagros Mountains of Iraqi Kurdistan escalated the war at the expense of Qasim. Despite Iraqi Air Force superiority, Baghdad troops on the ground lacked experience in fighting in the mountains. As fighting continued with heavy Iraqi losses, part of Iraqi Kurdistan territory fell under the control of the Peshmerga. ${ }^{265}$ Qasim's distracting management of the war and his profound distrust of military commanders led to the successive defeats of Iraqi Army and damaged his image in the military's eyes. To add insult to injury, his peace offers in November 1961 and March 1962 were rejected by Barzani. In the meantime, Qasim rejected Moscow's offer to cease the invasion and to accept Barzani's autonomous government in the north of Iraq. ${ }^{266}$ The war soon became a "full-fledged storm-cloud for Qasim.,"267

The war was a strategic asset for Iran. Almost all of the aid the Kurds received came from or passed through Iran. Aware of the Soviet Union's intensified support for the Iraqi Kurds, ${ }^{268}$ Tehran closed its eyes to the weapon smuggling from the Soviet Union. According to SAVAK reports, the Russians provided Barzani with weapons through Iran

\footnotetext{
conduct a pro-Western policy, especially in recent time." See Vladislove Zubok, "Spy vs. Spy: The KGB vs. the CIA, 1960-62", Cold War International History Project, Woodrow Wilson Center for Scholars, No 4 (1994), pp. 28-29.

${ }^{265}$ Baghdad D-635 to the U.S. Department of State, "Kurdish Revolt Reportedly Increase in Intensity; Qasim Offers Kurds "Last Chance"; Kurdish Propaganda Attacks Qasim", April 3, 1962 (NARA/RG59/R2/787.00/4-362), PP. 1-3.

${ }^{266}$ SAVAK Documents, No. 311/763, 20 January 1962.

267 Baghdad 127 to the U.S. Department of State, September 7, 1962 (KPL/NSF/Countries/BOX 117/Iraq.1961-62), pp.1-2.

${ }^{268}$ SAVAK Documents, No. 311/706/2-d, 26 April 1963.
} 
and Kurdish tribesmen, like Senatmamedi and Aghas of Shakkak Tribe. ${ }^{269}$ Barzani had also conveyed a message to Tehran via Ahmad Towfiq to convince Tehran to side with the Kurdish insurgency in Iraq. ${ }^{270}$ In the following months, elements in SAVAK played a key role in changing Iran's policy towards the Iraqi Kurds. Prime Minister Alam told Julius Holmes, the U.S. Ambassador to Tehran, that "up to the present Iran had adopted a handsoff policy only taking necessary steps to protect the Iran-Iraq border by the deployment of forces last summer when there was some possibility that Barzani wars might spill over into Iran. Alam said Barzani had approached the Shah on a number of occasions to seek assistance against Iraq. He made grand promises of incorporating Iraqi Kurdistan into Iran in return.

While the Shah had rejected his offers, elements of Iran's military believed helping the Kurds might be a viable means of undermining Qasim. On 24 May 1962, the State Department indicated that "important elements in the Government of Iran ... may be considering a change in basic Iranian policy from the past and present line of half-hearted opposition to the Kurdish rebellion to one of covert cooperation with the rebels.",271 Convinced by SAVAK, the Shah considered "more positive position with regard to Iraqi Kurds." ${ }^{272}$ Iran's military aid included ordinary guns, like Brno KAR98K, and bullets. The military aid flew freely across the border due to Barzani's "close and friendly" relations with Tehran. ${ }^{273}$ On the other side, Barzani was careful to avoid making trouble for Iran. He

\footnotetext{
${ }^{269}$ SAVAK Documents, No. 313/29188, 5 May 1963.

${ }^{270}$ SAVAK Documents, 4632, 28 November, 1962.

${ }^{271}$ The U.S. Department of State Ca-2856 to US Embassy Tehran, May 24, 1962 (NARA/RG59/R2/787.00/52462), P.1.

${ }^{272}$ Tehran 136 to the U.S. Department of State, August 2, 1962 (NARA/RG59/R2/787.00/8-162), PP. 1-2.
} 
warned Iranian Kurds several times not to take any step against the central regime in Tehran. ${ }^{274}$ In response to Iran's support, Qasim had tried to mobilize Kurdish tribes in Western Iran, mainly the Javanroudis, and provided them armament support. ${ }^{275}$ However, the Javanroudi revolt was easily suppressed by Iran's Army.

\section{The Iranians, the Americans, and the Kurds}

Interestingly, the Kurdish war became a problematic issue in Iranian-American relations. While Tehran considered the Iraqi Kurds as a strategic tool to press Iraq, the U.S. did not consider Iraq in the Soviet orbit, particularly after Qasim's purge of the ICP. The U.S. was instead suspicious of Barzani's ties with Moscow. The U.S. believed the establishment of an independent Kurdistan would destabilize both Iran and Turkey and provided the Soviets a strategic base at the heart of the Middle East. In late September 1961, the Kurds even promised the U.S. to join CENTO to function as a "bulwark against the Soviet Union." Nonetheless, James Atkins, the U.S. embassy officer in Baghdad, rejected their request and called the Kurdish insurgency an Iraqi internal affair. ${ }^{276}$ In the middle of the war, Barzani publicly pleaded for U.S. support, stating that "We could be useful to the United States. As the Communist party serves the interests of the Soviet Union, we could serve the United States ... Look at our strategic location on the flank of any possible Soviet advance into the Middle East through the Caucasus and remember that,

\footnotetext{
${ }^{273}$ Baghdad 150 to the U.S. Department of State, September 20, 1962 (NARA/RG59/R2/787.00/9-2062), PP.1-2.

${ }^{274}$ SAVAK Documents, No. 2/453, 12 January, 1961.

${ }^{275}$ SAVAK Documents, No. 163, 5 May 1963.

${ }^{276}$ Baghdad 177 to the U.S. Department of State; September 29, 1961 (NARA/RG59/R2/787.00/9-2961), PP. 1-2.
} 
whether as guerrillas or as regulars, we are the best soldiers in the Middle East.,"277 Although he promised that an independent Kurdistan would be "another state of the union where American firms would enjoy privileged access to Kirkuk oil fields, ${ }^{278}$ the U.S. rejected his appeals. For the U.S., supporting Barzani would raise domestic threats to Iran and Turkey. In the U.S. view, “[Iran's] interference ... portends more of danger than of advantage to the essential interests of Iran or the U.S." However, the U.S. request of Tehran to take "a policy of strict neutrality and watchful waiting", rather than "a commitment, overt or covert, to interference, ${ }^{279}$ fell on deaf ears.

\section{The Ramadhan Revolution of 1963}

By winter 1962, the Peshmerga had targeted vital Iraqi infrastructure of oil and gas pipelines, ${ }^{280}$ and conquered Duhok. ${ }^{281}$ In retaliation, Baghdad escalated air force raids. Nonetheless, siding with Iran helped Barzani to resist the Iraqi troops. By late 1962, the Kurdish forces inflicted a series of major defeats on the Iraqi Army and damaged its morale. ${ }^{282}$ After the humiliating failure of a twenty-month military campaign against the Kurds, Qasim became more politically isolated in Baghdad and that in turn, opened room for anti-Qasim Baath Party. ${ }^{283}$ After secret talks with the Kurds in January 1963, the Baath

\footnotetext{
${ }^{277}$ Dana Adams Schmidt, Kurdish Rebels confidents of victory in Iraq: Warn United States to Aid them or Soviet's Will, New York Times, September 10, 1962, pp.1-14.

${ }^{278}$ Baghdad to the U.S. Department of State, September 20, 1962, (FRUS 1961-1963, XVIII, 49.

279 The U.S. Department of State Ca-2856 to the U.S. Embassy Tehran, May 24, 1962 (NARA/RG59/R2/787.00/5-2462), P.1.

${ }^{280}$ Baghdad A-210 to the U.S. Department of State, August 27, 1962 (NARA/RG59/R2/787.00/8-2762), p. 1.

${ }^{281}$ London 3852 to Iran’s Ministry of Foreign Affairs, 19 February 1962.

${ }^{282}$ Baghdad 309 to the U.S. Department of State, December 23, 1962 (NARA/RG59/R2/787.00/12-2362), p. 1.

${ }^{283}$ SAVAK Documents, No. d/16/12509, 7 February 1961.
} 
leader Showkat Aqrawi asked Ahmad not to launch a new invasion in the middle of the Army cooperation with coup plotters. In return, they promised the KDP to concede large degree of autonomy to Kurdistan. ${ }^{284}$ On 8 February 1963, a coalition of pro-Nasser forces, the Baath officers, and powerful military generals, headed by Abdul-Salam Arif, launched a coup, later known as the Ramadan Revolution. Qasim was brought to the court under a Arif presidency and was then brutally executed. ${ }^{285}$ The coup plotters accused Qasim of the formation of a "Terror Era" and of weakening the "Arab-Kurdish fraternity." 286 Right after the coup, the Baath militia, the National Guard, initiated a brutal campaign against the Iraqi communist and made a "blood bath." ${ }^{287}$ The coup of 1963 also frightened the Tudeh leaders. ${ }^{288}$ It seemed that Iran's non-state foreign policy had ultimately borne fruit.

\footnotetext{
${ }^{284}$ Qaneifard, Erfan, Pas az Shast Sal: Zendegi va Khaterat-e Jalal Talabani [After Sixty Years: The Life and Memories of Jalal Talabani] (Elm Publication, Tehran) p. 685.

${ }^{285}$ The new regime consisted of a three-men of Nasserist Arif as President, the Baathist General Ahmad Hasan al-Bakr as Prime Minister, and Ali Salih al-Saadi as Deputy Prime Minister, Minister of the Interior, and Secretary of the Regional (Iraq) Baath Party, all established the National Council of the Revolutionary Command (NCRC) that exercised supreme power.

${ }^{286}$ The Declaration of Iraq Ramadhan Revolution, Baghdad to Iran's Ministry of Foreign Affairs, February $8,1963$.

287 CIA, "Background on 8 February Revolt in Iraq". OCI No. 0487/63, February 8, 1963 (JFK/NSF/RKF/Box426/Iraq.1961-63), pp.1-2.

${ }^{288}$ SAVAK Documents, No. 312/1211, 6 July 1963.
} 


\section{Creation-The Lebanese Shia}

"We should combat and contain the threat [of Nasserism] in the East coast of the Mediterranean to prevent shedding blood on the Iranian soil," Colonel Pashaie explained in a SAVAK meeting. ${ }^{289}$

\section{Pan-Arabism and Tehran-Beirut Connection}

The rise of Pan-Arabism prompted Tehran to contain Cairo in the Middle East. In addition to the formation of the Baghdad Pact, Tehran turned its attention to the eastern Mediterranean to challenge Nasser in Lebanon, as one of the cultural-intellectual centers of the Arab World. To contain the Egyptians, Tehran began cultivating connections with Lebanese communities. Despite historically religious-cultural ties with the Lebanese Shia, Iran initially focused on building ties with powerful Maronite elites. Already consolidating their position in Lebanon by assuming the presidency since Lebanon's independence, the Christian Maronite elites considered Pan-Arabism as a new driving force for the Arab Sunni to challenge the political order. In the aftermath of the Suez Crisis of 1956, President Camile Chamoun approached the U.S. and the UK, and stood aside from the Baghdad Pact members, especially Iran. While the UAR-backed Pan-Arab elements in Lebanon, like Saheb Salam, Walid Jumblatt, and Ibrahim Kulaylat, supported Egypt, President Chamoun and parts of the Maronites elite tacitly sided with the invasion of Suez and refused to break diplomatic relations with the West.

In December 1957, the Shah met Chamoun. In the meeting, both leaders stressed opposing any foreign intervention, i.e., the Egyptian intervention, in the domestic affairs

\footnotetext{
${ }^{289}$ To discuss more the Green Plan see Letter from Isa Pejman, reprinted in M. Alamuti, Iran dar Asr-i Pahlavi [Iran in the Pahlavi Era] Vol.II, Jang-i Qodrat dar Iran [Power Struggle in Iran] (London, 1992) pp. 521-3.
} 
of their countries. ${ }^{290}$ Shortly after that, the formation of the UAR brought political turmoil within the Arab societies, including Lebanon. While the Maronites intended to keep Lebanon aligned with the West, the Sunni led by Prime Minister Rashid Karami pushed Beirut to join the UAR. In May 1958, Chamoun asked Iran, Turkey, and the Arab League to support Beirut against the UAR-backed Sunni-Druze parties in Lebanon. ${ }^{291}$

It was only Iran that sided with Beirut by instructing SAVAK to deliver military aid to the Maronitess. The operation was managed by Air Force Colonel Hamid Nasseri, Iran's military attaché in Beirut, and particularly by Mansour Qadar, director of Iran's consulate in Damascus at the time. ${ }^{292}$ Iranian support for Beirut convinced Israel to provide the Maronitess with the Soviet-made weapons already captured in the 1956 Suez War. The Israeli armaments were loaded at Mehrabad airport, Tehran, and then delivered to proChamoun forces in Beirut through SAVAK. ${ }^{293}$ SAVAK-Mossad-Beirut operation was monitored by Ahmad Azima, a naval officer in SAVAK's Foreign Intelligence section, and Emir Farid Chehab, Director of General Security. ${ }^{294}$ Rahmat Atabaki, Iran's ambassador to Beirut, was also involved in the operation. Nonetheless, Tehran-Beirut alliance did not lead to building an effective bulwark against Pan-Arabism. According to Qadar, "ProChamoun forces received armaments through Iran. However, they sold most of the

\footnotetext{
${ }^{290}$ Summary of communiqué on the talks between President Sham'un and the Shah of Iran, Beirut, 23 Dec. 1957, in M.S. Agwani (ed.), The Lebanese Crisis, 1958: A Documentary Study (Bombay, 1965), p.29.

${ }^{291}$ The UAR supporter parties included the Independent Nasserite Movement (INM or Harakat al-Nasiriyin al-Mustaqillin or simply Al-Murabitoun) led by Ibrahim Kulaylat, the Progressive Socialist Party (PSP or alHizb al-Taqadummi al-Ishtiraki) led by Kamal Jumbalatt, and the Lebanese Communist Party or LCP.

${ }^{292}$ According to Qadar, it seemed Nasseri was not reliable at the time. He was also one of Major General Batmanghelich's relatives. See Interview with General Mansour Qadar, Oral History, Foundation for Iranian Studies.

${ }^{293}$ Interview with General Mansour Qadar, Oral History, Foundation for Iranian Studies.

${ }^{294}$ Chehab was also the head of the Anti-Communism Section of Lebanon.
} 
weapons to pro-Nasser forces! Nasserist elements also sold weapons to Pro-Chamoun forces. There was a huge corruption. It was a totally fruitless operation. ${ }^{, 295}$ Iran needed a strong ally in Lebanon.

\section{The Iraqi Coup of 1958 and SAVAK's 'Green Plan'}

On 14 July 1958, the Iraqi Hashemite dynasty was overthrown in a coup. This event, along with the rise of the UAR-backed militias in Lebanon instigated Chamoun to plead with President Eisenhower for military support. At Saudi King Saud's request, ${ }^{296}$ as well as the Shah's pressure in his meeting with Eisenhower in July $1958,{ }^{297}$ the U.S. deployed the Sixth Fleet marines in Beirut in operation Blue Bat on July $15 .^{298}$ Simultaneously, British troops landed in Jordan. However, Lebanon's internal crisis persisted until Chamoun was replaced by Army commander Fuad Chehab on 31 July 1958. Chehab immediately implemented political reforms and social developments to slow down the tide of Nasserism. ${ }^{299}$ Though partially successful, Chehab's political reform did not prevent the rise of Pan-Arabism in Lebanon. Fueled by the 1958 Iraq coup, Pan-Arabism had attracted many eyes and hearts among young, urban Sunni and Druze.

\footnotetext{
${ }^{295}$ Interview with General Mansour Qadar, Oral History, Foundation for Iranian Studies.

296 Memorandum of Conference with President, White House, 14 July 1958, (FRUS 1958-1960, Vol. XI, 212).

297 The U.S. Department of State telegram, 16 July 1958, (FRUS, 1958-1960, Vol. XI, pp.306-308). The Shah's doubts are seen again in 'internal Political Situation in Iran', the U.S. Department of State Memorandum, 788.00/11 Feb. 1961, FOIA; and CIA, 'The Arab Threat to Iran'.

298 See Beirut 358 to the U.S. Department of State, July 14, 1958 (FRUS/1958-60/XI/doc.121), p.208; Eisenhower, pp.271-271; White House, Memorandum of Conference with the President, July 14, 1958 (FRUS/1958-60/XI/doc.128), pp.226-28; and U.S. Navy, Director of Naval Operations to the Commander in Director, U.S. Naval Forces, July 15, 1958 (FRUS/1958-60/XI/doc.130), p.231.

${ }^{299}$ Chehab was well aware of the disproportionate power division in Lebanese society at the expense of marginalized Sunni, Druze and Shia communities. To secure dominant Maronite control of the Lebanese political realm, he introduced socio-political reforms and recognized Muslim political activity and role.
} 
The U.S. limited action convinced the Shah that he could not rely on his allies in containing Cairo. Thus, he instructed Director Bakhtiar to prepare a plan to contain a growing threat of Pan-Arabism. Led by Colonel Hassan Pakravan, the Iranian security service planned to restore Hashemite monarchy of Iraq. ${ }^{300}$ While the 'Rescue Iraq' plan was a failure for Tehran, SAVAK continuous visits to Beirut set a benchmark in a geographical zone beyond the Iraqi Kurdistan. As a democratic, yet fragile, society, rife with multifarious religious-ethnic identities, Lebanon was a perfect target for Tehran to build its non-state foreign policy. SAVAK soon implemented a new plan, known as the 'Green Plan'. As Major Pashaie's argued, "We should combat and contain the threat [of Nasserism] in the East coast of the Mediterranean to prevent shedding blood on the Iranian soil. ${ }^{301}$ Iran's aim of shaping the Green Plan was to contain Pan-Arabism in Lebanon, instead of its western border with Iraq, by making connections with the Lebanese Shia, rather than the Maronites. Led by Air Force officer Hamid Nasseri, Head of SAVAK Station in Beirut, ${ }^{302}$ SAVAK's Green Plan increased Iran's financial support for the Shia community to $\$ 33,000$ annually. Earlier, Iran’s slight support of the Middle Eastern Shia, including the Lebanese Shia, was provided through the Pahlavi Foundation (Bonyad-i Pahlavi--later called as the Alavi Foundation after the 1979 Revolution). The Foundation channeled financial aid to the Shia communities of the region through religious networks,

\footnotetext{
${ }^{300}$ Letter from Isa Pejman, reprinted in M. Alamuti, Iran dar Asr-i Pahlavi [Iran in the Pahlavi Era] Vol.II, Jang-i Qodrat dar Iran [Power Struggle in Iran] (London, 1992) p.521; and Qaneifard, Erfan, Tondbad-e Havades: Goftogooi ba Isa Pejman [Hurricane of Events: A Dialogue with Isa Pejman] (Elm Publication, Tehran, 2011) p. 95.

${ }^{301}$ To discuss more on the Green Plan see Pejman letter, in Alamuti, Iran dar Asr-i Pahlavi, Vol.II, Jang-i Qodrat dar Iran (London, 1992), pp.521-3.

302 The U.S. State Department, 4 May 1958, (FRUS, 1958-1960, Vol.XI, 29).
} 
especially Grand Ayatollah Muhammad-Hussein Borujerdi. Under the Green Plan, SAVAK, instead of the Marja'iyya networks, directly distributed 80 percent of financial aid to Shia schools and clergies in Lebanon. ${ }^{303}$

Though the Shia community was SAVAK's major target, the Green Plan provided networks with other Lebanese communities and parties. In the eve of the parliamentary election of 1960, Tehran launched an anti-Nasser campaign to weaken Pan-Arabism. SAVAK dedicated $\$ 330,000$ to cover financial expenses of the Maronite Phalanges--also known as the Kataeb Party (al-Kataib al-Lubnaniya or Phalangist Party)--and its leader Pierre Gemayel, ${ }^{304}$ former president Chamoun, and National Block (Al-Kutlah AlWataniyyah) led by Raymond Edde. ${ }^{305}$ The Dashnak Party, a right-wing Armenian party, was also supported when Iran approved Yerevan-Beirut flight passing its territory. SAVAK indirectly supported anti-Nasser newspapers and magazines, particularly Al-Hayat and its well-known columnist, Kamel Morwa, and the Daily Star. ${ }^{306}$ The Syrian Social Nationalist Party (Al-Hizb Al-Suri al-Qawami al-Ijtimai or SSNP) was among SAVAK's initial targets since they used to receive financial support from Hashemite Iraq. ${ }^{307}$ However, the Shah

\footnotetext{
${ }^{303}$ Beigi, Abbas William, The Shah's Lebanon Policy: The Role of SAVAK (January,1997) Middle Eastern Studies. 33 (1): 67.

${ }^{304}$ Letter from Isa Pejman, reprinted in M. Alamuti, Iran dar Asr-i Pahlavi [Iran in the Pahlavi Era] Vol.II, Jang-i Qodrat dar Iran [Power Struggle in Iran] (London, 1992) p.524; Stoakes, The Super vigilantes: The Lebanese Kataeb Party as a Builder, Surrogate, and Defender of the State, (January 1975) Middle Eastern Studies, 11 (1): 233.

${ }^{305}$ Beigi, Abbas William, The Shah's Lebanon Policy: The Role of SAVAK, (January,1997) Middle Eastern Studies, 33 (1): 70.

${ }^{306}$ CIA, Intelligence Memorandum: The Arab Threat to Iran, 21 May 1966, in the Declass. Docs. 1988, \#3107, LOC, and M. Copeland, The Game of Nations (London, 1969), pp.246-7.

${ }^{307}$ D. Little, Cold War and Covert Action: The United States and Syria, 1945-1958 (Winter 1990) Middle East Journal, 44 (1): 64.
} 
himself ordered the removal of the SAVAK list due to the SSNP emphasis on the concept of the Greater Syria after the formation of the UAR.

\section{Sadr and Tehran}

By the late 50s, Musa Sadr's reputation in Qom as a young Mujtahid had flourished. ${ }^{308}$ However, a constitutive event changed the trajectory of his life. In December 1957, Seyyed Abd al-Husayn Sharaf al-Din died, and Sadr was immediately invited by Sharaf al-Din's followers to Tyre. Indeed, Sharaf al-Din had left a will naming Seyyed Musa as his successor before his death. ${ }^{309}$ Seyyed Ja'far, Sharaf al-Din's son, asked Seyyed Reza Sadr to convince his younger brother to lead the Shia in Tyre. ${ }^{310}$ According to Ayatollah Seyyed Mohammad-Ali Abtahi, Sharaf al-din's children asked Seyyed Musa to lead the Shia in the south of Lebanon in their father's funeral ceremony in Najaf. They also went to Qom and asked Grand-Ayatollah Boroujerdi to convince Seyyed Musa to accept to go to Lebanon. Indeed, most of Lebanese Shia clergy were old and corrupt at the time. ${ }^{311}$ Boroujerdi agreed and dispatched Seyyed Musa to Lebanon. ${ }^{312}$

In addition to Sharaf al-Din's Testament, it seems Sadr's departure to Southern Lebanon had been part of Grand-Ayatollah Boroujerdi's religious plan. As the most legitimate cleric and the last Shia Marja whose religious authority was consensually

\footnotetext{
${ }^{308}$ One who is qualified to exercise ijtihad in the evaluation of Sharia.

309 Tabatabai, Mohammad Sadeq, Kahterat-e Siasi Ejtemai [Socio-political Diaries] (Moassese Tanzim Nashr Asar Emam Khomeini, 1388) vol. 1, p. 89.

${ }^{310}$ Interview with Seyyed Hussein Sharaf al-Din (he was Seyyed Abd al-Husayn Sharaf al-Din's grandson and Seyyed Musa's brother-in-law."

See: http://www.lakzaee.com/index.php?option=com_content\&task=view\&id=2135\&Itemid=64.

${ }^{311}$ Interview with Major General Mansour Qadar, Oral History, Foundations for Iranian History.

${ }^{312}$ Abtahi was Seyyed Musa's classmate in Hawza Qom. See: http://www.mashreghnews.ir/fa/news/459203.
} 
accepted by the Shia World, Boroujerdi took an innovative strategy by dispatching his students to other countries to keep and expand Shia fiqh. In doing so, Mehdi Haeri-Yazdi was sent to the U.S. and Mohammad Mohagheghi Lahiji was sent to Hamburg in the late 50s. Boroujerdi had initially intended to send Seyyed Musa Sadr as his representative in Italy with full authority. However, Seyyed Musa declined Grand-Ayatollah's request; instead, he asked Boroujerdi to dispatch him to Lebanon. Other senior Marjas, including Ayatollah Abul-Qasim Khu'i and Ayatollah Mohsen al-Hakim, as well as Sheikh Morteza Al-Yasin, had already expressed their request to Sadr to accept leading the Shia in Lebanon. Despite Sadr's family's objection, ${ }^{313}$ Grand-Ayatollah agreed and Sadr traveled to Tyre in late 1959 .

In the aftermath of the 1953 CIA-orchestrated coup against nationalist Prime Minister Mohammad Mosaddegh, the Shia Marja and ulama, particularly Ayatollah AbolGhasem Kashani, Mosaddegh's former ally, in Iran had been forcefully marginalized from the political realm. With a tightened political atmosphere in Iran, the majority of Shia ulama followed Grand Ayatollah Borujerdi's apolitical line. Their activities were limited to religious ones, including rallying people against the Bahais. For a young, ambitious clergyman who was fond of political activity, leaving Iran and leading a community, even a remote and powerless one, was a windfall opportunity.

According to another narrative, SAVAK seemed to play a key role at this juncture. With the Green Plan, SAVAK had become more involved in detailed politics in Lebanon, particularly in the South. In the aftermath of Sharaf al-Din's death, Director Bakhtiar asked

\footnotetext{
${ }^{313}$ Interview with Seyyed Hussein Sharaf al-Din (he was Seyyed Abd al-Husayn Sharaf al-Din's grandson and Seyyed Musa's brother-in-law). See:

$\mathrm{http}: / / \mathrm{www} \cdot$ lakzaee.com/index.php?option=com_content\&task=view\&id=2135\&Itemid=64.
} 
Seyyed Nasser al-Din, Sharaf al-Din's elder son who had been studying in Hawza in Qom to lead the Lebanese Shia. Pressed by Seyyed Ahmad Tabatabaie Qomi, a close Sadr's relative, ${ }^{314}$ Bakhtiar changed his mind and considered Seyyed Musa as a possible leader of the Shia in Lebanon. In his meeting with young Sadr, Bakhtiar was impressed by his personality. Bakhtiar agreed with his leadership under one condition, that Sadr should cooperate with Tehran, or according to Qadar, to be "Iran's ally in Lebanon."315 As Qadar claimed, with Bakhtiar's agreement, Boroujerdi--who never objected to the government-appointed Sadr as the Imam of Tyre. ${ }^{316}$ Bakhtiar immediately gave instruction to prepare Seyyed Musa's travel to Lebanon. ${ }^{317}$ In the wake of Iran's search to build its ties with the Lebanese Shia, Sadr's ambitions to lead the Shia community, his Lebanese-Iranian background, his approval by Sharaf al-Din, Boroujerdi's religious plan, and SAVAK's Green Plan all resulted in Sadr's leaving Iran for the south of Lebanon.

\section{The Young Leader}

Sadr arrived in the south of Lebanon in late 1959. Upon his arrival, he faced some protests from several Lebanese Shia who backed Ayatollah Seyyed Mohammad Hussein Fadlallah as the head of the Shia. Though religious, Sadr's opposition had an Arab-

\footnotetext{
${ }^{314}$ Seyyed Ahmad Tabatabai-Qomi was Seyyed Musa's relative through the latter's maternal grandfather, Sayyid Agha Hussein Qomi. Mansour Qadar claimed Tabatabaie was Musa Sadr's second or third cousin. Qadar also claimed that Tabatabaie had extensive connections with Shia clergymen and Teymour Bakhtiar. He also claimed that it was Sadr himself who asked Seyed Ahmad to convince Bakhtiar and Boroujerdi to appoint himself as the head of the Shia in Lebanon. See Interview with Major General Mansour Qadar, Oral History, Foundations for Iranian History; and C. Bakhtiar, Ma fidélité (Paris, 1982), p.217 and Beigi, Abbas William, The Shah's Lebanon Policy: The Role of SAVAK, Middle Eastern Studies, vol. 33, No. 1 (January,1997). p. 72.

315 Qadar claimed that Sadr was secretly educated by SAVAK for four months. He received 1500 Lebanon Lir (4 million Toomans). Interview with Major General Mansour Qadar, Oral History, Foundations for Iranian History.

${ }^{316}$ Interview with Major General Mansour Qadar, Oral History, Foundations for Iranian History.

${ }^{317}$ SAVAK Documents, No. 231/466, 10 September 1957.
} 
superiority point of view, criticizing Iranian-born Seyyed. However, Sadr's charisma soon attracted the Shia hearts. "Sadr was a handsome man ... He was a smart, educated, talkative and charismatic man., ${ }^{318}$ A tall (66"), good-looking with piercing green eyes, intelligent, and modern 'Man of God' who spoke stylish Arabic and French was supposed to change the Shia position in Lebanon.

The Shia had been suffering poverty and underdevelopment with a lack of political identity of their own. Marginalized by a unique sectarian system of political representation, the Lebanese Shia lacked considerable political authority and privileges. Despite their growing numerical weight, the Shia's requests for a larger proportion of positions in the decision-making process and reshaping Lebanese national identity had been ignored. It was in this context that Sadr began fighting for promoting the downtrodden and disenfranchised of his community and reviving their collective identity. He began taking a road of institutionalization. In contrast to most of the traditional clergymen, Sadr was a clearsighted man who "embraced modern technology and understood both the power of public opinion and the tools of popular mobilization in the modern world. ${ }^{319} \mathrm{He}$ taught Persian language and several classes on Iran at the Amaliyah School, Fiqh at a Sunni school of AlMaghasid, and Islamic philosophy at St. Joseph University in Beirut. He also reestablished religious institutions and charitable foundations, like Jami'at al-Birr wa al-Ihsan (Community of Goodness and Welfare) wherein Shia orphans were trained, ${ }^{320}$ as well as al-Mu'assasa al-Ijtima'iyya (The Social Institute), a Shia orphanage in Tyre. In 1963, Sadr

\footnotetext{
${ }^{318}$ Interview with Major General Mansour Qadar, Oral History, Foundations for Iranian History.

${ }^{319}$ Bonnin, Richard, Arrows of the Night: Ahmed Chalabi and the Selling of the Iraq War (Anchor; Reprint edition November 13, 2012) p. 57.

${ }^{320}$ Jami'at al-Birr wa al-Ihsan was first established by Seyyed Abd al-Husayn Sharaf al-Din.
} 
founded Bayt al-Fatat (The Girls' Home), a nursery and sewing school, and then established Ma'had al-Dirasat al-Islamiyya (The Institute of Islamic Studies) as well as 'Maahad a-Darasat al-Eslamiyya' (the center of Islamic Research). He also established a carpet weavering factory. ${ }^{321}$ Sadr's innovative activity and modern ideas were gradually supported by wealthy merchants and urban youth.

SAVAK initially welcomed Sadr's social activities. His programs could contain both Pan-Arabism and Marxism in Lebanon by improving the Shia position and dissuading them from joining Pan-Arab parties. While initially considered as an inclusive ideology, Pan-Arabism did not attract the Shia minority since the idea of a Greater Arab Nation would be another manifestation of a predominant Sunni authority. A Shia community with a strong collective identity would function as Iran's natural ally by counterweighting Sunni Pan-Arab powers. In contrast to Iraqi Kurdistan, Tehran avoided providing military support for its ally in the east coast of the Mediterranean; rather, it was Sadr's message that could accomplish Iran's Green Plan. Sadr maintained a close connection with the Iranian embassy and SAVAK's station in Beirut. Initially, he was in touch with Nasseri. Qadar claimed that "Nasseri was an angry and hot-tempered, while Sadr was a Machiavellian talkative man. So, they could not work with each other." ${ }^{, 322}$ On the one side, ambitious Bakhtiar who had a plan to gather political and religious elites around himself considered Sadr as a possible strong ally. As Qadar claimed, he instructed Sadr to connect himself through Pashaie and bypassed Iran's embassy. Sadr had a weekly meeting with Major

\footnotetext{
${ }^{321}$ Seyyed Musa asked his older brother, Seyyed Reza Sadr, to prepare raw materials for the factory. See http://www.imamsadr.com.

${ }^{322}$ Qadar claimed that Sadr was financially supported by Bakhtiar. These financial supports helped Sadr to centralize the Lebanese Shia. Interview with Major General Mansour Qadar, Oral History, Foundations for Iranian History.
} 
Pashaie, head of SAVAK Station in Beirut, from 20 November 1960 to 20 December 1963. ${ }^{323}$ In addition to his charisma, it was Pashaie who initially facilitated Sadr's connection with Lebanese elites in Beirut. These connections developed a long-term friendship between Sadr and Pashaie. According to SAVAK documents, Sadr put emphasis on his Iranian background and expressed his great respect for Iran in his speeches in several meetings. ${ }^{324}$ Nonetheless, Sadr never became a lackey agent for the Shah's regime. He was aware of keeping his distance from the regime and never accepted Tehran's direct financial support. Sadr still believed that the Shah's direct support of the Shia might prompt other regional countries to obstruct the Shia interests in Lebanon. Within a fragmented society like Lebanon, Iran's direct support for the Shia could fuel a devastating regional competition and power interventions in Lebanon. Furthermore, a remote, non-Arab state like Iran, with its covert relation with Israel, could pose a threat to a marginal community like the Shia. Despite these concerns, Sadr still kept his ties with Iranian officers.

\footnotetext{
${ }^{323}$ Beigi, Abbas William, Beigi, Abbas William, The Shah's Lebanon Policy: The Role of SAVAK (January 1997) Middle Eastern Studies, vol. 33 (1): 73.

${ }^{324}$ SAVAK Documents, No. do.231/362, 7 September 1963.
} 


\section{Chapter 4}

\section{Ascension: Iran's Non-State Foreign Policy in 1963-1968}

Iran's non-state foreign policy became more proactive in this period. The coup of 1963 was a major victory for Iran's non-state foreign policy. However, the Iraqi threat to Iran was still alive. Despite its anti-communist nature, the Baath-Arif regime overemphasized its Pan-Arab tone, declared a territorial claim on the Eastern bank of Arvand Rud and the Iranian province of Khuzestan, and revived negotiations with Nasser over the Arab Unity. Therefore, when Baghdad reinvaded Kurdistan in Summer 1963, Tehran intensified its support for the Iraqi Kurds. Despite the U.S. clear objection, under both the Kennedy and the Johnson presidencies, Iran sided with the Kurds in order to contain Pan-Arab Iraq. Iran's connections with the Iraqi Kurds turned away the Iraqi Army from posing a threat to Khuzestan and the Persian Gulf.

Simultaneously, Iran kept its ties with the Lebanese Shia in order to set a bulwark against Nasser's leverage in Lebanon. This connection was strong enough that even Sadr's indirect support for the riot of 1964 and Ayatollah Khomeini, as well as former SAVAK Director Bakhtiar's meeting with Sadr, did not lead to a transformation of Iran's non-state foreign policy in Lebanon. Conversely, Iran's ambassadors to Beirut were in complete coordination with Sadr whose reputation as a national figure reached its zenith in the late $60 \mathrm{~s}$. 


\section{Ascension-The Iraqi Kurds}

"Wherever the Kurds live, it is Iran.” Mullah Mustafa Barzani

“The Kurds are Iranian wherever they live.” Ibrahim Ahmad

\section{The First Baath Regime}

In the aftermath of the coup of 1963, the Shah thought that formation of an anticommunist regime in Baghdad would decrease the Soviet leverage in the region. Despite initial cooperation with Iraq in extraditing communist refugees, Tehran was suspicious of intimate Baghdad-Cairo relations. The coup of 1963 revived the issue of Arab unity among Egypt, Iraq, and Syria. With the negotiation between Iraq and Egypt on 22 February 1963, the Shah concluded that the coup would lead to Egyptian power expansion in the region. Iran needed the Iraqi Kurds most.

Though initially hailing the coup, both the Kurd and the Arab-speaking Shia population of Iraq opposed becoming part of a "larger Arab entity dominated by the Sunni Arab." 325 Upon the arrival of an Iraqi delegation to Cairo for the second round of talk, Barzani dispatched Talabani there to meet Nasser. ${ }^{326}$ Nasser was among the few Arab leaders who believed in a peaceful solution of the Kurdish question. ${ }^{327}$ With the coup of 1963, he urged Baghdad to establish an Iraqi federal system, like Yugoslavia and the USSR, and authorize autonomy for the Kurdish minority. In a meeting with Nasser, Talabani expressed a long-standing Kurdish-Arab friendship while arguing that Iraq unity with Egypt and Syria would water down the Kurdish population and marginalize them

\footnotetext{
${ }^{325}$ CIA, Office of Current Intelligence, OCI No. 2024/63, 13 June 1963.

${ }^{326}$ SAVAK Documents, No. d/16/12509, 7 February 1961.

${ }^{327}$ In the heyday of Qasim's coup, Nasser had warmly received Ibrahim Ahmad in October 1958 and promised him to install a Kurdish radio broadcast.
} 
more in an Arab-dominated society. Thus, he asked for Cairo's guarantee to support an autonomous Kurdistan. Although Nasser "gave his full backing to Kurdish demands for autonomy within Iraq and hoped that [a] rapid agreement could be reached,"328 he warned the Kurds of the Shah's instrumentalist view towards the Kurdish war. "Be aware that Mohammad Reza Shah is the Kurds' enemy. He possesses a great portion of the Kurdish population. If he supports you, it is because he wants to use you against the Arabs to achieve his goals," 329 Nasser told Talabani. He also asked the Kurdish delegation to postpone their demand for the regional government. ${ }^{330}$ As another negotiation with Baghdad began on 5 March 1963, the KDP announced their demands and asked the Arab leaders to recognize Kurdistan as "the fourth pillar, though depending on Iraq pillar, in a tripartite Arab Federation of Egypt, Syria, and Iraq. ${ }^{, 331}$ The Kurdish leaders threatened to leave the negotiations if Baghdad refused their demands. ${ }^{332}$ Nevertheless, fear of the Iraqi

\footnotetext{
${ }^{328}$ Baghdad 501 to the U.S. Department of State, March 1, 1963 (KPL/NSF/Countries/Box117a/Iraq.3/635/63/doc.2), pp.1-2.

${ }^{329}$ Qaneifard, Erfan, Pas az Shast Sal: Zendegi va Khaterat-e Jalal Talabani [After Sixty Years: The Life and Memories of Jalal Talabani] (Elm Publication, Tehran) p.783.

${ }^{330}$ Baghdad 501 to the U.S. Department of State, March 1, 1963 (KPL/ NSF/Countries/Boxes117a/Iraq.3/635/63/doc.2), pp.1-2; Heikal, Nasser's ghostwriter and editor-in-chief of the Al-Ahram, also put emphasis on the peaceful settling the Kurdish question in the north of Iraq. See Baghdad 774 to Iran's Ministry of Foreign Affairs, 28 April 1963.

${ }^{331}$ London 1305 to Iran's Ministry of Foreign Affairs, 2 August 1963. Their major demands included: 1. The recognition of Iraq with two mutual nations of the Kurd and the Arab with equal rights, 2. The formation of a Kurdish autonomous region constituted of Sulaymaniyah, Kirkuk, Erbil, and the Kurdish-inhabitant of Mosul, 3. The establishment of an executive council as well as legislative council for the administration of the Kurdish region and membership of the Kurdish leaders to the Revolutionary Council, 4. The proper division of money coming from Oil and border Customs between the Kurds and the Arabs and 5. The membership of the Kurds in the government with regards to their population. See London to Iran's Ministry of Foreign Affairs, 8 May 1963.
}

332 On 8 April 1963 Jalal Talabani stated that "If Iraq wants to join the UAR, the Kurds must have their autonomous government. If Iraq decides to be annexed in the greater alliance with other Arab countries, then the Kurds should have their provincial identity. The Kurds have no intention to get independence." See Qaneifard, Erfan, Pas az Shast Sal: Zendegi va Khaterat-e Jalal Talabani (After Sixty Years: The Life and Memories of Jalal Talabani), Elm Publication, Tehran, p.710. Barzani also threatened Baghdad of the 
Shia' possible demand of autonomy convinced Baghdad to adopt a hardline policy towards the Kurds. ${ }^{333}$ On 10 March 1963, Ali Salih al-Saadi stated that Iraq was only ready for a cultural, instead of political, autonomy of the Kurds. ${ }^{334}$ Baghdad claimed that most of the Kurdish tribes would not follow Barzani’s fruitless adventure. ${ }^{335}$ In mid-April 1963, Iraq, Egypt, and Syria signed a formal agreement to form the Arab Confederal Republic while the Kurds' rights were mentioned. ${ }^{336}$

\section{J.F.K versus the Shah}

Since the outbreak of the Kurdish War in 1961, Iran's non-state foreign policy had stood in contrast with the U.S. policy in Iraq. The U.S. had welcomed the formation of the anti-communist Baath regime. "As a result of the Iraqi coup," the U.S. Department of State argued, "the Soviets suffered a setback in Iraq and their general Middle Eastern policies. ${ }^{\not 37}$ In the U.S. view, the formation of an anti-communist federation of Iraq, Egypt, and Syria would function as a major bulwark against the Soviet infiltration in the region. ${ }^{338}$ The U.S. ambassador to Beirut declared that "the U.S. supports the Baath regimes of Iraq

resumption of war, unless the Iraqi regime and the Arab Federation accepted the autonomy of the Kurdish region. See Amman 198/21/2 to Iran's Ministry of Foreign Affairs, 8 May 1963.

${ }^{333}$ CIA, Office of Current Intelligence, OCI No. 2024/63, 13 June 1963. Although the Kurds took steps to show their good will by releasing 1500 Arab prisoners, the Baath regime did not release Kurdish prisoners and instead tightened the economic blockade. Baghdad 500 to U.S. Department of State, March 1, 1963 (KPL/ NSF/Countries/Boxes117a/Iraq.3/63-5/63/doc.1), pp.1-3.

${ }^{334}$ As the Secretary General of the Regional Command of the Iraqi Ba'ath Party, al-Saadi was the most influential figure in Baghdad.

${ }^{335}$ Amman 276/21/2 to Iran's Ministry of Foreign Affairs, 20 May 1963.

${ }^{336}$ McDowall, David, A Modern History of the Kurds (London, New York 2004) p.313.

${ }^{337}$ The U.S. Department of State, Bureau of Intelligence and Research, "Implications of Iraqi Coup for Soviet Policy,” BSB-25, February 15, 1963 (JKF/NSF/RKF/Box426/Iraq-1961-63), pp.1-2.

${ }^{338}$ CIA, 'The Soviet Role in the Arab World', DNSA, Soviet Estimate Collection, Item Number: SE00382, 6. 
and Syria since they follow anti-communist policies. The U.S. also avoids turning away from Nasser because he may approach the communists." 339 They were still worried about destructive results of the Kurdish War in weakening the Iraqi anti-Communist regime and spurring the Kurdish separatist groups in Turkey and Iran that could be used by Moscow. ${ }^{340}$ The Kurds had already asked the U.S. officials to press Baghdad for a peaceful settlement of the crisis. ${ }^{341}$ Nonetheless, their appeal was turned down. The American officials argued that the Kurdish question was "strictly an internal Iraqi matter in which there is no role for the United States either directly or indirectly." ${ }^{342}$ Indeed, the U.S. support for Baghdad stood in sharp contrast with Iran's non-state foreign policy. The Kennedy administration pressed Iran not to interfere in the crisis, warning Tehran to "keep [its] hands off" Iraq. The U.S. officials argued that the Shah's policy towards the Iraqi Kurds was so "short-sighted" that it could be "inimical to Iran's overall security interests." 343 They also warned the Shah to "stay out of what could become a political and military morass for a foreign state.",344 However, when the U.S. secretly provided arms for the Iraqi army, ${ }^{345}$ the Shah intensified Iran's support for the Kurds to undermine the U.S. policy.

\footnotetext{
339 Jeddah 1249 to Iran's Ministry of Foreign Affairs, 10 August 1963.

340 (FRUS, 1961-1963, Vol. XVIII, Near East, 1962-1963, p. 674); and CIA, 'The Soviet Role in the Arab World', DNSA, Soviet Estimate Collection, Item Number: SE00382, 5.

${ }^{341}$ Baghdad 500 to the U.S. Department of State, March 1, 1963 (KPL/ NSF/Countries/Boxes117a/Iraq.3/635/63/doc.1), pp.1-3.

${ }^{342}$ The U.S. Department of State CA-9411 to Certain Posts, "Interim Policy Guidelines for Dealing with Iraq and with the Implications for the Middle East of the Recent Iraqi Coup," March 2, 1963 (FRUS/196163/XVIII/doc. 174), pp.382-389.

${ }^{343}$ White House, Memorandum, Saunders to Bundy, April 2, 1963 (JKF/NSF/RKF/Box426/Iraq-1961-63White House Memoranda," p.1.

${ }^{344}$ Ibid.

${ }^{345}$ SAVAK Documents, No. 1083, 28 July 1963; Komer to Bundy, March 1, 1963, FRUS 1961-1963, XVIII, 305.
} 
By early June 1963, the last round of Iraqi-Kurdish negotiation, especially over Kirkuk's rich oilfields, deadlocked. Although Arif was partly inclined to settle the crisis peacefully, the Baath Prime Minister Hassan al-Bakr could not digest a peace agreement with Barzani who had brutally suppressed the 1959 Baath riot in Mosul. As Moscow gradually sided with the Kurds and initiated an anti-Baath radio broadcasted in Iraqi Kurdistan, the U.S. thought that a "failure to find a political solution to the Kurdish problem would benefit only the Soviets and the Iraqi communists.."346 Barzani apparently agreed with the negotiation and asked Baghdad to establish a national unity regime of both left and right groups--a request that, according to Talabani, was against the peace process. ${ }^{347}$ Amidst the fragile negotiations, Iraqi forces had mobilized and built up military posts in the Kurdish area. Air strength had been augmented proportionately. ${ }^{348}$ On 5 June 1963, the Baath troops surrounded Sulaymaniyah and proclaimed martial law. The Kurds, in return, threatened to explode oil pipelines. ${ }^{349}$ War was inevitable.

\section{The First Baath-Kurdish War}

On 9 June 1963, Baghdad launched an invasion of Iraqi Kurdistan with 45,000 Iraqi troops, nearly two-thirds of the Iraqi army. ${ }^{350}$ As a heavy bombardment of Kurdish villages

\footnotetext{
${ }^{346}$ The U.S. Department of State CA-9411 to Certain Posts, "Interim Policy Guidelines for Dealing with Iraq and with the Implications for the Middle East of the Recent Iraqi Coup," March 2, 1963 (FRUS/196163/XVIII/doc.174), pp.382-389.

${ }^{347}$ SAVAK Documents, No. 234/0876, 24 August 1963.

${ }^{348}$ CIA, Office of Current Intelligence, OCI No. 2024/63, 13 June 1963.

${ }^{349}$ Kuwait 1897 to Iran's Ministry of Foreign Affairs, 6 July 1963.

350 CIA, “Iraq-Kurdish Rebellion,” OCI No. 2024/63, June 13, 1963 (KPL/NSF/Countries/Box117a/Iraq.6/63-8/63/doc.7), p.2.
} 
began, ${ }^{351}$ Radio Baghdad called the Kurdish Peshmerga communist and separatist. ${ }^{352}$ The Baath forces arrested the Kurdish delegate in Baghdad, ${ }^{353}$ and gave an ultimatum to the Kurds to surrender their weapons and announced a 280 thousand dollar award for killing Barzani. ${ }^{354}$ President Arif claimed, "The Kurdish insurrection will finish soon. There is no more room to tolerate them." ${ }^{\prime 35}$ In the meantime, Iraqi newspaper al-Jamahir highlighted the Kurdish-Communist connections and denounced the Soviet infiltration in Iraq. The alShaab newspaper also accused Barzani of his efforts to build an "Oil Empire" in the north of Iraq. ${ }^{356}$ Meanwhile, Iraqis mobilized anti-Barzani tribes. ${ }^{357}$ Baghdad expected an easy victory. ${ }^{358}$ According to the al-Minar newspaper, however, "It is said that history repeats itself; however, it seems it does so in Iraq continuously." ${ }^{359}$

The Kurdish War of 1963 widened a gap between the pro-Nasser forces, like the Harikat Party, on the one side, and the Baath Party, on the other side, in Baghdad. Although

${ }^{351}$ CIA, Office of Current Intelligence, OCI No. 2024/63, 13 June 1963.

${ }^{352}$ Qaneifard, Erfan, Pas az Shast Sal: Zendegi va Khaterat-e Jalal Talabani [After Sixty Years: The Life and Memories of Jalal Talabani] (Elm Publication, Tehran) p.720.

${ }^{353}$ London 1305 to Iran's Ministry of Foreign Affairs, 2 August 1963.

${ }^{354}$ New York 514 to Iran’s Ministry of Foreign Affairs, 14 June 1963.

${ }^{355}$ Qaneifard, Erfan, Pas az Shast Sal: Zendegi va Khaterat-e Jalal Talabani [After Sixty Years: The Life and Memories of Jalal Talabani] (Elm Publication, Tehran) p.720.

${ }^{356}$ Baghdad 1788 to Iran’s Ministry of Foreign Affairs, 19 June 1963.

${ }^{357}$ Including the Zibari, headed by Sheikh Mahmoud Zibari, Zakho tribes, headed by Haj Shamdin Agha, and Naqshbandi Sufi leaders, like Sheikh Masoud Naqshbandi and Sheikh Jalal al-Din Berifkani. Baghdad 1639 to Iran's Ministry of Foreign Affairs, 13 June 1963.

${ }^{358}$ Baghdad 854 to the U.S. Department of State, June 10, 1963 (KPL/NSF/Countries/Box117a/Iraq.6/638/63/doc.3), pp.1-3.

${ }^{359}$ Amman 438/28/2 to Iran's Ministry of Foreign Affairs, 16 June 1963. 
the Baath Party had been initially backed by Nasser, ${ }^{360}$ they never fully supported political unity with Cairo and Nasser's leadership. ${ }^{361}$ Thus, the Baath parties of Syria and Iraq limited most Nasserist newspapers and purged their elements from the government and the army. ${ }^{362}$ In retaliation, Cairo launched harsh propaganda against Baghdad. ${ }^{363}$ While the Baath regime framed the formation of Kurdistan as a "new Israel," planned by "Imperialism, Communism, and Zionism" and headed by Barzani as "one of their agents" to "contain the Arab Unity," Cairo denounced the Baath Party as a "war criminal" against the Kurds. ${ }^{364}$ Although Nasser's support for the Kurds was "not decisive,", 365 the idea of Iraqi unity with Egypt cracked with the Kurdish War. In a unique historical juncture, Tehran sided with its principal regional enemy over the support for the Kurds.

In the meantime, Baghdad approach the Baath regime of Syria to revive the Arab Unity. Syrian Prime Minister Salah ad-Din al-Bitar promised Iraq military cooperation to

\footnotetext{
${ }^{360}$ Al-Samarrai, Wafiq, Hottam al-Bawabat al-Sharqi [The Destruction of the Eastern Gate] translated in Farsi, (Tehran, Markaz Asnad va Tahghighat-e Defa-e Moghaddas) p. 36.

${ }^{361}$ The declaration announced after the meeting of the Arab leaders gave unchallenged power to the president of the Arab Federation's supposedly Nasser. Mohammad Hassanein Heikal stressed "the political Unity of Command" under Nasser's leadership and explained the rising alliance between "Imperialism and Israel" against the "Arab Unity" with its "Three-Stars Flag." Baghdad 774 to Iran's Ministry of Foreign Affairs, 28 April 1963. Conversely, the Baath leaders rejected personal leadership and Nasser's dominance over Iraq, Syria and possibly Jordan. King Hussain had expressed his agreement to join the Arab Federation if each member would have equal power. The Baath leaders demanded a conciliar leadership with equal power in the decision-making process.

${ }^{362}$ London 1305 to Iran's Ministry of Foreign Affairs, 2 August 1963.

${ }^{363}$ Nasser pointed "Being friend with Fascist Baath is impossible". See Qaneifard, Erfan, Pas az Shast Sal: Zendegi va Khaterat-e Jalal Talabani [After Sixty Years: The Life and Memories of Jalal Talabani] (Elm Publication, Tehran) p.722.

${ }^{364}$ Baghdad 1626 to Iran's Ministry of Foreign Affairs, 12 June 1963.

${ }^{365}$ SAVAK Documents, No. 311-2-v-791, 26 May 1963; London to Iran's Ministry of Foreign Affairs, 13 June 1963; SAVAK Documents, No. 311-2-v-791, 25 July 1963.
} 
crush the Kurdish rebels. ${ }^{366}$ A possible spill-over into its Kurdish minority and a discovery of oilfields in its predominantly Kurdish populous province of Jazira convinced Damascus to participate in the Kurdish War. ${ }^{367}$ Damascus provided aircraft and armored vehicles and dispatched 6,000 soldiers to join the military campaign against the Kurds. This cooperation would usher in the Iraqi-Syrian unity, Iran's Ministry of Foreign Affairs argued. ${ }^{368}$ Backed by Damascus, the Iraqi Army savagely destroyed the Kurdish villages and massacred the civilian Kurds. ${ }^{369}$ By September 1963, the Iraqi Army had captured major parts of the Iraqi Kurdistan, including Barzan and Sulaymaniyah. ${ }^{370}$ Nevertheless, Baghdad's initial plan to suppress the Peshmerga in a few weeks proved to be unrealistic. Rather, its "costly, prolonged campaign" to Kurdistan widened a breach between the Kurds and Arabs. ${ }^{371}$ By Summer 1963, the Kurdish War had become a major regional issue.

Meanwhile, Moscow threatened Baghdad to support the Kurds. ${ }^{372}$ After the SyrianIraqi invasion of Kurdistan, the Russians intensified their anti-Baath propaganda and

\footnotetext{
${ }^{366}$ Baghdad 1639 to Iran's Ministry of Foreign Affairs, 13 June 1963.

${ }^{367}$ On 23 August 1962, the Syrian government conducted a special population census only for Jazira against the Kurds.

${ }^{368}$ London to Iran's Ministry of Foreign Affairs, 25 September 1963.

${ }^{369}$ London 1305 to Iran's Ministry of Foreign Affairs, 2 August 1963.

${ }^{370}$ McDowall, David, A Modern History of the Kurds (London, New York 2004) p. 315.

${ }^{371}$ CIA, Office of Current Intelligence, OCI No. 2024/63, 13 June 1963.

${ }^{372}$ New York 564 to Iran's Ministry of Foreign Affairs, 21 June 1963.
} 
suspended their military aid to Baghdad. ${ }^{373}$ The ICP leaders also sided with the Kurds. ${ }^{374}$ Barzani, in return, permitted the communists to enter Iraqi Kurdistan. ${ }^{375}$ On 6 May 1963 , the Soviet Union officially announced its support for the Kurds,${ }^{376}$ pressing the UN to investigate the Kurdish War and to level charges of genocide against Baghdad. ${ }^{377}$ The Russian move prompted the U.S. to intensify its support for Baghdad. When the Kurds delivered a letter to the U.S. consulate in Tabriz, Iran, and asked the U.S. to press Baghdad for a truce or ceasefire, ${ }^{378}$ the U.S. rebuffed it. By Fall 1963, the Kurdish War had become a Cold War battlefront.

In contrast to the U.S., Iran viewed the Kurdish War through the regional lens, rather than the international Cold War one. The resumption of the war was Iran's major tool to resist Pan-Arabism. In early September 1963, Barzani traveled to Tehran to meet the Shah for the first time and asked him for more substantial support. The Shah agreed and instructed SAVAK to mobilize in support of the Kurds. On September 16, Director Pakravan met Julius C. Holmes, the U.S. ambassador to Iran, and asked him to consider the Shah's view on the Kurds. According to the Shah, Pakravan stated, Barzani's main goal

\footnotetext{
${ }^{373}$ London 1305 to Iran's Ministry of Foreign Affairs, 2 August 1963; CIA, "Moscow Turning Against Baathist Regime in Iraq," Current Intelligence Weekly Summary, June 28, 1963 (JKF/NSF/RKF/Box426/Iraq-1961-63/doc.23), p.9.

374 Anwar Mustafa, a high-ranking member of the ICP, heavily supported the Kurds and lashed out at Baghdad for a "criminal slaughter of the innocent Kurdish people." Paris 36 to Iran's Ministry of Foreign Affairs, 7 July 1963.

${ }^{375}$ SAVAK Documents, No. 313/38548, 19 December 1963.

${ }^{376}$ London 1305 to Iran's Ministry of Foreign Affairs, 2 August 1963.

377 On July 27, 1963, Outer Mongolia, one of the Soviet satellites, asked the UN. See USUN 12 to the U.S. State Department, July 2, 1963 (KPL/NSF/Countries/Box117a/Iraq.6/63-8/63/doc.21), p.1.

${ }^{378}$ Tabriz 1 to the U.S. Department of State, July 24 (KPL/NSF/Countries/Box117a/Iraq.6/63-8/63/doc.31), pp.1-2; and Tehran A-67 to U.S. Department of State, "Mullah Mustafa Barzani's Letter to President Kennedy," letter attached, July 30, 1963 (NARA/RG59/CFPF/Box3944/POL-13-Non Party Blocs [Iraq] 2/1/63), pp.2-3.
} 
was a "limited autonomy," rather than an "independent Kurdistan," and the Kurdish leader preferred negotiating with Baghdad; therefore, the U.S. should deliver a strong guarantee for the Kurds to convince them to stop the war. ${ }^{379}$ Well-aware of the reason behind the U.S. support for Baghdad, i.e., the anti-communist nature of the Baath regime of Baghdad, ${ }^{380}$ the Shah was confident that his determining role in building the U.S.-Kurdish alliance would transform Barzani's image to that of an opportunist, rather than a Russian puppet. ${ }^{381}$ It was the first time that Tehran officially conducted diplomacy on behalf of the Kurds.

Nonetheless, the Shah's request was turned down by the Kennedy administration. The Department of State recommended that an "essential part of any policy must be to beat up the Shah on this score." ${ }^{382}$ The U.S. ambassador to Baghdad also warned Iran's ambassador of Tehran's support of the Kurds. ${ }^{383}$ But Tehran did not consider it and kept providing "limited support to the Kurds." ${ }^{384}$ SAVAK transported weaponry that was mainly prepared from Europe to Iraqi Kurdistan. ${ }^{385}$ In addition to facilitating Israeli assistance in providing food for the Kurds, ${ }^{386}$ Iran purchased a radio transmitter from Germany for the Kurds, ${ }^{387}$ later smuggled it into Iraqi Kurdistan, and set it up in a large

\footnotetext{
${ }^{379}$ Tehran 276 to U.S. Department of State, September 17, 1963 (KPL/NSF/Countries/Box117a/Iraq.9/6311/63/doc.8), pp.1-3.

${ }^{380}$ SAVAK Documents, No. 1106, 30 July 1963.

${ }^{381}$ White House, Memorandum, Komer to Bundy, June 19, 1963 (KPL/NSF/Countries/Box117a/Iraq.6/638/63/doc.12), p.1.

${ }^{382}$ Ibid.

${ }^{383}$ SAVAK Documents, No. 234/535, 30 September 1963.

${ }^{384}$ CIA, Office of Current Intelligence, OCI No. 2024/63, 13 June 1963.

${ }^{385}$ CIA, 'Iran Increases Clandestine Support of Kurds in Iraq,' Central Intelligence Digest, October 7, 1963 (JKF/NSF/RKF/Box426/Iraq. Kurds-1961-63/doc.1), p.1.

${ }^{386}$ SAVAK Documents, No. 1540, 2 October 1964.
} 
cave with modern tools. ${ }^{388}$ Monitored by Pejman and Isa Zabihi, ${ }^{389}$ the Free Radio of Kurdistan Democratic Party, also known as Radio SAVAK among Kurdish people, launched anti-Baghdad propaganda. ${ }^{390}$ Most of the KDP declarations were published under SAVAK's monitoring in Iran's embassy in Baghdad. ${ }^{391}$ At the same time, Iran ignored Iranian Kurds across the border with Iraq. ${ }^{392}$ Indeed, Barzani's resistance against the Iraqi army encouraged the Iranian Kurds, particularly from Mahabad, to join the Peshmerga in their fight with Baghdad. ${ }^{393}$ By Summer 1963, the Kurdish revolt had been a significant element in Iran's non-state foreign policy.

\section{The Iraqi Kurdish Ceasefire of 1964}

As the war was spiraling out of control, the power struggle in Baghdad escalated over the issue of Arab unity. While al-Saadi supported unity with Syria, Prime Minister alBakr tried to resume unity with Nasser. The clash finally convinced Arif to purge the Baath Party in a coup of 18 November $1963 .{ }^{394}$ The collapse of the Baath government

\footnotetext{
${ }^{387}$ Beirut 236 to U.S. Department of State, September 13, 1963 (KPL/NSF/Countries/Box117a/Iraq.9/6311/63/doc.4), p.2.

${ }^{388}$ SAVAK Documents, No. 313/38548, 29 November 1963.

${ }^{389}$ Mullah Mustafa's close aid.

${ }^{390}$ The radio was initially called as Radio 'Voice of Kurdistan'. Feared of its repercussions on the Kurdish populations in both Iran and Turkey, the Shah and General Pakravan rejected the name. So, its name changed to Free Radio of Kurdistan Democratic Party - See Qaneifard, Erfan, Tondbad-e Havades: Goftogooi ba Isa Pejman [Hurricane of Events: A Dialogue with Isa Pejman] (Elm Publication, Tehran, 2011) p. 132.

${ }^{391}$ Qaneifard, Erfan, Tondbad-e Havades: Goftogooi ba Isa Pejman [Hurricane of Events: A Dialogue with Isa Pejman] (Elm Publication, Tehran, 2011) p. 132.

${ }^{392}$ SAVAK Documents, No. 331/15417, 10 July, 1963; SAVAK Documents, No. 423/3438, 4 November, 1963.

${ }^{393}$ SAVAK Documents, No. 311/2-d/1476, 7 July, 1963.

${ }^{394}$ With the help of his brother, Brigade General Abdul-Rahman Arif, President Arif crushed the Baath Party, suppressed its National Guard Militia, and bombed its headquarters. CIA, "Military Activity and Possible Coup,” November 18, 1963 (KPL/NSF/Countries/Box117a/Iraq. 9/63-11/63/doc.63), p.1.
} 
disentangled Arif from the hardliner pressure on the Kurdish question. Convinced by Nasser and Algerian President Ahmad Ben Bella, Arif inaugurated rounds of negotiations with the Kurds. He also asked the Syrian army to leave the northern Iraq. Vying to gain dominance over Kurdistan, rather than keep fighting a bloody war with Baghdad, Barzani welcomed Arif"s goodwill. ${ }^{395}$ "We should stop fighting ... Arif is a [Muslim] believer, and the believer should be believed," Barzani stated. ${ }^{396}$ In contrast to SAVAK's prediction, Barzani signed a peace agreement with Arif on 10 February 1964. Although the ceasefire did not include Kurdish autonomy and used a Pan-Arab euphemism 'the Northern Region', instead of 'Kurdistan', Barzani accepted it and then launched a brutal campaign against the ICP. ${ }^{397}$ Barzani contended that "Iraqi state is like a father who thinks about the future and progress of its family and children." He also praised Nasser and claimed that the Kurds would be "ready in [joining the Arab regimes of the region in] fighting with Israel.",398

With the ceasefire of 1964, the U.S. diplomats in Baghdad appreciated Barzani for having "wisely resisted Persian blandishments" and urged him to "remain calm and try [to] work out [a] solution with GOI [Government of Iraq]. ${ }^{399}$ Conversely, the ceasefire shocked the Shah. The Iraqi Kurds who had been the main elements in Iran's non-state foreign policy left Tehran and sided with pro-Nasser Arif. The direct result of the ceasefire

\footnotetext{
${ }^{395}$ It seemed that Arif had been in contact with Barzani before the coup, asking him to keep fighting with the Baath. Qaneifard, Erfan, Pas az Shast Sal: Zendegi va Khaterat-e Jalal Talabani [After Sixty Years: The Life and Memories of Jalal Talabani] (Elm Publication, Tehran) p.873.

${ }^{396}$ Qaneifard, Erfan, Pas az Shast Sal: Zendegi va Khaterat-e Jalal Talabani [After Sixty Years: The Life and Memories of Jalal Talabani] (Elm Publication, Tehran) p.768.

397 The ceasefire partially recognized the Kurdish rights, including the cultural-linguistic rights within a unified Iraq, lift the economic blockade, and release prisoners. SAVAK Documents, No. 316/16041, 7 July 1964.

${ }^{398}$ Baghdad 6020 to Iran's Ministry of Foreign Affairs, 23 February 1964.

${ }^{399}$ Baghdad 486 to U.S. Department of State, December 16, 1964, FRUS 1964-1968, XXI, 171.
} 
would be the creation of a larger Arab entity at Iran's western borders, as well as Barzani's possible intrusion into Iranian Kurdistan. According to SAVAK, the formation of an autonomous government in Iraqi Kurdistan would instigate the Iranian Kurds to achieve the same concessions in Iran. ${ }^{400}$ The ceasefire had been also welcomed by Iranian Kurds who saw it as a historic victory for all the Kurds. ${ }^{401}$ By late 1964, Iran had been encountered by rising threats of Pan-Arabism and Kurdish Secessionism.

\section{The Kurdish Civil War}

The peace agreement of 1964 was a major setback for Iran. To add insult to injury, a bloody civil war erupted among the Iraqi Kurds. Ahmad and Talabani denounced the ceasefire since the agreement excluded local autonomy for the Kurds, and criticized Barzani for signing the agreement without consulting with the KDP members. ${ }^{402}$ It ended in splitting the KDP into two competing factions of pro-Barzani and Ahmad-Talabani. ${ }^{403}$ The Iranian army also viewed tension between Barzani with Talibani and Ahmad as a fake one as both planned to ease the armed Peshmerga entrance in Iran. ${ }^{404}$ Conversely, SAVAK considered historical enmity among the Kurdish tribes and the harsh arguments over the

\footnotetext{
${ }^{400}$ SAVAK Documents, No. 2r/75, 27 March 1963.

${ }^{401}$ SAVAK Documents, No. 313/44155, 6 March 1964.

${ }^{402}$ Qaneifard, Erfan, Pas az Shast Sal: Zendegi va Khaterat-e Jalal Talabani [After Sixty Years: The Life and Memories of Jalal Talabani] (Elm Publication, Tehran) p.148.

${ }^{403}$ Ahmad-Talabani's supporters were the members of the Central Committee of the KDP, including Ali Asgar, Omar Dababeh, Nouri Shah-Veys, Ahmad Taha, Omar Mustafa, Ali Abdullah, and Halmi Ali Sharif The U.S. Department of State 198 to U.S. Embassy Tehran, September 3, 1964 (FRUS/196468/XXI/doc.166); Tehran A-466 to the U.S. State Department, "Implications of the Kurdish Cease-Fire: One Iranian Official View," enclosure 1, February 29, 1964 (NARA/RG59/CFPF/1964-66/Box2339/POL 13-3Ethnic Minorities), p.1.

${ }^{404}$ Qaneifard, Erfan, Pas az Shast Sal: Zendegi va Khaterat-e Jalal Talabani [After Sixty Years: The Life and Memories of Jalal Talabani] (Elm Publication, Tehran) p. 893.
} 
ceasefire as major roots lurking beneath the Kurdish cleavage. ${ }^{405}$ Besides, Barzani's "selfishness, arbitrariness, unfairness, tribal backwardness and even his dishonesty" was a major obstacle for a democratic decision-making process in the KDP. ${ }^{406}$ According to Isa Pejman, "Barzani himself had neither talent nor interest to manage the party and its bureaucracy. On the contrary, it was Ahmad's intellectual image and personality that attracted the young, educated Kurds in the post-revolutionary era." ${ }^{407}$ The unbridgeable rift between the two camps was ultimately intensified with the ceasefire of 1964 .

Right after the ceasefire agreement, Pejman was sent to Haj Omran, Barzani's main stronghold, to see his reasons for the termination of the war without consulting with Iran. In response to Pejman's objection, Barzani reacted: "I am the Party" ${ }^{\text {"408 }}$--a claim that reminded Louis XIV's famous quote, “L'État, c'est moi” (I am the State). Despite Pejman's promise of Iran's heavy military aid, Barzani did not show any flexibility and replied, "We have not taken any step against Iran and its national interests. We only intended to negotiate with Arif our demands. Our demands are not against the Shah and Iran. On top of that, our Peshmerga have been tired of bloody fights with the modernized Iraqi Army." ${ }^{409}$ In return, SAVAK pressed the Ahmad-Talabani faction to oppose Barzani. The faction publicly denounced the agreement, reemphasized demand for a Kurdish autonomy, and declared

\footnotetext{
${ }^{405}$ A political division between these two camps highly evolved from an incompatible combination of the KDP support-bases, pro-Barzani's tribal villagers, nomads, and conservative elements of Kurdish society, on the one side, and pro-Ahmad's progressive minded intellectual, the urban, and educated Kurds, on the other side. SAVAK Documents, No. h4/2367, 1 May 1964; SAVAK Documents, No. 313/123, 9 February 1964.

${ }^{406}$ Dann, Uriel, Iraq under Qasim: A Political History, 1958-1963 (London, Praeger, 1969) p.335.

${ }^{407}$ Qaneifard, Erfan, Pas az Shast Sal: Zendegi va Khaterat-e Jalal Talabani [After Sixty Years: The Life and Memories of Jalal Talabani] (Elm Publication, Tehran) p.84.

${ }^{408}$ Ibid. p. 148.

${ }^{409}$ Ibid. p. 148.
} 
that Barzani was not the leader of the Kurdish movement anymore. Omar Dababeh claimed that Barzani had received "a black bag full of Iraqi Dinars" from Arif. ${ }^{410}$ In the meantime, Talabani went to Tehran to consult with SAVAK and the Shah. Nevertheless, they were not able to challenge Barzani's position as the sole Kurdish leader. Barzani soon arrested their representatives upon their arrival at the KDP sixth Congress in Qala Dizeh in July 1964 and dispatched his oldest son, Idris, to their stronghold in Mawet when Talabani and Ahmad rejected Barzani's order for a full disarmament. ${ }^{411}$ Talabani and Ahmad withdrew their forces to Sardasht in the Northwest of Iran. ${ }^{412}$ They surrendered their weapons to Iran's Army and were then sent to Hamedan wherein they stayed until summer $1965 .^{413}$ The Kurdish civil war in the mid-60s divided the Iraqi Kurds for several decades and planted the seeds of a bloody Kurdish civil war in the 90 s. $^{414}$

The Kurdish civil war shook Iran's non-state foreign policy in Iraq. Nonetheless, Iran did not cut off all financial and logistical aid to Barzani. Despite the Shah's initial decision to terminate Iran's support, SAVAK played a key role in keeping connections with Barzani open. "Your Majesty, I think Arif and Prime Minister Abd al-Rahman al-

\footnotetext{
${ }^{410}$ Qaneifard, Erfan, Pas az Shast Sal: Zendegi va Khaterat-e Jalal Talabani [After Sixty Years: The Life and Memories of Jalal Talabani] (Elm Publication, Tehran) p.148.

${ }^{411}$ McDowall, David, A Modern History of the Kurds, London (New York 2004) p. 316.

${ }^{412}$ Including Omar Dababeh, Ali Asgari, and Aziz Aqravi.

${ }^{413}$ Qaneifard, Erfan, Pas az Shast Sal: Zendegi va Khaterat-e Jalal Talabani [After Sixty Years: The Life and Memories of Jalal Talabani] (Elm Publication, Tehran) p.148.

${ }^{414}$ Talabani later confessed, "One of the biggest mistakes I ever made was to break up with Barzani. I should not have done that. Generally speaking, we should not have acted in a way we did in summer 1964. At the time, I was criticizing both Mullah and Ahmad's positions. Both were radical and adamant. I should have stood in the middle ground. However, due to my strong commitment to the Party, I chose to stay with Ahmad and his followers." Qaneifard, Erfan, Pas az Shast Sal: Zendegi va Khaterat-e Jalal Talabani [After Sixty Years: The Life and Memories of Jalal Talabani] (Elm Publication, Tehran) p.991.
} 
Bazzaz will not eventually implement the agreement. Furthermore, the majority of the KDP leaders have been opposed to the agreement. Lastly, we have so far built up deep ties with both Kurdish factions. Thus, it would not be a good idea to leave them alone." ${ }^{415}$ The Shah was finally convinced not to halt the flows of arms from Iran to Barzani, though simultaneously he worked to lessen tension between two factions.

\section{Iraq-Egypt Unity and the Collapse of the 1964 Ceasefire}

The ceasefire Agreement of 1964 released Arif from a domestic war with the Kurds and in return, revived the formation of "one army, one economy, one nation" out of Iraq and Egypt. ${ }^{416}$ Backed by the Iraqi Army, Arif declared the unity plan with Egypt on 22 March 1964 and two months later, on May 26, a Joint Presidency Council under Nasser's leadership was established. ${ }^{417}$ With the suppression of a Baath plot by pro-Nasser forces in Baghdad, Cairo dispatched 6,000 men force to Iraq to secure the Iraqi regime. SAVAK, however, considered Nasser's move as Nasser's plan to sabotage Tehran. ${ }^{418}$ Later, Egypt began building up naval forces in Faw, Iraq's only port in the Persian Gulf, and joined Iraq's newly-founded council of The Arabian Gulf. ${ }^{419}$ With a military maneuver of Iraq and Egypt, the threat of Arab Unity reached its peak on Iran's western borders. ${ }^{420}$ It was in this context that Arif repeated Iraq's claim on Khuzestan. As the Shah argued, "the main

\footnotetext{
${ }^{415}$ Qaneifard, Erfan, Tondbad-e Havades: Goftogooi ba Isa Pejman [Hurricane of Events: A Dialogue with Isa Pejman] (Elm Publication, Tehran, 2011) p. 149.

${ }^{416}$ SAVAK Documents, No. 477, 27 May 1964.

${ }^{417}$ SAVAK Documents, No. 316/11439, 22 June 1964; SAVAK Documents, No. 321/26593, 16 October 164.

${ }^{418}$ SAVAK Documents, No. 1/1073, 6 September 1964.

${ }^{419}$ SAVAK Documents, No. 2/910, 7 August 1964.

${ }^{420}$ SAVAK Documents, No. 1470, 22 September 1964.
} 
threat to Iran is not the Soviet Union but the United Arab Republic." ${ }^{421}$ In this atmosphere, the Shah instructed SAVAK to revive the connection with Barzani.

As time wore on, the ceasefire of 1964 did not lead to a permanent peace. It was, in fact, a tactical move for both sides, giving them a break to regroup and consolidate their positions. $^{422}$ The announcement of the Iraqi Provisional Constitution in May 1964 without including their demands disappointed the Iraqi Kurds. At the same time, Barzani was under Iranian and Israeli pressure to resume the war with Baghdad. On 11 October 1964, Mullah Mustafa publicly raised a demand for an autonomous Iraqi Kurdistan. He also threatened Baghdad with a declaration of Independence in case of Iraqi unity with Egypt. ${ }^{423}$ Convinced by his army generals, Arif rebuffed Barzani's request. ${ }^{424}$ As the most powerful Iraqi institution since the late 50s, the Iraqi army had been opposed to concessions to the Kurds. According to SAVAK, "the most important factor to rule Iraq and keep stability in such a fragile country is to have the Iraqi Army on your side. ${ }^{\text {425 }}$ Nonetheless, it seemed Iraqi generals had forgotten the failures of Baghdad's Kurdish campaigns. ${ }^{426}$ Despite

${ }^{421}$ SAVAK Documents, No. 213/45247, 13 March, 1965.

${ }^{422}$ With his power secure in the KDP, Barzani began establishing three assemblies to administer Kurdish affairs. Mullah Mustafa established a Senate with forty-three members chaired by Shaykh Latif, a consultative assembly with eleven members under the presidency of Mamand Abbas Agha, and an executive 'Revolutionary Council' under his own direction. See O'Ballance, Edgar. The Kurdish Revolt, 1961---1970 (London: Faber and Faber Ltd., 1973). p.123.

${ }^{423}$ Barzani demanded controversial Kirkuk and Khaniqin oilfields, a fare-share of Iraqi oil income, and the recognition of the Kurdish language as an official language in Kurdistan. Baghdad 3298 to Iran's Ministry of Foreign Affairs, 29 October 1964.

${ }^{424}$ On 3 December 1964, Sobhi Abdul-Hamid, Iraqi Minister of Internal Affairs, rejected Barzani’s request and stated that "the central government has no plan to give an autonomy right to any region of Iraq." Qaneifard, Erfan, Pas az Shast Sal: Zendegi va Khaterat-e Jalal Talabani [After Sixty Years: The Life and Memories of Jalal Talabani] (Elm Publication, Tehran) p. 906.

${ }^{425}$ London 1305 to Ministry of Foreign Affairs, 2 August 1963.

426 The U.S. Department of State, INR, "The Kurdish Situation in Iraq", RNA-11, April 5, 1965 (JPL/NSF/Box.28/RWK/Iraq-Kurds [1964-March 1966]/doc.9), pp.3-12. 
Nasser's stress on a political and peaceful solution for the Kurdish question, ${ }^{427}$ Baghdad launched another invasion of Iraqi Kurdistan. The resumption of the Kurdish War favored Iran. To weaken Baghdad and Cairo, SAVAK and Mossad bypassed the U.S. and provided the Iraqi Kurds with logistics and ammunitions. Beyond providing arms for Barzani's Peshmerga, Iran tried to bridge a gap between two Kurdish factions. SAVAK was aware that since the resumption of the war, Arif had been supporting the Talabani-Ahmad faction to weaken Barzani's position. Backed by Baghdad, Talabani had opened KDP branches in Erbil and Rawandez. ${ }^{428}$ SAVAK considered this progress as Nasser's leverage over Arif in support of Talabani to stir up a revolution in Iran and weaken the Barzani-Iran alliance. ${ }^{429}$ According to SAVAK, the Iraqi plot was designed to instigate the Iranian Kurds. ${ }^{430}$ Within this context, Iran tried to put the two Kurdish factions together. With SAVAK's pressure, Ibrahim Ahmad wrote a letter to Mullah Mustafa on 16 March 1965 and asked him to forget inter-Kurdish enmity. With a growing desire to crack down on the Peshmerga, Baghdad launched vitriolic propaganda against Tehran. In April 1965, Naji Talib, Iraqi Foreign Minister, denounced Iran for its support of the Kurds and called Iran's interference a major factor for Iraqi failure in the Kurdish war. "Several loads of unidentified equipment were transported onto Iraqi soil in jeeps without license plates" from Iran, Talib claimed. ${ }^{431}$

\footnotetext{
${ }^{427}$ Nasser knew that the resumption of war in Kurdistan would certainly disrupt his Arab Unity plan. Baghdad 362 to U.S. Department of State, October 26, 1964 (FRUS/1964-68/XXI/doc.167).

${ }^{428}$ SAVAK Documents, No. 314/34828, 12 October 1965.

${ }^{429}$ SAVAK Documents, No. 232, 8 June 1967.

${ }^{430}$ Taher and Qobad Semiqto as well as Rahim Seyf Qazi, Qazi Mohammad's son, were supposed to be the head of Iranian Kurdistan SAVAK Documents, No. 4394, 25 August 1966.

${ }^{431}$ The U.S. Department of State, Memorandum of Conversation, “The Kurdish Problem,” December 10, 1964 (JPL/NSF/Box.28/RWK/Iraq [December 1963-March 1966]/doc.18a), pp.1-2.
} 
President Arif also pointed out that "a backward foreign regime [i.e., Iran] is supporting ethnic and tribal tensions in Iraq." ${ }^{432}$ Heikal also accused the Shah as "the West agent" against the Arab people by supporting the Iraqi Kurds and royalist guerrillas of the Mutawakkilite Kingdom against the pro-Nasser Yemen Arab Republic. In the same line, Brigadier general Abdul-Qadir Yasin put that the Kurds were directly supported by Iran and the Iranians provided 40,000 guns for them. ${ }^{433}$

\section{The Shah vs. Johnson}

The U.S. policy toward the Kurds and Baghdad was still at odds with its allies. ${ }^{434}$ In the wake of the resumption of the war in Iraqi Kurdistan, SAVAK and Mossad provided arms and financial aid to Barzani's Peshmerga. Both states were backed by London whose policy in the Persian Gulf was to contain Egypt. The UK ambassador to Baghdad, Stephen Egerton, had urged Barzani to renew a war with Arif and promised him support for their resurgence through Iran. ${ }^{435}$ According to the U.S. ambassador Strong, "Britain shares with Israel and the Shah a deep antipathy for Nasser ... given the depth of [British] hostility to Nasser and the importance of the [Persian] Gulf to the UK, the British may well engage in covert cooperation with Iran and Israel against a Nasserist dominated Iraqi regime as well as against Nasser elsewhere. ${ }^{236}$ In August 1964, SAVAK Director Pakravan met with MI6

\footnotetext{
432 SAVAK Documents, No. 231/45304, 19 March 1965.

${ }^{433}$ SAVAK Documents, No. 142613.

${ }^{434}$ Patterson E.A., 'Airgram from the Embassy in Iraq to the Department of State', FRUS, 1964-1968, Volume $X X I$, Document 177; and Patterson E.A., 'Telegram from the Embassy in Iraq to the Department of State', FRUS, 1964-1968, Volume XXI, Document 171

${ }^{435}$ U.S. Embassy Baghdad, Memorandum, "Indicators of British Activity Against Iraq and Cooperation with Iran in such Activity," October 15, 1964 (JPL/NSF/Box.28/RWK/Iraq [December 1963-March 1966]/doc. 23a), p.1.

${ }^{436}$ U.S. Embassy Baghdad, Memorandum, "Indicators of British Activity Against Iraq and Cooperation with Iran in such Activity,” October 15, 1964 (JPL/NSF/Box.28/RWK/Iraq [December 1963-March 1966]/doc.
} 
officials in London and successfully planned Iranian-English support for the Kurds. ${ }^{437}$ PanArabism had become a major denominator of Iran's, Israel's, and Britain's common interests. The Iraqi Kurds had become a tool to destabilize Iraq, to turn Baghdad away from a possible Arab-Israeli war, and to divert Egypt's interest in the Persian Gulf.

As the war raged in the north of Iraq, Arif asked the U.S. to press Iran to cut off its support for Barzani. The Johnson administration considered that the outbreak of the war would catalyze Moscow's subversive activity against Baghdad. Therefore, it turned down Barzani's request for the support. ${ }^{438}$ The White House tried to convince the Shah to abandon the support for the Kurds when Secretary Rusk met him in Tehran during his stay at the CENTO meeting on 7 April 1965. In the middle of the conversation, the Shah contended that he would not stop backing the Kurds unless a national regime was established in Baghdad. He also clarified his support for the Iraqi Kurds to tie down the Iraqi Army as long as Baghdad sided with Cairo. ${ }^{439}$ Iran was determined to support the Kurds, especially after the national anthems and flag unification of Iraq and Egypt of 31 May $1965 .{ }^{440}$ On August 13, the Department of the State informed the Iranian Ministry of

\footnotetext{
23a), p.2; London's goals were "to make obstacle in the unification of Iraq-Egypt," "keep internally Iraq divided and weak," and "keep its national interests in the Persian Gulf out of Baghdad's hands as well as protecting oil flowing from the Middle East." Baghdad A-424 to U.S. Department of State, enclosure: "Kurds - Iraq," no date (NARA/RG59/CFPF/1964-66/Box2339/POL 13-3-Ethnic Minorities), p.1.

${ }^{437}$ U.S. Embassy Baghdad, Memorandum, "Indicators of British Activity Against Iraq and Cooperation with Iran in such Activity," October 15, 1964 (JPL/NSF/Box.28/RWK/Iraq [December 1963-March 1966]/doc.23a), p.2.

${ }^{438}$ Tehran A-625 to U.S. Department of State, "Iran-Iraq: Letter to President Johnson from Mullah Mustafa Barzani,” March 12, 1965 (NARA/RG59/CFPF/1964-66/Box2339/POL 13-3-Ethnic Minorities), pp.1-2.

${ }^{439}$ Tabriz A-25 to State, "Iranian Government Policy in Kurdestan and its Effect on Kurdish Attitudes," March 24, 1966 (NARA/RG59/CFPF/1964-66/Box2339/POL 13-3-Ethnic Minorities), pp.5-9.

${ }^{440}$ SAVAK Documents, No. 314/16084, 1 June 1965.
} 
Foreign Affairs of the U.S. "concern over pressures by Iraqis arising out of Iranian assistance to Kurds. ${ }^{, 441}$ In response, Abbas Aram, the Iranian Foreign Minister, denied Iran's support for the Kurds and claimed, "it is Iraq that follows a policy to annoy Iran.",442

U.S. relations with Baghdad improved when Abd al-Rahman al-Bazzaz, a Westernoriented lawyer, was appointed as the first civilian prime minister in the post-1958 revolutionary Iraq. Right after an aborted coup, led by pro-Nasser Prime Minister Arif Abd ar-Razzak, President Arif ousted Nasserist elements from the cabinet and weakened Baghdad-Cairo relations. ${ }^{433}$ Prime Minister Bazzaz's first move was to urge the U.S. to press Tehran for its secret war against Baghdad in Iraqi Kurdistan. "Iranians were creating future trouble for themselves by continuing clandestine assistance to the Iraqi-Kurdish insurgents," Bazzaz told Rusk in October 1965. ${ }^{444}$ The U.S. shared his view since a "high degree of autonomy or independence for the Iraqi Kurds would be disruptive to area stability and inimical" to the U.S. "interests in the long run" by stirring up the Kurdish question in Turkey and Iran and could be hijacked by Moscow ${ }^{445}$ Thus, the best possible option for the U.S. was to convince the Kurds to participate in "the united Iraq.",446 Ambassador Strong advised the Kurds to avoid siding with external players, i.e., Iran, ${ }^{447}$

441 The U.S. Department of State 138 to U.S. Embassy Tehran, August 11, 1965 (FRUS/196468/XXI/doc.175).

${ }^{442}$ U.S. Department of State 138 to U.S. Embassy Tehran, August 11, 1965 (FRUS/1964-68/XXI/doc.175).

${ }^{443}$ SAVAK Documents, No. 313/20851, 27 June 1966; SAVAK Documents, No. 313/27705, 4 September 1965.

444 U.S. Department of State, Memorandum of Conversation, "Kurdish Affairs," October 8, 1965 (JPL/NSF/Box.28/RWK/Iraq [December 1963-March 1966]/doc.8), pp.1-2.

445 Baghdad A-424 to U.S. Department of State, "Analysis of the Kurdish Problem," October 30, 1965 (NARA/RG59/CFPF/1964-66/Box2339/POL 13-3-Ethnic Minorities), pp.1-2.

${ }^{446}$ Ibid. 
because Baghdad-Barzani's negotiations could "guarantee the framework of the country of Iraq" and "decrease the foreign interference." ${ }^{448}$ Indeed, the main U.S. concern in Iraq was to prevent communism and to keep the country out of Moscow's orbit. ${ }^{449}$ Iran's central objective, however, was to keep Iraq "weak, divided, and separate from Nasser" to advance its supremacy in the Persian Gulf. ${ }^{450}$ It was in this context that the U.S. embassy in Baghdad warned that "continued Iranian/Israeli intervention is a threat to the United States position in Iraq but, unfortunately, neither country is likely to be heedful of United States interests in this matter. ${ }^{, 451}$ Iran had effectively challenged U.S. interests.

\section{A Non-Arab Triangle: Iran, Israel, and the Kurds}

By fall 1965, the war had become a catastrophe for Iraq. In November 1965, with the Iranian Army's heavy support, the Kurds launched a successful attack against Iraqi strongholds. ${ }^{452}$ In retaliation, a few Iranian soldiers were shot by the Iraqi irregulars on 7 December 1965. The tension between two countries escalated when Iraqi MIG jets bombed a border post in Iran on 21 December 1965. Iran, in response, mobilized its troops along the frontier and intensified backing the Kurds and the Peshmerga pushed the Iraqi forces back with the substantial support of the Iranian artillery. As spring 1966 approached, the

\footnotetext{
${ }^{447}$ Patterson E.A., 'Telegram from the Embassy in Iraq to the Department of State', FRUS, 1964-1968, Volume XXI, Document 167.

${ }^{448}$ Ibid.

449 Baghdad A-424 to U.S. Department of State, enclosure: "Kurds - Iraq," no date (NARA/RG59/CFPF/1964-66/Box2339/POL 13-3-Ethnic Minorities), p.1.

${ }^{450}$ Ibid.

451 Baghdad A-424 to State, "Analysis of the Kurdish Problem," October 30, 1965 (NARA/RG59/CFPF/1964-66/Box2339/POL 13-3-Ethnic Minorities), pp.1-2.

${ }^{452}$ Tehran A-607 to U.S. Department of State, "The Iran-Iraq Crisis of December/January: An Analysis," March 5, 1966 (NARA/RG59/CFPF/1964-66/Box2339/POL 13-3-Ethnic Minorities), pp.2-3.
} 
Prime Minister Bazzaz took a risk and proposed to Barzani a decentralization law that could have economically, culturally, and socially rehabilitated Iraqi Kurdistan with a full recognition of the Kurdish identity. ${ }^{453}$ In the meantime, Bazzaz invited Iranian Prime Minister Amir Abbas Hoveyda to Baghdad. However, Iraqi military generals called for the termination of Iran's support for the Kurds before any negotiation between two countries and thus, wrecked the proposal. ${ }^{454}$ Both Arif and general Abd al-Aziz al-Uqaili, Iraq's Defense Minister and the Chief Commander of Iraq Army, were against the plan. ${ }^{455}$ They thought any concession to the Iraqi Kurds would weaken Baghdad. ${ }^{456}$ The secret talks with Barzani then broke down when Uqayli stated "military operations [would] continue until the [Kurds were] defeated. ${ }^{, 457}$ While Bazzaz argued that a peaceful settlement of the Kurdish question would be a major pre-condition for Iraqi progress, Uqayli determined to bring Barzani to his knees since he firmly believed "The West and the East, both, are creating a 'new Israel' in the north of Iraq. ${ }^{458}$ For Baghdad, an Iranian-Israeli-Kurdish

\footnotetext{
453 "The new administrative law will affirm the reality of Kurdish nationalism and will enable our citizens in the north fully to preserve their language and cultural heritage. It will also enable them to carry on local activities which do not conflict with the unity of the country and which in no way paves the way for the loss of any part of our homeland", Bazzaz explicated. See McDowall, David, A Modern History of the Kurds (London, New York 2004) p.318.

${ }^{454}$ Tehran A-607 to the U.S. Department of State, "The Iran-Iraq Crisis of December/January: An Analysis," March 5, 1966 (NARA/RG59/CFPF/1964-66/Box2339/POL 13-3-Ethnic Minorities), p.3.

${ }^{455}$ Baghdad A-801 to U.S. Department of State, "Confidential Contacts Between the Iraqi Government and the Kurdish Rebels," March 26, 1966 (NARA/RG59/CFPF/1964-66/Box2339/POL 13-3-Ethnic Minorities), pp.1-4.

${ }^{456}$ SAVAK Documents, No. 232/47162, 1 March 1966; SAVAK Documents, No. 233/43229, 12 April 1966.

${ }^{457}$ Baghdad A-792 to U.S. Department of State, "Iraqi Defense Minister Uqaili on Kurdish Situation; Outlook for Spring Campaign," March 26, 1966 (NARA/RG59/CFPF/1964-66/Box2339/POL 13-3-Ethnic Minorities), pp.1-2.

${ }^{458}$ Qaneifard, Erfan, Pas az Shast Sal: Zendegi va Khaterat-e Jalal Talabani [After Sixty Years: The Life and Memories of Jalal Talabani] (Elm Publication, Tehran) p. 916.
} 
triangular alliance was an existential threat. Israel had sided with Kurds to turn away the Iraqi army from an upcoming Arab-Israeli war on the Jordanian or Syrian fronts. In 1964, Kamran Bedir Khan, Barzani's envoy, was invited to Israel and met with Israeli leaders. Ben-Gurion then authorized Mossad to supply money, anti-tank and anti-aircraft weapons, and dispatched a Mossad envoy David Kimche to Iraqi Kurdistan. Kimche went to Iraqi Kurdistan and met Mullah Mustafa in May 1965. Geography, however, limited the Israeli agency in siding with the Iraqi Kurds. While Turkey had a close tie with Israeli leaders, Ankara's harsh anti-Kurd attitude led Israel to see Iran as the only possible conduit to assist Barzani. The Shah had already permitted limited Israeli support for the Kurds in $1961,{ }^{459}$ but he refrained from entering full cooperation with Israel in Iraqi Kurdistan. For Israel, the Shah's hesitation would be a big challenge its Doctrine of Periphery. As time wore on, Arif's territorial claim of Khuzestan and Arvand Rud weakened Iran's hesitation to fully cooperated with Israel in Iraqi Kurdistan. To alleviate the Shah's hesitation, Mossad Director Meir Amit met with SAVAK Director Pakravan in Paris. In the meeting, Pakravan warned Amit of Tehran's concern over the Kurdish threat and insisted that any operation should be coordinated with SAVAK. ${ }^{460}$ Pakravan also offered his Mossad counterpart to keep the cooperation in secret. Tel-Aviv immediately accepted Tehran's condition and agreed to exchange detailed information with SAVAK. They also decided to keep it in strict secrecy from other allies, particularly the U.S., and to deny support for the Kurds if

\footnotetext{
${ }^{459}$ Rubin, Avshalom, Abd al-Karim Qasim and the Kurds of Iraq: Centralization, Resistance, and Revolt, 1958-63, (2007) Middle Eastern Studies, 43 (3): 373.

${ }^{460}$ Parsi, Trita, Treacherous Alliance: The Secret Dealings of Israel, Iran, and the United States (Yale University Press, 2007) p.53.
} 
the covert cooperation was exposed. ${ }^{461}$ It was one of the rare instances wherein the U.S. allies, Iran and Israel, tried to bypass their superpower ally. ${ }^{462}$ However, the U.S. was aware of Israeli-Iranian secret meetings over the Kurdish issue, though the full extent of their cooperation was not clear to the White House. "Israel plays an important role in Iran and is known to be supporting the Iraqi Kurds," a memo prepared by Ambassador Strong raised Israel's cooperation with Iran in Iraqi Kurdistan for the first time. ${ }^{463}$ After several months of Israel's lobbying, the first agreement of the non-Arab triangle of Iran, Israel, and the Kurds was eventually sealed in May $1965 .{ }^{464}$ Dressed in traditional Kurdish costumes and escorted on Pejman, General Tzur and two senior Israeli military intelligence officers crossed the Iraqi border on foot to join Pakravan at Barzani’s headquarter in Haj Omran. ${ }^{465}$ After two days of talks, Israel offered a huge supply of arms, ammunition, and funds to Mullah Mustafa. Iran also provided the Kurds with funding and material assistance. More significantly, Iran became a major conduit for the Israeli military and medical aid. The Israeli shipment of weapons and ammunition, mostly the Russian-made weapons captured

\footnotetext{
${ }^{461}$ Schonmann, Noa, Israel's Phantom Pact: Foreign Policy on the Periphery of the Middle East: Foreign Policy in the Periphery of the Middle East (I.B. Tauris \& Co Ltd, 2015) p. 259.

${ }^{462}$ In another occasion, Iran and Israel went to great lengths to keep the U.S. in the dark of their secret Ballistic Missile cooperation, known as the Project Flower, in 1977-8. For more discussion, see Parsi, Trita, Treacherous Alliance: The Secret Dealings of Israel, Iran, and the United States (Yale University Press, 2007) pp. 74-78.

${ }^{463}$ U.S. Embassy Baghdad, Memorandum, "Indicators of British Activity Against Iraq and Cooperation with Iran in such Activity," October 15, 1964 (JPL/NSF/Box.28/RWK/Iraq [December 1963-March 1966]/doc.23a), p.2.

${ }^{464}$ Parsi, Trita, Treacherous Alliance: The Secret Dealings of Israel, Iran, and the United States (Yale University Press, 2007) p.13.

${ }^{465}$ Qaneifard, Tondbad-e Havades: Goftogooi ba Isa Pejman (Hurricane of Events: A Dialogue with Isa Pejman) (Elm Publication, Tehran, 2011) p. 165.
} 
by the Israelis in fighting with Arabs, reached Iraqi Kurdistan by the winter of $1965 .{ }^{466}$ The most remarkable impact of Israeli involvement in the north of Iraq was improvement in the Peshmerga's tactics. Before, the Peshmerga' victories were mainly because of the Iraqi army's "gross incompetence," rather than the Kurds' effective "guerrilla warfare" since they had "little aptitude for" this tactic. ${ }^{467}$ Conversely, after Mossad-SAVAK cooperation, the Kurds "refused to defend flat areas, let the government move into the mountains albeit at the cost of some casualties, attacked army supply lines and [were] now apparently attacking bivouac areas. ${ }^{468}$ Ironically, factions of SAVAK and the Iranian Army were against Iran-Israeli cooperation. They thought Iran's warm relation with Israel would considerably harm the country's regional position by exposing it to the Pan-Arab propaganda. They also argued that any possible credit for the Kurdish success in Iraq would eventually go to Israel, rather than Iran, since the Israelis' involvement in training Peshmerga had been more effective than Iranians'. It would, thus, provide the Jewish state a strategic space beyond its 'bloody borders' that might, in return, pose danger to Iran's national security some day in the future by planting the seeds of the Kurdish separatism. ${ }^{469}$ "I was called by major general Ali Motazed, Chief of SAVAK External Intelligence Organization, from Baghdad to Tehran. He told me that Chief Staff of the Israeli Army and

\footnotetext{
${ }^{466}$ It was a brilliant idea operated by SAVAK and Mossad. First, the ubiquitous Russian-made weapons throughout the Third World would not raise any curiosity in the middle of the Cold War. Second, and in contrast to American-made weapons, Soviet weapons would permit both Iran and Israel to deny their involvement inside Iraqi territory. Third, the presence of Russian arms in Iraqi Kurdistan would deepen tension between Moscow and Baghdad.

467 Baghdad A-1115 to U.S. Department of State, "Kurdish Revolution of 1961," June 30, 1965 (NARA/RG59/CFPF/1964-66/Box2339/POL 13-3-Ethnic Minorities), p.14-15.

${ }^{468}$ Ibid.

${ }^{469}$ Qaneifard, Erfan, Tondbad-e Havades: Goftogooi ba Isa Pejman [Hurricane of Events: A Dialogue with Isa Pejman] (Elm Publication, Tehran, 2011) p. 164.
} 
his deputy, accompanied by chiefs of the Second and the Third SAVAK directorates, met Barzani. I asked him of the necessity of Mossad's connections with the Kurds. He promptly replied back, 'Only the Shah knows," "'470 Pejman recalled. He was worried that with an Israeli strategic presence on Iran's western borders, there would be no more space for Iran. Nonetheless, neither SAVAK nor the Iranian Army dared to object to the Shah's decision. On the Kurdish side, there was no consensus over siding with Israel. While Barzani welcomed building ties with Israel, socialist Talabani and Ahmad were against it. They were also unaware of Kamran-Bedir Khan secret meetings in Europe and Israel. They knew that major Arab states, notably Egypt, and the Soviets were against the Israeli-Kurd connections. "The Russians promised us full-support for the Kurdish Movement. They even told me that the Kurds could keep their connection with the Shah against Baghdad. However, they strongly warned us not to make relations with Israel,” Talabani explained. ${ }^{471}$

\section{Shaky Baghdad}

In April 1966, Baghdad planned a final assault. However, President Abdul Salam Arif was killed in a helicopter crash on April $13 .{ }^{472}$ Arif's death prompted a power struggle in Baghdad between the civilian and military elements. After four days of internal debate and Bazzaz's interim presidency, General Abdul Rahman Arif, Arif's brother, became the new president. The Kurds welcomed Arif's unexpected death. ${ }^{473}$ In the meantime, the war

\footnotetext{
${ }^{470}$ Ibod. p. 164.

${ }^{471}$ Ibid. p. 785. Three decades later, and in the midst of the Kurdish Civil War of the 90s, he named Mullah Mustafa as an Israeli 'mercenary'. Ibid, p. 785.

${ }^{472}$ It was mostly believed that the crash was planned by Baathist elements in the Iraqi military- See "AbdulRahman Aref, 91, Former Iraqi President, Is Dead”, The New York Times. August 25, 2007.

473 According to Talabani, "Arif did not have good relations with the Kurds at all. I can clearly state that Qasim and Arif had a separate policy towards Kurds. Although we were fighting with Qasim, he was not anti-Kurds. Rather, Qasim strongly believed in political, bureaucratic, and cultural rights of the Kurds, though
} 
ground to a halt when Barzani announced a month-long ceasefire expecting Baghdad's new response to the Kurds' demands. In return, Arif ousted warmonger Uqayli and relied more on Bazzaz. Nevertheless, the Kurds' optimism soon evaporated. Finally, Iraqi generals won the debate over the war and launched another military campaign on 2 May $1966 .{ }^{474}$ The Iraqi army machine of 40,000 troops attacked the North. Their main goal was to cut mountain supply lines from Iran to Barzani's headquarters in Rawanduz. A hundred combat aircraft extensively bombarded the Kurds with poison gas, damaging Iranian villages close to the border with Iraq. ${ }^{475}$ The Iraqi army captured a strategic supply route road running to the Iranian border and strategic mountains, like Mount Zozik. ${ }^{476}$ Nevertheless, Iraqi generals were unaware of the depth of Mossad-SAVAK support for the Kurds. Logistically supported by the Iranian Army and SAVAK and commanded by Zuri Sagy, an Israeli officer, the Peshmerga surrounded the Iraqi Army at Mount Handren. After two days of a blood-bathing fight, 1,400 to 2,000 Iraqi soldiers were butchered, hundreds more captured, and large quantities of arms and ammunition abandoned. ${ }^{477}$ The Battle of Mount Handrin shattered Iraqi Army morale and brought its massive military offensive to a destructive humiliation. It was the peak of the Iran-Israel secret war in Iraqi Kurdistan.

in a limited way. In fact, minor tensions [between Qasim and the KDP] caused his disinclination in [the cooperation with] the Kurds. On the contrary, Arif had a Pan-Arab, Racist, and even Chauvinist view towards the Kurds. He believed that the Kurds are Arabs ... He had a ridiculous theory, claiming that the Kurds were Arabs whose language had been slightly diverted throughout the centuries since they had inhabited in the mountains!" Qaneifard, Erfan, Pas az Shast Sal: Zendegi va Khaterat-e Jalal Talabani [After Sixty Years: The Life and Memories of Jalal Talabani] (Elm Publication, Tehran) p.786.

${ }^{474}$ O’Ballance, Edgar, The Kurdish Revolt, 1961-1970 (London: Faber and Faber Ltd., 1973) pp.136-7.

${ }^{475}$ Paris 3800 to Iran's Ministry of Foreign Affairs, 18 March 1966.

${ }^{476}$ Baghdad A-212 to U.S. Department of State, "Kurdish and General Iraqi Situations," September 14, 1966 (NARA/RG59/CFPF/1964-66/Box2339/POL 13-3-Ethnic Minorities), p.1.

${ }^{477}$ Pollack, Kenneth. Arabs at War: Military Effectiveness, 1948-1991 (University of Nebraska Press, 2002) p.163. 
The Battle of Mount Handerin reaffirmed the futility of the use of brute force to settle the Kurdish question and thus forced Baghdad to offer Barzani a peace settlement. After a few weeks of talks, Prime Minister Bazzaz announced a 'Twelve Point Plan', known as the 'Bazzaz Declaration', on June 29, 1966. Covering major Kurdish demands, ${ }^{478}$ the Bazzaz Declaration was immediately accepted by Barzani, though the KDP Sixth Congress indicated that the Kurds would still push for autonomy in November 1966. The Bazzaz Declaration was also welcomed by the U.S. However, Arif's weak personality rendered him unable to end the power struggle in Baghdad. Although the Bazzaz Declaration deal was a breakthrough, it was harshly criticized by the Iraqi Army which was suspicious of Bazzaz's intention to limit the Army budget and privileges. With an aborted pro-Nasser coup of 30 June 1966, led by former prime minister General Aref Abdul-Razzaq, ${ }^{479}$ the Army intensified its pressure on Arif and Bazzaz was replaced with General Naji Talib on 6 August 1966 and ended the only civilian government in pre-2003 Iraq. The Battle of Mount Handerin slightly revived Baghdad-Tehran relations. Prime Minister Bazzaz pleaded with Saudi King Faisal to mediate between Iran and his country. After rounds of talks, along with the effective role of Iran's ambassador to Baghdad, Mehdi Pirasteh, the two countries came to lessen the tension by the removal of their heavy propaganda against

\footnotetext{
478 The Bazzaz Declaration included: 1. Recognition of Kurdish national rights; 2. Administrative decentralization to give effect to these rights; 3 . Recognition of Kurdish as an official language; 4. Kurdish representation in parliament; 5 . Kurdish share of official positions; 6 . Scholarships for Kurds and a Baghdad University branch in the North; 7. Kurdish local government officials; 8. Kurdish political organizations; 9. Amnesty for Kurds; 10. the Return of Kurdish guerrillas to previous posts and maintenance by some in an approved organization (i.e., Peshmerga); 11. The relief and economic assistance; and finally, 12. Resettlement of Kurds and others in their traditional locales. See Baghdad A-1065 to U.S. Department of State, "Iraqi Government's 12-Point Proposal to the Kurds," June 22, 1966 (NARA/RG59/CFPF/196466/Box2339/POL 13-3-Ethnic Minorities), pp.1-2.

${ }^{479}$ He was the chief commander of Air Force at the time. Baghdad 12 to U.S. Department of State, July 2, 1966 (FRUS/1964-68/XXI/doc.182).
} 
each other, the establishment of a common committee on their border disputes, and the withdrawal of Iran's Army from controversial spots on the borders. In December 1966, Foreign Minister Abbas Aram went to Baghdad, and in return, President Arif left Iraq to Tehran and met with the Shah in the Niavaran Palace on 13 March 1967. Both leaders came to an agreement on Arvand Rud and the Kurdish issue. Arif tried to cultivate a friendly personal relationship with the Shah. According to Ja'far Raed, a major Iranian diplomat, in the middle of the meeting, Arif suggested the Shah continue their discussion in a private meeting without any diplomats, ministries, and ambassadors. "Arif spoke just in Arabic. I was then called for the translation. In the meeting, Arif promised the Shah to put an end to the Arvand Rud crisis and realize the Shah's demands. He asked the Shah to cut off his support for the Kurds. The Shah immediately agreed." ${ }^{480}$ It was a strategic victory for the Shah. After all, the Shah's main goals were to win border disputes in Arvand Rud and prevent the formation of a pro-Nasser regime in Baghdad. Time was on the Shah's side.

\section{Transformative Years 1967-9}

On 5 June 1967, Israel launched a preemptive war against Egypt, Syria, and Jordan. The attack so surprised Iraq that it could not participate in the war, though Iraq's Third Armored Division had been already stationed in Jordan, close to West Bank. Beyond a swift and decisive victory of Tel-Aviv over the weak Jordanian army, the Kurdish threat had pinned down the Iraqi Army in Kurdistan. Morally beaten down by the Battle of Mount Handren, Baghdad did not want to take a risk and divert its army away from Kurdistan. ${ }^{481}$

\footnotetext{
${ }^{480}$ Qaneifard, Erfan, [Tondbad-e Havades: Goftogooi ba Isa Pejman (Hurricane of Events: A Dialogue with Isa Pejman] (Elm Publication, Tehran, 2011) p. 159.

${ }^{481}$ Pollack, Kenneth. Arabs at War: Military Effectiveness, 1948-1991 (University of Nebraska Press, 2002) p.167.
} 
Shortly before the outbreak of the Six Days War, "an Israeli agent ... visited Mullah Mustafa to arrange, if possible, some Kurdish action to tie down the Iraqi army." Although the Kurds did not launch an invasion in June 1967, the Kurdish-Israeli military coordination reaffirmed SAVAK's and the Iranian Army officers' suspicion of the Israel's growing leverage in Iraqi Kurdistan. It showed that Barzani could bypass SAVAK and team up against any regional states. On top of that, the devastating Israeli victory over its Arab neighbors spurred radicalism and anti-American zeal in the Arab World. More significantly, Baghdad's ineffective reaction in the war weakened the moderate Arif regime in favor of "extremists in [the] name of national unity." ${ }^{\text {" }} 83$ With damaged prestige after the Battle of Mount Handrin and the Six Day War, Arif's regime was subject to increasing plots led by the Baath and Arab nationalist groups. ${ }^{484}$ The Iraqi threat to Iran had been almost eliminated. The post-war tectonic shifts in the geopolitical trends of the Middle East were later followed in 1968 by London's announcement of a withdrawal of its military forces from 'East of Suez' by the end of 1971. Amidst the ensuing anti-American zeal following the Six Day War, the British withdrawal announcement intensified Moscow's move to shore up its leverage inside Iraq. On 2 April 1968, Moscow signed an oil deal with Baghdad, and on 11 May, Russian naval forces entered the Persian Gulf for the first time since 1903 and visited the Iraqi port of Faw. It was a significant advance in the Russian-

\footnotetext{
${ }^{482}$ U.S. Department of State, Bureau of Intelligence and Research, "New Kurdish Insurgency Threatens," IN-709, September 1, 1967 (FRUS/1964-68/XXI/doc.197).

${ }^{483}$ Baghdad 2143 to U.S. Department of State, June 8, 1967 (FRUS/1964-68/XXI/doc.195).

${ }^{484}$ According to the CIA, "the balance of forces is such that no group feels power enough to take decisive steps; the result is a situation in which many important political and economic matters are simply ignored." CIA, "Iraq: The Stagnant Revolution," SM 11-68, May 22, 1968 (JPL/NSF/HSF/Box16/Iraq 4/1/661/20/69/doc.25), pp.1-15.
} 
Iraqi relations that alarmed the Americans. For the first time, "the [Kurdish] problem [was not] so ticklish." Harold Saunders suggested the White House launch a support for the Kurds "until there seem good reason to change it."

\section{Iran's non-Kurdish Proxies}

Bazzaz's removal, Arif's weak personality, and an imminent coup in Baghdad deepened the Shah's hesitation over the negotiation with Arif to put an end to border disputes. Despite Arif's acceptance of Iran's full territorial demands in the Tehran statement, the Shah did not want to bet on a weakened regime plunged in harsh power struggle. At the same time, Iran refrained putting all its eggs in the Kurdish basket in Iraq. The Iraqi Shia and the anti-Nasser Baath Party had been Iran's secret targets. Although the Iraqi Shia-SAVAK was not effective after the Iraqi coup of 1958, Iran had kept its connections with the Shia. In the mid-60s, the threat of Iraqi-Egyptian alliance had prompted the Iraqi Shia. Both the Kurds and the Shia were against the unification with Egypt. ${ }^{486}$ In Karbala, the Shia senior clergymen lashed out at the Pan-Arab alliance, ${ }^{487}$ and criticized Egyptian control over Baghdad. ${ }^{488}$ Along with the Shia ulama, the Fatemi Party was against Egypt-Iraq unification. As a Shia party that still supported Qasim's ideas, ${ }^{489}$ the Fatemi Party had promised Barzani Shia support for Kurdish autonomy. ${ }^{490}$ With

\footnotetext{
${ }^{485}$ Saunders, a major aide on the Middle East National Security Council, pointed this suggestion out after a secret talk with Shawfiq Qazzaz, Barzani's emissary. White House, "Memo for Mr. Goldstein," March 13, 1968 (JPL/NSF/HSF/Box16/Iraq 4/1/66-1/20/69/doc.6), p.1.

${ }^{486}$ SAVAK Documents, No. 326/609, 8 June 1964.

${ }^{487}$ SAVAK Documents, No. 768, 15 July 1964.

${ }^{488}$ SAVAK Documents, No. 1097, 14 August 1964.

${ }^{489}$ SAVAK Documents, No. 7 March 1965.

${ }^{490}$ SAVAK Documents, No. A-872, 4 December 1964.
} 
Tehran's advice, the Fatemi Party had also tried to make the Iraqi Kurds and the Baath Party come close together against Arif. ${ }^{491}$ Despite Iraqi propaganda against the Shah and framing him as an Israeli ally, Iran had formed a second front in southern Iraq against Baghdad. As Iran's leverage among the Iraqi Shia increased, Arif threatened to oust the Shia clergies, particularly Ayatollah Hakim, to Iran. Such a bold move was harshly criticized by the Shia communities in the region. ${ }^{492}$ Although Arif did not act on his threat, anti-Baghdad sentiments grew among the Shia political organizations. Founded in 1943 by Michel Aflaq and Salah al-Din al-Bitar, the Baath Party's political slogan of 'unity, freedom, and socialism' expressed a new brand of Pan-Arabism and socialism. In spite of praising the revolutionary activism to achieve Arab unity, the Baath Party was the most significant force that challenged Nasser in the Arab World in the 60s. Additionally, the Baath's anti-communist ideology fit Iran's national security. SAVAK had cooperated with the Baath Party in a bloody suppression of the ICP. ${ }^{493}$ The Baath military offensive against the Kurds in summer 1963 apparently terminated its relations with SAVAK; however, when Arif ousted the party from power in spring 1964, SAVAK revived the connection with its leaders, particularly former prime minister Ahmad Hassan al-Bakr. Nevertheless, the Baath-SAVAK covert cooperation did not result in consequential outcomes, mainly due to Iran's priority for the formation of a pro-Hashemite regime in Baghdad. ${ }^{494}$

\footnotetext{
${ }^{491}$ SAVAK Documents, No. 313/35298, 1 January 1965.

${ }^{492}$ SAVAK Documents, No. 313/20615, 5 July 1965.

${ }^{493}$ Qaneifard, Erfan, Tondbad-e Havades: Goftogooi ba Isa Pejman [Hurricane of Events: A Dialogue with Isa Pejman] (Elm Publication, Tehran, 2011) p. 170.

${ }^{494}$ Qaneifard, Erfan, Tondbad-e Havades: Goftogooi ba Isa Pejman [Hurricane of Events: A Dialogue with Isa Pejman] (Elm Publication, Tehran, 2011) p.171.
} 


\section{Ascension-The Lebanese Shia}

"Sadr works [in favor of Iran's interest] as [effective] as three Iran's Ambassador to Lebanon," the Shah told SAVAK officers. ${ }^{495}$

"Sadr has become the 'Heart of Beirut'," a SAVAK report stated in the 60 s. ${ }^{496}$

\section{The First Tension}

By the mid-60s, Iran's non-state foreign policy in Lebanon was at its zenith. SAVAK's network with several Lebanese newspapers and elites, as well as with the Shia Lebanese, had successfully launched an anti-Nasser campaign in Beirut. In contrast to the Iraqi Kurds, the Lebanese Shia were never provided with Iran's military aid. Rather, it was Sadr's message that functioned as a bulwark against the ensuing threat of Pan-Arabism. Almost all Pan-Arab elements in Lebanon were Sunni, pressing Beirut for unity with the UAR or another larger Arab entity. Within this context, Sadr's efforts for the revival of the Shia identity through the removal of long-standing discriminations against the Shia communities weakened pro-Nasser elements. Seyyed Musa Sadr had become, in fact, the 'armature' of Iran's non-state foreign policy in Lebanon.

Beyond his personal charisma and Iran's limited support, specific power arrangements within Lebanon had provided Sadr an opportunity to revive the collective Shia identity. Challenged by the pro-Nasser, Sunni Lebanese, the Maronites considered Sadr as a possible ally against Nasser. Since the early 60s, Sadr had been constructing friendly relations with the Christians and their religious leaders. "Your Majesty! I have heard a lot of you! I do believe that the history of Lebanon is divided in 'Pre-Sadr and post-

\footnotetext{
${ }^{495}$ SAVAK Documents, No. h/7/9048, 14 October 1965.

${ }^{496}$ SAVAK Documents, No. (39-40).
} 
Sadr' era," Cardinal Franse Quoning, the Assyrian bishop told Sadr. ${ }^{497}$ In the early 60 s, the Maronites, particularly President Fuad Chehab, had financially supported Sadr. ${ }^{498}$ The Maronite-Shia alliance was reflected in the parliamentarian elections. ${ }^{499}$ According to the U.S. embassy in Beirut, Sadr's personality “challenges Nasser's popularity in Lebanon.”,500 Sadr's efforts to lay down the roots of the Shia revival was viewed by the Maronites and other Christian sects as a reliable bulwark against Nasser's infiltration in Lebanon. With the rise of the formation of a Shia-Maronite alliance against Nasser, it seemed Iran's nonstate foreign policy in Lebanon bore fruit. Nevertheless, Sadr's image in Tehran was tarnished for the first time in June 1963. In the aftermath of the Shah's reforms, known the 'White Revolution,' several Iranian Shia clerics, particularly Ayatollah Ruhollah Khomeini, challenged the Shah's growing power. Along with other religious figures, Musa Sadr signed a letter against the Shah. ${ }^{501}$ In the meantime, waves of the demonstration, later known as the Movement of 15 Khordad, soon erupted throughout Iran and transformed into a violent riot. Immediately, the Shah and SAVAK denounced external powers, especially Egypt, for backing the riot. Right after the demonstrations, Sadr attempted to release Ayatollah Khomeini who had been condemned to death. In doing so, he asked his teacher, Ayatollah Seyyed Abul-Qassim Khu'i, to convince the Shah to stop Ayatollah

\footnotetext{
${ }^{497}$ Kamalian, Mohsen and Ali-Akbar, Ranjbar-Kermani, Ezat-e Shia, (winter 1377, Sahife Kherad press, Qom) p.20.

498 Qadar claimed that the Maronites bought a magnificent building for him in Hazemiya. Interview with Major General Mansour Qadar, Oral History, Foundations for Iranian History.

${ }^{499}$ Interview with Major General Mansour Qadar, Oral History, Foundations for Iranian History.

500 SAVAK Documents, No number, 15 June 1966.

${ }^{501}$ SAVAK Documents, No. 241/573, 17 July 1965.
} 
Khomeini's execution. ${ }^{502}$ Sadr also met Pope Paul VI and asked him to press the Shah. Indeed, Sadr's efforts, along with the Pope's request, General Hasan Pakravan's and Ayatollah Shariatmadari's effective intervention ${ }^{503}$ and, more significantly, Ayatollah Hossein-Ali Montazeri efforts, were key factors in convincing the Shah to renounce the death sentence. Meanwhile, Iran's embassy in Beirut heavily criticized Sadr for signing an anti-Shah letter. Sadr tried to assuage the tension, stating that he signed the letter just to keep his connections with Iranian clerics safe. ${ }^{504}$ He told the Papal Foreign Minister that 'the Grand Ayatollahs had no general objection to the White Revolution, though they want to modify some details; unfortunately, some adventurers were behind the recent riot in Iran and grand clergies' concerns were soon alleviated." ${ }^{, 505}$ Despite SAVAK's suspicion, Tehran did not want to cut off its strategic ties with him. Sadr also refrained from escalating tension with Iran. After all, Sadr's leverage in the Lebanese society was unstoppable.

\section{Imam's Popularity}

Sadr soon achieved socio-political successes in Lebanon and gained an unprecedented prestige for the Shia community. His achievements were mostly predicated on his ability to rally Shia power. His personal charm and enormous energy attracted a broad range of the Shia adherents. The cornerstone of Sadr's idea was based on the

\footnotetext{
${ }^{502}$ Ayatollah Kho'i confirmed that it was because of Sadr that the Shah released Ayatollah Khomeini. See http://fa.alalam.ir/news/1511871.

${ }^{503}$ While the hardliners in the regime, Prime Minister Alam and Nematollah Nasiri, the subsequent chief of SAVAK, pressed the Shah to execute Ayatollah Khomeini, General Hasan Pakravan, SAVAK Director, argued that Ayatollah's execution would anger the people and therefore convinced the Shah to allow Ayatollah Shariatmadari, a respected Marja in Qom, to declare Ayatollah Khomeini as a Marja, and thus, saved his life.

${ }^{504}$ Beigi, Abbas William, The Shah's Lebanon Policy: The Role of SAVAK (January 1997) Middle Eastern Studies, 33 (1): 74.

${ }^{505}$ SAVAK Documents, No. 231/2/8702, 16 December 1963.
} 
rejection of traditional Shiism based on the fatalistic acceptances of the Shia deprivation. His point of view stood in sharp contrast with a role of Shia religious figures in the society and the politics. For several centuries, the Shia in Lebanon preferred a 'quietist interpretation' that prescribed bearing the burden of living as an oppressed minority until the 'End of the World', when Mahdi, the Twelfth Imam, would return to establish a just government and society for humanity. Accordingly, Shia clerics should avoid engaging with politics since any government was a Ja'er (illegitimate) one; rather, they must dedicate their life to religion and religious activities. This point of view nurtured a deterministic worldview within which a faithful Shia must accept destiny just as Hussein ibn Ali [the Third Shia Imam] did at Karbala. Obviously, there was no room for socio-political reforms led by a clerical figure. Conversely, Sadr showed the Lebanese Shia another path. Much like the Latin American Catholic priests and their Liberation Theology, Sadr worked tirelessly to improve the status of the Shia community and give them a voice, identity, and power. Sadr once spelled out that "whenever the poor involved themselves in a social revolution it is a confirmation that injustice is not predestined. ${ }^{506}$ Sadr believed that a Shia cleric had both political and social obligation, beyond his religious role. Combining social activism with the Shia identity, he produced a distinct approach to political issues in Lebanon. This combination led to the construction of a new Shia collective identity distinct from the Sunni-led Arabs in Lebanon. Such a new point of view attracted modern strata within the Shia, like lawyers, and bridged the gap of untrustworthiness between modern and traditional as well as religious and secular parts of the community. Sadr soon gained a deep leverage within Lebanese society. His power reached its zenith to the point that during

\footnotetext{
${ }^{506}$ Norton, Augustus R. Hezbollah: A Short History (Princeton University Press, 2007) p. 40.
} 
Fitr Eid, President Helou sat between Sadr and Hasan Khaled, grand Mufti and leader of Lebanese Sunni. ${ }^{507}$ As a voice of reason, Sadr's leverage in Lebanon was so deep that it soon became popular in Lebanon to mimic his Persian accent. Nevertheless, his rising popularity was challenged by the Shia Zuama, especially Kamel Asaad and then Kazem al-Khalil (Kazem Bey). As a former minister of the government, Kazem Bey was one of the most influential Shia Zuama who saw in Sadr a threat to the Zuama's hegemony in the south of Lebanon. He had unsuccessfully launched a campaign against Sadr, accusing him of sexual improprieties. ${ }^{508} \mathrm{He}$ also denounced Sadr of working as Beirut's agent working of the Lebanese intelligence, effectively rearranged by President Chehab, in order to weaken Zuama. ${ }^{509}$ In addition to the Shia Zuama, the Sunni community saw Sadr as a threat to their status and power in Lebanon. City-dwellers, the Sunnis shared a historical enmity with the Shias in the country. The Nasserist elements in Lebanon, particularly AlMurabitoun (the Independent Nasserite Movement or INM) led by Ibrahim Kulaylat, harshly criticized Sadr for his objection to Pan-Arabism and accused him of supporting the Shah and the CENTO Pact. The Sunnis, no matter whether West-oriented, Pan-Arab or leftist, considered the Shia empowerment led by a Persian 'Seyyed' as a betrayal of the Sunni goals and a challenge to the gauzy-fiction Arab Unity. This could pose a threat to the cement-hard reality of the Sunni hegemony in Lebanon, and by extension elsewhere in the Middle East. However, Sadr was smart enough to deter and limit the threat of the Sunni and his Shia opponents. He supported Chehab's political reforms and social developments.

\footnotetext{
${ }^{507}$ Interview with Major General Mansour Qadar, Oral History, Foundations for Iranian History.

${ }^{508}$ Cobban, H. The Making of Modern Lebanon (London, 1985) p.172

${ }^{509}$ Johnson, M. Factional Politics in Lebanon: The Case of the Islamic Society of Benevolent Intentions (A1Maqasid) in Beirut (January 1978) Middle Eastern Studies, 14 (1): 74, n.31.
} 
He was, in fact, Chehab's main ally in strengthening the national army and the government's interference in economic affairs. These programs, Sadr thought, could keep the Shia safe from a possible Israeli invasion of the South and remove a long-standing discrimination against the Shia. On top of that, Chehab-Sadr's alliance was in perfect alignment with Iran's sub-state foreign policy to contain a regional advance of PanArabism in Lebanon. This alliance was later solidified as Seyyed Musa Sadr and his wife, Parvin Khalili, were granted their Lebanese citizenship on 24 March 1964. SAVAK initially reacted to the fact by suspending Sadr's Iranian citizenship. ${ }^{510}$ It was a temporary halt, though. Convinced by Pashaie, Sadr took a trip to Iran on 29 July 1965 and the Shah gave order to prevent the suspension of Sadr's citizenship. ${ }^{511}$ In the meantime, Sadr had been keeping open his ties with SAVAK and Iran's embassy in Beirut. On 5 November 1965, Sadr met General Khosravani and expressed his patriotism and loyalty to the Shah. After Sadr's trip to the West Africa, Manouchehr Davoudi, a political officer of Iran's embassy in Lebanon, met Sadr in Tyre on 14 July 1967 and asked if Iran's ambassador to Beirut could meet him. Sadr welcomed the idea and contended that his support of Iran was based on his "patriotism" and beyond politics. ${ }^{512}$ The Shah was right when he once argued that "Sadr works [in favor of Iran's interest] as [effective] as three Iran's Ambassador to Lebanon." ${ }^{513}$ Nevertheless, SAVAK had no homogenous view on Sadr. For instance, elements in SAVAK, like the Seventh Office, argued that Sadr and the Shia progress in

\footnotetext{
${ }^{510}$ SAVAK Documents, No. 821/5749, 29 July 1965.

${ }^{511}$ SAVAK Documents, No. 6300, 25 August 1965.

512 SAVAK Documents, No. 1584, 14 July 1967.

${ }^{513}$ SAVAK Documents, No. h/7/9048, 14 October 1965.
} 
Lebanon "would give Iran a privilege." $" 514$ At the same time, SAVAK accused Sadr of making an anti-Tehran move in his speech on 21 July 1966 when Sadr called the CENTO Pact a "American-British plot" ${ }^{515}$ These elements believed that Sadr's criticism of the CENTO Pact reaffirmed his Nasserist view. ${ }^{516}$ They also faulted Seyyed Musa's connections with Egypt and framed him as Cairo's agent in Lebanon. ${ }^{517}$ Although Bakhtiar's replacement in SAVAK was later called a major factor in changing the nature and essence of Sadr's ties with Tehran, ${ }^{518}$ what, in fact, lurked beneath the surface of such paradoxical analyses was Sadr's rising power in Lebanese politics. The more he became popular, the less he felt dependent on Iran and in turn, encouraged him to distance himself from Tehran, the SAVAK argued. Though open to Iran's support for the Shia, Seyyed Musa did not want to be framed as Tehran's agent in an Arabic country. In his interview on 15 August 1966, Sadr pointed out that he was "a religious leader" and he was "doing what he believed in" and while it might "be aligned with another ruler [he meant the Shah of Iran], but this should not be interpreted as his obedience to the external power [i.e., Iran]."519 Although these explanations did not convince pessimistic elements in SAVAK, ${ }^{520}$ the Shah still considered Sadr and the Lebanese Shia as Iran's potential ally to contain Pan-Arabism.

\footnotetext{
${ }^{514}$ SAVAK Documents, No. 12/54, 3 April 1967.

${ }^{515}$ SAVAK Documents, No. 212/877, 21 July 1966.

${ }^{516}$ SAVAK Documents, No. 241/573, 16 June 1965.

${ }^{517}$ SAVAK Documents, No. 241/573, 16 June 1965.

${ }^{518}$ Interview with Major General Mansour Qadar, Oral History, Foundations for Iranian History.

519 SAVAK Documents, No. 212/8219, 17 July 1966.

${ }^{520}$ SAVAK Documents, No. 4610/14/702, 17 May 1963.
} 


\section{Chapter 5}

\section{Limbo: Iran's Non-State Foreign Policy in 1968-1973}

In this period, Iran's non-state foreign policy reached its zenith. With the formation of the second Baath regime in Baghdad and the Iraqi invasion of 1969, Iran intensified its support for the Iraqi Kurds. Iran also pressed Iraq in Arvand Rud and then unsuccessfully planned an anti-Baath coup. In the meantime, the Shah put his weight behind the Kurdish appeals for the U.S. to side with Iran in challenging Baghdad. Extensively utilizing Cold War language - featuring the Soviet infiltration in the region by backing the Iraqi Baath the Shah finally convinced President Nixon and Kissinger at the Tehran Summit of 1972. It was the beginning of SAVAK-CIA-Mossad support for the Iraqi Kurds. In the meantime, the Shah gradually linked the Kurdish War with border disputes with Iraq in Arvand Rud. Therefore, this period was also the beginning of Iran's shift in its non-state foreign policy in Iraqi Kurdistan.

At the same time, Iran had kept its ties with Sadr open. However, a geopolitical shift in the regional power arrangement after the Six Day War of 1967 weakened Nasser's power and therefore, diminished the significance of Lebanon for Iran. In the meantime, Sadr's support for the Palestinian guerrillas, his connections with Arab states of the region, and his increasing support for the Iranian revolutionaries weakened his connections with Tehran. More significantly, it was Iranian Ambassador Qadar who weakened Sadr's relations with Iran when Sadr refused to work for him as an agent. This period was, in fact, the beginning of Iran's shift in its non-state foreign policy in Lebanon. 


\section{Limbo -- The Iraqi Kurds}

"The Soviet Union wants a red crescent [constituted] of Syria and Iraq," the Shah argued in his meeting with President Ford and Kissinger. ${ }^{521}$

Our people look at Your Imperial Majesty as a father and protector and is certain that any other door open to us had Your efforts behind it.... You have on many occasions stated .... that relations between Iran and Iraqi Kurds should be deeper than what exists between Turkey and Cyprus Turks."522

\section{The Baath Coup of 1968}

On 17 July 1968, the Iraqi Army-backed Baath Party successfully launched a coup and overthrew the Arif regime. ${ }^{523}$ New Prime Minister Ahmad Hassan Al-Bakr underpinned his position in the government, the Baath Party, and the army mostly with the help of Saddam Hussein's newly founded Baath security apparatus. ${ }^{524}$ In the next step, both Nasserist and Communist forces were purged from politics by Saddam. ${ }^{525}$ The anticommunist and anti-Nasserist nature of the Baath Party was initially welcomed by the Shah as Iran was the first country to recognize the Baath regime. In the Shah's view, the Baath coup in Baghdad was the third successive defeat for Nasser after the Six Days War and the Yemeni Civil War. Despite a growing anti-American sentiment in the Arab World in the post-1967 War, Iran was not a target for Iraqi propaganda.

\footnotetext{
${ }^{521}$ Memorandum of Conversation, Ford, the Shah, Kissinger, and Scowcroft, May 15, 1975. May 15, 1975.

522 Alam, Assadollah. Yad'dashtha-ye 'Alam: Virayesh va Muqaddamah az Alinaqi Alikhani [The Alam Diaries: Edited by Alinaqi Alikhani], Vol. III: 1973-1974 (Bethesda, MD: Iranbook, 1995), p. 115-116.

${ }^{523}$ The main coup plotters were Saddam Hussein, Colonel Ibrahim Abdel-Rahman Dawoud, Colonel Abd alRazzaq al-Nayif and Major Saadoun Ghaidan. See Al-Samarrai, Wafiq, Hottam al-Bawabat al-Sharqi [The Destruction of the Eastern Gate], translated in Farsi, (Tehran, Markaz Asnad va Tahghighat-e Defa-e Moghaddas) p. 38.

${ }^{524}$ As the leader of the coup's military operation, al-Bakr retained his position as Regional Secretary of the Baath Party and was named by Iraq's new supreme ruling body, the Revolutionary Command Council (RCC), as President, Prime Minister, Commander-in-Chief of the Armed Forces, and the Chairman of RCC.

${ }^{525}$ Tripp, Charles. A History of Iraq (Cambridge University Press, 2010) p. 188.
} 
However, the honeymoon between two countries ended soon. In the aftermath of the coup of 1968, Baghdad improved relations with the Soviets. ${ }^{526}$ Besides, Baghdad did not show flexibility in border disputes with Iran. In a meeting with the Shah, general Hordan Takriti, the chief of the Iraqi Airforce and the Prime Minister Deputy, did not accept the Thalweg Line, half the width in Arvand Rud, and repeated Iraq's claim of the eastern shore of Arvand Rud. Besides, Baghdad's chauvinist view towards the Kurds and the Shia deteriorated relations with Iran. Despite its claim to equality for ethnic-religious minorities, the Baath Party considered both communities as Iran's fifth column. Although al-Bakr blamed an Israeli-American subversion and stated "while Iraq was facing the enemy on the Arab-Israel front, the fifth column of agents of Israel and the U.S. was striking from behind, ${ }^{, 527}$ the Kurds and the Shia had a 'natural' proclivity towards Iran, Baghdad argued. It was within this context that Iraqi-Kurdish negotiations halted, and Baghdad chose to settle the Kurdish question with the use of brute force for the second time.

To weaken Barzani's position in Iraqi Kurdistan, Baghdad initially took a divideand-rule strategy by siding with Talabani and Ahmad. In contrast to Barzani's hesitation, they had welcomed the Baath regime in Baghdad. In October 1968, Barzani's loyal Peshmerga made Talabani-Ahmad forces suffer major setbacks. In return, the Iraqi Army launched a massive offensive on 3 January $1969 .{ }^{528}$ Tehran immediately increased its

\footnotetext{
${ }^{526}$ U.S. Department of State, Hughes to Rusk, "Right-wing Ba'thi Takeover in Iraq: Near-term Outlook," IN-618, August 6, 1968 (NARA/RG59/SN/1967-69/Box 2221/“POL 15-Iraq 1/1/67”), p.7.

${ }^{527}$ U.S. Department of State, Bureau of Intelligence and Research, Hughes to Rusk, "Iraq: Internal Stresses and the Search for the Bogeyman,” RNA-6, February 14, 1969 (FRUS/1964-68/XXI/doc.251), p.6.

${ }^{528}$ Keesing's Record of World Events (formerly Keesing's Contemporary Archives), Volume XVII, February, 1970 Iraq, Page 23827.
} 
assistance to Barzani by supplying sophisticated artillery. After only three weeks, the Baath military campaign was brought into a stalemate by the freezing winter of $1969 .{ }^{529}$ Despite the sudden impasse in the war, the Shah ordered Barzani to paralyze Iraqi oil installations in Kirkuk and Mosul. On 1 March 1969, the Peshmerga shelled the Iraq Petroleum Company (IPC) installations and cut short Iraq's oil pumping capacity. It was a devastating blow to Baath prestige. ${ }^{530}$ "The Shah felt great. I had been secretly informed that the Kurds bombed Iraqi oil pipelines in Mosul and Kirkuk. Therefore, the oil companies are going to make an excuse of not cooperating with Iraqis due to the lack of security in Iraq and in return, switch their production targets to Iran at the expense of Iraq." ${ }^{, 531}$ The Iraqi Army broke the impasse in Kurdistan; however, its offensive again ended in April as border tension with Tehran escalated. Unlike past Iraqi invasions of Kurdistan, Iran pressed the Baath regime with the threat of direct fighting in Arvand Rud.

\section{Arvand Rud Crisis of 1969}

Iran's support for the Iraqi Kurds had been gradually intertwined with a longstanding border dispute with Iraq in Arvand Rud. As a wide waterway formed by the confluence of the Euphrates, the Tigris, and the Karun rivers, Arvand Rud or Shatt al-Arab has served as a constant source of conflict between Iran and Iraq--and the Ottoman Empire as the predecessor of the Iraqi state. The roots of such a centuries-long contention dated back to the Ottoman-Safavid wars over control of Mesopotamia. Even the 1639 Treaty of

\footnotetext{
${ }^{529}$ O’Ballance, Edgar. The Kurdish Revolt, 1961-1970 (London: Faber and Faber Ltd., 1973) p.151.

${ }^{530}$ Keesing's Record of World Events (formerly Keesing's Contemporary Archives), Volume XVII, February, 1970 Iraq, p. 23827.

${ }^{531}$ Alam, Assadollah. Yad'dashtha-ye 'Alam: Virayesh va Muqaddamah az Alinaqi Alikhani [The Alam Diaries: Edited by Alinaqi Alikhani] Vol. I: 1968-1970 (Bethesda, MD: Iranbook, 1995), p. 143.
} 
Zuhab did not settle the contention over the control of the waterway. ${ }^{532}$ The Second Treaty of Erzurum and then the Istanbul Treaty of 1913 confirmed the Ottoman-Iranian frontier running along the Thalweg Line. ${ }^{533}$ The 1937 Treaty, however, recognized the Iran-Iraq frontier along the low-water mark on the Iranian shore of the waterway and gave newlyindependent Iraq almost the entire Arvand Rud, except at Abadan and Khorramshahr where the treaty set the frontier along the Thalweg Line. ${ }^{534}$ The Treaty, in fact, guaranteed Iraq's full sovereignty over Arvand Rud as its only functional access to the Persian Gulf and, in return, stripped Iran of one of its major naval outlets. The Shah believed the terms of the treaty gave British-backed Baghdad full control of navigation on Arvand Rud with a potential to endanger Iran's Abadan refinery and the strategic port of Khorramshahr. ${ }^{535}$ Despite its lack of power to enforce his claim, Baghdad had considered the entire Arvand Rud up to the Iranian shore as its internal territory. Conversely, the Shah had argued several times that almost all river borders ran along the Thalweg Line, dividing the border river into two equal sections between the neighboring states. The Shah intended to rid the Pahlavi dynasty of the Treaty of 1937.

In addition to containing the Pan-Arab regimes of Baghdad and thwarting a possible threat of Soviet encroachment in the Persian Gulf, the Shah had gradually become the Iraqi Kurds' major patron in order to make Baghdad concede in Arvand Rud. Since the mid-60s,

\footnotetext{
532 On 17 May 1639, Iran and the Ottoman Empire signed the Treaty of Zuhab. According to the treaty, Iran irrevocably lost Mesopotamia, the modern Iraq, to the Ottomans. Since the Persian Empire of the Achaemenids, Iraq was part of various Persian empires.

${ }^{533}$ World War I canceled the terms of the Istanbul Treaty of 1913.

${ }^{534}$ Boundary Treaty and Protocol Concerning the Shatt-al-Arab Waterway, 190 UNTS 4423 (4 Jul. 1937)

${ }^{535}$ Despite repositioning of the Abadan port facilities to Kharg island in the Persian Gulf--a development that could cover up to 98\% of Iran's oil exports-- the vast Iranian oil fields and Abadan Refinery were still within reach of Iraqi artillery and air power.
} 
the Shah's long strategy in Iraqi Kurdistan had been to “exploit tension with Iraq to force [a] solution to [the] Shatt issue." 536 The Shah self-confidently told the U.S. ambassador Armin Meyer that he would "wait a few more years" to settle down the border dispute in Arvand Rud since Iraq would finally "come to Iran in the hope of sharing the burden, and dividing [the] Shatt between them. ${ }^{, 537}$ It seemed he was ready to abandon Iran's 'trump card', the Iraqi Kurds, but only under Baghdad's readiness to concede in Arvand Rud. However, no Pan-Arab Iraqi government had so far dared to accept a territorial concession to its historical enemy: The Iranians.

In the middle of an on-and-off truce in Kurdistan, Baghdad took a venturous risk towards its eastern neighbor. On 15 April 1969, the Deputy Foreign Minister of Iraq claimed that Iraq considered Arvand Rud as part of its territory and, thus, demanded that Iranian vessels lower the Iranian flag upon entry into the waterway and withdraw any navy personnel on board ships in the river. Baghdad warned that if its demands were not met, it would "not permit in future any Iranian ship entering the Shatt-al-Arab."538 In response, the Shah abrogated the Treaty of 1937 in April 1969 and declared it "valueless and null and void" since Iraq had violated its Treaty obligations. ${ }^{539}$ The Baath leaders threatened war over Iran's bold move and claimed the right to take legal and legitimate counteraction. A harsh propaganda erupted. President al-Bakr gave a tirade speech and threatened Iran

\footnotetext{
${ }^{536}$ Tehran A-1044 to U.S. Department of State, “Iran-Iraq Relations,” January 20, 1966 (FRUS/196468/XXI/doc.179).

537 Tehran A-1044 to U.S. Department of State, “Iran-Iraq Relations,” January 20, 1966 (FRUS/196468/XXI/doc.179).

${ }^{538}$ Abdulghani, Jasim, Iraq and Iran: The Years of Crisis, The Johns Hopkins University Press (October 1, 1984), p. 118.

${ }^{539}$ Ibid. p. 119.
} 
that "I would be neither Arab nor Muslim if I forget this [Iran's] position. They [Arab and Muslim] are in my hands. I will shoot them [to Iran] whenever I want." ${ }^{, 540}$ General Salih Mahdi Ammash, Minister of Interior Affairs, called the Shah as a "sheep."541 On the other side, Alam was worried about an outbreak of a war with Iraq, "I know Iranian mentality. A slight defeat would make Iran unstable, especially a defeat from a country that is not a [real] country." $" 542$ The war was apparently inevitable.

Tehran escalated the tension to an almost full-scale war by putting the Iranian army on red alert. Aware of Iraq's weaker position-60,000 Iraqi troops had been already deployed in Iraqi Kurdistan and three Iraqi brigades had been stationed in Jordan-- ${ }^{543}$ the Shah ordered an Iranian tanker, the 1176-ton Iranian merchant ship Ebn-i-Sina (Avicenna), escorted by heavy Iranian jet fighters and heavily armed naval vessels, to sail down the waterway into the Persian Gulf without lowering Iranian flag on 22 April $1969 .{ }^{544}$ Iranian freighters, like Arya Far, continued passing Arvand Rud with Iranian flags flying. Despite putting its army on full alert at Basra, Iraq failed to endanger the Iranian vessel. Iran's heavy tanks, aircraft, and artillery dissuaded the Baath leaders from blocking the waterway. It was a major blow for Baghdad.

\footnotetext{
540 Al-Samarrai, Wafiq, Hottam al-Bawabat al-Sharqi [The Destruction of the Eastern Gate], translated in Farsi, (Tehran, Markaz Asnad va Tahghighat-e Defa-e Moghaddas) p. 52.

${ }^{541}$ Ibid. p. 53-4.

542 Alam, Assadollah. Yad'dashtha-ye 'Alam: Virayesh va Muqaddamah az Alinaqi Alikhani [The Alam Diaries: Edited by Alinaqi Alikhani], Vol. I: 1968-1970 (Bethesda, MD: Iranbook, 1995), p. 172-3.

${ }^{543}$ O’Ballance, Edgar. The Kurdish Revolt, 1961-1970 (London: Faber and Faber Ltd., 1973) p. 154.

${ }^{544}$ Rouhollah K. Ramazani, The Persian Gulf: Iran’s Role 44 (1972).
} 
The only retaliatory measure Baghdad took was to maltreat and evict thousands of Iranians resident in Iraq, as well as banning Iranian goods. ${ }^{545}$ Iraq also banned importing Iranian commodities in order "to support the goals of the Arab Nation." ${ }^{, 546}$ On 8 September 1969, an Iranian civilian was hanged after being convicted of spying for the U.S. and Israel.

On September 18, Baghdad Radio announced that 30 Iranian soldiers had been shot and 14 others arrested by Iraqi forces near an area controlled by the Kurds. Iran's Foreign Minister Ardeshir Zahedi denied the report on the following day, stating that "certain elements of the population of the frontier regions, whose families are the object of almost daily bombing and napalm attacks by the Iraqi forces engaged against Mullah Barzani's troops, may have been driven to participate in the fighting without the Persian Government's knowledge. ${ }^{547}$ Although Baghdad brought the case to the attention of the UN Security Council, the Arvand Rud Crisis was Iran's considerable victory.

\section{The Aborted Coup Plot}

In the aftermath of the humiliating Arvand Rud Crisis, the Kurdish Peshmerga smashed the Iraqi army and occupied Penjwin and Qala-Diza by late June $1969 .^{548}$ The Iraqi Army reopened an offensive in August 1969 to seal the border with Iran and cut off Kurdish arms supply routes. The Iraqi Air Force began dropping napalm and nitric acid bombs on the Kurdish villages. ${ }^{549}$ However, the offensive halted again because of a harsh

\footnotetext{
${ }^{545}$ Abdulghani, Jasim, Iraq and Iran: The Years of Crisis (The Johns Hopkins University Press, October 1, 1984) p. 121; Ramazani, The Persian Gulf, at p. 44.

${ }^{546}$ Baghdad 2202 to Iran's Ministry of Foreign Affairs, 26 August 1969.

${ }^{547}$ Keesing's Record of World Events (formerly Keesing's Contemporary Archives), Volume XVII, February, 1970 Iraq, Page 23827.

${ }^{548}$ Ibid.

${ }^{549}$ Ibid.
} 
winter. In addition to the Iraqi Army's incompetent tactics, Iran's heavy support for the Kurds convinced a faction of the Baath Party, led by Saddam Hussein, to seek a peaceful and amenable solution of the Kurdish crisis in order to avoid giving the Shah territorial concessions over Arvand Rud. For the Baath Party, any territorial concession to the Persian Shah would shatter the fragile legitimacy of the Baath regime at home and erode its claim to being champions of Pan-Arabism. In June 1969, the Baath regime entered into secret negotiations with Barzani at Michel Aflaq's residence in Beirut. ${ }^{550}$ The Kurdish delegation refused to consider any principle for a settlement other than the Bazzaz Declaration of 1966 while at the same time, the Iraqi Army continued its on-and-off military operations against the Peshmerga. In early October 1969, Baghdad offered an agreement to the Kurds but they refused it. ${ }^{551}$ Mullah Mustafa never trusted the Baathists. In an interview with a correspondent of Le Monde, he stated that "we cannot sit at the same table with wolves." 552 The Iraqi Ambassador to Paris replied to these claims by stating that the total population

\footnotetext{
${ }^{550}$ As the founder and major theoretician of the Baath Party, Aflaq pressed Baghdad leaders to settle the Kurdish question peacefully. In an article published on Oct. 17, 1969, Aflaq wrote that "Kurdish nationalism reflects a legitimate feeling which is not to be condemned, but which has been exploited and whose aims have been distorted. Not being a creation of imperialism, it is not opposed to the interests of the Arab revolution." He also addressed this fact that both Kurds and Arabs had lived together for centuries and stressed that Iraq "must frustrate the plans of the imperialists who seek to create a gulf of hatred between the two peoples." See Keesing's Record of World Events (formerly Keesing's Contemporary Archives), Volume XVII, February, 1970 Iraq, Page 23827.

${ }^{551}$ Baghdad promulgated the new provincial division of the country into 16 departments, instead of 14 provinces as in the past, with a large measure of local autonomy through elected councils; there would be three Kurdish departments: Sulaimaniya, Erbil, Dehok, and one Arab-Kurdish department, Kirkuk. The Baath regime also agreed to the use of the Kurdish language in all educational institutions in Kurdish areas, the foundation of a university at Sulaimaniya, the formation of a Kurdish writers' association, the establishment of a Kurdish publishing house, and the publication of a newspaper and a magazine in Kurdish. See Ibid, Page 23827.

${ }^{552}$ In addition to these claims, Barzani stated that the Central Government in Baghdad must consist of an Arab President, a Kurdish Vice-President, and a Cabinet in which the distribution of portfolios between Arabs and Kurds was proportionate to the size of the two communities. On top of that, in Kurdistan (consisting of the provinces of Sulaimaniya, Kirkuk and Erbil, and the areas of Mosul and Diyala provinces with a predominantly Kurdish population) there should be an elected Legislative Council and an Executive Council. Le Monde, 21th December of 1969.
} 
of the northern provinces was only $1,500,000$ of whom 500,000 were non-Kurds, and claiming that the Kurds had "succeeded only in disturbing a narrow strip of the frontier, thanks to Teheran's complicity." 553 Nevertheless, Baghdad leaders were determined to rob Iran of its Kurdish trump card.

Aware of the Iraqi-Kurdish negotiations, the Shah instructed SAVAK to run an anti-Baath coup. Since the Iraqi coup of 1958, SAVAK had built up covert and complicated networks of Iraqi dissidents. Despite an increasingly controlled atmosphere of Baghdad, these networks remained partially intact during the Qasim and Arif brothers presidencies. These underground networks had been constituted of opponent Iraqi military generals, Shia civilians, and the Kurds living in Baghdad. Chief among the military elements were general Abdul Ghani al-Rawi, general Saeed Salibi, and Colonel Salih Mahdi al-Samarrai. ${ }^{554}$ They were opposed to the Baath new decision for a peaceful settlement of the Kurdish issue and its proclivity towards Moscow. Among the Shia civilians were Seyyed Mahdi al-Hakim, Ayatollah Mohsen al-Hakim's son, ${ }^{555}$ and Ahmed Chalabi, Abdel-Hadi Chalabi's son, who had joined up with a small group of Kurdish and SAVAK in Iran. After meeting with Barzani in Iraqi Kurdistan, Chalabi "acted as both a courier and a mediator, traveling to London, Spain, Jordan, and elsewhere to deliver messages and negotiate on behalf of the

${ }^{553}$ Keesing's Record of World Events (formerly Keesing's Contemporary Archives), Volume XVII, February, 1970 Iraq, Page 23827.

${ }^{554}$ Al-Rawi was the former Third Deputy Premier in former President Arif government who had been in Teheran for several months. Salibi was the commander of Baghdad military base. Al-Samarrai, Wafiq, Hottam al-Bawabat al-Sharqi [The Destruction of the Eastern Gate], translated in Farsi, Markaz Asnad va Tahghighat-e Defa-e Moghaddas, p. 55; Qaneifard, Erfan, Tondbad-e Havades: Goftogooi ba Isa Pejman [Hurricane of Events: A Dialogue with Isa Pejman] (Elm Publication, Tehran, 2011) p.180

${ }^{555}$ Al-Samarrai, Wafiq, Hottam al-Bawabat al-Sharqi [The Destruction of the Eastern Gate] translated in Farsi, (Tehran, Markaz Asnad va Tahghighat-e Defa-e Moghaddas) p. 55. 
conspirators... including leading figures from Iraq's Shia community." ${ }^{556}$ In Lebanon, Chalabi facilitated connections between the Kurdish delegation and Carolan, the U.S. Ambassador to Beirut, pushed the U.S. officials to "step up their support of Barzani," and "to cut out the untrustworthy Shah as the middleman." 557 He was also in direct contact with SAVAK Director Nematollah Nassiri. On 15 April 1969, Davoud Taher, the Third Secretary of Iran Embassy to Baghdad, contacted the Iraqi military elements, and on September 28, Iraqi coup plotters met Iranian representatives at Iran Embassy in Kuwait. ${ }^{558}$ General al-Rawi, the leader of the coup, was fully cooperating with the Iran embassy in Baghdad and about 300 officers were "privy to the plot."559 Although Tehran tried to keep the Americans in the dark, they noticed the Iranian-orchestrated to overthrow the Baath regime. ${ }^{560}$ The Shah was gravely concerned about the plan with details. ${ }^{561}$

Nevertheless, Istikhbarat, the Iraqi security services, succeeded in infiltrating SAVAK's networks. ${ }^{562}$ On 20 January 1970 , on the night of the projected coup, the plotters

\footnotetext{
${ }^{556}$ Chalabi's wedding was officiated by Seyyed Musa Sadr, a close friend of the Chalabi family. Bonnin, Richard, Arrows of the Night: Ahmed Chalabi and the Selling of the Iraq War (Anchor; Reprint edition November 13, 2012) p. 57.

${ }^{557}$ Bonnin, Richard, Arrows of the Night: Ahmed Chalabi and the Selling of the Iraq War (Anchor; Reprint edition November 13, 2012) p. 57.

558 Keesing's Record of World Events (formerly Keesing's Contemporary Archives), Volume XVII, February, 1970 Iraq, Page 23827.

559 Keesing's Record of World Events (formerly Keesing's Contemporary Archives), Volume XVII, February, 1970 Iraq, Page 23827.

${ }^{560}$ Talcott Seelye, "How to Buy a Revolution: Talk with an Iraqi Plotter," October 15, 1969 (FRUS/196468/XXI/doc.262), pp.1-4.

${ }^{561}$ Qaneifard, Erfan, Tondbad-e Havades: Goftogooi ba Isa Pejman [Hurricane of Events: A Dialogue with Isa Pejman] (Elm Publication, Tehran, 2011) p. 180.

${ }^{562}$ It seems that an Iraqi officer learned of the plot in December and reported it to the government. However, a Syrian press agency report stated that the government had known of the plot for three months before its suppression. Keesing's Record of World Events (formerly Keesing's Contemporary Archives), Volume XVII, February, 1970 Iraq, Page 23827.
} 
gathered at the Rashid military camp just outside Baghdad, fell in Istikhbarat's trap. The next day, the Baath regime announced the SAVAK-backed coup. According to Iraqi officials, SAVAK had supplied the coup plotters with 3,000 sub-machine-guns, 650,000 rounds of ammunition and two mobile radio transmitters in coordination with Iranian embassies in Baghdad and Kuwait. ${ }^{563}$ They also claimed to have acquired all meeting conversations between the coup plotter and Iranian representatives. Several Iraqi military elements were executed. ${ }^{564}$ Three SAVAK members, including Ismail Nahid, the head of SAVAK station in Baghdad and the plot coordinator, as well as several Kurds and IranianIraqis, were arrested with a bunch of secret documents. Baghdad also expelled Ezzatollah Ameli, Iran's ambassador to Baghdad, Davoud Taher, and Ismail Nahid on 22 January $1970 .{ }^{565}$ In retaliation, the Iraqi ambassador to Tehran and the military attaché were forced to leave Iraq. ${ }^{566}$ Iran also increased its troops along the border. In return, Baghdad to notify the $\mathrm{UN}$ and to object Iranian armed provocations as a threat to peace and security in the Middle East and the world. Zahedi threatened Baghdad that in case of the Iraqi invasion,

${ }^{563}$ Keesing's Record of World Events (formerly Keesing's Contemporary Archives), Volume XVII, February, 1970 Iraq, Page 23827.

${ }^{564}$ Despite al-Rawi's escape to Iran, 87 generals, soldiers, and civilians, including general Mosleh and Brigadier Sirri, all accused of participation in the plot, were executed, together with seven other persons previously condemned on charges of espionage in the next four days. Conspirators condemned in a special court consisting of Captain Jazrawi (a member of the Revolutionary Command Council), Mr. Nazem al-Zar (head of the Security Police) and Mr. Ali Reda (director of the Council's public relations office). See Keesing's Record of World Events (formerly Keesing's Contemporary Archives), Volume XVII, February, 1970 Iraq, Page 23827.

${ }^{565}$ Iran's military attaché, the assistant military attaché, and the press attaché in Baghdad, together with the staffs of the Iranian consulates in Karbala and Basra, were also deported from Iraq.

566 On returning to Baghdad on January 28 the Iraqi Ambassador alleged that Iranian authorities had "brutally" treated himself and his staff, in violation of diplomatic practice. Tehran strongly objected to 'illtreatment' of Majid Mehran, Iranian Charge d' Affairs in Baghdad who had been stopped by frontier guards to search him and his car. Iran also protested the way Iraq treated AbdulKhaleq Bushehri-Zadeh, the Second Secretary at Iran's Embassy, who had been kidnapped and tortured. See Keesing's Record of World Events (formerly Keesing's Contemporary Archives), Volume XVII, February, 1970 Iraq, Page 23827. 
Iran would not hesitate to retaliate "fire by fire" and to "reduce to ashes the area from which the attack would originate. ${ }^{567}$ With both UN and Turkey's interventions, ${ }^{568}$ the tension did not lead to the outbreak of war.

Baghdad also reacted to Iran's aggressive posture by backing Teymour Bakhtiar, the first SAVAK director and the Shah's major opposition leader. Bakhtiar had been ousted by the Shah on March 1961 after his suspicious trip to the U.S. and talks with J.F.K on leading a coup against the Pahlavi regime. After going into exile in Europe a year later, he traveled from Switzerland to Lebanon where he was temporarily arrested with Iran's request in Beirut. While the Shah issued a warrant for his arrest, Bakhtiar entered Iraq and set up his headquarters wherein several Iranian volunteers were recruited to form an armed underground movement against the Shah. On 19 June 1970, Iraq granted political asylum to Bakhtiar. Baghdad also set up three to five radio stations to transmit anti-Shah propaganda and allocated 50 million US Dollars to anti-Shah activities. ${ }^{569}$ Saddam himself confessed that "we gave them a radio program for seven long years; we gave them money and arms and whatever they needed to fight the Shah., ${ }^{, 570}$ Nevertheless, Bakhtiar was finally assassinated by SAVAK agents in Saadieh, near Khaneqin, on 12 August 1970.

\footnotetext{
${ }^{567}$ Keesing's Record of World Events (formerly Keesing's Contemporary Archives), Volume XVII, February, 1970 Iraq, Page 23827.

${ }^{568}$ General Ammash, Iraq Minister of the Interior, arrived in Ankara on February 3 and handed a message from President Bakr to President Sunay, asking Turkey to use her influence with the Tehran Government to prevent the all-out war. Orhan Eralp, secretary-general of the Turkish Ministry of External Affairs, thereupon flew to Teheran on the same day to inform the Shah of the Iraqi-Turkish talks.

${ }^{569}$ Abdulghani, Jasim, Iraq and Iran: The Years of Crisis, The Johns Hopkins University Press (October 1, 1984), p. 52.

${ }^{570}$ Ibid. p. 52.
} 
Although Tehran did not encounter any Iraqi military retaliation on the ground, the aborted coup of 1970 destroyed SAVAK networks in Baghdad. SAVAK unsuccessfully tried to revive Iranians' networks in Iraq in Summer 1972. ${ }^{571}$ The Shah never forgave Nasiri for his incompetence in leading the plot. ${ }^{572}$ The worst had yet to come. Iran's brinkmanship with Iraq in Arvand Rud and the aborted plot convinced Baghdad of an IraqiKurdish agreement.

\section{The March Accord of 1970}

Three days after the suppression of the aborted plot, Baghdad issued a decree in support of a peaceful settlement of the Kurdish question by reaffirming the Bazzaz Declaration. ${ }^{573}$ Although al-Bakr refused the Kurds' demands in late January $1970,{ }^{574}$ both Iran and Israel were worried about their losses in the north of Iraq. On 4 March 1970, Idris, Barzani's older son, met with Nasiri and Israeli intelligence officers in Tehran. Both Iranians and Israelis pressed the Kurds to reopen the war with Baghdad. The Mossad promised them weaponry while SAVAK promised to increase Iran's financial support to

\footnotetext{
${ }^{571}$ Alam, Assadollah. Yad'dashtha-ye 'Alam: Virayesh va Muqaddamah az Alinaqi Alikhani [The Alam Diaries: Edited by Alinaqi Alikhani], Vol. II: 1973-1974 (Bethesda, MD: Iranbook, 1995), p. 299.

572 Qaneifard, Erfan, Tondbad-e Havades: Goftogooi ba Isa Pejman [Hurricane of Events: A Dialogue with Isa Pejman] (Elm Publication, Tehran, 2011) p.181.

${ }^{573}$ Earlier, al-Bakr signaled his willingness to negotiate with Barzani and dispatched Major-general Fuad Aref, a former Kurdish Minister, in late December 1969. Aref advised Barzani that any agreement must be registered with the UN to ensure its implementation. Keesing's Record of World Events (formerly Keesing's Contemporary Archives), Volume XVII, February, 1970 Iraq, Page 23827.

574 The delegation demanded (1) some form of partial home rule, recognition of the Kurds' national right to their own language and culture, and the spending of 80 percent of the national budget on schools, roads, hospitals and other capital projects in the Kurdish areas of Iraq; (2) the removal of Arab tribes settled in Kurdistan; (3) the disbanding of Talabani's Peshmerga; (4) the withdrawal of the Iraqi Army from strategic positions within Kurdistan, with the Kurdish forces doing the same on their side of the front; (3) setting up of machinery to implement the settlement, with a guarantee of the agreement by the United Nations; and (4) maintenance of a reduced Kurdish force as a national guard for northern Iraq. See O'Ballance, Edgar. The Kurdish Revolt, 1961 ---1970 (London: Faber and Faber Ltd., 1973), p. 157-8 and Keesing's Record of World Events (formerly Keesing's Contemporary Archives), Volume XVII, February, 1970 Iraq, Page 23827.
} 
\$3 million a month. In February 1970, Iranian and Israeli funding had been around 3.3 million US Dollars. ${ }^{575}$ Director Nassiri told Idris that "Iran was fully behind the Israeli plan to renew the fighting in Northern Iraq ... and Barzani needs to carefully note what the Israelis were suggesting." 576

Nonetheless, Barzani had already made his decision. As Idris was in Tehran, President al-Bakr sent Saddam Hussain to Kurdistan to reach a peace agreement. ${ }^{577}$ After a month talking about details, they reached an agreement, known as the March Accord of 1970. By recognizing the bi-national identity of Iraq, the Accord concluded that "History will bear witness that you [the Kurds] did not have and never will have as sincere a brother and dependable an ally as the Arab people." ${ }^{, 578}$ Barzani himself received a monthly income while his Peshmerga were paid as border guards. By April 1970, major parts of the Accord had been implemented. ${ }^{579}$ Some Baath elements were optimistic about the settlement of the Kurdish question. Tariq Aziz stated, "We were sincere when we announced the March Accord. It was not [a mere] propaganda." ${ }^{, 50}$ Even pessimistic Barzani saw a remarkable development towards the formation of a Kurdish state. Barzani stated in December 1970

\footnotetext{
${ }^{575}$ CIA, Information Cable, March 9, 1970. (FRUS 1969-1976, E-4, 267).

${ }^{576}$ CIA, “Israeli Aid to Kurdish Rebels,” March 7, 1970 (FRUS/1964-68/XXI/doc.267), pp.1-3.

577 At the time, Saddam was a Vice President and Chairman Deputy of the RCC of Iraq and Assistant Secretary General of the Baath Party,

${ }^{578}$ Harris, G. S. Ethnic Conflict and the Kurds (1977) Annals of the American Academy of Political and Social Science, 433 (1): 118-120.

579 The Baath regime appointed five Kurdish men to the cabinet, though in junior-level ministries and provincial posts, began reconstructing impoverished regions of Iraqi Kurdistan, taught the Kurdish language for the first time in schools, and established a Legislative Assembly in Erbil with theoretical authority over the Kurdish provinces of Dahuk, Erbil, and Sulaymaniyah.

${ }^{580}$ McDowall, David, A Modern History of the Kurds (London, Tauris. 2005) p.528.
} 
that "for the moment we are optimistic. After ten years of fighting, the Iraqi Government offered us autonomy last March and so far they seem to be implementing the agreement." 581

The March 1970 Accord was a failure for Iran. "If it [the Accord] results in significant outcomes, at least 20,000 Iraqi army troops will turn from borders with Kurdistan to our western borders and Iraq will be unchained [of the Kurdish insurgency] ... It would also spark the formation of independent Kurdistan in Iran and Turkey,” Alam was worried about the Accord. ${ }^{582}$ In July 1970, Saddam defied Tehran, claiming that "we are ready to confront agents of Iran, America, and Britain, and all the reactionaries." 583 Although Barzani kept strategic positions safe along the border with Iran and the supply routes, the Accord would apparently undercut the Shah's plan in linking the KurdishArvand Rud issues.

As time wore on, however, it became clear that Baghdad was buying time. Though labelled a "total and final" solution by Saddam, the Accord contained controversial issues that made its real implementation uncertain. ${ }^{584}$ Baghdad refused to appoint a Kurdish vice president and to give oil-rich Kirkuk to the autonomous Kurdistan. Rather, it continued the Arabization policy in order to decrease Kurdish standings in the contested cities of Kirkuk and Khaneqin. Viewing autonomy as a trap for the Kurds and an opportunity for Baghdad to revitalize its military machine, Barzani was not prepared to settle for "the mere trappings

\footnotetext{
${ }^{581}$ Ibid. p.529.

582 Alam, Assadollah. Yad'dashtha-ye 'Alam: Virayesh va Muqaddamah az Alinaqi Alikhani [The Alam Diaries: Edited by Alinaqi Alikhani], Vol. I: 1968-1970 (Bethesda, MD: Iranbook, 1995), p. 393.

${ }^{583}$ Abdulghani, Jasim, Iraq and Iran: The Years of Crisis (The Johns Hopkins University Press, October, 1984) p. 52.

${ }^{584}$ To establish the autonomous Kurdish region, a mutually agreed census would determine Kurdish-majority areas of Iraq.
} 
of autonomy" where the Bath would "retain all the essentials of real political power in their own hands." ${ }^{585}$ By summer 1970, the Kurds had begun "strengthening their forces and lining up potential allies." ${ }^{586}$ Amidst Barzani's hesitation to join a national unity government, Baghdad devised a Russian-backed covert plot to assassinate him on 29 September $1971{ }^{587}$ Despite the regime's denial, Barzani was convinced Saddam was behind the plot. ${ }^{58}$ Lacking trust in Baghdad, Barzani was still suspicious of Iran's full support for the Kurds. Interestingly, SAVAK was well aware of his suspicion. ${ }^{589}$ Barzani thought that the Shah's brute pragmatism would sell the Kurds for a territorial concession over Arvand Rud. He was also tired of Iran's “heavy-handed control over Kurdish activities. ${ }^{.590}$ To avoid putting all his eggs in the Iranian basket, Barzani had been pleading with other regional states, particularly Jordan and Saudi Arabia, for support. King Faisal of Saudi Arabia had already "endorsed the idea of an Iraqi revolt in principle," but he needed more reliable sources before making any move. ${ }^{591}$ Given Iraq's ineffective support

${ }^{585}$ Beirut A-38 to the U.S. Department of State, February 2, 1972, FRUS 1969-1976, E-4, 297.

${ }^{586}$ CIA Information Cable, August 10, 1970, FRUS 1969-1976, E-4, 273.

587 U.S. Department of State, Bureau of Intelligence and Research, "The Kurds of Iraq: Renewed Insurgency?" 31 May 1972 (NPL/HAK/Box138/Kurdish Problem-Vol. I/June 1972-Oct 1973), p.3; U.S. Interests Section to U.S. Embassy Brussels, "Attempt on the Life of AL-BARZANI," October 4, 1971 (NARA/RG59/Records Relating to Iraq/1966-1972/Box12/POL 23-7), p.2, and Lawrence, Quil. Invisible Nation: how the Kurds' quest for Statehood is shaping Iraq and the Middle East, New York: Walker \& Co. 2008. p. 22.

588 Belgian Ministry of Foreign Affairs and Trade to the U.S. Department of State, "REPIR: Reports on Assassination Attempt Made on Al-Barzani," November 2, 1971 (NARA/RG59/Records Relating to Iraq/1966-1972/Box12/POL 23-7), p.2, Primakov, Yevgeny. Russia and the Arabs: Behind the scenes in the Middle East from the Cold War to the present. New York: Basic Books. 2009. p. 334)

589 National Security Council, Memorandum, Saunders to Kissinger, "Supporting the Kurdish Rebellion," March 27, 1972 (FRUS/1964-68/XXI/doc.301), p.3.

${ }^{590}$ Beirut 222 to U.S. Department of State, July 16, 1971, FRUS 1969-1976, E-4, 292.

${ }^{591}$ Baghdad 291 to U.S. Department of State, March 14, 1970 (NPL/NSC/NSF/Box601/Country Files/Middle East/Iran/Vol. I/1/20/69-5/31/70), p.1. 
for the PLO in the Black September, ${ }^{592}$ King Hussein had been interested in the Kurdish War. He promised Barzani to convince the U.S. to reconsider its strategy towards the Iraqi Kurds. ${ }^{593}$ But none of these states had the potential to back the Kurds against Baghdad.

\section{Baghdad-Moscow Connection and the Shah's Cold War Language}

The March Accord released Baghdad from a decade-aged war in Kurdistan and, instead, gave it an opportunity to turn its attention to the regional issues. In late 1969, the Baath regime attempted coming to terms with both the Kurds and the Communists to broaden its political base of support and to draw Moscow to its side. ${ }^{594}$ Although the Russian knew that their alliance with Baghdad might damage its image among ethnic minorities in the world, including the Kurds, they finally put their eggs in the Iraqi basket since they did not want to miss a power vacuum in the Persian Gulf. Therefore, Barzani was pressed by the Russians, through a combination of pressure and bribery, to settle the issue which finally led to the March Accord. Baghdad-Moscow relations underwent a major thaw as Iraq signed covert arms deals with the Soviets in September $1971 .{ }^{595}$ In February 1972, Saddam Hussein visited Moscow and signed several military and economic

\footnotetext{
${ }^{592}$ Black September refers to the civil war in Jordan between 16 and 27 September 1970, a bloody conflict erupted between the PLO and the Jordanian Armed Forces. Armed conflict ended with the expulsion of the PLO leadership and thousands of Palestinian fighters to Lebanon.

${ }^{593}$ Baghdad 291 to U.S. Department of State, March 14, 1970 (NPL/NSC/NSF/Box601/Country Files/Middle East/Iran/Vol.I/1/20/69-5/31/70), p.1.

${ }^{594}$ In contrast to its short reign in 1963 , the Baath regime tried to drag the ICP into power by appointing communist leaders and the release of most of the Communists in prison. On January 28, 1970, general Takriti said at a press conference in Beirut that several Communists had been reinstated in their posts in the Administration, and that those whose posts had been filled were nevertheless receiving their salaries. See Keesing's Record of World Events (formerly Keesing's Contemporary Archives), Volume XVII, February, 1970 Iraq, Page 23827.

${ }^{595}$ It included anti-aircraft guns, anti-tank rockets, armored personnel carriers, and fighter aircraft. See CIA, "Moscow and the Persian Gulf," IM-0865/72, May 12, 1972 (FRUS/1964-68/XXI/doc.307), p.2; U.S. Department of State 12737 to U.S. Embassy Iran, January 22, 1972 (FRUS/1964-68/XXI/doc.295).
} 
agreements. ${ }^{596}$ On 9 April 1972, the Treaty of Friendship and Cooperation that involved a fifteen-year Moscow military and economic aid and commitment to Baghdad was signed. Following the Kosygin visit to Baghdad in April 1972, Communists were appointed to the cabinet and the Baath Party allowed the ICP to formally participate in a National Patriotic Front, though the real power was still in its hands. As Baghdad's dependence on Moscow decreased, mainly because of skyrocketing oil revenues following the Oil Crisis 1973-4, the ICP was gradually suppressed.

The warm Baghdad-Moscow relations concerned the Shah. In the broader context of détente at the international level and the U.S. disinclination for direct intervention in the region, the Russian inroads in Baghdad were considered by the Shah as a growing threat to Iran. The Shah was worried about its unpredictable results, stating that the Treaty was "a prestigious declaration for both sides; however, it was thinkable." that the full implementation of the March Accord would blow down Iran's non-state foreign policy in Iraqi Kurdistan and, that in turn, could unshackle Iraq to interfere in the Persian Gulf area. It was unacceptable for a man who saw his country as the natural heir to the British in the Persian Gulf. In the Shah's view, the Accord was not only a prelude to Moscow's quest for supremacy in the region but also a harbinger of the establishment of the greater Kurdish entity. For the first time since the coup of 1958, Iran's major geocultural threats of Pan-Arabism, Communism, and Kurdish Separatism were all combined. Under this circumstance, his only way to convince Barzani to reopen fighting with Baghdad was to drag the U.S. into the Kurdish War.

\footnotetext{
${ }^{596}$ Moscow 1501 to U.S. Department of State State, February 18, 1972, FRUS 1969-1976, E-4, 298.

597 Alam, Assadollah. Yad'dashtha-ye 'Alam: Virayesh va Muqaddamah az Alinaqi Alikhani [The Alam Diaries: Edited by Alinaqi Alikhani], Vol. II: 1973-1974 (Bethesda, MD: Iranbook, 1995), p. 328.
} 
The Shah began lobbying the Nixon administration to abandon its hands-off policy toward the Iraqi Kurds. His major tool to convince the U.S. was his strategic use of the Cold War language that framed the Kurdish War and Baath-Kremlin relations as a Soviet wider plan to infiltrate the region. Just a few days after signing the Accord, Prime Minister Amir-Abbas Hoveyda clarified the Shah's view of the Accord to Douglas MacArthur, the U.S. ambassador to Tehran, as a "very grave development greatly increasing [the] threat to [the] Persian Gulf area and [the] Arabian Peninsula." Hoveyda--in reality, the Shah-asserted that Baghdad was "very much under the influence of the Soviets because of its dependence on Soviet military and other aid for survival." He also added that the March Accord would unchain Baath Iraq from Kurdistan and allowing it to deploy about 20,000 Iraqi troops and resources in the Persian Gulf "for subversion and another mischief against the small Persian Gulf states or Israel.” For the Shah, Hoveyda added, the Accord was also a harbinger for the Russians to "begin to play on [a] strong national sentiment of Kurdish people to stir up Turkish and Iranian Kurds in subversive activities holding out bait of an enlarged independent Kurdish state." 598 He concluded that the accord of 1970 would "prepare for next step in [the] Soviet plan which is eventual transformation of autonomous Iraqi Kurdish province into autonomous Kurdish state with [a] view to enlarging Kurdish state until it eventually has contiguous borders with [the] Soviet Union which will thus enable [the] Soviets to overcome [the] present Turkey-Iran barrier to their direct penetration of [the] Middle East. ${ }^{, 599}$ It was a major manifestation of the Shah's strategic

\footnotetext{
${ }^{598}$ Tehran 928 to U.S. Department of State, March 12, 1970, FRUS 1969-1976, E-4, p.53.

${ }^{599}$ Tehran 00928 to U.S. Department of State, "Soviet-Iraq Threat to Middle East (Shah's Views)," March 12, 1970 (FRUS/1964-68/XXI/doc.53), pp.1-3.; and Tehran 928 to U.S. Department of State, March 12, 1970, FRUS 1969-1976, E-4, p.53.
} 
use of Cold War language. "Preponderantly communist" means, the establishment of an Iraqi national unity government would unleash the Iraqi army in the Persian Gulf and increase the possibility of the rise of communists in Baghdad, the Shah thought. ${ }^{600}$ It was "a status similar to that of the East European satellites." ${ }^{601}$ In the same line, an Iraqi national unity government "would include communists, Nasserists and Kurds subservient to the Baath ... and would represent a situation antithetical to both Iranian and U.S. interests." ${ }^{\text {,602 }}$ For the U.S., however, the Kurdish War was less an element in the Cold War contest with Moscow than a far-away local-regional conflict.

\section{The American Hesitation}

For more than a decade, the U.S. had refrained from intervening in the Kurdish War. Although the U.S. State Department agreed with increasing support for modernizing Iran's military forces to deter the Russian threat, it had rejected the Shah's framing of the March Accord of 1970 as a major part of a "Moscow's master plan" for the formation of a "Kurdish corridor" into the Persian Gulf since it seemed "unlikely that the Soviets would want to risk damaging their carefully nurtured relations with Iran and Turkey." ${ }^{, 603}$ The State Department thought both Iran and Israel had overstated the Soviet threat. ${ }^{604}$ Even Iraqi bold reaction to Iran's retaking of its three strategically Persian Gulf islands was not framed as

\footnotetext{
${ }^{600}$ National Security Council, Memorandum, Saunders to Kissinger, "Supporting the Kurdish Rebellion," March 27, 1972 (FRUS/1964-68/XXI/doc.301), pp.3-4.

${ }^{601}$ Ibid.

${ }^{602}$ National Security Council, Memorandum, Saunders to Kissinger, "Supporting the Kurdish Rebellion," March 27, 1972 (FRUS/1964-68/XXI/doc.301), p.3.

${ }^{603}$ Tehran 00928 to U.S. Department of State, "Soviet-Iraq Threat to Middle East (Shah's Views)," March 12, 1970 (FRUS/1964-68/XXI/doc.53), pp.1-3.

${ }^{604}$ Baghdad 291 to U.S. Department of State, March 14, 1970 (NPL/NSC/NSF/Box601/Country Files/Middle East/Iran/Vol.I/1/20/69-5/31/70), p.1; and U.S. Department of State 54598 to U.S. Embassy in Tel Aviv, "Soviet Pressure for Iraqi-Kurdish Agreement," April 14, 1970 (FRUS/1964-68/XXI/doc.269), p.3
} 
a threat to Persian Gulf security. ${ }^{605}$ The Department also rejected Iraq's growing leverage in the Arab World after signing the Accord ${ }^{606}$ rather, it argued that with warming relations with Moscow, the Iraqis had been "isolated even from the mainstream of Arab world."607 As Marshal Andrei Grechko, the Soviet Defense Minister, visited Baghdad to seal the arms deal, ${ }^{608}$ the Department did not consider it as a "part of aggressive policy in the Persian Gulf aimed at Iran;" rather, it was framed as a step "designed to placate Baghdad, not to pose [a] threat to the Shah." ${ }^{609}$ The Treaty of Friendship was also called "nothing surprising or sudden but rather a culmination of existing relationships. ${ }^{.610}$ Calling it another version of the former Soviet agreements with India and Egypt ${ }^{611}$ the Department thought that a major driving force behind signing the Treaty was less based on the geopolitical realities rather than the initiative of Saddam Hussein who was seeking Russian support for consolidation his power. ${ }^{612}$ Within this context, Joseph Farland, the U.S. Ambassador to Iran, stated that any support for the Iraqi Kurds would generate "far too much risk

${ }^{605}$ On 30 November 1971, Baghdad harshly reacted to Iran's retaking of its islands, Abu Musa and the Greater and Lesser Tunbs, by breaking diplomatic relations with Tehran, expelling 60,000 Iraqi residents of Iranian origin, claiming Khuzestan, and intensifying support for both Arab and Baluchi separatists in Iran.

606 The U.S. Department of State 213299 to Tehran, November 24, 1971, FRUS 1969-1976, E-4, 294. Claiming that Iraqi army threat was too exaggerated by the Shah, the U.S. embassy in Beirut advocated sticking to a long-standing hands-off policy since the Iraqi army "could not fight its way out of a wet paper bag" after the Baath destructive purges. Beirut A-38 to U.S. Department of State, February 2, 1972, (FRUS 1969-1976, E-4, 297).

${ }^{607}$ U.S. Department of State 67409 to Certain Posts, April 21, 1971, (FRUS 1969-1976, E-4, 286).

${ }^{608}$ Beirut A-38 to U.S. Department of State, February 2, 1972 (FRUS/1964-68/XXI/doc.297), pp.8-9.

${ }^{609}$ The U.S. Department of State 12737 to U.S. Embassy Iran, January 22, 1972, (FRUS, 1969-1976, E-4, doc.295).

${ }^{610}$ National Security Council, “Iraq,” May 18, 1972 (FRUS/1964-68/XXI/doc.308), p.5.

${ }^{611}$ Saunders to Haig, March 27, 1972, (FRUS 1969-1976, E4, 301).

${ }^{612}$ Eliot to Kissinger, April 13, 1972, (FRUS 1969-1976, E-4, 305); Kissinger, Years of Renewal, (New York: Simon \& Schuster, 1999). p.581. 
compared to the limited benefit gained." ${ }^{, 613}$ Harold Saunders also argued that the U.S. involvement in the obscure, faraway Kurdish War might be "regarded by the Soviets as a move directed against them." ${ }^{, 614}$ For Saunders, both Iran and Israel were trying to draw the U.S. into the crisis by overemphasizing the Iraqi-Russian ties while at the same time they were capable of assisting the Kurds without U.S. support. They "absolutely needed nothing from us except that they want to involve us" in Iraqi Kurdistan, Saunders argued. ${ }^{615}$ Time was not on Iran's side.

In the meantime, Barzani became more determined to reorganize his Peshmerga for an upcoming Baath military campaign. Despite his suspicion of Tehran, he did not listen to Russian Rumanytsev's warning not to "trust to the Shah." ${ }^{, 616}$ Barzani joined SAVAK in planning a coup plot against Baghdad led by Colonel Abd al-Razzaq al-Nayif in March 1972. ${ }^{617}$ Although SAVAK provided military and financial needs for the plot, Barzani suspected that SAVAK would not "implement the promises." Neither Barzani nor Iraqi opposition would welcome "direct control or intervention by Iran in Iraqi internal affairs." ${ }^{618}$ Therefore, Barzani pleaded with the U.S., as well as the UK and King Hussein

\footnotetext{
${ }^{613}$ Kissinger, Henry. Years of Renewal (New York: Simon \& Schuster, 1999). p. 581.

${ }^{614}$ National Security Council, Memorandum, Saunders to Kissinger, "Supporting the Kurdish Rebellion," March 27, 1972 (FRUS/1964-68/XXI/doc.301), p.1; Saunders to Haig, March 27, 1972, (FRUS 1969-1976, E-4, 301).

${ }^{615}$ National Security Council, Memorandum, Saunders to Kissinger, "Supporting the Kurdish Rebellion," March 27, 1972 (FRUS/1964-68/XXI/doc.301), p.1; Saunders to Haig, March 27, 1972, (FRUS 1969-1976, E-4, 301).

${ }^{616} \mathrm{He}$ was a Soviet advisor who led a high-level delegation dispatched to Kurdistan to convince Barzani to join the ICP in a National Patriotic Front on 28 February 1972. Saunders to Haig, March 27, 1972, (FRUS 1969-1976, E-4, 301); Helms to Kissinger, Rogers and Laird, March 31, 1972, (FRUS 1969-1976, E-4, 303).

${ }^{617}$ Al-Nayif was the former Iraqi prime minister and military chief.

${ }^{618}$ Helms to Kissinger, Rogers, and Laird, March 29, 1972, (FRUS 1969-1976, E-4, 302); Helms to Kissinger, June 6, 1972, (FRUS 1969-1976, E-4, 313).
} 
of Jordan, to support the plot. ${ }^{619}$ At the same time, SAVAK urged the CIA to support the coup plotters by "providing financial and military support" and "drawing together Iraqi exiles who would comprise the nucleus of a separatist government initially harbored by Barzani. ${ }^{, 620}$ Nevertheless, the State Department downgraded the possibility of the debacle of the Baath regime, arguing that a new Iraqi regime would be weak and dependent on the Soviets due to Barzani's "umbilical cord with Moscow." According to the State Department, any cooperation in a coup would be framed as a major example of a U.S. alliance with non-Arab countries against the Arab states and damage strategic relations with the Arab allies of the U.S. Furthermore, it would possibly result in the formation of a Kurdish state in Iraq that would, in return, boost Kurdish nationalism in Iran and Turkey and culminate in the "further fragmentation in an already fragmented area." ${ }^{621}$ In the same line of thought, CIA asserted that any American involvement in the plot could be "regarded by the Soviets as a move directed against them." ${ }^{, 622}$ The U.S. still did not want to side with Iran in Iraqi Kurdistan.

\footnotetext{
${ }^{619}$ Both Iraqi oppositions and the Kurds insisted on King Hussein's involvement in the plot because 1) Jordan would be the best alternative to Iran as a conduit for the U.S. assistance and 2) King Hussein of Jordan was the Shah's intimate friend and would mediate between Tehran and the Kurds. See Killogre to Sisco, April 3, 1972, (FRUS 1969-1976, 3-4, 304).

${ }^{620}$ CIA, Memorandum, Waller to Sisco, "Intention of Kurdish Leader Al-Barzani to Approach the United States Government for Assistance; Iranian Intelligence Request for Expression of United States Government Willingness to Overthrow the Ba'thi Regime of Iraq," March 9, 1972 (FRUS/1964-68/XXI/doc.299), p.1-2; CIA, Memorandum, Helms to Kissinger, et al., "Kurdish Efforts to Recruit International Support...," March 29, 1972 (FRUS/1964-68/XXI/doc.302), p.1.

${ }^{621}$ The U.S. Department of State, Memorandum from Seeyle, "Some Reasons Why We Should Not Support Barzani Against the Iraqi Government," March 14, 1972 (NARA/RG59/Records Relating to Iraq/19731975/Box1/POL 13), p.1.

${ }^{622}$ National Security Council, Memorandum, Saunders to Kissinger, "Supporting the Kurdish Rebellion," March 27, 1972 (FRUS/1964-68/XXI/doc.301), p.1.
} 


\section{Tehran Summit of 1972}

By early 1972, the U.S. still resisted siding with its regional allies, Iran and Israel, against Baghdad, even when King Hussein of Jordan joined the Shah's campaign to press the White House. ${ }^{623}$ However, the Shah did not abandon his hope to convince the U.S. to reconsider its hands-off policy. In February 1972, President Nixon's visit to Beijing initiated the new U.S. policy later consolidated by the historical Moscow Summit in May 1972. In the Shah's view, the Nixon-Brezhnev Strategic Arms Limitations Treaty (SALTI) demonstrated the U.S. disinclination to fully support its allies and its recognition of Moscow's zones of influence, including Iraq and possibly the Persian Gulf, at the zenith of the Cold War.

Nixon and Kissinger arrived in Tehran and met the Shah in Saadabad Palace just a day after the Moscow Summit. During his lunchtime with the Shah, Nixon reemphasized his special relation with Iran and said, "The Kremlin was a palace, but staying there for eight days was very stifling. I am breathing here in the Shah's personal house since we share the same house and I feel myself at home."624 Aware of the Shah's concern of the potential consequences of the Moscow Summit for Iran, Nixon pledged full support and provided Iran with modern weaponry, particularly F-14s and F-15s, to deter the Soviet ultra-modern Mig-23 jets recently given to Baghdad. ${ }^{625}$ "Nixon gave me anything I had

\footnotetext{
${ }^{623}$ Kissinger, Henry. Years of Renewal (New York: Simon \& Schuster, 1999). p. 581; SAVAK had already offered a secret 'corridor', Jordan, to channel assistance "with only Barzani being aware." U.S. Department of State, Memorandum from Scotes, "Kurdish Appeal for U.S. Assistance," Memorandum of Conversation, April 3, 1972 (NARA/RG59/Records Relating to Iraq/1966-1972/Box14/POL 13), p.2.

${ }^{624}$ Alam, Assadollah. Yad'dashtha-ye 'Alam: Virayesh va Muqaddamah az Alinaqi Alikhani [The Alam Diaries: Edited by Alinaqi Alikhani], Vol. II: 1970-1972 (Bethesda, MD: Iranbook, 1995), p. 286.

${ }^{625}$ White House, Memorandum of Conversation, "May 31, 1972 - 10:30 a.m. to 12:00 p.m.," (FRUS/196468/XXI/doc.201), p.3.
} 
asked," the Shah victoriously told Alam. ${ }^{626}$ Nixon's decision was based on the U.S. "need to ensure friendly relations with the Iranian monarch as the key figure in maintaining Iran's stability." ${ }^{\text {, }}$ More significantly, his decision laid the foundations for the Nixon Doctrine by making Iran the sole pillar in the Middle East "with the Saudi pillar being a nominal pillar there for obvious necessary regional political reasons." ${ }^{628}$ It was a victory for the Shah.

The Shah also pressed Nixon to support the Iraqi Kurds. ${ }^{629}$ Subtly applying the Cold War language, the Shah framed the national unity government in Baghdad as the Soviet plan to "establish a coalition of the Kurds, the Baathists, and the Communists." He argued that "the Kurdish problem instead of being a thorn in the side [of the Baath regime of Baghdad] could become an asset to the Communists" against Iran and Turkey. When Kissinger asked "What could be done?" the Shah quickly replied back "Iran can help with the Kurds. ${ }^{, 630}$ He repeated his request the next day by asserting that the immediate danger to Iran came "mostly from Baghdad, or at least Baghdad would take credit for it." ${ }^{631}$ Next

\footnotetext{
${ }^{626}$ Alam, Assadollah. Yad'dashtha-ye 'Alam: Virayesh va Muqaddamah az Alinaqi Alikhani [The Alam Diaries: Edited by Alinaqi Alikhani], Vol. II: 1970-72 (Bethesda, MD: Iranbook, 1995), p. 287.

${ }^{627}$ Offiler, US Foreign Policy and the Modernization of Iran: Kennedy, Johnson, Nixon and the Shah, Palgrave Macmillan UK, 2015. Ben P.

${ }^{628}$ Harold Saunders in an interview with William Burr, February 24, 1987, Washington, DC, tape 2B, FISOHC in Nixon, Kissinger, and the Shah: The United States and Iran in the Cold War by Roham Alvandi (Oxford University Press, Oxford, UK, 2014).

${ }^{629}$ White House, Memorandum of Conversation, May 30, 1972 - 5:35 to 6:35 p.m. (FRUS/196468/XXI/doc.200), pp.1-2; and Memorandum of Conversation, May 31, 1972 - 10:30 a.m. to 12:00 p.m. (FRUS/1964-68/XXI/doc.201), pp.1-3.

${ }^{630}$ Memcon, May 30, 1972, (FRUS 1969-1976, E-4, 200).

${ }^{631}$ Memcon, May 31, 1972, (FRUS 1969-1976, E-4, 201).
} 
time, the Shah subtly played with the U.S. sensitive issues of the spread of communism and separatism in the region.

At the same time, an analysis outlined by the Bureau of Intelligence and Research warned against U.S. engagement in Iraqi Kurdistan since it would be a lose-lose game and advocated rejecting the Shah's plan to draw the U.S. into the Kurdish War. ${ }^{632}$ The analysis argued that the 69-year-old Barzani, "the only Kurdish leader who can unite his people to the point of armed insurgency" and "whose personal appeal has been stronger than any Kurdish figure of this generation," saw "the goals that his people fought for and almost attained slipping away unless he can force some substantial political gains in what may be his last campaign. He probably also foresees that if he declines this challenge, his personal leadership is doomed." The analysis added that Barzani had two destructive options. While joining the national unity government would terminate his efforts for an autonomy in Iraqi Kurdistan, fighting a "long-drawn-out insurgency" would not be conclusive. The analysis also predicted that Barzani's defeat would create "a complaisant pro-Baath or even proSoviet clique in control of Iraqi Kurdistan [that] could of course bring pressure on Iran and even create a nuisance in eastern Turkey." 633 Nonetheless, the analysis fell on deaf ears. Nixon had agreed that "American participation in some form was needed to maintain the morale of such key allies as Iran and Jordan, disparate as their motives were, and as a

\footnotetext{
${ }^{632}$ Research Study RNAS-10 prepared by the U.S. Department of State, May 31, 1972, (FRUS 1969-1976, E-4, 201).

${ }^{633}$ Research Study RNAS-10 prepared by the U.S. Department of State, May 31, 1972, (FRUS 1969-1976, E-4, 201).
} 
contribution to the regional balance of power." ${ }^{\prime 34}$ Enticed by the Shah's Cold War language, both Nixon and Kissinger agreed to support the Iraqi Kurds. ${ }^{635}$

The Shah was confident that he could transform the U.S. policy on Iraqi Kurdistan. "When I talked with Nixon on Kurdistan, Iraq and the Soviet's influence in [Iraq], he turned very sad and told me he would implement any thwarting plan I offered," he told Alam. ${ }^{636}$ The Shah's agency in changing the Americans' policy was heavily based on his 'special relationship' with Nixon. Indeed, Nixon saw Iran as America's “one friend there” and "by God if we can go with them, and we can have them strong, and they are in the center of it, and a friend of the United States, I could not agree more--it is something." ${ }^{\circ 37}$ Additionally, both Nixon and Kissinger knew little about the origin and dynamics of the Kurdish question. "We did not know much about Kurds ... we thought they were some kind of hill tribe." 638

The Tehran Summit of 1972 was a watershed in the Kurdish War. Although their effort to meet Nixon and Kissinger was rejected, ${ }^{639}$ the Kurds could not be happier because of the U.S. policy shift. A day after Nixon's departure from Tehran, Baghdad nationalized the Iraqi Petroleum Company. It was a critical move that right fell into the Shah's Cold

\footnotetext{
${ }^{634}$ Kissinger, Henry. Years of Renewal (New York: Simon \& Schuster, 1999). p. 581

${ }^{635}$ Kissinger, Henry, White House Years, (Little Brown \& Co, Boston, Massachusetts, 1979) pp. 1264-1265; Kissinger, Henry. Years of Renewal (New York: Simon \& Schuster, 1999). p. 583.

${ }^{636}$ Alam, Assadollah. Yad'dashtha-ye 'Alam: Virayesh va Muqaddamah az Alinaqi Alikhani [The Alam Diaries: Edited by Alinaqi Alikhani], Vol. II: 1973-1974 (Bethesda, MD: Iranbook, 1995), p. 306.

${ }^{637}$ Conversation among President Nixon, MacArthur, and Haig, Washington, April 8, 1971, FRUS 19691976, E-4, 122.

${ }^{638}$ Randal, Jonathan After Such Knowledge, What Forgiveness? My Encounters with Kurdistan. (London: Westview Press, 1999) p.149.

${ }^{639}$ Helms to Kissinger, June 6, 1972, (FRUS 1969-1976, E-4, 313).
} 
War language and justified Iran's non-state foreign policy in containing the "first Soviet penetration of a major oil producer in the Middle East." ${ }^{\circ 40}$ Only a week later, the Shah asked Kissinger to receive Idris Barzani and Mahmoud Othman to get the cooperation going. ${ }^{641}$ Despite a strong objection in the State Department, ${ }^{642}$ Kissinger met with the Kurdish delegates. A few days later, John Connelly, former Treasury Secretary, went to Tehran and informed the Shah of the U.S. paradigm-shifting decision to assist the Kurds. ${ }^{643}$ It was a new era in the Kurdish war.

To initiate the operation, the CIA assessed that the U.S. would need to dedicate $\$ 24$ million annually for the Kurds only to pay the salaries of Barzani's 50,000-man army. ${ }^{644}$ Despite Saunders' warnings, ${ }^{645}$ CIA Director Richard Helms and Colonel Richard

${ }^{640}$ Randal, Jonathan. After Such Knowledge, What Forgiveness? My Encounters with Kurdistan (London: Westview Press, 1999). p.152.

${ }^{641}$ National Security Council, Memorandum, Saunders to Kissinger, "Message from Shah on Kurds," June 7, 1972 (FRUS/1964-68/XXI/doc.313), pp.1-3.

${ }^{642}$ On 7 June 1972, Harold Saunders rejected the Shah's request to give highest-level U.S. contact to the Kurds and warned Kissinger to avoid direct engagment in Iraqi Kurdistan. He cautiously warned Kissinger that "the best that could be achieved would be a stalemate, and if the battle turned against the Kurds, we would have neither the assets nor the interest to provide decisive support." He also advised against any direct support and added that due to the availability of "the financial resources in (may be Iran) ..., the U.S. should consult with the regional countries which it is already supporting in a variety of ways." Furthermore, Saunders was worried that US intervention would be seen by Moscow as a "direct counter Soviet move," "since the Soviets have made an effort recently to persuade the Kurds to join the Baath Party in a national unity government in Baghdad." he also offered to meet with the two Kurdish envoys, "Idris Barzani, son of the Kurdish leader, and Mahmoud Othman" in Kissinger's place, so as to avoid giving Barzani the impression of a commitment by the White House to his cause. Lastly, he advised that "If we were to decide to help them, I would assume we would want our hand to be hidden". See 'From Harold H. Saunders to Kissinger, Subject: Message from Shah on Kurds, June 7, 1972.'

${ }^{643}$ United States Congress, House Select Committee on Intelligence, CIA: The Pike Report (Nottingham, England: Spokesman Books, 1977). pp.196, 212.

${ }^{644}$ Waller to Helms, June 12, 1972, (FRUS 1969-1976, E-4. 315).

${ }^{645}$ Saunders was worried that the American role would not remain secret, and in return, would damage the US détente with the USSR as well as the White House image before the Arab world. He also believed that both Tehran and Tel-Aviv had already provided the Kurds essential needs, so the U.S. support was not necessary. See Saunders to Haig, June 23, 1972, (FRUS 1969-1976, e-4, 318). 
Kennedy, a senior member of the NSC staff, met Kurdish delegates on 30 June 1972. Helms expressed "the sympathy of the U.S. for the Kurdish movement" and "readiness to consider their requests for assistance" while stressing the covertness of the operation. He warned them that "the relationship could indeed be soured by a failure to honor our need for such secrecy." More significantly, Helms clearly told them that only "because the Shah wanted the American government to help" Barzani Peshmerga, they were being supported and, therefore, they should not think of bypassing Tehran to deal directly with the White House. ${ }^{646}$ At the end of the meeting, he called Iran a conduit to channel the U.S. military aid ${ }^{647}$ Despite initial warnings, the CIA argued right after the meeting with the Kurds that the U.S. support for the Kurdish operation was justified by the Soviet and Iraqi threat to Western interests. ${ }^{648}$ "There can be no doubt that it is in the interests of ourselves, our allies, and other friendly governments in the area to see the Baath regime in Iraq kept off balance and if possible overthrown, if this can be done without increasing Soviet influence in Iraq or escalating hostilities to a dangerous international level," the report advocated support for the Iraqi Kurds. ${ }^{649}$ The Shah's 'Cold War language' was finally heard by the Americans.

\footnotetext{
${ }^{646}$ Randal, Jonathan, After Such Knowledge, What Forgiveness? My Encounters with Kurdistan (London: Westview Press, 1999). p.153.

${ }^{647}$ CIA, "Washington Meetings with Kurdish Representatives," July 5, 1972 (FRUS/1964-68/XXI/doc.319), pp.1-4; Memcon, July 5, 1972, (FRUS 1969-1976, E-4, 319).

${ }^{648}$ The CIA analyzed that any support for the Kurds would result in bringing up a "definite possibility" of Moscow's engagement in the war as well as posing threat to "acutely sensitive" Ankara with the rise of Kurdish nationalism. Beyond Mullah Mustafa's age and lack of a next strong leader as well as dividing "deep factional cleavages rooted in tribal, political, and social conflicts" among the Kurds, the U.S. support could undermine the State Department's plans to revive diplomatic relations with Baghdad. CIA, "Support for Barzani: A Preliminary Estimate," no date (FRUS/1964-68/XXI/doc.321, attachment C), pp.12-13. pp.1-18.

${ }^{649}$ White House, Memorandum, Haig to Kissinger, "Kurdish Problem,” July 28, 1972 (FRUS/196468/XXI/doc.321), p.9.
} 
In the meantime, 15,000 Russian military personnel withdrew from Egypt. It was a tectonic shift in the regional power arrangement. ${ }^{650}$ By summer 1972, Baghdad had become a valuable element in Moscow's Middle Eastern strategy ${ }^{651}$ It was a game-shifting moment for the Shah that "made that [supporting the Kurds] is more important than ever." ${ }^{652}$ As Kissinger recalled, the U.S. was "very receptive to helping the Kurds," ${ }^{, 653}$ Thus, he chose a strategy to "weaken any country tied up with the Soviet Union." On 1 August 1972, the Kurdish operation was set in motion.

\section{A Triangular Cooperation in Iraqi Kurdistan}

Shortly after Nixon's victory in the presidential election of 1972, Barzani received the CIA's first financial support and shipment of arms through SAVAK. ${ }^{654}$ In a meeting with the Shah, King Hussain agreed to support the Kurds with weapons "captured [from Palestinian] Fedayeen" during the Black September of 1970. Through SAVAK, CIA, and Mossad, 14 planes were loaded full at Mehrabad Airport and then delivered to the Peshmerga. ${ }^{65}$ The Kurdish operation was run by the Iranian Colonel Pejman and General Manuchehr Hashemi, the head of SAVAK's Eighth Office, Arthur Callahan, CIA station

\footnotetext{
${ }^{650}$ Kissinger, Henry. Years of Renewal (New York: Simon \& Schuster, 1999). p. 584.

${ }^{651}$ Ibid.

${ }^{652}$ White House, Memorandum, Haig to Kissinger, "Kurdish Problem," July 28, 1972 (FRUS/196468/XXI/doc.321), p.1.

${ }^{653}$ Randal, Jonathan. After Such Knowledge, What Forgiveness? My Encounters with Kurdistan (London: Westview Press, 1999). p.151.

${ }^{654}$ White House, Memorandum, Kissinger to the President, "Progress Report on the Kurdish Support Operations,” October 5, 1972 (FRUS/1969-76/E-4/doc.325), p.1.

${ }^{655}$ The first planeload of 10 tons of Soviet-made arms and ammunition, including 500 Kalashnikov AK-47 assault rifles, 500 Soviet submachine guns, and 200000 rounds of ammunition reached Iraqi Kurdistan. By the end of October, the Kurds received 222000 pounds of arms and ammunition from CIA stocks as well as 142000 pounds through Iran. See White House, Memorandum, Kissinger to the President, "Progress Report on the Kurdish Support Operations," October 5, 1972 (FRUS/1969-76/E-4/doc.325), p.1.-103. See also Interview with Major General Mansour Qadar, Oral History, Foundations for Iranian History.
} 
chief in Tehran, Langley, and Israeli David Kimche. ${ }^{656}$ In contrast to CIA, both SAVAK and Mossad had permanent military and intelligence liaison officers in Haji Omran. Training Peshmerga, Israel's few platoons rarely engaged in heavy fighting. ${ }^{657}$ Iran's larger military presence was comprised of one artillery battalion, one anti-aircraft battalion, and a few SAVAK operatives. ${ }^{658}$ Iran then provided the Kurds with long-range artillery support. On the American side, former CIA Director Richard Helms, the U.S. new ambassador to Tehran, was a key figure. ${ }^{659}$ Functioning as the "American Number One"660 and the U.S. "super ambassador" in the region, ${ }^{661}$ Helms's views on the Kurdish operation and Iran's affairs were unchallenged by CIA and the State Department doubled the extent and secrecy of the U.S. involvement in Iraqi Kurdistan. CIA aid continued to be loaded on planes at Mehrabad airport, Tehran, and finally delivered to the Kurds through SAVAK. ${ }^{662}$ As Iran increased its annual financial support to $\$ 30$ million, the U.S. raised its annual support from $\$ 3$ million to $\$ 5$ million. Israel also provided Barzani with $\$ 50,000$ monthly stipend. These aid was donated to make Barzani stick to the "defensive posture" to keep the secrecy of the operation. Kissinger stated that "We may wish to ... avoid the impression

\footnotetext{
${ }^{656}$ James Schlesinger in an interview with William Burr, Washington, May 15, 1986, Tape 1A, FISOHC.

${ }^{657}$ The only major exception was the Battle of Mount Hendrin. Parsi, Trita, Treacherous Alliance: The Secret Dealings of Israel, Iran, and the United States (Yale University Press, 2007) p.54; Yaacov Nimrodi was an Iraqi Jew who served as the Israeli army's first military attaché in Tehran

${ }^{658}$ Parsi, Trita, Treacherous Alliance: The Secret Dealings of Israel, Iran, and the United States (Yale University Press, 2007) p.54.

${ }^{659}$ Helms was the Shah's old friend since they attended the same college in Switzerland. Helms's appointment as the U.S. ambassador to Tehran was a perfect relocation for Iran's non-state foreign policy. The Shah saw this as "the ultimate recognition of his country's importance." CIA Station in Tehran to Helms, December 11, 1972, CIA-Helms.

${ }^{660}$ CIA Station in Tehran to Helms, January 11, 1973, CIA-Helms.

${ }^{661}$ Conversation, Nixon and Helms, January 25, 1973.

${ }^{662}$ Kissinger to Nixon, March 29, 1973, (FRUS 1969-1976, XXVII, 207).
} 
of a long-term escalating commitment by telling Barzani that we will provide these additional funds for this year on a monthly basis but, in any event, would emphasize that we share the Shah's view regarding maintenance of the defensive posture of the Kurds.",663 By early 1973, all roads had led to Tehran.

Interestingly, the State Department was bypassed by the Shah and CIA. The State Department had opened the U.S. Interests Section in Baghdad on December 1972. Nonetheless, its head, Arthur Lowrie, was unaware of SAVAK-CIA-Mossad covert cooperation. ${ }^{664}$ Baghdad leaders were aware of Iranian, Israeli, and, recently, Jordanian support for the Kurds ${ }^{665}$ however, they did not know about CIA involvement in Kurdistan. The real winner of the operation was the Shah. He had successfully kept Barzani out of the Iraqi national unity government and prevented Baghdad from deploying its army along Arvand Rud. With the U.S. massive arms sales to Iran, the Shah argued that Iraq would turn more to the Soviets that, in turn would lead to a Cold War arms race in the region, a situation that would facilitate framing Baghdad as a Soviet satellite and, therefore, justify his non-state foreign policy in Iraqi Kurdistan.

\section{The Shah's Hesitation}

Amid the Kurdish operation, the Watergate Scandal planted in the Shah's mind the seeds of doubt over the support for the Iraqi Kurds. He thought the Watergate Scandal might dissuade the White House from continuing to back Iran's non-state foreign policy in

\footnotetext{
${ }^{663}$ Kissinger, Henry. Years of Renewal (New York: Simon \& Schuster, 1999). p. 385.

${ }^{664}$ In early December, Lowrie had no clue about CIA secret operation and instead, assessing the stalemate in the north of Iraq as such that "Neither side seems to want a renewal of large-scale fighting, but neither is there sufficient mutual confidence to bring about the implementation of the agreement." See Baghdad A-6 to U.S. Department of State, December 1, 1972, (FRUS 1969-1976, E-4, p. 328).

${ }^{665}$ Baghdad 92 to U.S. Department of State, December 19, 1972, (FRUS 1969-1976, E-4, p. 329).
} 
Iraqi Kurdistan. In a wider, international perspective, he was concerned about the U.S. ability to contain Moscow amid its withdrawal from Vietnam. The Watergate Scandal was "unfortunate for everyone." ${ }^{, 666}$ Within this atmosphere, the Shah began testing a diplomatic solution with Iraq. Iran's paralyzing support for Barzani had already convinced Baghdad of the importance of the détente. ${ }^{667}$ Due to Iran's upper hand in the power equation, the Baath leaders had “a healthy respect for the Shah's military edge and have backed down from military confrontation whenever large-scale action seemed likely. This caution is likely to persist even in the face of provocations by the Shah." ${ }^{668}$ Iranian Foreign Minister Abbas-Ali Khalatbari met with his Iraqi counterpart in Geneva in April 1973; however, talks were quickly stopped as Baghdad strongly rejected accepting the Thalweg Line in Arvand Rud. ${ }^{669}$ The Shah knew that Baghdad would not accept the Thalweg Line unless Iran cut off its support for the Kurds. Besides, he knew that Barzani would not last forever. Although the Shah's "tough play for the moment" in Geneva did not result in a decisive outcome ${ }^{670}$ the meeting brought his major goal to the fore for the first time: 'Leave the Kurds, Take Arvand Rud'.

On the other side, the Geneva talks perturbed the Kurds. Informed of the secret talks by two Soviet diplomats, ${ }^{671}$ Barzani went to Tehran to seek the Shah's view. Barzani

\footnotetext{
${ }^{666}$ Helms to Kissinger, July 7, 1973 (CIA/FOIA/Helms), pp.1-8.-126.

${ }^{667}$ Baghdad 266 to U.S. Department of State, May 17, 1973, (NPM, NSCF, CFME, Box 603).

${ }^{668}$ National Intelligence Estimate 36-2-72, December 21, 1972, (FRUS 1969-1976, E-4, 330); and CIA, NIE 36.2-72, "Iraq's Role in Middle Eastern Problems," December 21, 1972 (FRUS/1964-68/XXI/doc.330), pp.114.

${ }^{669}$ CIA Station in Tehran to Helms, January 11, 1973, CIA-Helms.

${ }^{670}$ Tehran 3974 to U.S. Department of State, June 9, 1973, RG59, SNF 1970-73, Box 2380.

${ }^{671}$ Memorandum, [excised] to Helms, "Your Memorandum relaying Shah's Statement Concerning Barzani," June 11, 1973 (CIA/FOIA/Helms), pp.1-6; and Helms to [excised], June 9, 1973 (CIA/FOIA/Helms), p.1.
} 
raised the possibility of the Kurds' joining the national unity government. The Shah's response was short, yet decisive: "Do so if you want to commit suicide!"672 The Shah, instead, suggested Barzani ask Baghdad to hold free elections as his precondition to join the Baath and the ICP since it would both diminish Moscow's pressure on the Kurds and perturb Iraqi leaders due to their inability to hold a free election. ${ }^{673}$ Concerned about the American commitment, Barzani asked the Shah to "speak on our behalf in the U.S. or any other place you find it necessary and we are ready to accept the commitments needed from us and the way Your Majesty thinks those commitments should be made." ${ }^{674}$ He also asked the Shah about "the moral support of the U.S" and to guarantee "full American understanding and backing" for the Peshmerga. The Shah confidently responded, "We could provide that. ${ }^{\prime 675}$ Aware of the Shah's possible treachery in selling him out in an exchange for Iraqis' territorial concession in Arvand Rud, Barzani tried to receive more money and arms by threatening his allies to join Baghdad. In the meeting with Helms, Othman and Masoud Barzani had pleaded with the U.S. and Iran for heavier weaponry support since Baghdad would soon attack them with "poison gas." ${ }^{, 676}$ On 23 July 1973, Helms advised Kissinger to modestly increase the Kurds' monthly payments in return for not equipping them with offensive weapons. Kissinger agreed and wrote, "they [the Kurds]

\footnotetext{
${ }^{672}$ Helms to CIA Offal, June 9, 1973, and CIA Official to Helms, June 11, 1973, CIA-Helms.

${ }^{673}$ Helms to Kissinger, August 25, 1973 (CIA/FOIA/Helms), pp.1-2.

${ }^{674}$ Alam, Assadollah. Yad'dashtha-ye 'Alam: Virayesh va Muqaddamah az Alinaqi Alikhani [The Alam Diaries: Edited by Alinaqi Alikhani], Vol. III: 1973-1974 (Bethesda, MD: Iranbook, 1995), p. 115-116.

${ }^{675}$ Helms to Kissinger, August 25, 1973 (CIA/FOIA/Helms), pp.1-2.

${ }^{676}$ See CIA Station in Tehran to Helms, December 11, 1972, CIA-Helms.
} 
ought to have enough money so that they can remain a thorn in the side of the [Iraqi] government." ${ }^{677}$ It was a lucrative deal for Barzani.

Iran's non-state foreign policy in Iraqi Kurdistan had widened a gap within the U.S. top foreign policy decision-making processes. The CIA, Helms, Kissinger, and Nixon had accepted the Shah's portrayal of the Kurdish War as a Cold War battleground and, therefore, the significance of backing the Kurds to contain Iraq as a "satellite country of the Soviet Union.",778 Conversely, the State Department called it a "self-fulfilling prophecy." ${ }^{679}$ In his late July analysis, Lowrie advocated that the White House "disassociate" itself from the Kurdish crisis. He argued that "Kurdish resistance to compromise with [the] Baath would end if Iran stopped its assistance," arguing that any settlement between the Kurds and Baghdad would also serve the U.S. interests by terminating Kurdish war and diminishing Iraq's dependence on Moscow. ${ }^{680}$ Lowrie's view on the Bath leaders' efforts of "demonstrating their independence" from the Soviet was empowered by the Iraqi new policy. ${ }^{681}$ In March 1973, Baghdad had reached an unexpected deal with the Western oil companies. ${ }^{62}$ After the aborted coup of 30 June 1973 , led by Istikhbarat Director Nazim Kazzar, Saddam stated that "Iraq would welcome moves by the

\footnotetext{
${ }^{677}$ Memcon, July 23, 1973, FRUS 1969-1976, 24.

${ }^{678}$ Tehran 4475 to U.S. Department of State, June 25, 1973, (FRUS 1969-1976, XXVII, 218).

679 Baghdad 379 to U.S. Department of State, “Iraqi-Soviet Ties," July $1, \quad 1973$ (NARA/AAD/RG59/CFPF/ET/1973), pp.1-2.-150.

${ }^{680}$ Ibid.

${ }^{681}$ Baghdad 202 to U.S. Department of State, March 3, 1973, (FRUS 1969-1976, XXVII, 212).

${ }^{682}$ Eliot to Kissinger, March 3, 1973, (FRUS 1969, XXVII, 203).
} 
U.S. and Britain that could lead to [a] normalization of relations" ${ }^{683}$ However, the White House was still following the Shah's view.

The SAVAK-CIA-Mossad covert cooperation in Iraqi Kurdistan reached its zenith with the Shah's visit to the United States. On 24 July 1973, the Shah met Nixon in the Oval Office and informed him of Iran's intention to prevent "a coalition of the Baath Party, the Kurds, and the Communists." Convinced by his analysis, Nixon agreed to "a policy of total cooperation. ${ }^{.684}$ A day after, in the meeting with Kissinger and Helms, he requested more support for the Kurds. While re-expressing his disagreement with an independent Kurdistan, the Shah underscored the Kurds' significance as “the only lever over the Iraq's Government" for the U.S. and Iran. He framed the Kurds as "a trump card that we [Iran and the U.S.] do not want to let go," assuring Kissinger that the Kurds had already "promised not to do anything without our okay." ${ }^{685}$ In the next meeting, the Shah informed Kissinger that he had told Barzani "absolutely not to participate in a coalition government. I told them to stop receiving [the] Soviet representatives or the Baath representatives from Baghdad. But if we are going to ask that of them, we will have to give them some more money." ${ }^{986}$ Besides, the Shah knew that Kissinger and the CIA had been aware of Iran's secret talks with Iraq in Geneva. In order to deemphasize the possibility of a deal with Baghdad, he acutely framed the Geneva meeting as the Iraqis' move intending "to gain time" since they felt "weak." ${ }^{687}$ Shortly after the Shah's departure to Tehran, Kissinger

\footnotetext{
${ }^{683}$ U.S. Department of State 140125 to U.S. Interests Section Baghdad, "Press Interview with Saddam Hussein," July 17, 1973 (NARA/AAD/RG59/CFPF/ET/1973), pp.1-2.

${ }^{684}$ Memorandum from Kissinger for the President's File, undated, (FRUS 1969-1976, XXVII, 28).

${ }^{685}$ Memorandum from Kissinger for the President's File, undated, (FRUS 1969-1976, XXVII, 28).

${ }^{686}$ Memcon, July 27, 1973, (FRUS 1969-1976, XXVII, 30).
} 
instructed the CIA to begin "stockpiling arms for contingency supply" for an upcoming Iraqi-Kurdish war and to increase the Kurds' monthly financial support by 50 percent. ${ }^{688}$ At the same time, the Shah enhanced annual financial support for Barzani to "a little more" than 50 percent to $\$ 30$ million. ${ }^{689}$ "Impressed and gratified," the Shah considered it as the U.S. "symbolic" support of Iran's non-state foreign policy. ${ }^{690}$

\section{The October War and the Rising Iraqi Threat}

On 6 October 1973, Egypt and Syria launched a surprisingly joint attack in the Israeli-occupied positions in the Sinai Peninsula and the Golan Heights. In the middle of their initial defeats in the battlefront, the Israelis pressed Barzani to launch an offensive in the north of Iraq to keep Baghdad out of the war. Nine days after the outbreak of the war, Barzani informed Kissinger that "the [Israelis] suggest we try to gain territories in Kurdistan while it is busy with the war. They promised that they will study helping us with arms with Iran. No troops have been withdrawn from our area and we have no such offensive weapons. We like to know your opinion on this. ${ }^{\text {} 691}$ However, Kissinger was uncertain of the feasibility of the Israeli plan. ${ }^{62}$ Thus, he asked Helms to inform the Shah.

\footnotetext{
${ }^{687}$ Ibid.

${ }^{688}$ Kissinger to Helms, August 16, 1973, (FRUS 1969-1976, XXVII, 229); Helms to Kissinger, August 17, 1973 (CIA/FOIA/Helms), p.1. Kissinger responded to Helms' cable in WH 31939.

${ }^{689}$ Helms to Kissinger, August 25, 1973 (CIA/FOIA/Helms), pp.1-2; Kissinger, Years of Renewal, p.585.

${ }^{690}$ Helms to Kissinger, August 25, 1973, (CIA/FOIA/Helms), pp.1-2.

${ }^{691}$ [excised] to Director, October 15, 1973 (CIA/FOIA/Helms), p.1.

${ }^{692}$ Kissinger recalled, "the Kurds possessed very few heavy weapons; such artillery as they had was manned by Iranians who never ventured far from the Iranian border. The Kurds were capable of defending their mountainous homeland where Iraqi tanks and aircraft found it difficult to operate. But their lightly armed forces did not stand a chance in the flat terrain beyond their homeland against a large Iraqi army equipped with advanced Soviet heavy weapons and hundreds of tanks. An offensive beyond the redoubt would have guaranteed the complete destruction of Kurdish military forces." Kissinger, Henry. Years of Renewal (New York: Simon \& Schuster, 1999). p.586-7.
} 
The Shah strongly opposed the proposal and called it "suicidal.",693 Aware of the Kurds' lack of heavy offensive weapons, the Shah argued that any Peshmerga offensive would end in a fiasco. He also disagreed with the destruction of the Kurds for Israel's security, stating that "I do not want the Kurds to be proxies of Israel and America." 694 Ambassador Helms shared the Shah's view and warned Kissinger of that "If they [the Iraqi Kurds] were to get chewed up militarily, it would deprive the Shah of his 'Kurdish card' and he does not want to see that." ${ }^{695}$ With the Shah's advice, Kissinger "considered it unwise to tie the Kurds too explicitly to Israel's tactical preferences and thereby bring down on the already beleaguered Kurds the wrath of other Arab states, ${ }^{, 696}$ and ordered Barzani to reject Israeli’s proposal. ${ }^{697}$ Once again, the Shah showed his central role in the political dynamics of the Middle East.

Despite his claim that Iran could "crush Iraq in a few hours," concerned about Saddam Hussein's rising power in Baghdad. After convincing the ICP to join to the national unity government, he had received Russian heavy armaments. ${ }^{699}$ The October War of 1973 also empowered the Iraqis. Unaware of a coordinated surprise attack

\footnotetext{
${ }^{693}$ Kissinger, Henry. Years of Renewal (New York: Simon \& Schuster, 1999). p.586-7.

694 Alam, Asadollah, Yad'dashtha-ye 'Alam: Virayesh va Muqaddamah az Alinaqi Alikhani [The Alam Diaries: Edited by Alinaqi Alikhani], Vol. III: 1973-1974 (Bethesda, MD: Iranbook, 1995), 222.

${ }^{695}$ Helms to Kissinger, October 16, 1973, NSA, KSWWOF, Box 19, GRFL.

${ }^{696}$ Kissinger, Years of Renewal, (New York: Simon \& Schuster, 1999). p. 587.

${ }^{697}$ White House, WH32507 to U.S. Embassy Tehran, October 3, 1973 (CIA/FOIA/Helms), p. 1;-159.

${ }^{698}$ The U.S. Department of State 118336 to Tehran, (FRUS 1969-1976, XXVII, 59); Tehran 2166 to the U.S. Department of State, (FRUS 1969-1976, XXVII, 39).

${ }^{699}$ Including two hundred helicopters and fourteen TU-22 Blinder supersonic bombers. Alam, Assadollah. Yad'dashtha-ye 'Alam: Virayesh va Muqaddamah az Alinaqi Alikhani [The Alam Diaries: Edited by Alinaqi Alikhani], Vol. III: 1973-1974 (Bethesda, MD: Iranbook, 1995), p. 213; Baghdad 513 to the U.S. Department of State, "Iraqi-Indian Relations," September 23, 1973 (NARA/AAD/RG59/CFPF/ET/1973), p.1.
} 
launched by its allies in Cairo, Damascus, and Moscow, ${ }^{700}$ Baghdad refused to participate in the Arab oil embargo because the sale of oil provided Baghdad with petrodollars. It was within this context that Kissinger painted Baghdad as "the principal Soviet client in the Middle East" during his visit to Tehran in November 1973. He contended "that the Ba'ath government under Saddam Hussein continued to finance terrorist organizations ... and that it was the driving force in the rejectionist front seeking to block Arab-Israeli peace initiatives ... whose instability we should continue to promote." ${ }^{701}$ By late 1973, commitment to the Pahlavi monarch had overshadowed anything else for the United States.

\footnotetext{
${ }^{700}$ Baghdad 596 to U.S. Department of State, "Post War Assessment of Iraq and Policy Recommendations," November 4, 1973 (NARA/AAD/RG59/CFPF/ET/1973), pp.1-3.

${ }^{701}$ Kissinger, Henry. Years of Renewal (New York: Simon \& Schuster, 1999). p.385.
} 


\section{Limbo -- The Shia Lebanese}

"I asked the Shah to build a hospital for the Shia. Then, we can build a university for them, too. The Shah agreed. But Qadar attempted to dissuade the Shah." Sadr told Ehsan Naraghi. ${ }^{702}$

\section{The Six-Day War and the Decline of the Nasserism}

On 5 June 1967, Israel defeated the Arab armies in the Six-Day War and destroyed the credibility of Nasserism. The scale of Israel's devastating victory with a rapid seizure of large areas of Arab territories marked a major transformation in the Shah's calculation of the power arrangement in the Middle East. Israel's crushing defeat of Arab regimes did not prompt the Shah to see the Jewish state as a threat to Iran. The fiasco of 1967 convinced Nasser to reevaluate his strategy of seeking regional primacy by siding with the Soviets and challenging the U.S. and Iran. ${ }^{703}$ A gradual thaw between Iran and Egypt emerged. A month after a normalized relation with Tehran, Nasser died and the Shah was no longer threatened by his major foe in the region. ${ }^{704}$ It was the last nail in the coffin of Nasserism.

As Pan-Arab sentiment was hammered down, the threat of Egypt lessened. It was a paradigm-shifting moment for Iran's non-state foreign policy on the east coast of the Mediterranean. With Cairo's lack of power to pose a threat to Iran's national security, the

\footnotetext{
${ }^{702}$ Naraghi’s interview with Khabar-Online, 2 May 2011.

${ }^{703}$ With Kuwaiti mediation, Nasser tried to lessen his tension with the Shah. Aware of Nasser's miserable situation, the Shah asked Cairo to issue an official apology to Iran for its previous provocations toward Tehran as a pre-condition for the revival of diplomatic relations with Egypt. Nasser had no option but to accept the Shah's demand. A year before his death, The Egypt Ambassador to Belgrade, Serbia, talked to Iran's ambassador and expressed Cairo's inclination to revive diplomatic relations with Tehran. Then. Egypt took the first step toward the resumption of ties with Iran when he agreed to a joint communiqué announcing the resumption of full diplomatic relations in August 1970. Tehran-Cairo relations' major thaw when Prime Minister Hoveyda participated in Nasser's funeral. Interview with Major General Mansour Qadar, Oral History, Foundations for Iranian History; Parsi, Trita, Treacherous Alliance: The Secret Dealings of Israel, Iran, and the United States (Yale University Press, 2007) p. 32.

704 Alam, Assadollah. Yad'dashtha-ye 'Alam: Virayesh va Muqaddamah az Alinaqi Alikhani [The Alam Diaries: Edited by Alinaqi Alikhani], Vol. I: 1968-1970 (Bethesda, MD: Iranbook, 1995), p. 125.
} 
necessity of containing Egypt and therefore, Iran's need for the Lebanese Shia disappeared. Indeed, the Six-Days War had huge ramifications for Iran's ties with the Lebanese Shia. Besides, four factors forced Tehran to shift its non-state foreign policy in Lebanon: Sadr's connections with Palestinian guerrillas, his connections with the Iranian opposition, his connections with Arab powers of the region, and, finally, his tension with Iran's embassy in Beirut. By the late 60s, however, Sadr's popularity had been still unscathed.

\section{The Supreme Islamic Shia Council}

In April 1966, Sadr prepared a plan to establish a major Shia institution, the Supreme Islamic Shia Council (al-Majlis al-Eslamiya a-Shii al-A'la or SICS) to "unify all the Shia" against social injustice and political and economic marginalization and to fight "for their rights." ${ }^{, 705}$ On 15 August 1966, Sadr had asked Beirut to approve the plan. The plan was ultimately signed by Chehabist President Charles Helou in 1967. On 29 May 1969, the SICS was officially established and Sadr was appointed as its first Chairman, defeating his unremitting opponent Kamel al-Asaad (Kamel Bey). ${ }^{706}$ The establishment of the SISC was Sadr's most impressive achievement, providing the Shia a powerful representative body independent of the Sunni majority. It declared the Shia community as a Lebanese legal community. It was, in fact, a watershed in the crystallization of the Shia identity.

The SICS soon made a demand on Beirut for socio-economic, political supports, including defending the South, developing the Shia territory, and increasing the

\footnotetext{
${ }^{705}$ SAVAK Documents, No. 212s/1445, 19 September 1966.

${ }^{706}$ Kamel Asaad was a former Speaker of Parliament, former Minister of Education and Fine Arts, and an influential Shia zaim (notable) from al-Tayyiba.
} 
governmental positions for the Shia. Later entitled 'Imam' by his followers, ${ }^{707}$ On 10 August 1969, Sadr began defying both traditional Shia clerics and leftists as he called for all Lebanese communities tto work equally hard to implement political reform and to fight deprivation in all regions of Lebanon. The declaration reaffirmed Sadr's image as a leading political figure in Lebanon. According to SAVAK, "Seyed Mousa Sadr is a Shia clergy with a 'strange' position in Lebanon as such that he has become the 'Heart of Beirut'. No Lebanese [politician] dares to disobey his commands. Whenever he leaves or enters Lebanon for his short trips, all Beirut elites should welcome him. He is far more powerful than Lebanese President. One can easily find his images in all Lebanese newspapers and magazines as well as Beirut bazaars ... Sadr has established various foundations in Beirut. He is the head of Shia Council and was entitled Imam by his followers. [There was a rumor that] the Lebanon President feared his power. All military generals are Sadr's Fedayeen. It would be unbelievable if any political actor disobeys his orders ... There is no power beyond Sadr's power in Beirut and whenever he intends, he travels to any part of the world with a special ceremony ... In short, Sadr means Lebanon and Lebanon means Sadr." ${ }^{708}$ Time seemed to be on Sadr's side.

The establishment of the SICS was welcomed by the Maronites since the Shia rise would weaken the Pan-Arab Sunni front. Conversely, the Sunni lashed out at Sadr's SICS. Earlier before, the Sunni elites had unsuccessfully tried to dissuade Sadr from the establishment of the SICS by offering him the post of deputy of the Sunni-dominated

\footnotetext{
${ }^{707}$ While the Sunnis use the term for leaders of any organized group activities, like prayers, the Shia had never ascribed it to a religious figure, since Imam was a 'Baraka' (divine gift) and only a Ma'sum (moral infallible) would enjoy this. But Sadr was the first Shia clergy who was entitled as Imam right before Ayatollah Seyyed Rohullah Khomeini was later entitled it in the 1979 Islamic Revolution.

${ }^{708}$ SAVAK Documents, No. (39-40).
} 
Islamic Coalition. With his refusal, the Sunni leaders, including Sheikh Hassan Khaled, the Sunni Mufti and the Head of the Islamic Coalition, called the SICS Sadr's betrayal of the Muslim front against the Christians. Nasserist elements in Lebanon, whose major members were the Sunni, argued that "appointing a Mufti for the Sunni and an Imam for the Shia would be nonsense since all the Muslim should be united." ${ }^{709}$ Both Leftists and Palestinians also opposed the formation of the SICS. Some elements in the Shia community, including influential Lebanese politicians, landowners, and traditional clerics, criticized Sadr and the Council. Sheikh Hussein Khatib, ${ }^{710}$ Riadh Taha, ${ }^{711}$ Ja'far Sharaf al-Din, ${ }^{712}$ and Kamel alAsaad were Sadr's major foes in the South. These Shia elites rallied both Sunni and Shia mercenaries chanting, 'We do not want an Iran's Servant', against Sadr. ${ }^{713}$ Sadr, in response, assured them that "the new-founded SICS was not [established] in order to add troubles as a new sect; rather, it intends to lessen these sectarian cleavages [in Lebanon]." ${ }^{714}$ Nonetheless, the Sunni leaders denounced him as the Shah's agent in Lebanon. Sunni newspapers launched an anti-Sadr campaign and framed Sadr as "one of the Iranians, who are [all] the Shah's spies, who just came here [Lebanon] yesterday and now intends to control the Lebanese people destiny in his hands. ${ }^{, 715}$ Sadr was also accused of working for

\footnotetext{
${ }^{709}$ SAVAK Documents, No. 212/306, 3 May 1965.

${ }^{710}$ Khatib was an influential Shia clergy.

${ }^{711}$ Taha was a pro-Iraqi Baath politician. See SAVAK Documents, No. 212/971, 1 July 1970.

712 Ja'afar was Seyyed Abdol-Hussein Sharafoddin's son who did not have a good relationship with Sadr since he saw Sadr as a usurper of his father's title.

${ }^{713}$ SAVAK Documents, No. 212/1494, 11 August 1970.

${ }^{714}$ Sadr's declaration, 29 May 1969.

${ }^{715}$ SAVAK Documents, No number, No date.
} 
SAVAK and of being someone whose political moves were based on "SAVAK's future master plan. ${ }^{, 716}$ In the wake of Iran's policy shift from Lebanon, Sadr was still considered by his Lebanese foes as the Shah's agent.

\section{Palestinian Cause}

Geography and history have both cursed Lebanon with the Palestinian Cause. Since the Balfour Declaration of 1948, Lebanon's security had become vulnerable in the face of both threats of a foreign state, i.e., Israel, and non-state actors, i.e., Palestinian guerrillas. Right after the creation of Israel, one hundred thousand Palestinians fled into Lebanon and stayed in their camps on the southern border. Lebanese insecurity escalated when the Palestine Liberation Organization (PLO) was established in the Arab Summit of Amman, June 1964. Although the Lebanese Army trained dozens of Palestinian guerrillas after the Six-Day War of $1967,{ }^{717}$ Beirut criticized the formation of the PLO camps on its soil. However, the Palestinian guerrillas established a virtual state-within-a-state in West Beirut and part of southern Lebanon. Some of the PLO leaders, like Ahmad Shukeiri, the first PLO chief, stayed in Lebanon until 1968. After all, the Palestinian guerrillas had been supported by the Sunni Lebanese. Sunni Arab countries, like Libya, supported the Palestinian immigration to southern Lebanon. On top of that, PLO presence in Lebanon forced Israel to target the south of Lebanon. In January 1965 Fatah, the strongest faction of the PLO, launched its operations from the South, causing the Israeli Army to invade Lebanon. In return, Beirut blamed the PLO for the Israeli invasion. ${ }^{718}$ The Black September

\footnotetext{
${ }^{716}$ Ghassan Tueni, head of An-Nahar, was also accused of Tehran's agent. See SAVAK Documents, No. (p.50).

${ }^{717}$ Y. Sayigh, Turning Defeat into Opportunity: The Palestinian Guerrillas after the June 1967 War, (Spring 1992) Middle East Journal, 46 (2): 260.
} 
of 1970 accelerated the presence of armed Palestinian guerrillas in Lebanon that, in return, revived skirmishes between Beirut and the PLO.

Sadr had initially supported the Palestinians. Putting emphasis on Islamic unity, Sadr considered the Palestine cause as a common denominator of the Muslim interests. Sadr had, in fact, convinced the Palestinian groups to establish the PLO. "Your struggles would be fruitless as long as you yourself do not claim your land and, instead, give others authority to act on behalf of you," Sadr had told Arafat. ${ }^{719}$ A significant portion of the Fatah members were young Lebanese Shia with a deep sympathy for the Palestinian plight. Many young Shia had been training in the PLO camps in Yamunah and Ayn al-Boniyyeh around Baalbek. Sadr's famous slogan, "We want Bayt al-Maqdis (Jerusalem) before Sour [the najor Shia city in the south of Lebanon]," represented his view towards the Palestinian Cause. ${ }^{720}$ Despite major disagreements, the Sunni Lebanese and the PLO welcomed Sadr's growing support for the Palestinian armed militias. Nevertheless, the Maronites and other Christian communities began distancing themselves from Sadr.

SAVAK gradually framed Sadr's close relations with the PLO as an example of rising Islamism backed by radical leftist groups. The situation deteriorated when Sadr criticized Tehran for abandoning Palestinians and instead supporting Israelis. "The Iranian

\footnotetext{
${ }^{718}$ The Israeli Air Force targeted high-ranking PLO officials, the headquarters of the Democratic Front for the Liberation of Palestine (DFLP), and refugee camps, like Nahr al-Band and Badawi, the most significant guerrilla training headquarters for Palestinians, and other revolutionary international groups like Chinese, Japanese, Turks, Cypriots, and Iranians. The central government of Lebanon declared the state of emergency in April 1969 and launched a major offensive against the Syrian-backed Palestinian group of As-Sa'iqa in the southern Lebanon. After on-and-off fighting between Palestinian guerrillas and the Lebanese Army, the PLO and Beirut signed an agreement in late 1969 and accepted the ceasefire.

${ }^{719}$ See http://tarikhirani.ir/Modules/News/Phtml/News.PrintVersion.Html.php?Lang=fa\&TypeId=4\&NewsId=924.

${ }^{720}$ Seyyed Hadi Khosrowshahi, Jonbesh-e Amal va Emam Musa Sadr [Amal Movement and Imam Musa Sadr], See http://iscq.ir/?part=menu\&inc=menu\&id=41.
} 
people supported the Arab because they were Muslim. Unfortunately, the Iranian government did not support the Palestinians and, instead, had good relations with Israel ... Iran could have supported the Palestinians by providing them with weapons as [Iran did in] Pakistan." 721 In the aftermath of the decline of the Nasserism, the Shia-PLO alignment exacerbated Tehran-Sadr relations.

As time wore on, however, the relations between Sadr and the PLO worsened. The PLO guerrilla wars from southern Lebanese soil led to devastating and unstoppable campaigns by the Israel Defense Forces (IDF). Although the Shia had shown their fidelity to the Palestine cause, the undisciplined Palestinian guerrillas took over the Shia farms and villages, cutting off their roads and forcibly recruiting the young Shia into their militias. ${ }^{722}$ By the early 70s, the Shia had been forcibly engaged in the bloody Palestinian cause, fighting with the Israelis and the PLO's foes in Lebanon. Indeed, the Palestine cause brought the Shia only suffering, and the south of Lebanon turned into a bloody battle zone. Therefore, Sadr pleaded with both Beirut and other Arab states to consider the Shia plight. He began denouncing the PLO for prompting Israeli raids on the South. In May 1970, Sadr publicly objected the Palestinian guerrillas' behavior with the Shia girls and women. ${ }^{723}$ "The South is the most explosive region in Lebanon ... While the Shia initially supported the Palestinian militias, some of the Palestinians began making trouble for the Shia, like imposing a levy on the Shia ... I tried persuading the Shia that these radical subversions

\footnotetext{
${ }^{721}$ The Shah backed Islam-Abad in wars with India in 1965 and particularly 1971. SAVAK Documents, No. 316/2818, 8 September 1970.

${ }^{722}$ Nasr, Vali, The Shia Revival: How conflicts within Islam Will Shape the Future (W.W. Norton \& Company, 2007) p. 111.

${ }^{723}$ SAVAK Documents, No. 212/320, 9 May 1970.
} 
have nothing to do with real Palestinian guerrillas," Sadr contended. ${ }^{724}$ Additionally, a growing flux of Sunni Palestinian refugees could demographically jeopardize the Shia position in the South that would, in turn, force the Shia to immigrate to Beirut and live in ghettos in deep poverty and prompt Israel to attack the South. With Beirut's inability to defend the South from Israel and the anarchy-causing PLO, Sadr stressed the national unity of Lebanon. However, his support for a more functioning state in Lebanon prompted the Palestinians to denounce him as a Lebanese Intelligence agent. ${ }^{725}$ Indeed, nobody recognized the Shia appreciation and faithful support for the Palestinians. Once again, the Shia pain was ignored by the Sunni leaders.

The rising tension between Sadr and the PLO did not decrease Tehran's suspicion. Instead, Iran's embassy in Beirut accused Seyyed Musa of having close ties with radical Palestinian militias and their leaders, like George Habash and Nayef Hawatmeh. ${ }^{726}$ While Seyyed Musa Sadr clearly did not support the Palestinian militias in the South as it would harm the Shia, he had been labeled by SAVAK as a 'natural' ally of radical Palestinian.

\section{Sadr and Arab Regimes}

Lebanon's fragile state, its fragmented political arena and weak national identity all provided room for the Arab states to build connections with other Lebanese communities. These ties allowed Lebanese elites and groups to maneuver and play off outside powers against each other. In the aftermath of Iran's gradual shift from the south of Lebanon, Sadr began seeking an external supporter for his community. Syria and its politically ruling

\footnotetext{
${ }^{724}$ SAVAK Documents, No. 213/895, 11 March 1978.

${ }^{725}$ Norton, Augustus R. Amal and The Shia: Struggle for the Soul of Lebanon (Austin, TX: 1987) p.43; Ajami, Fuad, The Vanished Imam: Musa Al Sadr and The Shia of Lebanon (London, 1986) p.175.

${ }^{726}$ SAVAK Documents, No. 213/54013, 6 April 1974.
} 
Alawite elites were the first targets. Excoriated by the Sunni as disbelievers (kuffar) and idolaters (mushrikun), the Alawite community had been marginalized from the larger Islamic community. ${ }^{727}$ There had been also a small Alawite community in Tripoli and the Akkar district, in the north of Lebanon, persecuted by the Sunni Ottomans for centuries. Even after Lebanon's independence, they were not entitled as a legal community. In the aftermath of the establishment of the SCIC, the Alawite efforts to seek an ally in Lebanon were welcomed by Sadr. Although the Lebanese Shia had no historical ties to the Alawites, Sadr built a friendly relation with al-Alwashi, the leader of the Lebanese Alawites in Tripoli, and brought the Alawite community of Lebanon under the Twelver Shia jurisdiction. ${ }^{728}$ Despite the "uncomplimentary references to the Alawis in the Twelver sources," Sadr's preaching for the revival of the Shia collective identity and Muslim unity as well as his ambition "to extend his reach into the north of Lebanon," to take an inclusionary policy towards the Alawite community. In late 1969, in a contentious meeting of the SISC, Sadr declared the Alawite community as a branch of the greater Shia community and brought them under his wing. Despite an initial Alawite religious shaykhs' disinclination, it was Alawite Hafiz Assad's rising power after the coup of 18 May 1971 and the Sunni violence of 1973 that convinced the Alawites as a non-

\footnotetext{
${ }^{727}$ Ayatollah Muhsin al-Hakim, a major Twelver Shia Marja in Najaf, was the first Shia leader who considered the Alawite issue by dispatching Shaykh Habib Al Ibrahim, a Shia celeryman of the Lebanese Bekaa Valley, to the Alawite region in 1947. See Martin Kramer, "Syria's Alawis and Shi 'ism," in Shi 'ism, Resistance, and Revolution, ed. Martin Kramer (Boulder, Colorado: Westview Press, 1987), pp. 237-54.

${ }^{728}$ SAVAK Documents, No. 212/4822, 7 February 1972.

${ }^{729}$ Martin Kramer argues that Ayatollah Mohammad-Kazem Shariatmadari corresponded with Shaykh Ahmad Kiftaru, Sunni grand mufti of Syria and faithful servant of the Syrian regime. In the meeting with Shariatmadari in Qom in summer of 1973, Shaykh Ahmad urged Shariatmadari to recognize the Alawites. But Shariatmadari kept his silence and made no gesture to Syria's Alawi religious shaykhs, who claimed so insistently to be his coreligionists. See Martin Kramer, "Syria's Alawis and Shi 'ism," in Shi 'ism, Resistance, and Revolution, ed. Martin Kramer (Boulder, Colorado: Westview Press, 1987), 237-54.
} 
Muslim community to strengthen the Shia-Alawite ties in the Levant. On the one hand, the new regime of Assad needed religious legitimacy. On the other hand, the Lebanese Shia needed a powerful patron. This situation convinced Sadr to cultivate friendly, strategic connections with Damascus. ${ }^{730}$ In July 1973, Sadr issued his historical fatwa on the recognition of the Alawite as Shia co-religionists and "appointed a local Alawi to the position of Twelver mufti of Tripoli and northern Lebanon." ${ }^{, 731}$ It was a decisive politicalreligious move that opened a way for the inclusion of the Alawite community into the jurisdiction of an appointee of the SISC. ${ }^{732}$ Sadr's fatwa also legitimized Assad's regime and "prevented its fall" in a country with a Sunni majority. ${ }^{733}$ Damascus, in response, gave full support to the Shia with political, financial, and military aid. Back then, the Syrian national interests and the interests of Lebanese Shia became intertwined.

The growing Lebanese Shia-Damascus alliance threatened both the Maronites and Palestinian supporters. In spite of sharing the same view with the Shia over blaming the PLO radicalism, the Maronites could not accept Syria as a powerful patron of a Lebanese community. "Surrounded by Syria from north and east," the Lebanese government had

\footnotetext{
${ }^{730}$ SAVAK Documents, No. 211/1064, 25 May 1971.

${ }^{731}$ Martin Kramer, “Syria's Alawis and Shi'ism, " in Shi'ism, Resistance, and Revolution, ed. Martin Kramer (Boulder, Colorado: Westview Press, 1987), pp. 237-54.

${ }^{732}$ In the meeting, Sadr pointed to the partnership of both Lebanon's Alawite and Twelver Shia since both had suffered from persecution and oppression. "Today, those Muslims called Alawis are brothers of those Shi'ites called Mutawallis by the malicious ... When we heard voices within and beyond Syria, seeking to monopolize Islam, we had to act, to defend, to confront ... We direct the appeal of this gathering to our brethren, the Alevis of Turkey. We recognize your Islam." The new mufti, Shaykh Ali Mansur, stated: "We announce to those prejudiced against us that we belong to the Imami, Ja'fari [Twelver] Shi'a, that our school is Ja'fari, and our religion is Islam." See Martin Kramer, "Syria's Alawis and Shi'ism," in Shi'ism, Resistance, and Revolution, ed. Martin Kramer (Boulder, Colorado: Westview Press, 1987), pp. 237-54.

${ }^{733}$ Fawzi al-Qawuqji, the former head the Arab Liberation Army (Jaysh al-Inqadh al-Arabi or ALA). See SAVAK Documents, No. 212/4164, 11 December 1971.
} 
considered relations with Syria "vital and substantial" since its independence. ${ }^{734}$ After all, Syria was still seeking to realize the idea of the Greater Syria that encompassed the Levant and western Mesopotamia. ${ }^{735}$ The idea was obviously against the Maronites who saw Syrian nationalism as an existential threat to Lebanon. In the view of the Maronites, Sadr's growing closeness with Damascus was the first alignment between a Shia community and a Pan-Arab regime.

Despite a major conflict of interests with Damascus, Iran was not prompted by Sadr-Assad's Syrian relations. Since the emergence of Baghdad-Damascus competition, the Shah had considered a more remote Syria as a possible lever over Baghdad. SAVAK had recommended that the Shah employ Damascus against Baghdad. "In the mid-70s, I suggested that the Shah have a friendly relation with Damascus due to the Syrian enmity with Baghdad. I reminded the Shah that I had a close relation with Assad. We [Qadar and Assad] used to live in a neighborhood in Damascus. In the aftermath of the Black September of 1970, he invited me to visit Damascus. In the meeting, he pointed to the desk in the middle of the room and said, "Imagine the desk is Iraq. Why cannot we shake hands above the desk? We can bypass Iraq. Well, of course, His Imperial Majesty should not expect me to officially announce Syria's support for Iran's retaking of three islands in the Persian Gulf [i.e., Abu Musa, Great Tunb, Small Tunb]. But, I believe those islands were yours [Iranians]. Do not pay attention to newspapers and the media," Qadar claimed his role in convincing the Shah to have a closer relation with Assad. A growing Assad-Sadr

\footnotetext{
${ }^{734}$ Madrid 1982 to Iran’s Ministry of Foreign Affairs, 8 October 1970.

${ }^{735}$ When Lebanon won its independence from France in 1943, the Syrian regime futilely objected to the French government for carving out generous chunks of its territory to shape Lebanon and weaken ArabNationalism.
} 
relation did not prevent the revival of Tehran-Damascus diplomatic relations forged in order to contain Iraq.

However, Tehran immediately criticized a thaw in Sadr-Nasser relations. In the $60 \mathrm{~s}$, Sadr's efforts to revive the Shia collective identity were initially criticized by Nasser and the Lebanese Nasserist groups. ${ }^{736}$ There were some rumors that several Nasserist elements in Lebanon had planned to assassinate Sadr. ${ }^{737}$ However, a geopolitical reshuffle following the Six-Day War pushed Cairo to reconsider its regional policy. After his short trip to Kuwait in March 1970, Sadr was invited to Cairo. ${ }^{738}$ In an interview with Mohamed Hassanein Heikal in Cairo on 12 March 1970, Sadr talked about his extensive connections with the Iranian revolutionaries. ${ }^{739}$ A few hours later, he met with Nasser. In the meeting, Nasser stressed that Egypt had no enmity with the Shah of Iran and he was fully ready for the revival of the diplomatic relations with Tehran, though the Iran-Iraq crisis of Arvand Rud had been the main obstacle against the move. ${ }^{740}$ Nasser also permitted Sadr to give the Friday speech in al-Azhar, Sunni's most prestigious, religious university. ${ }^{741}$ Iranian officials soon reacted to his meeting with Nasser. In the Shah's threat assessment, the ShiaEgyptian ties could revive the weakened Pan-Arabism in Lebanon or cement a new Arab Unity including both the Shia, Sunni, and even Christians. Besides, Sadr's turn to Egypt

\footnotetext{
${ }^{736}$ SAVAK Documents, No. 212/306, 3 May 1965.

${ }^{737}$ SAVAK Documents, No.3000/A, 27 August 1967.

${ }^{738}$ It was Sabri Hamada, Speaker of the Lebanese Parliament, who arranged the meeting between Nasser and Sadr. Conversely, both Kamal Jumblatt, the Druze leader of PSP, and Hasan Khaled, the Sunni Mufti, had unsuccessfully tried to dissuade Nasser of meeting Sadr.

${ }^{739}$ Interview with Zahir Assiran. See: http://www.shianews.com/fa/news/78226.

${ }^{740}$ SAVAK Documents, No.212/83, August 1970.

${ }^{741}$ Tabatabai, Mohammad Sadegh, Khaterat-e Siasi Ejtemai [Socio-political Diaeries] (Moassese Tanzim Nashr Asar Emam Khomeini, 1388) vol. 1, p. 221.
} 
could trigger Islamic revivalism--later called Islamism--in Iran. Due to his popularity among the Iranian Shia clergies, Sadr's connection with Nasser could also prompt the consolidation of the Arab-Black Threat. It was in this context that Iran's embassy in Beirut and elements in SAVAK framed him as an Egyptian agent. Aware of the Shah's suspicion of his meeting with Nasser, Sadr tried to assuage the tension. On 17 April 1970, Sadr reported to Manouchehr Davoudi details of his meeting with Nasser and added that Egyptian policy had become more moderate and rational in the post-1967 era. He also wished to see Tehran support the Lebanese Shia by providing them military aid. ${ }^{742}$ However, his request was rejected. Tehran was still suspicious about Sadr's contacts with Cairo.

In the post-1967 period, the Baath leaders tried to portray Iraq as a new leader of the Arab World. Baghdad began supporting several Shia clergies to gain a strategic space in the south of Lebanon and to contain Syria, and to some degree, Iran there. With its majority Shia population, Iraq apparently had a potential to attract the Shia clergymen against Tehran as well as to placate its Shia opponents. The Iraqi Baath had considered Sadr as a threat to its regional interests. Baghdad, in fact, saw Sadr as Najaf's anti-Baath representative in Lebanon. ${ }^{743}$ Sadr's close relations with Hafiz Assad and dissident Shia clerics, particularly his cousin, Ayatollah Muhammad Baqir Sadr, convinced Baghdad to mobilize anti-Sadr elites in Lebanon led by Kamel al-Asaad, Sheikh Hassan Khaled, and Riadh Taha ${ }^{744}$ However, Sadr was cautious in dealing with Iraqi-backed elites in Lebanon

\footnotetext{
${ }^{742}$ SAVAK Documents, No. 316, 27 August 1970.

${ }^{743}$ SAVAK Documents, No. 212/13518, 11 August 1970.

${ }^{744}$ SAVAK Documents, No. 212/971, 1 July 1970.
} 
since Baghdad might get revenge by killing Ayatollah Sadr. ${ }^{745}$ Since the tightening of the Iraqi political situation for the Shia, Sadr had tried to convince Iran to support the Iraqi Shia Ayatollahs. In his talk with Davoudi, Sadr stated that "Ja'far Sharaf al-Din has built secret ties with the Iraqi Istikhbarat after a diplomatic halt in Iran-Lebanon relations." $\mathrm{He}$ also stated that the Iraqis had dispatched 86 killers to assassinate him. ${ }^{746}$ While Sadr indirectly tried to convince Tehran to shift its policy in Lebanon, SAVAK preferred to stay out of intra-Shia tension. Besides, SAVAK argued that the main Iraqi allies in Lebanon were leftists and Palestinian guerrillas, instead of the Shia. While Sadr's view towards Baghdad was in accord with Iran's policy, Tehran ignored his potential to jeopardize Iraq's interests in both Lebanon and Najaf.

In addition to the unity of Lebanon and disapperance of the discrimination against the downtrodden Shia communities, Sadr's message had ushered in the revival of Islam and the Islamic unity. Although he fought the dominant Sunni view over the recognition of Lebanese Shia, Sadr kept preaching the significance of unity in the Islamic World. To accomplish this mission, he tirelessly tried to unite the Arab leaders' views over the regional conflicts. He approached the Saudis, particularly Prince Abdullah who financially supported Sadr in the establishment of the Ameliah School and other Shia institutions. ${ }^{747}$ Prince Abdullah-Musa Sadr's friendship grew so that Sadr had been permitted reconstructing of the sacred al-Baqi Cemetery. ${ }^{748}$ SAVAK criticized Sadr's connection

\footnotetext{
${ }^{745}$ Interview with Mohammad-Sadegh Tabatabaie, (Winter 1377) Quarterly Periodical Mofid, IV (IV). See also SAVAK Documents, Imam Musa Sadr, vol. II, p. 347.

${ }^{746}$ SAVAK Documents, No.316, 7 May 1970.

${ }^{747}$ SAVAK Documents, No. 223/10, 24 March 1966.

${ }^{748}$ Masira al-Imam al-Seyyed Msa al-Sadr [Seyyed Musa Sadr's Journey], Vol III, Second Edition, p. 357. See http://moodkerbes.info/1394/02/01/imam-sadr-and-Al-Baqi. Jannat al-Baqi cemetery is in Medina,
} 
with regional states. Ambassador Qadar claimed, "Sadr went to Saudi Arabia and gave a speech, stating that 'I am here because of our first Calipha, Abu Bakr, was from here.' As a Shia, Sadr should not have said that. Then, King Khaled instructed the distribution of Sadr's speech among the Shia in Saudi Arabia." ${ }^{749}$ At the same time, Sadr was invited by Arab sheikhdoms of the Persian Gulf. In March 1973, Sadr went to Bahrain, Qatar, and then the UAE. Although Sadr had no intention of making an anti-Iran move, SAVAK thought Sadr's connections with the conservative Arab regimes of the Persian Gulf could provide him financial aid. With this aid, SAVAK concluded, Sadr could "build a university in the south of Lebanon for all the Shia in the world that might, in return, function as a strategic base for anti-Shah opposition in the region and beyond." Therefore, SAVAK suggested that "it would be better for Tehran to open an Islamic Shia university in Iran to oppose Sadr's anti-Shah plan that could pose a threat to Iran's national security." ${ }^{, 750} \mathrm{Sadr}$ had been gradually framed as a foe.

\section{Bakhtiar and Sadr}

Tehran-Beirut relations went downhill over Brigadier General Teymur Bakhtiar's issue. In the mid-50s, he had waged a ruthless campaign to crush anti-Shah forces. ${ }^{751}$ As the youngest three-star general, Bakhtiar was then appointed as the first SAVAK director in February 1956. Bakhtiar had created and managed an initial phase of Iran's non-state

Saudi Arabia, in the southeast of the Masjid al-Nabawi (The Prophet's Mosque). The cemetery contains many of the Prophet's companions and his relatives, the Shia Imams. The Wahhabi regime of Riyadh destroyed the cemetery in 1926.

${ }^{749}$ Interview with Major General Mansour Qadar, Oral History, Foundations for Iranian History.

${ }^{750}$ SAVAK Documents, No. 334/936, 10 June 1973.

${ }^{751}$ Bakhtiar captured and then executed Hossein Fatemi, Mossadegh's minister of foreign affairs. He also shattered down the Tudeh Party. 
foreign policy between 1958-61. However, his fast rise soon stalled as Prime Minister Ali Amini warned the Shah of Bakhtiar's secret connections with President Kennedy. Worried about an American-backed coup, the Shah dismissed Bakhtiar in 1961 and then forced him to live in exile in Geneva, Switzerland. Despite blaming Nasser for backing demonstrations organizers, ${ }^{752}$ the Shah was suspicious of Bakhtiar's indirect intervention in the riot of 1963. With a growing tension in the Shah-Bakhtiar relations, the former SAVAK director began reviving his secret networks within SAVAK and Iran's allies in the region. Ambassador Qadar claimed of the existence of a strong pro-Bakhtiar group within SAVAK. "The head of this group was Colonel Pashaie. Other major members were Tajbakhsh, Azmoun, Pejman, Savadkouhi, and to some degree Alavi-kia," Qaar claimed. ${ }^{753}$ Bakhtiar also tried to contact with Iranian dissidents in Europe, Lebanon, and Iraq, including Ayatollah Khomeini, Reza Radmanesh, and Mahmoud Panahian. ${ }^{754}$ Seyyed Musa Sadr was also among Bahktiar's major targets. Ambassador Qadar accused Sadr of having permanent contacts with Bakhtiar even after Bakhtiar's exile to Europe. He claimed, "when the Shah discharged Bakhtiar, Sadr cut his ties with Tehran and, in return, SAVAK terminated his financial support. Sadr, however, never cut his connection with

\footnotetext{
${ }^{752}$ Nasser's connections with demonstrations organizer were fake. Even Qadar confessed, "It was not real." He added, "At that time dollar was more expensive in Tehran while gold was cheaper in comparing to Beirut. Thus, a bunch of money-changers was involved in money smuggling between Tehran and Beirut. In the wake of the riot, one of them, Abdul-Hadi Abachi, who had offices in both Beirut and Damascus, sent more than 1 million dollars to Tehran. The money was seized at the Mehrabad Airport and Abachi was later arrested. SAVAK soon accused Nasser of financially backing demonstrations organizers. While Bakhtiar had been sending money to Iran [to challenge the Shah's authority], it was nothing to do with him. It was in short a fake story narrated for the media at the time." See Interview with Major General Mansour Qadar, Oral History, Foundations for Iranian History.

${ }^{753}$ Interview with Major General Mansour Qadar, Oral History, Foundations for Iranian History.

${ }^{754}$ Reza Radmanesh was the General Secretary of the Tudeh Party from 1948 to 1969 and Mahmoud Panahian was the War Minister of the Soviet-backed Azarbaijan People Government and the head of National Front of Iranian Nations.
} 
Bakhtiar. When I was charge d' affairs in Iran's embassy in Beirut, Teymur Bakhtiar entered Lebanon five times between 1965-67. Although Tehran pressed me to arrest Bakhtiar, I asked the officials to hold since Bakhtiar's secretary in Beirut, Bahr al-Oloum, had been SAVAK's agent ... Speaking fluently in Farsi, Bahr al-Oloum was an Iraqi man who had extensive networks with several Iranian clergies. Seyyed Musa Sadr and Colonel Pashaie both participated in these meetings ...We were fully aware of Bakhtiar and his allies' detailed plans." ${ }^{, 755}$ In the 60s, Bakhtiar and Ayatollah Khomeini were the Shah's leading dissidents.

In 1969, Bakhtiar entered Lebanon but, surprisingly this time he was arrested. Despite the Shah's insistence, Bakhtiar was not extradited to Tehran and he finally left Beirut on 4 April 1969. Iran immediately broke its diplomatic relation with Lebanon. "The Shah got so angry that he ordered to sell all the furniture of the Iran's embassy in Lebanon since, according to the Shah, there would be no return anymore." ${ }^{756}$ While the Maronites regime of Beirut and President Helou were responsible for the Iranian-Lebanese diplomatic tension, SAVAK soon criticized Sadr since he "single-handedly pressed Beirut to release Bakhtiar," according to Qadar. ${ }^{757}$ In reality, when Bakhtiar traveled to Beirut, Sadr had a secret meeting with him. Qadar claimed, “when I was appointed as Iran's ambassador to Jordan, Bakhtiar came to Beirut two more times. Interestingly, Manouchehr Zelli, Iran's ambassador to Beirut at the time, was not aware of his extensive connections in Beirut since SAVAK had not informed him. When Bakhtiar entered Lebanon, Zelli reacted and

\footnotetext{
${ }^{755}$ Interview with Major General Mansour Qadar, Oral History, Foundations for Iranian History.

${ }^{756}$ Ibid.

${ }^{757}$ Ibid.
} 
unintentionally politicized the case. Despite Ambassador Zelli's tireless efforts and Tehran's financial investment and heavy payment to the Lebanese officials, including President and Parliament Speaker, Kamel Asaad, Sadr who had assigned a lawyer for Bakhtiar's case convinced Beirut to release him. With Bakhtiar's release, Sadr's secret relations with him were disclosed., ${ }^{, 758}$ Nevertheless, Sadr refused any cooperation with Bakhtiar against Tehran. Sadr argued he never agreed with Bakhtiar's plot to overthrow the Pahlavi regime of Tehran and his meeting with the SAVAK former director was arranged just because of his religious position in Lebanon. ${ }^{759}$ Sadr explained to Manouchehr Davoudi that he was an Iranian who "loves the country but it seems that I have been punished because I am an Iranian. Wrongly reported by Ja'far Sharaf al-Din, the Iranian regime thinks that I have been one of those who prevented Bakhtiar's extradition to Iran." ${ }^{760}$ Nonetheless, Sadr's efforts to purge himself of Bakhtiar's anti-Shah activities fell on deaf ears. Although Tehran-Beirut relations were ultimately renewed in July 1971 with former president Camille Chamoun meeting with the Shah in Tehran, SAVAK never stopped denouncing Seyyed Musa for having secret connections with Bakhtiar.

\section{The Iranian Revolutionaries}

In contrast to his ambiguous ties with Bakhtiar, Sadr's direct and indirect support for the Iranian opposition had huge ramifications for Iran's non-state foreign policy in Lebanon. Since the 50s, Beirut had been a major bridgehead for a wide variety of intellectuals and political dissidents. Lebanese open politics, at least compared to other regional states, soon

\footnotetext{
${ }^{758}$ Interview with Major General Mansour Qadar, Oral History, Foundations for Iranian History.

${ }^{759}$ SAVAK Documents, No. 27 December 1971.

${ }^{760}$ SAVAK Documents, No. 316, 6 May 1970.
} 
became a magnet for several Middle Eastern opposition groups to establish their branches in Beirut. In the aftermath of the U.S.-orchestrated coup of 1953 and the reinstallation of the Shah on the Peacock Throne, anti-Shah dissidents, including the Pro-Mossadegh National-Front and the communist Tudeh Party, were effectively suppressed. Radical religious forces, especially Ayatollah Seyyed Rouhollah Khomeini and Nehzat-e Azadi-e Iran (the Freedom Movement of Iran), were both exiled and suppressed after the riot of June 1963. The rest of the conservative clergy had been cowed, co-opted, or, like Grand Ayatollah Boroujerdi, took an a-political line. By the mid-60s, however, the suppression of old popular opposition parties gradually radicalized the dissidents and left armed violence as the only means of inflicting damage on the Pahlavi regime. Inspired by Mao and the Third World revolutionary revolutions in Algeria, Cuba, Palestine, and Vietnam, a new wave of Iranian dissidents, mostly young students, emerged. Chief among them were the 1slamist-leftists Sazman-e Mojahedin-e Khalq-e Iran (People's Mojahedin of Iran or MEK) and the Marxist-Leninist Sazman-e Cherik-ha-ye Fadaiyan-e Khalq (Organization of the Iranian People's Fadaiyan Guerrillas or Fadaiyan). The presence of Palestinian military bases in Lebanon provided a safe ground for Nehzat-e Azadi-e Iran--Shakhe Kharej (the Freedom Movement of Iran-External Branch), the Mojahedin, and the Fadaiyan. By the late-60s, their activities had been effectively monitored by the powerful SAVAK. SAVAK extensively used its connections with the Lebanese General Security Directorate to control Iranian militant groups. Nonetheless, when Suleiman Frangieh gained power in 1970, the Lebanese security service was soon purged of pro-Chehab forces ${ }^{761}$ and in turn, Iran's intelligence power in Lebanon was limited.

\footnotetext{
${ }^{761}$ F. Stoakes, The Supervigilantes: The Lebanese Kataeb Party as a Builder, Surrogate and Defender of the State, (January 1975), Middle Eastern Studies, 11 (1): 220.
} 
Rooted in the Islamic Student Associations, a student club aiming at preventing the expansion of communism in Iran in the post-World War II era by putting emphasis on the compatibility of Islam and modernity, the Freedom Movement of Iran (FMI) was founded by religious-liberal members of the pro-Mossadegh National Front, i.e., Mehdi Bazargan, then the first Prime Minister after the Islamic Revolution, Ayatollah Seyyed Mahmoud Taleghani, an influential reformist and senior clergy, and Yadollah Sahabi, a reformist politician, in $1961 .^{762}$ The FMI was outlawed after backing the demonstrations of 1963. Shortly after that, its young member established the external wing of the FMI. ${ }^{763}$ After an unsuccessful meeting in Algeria, Mostafa Chamran, Sadegh Ghotbzadeh, and Ebrahim Yazdi established Sazeman-e Makhsus-e Eettehad va Amal (Special Organization for Unity and Action or SAMA) in July 1964 in Egypt. ${ }^{764}$ After two years of military training at the al-Khas, a garrison 90 kilometers from Cairo, the SAMA left Egypt in 1966, due to Nasser's increasingly anti-Iran attitude--referring to the Persian Gulf as the 'Arabian Gulf' and to Iran's Khuzestan as 'Arabistan'. The SAMA then moved its base to Beirut; however, with Tehran's pressure, both Yazdi and Chamran returned to the United States.

In the meantime, Sadr asked his friends, Mehdi Bazargan and Ibrahim Yazdi, to find a "committed" director for the Burj al-Shimali Technical Institute. ${ }^{765}$ Sadr was going

\footnotetext{
${ }^{762}$ Before the Freedom Movement of Iran, they cooperated with Ayatollah Zanjani in the establishment of an underground organization, the National Resistance.

${ }^{763}$ All SAMA members became leading figures after the Islamic Revolution. Ebrahim Yazdi (Iran's second Foreign Minister after the Revolution), Mostafa Chamran Savehie (Iran's First Minster of Defense after the Revolution), and Sadegh Ghotbzadeh (Ayatollah Khomeini's spokesperson and the head of National Iranian Radio and Television after the Revolution) in the USA, Ali Shariati (the main ideologue of the Islamic Revolution) Abolhassan Banisadr (Iran's first president) in France, and Seyyed Sadegh Tabatabai (Seyyed Musa Sadr's nephew and Deputy Prime Minister) in Germany.

${ }^{764}$ SAVAK Documents, No.213/16463, 16 October 1977.

${ }^{765}$ Tabatabaie, Mohammad Sadegh, Khaterat-e Siasi Ejtemai [Socio-Political Diary] (Moassese Tanzim Nashr Asar Emam Khomeini, 1388) vol. 2, p.16.
} 
to establish a Technical Institute, a vocational institute in the southern town of Burj alShimali and outside of Tyre where both ideological and technical training was provided. Mostafa Chamran then left the U.S. for Lebanon for the second time in 1971. Chamran soon became a major figure of the Iranian opposition in Lebanon. As a "former member of Iranian Student Confederation" "766 and "National Front supporter,"767 Chamran was "a highly-educated student in the U.S. who had become pessimist of Iran's regime."768 After his graduation, he soon left the U.S. for Cuba to receive military training. ${ }^{769} \mathrm{He}$ left his position as a senior research staff scientist at Bell Laboratories and NASA's Jet Propulsion Laboratory to go to Egypt to found SAMA. In Egypt, he was chosen as SAMA's military head. Upon his return to the U.S., he continued revolutionary activities. ${ }^{770}$ According to SAVAK, Chamran was "a very religious man. While his friends regret why Chamran is so religious, he sees the issue in a strange cold-blooded mood."771 "Chamran was pure, praiseworthy, honest, decent, respected, and clever man. He led a humble life in Tyre with only two small rooms. We tried several times to entice him to cooperate with Iran and to dissuade him to struggle against the regime," Qadar also confirmed Chamran's special

\footnotetext{
${ }^{766}$ SAVAK Documents, No.213/265, 16 July 1975.

${ }^{767}$ Interview with Major General Mansour Qadar, Oral History, Foundations for Iranian History.

${ }^{768}$ Chamran received an M.S. degree from the Texas A\&M University and a Ph.D. in electrical engineering and plasma Physics in 1963 from the prestigious University of California, Berkeley. See SAVAK Documents, No.222/2158, 16 March 1973.

${ }^{769}$ Zabih, Sepehr, Aspects of Terrorism in Iran, (September 1982). Annals of the American Academy of Political and Social Science. International Terrorism (Sage Publications) 463: 84-94.

${ }^{770}$ Chamran founded a group, Red Shiism, in San Jose with the aim of training militants. A year later, in 1968, Ebrahim Yazdi and Chamran founded another group, the Muslim Students' Association of America (MSA), with extensive branches in the U.S. and France.

${ }^{771}$ SAVAK documents, 27 August 1967.
} 
personality. ${ }^{772}$ Despite his anti-Tehran position, he "was never a socialist-communist activist. ${ }^{, 773}$ He was an anti-communist figure, though interested in Ernesto Che Guevara. ${ }^{774}$ He, in fact, "believed in what he believed." "775 Chamran soon became Sadr's right-hand man. The Chamran-Sadr relation was a "lover-beloved" one as such that Chamran called Seyyed Musa Sadr as "the one whom I love more than anything else," "Imam Ali's manifestation," and "Imam Hussein's heir.,"776 Chamran also had a deep influence on Sadr. ${ }^{777}$ In the Technical Institute, Sadr and Chamran took an innovative way to train the Shia community. Qadar claimed that Chamran held relations with the U.S. embassy in Beirut! Therefore, he denounced Chamran of "abusing the Americans to achieve his revolutionary goals and Islam." 778 SAVAK also believed that it was Chamran who connected Sadr with "foreign officials." ${ }^{, 779}$ In post-revolutionary Iran, Chamran became a major symbol of martyrdom among religious revolutionaries who left academic careers and prestigious positions in the U.S. to wage struggles against the Shah and Imperialism.

Chamran was not the only pro-Sadr figure among Iranian revolutionaries. According to Qadar, while Chamran was Sadr's connection with the U.S., it was Sadegh

\footnotetext{
${ }^{772}$ Interview with Major General Mansour Qadar, Oral History, Foundations for Iranian History.

${ }^{773}$ Interview with Major General Mansour Qadar, Oral History, Foundations for Iranian History.

${ }^{774}$ SAVAK documents, 27 August 1967.

${ }^{775}$ Interview with Major General Mansour Qadar, Oral History, Foundations for Iranian History.

776 Tabatabaie, Mohammad Sadegh, Khaterat-e Siasi Ejtemai [Socio-Political Diary] (Moassese Tanzim Nashr Asar Emam Khomeini, 1388) vol. 2, pp.83-84.

${ }^{777}$ SAVAK Documents, No.5489, 29 July 1974.

${ }^{778}$ Interview with Major General Mansour Qadar, Oral History, Foundations for Iranian History.

${ }^{779}$ SAVAK Documents, No.849, 25 August 1977.
} 
Ghotbzade who connected Sadr with the European countries. ${ }^{780}$ Sadr's alleged European connection through Sadegh Ghotbzadeh was also considered as a threat by SAVAK. ${ }^{781}$ SAVAK had monitored Sadr's contact with Ghotbzadeh from the very beginning. ${ }^{782}$ Through Ghotbzadeh, Sadr bought a four-floor building on Kennedy Street in Paris, to establish an Islamic Association there and Ghotbzadeh lived on its Fourth floor. ${ }^{783}$ Ghotbzadeh was not as pure as Chamran. ${ }^{784}$ "Despite his long-standing friendship with Ghotbzadeh, Chamran even had a negative view towards Ghotbzadeh's revelry," Qadar claimed. ${ }^{785}$ Tehran complained to Sadr of his support for Ghotbzadeh several times. ${ }^{786}$ But SAVAK's request fell on deaf ears. While Sadr saw Ghotbzadeh as "moderate and rational," 787 SAVAK viewed him a "pro-communist", "Islamist Marxist", and "one of the leaders of the National Front" who was running sabotage activities against Tehran. ${ }^{788} \mathrm{Sadr}$

\footnotetext{
${ }^{780}$ Interview with Major General Mansour Qadar, Oral History, Foundations for Iranian History.

${ }^{781}$ SAVAK Documents, No.213/479, 15 January 194.

${ }^{782}$ SAVAK Documents, No.21/3916, 22 December 1971; SAVAK Documents, No. 30 September 1971.

${ }^{783}$ Qadar claimed that Ghotbzadeh and Sadr had revelry and pleasure there. He also accused Sadr of using drugs and drinking wine. See Interview with Major General Mansour Qadar, Oral History, Foundations for Iranian History.

${ }^{784}$ Interview with Major General Mansour Qadar, Oral History, Foundations for Iranian History.

${ }^{785}$ Interview with Major General Mansour Qadar, Oral History, Foundations for Iranian History.

${ }^{786}$ SAVAK Documents, No.213/479, 15 January 1974; SAVAK Documents, No. 5636-5637, 24 November 1974; SAVAK Documents, No. 9, 10 November 1976; SAVAK Documents, No. 134/3583, 10 November 1976; SAVAK Documents, No. 170/033-3/1068, 7 May 1977; SAVAK Documents, No. 213/16463, 16 October 1977.

${ }^{787}$ SAVAK Documents, No.6335, 12 December 1973

${ }^{788}$ SAVAK Documents, No.213/54013, 6 April 1974; SAVAK Documents, No.2219/8, 1 March 1976.
} 
also facilitated the connections between the Iranian dissidents and Damascus. ${ }^{789}$ In SAVAK's view, Sadr was attempting to unite the Iranian opposition against the Shah. ${ }^{790}$ With Chamran's move to Lebanon, a wave of anti-Shah, young Iranians found their way to Lebanon. Sadr was accused of having ties with pro-National Front students, as well as radical militant groups of the Islamist-leftist Mujahedin and even the Marxists-Leninist Fadaiyan. Founded by six former members of the FMI on 5 September $1965,{ }^{791}$ the Mojahedin had been heavily influenced by Bazargan, Taleghani, and especially Ali Shariati, the main ideologue of the Islamic Revolution. The Fadaiyan was founded by the National Front former member Bijan Jazani and other young Marxist students in the early 60s. ${ }^{792}$ Though staying by and large out of the Lebanese politics, both groups were suspicious of Seyyed Musa Sadr. their suspecions was mainly due to their close ties with radical Palestinian guerrillas. The Fadaiyan were mostly trained at the Fatah military camps in Jordan and then in Lebanon by George Habash's Popular Front for the Liberation of Palestine (PFLP) ${ }^{793}$ and Ahmad Jibril's Popular Front for the Liberation of PalestineGeneral Command. Besides, the Fadaiyan gradually took an anti-Damascus position, especially when Abu Abbas split from Jibril's group. The Fadaiyan's anti-Syrian position and ties with radical Palestinian groups were two major factors for their lack of trust and even enmity toward Sadr. Despite their ideological differences, the Mojahedin shared the

\footnotetext{
${ }^{789}$ Sadegh Ghotbzadeh had received a Syrian passport.

${ }^{790}$ Interview with Major General Mansour Qadar, Oral History, Foundations for Iranian History.

${ }^{791}$ Including Mohammad Hanifnezhad, Saeed Mohsen and Ali-Asghar Badizadegan.

${ }^{792}$ Including Hasan Zia-Zarifi, Amir-Parviz Pouyan, Masood Ahmadzadeh, Hamid Ashraf and Meftahi. The Fadaian officially announced their presence in Iran's politics on 8 February 1971 when the Fadian Guerrillas unsuccessfully attacked to an Iranian military base in Siahkal, in the north of Iran.

${ }^{793}$ SAVAK Documents, No. 213/869, 7 March 1978; 25 February 1978.
} 
Fadaiyan attitude towards Sadr. In the aftermath of 1963, the Mojahedin started contacting with the PLO members in Dubai, UAE, for the first time. ${ }^{794}$ With these contacts, in July 1970 several Mojahedin members left Iran for the Fatah bases in Lebanon and Jordan. Major among them was Massoud Rajavi who revived the non-Marxist-Leninist section of the group in 1978. As time wore on, Beirut became a bridgehead for Mojahedin's external branches in Damascus, Aden, Baghdad, Paris, London, and Tripoli (Libya). As Sadr's relations with the PLO deteriorated, the Mojahedin began criticizing him and Chamran. In fact, there was no alignment between Sadr with either Iranian militias.

Despite the left-leaning ideologies of the Fadaiyan and the Mojahedin and their tension with Sadr, SAVAK still stressed their secret ties with Iranian armed groups. While the Mojahedin was mainly supported by Kamal Jumblatt's Progressive Socialist Party, SAVAK denounced Sadr for his financial support for them. "The first thing Sadr did was to make a connection between the Palestinian groups and Shariatmadari. Seyyed Musa asked financial support for the Shia and Volunteers for the liberation of Palestines. However, the money was for the Iranian Mojahedin who were being trained by the Palestinian. An enormous amount of money, 5 million dollars, was delivered to Sadr under the label of support for the Shia homeless in the south of Lebanon and volunteers for the Liberation of Palestine. I do not know if Shariaatmadari knew the money was for the Mojahedin. The money was then split among the Palestinian groups as well as the Mojahedin, instead of the Shia people. The major director was certainly Sadr," Qadar claimed. $^{795}$ SAVAK also believed that the Libyan regime had supported the Mujahedin

\footnotetext{
${ }^{794}$ Beigi, Abbas William, The Shah's Lebanon Policy: The Role of SAVAK (January,1997) Middle Eastern Studies 33 (1): 78.

${ }^{795}$ Interview with Major General Mansour Qadar, Oral History, Foundations for Iranian History.
} 
through Sadr. ${ }^{796}$ Despite Sadr's denial, SAVAK did not stop accusing him of being a Godfather of the Iranian opposition groups.

In addition to the FMI, the Mojahedin, and the Fadaiyan, Ayatollah Seyyed Ruhollah Khomeini's disciples had been active in Lebanon since the late 60s. Ayatollah Khomeini's harsh speech against the Shah, denouncing him as a "wretched, miserable man," and the subservient bloody demonstrations of June $5^{\text {th }}, 1963$, heralded the rising power of the Shia clergymen. Sadr played a key role in saving Ayatollah from execution. A year later, on 26 October 1964, Ayatollah Khomeini criticized the Shah for granting diplomatic immunity to the U.S. military personnel in Iran. This time, he was exiled to Bursa, Turkey, and then to Najaf, Iraq, where he spent more than 14 years. Shortly after Ayatollah Khomeini's arrival at Najaf, Sadr, who saw him as Imam al-Akbar (the Greater Imam), arranged his first interview with a foreign journal. Lucien George, a Le Monde reporter who had been converted to Islam by Seyyed Musa Sadr, entered Iraq with Sadegh Ghotbzadeh and interviewed Ayatollah Khomeini. ${ }^{797}$ Ayatollah Khomeini, in return, had a good relation with Sadr, apparently considering Musa Sadr as his substitute. ${ }^{798}$

In the aftermath of his exile, Ayatollah Khomeini's ties with Sadr were soon monitored by SAVAK. In SAVAK's view, the Sadr-Khomeini connections could promote Shia Islamism, destabilize domestic politics and endanger Iran's policy in Iraq and the Levant by instigating the Shia communities there against the Shah. Exaggerating Sadr's role, Ambassador Qadar claimed that "even Khomeini was led by Sadr. It was Sadr who

\footnotetext{
${ }^{796}$ SAVAK Documents, No. 1013, 9 March 1974.

${ }^{797}$ Interview of Ayatullah Khumayni with the Correspondent of Le Monde, Lucien Ge (Liberation Movement of Iran, 1978).

${ }^{798}$ SAVAK Documents, No. (62).
} 
was a real theorist behind Khomeini." ${ }^{, 799}$ Indeed, several elements were suspicious of the Sadr-Khomeini connections. This suspicion increased when Sadr left Tyre for Najaf to visit Ayatollah Khomeini on 6 April $1968{ }^{800}$ SAVAK believed that Iranian students in Western Germany (i.e., Sadegh Tabatabaie, Sadr's nephew) as well as pro-National Front political magazines and newspapers, like Bakhtar-e Emrouz (the West Today) and Khabar-nameh Jebhe-e Melli (National Front Newsletter), facilitated these connections. ${ }^{801}$ According to SAVAK, Ebrahim Yazdi, Mustafa Chamran, and Sadegh Ghotbzadeh were responsible of making connections between Ayatollah Khomeini with Seyyed. ${ }^{802}$

With the Baath Party's growing anti-Shia repression strategy to weaken Tehran's alleged ties with the Iraqi Shia, the Shia senior clergies were pushed to leave Iraq to Lebanon. In the middle of Baghdad's forced expulsion of a number of Iranians and Iraqis of Iranian origins from the country, Ayatollah Khomeini was invited by Sadr to move to Lebanon. Although the invitation was respectfully rejected, Sadr tried to meddle between Baghdad and the Shia Ayatollahs. Qadar claimed that "Seyyed Musa sent a message to Khomeini. SAVAK controlled the letter through Bakhtiar's secretary. In the letter, Sadr asked Khomeini to warn Baghdad leaders that the Shia deportation from Iraq would confirm Iran's position in support of the Iraqi Shia. ${ }^{9003}$ Though Ayatollah Khomeini did not leave Iraq and decided to stay in Najaf, some of his disciples left Iraq for the south of

\footnotetext{
${ }^{799}$ Interview with Major General Mansour Qadar, Oral History, Foundations for Iranian History.

${ }^{800}$ SAVAK Documents, No. 537, 28 April 1968.

${ }^{801}$ SAVAK Documents, No. 315/7480, 9 August 1968; SAVAK Documents, No. 315/115606, 8 March 1969.

${ }^{802}$ Interview with Major General Mansour Qadar, Oral History, Foundations for Iranian History.

${ }^{803}$ Interview with Major General Mansour Qadar, Oral History, Foundations for Iranian History.
} 
Lebanon. As time wore on, however, these pro-Ayatollah Khomeini elements weakened ties between Ayatollah and Sadr. Indeed, the presence of Iranian opposition not only accelerated Iran's turn away from aligning with the Lebanese Shia, but also intensifyed tensions between Musa Sadr and the Iranian revolutionaries. Sadr's trip to Tehran hammered the final nail in the coffin of his relations with pro-Ayatollah Khomeini elements.

\section{A Controversial Trip}

By the early 70 s, Sadr had been still optimistic about convincing Tehran to reconsider its non-state foreign policy. With Cairo's waning power in the region, Iran's regional rise could protect the Shia interests in the south of Lebanon, Sadr thought. According to SAVAK, Sadr was "an intellectual, smart, and cautious politician who had been successfully attracting the Christian leaders and become the head of Shia community. He has clergies' characteristics, like ambitiousness and demagoguery... He is trying to approach Iran to improve its leverage in Lebanon, and that is why he has not done anything wrong against Your Majesty!" ${ }^{804}$ In his meeting with Seyyed Hossein Nasr, the head of the Literature School at Tehran University and a major Iranian philosopher, Sadr asked him to inform the Shah of an imminent Israeli invasion of the south of Lebanon. He pleaded with the Shah for Iran's support since the Shah "could put pressure on the White House to stop Israeli raid on Lebanon." ${ }^{, 805}$ Though his request fell on deaf ears, Tehran still did not want to fully abandon Sadr. Therefore, Sadr's request of Roknoddin Ashtiani, Iran's ambassador

\footnotetext{
${ }^{804}$ SAVAK Documents, No. 213/1940, 8 November 1972.

${ }^{805}$ SAVAK Documents, No. 4 March 1970.
} 
to Lebanon, ${ }^{806}$ to revive friendly relations with Tehran was welcomed. Apparently, to gain leverage over the Shia leader, Ashtiani facilitated Sadr's trip to Tehran and arranged a meeting with the Shah for him. Shortly before Sadr's trip to Iran, SAVAK recommended that the Ministry of Foreign Affairs ask the Shia senior clergies in Qom to invite him. ${ }^{807}$ It was a step taken by Tehran to increase Sadr's prestige as a religious leader of the region and therefore, to make his meeting with the Shah more substantial. With Ayatollah Shariatmadari's official invitation, Sadr left Beirut for Tehran on 26 November 1971. On 18 December 1971, Sadr met Prime Minister Amir-Abbas Hoveyda and Khalil al-Khalil, Lebanon's Ambassador to Tehran. He informed Hoveyda of the Lebanese Shia's "improper political situation in Lebanon." Sadr repeated his request for support and contended that "all the Shia, including the Lebanese Shia, respected the Shah and saw him as their leader." Expressing his patriotism, Iranian background, and loyalty to the Shah, Sadr expressed regret for the recent tensions with Tehran due to "some lower officers" activities" in Lebanon. Lastly, Sadr suggested to Hoveyda that Iran could gain more leverage within Lebanon and the Shia community with the establishment of a university or hospital for the Shia. ${ }^{808}$ In the meeting with the Pahlavi monarch, Sadr repeated his request. The Shah agreed and promised him to allocate 30 million dollars for the establishment of a university, a hospital, and a Dar al-Fatwa for the Shia community. ${ }^{809}$ Backed by Hoveyda

\footnotetext{
${ }^{806}$ Ashtiani was Sadr's relative. He was from Khorasan clergies. Qadar claimed that Ashtiani jumped on the opportunity to plan a meeting between the Shah and one of his relatives. Ashtiani played a major role in convincing the Shah to meet with Sadr. See Interview with Major General Mansour Qadar, Oral History, Foundations for Iranian History.

${ }^{807}$ SAVAK Documents, No. 212/17101, 27 April 1971; SAVAK Documents, No. 312/1233, 17 May 1971.

${ }^{808}$ SAVAK Documents, No. h/15-264(s)-49, 18 December 1971.

${ }^{809}$ Interview with Major General Mansour Qadar, Oral History, Foundations for Iranian History.
} 
and authorized at the Parliament, the money was approved to be delivered through Jami'ate Shir va Khourshid-e Sorkh-e Iran [the Red Lion and Sun Society (the Iranian Red Cross)]. ${ }^{810}$ The meeting apparently initiated a thaw in Sadr-Tehran relations.

There were other reasons behind Sadr's meeting with the Shah. Shortly after Sadr's arrival in Tehran, some leading figures of the opposition, including Mehdi Bazargan, Morteza Mottahari, Seyyed Mohammad-Husain Beheshti, and Yadollah Sahabi, asked Sadr to dissuade the Shah from the execution of the Mojahedin founding leaders. ${ }^{811}$ According to Ali Hojjati-Kermani, "in a meeting held in Beheshti's house, they asked Sadr to meet the Shah to prevent the Mojahedin' execution. Beheshti insisted on his request... A few nights later, Abbas Masoudi asked Sadr if he would meet the Shah. Seyyed Musa responded that he had not made his decision yet. I was there... In fact, Sadr was pushed to meet with the Shah.." ${ }^{812}$ They thought that Sadr had leverage over the Shah and would convince him to reconsider his instruction. Some political prisoners' families, like AliAkbar Hashemi-Rafsanjani's, also asked Seyyed Musa to convince the Shah to release the revolutionaries. ${ }^{813}$ Although Sadr argued that the authoritarian Pahlavi monarch would never accept his intervention, his comments fell on deaf ears. Alam himself called Seyyed Musa and his older brother, Seyyed Reza, to set a meeting with the Shah. ${ }^{814}$ On 29 February

\footnotetext{
${ }^{810}$ Alam advised the government to deliver money to the Lebanese Shia through the Red Lion and Sun Society'. Beigi, Ibid. p. 81.

811 They were Mohammad Hanifnejad, Ali-Asghar Badizadegan, Saeed Mohsen, Ali Bakeri, and Naser Sadegh. See also http://www.mashreghnews.ir/fa/news/459203/

${ }^{812}$ KhosrowShahi, Seyyed Hadi, Yad-Nameh Emam Musa Sadr [Imam Musa Sadr's Memoirs], 1387, pp. 384-5.

${ }^{813}$ SAVAK Documents, No. (66)

${ }^{814}$ Sadr, Seyyed Mohammad, Enghelab va Diplomacy dar Khaterat-e Seyyed Mohammad Sadr [Revolution and Diplomacy in Seyyed Mohammad Sadr's Memories], Soureh Mehr publication, pp. 36-8. See also http://khateemam.com/1392/12/25/4/4216.html/.
} 
1972, Sadr met Alam, the Minister of Court, to see if the Shah would accept his request. Later, and in the meeting with the Shah, Sadr repeated his request. Although the Shah initially promised Seyyed Musa not to execute the prisoners, he never kept his promise. ${ }^{815}$ The Mojahedin founders' were executed on May 24, 1972.

Ironically, Sadr's opponents in the Qom Hawza, as well as radical revolutionaries in Iran and Lebanon, accused him of being the Shah's agent. ${ }^{816}$ Seyyed Hamid Rohani (Ziarati), another pro-Khomeini revolutionary, ${ }^{817}$ criticized Sadr for his meeting with the Shah, stating that "Sadr's relations with the Pahlavi regime were not limited to his meeting with the Shah; rather, he had relations with Iranian officials in Lebanon and the Court in Tehran. The Shah's mother had apparently met Sadr. Sadr's close relations with the dictators in the region had tarnished his image before [the Iranian] liberators." ${ }^{, 18}$ Sadr's meeting with the Shah damaged his image among the radical Iranian revolutionaries. "Mr. Davani, we have two problems here [Lebanon]. When we come to Iran, some of our opponents call us the Shah's spy. When we are here [those] Iranians call us pro-Nasser and pro-Sunni. What should we do? None of them like us," Sadr told Ali Davani, a major scholar in Islamic Studies. ${ }^{819}$ This was a major blow to him; however, Sadr never expressed his anger. According to Hojjati-Kermani, "When I asked him of those objections, he smiled and told me: 'God knows why I met the Shah.' He magnanimously ignored the issue."’20

\footnotetext{
${ }^{815}$ Tabatabaie, Mohammad Sadegh, Khaterat-e Siasi Ejtemai [Socio-Political Diary], Moassese Tanzim Nashr Asar Emam Khomeini, 1388, vol. 1, p. 211.

${ }^{816}$ SAVAK Documents, No. (67).

${ }^{817}$ Founder and former head of Islamic Revolution Document Center.

${ }^{818}$ See http://tarikhirani.ir/Modules/News/Phtml/News.PrintVersion.Html.php?TypeId=4\&NewsId=1649.

${ }^{819} \mathrm{http}: / / w w w . m a s h r e g h n e w s . i r / f a / n e w s / 459203$.
} 
In addition to the Iranian radical revolutionaries, Sadr's trip to Tehran was criticized by the Shah's regional foes, especially Baghdad. Colonel Walid Mahmoud Sirat, Iraq's attaché in Beirut, called Sadr the Shah's agent who traveled to Tehran in the wake of Iran's "'illegal" conquest of three disputed islands in the Persian Gulf. ${ }^{821}$ On top of that, a rumor popped up in Beirut that Sadr's trip was a plan to convince the Shah to interfere in the Lebanese election to support himself and Camille Chamoun. ${ }^{822}$ Despite these rumors, the Shah's approval of the financial aid to the Shia community kept ties with Sadr open. However, a SAVAK officer single-handedly cut off Iran's connections with the Shia community in Lebanon.

\section{Qadar Duel with Sadr}

Sadr's tension with Qadar affected the trajectory of Tehran-Sadr ties. After the revival of Tehran-Beirut diplomatic relations, Roknoddin Ashtiani was appointed as Iran's ambassador to Lebanon. Both Ashtiani and his deputy, Lavasani, had religious backgrounds that successfully rehabilitated the Lebanese Shia connections with Tehran. Besides, Sadr's reputation in Lebanon was still at its peak. According to SAVAK, Sadr "has a dense religious-friendship-family network in Iran." ${ }^{\$ 223}$ Shortly before Sadr's trip to Europe, SAVAK recommended that the ministry of foreign affairs dispatch representatives when Sadr entered the European countries. With this, SAVAK officials argued, Sadr's

\footnotetext{
${ }^{820}$ Khosrowshahi, Seyyed Hadi, Yad-Nameh Emam Musa Sadr [Imam Musa Sadr's Memoirs] 1387, pp. 3845.

${ }^{821}$ SAVAK Documents, No. 212/4412, 18 December 1971.

${ }^{822}$ SAVAK Documents, No. 212/4965, 6 February 1972.

${ }^{823}$ SAVAK Documents, No. 213/1940, 8 November 1972.
} 
prestige would prosper and, in return, his dependency on Iran would increase. ${ }^{824}$ Nonetheless, when these elements were replaced by Qadar, a new era in the IranianLebanese Shia connection commenced. With his diplomatic and security background, Qadar was assigned as both Iran's Ambassador to Beirut and chief of SAVAK Station in Lebanon in August 1973. Qadar himself claimed that Tehran needed his experience to run the embassy in Beirut since "the political situation in Jordan had been pacified but the Lebanese society was on the edge of a deepening tension. Thus, the Shah instructed me to go to Beirut due to the experience of the Jordanian situation." ${ }^{, 825}$ With his conspiratorial mind, ${ }^{826}$ Qadar soon purged the embassy of his rivals. ${ }^{827}$ As a next step, he approached Sadr to monitor the Iranian dissidents. Qadar pressed Sadr to be his agent, rather than dealing with him as a respected Shia clergy or an influential Lebanese leader. Despite needing Tehran's support, Sadr rejected the deal. In the wake of growing tension in

\footnotetext{
${ }^{824}$ SAVAK Documents, No. 3266, 11 August 1972.

${ }^{825}$ Interview with Major General Mansour Qadar, Oral History, Foundations for Iranian History.

${ }^{826}$ Qadar claimed, “When I was appointed as Iran's ambassador to Beirut, the Lebanese government warned Tehran not to appoint me there. The Lebanese newspaper launched a campaign against me since I was apparently a member of military-security force. They told the Shah that Lebanese security forces might not be able to prevent Qadar's assassination. The Shah, however, reacted harshly and said: "if you cannot provide security for our ambassador, so let us know not to dispatch any ambassador there. Otherwise, Qadar would be our only candidate in our embassy there". Shortly before going there, Iran's Foreign Minister told me: "Qadar. Are you sure you want to go there? You are going to Laneh-Zanbour". I replied him back, "yes, Sir. I will do what His Imperial Majesty wants me." See Interview with Major General Mansour Qadar, Oral History, Foundations for Iranian History.
}

${ }^{827}$ It seemed Qadar led a coup against Ambassador Ashtiani by accusing him of having a secret connection with Foreign Minister Hussein Fatemi, former Prime Minister Mossadegh's closest adviser (Mossadegh had been born into the Ashtiani clan, and Mohammad Hussein Ashtiani allegedly had phoned a warning to Mossadegh three days before the coup of 1953 that Nassiri was on his way with the royal decree dismissing him; see Dr M. Mosaddegh (H. Katouzian, ed.) and Mosaddegh's Memoirs (London, 1988), p.69.) Qadar also pulled the rug under Colonel Abbas Shaghaghi's feet, chief of SAVAK Station in Beirut, with General Nasiri's support. Nasiri, the chief of SAVAK, had disliked Shaghaghi since they had served together in the Imperial Guard in 1953. Shaghaghi had allegedly played a part in blocking Teymur Bakhtiar's extradition to Iran. Lastly, Qadar changed the personnel of Iranian embassy, like Kiafar. See Beigi, Abbas William, The Shah's Lebanon Policy: The Role of SAVAK, Middle Eastern Studies, vol. 33, No. 1 (January,1997), p. 81. 
Lebanon and deepening enmity with the Palestinian guerrillas and the Shia Zuama, Sadr believed a direct connection with an external security service might have discredited his prestige and his socio-political capital. With Sadr's refusal to cooperate with him against the Iranian opposition, Qadar framed Sadr as a major problem for Iran. "After meeting with President, Patriarch Maouchi, the religious head of the Maronites, and Hasan Khaled, Sunni Mufti, I met with Musa Sadr. I knew that Musa Sadr's machination had been behind all uproar against Iran and me. Sadr knew that it was me who disclosed Bakhtiar's connections in Beirut," Qadar claimed. ${ }^{828}$

The worst was yet to come. The Shah's approval of the financial support for the Lebanese Shia could revive Sadr-Tehran relations. However, it could pose a threat to Qadar who had been tirelessly attempting to expand his influence in Lebanon. When the word reached Qadar, he tried to persuade Prime Minister Hoveyda to reverse the financial aid process by dedicating money through the Ministry of Foreign Affairs and in following, the Iranian embassy in Lebanon. The Shah, however, rejected his plan. Qadar's hatred of Sadr increased. As time wore on, though, he ultimately changed Tehran's policy towards Sadr. Although the Shah initially gave an orders to dedicate financial support to Sadr, a commission of SAVAK, Ministry of Foreign Affairs, and Ministry of Education held a meeting on 15 March 1972 and rejected the idea of establishing a university in Lebanon. In return, Hoevyda offered to dedicate 30 education scholarships for Lebanese Shia students. Regarding the hospital, the commission voted to establish a small clinic in Tyre. ${ }^{829}$ As Sadr was informed of the decision, he called Iran's embassy in Beirut "liar"

\footnotetext{
${ }^{828}$ Interview with Major General Mansour Qadar, Oral History, Foundations for Iranian History.

${ }^{829}$ SAVAK Documents, No. 16 March 1972.
} 
and mentioned that "they [Iran's embassy] would not give any Shia applicant a bourse unless to the specific one (one with a network with Tehran)." 830

Conversely, Qadar denied his decisive role at this juncture. "Sadr had secret connections with Gaddafi. Gaddafi had already asked Sadr to open a mosque in Munich. In 1972, Sadr flattered Gaddafi and instead, criticized the Shah in Munich. One of SAVAK's agent recorded his speech and informed the Shah. The Shah who was informed of Ambassador Ashtiani's family relations with Sadr immediately discharged Ashtiani and appointed me as Iran's ambassador to Beirut... Shortly before leaving Tehran for Beirut, the Shah told me: 'I already instructed to dedicate 20 million dollars to Sadr. Do not tell Sadr that we do not want to pay them money, rather play with him.' But Sadr thought it was me who set obstacles in this process. That is why he planned to assassinate me," Qadar claimed. ${ }^{831}$ Qadar's narrative was wrong. According to Ehsan Naraghi, an Iranian writer and Queen Farah Pahlavi’s former adviser, it was Qadar who convinced Tehran to change its policy towards Sadr. "Sadr told me that Qadar had cut off relations between the Lebanese Shia and Tehran." He noted that the Shah was supposed to support Sadr financially to build a hospital for the Lebanese Shia. "Imam Sadr himself told me he had talked with Shah," Naraghi put. "Imam said that 'I told the Shah that Arabs [regimes of the region] support the Sunni in Lebanon while the Europeans and the Americans both support the Maronites. The Shias, on the other hand, have not been able to find an [external] supporter. In response, the Shah assured me that he would do anything I wanted. I asked him to build a hospital for the Shia. It could have been later followed by the establishment

\footnotetext{
${ }^{830}$ SAVAK Documents, No. 6095, 6 February 1975.

${ }^{831}$ Interview with Major General Mansour Qadar, Oral History, Foundations for Iranian History.
} 
of a medical university and then a major university for the Shia. The Shah agreed but Qadar single-handedly changed the plan.' Qadar, in return, tried to build a few clinics instead of a hospital. He insisted on naming them after the Shah's name. Sadr protested Qadar's plan, arguing that no external support would be delivered in this way. Qadar used this issue against Sadr and discredited him in the Shah's eyes. ${ }^{~} 832$ Naraghi's narrative was repetitted by Seyyed Hadi Khosroshahi. Interestingly, both Kamel Asaad and Ja'far Sharaf al-Din blamed Sadr for disrupting the Shah's funding for the Shia. ${ }^{83}$

Iran's disinclination to support Sadr gave an opportunity to the Russians to support his plans. On 12 December 1972, Sadr was invited by Sheikh Ziaddin Babakhanov, Mufti of Tashkent in the Central Asia, to the USSR. After his trip that was "considerable" and "thinkable" for the Shia, ${ }^{834}$ the Soviet promised Sadr to dedicate 15 million Lebanon Lire to build a hospital. When he was asked whether if this support might anger other countries, especially Iran, Sadr responded that he had already asked Iran to build the hospital but the Iranian leaders agreed to build just some clinics. ${ }^{835}$ Sadr's trip, however, gave Qadar a pretext to frame him as a powerful element of the Russian plot in the Levant. SAVAK believed that the Russian support of Sadr would give them strategic room in the south of Lebanon. ${ }^{836}$ Sadr refused to accept Moscow's support. Sadr, in fact, did not want to escalate his tension with Tehran.

\footnotetext{
832 See Fars News Agency, Interview with Ehsan Naraghi, http://www.farsnews.com/newstext.php?nn=8711240772.

${ }^{833} \mathrm{See}$ http://tarikhirani.ir/Modules/News/Phtml/News.PrintVersion.Html.php?Lang=fa\&TypeId=4\&NewsId=924.

${ }^{834}$ SAVAK Documents, No. 212/509, 24 November 1972.

${ }^{835}$ SAVAK Documents No. 213/2491, 26 December 1972.

${ }^{836}$ SAVAK Documents, No. 213/54013, 6 April 1974.
} 
Though disappointed, Sadr made efforts to reconsider Iran's attitude towards the Lebanese Shia. He pointed out that his relations with Tehran had been prospering during Ambassador Ashtiani's time in Beirut; however, the situation deteriorated when Qadar was appointed to Beirut. He added that "the new ambassador [Qadar] wanted me to be an agent and to control all of my meetings and talks." In his interview with Mohammad Anan, the editor of al-Hayat, Sadr threatened that he would make public Iran's enmity with the Lebanese Shia and would declare that the new Iranian ambassador had been appointed just to gather information against the Shia ${ }^{837}$ Sadr contended that Qadar was a dangerous man who was seeking to defeat the Lebanese Shia since he believed that all the Shia affairs should be controlled by him. Sadr argued that with the replacement of Ashtiani with Qadar, Iran's diplomacy was transformed into an intelligence activity and security service that would endanger Iran's interests in Lebanon. ${ }^{838}$ Despite his efforts, Sadr did not succeed in making Tehran reconsider its policy towards the Lebanese Shia. His image had been effectively tarnished by Ambassador Qadar.

\footnotetext{
${ }^{837}$ SAVAK Documents, No. 213/479, 15 January 1974.

${ }^{838}$ SAVAK Documents, No. 213/2395, 26 January 1974.
} 


\section{Chapter 6}

\section{Downfall: Iran's Non-State Foreign Policy in 1973-1977}

In this period, Iran entirely transformed its non-state foreign policy. As the war changed at the expense of the Iraqi Kurds and the possibility of direct war with Baghdad increased, the Shah bypassed his American and Israeli allies and terminated his support for Mullah Mustafa Barzani. In the Algiers Agreement of 1975, Iraq accepted territorial concession to Iran in Arvand Rud while Iran cut off backing the Iraqi Kurds. The resistance of the Kurdish Peshmerga, who had increasingly depended on the Iranian Army, soon collapsed.

In the meantime, Ambassador Qadar and SAVAK finally convinced Tehran to shift its policy towards the Lebanese Shia. The Lebanese Civil War of 1975 weakened Sadr's position and deepened a gap between the Shia community and other Lebanese communities and parties, as well as the PLO and Arab regimes. Despite rising tension between Sadr and pro-Ayatollah Khomeini elements, the increasing presence of the Iranian Revolutionaries in the south of Lebanon tarnished Sadr's image in Tehran. The Pahlavi regime ultimately broke its relations with Seyyed Musa Sadr and stripped him off his Iranian passport. 


\section{Downfall: The Iraqi Kurds}

"They [the Kurds] weren't fighting; we were fighting [in Iraqi Kurdistan against the Iraqi Army]. The Kurds weren't fighting," the Shah told President Ford. ${ }^{839}$

"No matter what the Shah does, he loves the Kurdish people very much," President Anwar Sadat wrote a letter to Mullah Mustafa Barzani. ${ }^{840}$

"The Shah sold out the Kurds," Prime Minister Yitzhak Rabin bitterly complained of the Shah to Kissinger. ${ }^{841}$

\section{Shuttle Diplomacy}

By late 1973, Iran had successfully tied down the Iraqi Army in Kurdistan and prevented Barzani's joining the national unity government in Baghdad. Nevertheless, the Shah witnessed an accelerating rise of Baghdad. Even the revival of diplomatic relations after the October 1973 War with Iraq did not diminish the Iraqi threat. ${ }^{842}$ On 4 February 1974, skirmishes along the Iranian-Iraqi borders unexpectedly broke out. Six days later, these clashes escalated into almost a war involving artillery exchanges. ${ }^{843}$ In addition to the Kurdish crisis and disputes over Arvand Rud, what lurked beneath this confrontation was Kissinger's shuttle diplomacy. ${ }^{844}$ With Anwar Sadat's help, Kissinger had convinced

${ }^{839}$ Memorandum of Conversation, Ford, the Shah, Kissinger, and Scowcroft, May 15, 1975. Ford Library, National Security Adviser, Memoranda of Conversations, Box 11.

${ }^{840}$ An Interview with Dr. Ahmad Chalabi: How is it possible that Saddam Hussein is still in power in Baghdad? See http://www.pbs.org/wgbh/pages/frontline/shows/saddam/interviews/chalabi.html.

${ }^{841}$ Memcon, March 9, 1975, NSA, Kissinger Reports on USSR, China and Middle East Discussions, Box 3, GRFL.

${ }^{842}$ On October 7, 1973, Iraq opened its embassy in Tehran. In addition to signaling a turn in their regional policy, Iraqi leaders' main intention in reviving the relations with Tehran, and later London, was to take retaliatory measures against Anwar Sadat, Hafiz Assad, and Russians since the Iraqis felt humiliated by not having been informed by their Arab friends of a coordinated attack in the Yom-Kippur War.

${ }^{843}$ United States Mission to the United Nations 472 to the U.S. Department of State, "Iraqi Request for SC Meeting," February 12, 1974 (NARA/AAD/RG59/CFPF/ET/1974), pp.12; and Tehran 1159 to the U.S Department of State, "Iraqi-Iranian Border Clashes," February 11, 1974 (NARA/AAD/RG59/CFPF/ET/1974), pp.1-2.

${ }^{844}$ Amid his Arab-Israeli peace-building efforts in the post-October War of 1973, Kissinger was faced with a critical problem of managing the Israeli Army withdrawal from the Syrian Golan Heights. Though securing 
the Pahlavi monarch to press Baath Iraq along the border in order to force Baghdad to withdraw its troops from the Golan Heights and to secure s's withdrawal from there in May

1974. "The Egyptians asked me to ask the Shah to put pressure on Iraq so Iraqi troops all leave Syria.... That is why there was trouble in February between Iraq and Iran," Kissinger told Israeli Prime Minister Golda Meir. ${ }^{845}$ Tied down in Kurdistan and unable to launch an offensive, Baghdad demanded that the UN Security Council convened an urgent meeting to condemn Iran's aggression. ${ }^{846}$ Despite the Shah's tough move, ${ }^{847}$ the weaker Iraq

a disengagement agreement in January 1974 and Tel-Aviv's withdrawal from the Sinai Peninsula, he saw an Iraqi armored brigade, about one-third of Iraq's Army, in Syria as a threat to his peace initiative. Right after reopening diplomatic relations with Iran and neutralizing the eastern border, Iraq had dispatched an armored brigade to Syria to fight with teh Israelis. See Kissinger, Henry. Years of Renewal (New York: Simon \& Schuster, 1999). p.586. Baghdad soon withdrew from the Syrian front in the middle of the War, due to Iraqi leaders' anger at Egyptian-Syrian covert cooperation. However, with Libyan and Algerian interferences, Baghdad resent the army in November 1973. See Baghdad 600 to U.S. Department of State, "Iraq Rejoins Battle," November 7, 1973 (NARA/AAD/RG59/CFPF/ET/1973), pp.1-2.

${ }^{845}$ White House, Memorandum of Conversation, Kissinger and Meir, May 7, 1974 (DNSA/KT01143), p.12.

${ }^{846}$ U.S. Mission to the United Nations 531 to U.S. Department of State, "Baghdad: SC Meeting on Iraqi Complaint," February 15, 1974 (NARA/AAD/RG59/CFPF/ET/1974), p.1; and U.S. Mission to the United Nations 575 to State, "Iraqi Complaint in SC," February 20, 1974 (NARA/AAD/RG59/CFPF/ET/1974), pp.1-2. In its file submitted to the Security Council, Baghdad stated that "The situation on the frontier is deteriorating rapidly as the Iranian aggression continues and heavy massing of Iranian troops on the borders is still in progress ... Iranian forces at different levels are concentrated in the border area and continue their military actions, openly violating Iraqi territory in a planned manner while Iranian air force fighters violate Iraqi airspace threatening Iraq's national security and sovereignty. See SCOR Supp. S/11216 (12 Feb. 1974). Iran, in turn, accused Iraq of cross-border attacks and demanded compensation for losses incurred. See SCOR Supp. S/11218 (12 Feb. 1974). Yemen, the UAE, and Libya joined the Council debate and contended that 'Iran's aggression against Iraqi border posts could be regarded as an escalation of tension and an invitation to large-scale hostilities.' See Sturchler, Nikolas, The Threat of Force in International Law, 2009, p. 231.

${ }^{847}$ To avoid using a veto to block the likely Security Council resolution against Tehran, Kissinger asked the Shah to accept a watered-down consensus statement, earlier passed on February 28 and let the Security General investigate the event. See U.S. Mission to the United Nations 634 to U.S. Department of State, "Developments in Iraqi SC Complaint," February 26, 1974 (NARA/AAD/RG59/CFPF/ET/1974), pp.1-2; U.S. Mission to the United Nations 674 to U.S. Department of State, "Iraqi Complaint in SC," February 27, 1974 (NARA/AAD/RG59/CFPF/ET/1974), p.1; U.S. Mission to the United Nations 697 to U.S. Department of State, "SC Adopts Consensus in Iran-Iraq Dispute," February 28, 1974 (NARA/AAD/RG59/CFPF/ET/1974), pp.1-2; and United Nations Security Council, "Note by the President of the Security Council," February 28, 1974, S/11229, pp.1-2. But the Shah ignored it. See Tehran 1735 to U.S. Department of State, "Iran-Iraq Border Clash," March 4, 1974 (NARA/AAD/RG59/CFPF/ET/1974), p.1; and Tehran 1779 to State, "Latest Iran-Iraq Border Clash," March 5, 1974 (NARA/AAD/RG59/CFPF/ET/1974), p.1. 
intended to bring Tehran to the negotiation table. Thus, Saddam asked Iran's ambassador to Baghdad to convey an invitation of the Shah to Baghdad to negotiate a "package deal" on 3 March $1974 .{ }^{848}$ Nothing happened, though.

\section{The Collapse of the March Accord}

The lack of clarity about issues in the March Accord, including the degree of autonomy of the Kurdish region, had cast doubt on its longevity and effectiveness. ${ }^{849}$ By the end of fall 1973, the Iraqi army had strengthened its position in the plains of Iraqi Kurdistan while the Peshmerga controlled mountainous areas. Despite periodic skirmishes throughout 1973, particularly in Kirkuk and Sinjar, neither Iraqis nor Kurds stopped the outbreak of the war. Backed by Iranians, Israelis, and Americans, Barzani had reorganized the Peshmerga. In October 1973, he announced the Kurds' demands to control Kirkuk and its oilfields. ${ }^{850}$ Rejecing Barzani's demands, Baghdad unilaterally promulgated a limited autonomy law for Iraqi Kurdistan on 11 March $1974 .{ }^{851}$ Baghdad's proposal did not fulfill promises made in reasons to the Kurds' demands in $1970 .{ }^{852}$ In addition to pressing Barzani

\footnotetext{
848 "Meeting Held at the Iraqi Foreign Ministry in Baghdad on Monday, 8 April 1974, at 5.30 pm," S-09040022-08, UNARMS.

${ }^{849}$ The U.S. Department of State 37806 to Tehran, “Soviet-Iraq Threat to Iran in Middle East," March 14, 1970 (FRUS/1964-68/XXI/doc.268), pp.1-3.

${ }^{850}$ Postponed twice, the census for disputed areas had been unable to remove the long-term obstacle of his proposed capital of the Kurdish state: Kirkuk. Earlier before, in 1972, Barzani rejected Baghdad's proposal to apply the 1957 census figures to Kirkuk that would demonstrate the majority of Iraqi Turkmen in the city who were likely to prefer the Baath rule due to the bloody days of July 1959.

${ }^{851}$ The Baath-imposed autonomy law established under the auspices of more than six anti-Barzani and socialists Kurds. See McDowall, David, A Modern History of the Kurds (London, New York 2004) pp. 332335.

852 Baghdad 136 to U.S. Department of State, "Nominal Autonomy for Kurdistan," March 10, 1974 (NARA/AAD/RG59/CFPF/ET/1974), pp.1-2.
} 
by giving him two weeks to accept, Baghdad intended to show Tehran its will to break the stalemate in Kurdistan. The scene was set for the collapse of the March Accord.

Stuck with the choice of either resuming the war or surrendering to Baghdad, Barzani went to Tehran. On 18 March 1974, Barzani met the Shah and begged him to equip the Peshmerga with anti-tank and anti-aircraft weapons in order to launch a wholesale raid on Iraq. He asked the Shah to allow the Kurds to declare an autonomous Kurdistan and to provide $\$ 180$ million to $\$ 360$ million annually in financial support to cover expenses, as well as Iran's recognition and diplomatic support at the UN, otherwise he would "seek asylum in Iran, and tell the Kurdish people to make the best deal they can with the Baath. ${ }^{" 853}$ The Shah promised him to increase military and financial aid but he stated he needed to consult his allies on his autonomy declaration. ${ }^{854}$ Barzani repeated requests to Arthur Callahan in Tehran. Nevertheless, the Americans refused to respond to him clearly and suggested that the Shah was in a better position to act on his requests. ${ }^{855}$ On 21 March 1974, new CIA Director William Colby slightly objected to any increase in U.S. support for the Kurds. ${ }^{856}$ He believed the U.S. primary goal for its covert cooperation with SAVAK was less to support an autonomous Kurdistan than to maintain the stalemate in Kurdistan. ${ }^{857}$ The NSC and general Brent Scowcroft warned against Kurdish

\footnotetext{
${ }^{853}$ Helms to Scowcroft, March 18, 1974, CIA-Helms; Helms to Scowcroft, March 18, 1974, (FRUS, 19691976, Vol XXVII,).

${ }^{854}$ United States Congress, House Select Committee on Intelligence, CIA: The Pike Report (Nottingham, England: Spokesman Books, 1977). P.197.

${ }^{855}$ Helms to Scowcroft, March 20, 1974 (CIA/FOIA/Helms), pp.1-2.

856 CIA, Memorandum for Kissinger, "Mullah Mustafa Barzani's Request," March 21, 1974 (NPL/HAK/Box138/Kurdishs Problem-Vol. I/June 1972-Oct 1973), p.1.

${ }^{857}$ United States Congress, House Select Committee on Intelligence, CIA: The Pike Report (Nottingham, England: Spokesman Books, 1977). P.214.
} 
independence. ${ }^{858}$ Though eager to help the Kurds, both Kissinger and the Shah were reluctant to accept an independent Kurdistan and to enhance their support beyond what the Kurds required to keep fighting. The Shah ultimately convinced Barzani to postpone the independence announcement by increasing Iran's annual support from $\$ 30$ million to $\$ 74$ million. With the Shah's increasing support for the Kurds "to avoid creating a situation where they would have to capitulate to Baghdad, ${ }^{, 859}$ Kissinger instructed a modest increase in support for the Kurds to $\$ 8.06$ million annually in order to "keep the Iraqi Government tied down and to limit its capacity for adventures abroad." ${ }^{860}$ Sharing the Shah's limited support policy, he avoided taking a policy for a permanent disintegration of Iraq since "an independent Kurdish area would not be economically viable and [the] U.S. and Iran [had] no interest in closing [the] door to good relations with Iraq under moderate leadership." ${ }^{\prime 861}$ In his message to the Shah and then to Barzani, Kissinger argued that "supporting a Kurdish

${ }^{858}$ The National Security Council and Scowcroft suggested financially supporting the Kurds with a "token amount" of $\$ 500,000$ to $\$ 750,000$ in refugee aid. They were also worried about exposing the operation that could provoke Turkey, the USSR, and Arab states. They contended that Barzani's announcement of a "kind of rump government" that "would be ... a dangerous point and gratuitously provoke Iraq (with strong Soviet and possibly even Turkish support) [into war]" and "would give Iraq no choice but to launch a major attack against Kurdistan if it [was] to protect its national integrity" without any guarantee of the Shah's support. Also, it "would project [the U.S.] beyond the boundaries of a covert and would operation, making secrecy impossible thus jeopardize other policy equities.. ${ }^{858}$ The NSC argued that any support for the Kurds should demonstrate the U.S. sympathy with the Kurdish uprising while dissuading Barzani from asking for so much that the U.S. could not keep the operation covert since the U.S. was not able to "play a prime role in the new ballgame." See White House, Memorandum, Scowcroft to Helms, no date, (NPL/HAK/Box138/Kurdish Problem-Vol. II/doc.7), p.1-4.

${ }^{859}$ Kissinger, Henry. Years of Renewal (New York: Simon \& Schuster, 1999). pp.588-589.

${ }^{860}$ Kissinger to Nixon, April 11, 1974, NSA, KSWWOF, Box 19, GRFL; The support included additional amounts up to $\$ 1$ million to continuing the subsidy for "refugee relief" as well as increasing financial contribution to $\$ 8$ million and providing a 900,000-pound stockpile of non-attributable small arms and ammunition. Kissinger to Nixon, April 11, 1974, NSA, KSWWOF, Box 19, GRFL; and U.S. Department of State, Memorandum of Conversation, "The Secretary's Principals and Regionals Staff Meeting, Monday, April 22, 1974 - 3:00 p.m.," April 23, 1974 (DNSA/KT01111), p.41; Kissinger to Nixon, June 24, 1974, NSA, KSWOF, Box 19, GRFL.

${ }^{861}$ The U.S. Department of State, Memorandum of Conversation, "The Secretary's Principals and Regionals Staff Meeting, Monday, April 22, 1974 - 3:00 p.m.," April 23, 1974 (DNSA/KT01111), p.41. 
government on a long-term basis on the scale which Barzani requests would be beyond our financial resources for this project and could not be carried out [secretly]. We do not feel an open confrontation with [the] government of Iraq would serve [the] U.S. and Iranian interests or the interest of long-term Kurdish survival. ${ }^{\$ 862}$ The Americans considered the Shah's "continued heavy support to the Kurds" as a "better indicator of his real attitude than the reestablishment of diplomatic relations and the cessation of direct military confrontation with Iraq and Iranian forces in the border areas." ${ }^{\text {863 }}$ The logic of Iran's nonstate foreign policy in Iraq had been accepted by the White House.

Mullah Mustafa Barzani accepted the Shah's argument and the Pahlavi Monarch, in return, appreciated his position to "adhere to the line that they consider themselves a part of Iraq and are only defending themselves against an oppressive and illegal regime and are seeking democratic liberties for all the people of Iraq." ${ }^{\prime 864}$ Therefore, Barzani let Baghdad's deadline pass on March $26 .{ }^{865}$ It was the end of the four-year fragile truce. However, his position was shaken when his son Ubeydullah, as well as several high-ranking KDP Politburo members and Iraqi leftists sympathetic to the Kurdish demands, considered his decision as a betrayal of the KDP's socialist origins and ultimately defected to Baghdad. As Ubeydullah stated, his father did not "want self-rule to be implemented even if he were given Kirkuk and all of its oil. His acceptance of the law will take everything from him,

\footnotetext{
${ }^{862}$ Kissinger to Helms, undated, NSA, KSWWOF, Box 19, GRFL; Memorandum, Kissinger to Helms, no date (NPL/HAK/Box138/Kurdish Problem-Vol. II/doc.20), pp.1-2.

${ }^{863}$ [Excised] to [Excised], June 27, 1974 (CIA/FOIA/Helms), pp.1-2.

${ }^{864}$ Helms to Kissinger, May 21, 1974, CIA-Helms.

${ }^{865}$ The U.S. Department of State, Memorandum of Conversation, "The Secretary's Principals and Regionals Staff Meeting, Monday, April 22, 1974 - 3:00 p.m.," April 23, 1974 (DNSA/KT01111), p.41
} 
and he wants to remain absolute ruler." ${ }^{\prime 866}$ Barzani's reaction was to assassinate his rivals via the Parastin, his SAVAK-Mossad-trained security forces. On the other side, Baghdad saw Barzani's bold move as tantamount to a declaration of independence. ${ }^{867}$ Baghdad called up its reserves on 6 April 1974, tightened an economic blockade of Kurdistan, and the Iraqi air force began sporadically bombing the Peshmerga positions. ${ }^{868}$ The scene was set for the last war.

\section{The Last War}

In spring 1974, clashes erupted between the Iraqi Army and the Kurdish Peshmerga. With Turks' sealing their border with Iraq, ${ }^{869}$ Iran's border became the only route for the Kurds. It was a "desperate situation" for them. ${ }^{870}$ The escalated skirmishes soon changed to a full-scale war when Barzani rejected Saddam's ultimatum. ${ }^{871}$ Baghdad finally launched its major ground offensive. At the same time, another round of TehranBaghdad secret talks resumed. With the mediation of the UN secretary-general Kurt Waldheim, Saddam expressed his eagerness to end the tension with Tehran. ${ }^{872}$ The cornerstone of the Iraqi package deal was based on the intertwined Arvand-Kurdish

\footnotetext{
${ }^{866}$ McDowall, David, A Modern History of the Kurds, London, New York 2004, p. 337.

867 Tabriz 7 to the U.S. Department of State, "Kurdish War in Iraq: Iranian Inputs," June 9, 1974 (NARA/AAD/RG59/CFPF/ET/1974), p.1

868 Tabriz 7 to the U.S. Department of State, "Kurdish War in Iraq: Iranian Inputs," June 9, 1974 (NARA/AAD/RG59/CFPF/ET/1974), p.1; and CIA, Memorandum, Colby to Kissinger, "Transmittal of Kurdish Democratic Party Autonomy Plan for the Kurdish Area of Iraq," April 16, 1974 (NPL/HAK/Box138/Kurdish Problem-Vol.II/doc.21), p.3; The Iraqi Army included two divisions of special mountain troops, one regular infantry division, and two armored brigades, supported by four air squadrons. Baghdad 221 to State, April 11, 1974, (FRUS 1969-1976, XXVII, 245).

${ }^{869}$ Helms to Scowcroft, March 18, 1974, (FRUS 1969-1976, XXVII, 242).

${ }^{870}$ Memcon, March 21, 1974, 01078, DNSA.

${ }^{871}$ Baghdad 280 to the U.S. Department of State, May 1, 1974, (FRUS 1969-1976, XXVII, 249).

${ }^{872}$ Weckmann-Munoz to Waldheim, April 30, 1974, S-0303-0003-01, UNARMS.
} 
complex: Baghdad's territorial concession in Arvand Rud in exchange for Tehran's abandonment of support for the Kurds. Although the deal would be a brilliant achievement for the hawkish Shah who already claimed that Iran could "easily destroy ... an artificial state [Iraq] ... and a mere creation of [Winston] Churchill [Iraq]," ${ }^{, 73}$ it would be undoubtedly "at the expense of the Kurds of Iraq." ${ }^{874}$ However, the Shah thought that the Iraqi leaders were still not ready for the 'Grand Bargain'. Although the resumption of the war could break his delicate balance policy in Iraqi Kurdistan, the Shah took a risk and expressed his commitment to Barzani. ${ }^{875}$ In the meantime, the Shah tried to reconcile a long-standing tension within the Kurds. Thus, he instructed Colonel Pejman to convince Jalal Talabani and Ibrahim Ahmad to rejoin Barzani against the Baath offensive. Pejman accomplished the mission and Tehran allocated generous financial aid to the anti-Barzani group and assigned Captain Taha Nouri to establish ties with them and SAVAK in Tehran. $^{876}$

Despite Iran's support, the Peshmerga were in trouble. The Shah was worried about coming waves of Kurdish refugees. ${ }^{877}$ With the Iraqi air force's relentless bombing campaign, called a "genocidal war" ${ }^{\text {" }} 78$ by Helms, civilian Kurds crossed Iran's border. By late June, several camps had been built for 25,000 refugees along the border. ${ }^{879}$ The U.S.

\footnotetext{
873 Ibid.

${ }^{874}$ Ibid.

${ }^{875}$ Tehran 3088 to U.S. Department of State, April 20, 1974, NPM, NSCF, CFME, Box 603.

${ }^{876}$ Other anti-Barzani's main figures were Omar Dababeh, Isa Zabihi, and Yadolah Fili. See Qaneifard, Erfan, Tondbad-e Havades: Goftogooi ba Isa Pejman [Hurricane of Events: A Dialogue with Isa Pejman] (Elm Publication, Tehran, 2011) p.173.

${ }^{877}$ Helms to Scowcroft, July 8, 1974, CIA-Helms.

${ }^{878}$ Helms to Scowcroft, March 20, 1974 (CIA/FOIA/Helms), pp.1-2.
} 
could not significantly increase its support since they had "reached the upper limits of concealable assistance. ${ }^{, 880}$ Nevertheless, the Shah insisted he needed additional assistance. He pointed to Baghdad-Moscow connections and warned of "the grave consequences--for Iran and the entire Persian Gulf--should Kurdish resistance collapse. ${ }^{981}$ The situation in the north of Iraq was contrary to Iran's interests.

By late August, the Iraqi Army had crushed the Peshmerga, conquered their key strongholds, and cut off strategic supply routes from Iran. ${ }^{882}$ To preventa a Baghdad victory, Iran took a more hawkish position. The Shah aligned three armored divisions, two infantry divisions, and two infantry brigades along the border with Iraq. Minor skirmishes soon erupted. ${ }^{883}$ On 23 August 1974, a five-hour battle between two armies occurred. ${ }^{884}$ Nevertheless, the Iraqi Army was cautious not to incite the Iranians to attack. ${ }^{885}$ With the U.S. refusal of Barzani's request for anti-aircraft missiles, ${ }^{886}$ the Shah instructed SAVAK

879 Tabriz 12 to the U.S. Department of State, "Kurdish Refugees in Iran," June 31, 1974 (NARA/AAD/RG59/CFPF/ET/1974), p.1.

${ }^{880}$ Helms to Kissinger via Scowcroft, July 8, 1974 (CIA/FOIA/Helms), pp.1-4.

${ }^{881}$ Kissinger, Henry. Years of Renewal (New York: Simon \& Schuster, 1999). p.590.

882 Tabriz 20 to the U.S. Department of State, "The Kurdish War in Iraq," September 4, 1974 (NARA/AAD/RG59/CFPF/ET/1974), pp.1-10. See also O'Ballance (1996), p.96.

${ }^{883}$ Tehran 6788 to the U.S. Department of State, "Iran-Iraq Border Incidents Mar Talks in Istanbul," August 14, 1974, (NARA/AAD/RG59/CFPF/ET/1974), pp.1-2.

${ }^{884}$ Tehran 7134 to the U.S. Department of State, "Iran Details Additional Border Violations by Iraq," August 25, 1974 (NARA/ AAD/RG59/CFPF/ET/1974), p.1.

${ }^{885}$ Baghdad 564 to the U.S. Department of State, August 29, 1974, FRUS 1969-1976, XXVII, 260.

${ }^{886}$ Barzani's request was "to meet the threat of highflying bomber aircraft" was ignored since it was "just too big (would require prime movers to transport), too complicated and too expensive to pursue." Scowcroft to Helms, August 22, 1974 (CIA/FOIA/Helms), p.1. Instead, the Americans arranged the delivery of AK-47s as well as making \$1 million available for SAVAK and CIA help to purchase anti-tank weapons for the Kurds. Scowcroft to Helms, August 22, 1974 (CIA/FOIA/Helms), p.1. 
to equip the Peshmerga with anti-air craft weapons. These anti-Iraqi MIGs weapons were carried by mules via dangerous routes in the Zagros Mountains. Dressed in Kurdish clothes, the Iranian troops, gendarmes, and military advisors fought side by side with the Kurds against the Iraqi army. By late summer 1974, Iran had effectively deployed artillery and air defense units inside the rebel-held territory of Iraqi Kurdistan ${ }^{887} \mathrm{~A}$ battalion of longrange $175-\mathrm{mm}$ artillery bombed strategic Iraqi Army positions from across the Iranian border. ${ }^{888}$ These units were all controlled by Iranian officers. Iran was still backing the Iraqi Kurds.

Nevertheless, the Kurds' situation appeared dire in the face of the Iraqi ground offensive. In addition to heavy casualties, Barzani's headquarter in Haji Omran had been under direct fire from Iraqi long-range artillery. ${ }^{889}$ By October 1974, Baghdad had conquered the majority of Kurdish territory since the outbreak of the Kurdish uprising in September 1961. Following Barzani's request for food, arms, and ammunition in his October 1974 meeting with the Shah, ${ }^{890}$ The Iranian Army crossed the border and empowered the Peshmerga positions with artillery units. ${ }^{891}$ To halt Iraqi heavy air bombardment, SAVAK also decided to provide the Peshmerga a strategic air route.

\footnotetext{
${ }^{887}$ Paper Prepared in the Office of Current Intelligence, Central Intelligence Agency, DCI/NIO 1039-75, Washington, May 1, 1975, FRUS, 1969-1976, Iran-Iraq, 1973-1976 Volume XXVII. Central Intelligence Agency, NIC Files, Job 79R01142A, Box 5, Folder 5. Secret; [handling restriction not declassified]. A note on the first page reads: "This paper was produced under the auspices of the National Intelligence Officer for the Middle East. It was drafted by CIA (OCI) and coordinated with State/INR and DIA."

${ }^{888}$ Intelligence Note prepared in the Bureau of Intelligence and Research, November 18, 1974, (FRUS 19691974, XXVII, 267, Tab B).

${ }^{889}$ Barzani to Kissinger, October 22, 1974, NSA, KSWWWOF, Box 19, GRFL.

${ }^{890}$ Parsons (Tehran) to Wright (London), October 24, 1974, Foreign Common Office 8/2309.

${ }^{891}$ CIA Memorandum, "Defense and Humanitarian Support for General Barzani”, October 31, 1974, NSA, KSWWOF, Box 19, GRFL.
} 
Marshal Khatam, the chief commander of Iranian air force, was instructed to accomplish the mission. Three Iranian Phantoms, with Iranian Kurd pilots, were supposed to bombard an Iraqi stronghold in order to open an air supply line for the Kurds. The Shah, however, suddenly changed his mind and gave an order to stop the plan. ${ }^{892}$ The Shah still kept sticking to the logic of a limited war.

In the meantime, sdoubled its pressure on the White House to increase military aid to the Kurds. ${ }^{893}$ SAVAK had delivered Israel's Russian-made anti-tank and anti-aircraft missiles captured during the Yom Kippur War of 1973 to the Peshmerga ${ }^{894}$ In late October 1974, Tel-Aviv increased arms delivery through Iran's territory. ${ }^{895}$ Heavily backed up by Iranian-Israeli logistics and weapons, the Peshmerga finally "destroyed several Iraqi tanks" and prevented the Iraqi advance. ${ }^{896}$ At the same time, three Iraqi jets, including an Iraqi TU-16 Badger, were shot down by Iranian artillery units with British-made Rapiers on December 14 and $15 .{ }^{897}$ Nevertheless, the Shah still refrained launching a full-blown raid on Iraq.

${ }^{892}$ Qaneifard, Erfan, Tondbad-e Havades: Goftogooi ba Isa Pejman [Hurricane of Events: A Dialogue with Isa Pejman] (Elm Publication, Tehran, 2011) p.196.

893 "Cable from Jerusalem Translated by Shalev and Dictated to General Scowcroft", August 24, 1975, NSA, KSWWOF, Box 19, GRFL; Note prepared by the Government of Israel, August 24, 1974, NSA, KSWWOF, Box 19, GRFL.

${ }^{894}$ Scowcroft to Helms, August 24, 1974 (CIA/FOIA/Helms), p.1; Helms to Scowcroft, August 25, 1974 (CIA/FOIA/Helms), p.1; Memcon, September 17, 1974, NSA, KSWWOF, Box 19, GRFL; Kissinger, Henry. Years of Renewal (New York: Simon \& Schuster, 1999). p.591.

895 211- White House, Memorandum of Conversation, Kissinger and Dinitz, October 19, 1974 (DNSA/KT01377), p.9.

${ }^{896}$ Including Sagger (AT-3) and Strela missiles (SA-7). White House, Memorandum of Conversation, Kissinger and Rabin, November 7, 1974 (DNSA/KT01405), pp.10- 11.

${ }^{897}$ Alam, Assadollah. The Shah and I: The Confidential Diary of Iran's Royal Court, 1968---1977 (New York: I. B. Tauris, 1991), p.403. 


\section{Grand Bargain Preparation}

As the tides of the war escalated at the expense of the Kurds, the Pahlavi monarch's willingness to reach a deal with Baghdad increased. Besides, Richard Nixon's resignation in August 1974 and the Shah's lack of confidence in the U.S. commitment to the Kurdish covert cooperation convinced Iranians to seal a deal with Baghdad. In addition to an Iraqi new diplomatic policy-lessening tension with Western Europe and a major thaw in relation with the U.S.-Egyptian President Anwar Sadat and King Hussein of Jordan asked the Shah to resume secret talks with Baghdad. Sadat told the Shah that Baghdad honestly intended to withdraw from Moscow's orbit. ${ }^{898}$ Nevertheless, the Shah was still unconvinced that Baghdad was serious about a settlement. ${ }^{899}$ Calling the Baath Party a "bunch of thugs and murderers implacably hostile to him" in Baghdad," 900 he considered Iraqi diplomatic efforts as a "tactical move to divert attention from Iraq's serious internal problems." 901

On the other side, the Baath leaders were still doubtful about the Iranians' interest in reopening diplomatic talks. They thought that the Shah never left the Kurds and strived to collapse Iraq. As Iraqi Foreign Minister Shathel Taqa told Lowrie, "if [the] Shah or anyone else has [any] idea of new Bangladesh in Iraq he is very mistaken.” According to Taqa, "Barzani is not representative of the Kurds, he is in his last days, and those who are

\footnotetext{
${ }^{898}$ Similarly, the State Department considered Baghdad's détente efforts as its larger move to distance the country from the Soviet. Baghdad 1109 to the U.S Department of State, August 2, 1974, NPM, NSCF, CFME, Box 603; and U.S. Department of State 170249 to Tehran, August 5, 1974, (FRUS 1969-1976, XXVII, 256).

${ }^{899}$ Amman 7404 to U.S. Department of State, December 11, 1974, NSA, PCFMESA, Box 22, GRFL.

900 Tehran 10954 to the U.S. Department of State, December 30, 1974, NSA, PCFMESA, Box 14, GRFL.

${ }^{901}$ Tehran 6206 to U.S. Department of State, July 28, 1974, NPM, NSCF, CFME, Box 603.
} 
betting on him are betting on a losing horse. ${ }^{902}$ Furthermore, Iran's non-state foreign policy in Iraqi Kurdistan had been a major component of Iran's strategy towards Iraq for a long time, the Iraqi leaders argued. Despite their claims, Iraqis were aware that the fate of the war was not in their hands. They were also under Moscow's heavy pressure from Moscow. "It is better to negotiate with Iran and it would not be wise to involve yourself in two fronts [Iran and Kurdistan]," the Soviet leaders told Saddam. ${ }^{903}$ Even Sheikh Mohammad bin Mubarak al-Khalifa, Bahraini Foreign Minister, hinted to Saddam that the best way to cooperate with the Persian Gulf countries was to settle border disputes with Iran and Kuwait. The Iraqis felt lonely in the region. ${ }^{904}$

Between 12 August and 1 September 1974, a low-level preliminary diplomatic negotiation led by Iranian Ambassador Abdul-Rahman Sadrieh and Iraqi Ambassador Talib Shabib was held in Istanbul. ${ }^{905}$ Although Tehran remained belligerent, both two parties "swallowed some of their pride." 906 The Istanbul negotiation ended with the parties issuing a joint communiqué, facilitating a foreign minister-level meeting on the sideline of the UN General Assembly. In mid-October 1974, Foreign Minister Abbas-Ali Khalatbari met his Iraqi counterpart Shathel Taqa in New York. ${ }^{907}$ However, negotiations were inconclusive. Talks were "tough, and certainly not smooth" since "neither side [could]

\footnotetext{
${ }^{902}$ Baghdad 564 to the U.S. State Department, August 29, 1974 (FRUS 1969-1976, XXVII, 710).

${ }^{903}$ Iran's Ministry of Foreign Affairs, no Number, no Date.

${ }^{904}$ Iran's Ministry of Foreign Affairs, no Number, no Date.

${ }^{905}$ Tehran 6788 to the U.S. Department of State, August 14, 1974; and Baghdad 583 to U.S. Department of State, September 7, 1974, RG59, CFPF 1973-76, AAD.

906 Baghdad 583 to the U.S. Department of State, "Iraqi-Iranian Conflict," September 7, 1974 (NARA/AAD/RG59/CFPF/ET/1974), pp.1-2.

907 Tehran 8821 to the U.S. Department of State, October 21, 1974, RG59, CFPF 1973-76, AAD.
} 
afford to make concessions", Khalatbari claimed. ${ }^{908}$ The Iraqis did not show any flexibility over Arvand Rud that was "the basic ingredient of any Iranian-Iraqi settlement." ${ }^{909}$ Despite his tough view, the Shah knew that the Kurds' positions looked vulnerable. He expressed his frustration with the Kurds to Kissinger, stating that "even if the Iraqis succeeded in destroying the Kurds, they will still be nailed down on the Iranian border where they would in any event prefer to be as against facing the Israelis on the Syrian front. ${ }^{910} \mathrm{He}$ was wellaware that Iran's growing involvement in the Kurdish War would threaten the country with a full-scale war with Baghdad.

The war was doubtlessly against the Iraqi Kurds. Only 40,000 Kurds with defensive weapons were fighting with 200,000 Iraqi troops. Besides, the mild winter of 1974-75 allowed Iraqi air forces to keep bombing the Peshmerga's strongholds "for several weeks." 911 It was only the Iranian artillery units along the border that supported the Peshmerga by hitting Iraqi positions with 300 rounds per day. ${ }^{912}$ The Iranian artillery support was "very effective" and that helped the Peshmerga who were "no longer withdrawing but were fighting tenaciously," the Shah contended. ${ }^{913}$ Indeed, the Iranian

\footnotetext{
${ }^{908}$ Tehran 8821 to the U.S. Department of State, "Iran and Iraq Resume Talks; Khalatbary at UNGA," October 21, 1974 (NARA/AAD/RG59/CFPF/ET/1974), p.1.

${ }^{909}$ Tehran 10592 to the U.S. Department of State, December 16, 1974, NSA, PCFMESA, Box 14, GRFL.

${ }^{910}$ Kisinger to Scowcroft, Isfahan, November 3, 1974, 0115Z, FRUS, 1969-1976, Iran-Iraq, 1973-1976, Vol XXVII; Scowcroft to Ford, November 3, 1974, NSA, Trip Briefing Books and Cables for HAK, Box 3, GRFL.

911 Tabriz 32 to the U.S. Department of State, "Iraqi Kurdish War: Failure of Iraqi Summer Offensive," December 2, 1974 (NARA/AAD/RG59/CFPF/ET/1974), pp.1-3.

${ }^{912}$ White House, Memorandum, "Defense and Humanitarian Support for General Barzani," October 31, 1974 (GFL/KSF/Box20//Kurds-10/15/73-12/5/74), p.1

${ }^{913}$ Helms to Kissinger via Scowcroft, November 13, 1974 (CIA/FOIA/Helms), pp.1-7.
} 
artillery fire forced Baghdad to withdraw the army from the valleys and secured the Kurds' strongholds at Haji Omran. By December, Iranians had built a new supply route to Iraqi Kurdistan. However, the Kurds were unable to prevent losses. Recently reorganized by Russian advisors, the Iraqi Army had crushed the Peshmerga strongholds in the mountains. As the Shah told Callahan, a mere Iran's support had not been able to change tides of the war mainly due to Iraqi new military tactics. ${ }^{914}$ "Unfortunately, the Iraqis had decisively defeated the Kurds. We sent them [the Kurds] several long-range cannons and anti-tank missiles. I think they will shatter the Iraqis. Nevertheless, it is the Russians, not the Iraqis, who defeated the Kurds," confided the Shah and he shared his concern with Alam over the Soviets' effective role in the war. ${ }^{915}$ Within this situation, the Peshmerga would not survive without Iran's direct intervention-- a bitter reality for the Shah who saw a war with Iraq as inevitable.

As the war was reaching a boiling point, the Pahlavi monarch began working on both offensive and defensive plans. He instructed the Iranian Army to prepare a plan to deploy forces inside Iraq and escalate tensions with Baghdad. Simultaneously, Alam, in full coordination with the Iranian Army and SAVAK, was instructed to prepare a plan to secure artillery pieces under any withdrawal from Iraqi Kurdistan. ${ }^{916}$ At the same time, the Shah was getting ready to make a grand deal with Baath leaders. On 4 December 1974, the Pahlavi monarch told Helms, "I wonder why the Iraqis do not simply settle with us" on Arvand Rud? "After all, the issues are minor as far as they are concerned," he added. Later,

\footnotetext{
${ }^{914}$ Helms to Kissinger via Scowcroft, November 13, 1974 (CIA/FOIA/Helms), pp.1-7.

915 Alam, Assadollah. Yad'dashtha-ye 'Alam: Virayesh va Muqaddamah az Alinaqi Alikhani [The Alam Diaries: Edited by Alinaqi Alikhani], Vol. III: 1974-1975 (Bethesda, MD: Iranbook, 1995), p. 211.

${ }^{916}$ Alam, Yad'dashtha-ye 'Alam: Virayesh va Muqaddamah az Alinaqi Alikhani [The Alam Diaries: Edited by Alinaqi Alikhani], Vol. IV: 1974-1975 (Bethesda, MD: Iranbook, 1995), p. 267.
} 
Helms found out through Alam that King Hussein was working as a secret intermediary between Tehran and Baghdad. ${ }^{917}$ He immediately informed Kissinger that "anything short of [an] Iraqi agreement to Iranian positions on the Shatt al-Arab and other border questions will get nowhere with Iran. The Shah holds firmly to his view that a different, 'decent' government is necessary for Baghdad. This is one of the reasons he militarily supports the Kurds. But an Iraqi agreement to settle with Iran might be tempting right now since the Kurdish War is becoming increasingly expensive and increasingly hazardous from the Iranian point of view. 918

Within this context, the Shah faced a decision either to escalate the war or negotiate on the Kurdish-Arvand issue. He knew the Iraqi Army's better position in the war and Baghdad's determination to finish off the Kurdish rebels in spring. Thus, the only available option for the Shah would be to intensify Iran's involvement in the war that could, in return, jeopardize his recently formed alignment with moderate Arab leaders, particularly Sadat. ${ }^{919}$ On top of that, the Shah was worried about Iran's weakened bargaining position. With the growing possibility of Kurdish failure, he did not want to lose the Iraqis' potential concession in Arvand Rud.

\footnotetext{
${ }^{917}$ Tehran 10429 to U.S. Department of State, “King Hussein’s Intermediary Role,” December 10, 1974 (NARA/AAD/RG59/CFPF/ET/1974), PP.1-2.

918 Tehran 10429 to U.S. Department of State, “King Hussein's Intermediary Role,” December 10, 1974 (NARA/AAD/RG59/CFPF/ET/1974), pp.1-2.

${ }^{919}$ In an interview with al-Bayraq, President Sadat contended that "the Shah of Iran is a wise, prudent leader with a power in the analysis of the regional and international politics." He also added that Cairo would try to meddle between Iran and Iraq. Beirut 3464 to Ministry of Foreign Affairs, 9 January 1975.
} 
With al-Bakr and Saddam's visit to Jordan on January 15, Baghdad showed its flexibility with regard to the deal. ${ }^{920}$ Two days later, another round of diplomatic talk began in Istanbul. In the meeting, Foreign Minister Khalatbari put emphasis on Iran's right in Arvand Rud while Iraqi Foreign Minister Saadun Hammadi asked Tehran to terminate its support for the Kurds. In fact, "Iran's approach was that once its demands on [Arvand Rud] were satisfied, [the] parties could then turn to resolving [the] Kurdish problem. Iraq, conversely, wanted to settle [the] Kurdish problem first and then deal with [the] Shatt-alArab. Furthermore, while Iraq would be willing to grant various unspecified facilities to Iran in [the] disputed region, it was unwilling to consider agreeing to Iranian sovereignty over the waters involved." ${ }^{.921}$ Despite significant disagreements, the Istanbul talks were successful as they set up to a meeting between the Shah and Saddam on the sidelines of the OPEC annual meeting in Algiers in March. ${ }^{922}$ Saddam knew that Iraq would not be able to unshackle itself from the Kurdish crisis without neutralizing Iran's support for the Kurds. The final decision was to pay the price for Arvand Rud and 'drink the cup of poison'.

The U.S. and Israel were both suspicious of the Shah's plan to deal with Baghdad and use the Kurds as the bargaining chip. ${ }^{923}$ However, neither Israel nor the U.S. was in a

\footnotetext{
${ }^{920}$ Baghdad 47 to the U.S. Department of State, "King Hussein's Invitation to Iraqi Leaders," January 17, 1975 (NARA/AAD/RG59/CFPF/ET/1975), p.1.

921 Ankara 904 to the U.S. Department of State, "Iran-Iraq Talks," January 31, 1975 (NARA/AAD/RG59/CFPF/ET/1975), p.1.

922 Baghdad 59 to the U.S. Department of State, "Iranian-Iraq Negotiations," January 22, 1975 (NARA/AAD/RG59/CFPF/ET/1975), p.1.

${ }^{923}$ On January 16, 1975, Yigal Allon, Israeli Deputy Prime Minister and foreign minister, repeated Tel Aviv's request of the need to speed up support for the Kurdish Peshmerga to hold off the Iraqi offensive. Informing Kissinger that the Iraqis had managed to hold their positions in the mountains for the first time ever, Allon pointed him out that the Shah appeared to be playing "his own game" and warned Kissinger that "to abandon the Kurds is a crime." See Memcon, January 16, 1975, 01477, NSA; and White House, Memorandum of Conversation, January 16, 1975 (DNSA/KT01477), pp.10-11.
} 
position to support the Kurds without Iran's consent. They knew that with the Shah's termination of support for Barzani, the U.S. and Israel operations would immediately come to an end. ${ }^{924}$ In the meantime, the Shah gave the Kurds the last chance. In early February, the Peshmerga launched a counter-offensive to dislodge the Iraqi army; however, the campaign soon failed. ${ }^{925}$ The Kurds were not as potent in military offensives due to their defensive fighting tactics. Their failure to push back the Iraqis convinced the Shah to settle border disputes with Baghdad.

In these circumstances, Kissinger met with the Shah in Zurich, Switzerland, on 19 February 1975. Disappointed by the Kurds' inability to resist the Baath military machine, the Shah informed Kissinger of his plan to meet with Saddam in Algeria to reach a deal and terminate backing the Kurds in return for a concession on Arvand Rud. He thought that the Kurds had "no guts left"; therefore, the Kurds would join the national unity government with Barzani's failure and endanger Iran's national security with the creation of "an autonomous Kurdish state which would be under the dominance of a communist Iraqi central government." The Shah was also worried about a possible internationalization of the conflict and the intervention of the UN Security Council. ${ }^{926}$ Conversely, Kissinger asked the Shah not to abondon the Kurds, arguing that "any assurances by Saddam regarding the governance of the Kurdish area ... would be worthless." He added that any agreement with untrustworthy Baath leaders was a "bad idea--particularly the idea that he

924 Baghdad 52 to U.S. Department of State, "Iraqi-Iranian Conflict," January 18, 1975 (NARA/AAD/RG59/CFPF/ET/1975), pp.1-2.

925 Tabriz 8 to U.S. Department of State, "Iraqi Kurdish War: Temporarily Quiet," February 2, 1975 (NARA/AAD/RG59/CFPF/ET/1975), pp.1-5.

\footnotetext{
${ }^{926}$ White House, Memorandum, Scowcroft to President Ford, February 19, 1975 (GFL, NSC, Middle East and South Asian Affairs Staff Files, December 2008 Opening, Box 9), pp.1-2
} 
believed the [Iraqis'] assurances that no Communist would be put in [charge of the autonomous Kurdistan].” Aware of Iran's new oil export terminal on Kharg Island and Tehran's lack of dependency on Arvand Rud for oil exportation, Kissinger highlighted a strategic gain from CIA-SAVAK cooperation in Iraqi Kurdistan against Iraqi-offered border concession. Kissinger reminded the Shah of his "own repeated warnings that the collapse of the Kurds would destabilize the entire area" and told him that any agreement with Baghdad would empower a pro-Moscow regime in the region and aid Iraqi communists to consolidate their power. He added that any agreement with Baghdad would prompt the Russian leaders' "adventurism" since they would "view Iran's retreat as symptomatic of the growing weakness of the West." Nonetheless, the Shah knew that the Kurds would not survive without increased support and if Iran stepped up its assistance, it would instigate a full-blown war with Bagdad. At the end of the conversation, however, the Shah half-heartedly assured him that Iran would not terminate its support for the Kurds soon. ${ }^{927}$

Despite the Shah's change of heart, Kissinger was still hesitant to increase the American-Kurdish connections without the Shah's consent. ${ }^{928}$ Earlier before, on 22 January 1975, he had turned down Barzani’s request for more Sagger anti-tank missiles. ${ }^{929}$

\footnotetext{
${ }^{927}$ Kissinger to Barzani, February 20, 1975, NSA, KSWWOF, Box 19, GRFL.

${ }^{928}$ On February $20^{\text {th }}$, Kissinger responded to Barzani's January letter. He wrote: "I want you to know of our admiration for you and your people and for the valiant effort you are making. The difficulties you have faced are formidable. I very much appreciated reading your assessment of the military and political situation. You can be assured that your messages receive the most serious attention at the highest levels of the United States Government because of the importance we attach to them." He also suggested that the Kurdish leader send an emissary in secret instead of making personal visit to the U.S., and added that "I am convinced that secrecy has been of paramount importance in maintaining our ability to do what we have done; it is only for this reason - plus our concern for your personal safety — that I hesitate to suggest a personal meeting here with you." See White House, Kissinger to Barzani, February 20, 1975 (GFL/KSF/Box20/Kurds-2/20/75-2/12/76), p.1.

${ }^{929}$ Letter, Barzani to Kissinger, January 22, 1975 (GFL/KSF/Box20/Kurds-2/20/75-2/12/76), pp.1-13.
} 
Concerned with losing the Kurdish card in a geopolitical duel with Moscow, Kissinger had also warned Tel Aviv that the Shah "may begin a negotiation with the Iraqis if they meet at OPEC, in exchange for a veto over whom they put in if Barzani gets driven out." ${ }^{, 930}$ In the same spirit, Barzani was not aware of the Shah's plan to leave the Kurds alone. Facing an Iraqi onslaught, a constant barrage of air and artillery fire, he stated that "it was becoming impossible ... to carry on fighting under existing circumstances" and pleaded with Tehran for more sophisticated weaponry and repeated his request to declare independence in late February 1975. Nevertheless, Barzani's request to meet the Shah was declined. "I went to see general Barzani in 1975 to warn him about this. He would not speak at the house, in the palace that the Iranians had given him to stay in. Although it was chilly, he took me out for a stroll in the garden, and I told him this. He said, 'Now I know why those scoundrels would not let me see the Shah.' He said that the second day, the Shah came from his ski holiday, returned to Tehran, stayed less than 24 hours, and flew out to Algiers and signed the agreement," Ahmad Chalabi recalled those days. ${ }^{931}$ On March 2, 1975, Ashraf Marwan, Sadat's advisor and Nasser's son-in-law, met with the Shah right after his return from Baghdad with a message from Saddam. He informed the Shah that "Saddam Hussein was ready to pull Iraq out of the Soviet orbit if Iran would remove the military pressure which was forcing Iraq into the arms of the Soviets. Marwan expressed the view that it was almost certain that Saddam would pull away from the Soviets as promised. ${ }^{932}$ The stage was set for the grand bargain.

\footnotetext{
${ }^{930}$ Kissinger, Henry. Years of Renewal (New York: Simon \& Schuster, 1999). p.593.

${ }^{931}$ In Interview with Dr. Ahmad Chalabi: How is it possible that Saddam Hussein is still in power in Baghdad? See http://www.pbs.org/wgbh/pages/frontline/shows/saddam/interviews/chalabi.html.

932 Tehran 2237 to the U.S. Department of State, "Iranian/Iraqi Agreement," March 10, 1975 (NARA/AAD/RG59/CFPF/ET/1975), p.1.
} 


\section{The 1975 Algiers Agreement}

On 3 March 1975, the Shah traveled to Algiers for the OPEC meeting. The meeting was hosted by President Houari Boumédienne who had close relations with the Shah. In a face-to-face meeting with Saddam after two days of intensive negotiations, the Shah agreed to freeze support for the Kurds while Baghdad recognized Iran's sovereignty over the eastern half of Arvand Rud. The signed communiqué sealed the Kurdish fate and set the Thalweg Line in Arvand Rud. ${ }^{933}$ Interestingly, the Shah's decision was made on the spot. Nobody was aware of his decision. Even Alam and senior SAVAK officials were kept in the dark. "We were totally surprised at how fast Iran and Iraq reached an agreement. We did not expect it," Iran's embassy in Beirut wrote to the Ministry of Foreign Affairs. ${ }^{935}$ The Shah permitted nobody to assess some provisions of the Algiers Agreement, including giving a little known oil-rich Iranian territory to Baghdad. ${ }^{936}$ Even after signing the Agreement, it was never given to the Iranian Parliament for ratification. Ambassador

\footnotetext{
${ }^{933}$ The terms of the Algiers Pact included: 1) Demarcation of the river frontier according to the Thalweg Line or median line; 2) Demarcation of land frontiers on the basis of the 1913 Constantinople Protocol and minutes of 1914 Frontier Demarcation Commission; 3) Strict and effective control along borders to end all subversive infiltration from either side, which meant the termination of Iran's support for the Kurdish Peshmerga and the termination of stirring up anti-government sentiment among minority groups, particularly the Arab population of Khuzestan as well as of allowing Iranian dissidents to promote their activities from Iraqi territory; and 4) The above three arrangements are indivisible elements of a comprehensive settlement. In addition, both parties agreed to remain in constant contact with Algerian leader Houari Boumédiène while the accord was implemented and that the foreign ministers would meet to establish a commission to implement the agreement. See Defense Intelligence Agency Notice, March 7, 1975, FRUS 1969-1976, XXVII, 273; and Baghdad 248 to U.S. Department of State, "Iraqi-Iranian Agreement," March 8, 1975. (NARA/AAD/RG59/CFPF/ET/1975), p.1.

${ }^{934}$ Col. Isa Pejman in an interview with Habib Lajevardi, Paris, March 4, 1983, Tape 1, Harvard University Iranian Oral History.

${ }^{935}$ Beirut 1004 to Iran's Ministry of Foreign Affairs, 14 June 1975.

${ }^{936}$ Parsi, Trita, Treacherous Alliance: The Secret Dealings of Israel, Iran, and the United States (Yale University Press, 2007) p.50.
} 
Helms was also "uninformed" and "puzzled" of the Algiers Agreement. ${ }^{937}$ Only Jamshid Amouzgar and Nasrollah Entezam, the chief of Iran's Oil Company, were allowed to accompany the Shah. More significantly, the Iranian troops fighting in Iraqi Kurdistan were not aware of the Shah's decision. Right after the Agreement, "two and a half battalions of Iranian artillery and antiaircraft guns and their troops, stationed in Iraq, were abruptly ordered back across the frontier." ${ }^{938}$ According to Alam, "one hundred pieces of field artillery, as well as anti-tank and anti-aircraft missiles, all managed by Iranian officers [in Iraqi Kurdistan], had to be destroyed because we do not have time to bring them back." ${ }^{939}$ After his return on March 7, the Shah told Alam that negotiations with Baghdad and OPEC had been so difficult that he slept only a few hours. ${ }^{940}$ Totally exhausted during the trip, the Shah had lost weight upon his return. Nevertheless, he was glad of his brilliant achievement in resolving the long-term dispute in Arvand Rud. In the Shah's view, the 1933 Agreement over Arvand Rud shamed for his reign. "I had been to some degree regretting my father's two decisions, the [1933] Concession Agreement and Arvand Rud issue. Both could be criticized one day, though there might not be any possibility [not to sign those two agreements]. Thank God, I completely solved Oil issue and Arvand Rud. Although We have not observed [the Saad-Abad Agreement of 1933] for 12 years, I did

\footnotetext{
${ }^{937}$ David Korn, “The Last Years of Mullah Mustafa Barzani,” 1/2 (1994), Middle East Quarterly, pp. 12-27

${ }^{938}$ Kimche, David, The Last Option, (New York: Maxwell Macmillan International, 1991) p.195.

939 Alam, Assadollah. Yad'dashtha-ye 'Alam: Virayesh va Muqaddamah az Alinaqi Alikhani [The Alam Diaries: Edited by Alinaqi Alikhani], Vol. IV: 1974-1975 (Bethesda, MD: Iranbook, 1995), p. 347.

${ }^{940}$ Alam, Assadollah. Yad'dashtha-ye 'Alam: Virayesh va Muqaddamah az Alinaqi Alikhani [The Alam Diaries: Edited by Alinaqi Alikhani], Vol. IV: 1974-1975 (Bethesda, MD: Iranbook, 1995), p.340.
} 
not want to remain a party to the agreement per se... Now at long last, I've been able to tear up the Arvand Rud treaty," the Shah told Alam after the Algiers Agreement. ${ }^{941}$

Hailed internationally and domestically as Iran's foremost triumph, the Algiers Agreement cut off Iran's non-state foreign policy in Iraqi Kurdistan. The Arab regimes did not hide their jubilation. ${ }^{942}$ There was no room for Barzani in the Shah's strategic assessment. Two days after the official announcement of the Algiers Agreement, the Shah instructed Nassiri to tell Barzani that the Iraq-Iran border would be closed in two weeks and Iran would terminate its support for the Kurds. ${ }^{943}$ Barzani was informed by General Modarresi who was in Iraq at the time and was told he would have two options: either to settle with Baghdad or to take refuge in Iran where they would be given safe haven if they agreed to surrender their weapons to the Iranian Army. ${ }^{944}$ Amidst the Peshmerga's desperate withdrawal to Iran before sealing the border, ${ }^{945}$ Barzani traveled to Tehran to talk to the Shah. According to Alam, the Pahlavi monarch was "embarrassed to meet him face to face." ${ }^{946}$ On March 11, the Shah only reluctantly met Barzani and Mahmoud Othman. ${ }^{947}$ He told them of his concern about a war with Iraq and pointed out that he had no choice

\footnotetext{
${ }^{941}$ Alam, Assadollah. Yad'dashtha-ye 'Alam: Virayesh va Muqaddamah az Alinaqi Alikhani [The Alam Diaries: Edited by Alinaqi Alikhani], Vol. IV: 1974-1975 (Bethesda, MD: Iranbook, 1995), p. 341.

${ }^{942}$ Syrian Foreign Minister Abd al-Halim Khaddam told Kissinger that "solving that problem has left a lot of satisfaction with us." Memcon, March 9, 1975, 01522, DNSA.

${ }^{943}$ Parsi, Trita, Treacherous Alliance: The Secret Dealings of Israel, Iran, and the United States (Yale University Press, 2007) p.29.

${ }^{944}$ Helms to Scowcroft, March 8, 1975, (FRUS 1969-1976, XXVII, 275).

${ }^{945}$ CIA weekly summary 0013/75, March 28, 1975, CREST.

${ }^{946}$ Parsi, Trita, Treacherous Alliance: The Secret Dealings of Israel, Iran, and the United States (Yale University Press, 2007) p. 57.

947 Alam, Assadollah. Yad'dashtha-ye 'Alam: Virayesh va Muqaddamah az Alinaqi Alikhani [The Alam Diaries: Edited by Alinaqi Alikhani], Vol. IV: 1974-1975 (Bethesda, MD: Iranbook, 1995), p. 346.
} 
but to sign the Agreement with Saddam. He added that it was "temporary" and was sure that Saddam would not observe the terms of the agreement. Furthermore, the Shah offered Barzani refuge in Iran with full financial support and promised him to keep the border open for the Peshmerga. When Othman tried to talk to the Shah on the issue, the Shah interrupted him and said "I am telling you my decision. There is nothing to discuss." 948 Barzani "acted stoically" to the Shah's orders. ${ }^{949}$

Infuriated by the Shah's decision, ${ }^{950}$ Barzani pleaded with Kissinger to help the Kurds. In his message, Barzani pointed out that "Our hearts bleed to see that an immediate by-product of this agreement is the destruction of our defenseless people in an unprecedented manner as Iran closed its border and stopped help to us completely and while the Iraqis began the biggest offensive they have ever launched and which is now being continued. Our movement and people are being destroyed in an unbelievable way with silence from everyone." He begged Kissinger to back the Kurds "to help [the Kurds] in these historically tragic and sad moments." "951 Kissinger, however, himself "was shaken ... by the Iranian decision ... because we had participated in it too ... the brutality of it" ${ }^{952}$ He was informed of the Agreement in the middle of his shuttle diplomacy trips to the region. On 8 March 1975, the Shah conveyed a message to Kissinger outlining the

\footnotetext{
${ }^{948}$ Ibid. pp. 326-327.

949 Beirut 3252 to the U.S. Department of State, "Kurdish/Iranian Relations," March 15,1975 (NARA/AAD/RG59/CFPF/ET/1975), p.1

${ }^{950}$ Kissinger, Henry. Years of Renewal (New York: Simon \& Schuster, 1999). PP. 594-596.

951 Tehran 1188 to U.S. Department of State, March 10, 1975, NSA, KSWWOF, Box 19, GRFL; and Helms to Kissinger via Scowcroft, March 10, 1975 (CIA/FOIA/Helms), pp.1-2.

952 Memcon, March 9, 1975, NSA, Kissinger Reports on USSR, China and Middle East Discussions, Box 3 , GRFL.
} 
background of his decision. ${ }^{953}$ In his message, the Shah argued that Saddam had promised "that Barzani and his people would have one week to decide whether they wanted to stay in Iraq or withdraw without bloodshed into Iran where they would find a haven and a decent life. They will be given until the end of the month for their withdrawal ... The second promise was that the security services of the two countries would work together, briefing each other on which Kurds were good and which were bad (read communist). This will, I hope, prevent the establishment of a communist Kurdish community in Barzani's territory." ${ }^{954}$ Indeed, the Shah intelligently applied Cold War language to justify his decision when he wrote "... I feel that I had to take a chance since otherwise the Kurdish cause would be hopeless in the relatively near future and I might be accused of having destroyed a chance for getting the Iraqis out of the Soviet orbit." ${ }^{" 955}$

In contrast to both Helms and Lowrie who finally shared the same view towards Iran-Iraq disputes, ${ }^{956}$ Kissinger had no reason to hail the agreement. Stunned by the Shah's decision and pressed by the Congress and American public opinion, he mentioned: "there was nothing I could say." ${ }^{, 957}$ In his telegram to the Shah, Kissinger stated, "with respect to the Kurdish question, there is little I can add to what I have already said to you personally during our recent meeting. This is obviously a matter for His Majesty to decide in the best

\footnotetext{
953 Tehran 2237 to the U.S. Department of State, "Iranian/Iraqi Agreement," March 10, 1975 (NARA/AAD/RG59/CFPF/ET/1975), p.1.

${ }^{954}$ Ibid.

${ }^{955}$ Ibid.

${ }^{956}$ Both thought the Algiers Agreement would bring a potential regional stability. Tehran 2254 to the U.S. Department of State, "Iraqi-Iranian Agreement," March 10, 1975 (GFL, Presidential Country Files for Middle East and South Asia, Box 14, Iran-State Department Telegrams: SECSTATE - EXDIS [1]), p.1.

${ }^{957}$ Kissinger, Henry. Years of Renewal (New York: Simon \& Schuster, 1999). p.595.
} 
interests of your nation. Our policy remains as always to support Iran as a close and staunch friend of the United States. I will, of course, follow with great interest the evolution of Iraqi-Iranian relations and of Iraqi policy in your area generally and toward the Soviet Union in particular." ${ }^{958}$ The Shah did not respond. ${ }^{959}$ Kissinger knew that the fate of the Iraqi Kurdish Movement had been sealed. He had agreed with CIA Director Colby's argument that "because American policy had been to channel aid through Iran ... any direct aid to the Kurds now that resistance was crumbling would be even less defensible than it had been in the past. [I doubt] the Shah— having ended his own aid to Barzani-would be willing to continue to serve as a conduit for American funds. ${ }^{\prime 960}$ Colby was right. Shortly after arriving back from Algiers, the Shah informed Helms "the cutoff of Iranian assistance to Barzani's Kurdish insurrection would also entail terminating all American assistance." ${ }^{" 961}$ After a week, Kissinger conveyed a message to Barzani, stating that "We appreciate the deep concern ... We can understand that the difficult decisions which the Kurdish people now face are a cause of deep anguish for them. We have great admiration for the courage and dignity with which those people have confronted many trials, and our prayers are with them. We will be talking with our Iranian friends and will be in contact with the General later." ${ }^{962}$ It was the end of an era for the Iraqi Kurds.

\footnotetext{
${ }^{958}$ Kissinger, Henry. Years of Renewal (New York: Simon \& Schuster, 1999). p.594.-275

959 Alam, Assadollah. Yad'dashtha-ye 'Alam: Virayesh va Muqaddamah az Alinaqi Alikhani [The Alam Diaries: Edited by Alinaqi Alikhani], Vol. IV: 1974-1975 (Bethesda, MD: Iranbook, 1995), p. 346.

${ }^{960}$ Kissinger, Henry. Years of Renewal (New York: Simon \& Schuster, 1999). p.595.

${ }^{961}$ David Korn, “The Last Years of Mullah Mustafa Barzani," 1/2 (1994), Middle East Quarterly, pp. 12-27.

${ }^{962}$ White House, Situation Room to Kissinger via Borg/Adams/Rodman, March 19, 1975 (GFL, Documents from the National Security Advisor: Trip Briefing Books and Cables for Henry Kissinger, December 2008 Opening, Box 6, 2/10-18/75 Middle East and Europe - 2/5-22/75 London and Middle East), p.1.
} 
Kissinger only asked Helms to secure U.S. interests, ordering him to "find a tactful way to mention the problem both the Iranian and U.S. Governments will face in the U.S. and elsewhere if there is a massacre and Barzani charges that he has been let down. The plight of the Kurds could arouse deep humanitarian concern. On the other hand, it would create an impossible situation if we were to be working at cross purposes with Iran."${ }^{.963}$ Helms had already recommended Kissinger "send [Barzani] some kind of comforting message, otherwise, and maybe anyway, we will get a batch of unpleasant publicity which we may be able to avoid" since "the Iranians clearly have blood on their hands and we to a lesser extent on ours." ${ }^{.964}$ The Shah had agreed with Helms and Callahan who were worried that "distressed and disconsolate" Barzani might unfold Iranian-American covert cooperation in Kurdistan. The best way to assuage the Kurds' "undesirable indiscretion" was, as Colby suggested Kissinger, to give Barzani his last monthly payment. ${ }^{965}$ Kissinger approved his recommendation of "a pitiful Band-Aid considering the tragedy about to descend on the Kurds." ${ }^{966}$ The Shah then instructed SAVAK to allocate Barzani's March payment. ${ }^{967}$

None of them, however, changed the fate of the Kurdish War. Shattered by the Shah's sudden decision and then Kissinger's letter, the traumatized Kurdish leader traveled

\footnotetext{
${ }^{963}$ Kissinger to Helms via Scowcroft, March 15, 1975 (GFL, Documents from the National Security Advisor: Trip Briefing Books and Cables for Henry Kissinger, December 2008 Opening, Box 6, 2/10-18/75 Middle East and Europe - 2/5-22/75 London and Middle East), pp.1-2.

${ }^{964}$ Helms to Kissinger via Scowcroft, March 10, 1975 (CIA/FOIA/Helms), pp.1-2; Scowcroft to Kissinger, Washington, March 10, 1975, 1930Z, FRUS, 1969-1976-Iran; Iraq, 1973-1976, Vol XXVII.

${ }^{965}$ CIA Memorandum for Scowcroft, March 13, 1975, NSA, KSWWOF, Box 19, GRFL; and Helms to Kissinger via Scowcroft, March 10, 1975 (CIA/FOIA/Helms), pp.1-2.

${ }^{966}$ Kissinger, Henry. Years of Renewal (New York: Simon \& Schuster, 1999). p.596.

967 TOHAK141 from Helms to Kissinger, March 19, 1975, DDRAC, Box 9, GRFL.
} 
back to his headquarter in Haji Omran on March 18 1975. He told his Peshmerga that "It was a hopeless situation but if anyone wanted to take up the battle in his place, he would give that man his full moral support." Without an open border and Iran's support, it would be fruitless to continue the war, the majority of the Peshmerga soon concluded. ${ }^{968}$ Right after Barzani fled to Iran on March 27-28, with the Peshmerga and their families, the Iraqi Army launched its final offensive while the Peshmerga families had been waiting to cross the border to Iran. The Shah initially thought that the Algiers Agreement would temporarily freeze Baghdad's military campaign against the Kurds. However, Saddam ordered an allout offensive against the Kurds. The Iraqi invasion "made the Shah ill." ${ }^{969}$ He saw Saddam had "immediately [violated] the letter and spirit of their Algiers agreement by ordering an all-out attack on the Kurds on all fronts. ${ }^{.970}$ It took almost a week until the Shah was able to convince the Baath leaders to halt its offensive and arrange a ceasefire on March 13, two days before the Tehran meeting of Iran-Iraq foreign ministers to implement the Agreement. ${ }^{971}$ With the expiration of the cease-fire and Iraq's offer of amnesty to the Peshmerga on 1 April 1975, Iraq conquered all the Kurds' strongholds without facing a major threat and finally sealed the border with Iran for the first time since September 1961. The Iraqi Kurdish ambition finally came to an end.

With the Shah's approval, more than 200,000 Kurdish refugees crossed the border to take exile in Iran and joined the thousands of refugees already in camps. Although

\footnotetext{
${ }^{968}$ Korn, David. "The Last Years of Mullah Mustafa Barzani," 1/2 (1994). Middle East Quarterly, P. 22.

969 Alam, Assadollah. Yad'dashtha-ye 'Alam: Virayesh va Muqaddamah az Alinaqi Alikhani [The Alam Diaries: Edited by Alinaqi Alikhani] Vol. IV: 1974-1975 (Bethesda, MD: Iranbook, 1995), p. 348.

970 Tehran 2351 to U.S. Department of State, "Iran/Iraq Relations," March 13, 1975 (NARA/AAD/RG59/CFPF/ET/1975), p.1.

971 The implication of the Iran-Iraq Agreement- DCI/NIO 1039-75, 1 May 1975.
} 
thousands of the Iraqi Kurds were internalized and socialized within Iranian society, especially through learning the Persian language, the settlement process in Iran was not without any problem. As general Fardoust, the deputy chief of SAVAK and the head of Royal Inspection, pointed out, "A third of the budget [assigned for the Kurd refugees] was [properly] consumed; however, the rest of it was stolen by Iranian officers." ${ }^{972}$ Alam also stated that "the Iraqi Kurds asked Iranian officials to keep the border open. Mullah Mustafa Barzani was concerned just about his own friends and family. The Shah, however, insisted on settling just Kurdish Peshmerga, not the civilians since Iraqis would never punish them. I replied to Your Majesty that we could not expect the Kurds to believe us. The Shah suggested that the Kurds could be supported by the International Red Cross." ${ }^{\text {973 }}$ Under the Shah's request, Saddam extended the period for the return of the refugees in Iran to Iraq until the end of April--and then for an additional 20 days. ${ }^{974}$ When Baghdad granted amnesty to all of the Kurd refugees, except Barzani's close Peshmerga, more than 70,000 civilians returned to Iraq to face an uncertain future by May 1975.

The Algiers Agreement made the Iraqi Kurds' fate worse. They were forcefully resettled in southern Iraq. The Algiers Agreement accelerated Baghdad's efforts to implement its assimilation policy, known as Anfal, towards the Kurds. The Baath leaders followed their brutal Arabization of Iraqi Kurdistan to set in place a demographic arrangement in favor of the Arabic speaking people. They also established a security belt

\footnotetext{
${ }^{972}$ Fardoust, Hossein and Abdollah Shahbazi, Khaterat-e Arteshbod-e Baznesheshteh Hossein Fardoust [The Memoirs of Retired General Hossein Fardoust] (Tehran, 1990).

973 Alam, Assadollah. Yad'dashtha-ye 'Alam: Virayesh va Muqaddamah az Alinaqi Alikhani [The Alam Diaries: Edited by Alinaqi Alikhani], Vol. IV: 1974-1975 (Bethesda, MD: Iranbook, 1995), p. 359.

974 The implication of the Iran-Iraq Agreement- DCI/NIO 1039-75, 1 May 1975.
} 
30 kilometers wide along Iraq's borders with Turkey and Iran. To create this cordon sanitaire, Baghdad destroyed more than 1400 Kurdish villages by 1978 and 600,000 ordinary Kurds were deported to resettlement camps ${ }^{975}$ while their houses were transferred to Arab families. Both Barzan and Rawandez villages were completely ruined. ${ }^{976}$ Around 100,000 Kurdish Peshmerga, including Barzani and his family, remained in Iran. A beautiful, furnished house, costing around 40 million Rial, was bought for Barzani in Karaj, near Tehran. Forty houses were also prepared for his close families in Tehran and several furnished houses were provided for the Peshmerga commanders in Karaj. ${ }^{977}$ SAVAK, and particularly Colonel Manouchehr Hashemi, the head of the Eighth Office, was in charge of controlling and monitoring the Kurdish refugees. Though frustrated, Barzani and his Peshmerga escaped the rest of the Kurds' fate. The deal was not as bad for the Barzanis as it was for the other Kurds.

\section{Betrayal or Necessity?}

The Algiers Agreement was the Shah's siege of 'Troy'. As in Homer's Iliad, however, the heroes faced tragic lives. The Shah could not escape from the tragic fate of the Kurds. When he was asked by Alam about the fate of the Kurds' "claims and autonomy," the Shah cold-bloodedly replied "Nothing", adding that "these people who have suffered defeat after defeat, they know very well that they could not survive ten days without our support in the face of the Iraqi offensive; what can they say now?" The Shah victoriously told Alam of Saddam's own admission during their four and a half hours of

\footnotetext{
${ }^{975}$ McDowall, David. A Modern History of the Kurds (London: I.B. Tauris, 2007 ed) p. 338-9.

976 The regime even offered financial payments to Arabs to marry Kurdish wives. McDowall, David. $A$ Modern History of the Kurds (London: I.B. Tauris, 2007 ed) p. 340.

977 Qaneifard, Erfan, Tondbad-e Havades: Goftogooi ba Isa Pejman [Hurricane of Events: A Dialogue with Isa Pejman] (Elm Publication, Tehran, 2011) p. 197.
} 
talks that Barzani's Peshmerga would have been easily eliminated by the Iraqi Army long ago had it not been for Iran's troops and artillery intervention. The Iraqi leader had told the Shah that "your unsparing sword cut down the flower of Iraqi youth." However, Alam did not see the Algiers Agreement as Iran's victory. He told the Shah that "the Kurds would have been given autonomy last year but you ordered them not to accept it and they obeyed you." The Shah replied to him that both "the Kurds and the Iraqis knew that it was all an act and that the Iraqis had [an] intention of taking over Kurdistan."${ }^{, 978}$ The day after, Alam informed the Shah of the Western newspapers and the Kurdish campaign against him for selling out the Kurds. The Shah answered, "We could not station our troops there and keep fighting forever." Alam responded back, "We had been practically transgressing Arvand Rud. We could have bargained more [with Iraq] on behalf of the Kurds because they have been under heavy Iraqi bombs and raids for recent 48 hours, though [Baghdad] declared amnesty." The Shah went silent. ${ }^{979}$ The next day, he saw the Shah in "poor spirits and deep in thought." "I think," Alam thought, "it was because of the Kurds issue and accusations over our unfaithfulness and abandonment." ${ }^{980}$

The Shah was heavily criticized by the international media for abandoning the Kurds. Angered with the American press, the Shah told President Ford, "I had to make a quick agreement with Iraq. I have to say this in the face of all the press reports that I had abandoned them. They [the Kurds] weren't fighting; we were. The Kurds weren't fighting. Sadat, Hussein, Boudemiene said, 'Give them [Iraq] a chance to cut loose from the Soviet

\footnotetext{
978 Alam, Assadollah. Yad'dashtha-ye 'Alam: Virayesh va Muqaddamah az Alinaqi Alikhani [The Alam Diaries: Edited by Alinaqi Alikhani], Vol. IV: 1974-1975 (Bethesda, MD: Iranbook, 1995), p. 341-2.

${ }^{979}$ Ibid. p. 343-4.

${ }^{980}$ Ibid. pp. 344.
} 
Union and adopt a more independent policy.' At Algiers I had talks which settled the borders and opened the way for Iraq to be more independent of the Soviet Union. Now, Iraq is offering a treaty for joint defense against local or outside powers. This protects Kuwait against them. I was trying to promote this for 4-5 years to the Saudis." ${ }^{981}$ The Shah, in fact, saw the Kurdish War as fruitless and infeasible. Even pessimist Alam thought that "Our Army was fighting there, rather than the Kurds who were harshly defeated... How could we keep such a place? However, the world does not know the issue and that is why they accused us of a betrayal [of the Kurds]." ${ }^{\text {" } 982} \mathrm{He}$ also added, "It has been more than a year that they [the Kurds] could not resist. Only we were keeping them. It would be unreasonable to spend money for the war and keep their immigrants (more than 300,000) with heavy expenses. The world criticizes us because it does not know of the details. But we go silent because we have no explanation now." ${ }^{983}$ These arguments did not make sense for the media, though.The Algiers Agreement also shook the Iranian-Israeli shared strategy of containment of Iraq. It made the eastern front more vulnerable for Israel. Although the Israelis had been informed of an imminent Tehran-Baghdad agreement, they did not expect the end of their operation in Iraqi Kurdistan in such a "dramatic and sad way." $" 984$ They thought the Kurdish War would last much longer. ${ }^{985}$ While Kissinger was informed by the

\footnotetext{
${ }^{981}$ Memorandum of Conversation, Ford, the Shah, Kissinger, and Scowcroft, May 15, 1975. Ford Library, National Security Adviser, Memoranda of Conversations, Box 11.

982 Alam, Assadollah. Yad'dashtha-ye 'Alam: Virayesh va Muqaddamah az Alinaqi Alikhani [The Alam Diaries: Edited by Alinaqi Alikhani], Vol. IV: 1974-1975 (Bethesda, MD: Iranbook, 1995), p. 346-7.

${ }^{983}$ Ibid. p. 348-9.

${ }^{984}$ Parsi, Trita, Treacherous Alliance: The Secret Dealings of Israel, Iran, and the United States (Yale University Press, 2007) p. 55.

${ }^{985}$ Interview with Major General Mansour Qadar, Oral History, Foundations for Iranian History.
} 
Shah personally, Israel was kept in the dark about the details of the Agreement until SAVAK officials told Uri Lubrani on 9 March $1975 .{ }^{986}$ By ignoring them as a secondary partner, the Shah had added insult to injury for the Jewish state. ${ }^{987}$ A day before the withdrawal of Iranian troops, SAVAK officers in Iraqi Kurdistan informed the Israelis of their sudden return to Iran describing it as a routine replacement of troops. Iran's decision exposed Mossad officers to risk in the face of the Iraqi Army advance. Israeli officers stationed in the north of Iraq, including Eliezer Tsafrir, David Kimche, and Zuri Sagy, had only two hours to flee to Piranshahr, a city in the northwest of Iran. "I was cursing Iran all the way to Tehran. I was terribly disappointed," Tsafrir recalled when he was almost surrounded by the Iraqi troops. ${ }^{988}$ Despite the Iraqi Kurds' request to Israel to support them through air force and deliver aid by parachute drops, ${ }^{989}$ Israel was aware of the brutal logic of geopolitics. They were not able to continue their cooperation with the Iraqi Kurds without the Shah's consent. For a decade Israel saw Barzani as a valuable asset to contain Iraq. The Shah's decision, however, cut off their unwavering support for the Iraqi Kurds. "The Shah sold out the Kurds", Prime Minister Rabin bitterly reacted to the Agreement. "I warned the Shah against it and he did it anyway," Kissinger expressed his sympathy with the Jewish leader. ${ }^{990}$ Though infuriated by Iran's strategic shift, Israel did not criticize the

\footnotetext{
${ }^{986}$ Kimche, David, The Last Option, (New York: Maxwell Macmillan International, 1991) p.195.

987 John A. Conway, “The Kurds and Israel,” Newsweek, April 7, 1975, 17.

988 Parsi, Trita, Treacherous Alliance: The Secret Dealings of Israel, Iran, and the United States (Yale University Press, 2007) p.56; and Randal, Jonathan. After Such Knowledge, What Forgiveness? My Encounters with Kurdistan (London: Westview Press, 1999). p.199.

${ }^{989}$ Kimche, David, The Last Option (New York: Maxwell Macmillan International, 1991) p.195-196.

${ }^{990}$ Memcon, March 9, 1975, NSA, Kissinger Reports on USSR, China and Middle East Discussions, Box 3, GRFL.
} 
Shah publicly. Only Lubrani expressed the Israelis' displeasure with it. However, his objection was bitterly rejected by a senior Iranian official who explained that Israel's weakness "was that she allowed sentiment to interfere with politics." 991 In Israel's view, the Shah's decision in March 1975 was a betrayal that was reminiscent of "what [British Prime Minister Neville] Chamberlain did with Hitler in abandoning Czechoslovakia." 992 The Algiers Agreement also hurt the U.S. and its geopolitical mastermind, Henry Kissinger. The U.S. covert Kurdish cooperation with SAVAK officially came to an end on 4 June $1975 .{ }^{993}$ Without the Shah's intervention, the U.S. would not have engaged "in a war so logistically difficult, so remote, and so incomprehensible to the American public." ${ }^{\circ 94}$ After three years of dedicating money and ammunition, Kissinger lost the Kurdish card just because of the "cold-blooded realist" Shah's policy. ${ }^{995}$ Besides, the Kurds' view added insult to injury. Suffering from cancer, Barzani visited the U.S. in the summer of 1975 for medical treatment. In a meeting, he reminded Kissinger that he was held responsible for the situation in Kurdistan because he had been forced to accept Iran's termination of the support for the Kurdish Peshmerga. But Kissinger refused Barzani's accusation and said, "What do they say we should have done without the Iranians? How could we have supported him if we had had the means?" 996 Indeed, Kissinger never

\footnotetext{
${ }^{991}$ Kimche, The Last Option (New York: Maxwell Macmillan International, 1991) p.195.

992 Parsi, Trita, Treacherous Alliance: The Secret Dealings of Israel, Iran, and the United States (Yale University Press, 2007) p. 57.

${ }^{993}$ Colby to Kissinger, June 4, 1975, (FRUS 1969-1976, XXVII, 289).

${ }^{994}$ Kissinger, Henry. Years of Renewal (New York: Simon \& Schuster, 1999). p.591.

${ }^{995}$ Memcon, February 7, 1975, NSA, Memcons, Box 9, GRFL.

${ }^{996}$ Minutes of the Secretary's Staff Meeting, July 30, 1976, 02000, DNSA.
} 
accepted blame for the failure of the U.S. policy in Kurdistan, blaming geography, history, and weakened U.S. power for the tragedy. The Shah himself considered the termination of Iran's support as the only option for the country. Despite all critiques, his decision in Algiers was rational. The Shah's preference was to keep Iran's non-state foreign policy alive in the north of Iraq. Iran's major goal in supporting the Kurds was to contain Iraq by pulling Baghdad away from Moscow's orbit and then making it concede in Arvand Rud. With their successive defeats in 1974 and early 1975, however, the Shah was dissuaded of the hope that the Peshmerga would crush the Iraqi Army. Indeed, as historical evidence shows, the Peshmerga would not have survived without Iran's direct interference and the Shah was right when he told Alam that "in truth we were the ones doing the fighting." 997 As the Shah pointed out, Barzani's Peshmerga "were making no progress in the war. They were running, not as fast as the South Vietnamese but nearly as fast. We Iranians would have to do the fighting. I decided I did not want a war with Iraq at the time when the Near East was a powder keg and the Russians supported Iraq and the United States suffered from a Watergate Complex". ${ }^{998}$ In this situation, the Shah had little choice but to get ready for a regional war--even an international war in case of Soviet support for Baghdad--with Iraq. Thus, when Iraq showed their flexibility over Arvand Rud, the Shah did not waste time, pulled the rug from under the U.S. and the Israel, and reached the long-term goal of his reign.

\footnotetext{
997 Alam, Alam, Assadollah. Yad'dashtha-ye 'Alam: Virayesh va Muqaddamah az Alinaqi Alikhani [The Alam Diaries: Edited by Alinaqi Alikhani] vol. IV, 1973-1974 (Bethesda, MD: Iranbook, 1995), pp. 326327.

${ }^{998}$ Joseph Kraft, “What Restrains the Shah?” Washington Post, April 27, 1975.
} 


\section{Downfall: The Lebanese Shia}

"Nobody can trust these people [Shia Clerics]," the Shah stated. ${ }^{999}$

"Do not expect me to act as Iran's agent...In contrast to the others, I want nothing for myself. The only thing I want is the progress of the Shia," Sadr to an officer of Iran's embassy in Beirut. ${ }^{1000}$

\section{Anti-Sadr Campaign}

As it was getting closer to the mid-70s, Sadr's prestige in Lebanese politics was weakened. His foe, ambassador Qadar, had rallied several Shia elites in the south of Lebanon, including Ja'far Sharaf al-Din, Kamel Asaad, and Seyyed Hassan Shirazi. As Abd al-Husayn Sharaf al-Din al-Musawi's elder son, Ja'far Sharaf al-Din had considered Sadr as a usurper of his title. Seeking power among the Shia community, Shirazi was an Iraqi-born clergy expelled from Najaf by the Baath forces. Having a "very close, friendly relation" with Qadar, ${ }^{1001}$ Asaad had been challenging Sadr since the early 60s to regain his past influence in Southern Lebanon. ${ }^{1002}$

Besides, Qadar had been preparing anti-Sadr reports to Tehran in order to frame him as a clergy disloyal to Iran. When Sadr took a trip to the Persian Gulf sheikhdoms, Qadar accusing him of calling the Persian Gulf the 'Arabian Gulf' in an interview with the Arab newspaper al-Havadeth. In reality, however, Sadr had stated that "the Shia should support the Arabness of the Persian Gulf." ${ }^{1003}$ Sadr argued that he had intended to highlight

\footnotetext{
${ }^{999}$ Beirut 213/191 to Ministry of Foreign Affairs. 18 April 1977.

${ }^{1000}$ SAVAK Documents, No. 213/94, 28 April 1975.

${ }^{1001}$ Interview with Major General Mansour Qadar, Oral History, Foundations for Iranian History.

1002 Sadr pointed out that he had no personal problem with Asaad; rather, he disagreed on dealing with the central regime in Beirut. See SAVAK Documents, No. 213/635-52/12/9)

1003 SAVAK Documents, No. 213/16054, 17 February 1975.
} 
the Shia identity and interest in the Persian Gulf. ${ }^{1004}$ However, his explanation fell on deaf ears. Qadar also attempted to frame Sadr as "the main supporter of the Iranian opposition in the region. ${ }^{1005}$ In reality, however, the majority of the Iranian revolutionaries had tense relations with Seyyed Musa Sadr.

\section{Sadr, Ayatollah Khomeini, and the Islamist Revolutionaries}

The presence of Palestinian guerrillas, Sadr's success in the formation of the Shia institutions, and Lebanon's specific geography and state identity provided an excellent opportunity for the Iranian revolutionaries to wage their struggle against the Pahlavi regime. Since the early 70s, pro-Ayatollah Khomeini Islamist forces had built their connections to the PLO factions. Although nationalists-religious revolutionaries of the FMI, like Yazdi, Ghotbzadeh, and Chamran, expressed their interests and loyalties to Ayatollah Khomeini, his main disciples comprised of young Islamists who gradually left Iran to organize anti-Shah operations from abroad. As the Baath regime tightened the political atmosphere and put pressure on Shia clerics in Iraq, Sadr invited Ayatollah Khomeini to Lebanon. Although Sadr's invitation was rejected by Ayatollah Khomeini, who preferred to stay in Najaf, some of Ayatollah Khomeini's disciples left Iraq for Beirut in the summer of 1972. Chief among them were Seyed Ali-Akbar Mohtashamipour, ${ }^{1006}$

\footnotetext{
${ }^{1004}$ Ibid.

${ }^{1005}$ SAVAK Documents, No. 213/479, 14 February 1974.

1006 Seyed Ali-Akbar Mohtashamipour was a revolutionary cleric who became Iran's ambassador in Damascus and Interior Minister after the Revolution. He also played a major role in the establishment of Hezbollah in 1982. He is one of the main Iranian figures who strongly advocated Iran's policy of "Export of the Revolution" in 80 s.
} 
Sheikh Mohammad Montazeri, ${ }^{1007}$ Jalal ad-Din Farsi, ${ }^{1008}$ Seyed Mohammad Gharazi, ${ }^{1009}$ and Sheikh Ahmad Nafari. ${ }^{1010}$ Mohtashamipour was a close follower of Ayatollah Khomeini who accompanied him in exile in Iraq and later France. He cofounded Rouhaniyoun-e Mobarez-e Kharej az Iran [the Combatant Clergies out of Iran], an armed group based in Syria and Lebanon, with Mohammad Montazeri, Mohammad Gharazi, and Sheikh Ahmad Nafari. ${ }^{1011}$ Gharazi was an Islamist revolutionary imprisoned by SAVAK,

\footnotetext{
${ }^{1007}$ Sheikh Abbas-Mohammad Montazeri was Ayatollah Hossein-Ali Montazeri's elder son who was killed amid the bloody civil war in a 1981 Mojahedin bombing in Tehran. In the aftermath of the Revolution, Montazeri and Mehdi Hashemi, Montazeri's brother-in-law, founded the Revolutionary Organization of the Masses of the Islamic Republic (SATJA) which played a major role in Iran's policy of the Export of the Revolution. He was also a member of the first Majlis in March 1980.

1008 Jalal ad-Din Farsi was an Afghan-origin Iranian Islamist revolutionary who was the candidate of the Islamic Republic Party (which included most important clerical figures like Ayatollah Khamenei, Beheshti, Hashemi Rafsanjani, Bahonar, and Mofatteh). His candidacy was, however, rejected when Sheikh Ali Tehrani, Ayatollah Khamenei's brother-in-law, and Abolhassan Banisadr's major ally, announced Farsi had an Afghan nationality. Farsi was the most important anti-Sadr, anti-Chamran politician among non-clerical, pro-Khomeini figures.
}

${ }^{1009}$ Gharazi was one of the key figures responsible for the establishment of the Islamic Revolutionary Guard Corps (IRGC) who became Minister of Petroleum from 1981 to 1985 and Minister of Posts from 1985 to 1997. He was also a member of the Iranian Majlis from 1980 to 1984 and also governor of Khuzestan Province in the wake of the Iraqi invasion of Iran and the outbreak of Iran-Iraq (1980-88) War. He was also an independent candidate in the 2013 presidential election.

${ }^{1010}$ His real name was Sefatollah Barzegar.

${ }^{1011}$ Other members of this group included: Ali Fallahian (Iran's Minister of Intelligence from 1989 to 1997), Ali Jannati (Iran's ambassador to Kuwait from 2006 to 2010 and Minister of Culture 2013-present), Abbas Agha-Zamani or Abu Sharif (the second commander of the IRGC from 1979-81), Mohammad Boroujerdi (one of the key founders of the IRGC), Alireza Aladpoush (one of the key founders of Iran's Construction Jihad, Jahad-e Sazandegi), Ahmad Movahedi (Iran's first representative in Lebanon after the Islamic revolution), Ali Younesi (Iran's Minister of Intelligence from 2000 to 2005), Mehdi Bakeri (Iran's military hero and one of the most famous commanders of the IRGC), Said Taghadosian (deputy of judicial assistant of President Hasan Rouhani from 2014 till present), Marziyeh Hadidchi (Tahereh Dabbagh) (one of the key founders of the IRGC), Ahmad Fazaeli, Mohsen Shojaie, Sedaghatnejad, Hasan Motaghi, Mohammad Vaghefi, Seyyed Salman (Ghahreman) Safavi (one of the founders of IRGC branch in Isfahan, general Rahim Safavi (the commander of the IRGC from 1997 to 2007), and the present director of London Academy of Iranian Studies), Habibollahi, Ali Sepahsalari, Serajoddin Mousavi (commander of the Islamic Revolution Committees from 1985 to 1990 and Iran's ambassador to Kuwait from 1997 to 2005), Mohammad-Ali Hadi Najafabadi (Iran's ambassador to UAE and Saudi Arabia in the 80s and 90s), Hasan Ebrahimi, Mahmoud Sharifian, Mohammad-Hossein Taremi (head of intelligence of Iran's national Radio and Television, Sedava-Sima), Sharifkhani and his wife, Zahra Pishgamifard (one of the major members of President Rouhani's main party, the Moderation and Development Party). 
he left Tehran for the Levant in $1976 .{ }^{1012}$ Inspired by Seyed Ali Andarzgoo, ${ }^{1013}$ he held ties with the revolutionaries in Lebanon, Syria, and Palestine. Jalal ad-Din Farsi was an alleged ideologue and theorist of this group who had close connections to Yasser Arafat and Muammar Gaddafi.

As time wore on, these revolutionaries became Sadr's major critics in Lebanon. These pro-Ayatollah Khomeini revolutionaries provocatively blamed Sadr for his meeting with the Shah. Ali-Akbar Mohtashamipour was disappointed with "Sadr's political line" and his "non-revolutionary behavior.","1014 Indeed, pro-Khomeini revolutionaries blamed Sadr for refusing to provide a share of the dedication of his logistics to the Iranian revolutionaries in challenging Tehran. Ali-Akbar Hashemi Rafsanjani, then-president of the Islamic Republic, also pointed to a deep tension between a group of Ayatollah Khomeini's supporters and Sadr. Rafsanjani himself was in Sadr's class when he was in Qom. "Sadr held a specific point of view towards [Pahlavi] Iran. Due to his special position among the Lebanese Shia, he had been connected to the Pahlavi regime. At the same time, he had an intimate relation with the revolutionaries. Moreover, the House of Khomeini, led by Haj Mostafa, held a deep grudge against Sadr. The main reason behind this tension was Mostafa's emphasis on Imam Khomeini's religious authority which was not respected by Sadr. Sadr could not follow Imam officially due to his role in the SICS. On top of that,

\footnotetext{
${ }^{1012} \mathrm{He}$ was arrested with 67 young pro-Mojahedin activists, though he had weak connections with the Mojahedin. According to Taghi Shahram, Gharazi was the only prisoner who wrote a letter to the officials, expressing his repent and regret. In the aftermath of the Mojahedin's ideological approach to Marxism, Gharazi cut off his connection with them.

${ }^{1013}$ Andarzgoo was a major member of the Jami'at-e Motalefeh-e Eslami (Islamic Coalition Population) who had a close connection to Ayatollah Khomeini. Mohammad Bokharaie and Andarzgoo killed former Prime Minister Ali Mansour. He has been known as "the lonely guerrilla of the Revolution."

${ }^{1014}$ Mohtashamipour, Ali-Akbar, Khaterat-e Siasi [Political Dieries] (Kahneh-e Andisheh-e Javan) Vol II. p. 143-150.
} 
Sadr could not ignore Iran's regime. He tried to keep his connection with Iran's embassy in Beirut. It was, of course, a type of struggle against the Shah; however, it was different with our strategy that was based on a clear objection against the regime... Some of the revolutionaries, like Mohammad Montazeri, were against Sadr and denounced him for being a conservative. They expected Sadr to oppose the Shah clearly. I tried to soften their position [towards Sadr]. When I went to Najaf, I talked to Imam and brought the issue to the fore." 1015 Sadr had attempted to justify his decision several times. He pointed out that his "cautious" decision not to highlight Ayatollah Khomeini in Lebanon was due to the Shah's leverage among the Shai community of Lebanon, and especially among Tehrandependent clergies. "Pro-Shah clergies in Lebanon see the Shah in a different way you [pro-Khomeini revolutionaries] see. Due to the extensive propaganda launched by Qadar, the Shah has been portrayed as a respected Shia leader who is attempting to save the Shia from poverty and misery. The embassy [of Iran to Beirut] simultaneously accuses me of creating obstacles against the Shah's support for the Lebanese Shia," Sadr explained. ${ }^{1016}$ Indeed, Sadr's major goal was to revive the Shia collective identity through the removal of poverty and deprivation. He was well-aware that a confrontation with the regime of Tehran by backing the Iranian revolutionaries would destroy the Shia position in Lebanon. But his argument fell on deaf ears.

A gap between pro-Ayatollah Khomeini elements and Sadr widened as Sadr expressed his condolences on the passing of Ayatollah Hakim to Ayatollah Abu al-Qasim

\footnotetext{
${ }^{1015}$ Hashemi Rafsanjani, Ali-Akbar, Doran-e Mobarezeh, Daftar-e Nashr-e Maaref, 1376, p. 278-276.

1016 Tabatabai, Mohammad Sadeq, Kahterat-e Siasi Ejtemai [Socio-political Dieries] (Moassese Tanzim Nashr Asar Emam Khomeini, 1388) vol. 1, p. 174.
} 
Khoie, instead of Ayatollah Khomeini, on 18 July $1970 .{ }^{1017}$ According to the Shia tradition, expressing condolences to an Ayatollah on the passing of a Marja meant the recognition of that Ayatollah as a new Marja. Sadr recognized Ayatollah Khoie as a new Marja and ignored Ayatollah Khomeini. Pro-Ayatollah Khomeini revolutionaries denounced Sadr for his intentional insult to their leader. One of the reasons that Sadr was close to these Ayatollahs, instead of Ayatollah Khomeini, was that they had agreed with Sadr's suggestion on Zabiha. ${ }^{1018}$ Amidst his efforts to improve the Shia community relations with the Maronites and other non-Muslim communities, Sadr had requested Ayatollah Hakim to declare a non-orthodoxy fatwa on Zabiha. Like Ayatollah Hakim, Ayatollah Khoie accepted the fatwa but Ayatollah Khomeini rejected any change in this religious rule. Sadr's controversial decision to approach Ayatollah Khoie also widened his relations with Mostafa Khomeini. In contrast to Ahmad Khomeini, Mostafa's major goal was to legitimize Ayatollah Khomeini's religious, rather than political-revolutionary, authority. Mostafa heavily criticized Sadr's decision and cut off relations with him. Conversely, several of Sadr's close friends believed that his religious endorsement of Ayatollah Khoie owed to Hakim's and Khoie's leverage in Lebanon. According to Seyyed Bagher Khosrowshahi, "Sadr was loyal to Imam Khomeini. Upon Sadr's arrival to Lebanon, most Shia were Ayatollah Hakim's followers. Imam [Khomeini] had not been as popular and therefore, Sadr could not ignore Ayatollah Hakim... Sadr had ordered to hang Ayatollah Hakim's portrait in the SICS building. As Ayatollah Khoie's reputation grew, Sadr put him

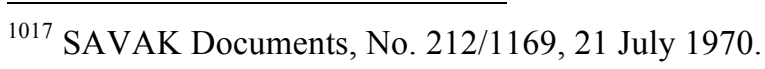

${ }^{1018}$ Zabiha is the Islamic method of slaughter, derived from the Quran and Sunnah.
} 
and then Imam Khomeini's portraits there." ${ }^{1019}$ Nevertheless, the majority of pro-Ayatollah Khomeini revolutionaries never forgot his siding with Ayatollah Khoie.

More substantially, a root of these tensions also stemmed from different views towards the Palestinian guerrillas. In the aftermath of the Black September of 1970, the Palestinian guerrillas established their military camps in the south of Lebanon where they began launching operations against Israel. In retaliation, the Shia towns and cities in the South were showered with Israeli missiles and bombs. In such a miserable situation, Sadr changed his policy towards the PLO. However, his position was heavily criticized by proAyatollah Khomeini revolutionaries, including the Combatant Clergies out of Iran. Sadr's blaming the Palestinian guerrillas for their unfortunate presence in the south of Lebanon caused Mohtashamipour "to worry." ${ }^{1020} \mathrm{He}$ also felt "the danger for the future of the Palestinians" because what he saw "would sour the minds of the people of the south and [would] create a situation where the Palestinians would not be able to attack Israel from the south of Lebanon."1021 Shocked by Sadr's position towards the Palestinians, Mohtashamipour decided to leave Lebanon because "the undesirable political situation in Lebanon was not proper for political inclinations of people like" him. ${ }^{1022}$

In addition to Mohtashamipour, Jalal ad-Din Farsi and Sheikh Ahmad Nafari were against Sadr's position on the Palestinian issue. Farsi was Sadr's main foe among the Iranian revolutionaries in Lebanon. ${ }^{1023}$ "While we are fighting along with Palestinians

\footnotetext{
${ }^{1019}$ See http://www.mashreghnews.ir/fa/news/459203.

${ }^{1020}$ Mohtashamipour, Ali-Akbar, Khaterat-e Siasi, p. 143-150.

${ }^{1021}$ Mohtashamipour, Ali-Akbar, Khaterat-e Siasi, p. 143-150.

1022 Mohtashamipour, Ali-Akbar, Khaterat-e Siasi, p. 143-150.
} 
against Imperialism and the Israelis, Jalal ad-Din Farsi and Mohammad Saleh are denouncing us for being an anti-Palestinian group," Chamran criticized Farsi's position towards Sadr. ${ }^{1024}$ However, Farsi believed that Sadr was against revolutionary actions in Lebanon. "Mr. Sadr was worried about our presence in Lebanon [that could] weaken his position. Thus, he planned to deport us from Lebanon," Farsi claimed. ${ }^{1025}$ In reality, however, both Farsi and Nafari had been arrested by the Lebanese police and were supposed to be deported to Iran but Sadr's personal intervention released them. ${ }^{1026}$ Not only Sadr but also Chamran was denounced as a traitor to the Palestinians, especially after his trip to Paris on 10 August $1975 .{ }^{1027}$ "Chamran took a trip to Paris and gave such an incendiary speech there against the Palestinian guerrillas that I thought the Palestinians would assassinate him," Farsi stressed Chamran's anti-Palestine position. ${ }^{1028}$ Asghar Jamalifard, known as Abou Hanif, also criticized Sadr. "Although I had planned to go to Dhofar, Oman, to fight with the Shah's Royal Army, I came to the south of Lebanon because Sadr convinced me to travel there... I participated in all Amal's military operations

\footnotetext{
${ }^{1023}$ Tabatabai, Mohammad Sadeq, Kahterat-e Siasi Ejtemai, Moassese Tanzim Nashr Asar Emam Khomeini, 1388, vol. 1, p. 172.

${ }^{1024}$ Ibid. p. 192.

${ }^{1025}$ Farsi, Jalalodin, Zavayay-e Tarik, p. 53.

${ }^{1026}$ Yazdi, Ebrahim, Naqsh-e Imam Musa Sadr dar Lubnan [Imam Musa Sadr's Role in Lebanon] p. 416; SAVAK Documents, No. 4440, 14 May 1974; SAVAK Documents, No. 3108, 21 June 1972; SAVAK Documents, No. 1034, 22 June 1972. SAVAK Documents, No. 213/671, 17 March 1974; SAVAK Documents, No. 4047, 5 April 1974; SAVAK Documents, No. 440, 14 May 1974; SAVAK Documents, No. 1034, 22 June 1972.

${ }^{1027}$ SAVAK Documents, No. 213/831, 10 August 1975.

1028 http://shakhsiatnegar.com/فارسى_الدين-جلال
} 
against the Phalanges. With Tel al-Zaatar, ${ }^{1029}$ wherein Sadr was responsible, I left Amal. ${ }^{, 1030}$ Ironically, even anti-Sadr Qadar did not share the revolutionaries' view towards Sadr. "The Shia in the south of Lebanon were never Israeli supporters. They were not fond of Israel; rather, they criticized the Palestinian guerrillas for provoking the Israelis to invade the South," Qadar argued. ${ }^{1031}$ Sadr and Chamran believed in maintaining a balance between the Shia interests and support for the Palestinians, whereas pro-Ayatollah Khomeini revolutionaries insisted on making Lebanon a frontier zone in fighting with Israel.

Although Sadr had expressed his respect to Ayatollah Khomeini and supported his Islamic struggle, pro-Ayatollah Khomeini elements were suspicious of Sadr's allegedly insincere views towards the Palestinians, the Shah, and Ayatollah Khomeini's religious authority. Sadr had praised Iranian clerics', especially Ayatollah Khomeini's, struggle against despotism in Iran and clarified that the Shia leaders were "influential among the [Iranian] people." ${ }^{, 1032}$ However, pro-Ayatollah Khomeini revolutionaries tried to drag their leader into their fight with Sadr. ${ }^{1033}$ Farsi criticized Sadr supporters. "This man [Chamran] went to each corner of the World with Musa Sadr. They both went to Moscow and laid flowers at the Vladimir Lenin Monument. However, he never came to Najaf to express his

\footnotetext{
${ }^{1029}$ The Tel al-Zaatar battle occurred during the Lebanese Civil War on August 12, 1976. Tel al-Zaatar was a Palestinian Refugee camp under United Nations Relief and Works Agency for Palestine Refugees in the Near East (UNRWA) with approximately 50,000-60,000 refugees in northeast Beirut.

${ }^{1030}$ Goftogo ba Asghar Jamalifard, Abou Hanif [A Conversation with Asghar Jamalifard, Abou-Hanif]. http://www.teribon.ir/archives/135456.

${ }^{1031}$ Interview with Major General Mansour Qadar, Oral History, Foundations for Iranian History.

1032 SAVAK Documents, No. 213/5701, 29 March 1973.

${ }^{1033}$ Tabatabai, Mohammad Sadegh, Kahterat-e Siasi Ejtemai [Socio-political Dieries], Moassese Tanzim Nashr Asar Emam Khomeini, 1388, vol. 1, p. 173.
} 
respect to Imam Khomeini," Farsi claimed. He added, "Chamran never saw Imam Khomeini as a good politician and leader. Instead, he saw Sadr as an ideal, perfect leader." ${ }^{1034}$ Even in Iraq, the anti-Sadr zeal was rising. "One night in early 1971, I think Mohtashamipour, Mohammad Taqi Shariati, Sadjadi, Seyyed Hamid Ziarati (Hamid Rouhani), ${ }^{1035}$ and I gathered in Sheikh Hasan Karoubi's house. That night, Ziarati vehemently criticized both Imam Musa Sadr and his cousin, Seyyed Muhammad-Baqir Sadr, and accused Musa Sadr of being a secret mercenary of Imperialism and Zionism in a way that nobody could find out. Ziarati also hinted that Musa Sadr was Ayatollah Khoie's follower, and not Imam's ... Following afternoon, I approached Imam and told him that "some of your students and followers have disrespected some Marjas and respectful Shia leaders, like Imam Sadr and Ayatollah [Mohammad-Baqir] Sadr. He got unexpectedly sad in a way that I thought I should not have raised the issue. Imam later warned his followers not to insult the Sadr."

Nonetheless, Ayatollah Khomeini never clarified his position in the dispute. There were some instances when the Ayatollah slightly expressed his disagreement with Sadr, particularly support for the Palestinian guerrillas. However, Sadegh Tabatabaie, Sadr's nephew, believed that "Imam [Khomeini] was not against Sadr. The only time he discredited with Sadr was when Sadr insisted on supporting the Shias in Lebanon. Imam

\footnotetext{
${ }^{1034}$ Farsi still believes that the 'myth of Chamran' has been constructed by the FMI. "When [in initial years of the Iran-Iraq War], the FMI had been constructing the myth of Chamran in a way that he had defended against Iraqi invasion with one Kalashnikov, killed them all and such nonsense, we did not react to avoid damaging our defense and national unity." http://shakhsiatnegar.com/فارسى-الدين-جلال.

${ }^{1035}$ Founder and former director of the Islamic Revolution Documents Center and present Director of the Historical Research Foundation and Encyclopedia of the Islamic Revolution.

1036 Tabatabai, Mohammad Sadeq, Kahterat-e Siasi Ejtemai [Socio-Political Dieries] (Moassese Tanzim Nashr Asar Emam Khomeini, 1388) vol. 1, pp. 108-110.
} 
[Khomeini] believed that this policy could not bridge a gap between two sects of Islam. Sadr, in response, asserted that the Shia should first change their position in the society of Lebanon from a marginal group to the central one." ${ }^{1037}$ Besides, Ayatollah preferred to stay out of the quarrel. As a revolutionary leader, Ayatollah Khomeini was smart enough not to take a clear position on the issue that could have divided his followers. Similar to his position towards Ali Shariati, a main ideologue of the Islamic Revolution, he never put all his eggs in one basket.

In the mid-70s, pro-Palestinian zeal was rising so much that some of the nonclerical revolutionaries joined radical pro-Ayatollah Khomeini supporters. Jebheh Melli-e Sevom (The Third National Front) and his main figure, Abolhassan Banisadr, criticized Sadr for his ambiguous political position towards the Palestinians. ${ }^{1038}$ It seems that even Iranian Islamists were torn between supporting Sadr and radical PLO. Not only Islamists but also leftist and other major Iranian opposition groups saw Sadr as a threat to their guerrilla operations in the south of Lebanon. Indeed, there was a deep competition among revolutionary groups to show themselves with a rightful and impeccable position in supporting the Palestinians. Within this context, Sadr's objection to Palestinian radicalism was framed as an anti-Islamist move. By the mid-70s, both SAVAK and the Iranian opposition groups, except the FMI, had framed Sadr as their scapegoat.

\section{Escalated Enmity}

The outbreak of the October War of 1973 set a fertile ground opportunity for Qadar's policy to make Tehran more suspicious of Sadr's intentions. Amidst the war, Sadr

\footnotetext{
1037 Tabatabai, Mohammad Sadegh, Kahterat-e Siasi Ejtemai, Moassese Tanzim Nashr Asar Emam Khomeini, 1388, vol. 1, p. 177.

${ }^{1038}$ See also Az Nameh-Ha-ye Chamran [From Chamran's letters], http://imamsadr-news.com/article/1311.
} 
asked Tehran to intervene in favor of the Arab side. He dispatched a telegram to Ayatollah Milani, a major Marja in Qom, to convince the Shah's regime to side with Arab "Muslims" and "provide the Arabs with weapons, planes, and military specialists."1039 When Tehran did not support the Egyptians and Syrians, ${ }^{1040}$ Sadr publicly, yet slightly, criticized the regime of Iran in Ashura 1973. On 28 March 1973, Sadr regretted Iran's policy in the War and stated that "Tehran could have cut selling oil to Israel."1041 Qadar's reports, however, exaggerated Sadr's enmity towards Tehran. Nonetheless, some officials in SAVAK objected to this view, recommending that the Shah pursue a policy to regain the leverage among the Shia, particularly after the rising Iraqi influence in Lebanon. The Shah initially agreed and instructed to attract Sadr to Iran. ${ }^{1042}$ However, it was soon revealed that Iran's embassy in Beirut did not intend to follow the Shah's policy. ${ }^{1043}$ Qadar, in fact, insisted on pressing SAVAK to pursue the Shah's instruction only "after Sadr proves his loyalty to Iran and improves his relations with Iran's embassy." "1044 Qadar cunningly intertwined

1039 SAVAK Documents, No. h/10277, 27 October 1973.

${ }^{1040}$ In reality, Iran surprisingly supported, yet indirectly, Cairo and Damascus. While Iran did not join the Arab oil embargo against Israel, the Shah delivered a large shipment of crude oil after Sadat's personal call to the Shah in the first days of the war. Iran also "extended medical aid to the Arabs and provided Saudi Arabia with Iranian pilots and airplanes to help resolve logistical problems. Iranian planes brought a Saudi battalion to the Syrian side of the Golan Heights. There, it picked up wounded Syrian soldiers and brought them to Tehran for treatment." Iran also "prevented Jewish Australian volunteers for the Israeli army from reaching Israel via Tehran." On top of that, Tehran helped the Soviets aid the Arab side by allowing "four civilian airplanes to fly spare parts to the Arabs." The Shah did all these unexpected moves without consulting the United States. See Parsi, Trita, Treacherous Alliance: The Secret Dealings of Israel, Iran, and the United States (Yale University Press, 2007) p. 47.

${ }^{1041}$ SAVAK Documents, No. 213/5701, 29 March 1973.

1042 SAVAK Documents, No. 213/8048, 10 April 1975.

1043 SAVAK Documents, No. p.380-1.

1044 SAVAK Documents, No. 213/19088, 7 May 1975. 
issues of Sadr's expressing loyalty to the Shah and serving as his own agent as the only pre-condition for the transformation of Iran's policy towards the Lebanese Shia.

Qadar claimed that Sadr had called the Shah an "Imperialist Stooge" and criticized him for the Shah's refusal of joining the Arab oil embargo to gain an economic and political victory even at the expense of the Arabs. ${ }^{1045} \mathrm{He}$ also rallied popular Lebanese newspapers against Sadr. ${ }^{1046}$ In early February 1974, al-Hayat, a famous Shia-oriented newspaper, criticized Sadr for his verbal attack on Tehran. ${ }^{1047}$ It highlighted the alleged Shia anxiety over possibly devastating consequences of Sadr's radical move that might push Iranians to reconsider their decision to build a hospital in the South. Besides, he introduced Sadr as a major obstacle to deporting Iranian opposition from Lebanon territory. "Sadr threatened Nasser al-Khalil, Khalil al-Khalil's brother (Lebanon ambassador to Tehran), that he would react to Beirut regime if the government extradited Iranian revolutionaries to Iran," Qadar reported to Tehran. ${ }^{1048}$ In another report, Qadar informed Tehran that "while the Lebanon regime intended to oust all the Iranian opposition, Sheikh Bahiyaj Taqiaddin, the Minister of Interior Affairs, finally refused to do so after his meeting with Sadr." ${ }^{\text {1049 }}$ Within this context, Qadar suspended Iran's dedicated money to build a hospital in Southern Lebanon on 4 February 1974. Qadar declared that Iran would not provide its financial support-around 30 million dollars--to the Shia as long as Sadr remained the head of the Shia. ${ }^{1050}$

\footnotetext{
1045 SAVAK Documents, No. 213/531, 30 January 1974.

${ }^{1046}$ SAVAK Documents, No. 213/545, 2 February 1974; SAVAK Documents, No. (33-4).

1047 SAVAK Documents, No. 213/549, 4 February 1974.

${ }^{1048}$ SAVAK Documents, No. 213/19, 3 April 1974.

1049 SAVAK Documents, No. 213/420, 20 May 1974.

${ }^{1050}$ SAVAK Documents, No. 213/563, 10 February 1974.
} 
Tensions escalated as Prime Minister Hoveyda dispatched a telegram to Qadar on 11 February and declared the Shah's order that Iran would not support the Lebanese Shia as long as Sadr was their leader. ${ }^{1051}$ It was a turning point in Iran's non-state foreign policy in Lebanon.

Qadar had also highlighted Sadr's connections with radical Arab regimes of the region. He reported that Gaddafi financially backed Sadr after the deterioration of Sadr's relations with Tehran. ${ }^{1052}$ To urge Tehran against Sadr, Qadar claimed that Sadr had also received financial assistance from the Baath regime of Baghdad. ${ }^{1053}$ When Sadr traveled to Damascus in spring 1974, SAVAK thought that he might visit Baghdad to talk to Iraqi leaders to convince them not to close the Najaf Hawza. ${ }^{1054}$ On top of that, Qadar framed Sadr's trip as a dangerous move against Iran's national security, arguing that "this opportunistic Mullah" would travel to Iraq to reconcile Baghdad-Damascus relations [against Iran]. ${ }^{1055}$ At the same time, Ambassador al-Khalil who had a close connection with Asadollah Alam complained of Sadr several times. ${ }^{1056}$ In a talk with al-Khalil, Alam disappointedly stated that "our common friend [Seyyed Musa Sadr] was, unfortunately, untrustworthy. He receives money from any country. Al-Khalil said that you Iranians should support the Shia. Why do you care about Sadr? He [al-Khalil] talked sense but I am

\footnotetext{
${ }^{1051}$ SAVAK Documents, No. 22h20/116364.

1052 SAVAK Documents, No. 213/2642, 11 February 1974.

${ }^{1053}$ SAVAK Documents, No. 213/2886, 12 March 1974.

${ }^{1054}$ SAVAK Documents, No. 1050-7051, 18 March 1974.

1055 SAVAK Documents, No. 584/m/8, 1 April 1974.

${ }^{1056}$ His father was Kazim al-Khalil, former minister of national economy.
} 
sure the Shah will not accept it." ${ }^{, 1057}$ In another meeting with Alam, al-Khalil repeated "why the Lebanese Shia should pay off for Sadr who had been the head of the Shia community but made the Shah unhappy. He is going to gather all the Shia notables to prevent the destruction of the Shia [community] and their hope to His Imperial Majesty. The Shah told me he had talked sense and told me to negotiate with al-Khalil."1058

The Sadr-Qadar enmity grew when an aborted plan for the assassination of Qadar was announced. Iran's embassy in Beirut quickly accused Sadr of leading the assassination. ${ }^{1059}$ "Pro-Bakhtiar elements planned to assassinate two Iranian security officers: general Pakravan and me. In the aftermath of Bakhtiar's death, it was Sadr who managed the plot. I was informed by both Khansari, administrative deputy of the Ministry of Foreign Affairs, and by SAVAK. The assassin had been recruited by Iraq's ambassador to Kuwait and was then connected to Bakhtiar and finally Sadr," Qadar claimed. ${ }^{1060} \mathrm{Sadr}$ strongly rejected Qadar's claim but the Iranian Ambassador intended to isolate his foe. In early April 1974, Sadr was invited by the U.S. government to take a trip to New York. ${ }^{1061}$ Qadar attempted to convince George McMurtrie Godley, the U.S. new ambassador to Beirut, to withdraw his invitation to Sadr. He framed Seyyed Musa as a "dangerous, opportunist Mullah who has had built connections with different anti-Shah regimes and

\footnotetext{
${ }^{1057}$ Alam, Assadollah. Yad'dashtha-ye 'Alam: Virayesh va Muqaddamah az Alinaqi Alikhani [The Alam Diaries: Edited by Alinaqi Alikhani] Vol. IV: 1974-1975 (Bethesda, MD: Iranbook, 1995), p. 47.

1058 Alam, Assadollah. Yad'dashtha-ye 'Alam: Virayesh va Muqaddamah az Alinaqi Alikhani [The Alam Diaries: Edited by Alinaqi Alikhani] Vol. IV: 1974-1975 (Bethesda, MD: Iranbook, 1995), p. 274.

${ }^{1059}$ SAVAK Documents, No. 213/79, 10 April 1974.

${ }^{1060}$ Qadar added that the assassin then became Director of the Islamic Propagation Organization after the Revolution Interview with Major General Mansour Qadar, Oral History, Foundations for Iranian History.

${ }^{1061}$ SAVAK Documents, No. 213/16, 4 April 1974.
} 
actors, like the Baath regime of Baghdad, Teymour Bakhtiar, Khomeini, Seyyed Mousa Ayatollah-Zadeh Esfahani, ${ }^{1062}$ Gamal Abdel Nasser, and even the Kremlin.” Godley politely replied that the decision [of inviting Seyyed Musa Sadr] had been already made before his arrival to Beirut. ${ }^{1063}$ Although Sadr did not travel to the U.S., Qadar did not stop heading his anti-Sadr campaign.

In addition to rallying its "trustworthy, pro-Shah clerics" in Tehran and framing Sadr as an "agent of foreign regimes,"1064 Qadar intended to weaken Sadr's religious authority in Iran. He said that "Sadr went to Vatican to talk about the unity of the religion. He mentioned there that there was no dichotomy between Shia, Sunni, Christian, Judaism or any other religion; therefore, we should unite against blasphemy, including Zionism. At the end of the meeting, he stood in front of the Sacred Cross and took a photo. The photo was extensively distributed among the Shia clergies and used against him." ${ }^{1065}$ SAVAK also prepared a plan to weaken Sadr's position in Lebanon. The plan was supposed to bypass Sadr and provide financial assistance to the poor Shia in the South through antiSadr clergies. With the support of anti-Sadr clergies, according to the plan, Iran could have built and managed a hospital without Sadr's permission. As the next step, a chain of anti-

\footnotetext{
${ }^{1062}$ Ayatollah-Zadeh Esfahani was an anti-Shah activist who held close ties with General Teymour Bakhtiar. He left Iran to Egypt to meet Nasser and then Iraq to wage struggle against the regime of Tehran. According to SAVAK, "Ayatollah-Zadeh Esfahani was in contact with Khalil Ebrahim Abdel-Hamid, the head of Hizb ut-Tahrir al-Islami (Islamic Party of Liberation). He also participated in secret weekly meetings in Najaf with Mostafa Khomeini, Sheikh Mousa Qomi, Mohammad Sadeghi, Seyed Morteza Nakhjavani Mohammad-Ali Molawi Arabshahi, talking about Iran's domestic affairs. See SAVAK Documents, 16 July 1966. SAVAK also reported that Ayatollah-Zadeh Esfahani, Mostafa Khomeini, and Mohammad Sadeghi planned to publish a magazine, Jomhoriyyat, in Iraq. See SAVAK Documents, 9 February 1966. Despite these initial connections, Mostafa Khomeini soon cut off his relations with Ayatollah-Zadeh Esfahani due to Esfahani's extensive networks with the Baath regime and Bakhtiar.

${ }^{1063}$ SAVAK Documents, No. 4290/m/8, 7 May 1974.

${ }^{1064}$ SAVAK Documents, No. reported from 312.

${ }^{1065}$ Interview with Major General Mansour Qadar, Oral History, Foundations for Iranian History.
} 
Sadr articles was supposed to be published in different Lebanese newspapers and magazines, stressing Sadr's ties with anti-Shah regimes of the region. The last step was supposed to invite anti-Sadr clerics to Iran. ${ }^{1066}$ Although the plan was not initiated, Sadr's supporters blamed Qadar for rallying anti-Sadr propaganda in Lebanon and Iran. ${ }^{1067}$

Sadr himself tried to convince Tehran to de-escalate the escalated tension. In a meeting with former president Kamil Chamoun, the Shah's old ally in Lebanon, Sadr contended that Iran's embassy in Beirut was his major enemy and blamed Qadar for inciting Kamel Asaad, Ja'far Sharf al-Din, and Seyyed Hasan Shirazi against him. ${ }^{1068}$ In early May 1974, Sadr met with several SAVAK officers in Beirut and strongly denied his disloyalty to the Shah. He told them that he was here [in Lebanon] as "a representative of the Shia in the World," and he would be "insane to ignore a great power in the region like Iran." He added that he could not reject invitations from anti-Shah regimes of the region since he, as a religious leader, must pursue such activities. "If Gaddafi invites me, I will go to Libya but if he wants me to insult the Shah and Iran, I will punch his face." ${ }^{1069}$ For the next time, he blamed Qadar for causing trouble for the Shia in Lebanon and repeated pleading with Iran for financial support to build a hospital in the South. Sadr argued that "in the post-Nasser era, the Shah can lead the Middle East by deepening its leverage in Lebanon that will surrender Iran's regional enemies, especially Iraq.” He finally promised, "I will do anything for Iran's policy."1070 Nobody considered his argument, though.

\footnotetext{
${ }^{1066}$ SAVAK Documents, No. (p.2111).

1067 SAVAK Documents, No. 213/572, 10 February 1974.

${ }^{1068}$ SAVAK Documents, No. 213/2722, 5 March 1974.

${ }^{1069}$ SAVAK Documents, No. 221/33631, 9 May 1974.

1070 SAVAK Documents, No. 221/33631, 9 May 1974.
} 


\section{The Movement of the Deprived and Amal}

By the early 70s, Sadr had transformed the once-marginal Shia community to one of the critical players in the Lebanese politics. According to one of SAVAK's reports, Sadr was "the only Lebanese leader who was attempting to improve Lebanon's situation. In contrast to most of the Lebanese leaders, he lacked any weakness." ${ }^{1071}$ He had successfully showed himself as a national, rather than sectarian, player in Lebanon. He had also pressed President Suleiman Frangieh for socio-economic reform in the South, including building a dam on the Litani River. As Sadr's relation with Frangieh soured, ${ }^{1072}$ he was denounced for having secret relations with Tehran. Antonie Frangieh, the President's elder son, claimed that Sadr had gathered opportunistic forces against Iran while simultaneously seeking Iran's support. ${ }^{1073}$

Amidst these pressures, Sadr and Hussein el-Husseini founded Harakat alMahroumin [the Movement of the Deprived] in March 1974 in order to push for political reform of the Lebanese system and to urge Beirut to fight deprivation in Lebanon. ${ }^{1074}$ Putting emphasis on peace and equality, as well as social justice, for all sectarian communities in Lebanon, the Movement had a non-sectarian message, crossing communal borders and uniting all Lebanese people. The Movement initially attracted supports from other sectarian leaders, like the Greek Catholic Archbishop, Mgr. Grégoire Haddad, and Father Yuakeem Mubarak. On 5 May 1974, more than 80 thousand of Sadr's followers

${ }^{1071}$ SAVAK Documents, No. 213/2218, 18 December 1974.

1072 SAVAK Documents, No. 213/2395, 26 January 1974.

1073 SAVAK Documents, No. 213/500, 19 January 1974.

1074 El-Husseini was then-speaker of the Lebanese Parliament and then-Amal's Secretary General in 1978. Husseini had a key role in brokering the Taif Agreement of 1990 that terminated the Lebanese Civil War (1975-90). 
rallied in Tyre to express their support for the Movement. On 14 December 1974, Yoakim Moubarak stated that Sadr had preserved the Arabic character of Lebanon with "an influential Islamic movement." 1075 In May 1974, Lebanon's Sunni-dominated Supreme Official Islamic Council expressed its support for the Shia. In September 1974, the Executive Committee of the Islamic Associations asked the Maronites government to respect the demands of the Muslim community, including the Shia. ${ }^{1076}$ The formation of Harakat al-Mahroumin also crushed the hegemony of the Shia zuama. It was "the Shia's first attempt to organize themselves independently of the traditional zuama." 1077

As a next step, Sadr established a military wing of the Movement of the Deprived, the Afwaj al-Mouqawma al-Lubnaniyya [Lebanese Resistance Detachments, known later as its acronym, Amal, ('Hope' in Arabic)]. On 20 January 1975, in an inflammatory preaching Sadr promised his followers to establish a militia against Israelis and anti-Shia groups in Lebanon. "Everybody, and not only the government, should defend his country, nation, and home ... and if the government ignores it, the nation should do it itself." Earlier, a nascent Shia militia was trained and supplied with weapons by the PLO's Fatah at their Beqaa military camps. ${ }^{1078}$ The formation of Amal was accidentally revealed on 6 July 1975 five days after an explosion of an anti-tank landmine at one of the Fatah camps in Ain alBaniyya, a small town near Baalbek, that killed 24 and wounded 42 Shia trainees. The accident pushed Sadr to publicly announce the formation of Amal. ${ }^{1079}$ Amal soon became

\footnotetext{
${ }^{1075}$ SAVAK Documents, No. 3260, 14 December 1973.

${ }^{1076}$ M. Halawi, A Lebanon Defied: Musa al-Sadr and the Shia Community (Oxford, 1992) p.190.

1077 Shanahan, Rodger, The Shi'a of Lebanon: Clans, Parties and Clerics (London and New York, Taurus Academic Studies, January 1, 2005).

${ }^{1078}$ Interview with Major General Mansour Qadar, Oral History, Foundations for Iranian History.
} 
so popular that it subsumed the Movement of the Deprived as both a military and political organization. Along with the Technical Institute of Burj al-Shimali and the Movement of the Deprived, Amal became the most significant symbol of Sadr's leadership, helping him to gain greater respect and the allocation of a larger share of governmental resources for the Shia population.

The formation of Amal shocked SAVAK. "We had no clue of this militia [Amal] before the accidental explosion," Qadar claimed. ${ }^{1080}$ SAVAK officials had already predicted the formation of a militia to support the Shia against their foes in Lebanon. ${ }^{1081}$ According to SAVAK, Sadr and Chamran had established a militia, called Janbaz, led by Qasim Mahdavi in Southern Lebanon. ${ }^{1082}$ However, SAVAK could not track down the formation of Amal. Worried about its connection with the Iranian revolutionaries, SAVAK began monitoring Amal's activities in Lebanon. SAVAK claimed that "more than 6,000 young men" were trained on Amal bases. ${ }^{1083}$ It also highlighted Chamran's leading role in the formation of the Amal. ${ }^{1084}$ "The real head of the Movement of the Deprived with full authority is, in fact, Chamran who controls all military and financial issues. However, since he is an Iranian, he has been following his activities secretly." 1085 According to SAVAK, he was the main figure of Amal who trained both Sadr's Shia followers and the Iranian

\footnotetext{
${ }^{1079}$ Beirut 213/243, from 213 to 713, SAVAK Documents, 8 July 1975.

${ }^{1080}$ Interview with Major General Mansour Qadar, Oral History, Foundations for Iranian History.

1081 SAVAK Documents, No. 212/82, 11 April 1970; SAVAK Documents, No. 4796-4797, 25 November 1974.

1082 SVAK Documents, No. 6552, 11 January 1974.

${ }^{1083}$ SAVAK Documents, No Number.

${ }^{1084}$ SAVAK Documents, No. 334/1988, 27 July 1973.

${ }^{1085}$ SAVAK Documents, No Number, No date.
} 
opposition. ${ }^{1086}$ "It was Chamran who established Amal. Chamran focused just on Lebanese domestic politics and Amal. Abu Sharif was also with Chamran." ${ }^{1087}$ The formation of Amal and Chamran's military leadership caused SAVAK to frame Amal as central headquarters for the Iranian revolutionaries. ${ }^{1088}$

Despite Sadr's prestige, the formation of Amal provoked both the Christians and the Leftists. ${ }^{1089}$ Earlier, a Shia armed group, the Fityan al-Ali [the Knights of [Imam] Ali], claimed an association with Sadr's Movement of the Deprived. It had destroyed a Christian town in the north of Beirut. "While Sadr strongly rejected his connection with Fityan alAli, Amal damaged Sadr's prestige among the Christians." ${ }^{, 1090}$ Besides, the Christians criticized Sadr's key role in the reconciliation of Damascus and the PLO. Aware of their long-running competition in Lebanon, Sadr had attempted to de-escalate tensions between Assad and Arafat. On 14 May 1973, Sadr went to Syria in order to convince Assad to lessen tension with the PLO. According to Assad, Sadr's trip was "better than any mediators from other countries." ${ }^{\not 1091}$ Sadr's activities had escalated domestic tensions.

\footnotetext{
${ }^{1086}$ SAVAK Documents, No. 5152, 4 September 1974; SAVAK Documents, No. 213602, 17 July 1975; SAVAK Documents, No. 213/1648, 19 February 1976; SAVAK Documents, No. 17/033-3/1068; 7 May 1977; SAVAK Documents, No. 4873-4872, 13 July 1974; SAVAK Documents, No. 334/1988, 27 July 1974; SAVAK Documents, No. 4990, 3 August 1974; SAVAK Documents, No. 5114, 3 September 1974.

${ }^{1087}$ Interview with Major General Mansour Qadar, Oral History, Foundations for Iranian History. Abbas Agha-Zamani or Abu Sharif was the second commander of the IRGC, proceeded by Jawad Mansouri, from 1979-81. Abu Sharif was one of the rare pro-Banisadr commanders in the IRGC. In the aftermath of Banisadr's impeachment in on 21 June 1981, he was appointed as Iran's ambassador to Islamabad, Pakistan.

${ }^{1088}$ SAVAK Documents, No.213/54013, 6 April 1974.

${ }^{1089}$ Interview with Major General Mansour Qadar, Oral History, Foundations for Iranian History.

${ }^{1090}$ Beirut 213/243, from 213 to 713, SAVAK Documents, 8 July 1975.

${ }^{1091}$ SAVAK Documents, No. 334/936, 2 June 1973.
} 


\section{The Lebanese Civil War of 1975}

In early 1975, the Phalanges (Kataeb), headed by Pierre Gemayel, and the Patriotic National Liberal (PNL), headed by Camille Chamoun, blamed the PLO and its Lebanese ally, the Lebanese National Movement (LNM), ${ }^{1092}$ for endangering Lebanon's national security. They also called for a referendum on the presence of the PLO in the South. The situation escalated as Maarouf Saad, Secretary-General of Popular Nasserite Organization who was also Sadr' ally, was assassinated by the Lebanese army on 6 March 1975. In retaliation, Sadr rallied its supporters a day later. Less than a week later, Sunni and Shia leaders called for the removal of the sectarian democracy; however, it was immediately rejected by the Maronites. On 13 April, tensions between the Maronites and the PLO escalated when unidentified gunmen killed two Phalangists. Hours later, the Phalanges massacred 30 Palestinian bus passengers. The 'Bus Massacre' soon transformed into a bloody, all-out war between the LNM and the PLO, on the one side, and the Kataeb militias, on the other side. Although the Shia become the cannon fodder for the PLO, Sadr had initially distanced the Shia from the war. With the resignation of the Lebanese military cabinet, Sadr began his political fast in a mosque in Beirut in order to prevent the extension of the civil war on 27 June 1975. After five days of fasting and meeting with Yasser Arafat and Syrian Foreign Minister Abd al-Halim Khaddam, Sadr finally broke the fast when Lebanese groups agreed to form a national unity cabinet and the new Prime Minister, Rashid Karami, met him. Sadr's political fast and then his participation in the security meeting of Aramoun of 24 September 1975, SAVAK illustrated his "key" role in the termination of the first round of the Civil War. ${ }^{1093}$

${ }^{1092}$ An ideologically eclectic front of both radical and reformist opposite parties against the Maronites. 
The Shah had already warned the Maronites of the widening tension in Lebanon. "Make the Christian leaders understand that the era of your domination over other Lebanese minorities has finished. Tell them that the durability of your leadership would not be feasible anymore. Thus, you need to deal with the Muslims. Otherwise, a domestic political explosion would erupt," the Shah instructed Qadar to convey his message to President Suleiman Frangieh in the early 70s. ${ }^{1094}$ In the heat of the War, the Shah advised President Elias Sarkis via Qadar that "the Muslims in Lebanon joined the Palestinians in fighting with you, the Christians, because you have not considered them in the politics." Qadar conveyed the message to the President, as well as other leaders, like Prime Minister Rashid Karami and former prime ministers, Saeb Salam and Abdallah el-Yafi. Nonetheless, the Shah's advice fell on deaf ears. ${ }^{1095}$

By September 1975, Lebanon was entangled in a full civil war. Despite its initial decision to stay out of the war, Amal was gradually dragged into it as the Shia intensified their moderate cooperation with the LNM and Fatah. In spite of recognizing the Maronites insecurity and their need for holding the power monopoly, Sadr had been blaming them for ignoring the underdeveloped Shia regions in the South. Amal counted about 1,500 to 3,000 armed militants backed by Arafat and Jumbalat. By early 1976, the LNM and PLO, along with their allies, controlled about $80 \%$ of Lebanon's territory. It was a major blow to the Maronites.

\footnotetext{
1093 Beirut 213/201, SAVAK Documents, 5 May 1975; Beirut 213/196, SAVAK Documents, 5 May 1975; SAVAK Documents, No.251514/245, 16 August 1975.

${ }^{1094}$ Interview with Major General Mansour Qadar, Oral History, Foundations for Iranian History.

1095 Interview with Major General Mansour Qadar, Oral History, Foundations for Iranian History.
} 
As time wore on, however, Sadr's relations with his allies turned sour. While the Shia were not heavily involved in the Civil War, they were among the major victims of the war. Amid the war, the South became the center of the PLO and therefore more Shia died in the fighting than members of any other communities in Lebanon. With the end of the first phase of the war, the South was under the full control of the PLO. To add insult to injury, several PLO guerrillas disrespected the Shia people, treating them in an uncivilized way, harassing the Shia inhabitants in 'Fatah-land' and raping Shia girls. ${ }^{1096}$ Though regularly expressing the sympathy of the Shia for the PLO, Sadr grew increasingly impatient with Fatah's loose organization and Israeli on-and-off invasions of the South. The Palestinians were finally blamed by Sadr for the Shia plight by drawing Israeli retaliatory attacks in to the region. On top of that, Sadr gradually saw Arafat's cooperation with Druze leader Kamal Jumblatt as a danger to the Shia community since the LNM competed with Amal to win Shia members. He also criticized the PLO for establishing astate-within-a-state in Lebanon. ${ }^{1097}$ It was within this context that Sadr changed Amal's position in the war and sided with the Maronites. ${ }^{1098}$ Amal officially abandoned the LNM in May 1976 when Syria intervened in Lebanon on the side of the Maronites militias and against the LNM and the PLO. By 1976, minor clashes between the PLO militias and Amal had increased to the extent that Sadr pressed Hafez Assad to deploy the Syrian Army in Lebanon. In the meantime, the Maronites were on the verge of defeat, particularly after the

\footnotetext{
${ }^{1096}$ Fatah-land refers to a part of southern Lebanon where Palestinian guerrillas set up their military bases in the aftermath of the Black September of 1970.

1097 The Cairo agreement of 3 November 1969 gave the Palestinian guerrillas permission to launch anti-Israeli operations from the south of Lebanon. The agreement, in fact, provided the PLO a status autonomy in the South that allows them to operate outside of Lebanese sovereignty.

1098 See also Interview with Major General Mansour Qadar, Oral History, Foundations for Iranian History.
} 
Damour Massacre, convincing President Frangieh to call for Syria intervention. Assad ultimately unleashed the Army on 1 June 1976 in order to bring the PLO back under Syrian influence. The Syrian troops soon occupied Beirut and other major cities and easily brushed aside the LNM and the PLO. The imposed cease-fire did not last long as Syrian-backed Phalanges managed to break through the defenses of the Tel al-Zaatar refugee camp in East Beirut in August 1976 and killed about 2,000 Palestinians. The Tel al-Zaatar catastrophe prompted the Arabs against the Maronites, Syrians, and Sadr. Siding with the Christians and the Baath Syrian had shattered Sadr's symbolic power in Lebanon.

\section{Seyyed's Loneliness}

The outbreak of the civil war obliterated most, if not all, of Sadr's achievements during the preceding years. For the Shia community, the war intensified tensions with the Maronites, the Druze, the Sunni Lebanese, and the Palestinians. Sadr's only achievement was siding with Assad. Indeed, Sadr's influence in Syria increased after his successful intervention in the termination of the civil war in Lebanon. ${ }^{1099}$ Nonetheless, he had been denounced as a Syrian mercenary and therefore, soon became the main target for several assassinations during summer $1976 .{ }^{1100}$ At the same time, the radical Maronite criticized Sadr and Amal for siding with the PLO in the initial round of the war. ${ }^{101}$ His major Shia foes, like Kamel Asaad, accused Sadr of spreading leftism and Marxism among the Shia through his militias. ${ }^{102}$ Interestingly, a majority of the Iranian revolutionaries criticized

\footnotetext{
${ }^{1099}$ SAVAK Documents, No. 213/425, 10 August 1977.

${ }^{1100}$ P. Theroux, The Strange Disappearance of Imam Moussa Sadr (London, 1987) p. 41.

${ }^{1101}$ SAVAK Documents, No. 213/161, 14 June 1977.

1102 SAVAK Documents, No. 213/445, 20 August 1977.
} 
his anti-PLO position. Amid the war, the Marxist Fadaiyan harshly denounced Sadr since they had supported anti-Syrian Abu Abbas, ${ }^{1103}$ the Sultat al-Majalis, and the Organization of Communist Action. The Fadaiyan were also against the Lebanese Communist Party because of its ties with the Iranian Tudeh party, ${ }^{1104}$ the Soviet, Libya, and Syria.

Feeling deprived of a powerful ally, Sadr stretched his hands towards Iran. In the middle of the war, he asked Iran's embassy to support the Shia, though he was well aware of Qadar's personal enmity. In a meeting with an officer of Iran's embassy in Beirut, ${ }^{1105}$ Sadr repeated his loyalty to Iran and argued that he was "forceful to show himself neutral towards Iran's policy because the Nasserist and the leftist had framed Iran as the Arab's enemy;" therefore, he had not been able to support Iran directly. Sadr contended that he was never against the Shah and his talks with Bakhtiar had nothing to do with plotting against Tehran's regime. In the same line, he claimed that his relations with the young Iranian opposition in the Europe were justified by the fact that he did not want "to see them fallen into the trap of the communism and he had, in return, called them for the priority of Islam." He also explained that he had signed the anti-Shah statement during the Iranian riot of 1963 just "to keep his position among the religious figures in Iran." Sadr also pointed out that his few radical speeches against Iran's policy were becuase the Palestinian, Baathist, and communist all had accused him of being an Iran's agent. He also mentioned that his interference in the recent bloody civil war had saved Lebanon from falling to a catastrophic situation. For the next time, Sadr raised the Shah's promise of the financial

\footnotetext{
${ }^{1103}$ Abu Abbas had been split from Jibril's group in the middle of the Lebanese civil war.

${ }^{1104}$ The Fadaiyan had a tense relation with the Tudeh Party, Iran's major Marxist party, denouncing the Party for its officer-agent relations with Moscow.

${ }^{1105}$ SAVAK Documents, No. 213/94, 28 April 1975.
} 
support for the Shia in his last trip to Iran. He said that after his reelection as the head of the SICS, he pleaded Iran tof support of the Shia in Lebanon. More significantly, he noted that "Do not expect me to act as Iran's agent," asking Iranian officials to understand his delicate balancing policy in Lebanon. At the end, he said that he would "lead the Shia in the direction of Iran's interests and facilitate its regional policy" as far as he could and repeated his request for Iran's support of the Shia. "In contrast to the others, I want nothing for myself. The only thing I want is the progress of the Shia." ${ }^{" 106}$ Despite his limited power, Sadr was inclined to revive relations with Iran. Nonetheless, his request was disregarded. SAVAK had considered his headquarters in Tyre as a major hub for the distribution of revolutionary statements and declarations against the Shah. ${ }^{1107}$ But Sadr was still adamant in reviving relations with Tehran.

The second round of the civil war broke out in April 1976 with Sadat's support of the Palestinian groups and leftists against the Syrian army. The war finally halted in October 1976 when Damascus accepted the proposal of the Arab League summit in Riyadh. After his trip to Kuwait and Saudi Arabia, Sadr met Qadar and reported result of his successful talks on the termination of the war in Lebanon. Sadr also asked Qadar to prepare a meeting with the Shah to convince the Pahlavi monarch to mediate between Assad and Sadat in Saudi Arabia. ${ }^{1108}$ Qadar reaffirmed Sadr's “exceptional position within both Lebanon and Syria;" however, he argued that Sadr's recent contacts with Iran's embassy had to do with the Syrian leaders who saw "Your Majesty's influence in the

\footnotetext{
${ }^{1106}$ SAVAK Documents, No. 213/94, 28 April 1975.

${ }^{1107}$ SAVAK Documents, No. 213/60, 25 April 1976.

${ }^{1108}$ SAVAK Documents, No. 223/998, 12 October 1976.
} 
Middle East."1109 Rejecting Sadr's requests, Qadar initiated his secret plan: Sadr's replacement with a yes-man.

\section{Shirazi vs Sadr}

Qadar had been looking to demote Sadr from his leadership position since the early 1970s. "Sadr was a very ambitious man who intended to be elected as a Lebanese president! Sadr once sent me a message to tell the Shah that the Shia were in the demographic majority in Lebanon and they would become more influential in case of free elections. When I reported his message, the Shah responded, "It seems Seyyed [Musa Sadr] is planning to be the President of Lebanon.' The Shah then added, 'there would be no problem if an Iranian is a president." Sadr was pleased as I informed him of the Shah's message," Qadar claimed. ${ }^{1110}$ Qadar could not tolerate a strong leader.

On 10 November 1976, David Kimche, Mossad's Deputy Chief, met with SAVAK Director general Nasiri and told him "I have an offer for you: Musa Sadr is done ... it is a good opportunity for you."1111 Ten days later, Nasiri gave orders to find an alternative to Sadr. Qadar initially nominated Ja'far Sharaf al-Din to be Sadr's substitute. ${ }^{1112}$ The next possible nominee was Ayatollah Mohammad-Taghi Qomi whose background would, according to Qadar, converge the Shia-Sunni interests in Lebanon. ${ }^{113}$ SAVAK even recommended replacing Sadr with his deputy, Sheikh Mohammad-Mehdi Shamseddin, and

\footnotetext{
${ }^{1109}$ SAVAK Documents, No. 213/595, 29 August 1976.

${ }^{1110}$ Interview with Major General Mansour Qadar, Oral History, Foundations for Iranian History.

${ }^{1111}$ SAVAK Documents, No number, no date.

1112 SAVAK Documents, No. 212/17025, 5 April 1971; SAVAK Documents, No. 212/14278, 9 March 1971.

1113 SAVAK Documents, No. 213/550, 6 February 1974.
} 
support his appointment as the leader of the Shia. ${ }^{1114}$ However, none of them was as charismatic as Sadr to lead the Shia community. Within this context, a militant Shia cleric came to the scene and soon became SAVAK's candidate for Sadr's substitute: Sayed Hassan Shirazi.

Born and raised in a leading Iranian-Iraqi family of religious figures, Sayed Hassan al-Shirazi was one of the key figures of the Shirazis. ${ }^{1115}$ In the wake of rising Qasim and the Iraqi Communist Party in the late-50s, he launched an anti-communist campaign by founding a Shia organization, al-Shabab al-Hosseini, in Iraq. With the establishment of the first Baath regime, he left Iraq for Lebanon but soon returned to Karbala when Abdul Salam Arif purged the Baath Party. In the meantime, Ayatollah Khomeini left Bursa, Turkey, to Najaf in October 1965. Shirazi soon built up friendly relation with Ayatollah Khomeini and his older son, Mostafa. In contrast to Arif's partial tolerance, the second Baath regime did not tolerate the Shirazis. In may 1969, Sayed Hassan's inflammatory preaching in Karbala caused the Iraqi security service to arrest and to torture him. After his release from the Baath prison, Mostafa Khomeini suggested that he leave Iraq for Syria and Lebanon. ${ }^{1116}$ In 1970, Shirazi left Karbala for Lebanon, where he began to gather followers and found different institutions. ${ }^{1117}$ In summer 1974, Shirazi left Lebanon and settled in

${ }^{1114}$ SAVAK Documents, No. 222/1182, 19 October 1977.

1115 Sayed Hassan Shirazi's father was Ayatollah Seyed Mahdi Hussaini Shirazi, and his brothers were Ayatollah Seyed Muhamad Shirazi, Ayatollah Seyed Mojtaba Shirazi and Ayatollah Seyed Sadegh Shirazi. Other members of the Shirazis were Grand Ayatollah Mirza Hassan Shirazi, leader of Iran's Tobacco Movement, and Grand Ayatollah Muhammad Taqi Shirazi, leader of the Iraqi revolution of 1920, Ayatollah Mohammad-Taqi Modarresi and Ayatollah Hadi Modarresi.

${ }^{1116}$ Tabatabaie, Fatemeh, Eqlim-e Khaterat [Region of Memories] (Emam Khomeini va Enghelab-e Eslami research Institute, Tanzim va Nashr-e Aasar-e Emam Khomeini Organization, 2001) Vol I. p. 298.

${ }^{1117}$ Shirazi founded a Hawza Ilmiyya--Hawza Ilmiyya is a seminary where Shia clerics are trained-and Madrasat [School] al-Imam al-Mahdi, in 1971. It was the first hawza in Lebanon founded by a non-Lebanese 
Damascus, ${ }^{1118}$ where he established the Zaynabeyyah Hawza in 1974 close to Damascus. ${ }^{1119}$ Shirazi’s growing power in Syria convinced President Assad to consider him as a possible card to play against both Iraq and even Sadr in a case of his betrayal. Affiliation to Damascus could provide Shirazi a strong patron in the region. Within this context, Shirazi developed a close relationship with the Alawite community and followed the path already paved by Sadr in the approval of the Alawite as Twelver Shia Muslims. He soon became a champion of the Alawite community in Syria and Lebanon. Earlier before, on 17 December 1972, Shirazi had stressed conformity of the Alawite beliefs in every respect to those of their Twelver Shia brethren, stating, "two words, Alawite and Shia, have the same meaning. This means that a Shia is an Alawi and an Alawi is a Shia."1120 Sadr's and Shirazi's decisive endorsement of the Alawite-Shia brethren provided religious legitimacy for Assad's regime of Syria.

Sadr-Shirazi relations seemed to be initially good. ${ }^{1121}$ As time wore on, however, their relations went downhill. Shirazi's ambition to play a more decisive role in the Levant, as well as growing anti-Sadr sentiments among Lebanese leaders, brought up a widening tension between Seyyed Musa and Sayed Hassan. Shirazi was soon supported by the Maronites, Sunni, and Shia zuama. ${ }^{122} \mathrm{He}$ was "secretly supported by President Serkis

cleric. The Madrasat was closed after Shirazi's assassination. Later, Dar al-Sadegh publication and later Jama'at al-Ulama al-Lubnaniyya (Ulama Community of Lebanon) in 1977.

${ }^{1118}$ SAVAK Documents, No. 4875-4874, 17 August 1974.

1119 The Zaynabeyyah Hawza was established in the vicinity of the shrine of Sayyidah Zaynab. It was the first Shia seminary in Sunni-majority Syria.

${ }^{1120}$ The pamphlet Al-Alawiyyun, Shi'at ahl al-Bayt (Beirut: 17 December 1972), preface.

${ }^{1121}$ Tabatabaie, Fatemeh, Eqlim-e Khaterat [Region of Memories] Vol I. (Emam Khomeini va Enghelab-e Eslami research Institute, Tanzim va Nashr-e Aasar-e Emam Khomeini Organization, 2011) p. 315. 
Naoum" against Sadr. ${ }^{123}$ The Maronites sided with Shirazi to remove Sadr from the SICS since "they have been angered by Sadr in the Civil War." ${ }^{1124}$ It was the convenient context for the ambitious Shirazi to gain leverage in Lebanon. "Shirazi met with Bashir Gemayel and promised him to keep the unity and national integrity of Lebanon ... The goal of these meetings is to empower Shirazi against Sadr who has been recently disgraced by the righthand Christian Maronite groups."1125 Shirazi’s siding with the Maronites, Sunni, and antiSadr Shia elites posed a threat to Sadr. After the title of 'Imam' was conferred on Shirazi by the Lebanon government, ${ }^{1126}$ the gap between Sadr and Shirazi became unbridgeable. ${ }^{1127}$ Chamran fervently criticized Shirazi for "gathering a bunch of orthodox Muslims, making us angry and ridiculing our martyrs. They do not believe in our martyrs since their alleged Marja [Shirazi] has not permitted fighting." ${ }^{" 128}$ Amidst a polemical

${ }^{1122}$ Shirazi was heavily supported by Maronite 'Patriarch Khoraish (Anthony Peter Khoraish was the $75^{\text {th }}$ Maronite Patriarch of Antioch and the Whole Levant between 1975 and 1986), Bachir Gemayel (Bachir Gemayel was one of the major Lebanese leaders in the Civil War. He was the supreme commander of the Lebanese Forces militia and president-elect assassinated on 14 September 1982), Amin Gemayel (Amin Gemayel was the leader of Kataeb Party and President of Lebanon, in place of his assassinated brother, Bachir, from 1982 to 1988), and Camille Chamoun,' Shia 'Kazim al-Khali, Kamel al-Asaad, Cheril al-Qeys and Mohsen Salim (A Shia politician and former Member of Parliament.),' and Sunni Sheikh Hassan Khaled. See Beirut 9830 to Ministry of Foreign Affairs, 25 July 1977; Beirut 213/30 to Tehran, from 213 to 231, 22 January 1978; Tabatabai, Mohammad Sadeq, Kahterat-e Siasi Ejtemai [Socio-political Diaries] (Moassese Tanzim Nashr Asar Emam Khomeini, 1388) vol. 1, p. 377.

${ }^{1123}$ Beirut to Tehran, SAVAK document, 14 April 1977.

${ }^{1124}$ Beirut to Tehran, No. 226, SAVAK document, 14 April 1977; Iran's Ministry of Foreign Affairs to SAVAK, 213 to 334.

${ }^{1125}$ Beirut 213/147, SAVAK documents, 20 April 1977.

1126 'Imam' was supposed to be entitled to the head of the SICS.

${ }^{1127}$ Tabatabai, Mohammad Sadeq, Kahterat-e Siasi Ejtemai, Moassese Tanzim Nashr Asar Emam Khomeini, 1388, vol. 1, p. 377.

${ }^{1128}$ Tabatabai, Mohammad Sadeq, Kahterat-e Siasi Ejtemai [Socio-political Dairies] (Moassese Tanzim Nashr Asar Emam Khomeini, 1388) vol. 1, p. 378. 
atmosphere in Lebanon, there was consensus among the Lebanese elites on the need to challenge Sadr.

On 16 April 1977, relations between Sadr and Shirazi deteriorated as a bloody fight between Sadr's supporters and Shirazi's followers erupted in Sayyidah Zaynab Mosque. ${ }^{1129}$ The Syrian regime soon limited Shirazi's activities and finally forced him to leave Syria for Beirut. Even Ayatollah Khomeini who had often avoided taking a clear position on internal cleavages among the Iranian opposition and the Shia condemned the Sayyidah Zaynab Mosque tragedy. In contrast to the majority of his followers, ${ }^{1130}$ Ayatollah Khomeini, who "was already convinced by Sheikh Nasrollah Khalkhali, Sadr's close friend," 1131 sided with Sadr and "declared a fatwa banning paying Sahm al-Imam (Share of Imam) $)^{1132}$ to Shirazi and Zeynabiyya in Summer 77." 1133

Given the circumstances, SAVAK capitalized the rift between the two Shia leaders to weaken Sadr's status in Lebanon and Syria. ${ }^{1134}$ SAVAK initially had no positive view towards Shirazi. For SAVAK, Shirazi was "an adventurous, non-trustworthy man who has

\footnotetext{
${ }^{1129}$ Beirut 146-145 to SAVAK, 17 April 1977.

${ }^{1130}$ Ayatollah Khomeini-Sayed Hassan Shirazi's connection was so extensive as such that Ardeshir Zahedi, Iran's Minister of Foreign Affairs, once claimed, "Khomeini launched the Revolution in Qom, but it was Shirazi who delivered his message to the World in Karbala." (al-Osbou al-Arabi, 2 July 1979, no 1029, p.28). Shirazi also tried to convince Ayatollah Khomeini to leave Iraq for Syria. Although Ayatollah considered seeking refuge in Damascus, he finally left Najaf to Paris by October 6, 1978.

1131 Ayatollah Nasrollah Sedghi Hasani, known as Khalkhali, was Ayatollah Khomeini’s close aide who financially supported pro-Khomeini forces. He died months before the Islamic Revolution, on 4 March 1978.

1132 According to hadiths, the share belonging to God, Prophet, and Dhi 1-Qurba (close relatives of the prophet) belongs to the leader of the Islamic society (the Prophet (s) or Imam). This share is called the Sahm al-Imam (share of Imam). Shia Marja, instead of Imam, receives this share during Occultation of Imam alMahdi and spends it the same as Imams did in the past as hadiths testify. See http://en.wikishia.net/view/Khums.

${ }^{1133}$ SAVAK 497, Syria to Tehran, 17 September 1977

${ }^{1134}$ SAVAK Documents, No. 213/191, 9 January 1977.
} 
supported Khomeini's treacheries. He has gathered adventurous gangs in Sayyidah Zaynab Mosque, Syria. Shirazi has a bad record and backing him would not be in Iran's interest." ${ }^{\prime 135}$ Nevertheless, a drastic shift in Iran's non-state foreign policy in Lebanon accelerated the question of Sadr's replacement. "Two years ago, a SAVAK representative in Beirut held a negotiation with Shirazi. At that time, however, Sadr's position was strong and the Christian supported him. However, now all forces and fronts saw him as a traitor and a foreigners' stooge," Qadar described Sadr's position in the post-War era. ${ }^{1136}$ Despite the lack of trust, Iran's embassy in Beirut began building a friendly connection with Shirazi to remove Sadr from Lebanon. In doing so, Qadar provided a well-prepared plan that was supposed to establish "an organization constituted of young, educated Shia to prevent the fall of the Shia community into the orbit of the Communism." ${ }^{1137}$ To convince Tehran officials, the plan was framed as a part of the demands requested by the "right-hand Christian forces" of Lebanon. According to Qadar, "they begged Iran for backing the organization since the [current] Shia leaders [Sadr] have lost their position due to their demagoguery, corruption, and leftism.." ${ }^{, 138}$ After negotiating with young Shia leaders, like Ezzeddin and Mohsen Salim, Qadar pressed for Sadr's removal from the SICS and his replacement with Shirazi. As a next step, Qadar suggested that Bachir Gemayel and Mohsen Salim convince the Vatican and Patriarch Khoraish, Vatican representative to Beirut, to approve Sadr's replacement. The Machiavellian ambassador also offered them

\footnotetext{
${ }^{1135}$ Beirut 213/147, SAVAK documents, 20 April 1977.

${ }^{1136}$ Beirut 213/191 to Iran's Ministry of Foreign Affairs. 18 April 1977.

${ }^{1137}$ Beirut 213/191 to Iran's Ministry of Foreign Affairs. 18 April 1977.

${ }^{1138}$ Ibid.
} 
to grant Shirazi Lebanese citizenship by introducing him as "an inhabitant of a Shia town in the Christian-based Kasrawan region." ${ }^{1139}$ Shirazi was then granted the Lebanese citizenship. The operation was soon approved by Patriarch Khoraish and then-president Sarkis Naoum. In the next step, Qadar met Sayed Hassan Shirazi to negotiate on his "future duties." Shirazi, in return, expressed his loyalty to Iran and stated "he had been the Shah's servant in the past and would be honored of this until his death." He added that he would not be "unfaithful and ungrateful like Sadr." 1140 Constituted of "young, educated Shia without any connections to corrupt, socialist-demagogic Shia leaders [i.e., Sadr]" and led by Mohsen Salim, the Qadar-backed list was "broadly advertised by Lebanese newspapers." $" 1141$ The operation was supposed to "launch a heavy propaganda in favor of Sayed Hassan Shirazi in Beqaa [Valley] and Baalbek" to change the power arrangement within the SICS and have Sadr lose its presidency. In a report, Qadar assured that "antiSadr political-religious leaders will likely support the plan. After Shirazi's appointment as the new head of the SICS, there would be an invisible Shia-Christian alliance... to prevent leftism among the Shia." ${ }^{1142}$ For the next time, Iranian officials highlighted the communist threat to justify their activities. The report was ultimately submitted to the Shah. However, the Pahlavi monarch did not welcome the plan, stating that "Actually, nobody can trust these people [Shia Clerics]. ${ }^{1143}$ Nasiri agreed with the operation, yet moderatetly, stating

\footnotetext{
${ }^{1139}$ Ibid.

${ }^{1140}$ Beirut 213/191 to Iran's Ministry of Foreign Affairs. 18 April 1977.

${ }^{1141}$ Ibid.

${ }^{1142}$ Beirut 213/191 to Iran's Ministry of Foreign Affairs. 18 April 1977.

${ }^{1143}$ Ibid.
} 
"in my view, none of these persons [Shirazi and Sadr] are trustworthy and we cannot trust them now and future. Shirazi's [political] record is not better than Sadr's; however, it would be great if they compete and then weaken each other." ${ }^{\prime 144}$ The Qadar-backed organization, the Shia Muslim Organization, was established; however, Sadr's charisma was untouchable enough to avoid challenge. By May 1977, the operation had failed and Shirazi and Qadar did not manage to establish an effective anti-Sadr front. ${ }^{1145}$

Nevertheless, Shirazi kept his ties with anti-Sadr forces in Lebanon, particularly the Maronites. ${ }^{1146}$ Iran's embassy in Beirut was still playing with him against Sadr. In a meeting with Qadar, Shirazi stated that "both Christian and Shia religious-political elites in Lebanon had been very displeased with Sadr's support for the Leftist and the Palestinian groups in the Civil War, of Sadr's blood smeared hands of the innocent Shia, and of the formation of the Amal." He informed Qadar of his candidacy, backed by these elites, for "the religious leadership of the Shia in Lebanon" as well as "the presidency of the SICS." At the end of the meeting, "Shirazi expressed his deep respect for the Shah" and stated "serving the leader of the Shia World, the Shah, is necessary and an honor for every Shia." ${ }^{1147}$ In another meeting with Qadar, Shirazi confirmed that "he had dedicated one hundred Lebanon Lira for his anti-Sadr campaign." Soon, he expressed his loyalty to the Shah, accentuating that "he had been the Shah's servant in the past and present and his view [towards the Shah] was different from his father's and brothers'." He contended that

\footnotetext{
${ }^{1144}$ Ibid.

${ }^{1145}$ Beirut 213/30, SAVAK Documents, 1 May 1977.

${ }^{1146}$ Beirut 213/33 to Tehran, SAVAK Documents, from 713 to 213, 31 January 1978.

${ }^{1147}$ Beirut 9830 to Iran's Ministry of Foreign Affairs, 25 July 1977.
} 
"when he had been insulted and tortured at the Baath prison, when they had shaved his beard, he rejected talking against Iran and the Shah in Radio Baghdad." Shirazi strongly rejected his past tensions with Tehran and contended that "he left his father's house when Khomeini had been invited there and he had not returned there yet [to express his objection]. He hoped not to be seen responsible for their brothers and father's activitiesShirazi's father and brother have no relations with Khomeini anymore." He lastly put emphasis on his specific way [that] saw the Shah as the leader of the Shia World and he had never deviated from this path." ${ }^{, 148}$ Pleased with Shirazi's obedience, Qadar attempted to convince SAVAK and Tehran to back Shirazi. "While he is not as smart and talkative as Sadr," "Sayed Hassan Shirazi is a talented, active young man who can be attracted to Iran [policy and interests] if he is well-supported by Iran"1150 and "the Christians and anti-Sadr Shia figures." ${ }^{\text {1151 }}$ Qadar insisted that "It is imaginable that Shirazi enjoys such power to be Sadr's substitute... He has come to the Iranian embassy in Beirut for the support." 1152 Calling Shirazi a "friend of Iran's embassy,"1153 Qadar used the Cold-War language to convince Tehran by highlighting his anti-communist background, claiming that "Shirazi plans to establish an organization to challenge Sadr. He has met with several

\footnotetext{
${ }^{1148}$ Beirut 471 to Iran's Ministry of Foreign Affairs, 10 September 1977.

${ }^{1149}$ Beirut 213/33 to Tehran, SAVAK documents, from 713 to 213, 31 January 1978.

${ }^{1150}$ SAVAK documents, 223/1479, 10 December 1977.

${ }^{1151}$ Beirut 213/33 to Tehran, SAVAK documents, from 713 to 213, 31 January 1978.

${ }^{1152}$ Iran's Ministry of Foreign Affairs 3334-8 to Setad Bozorg Arteshtaran, edare etelaat va zed-e etelaat, from 213 to 713 .

${ }^{1153} 25$ February 1978. SAVAK Documents, No.213/869, 7 March 1978.
} 
Lebanese leaders. Shirazi also stated that he had fought with Communism and now is interested in Iran and the Shah."

Shirazi, in return, provided information for Qadar on Sadr's connection with the Iranian revolutionaries, informing him of "joining several young Iranians, already dispatched by some dissident clerics under the label of Mojtahed to Damascus where Iranian Seyed Ahmad Vahedi has sent them to Chamran for military training in Amal military bases under the supervision of the Palestinian Fatah officers." ${ }^{1155}$ In another report, Shirazi informed Qadar of a group of young Iranians, tied with Fadayian, trained by the George Habash's group in Amal military bases. ${ }^{1156}$ Despite this cooperation, Qadar did not manage to replace Sadr with Shirazi. Indeed, Sadr's prestige within the Shia community, Lebanon, and the region was a major obstacle to the accomplishment of Qadar's plan. On top of that, Iran's change of heart in its policy towards Lebanon was a decelerator in taking an active role in Lebanon. Within this context, neither Qadar nor Shirazi was able to remove Sadr. Even after Sadr's disappearance, Shirazi could not fill his void. “After Sadr's disappearance, and despite his tension with Sadr, Shirazi intensified his activities. He has provided a proper opportunity to be Sadr's substitute by participating in different interviews. He once stated that the Shia World had lost one of the greatest and most unique

\footnotetext{
${ }^{1154}$ Beirut 213/30 to Tehran, SAVAK Documents, from 213 to 231, 22 January 1978.

${ }^{1155}$ SAVAK Documents, No. 213/869, 25 February 1978.

${ }^{1156}$ SAVAK Documents, No. 213/869, 7 March 1978.
} 
leaders." 1157 Only a year later, on 1 May 1980, Shirazi was shot to death in Beirut by agents of the Iraqi regime. ${ }^{158}$ Lebanon seemed to be doomed for the Iranian Shia clerics.

\section{Final Decision}

By early 1977, Qadar had successfully framed Sadr as a threat to Iran's national security and therefore, accelerated a shift within Iran's non-state foreign policy in Lebanon. Although the Civil War and siding with Syria had weakened Sadr's image among the Palestinian, SAVAK still denounced him for having connections with the PLO. ${ }^{1159}$ With the collapse of Qadar's plan aimed at replacing Sadr with Shirazi, SAVAK and Qadar came to a conclusion to paint Sadr with an anti-Shia brush. The main target was the religious part of the Iranian society, especially senior clerics and Shia Marja. With the outbreak of the Civil War, several Iranian clerics had been dispatched by Ayatollah Shariatmadari to support the Lebanese Shia financially. On 5 March 1976, these clerics entered Lebanon to assess the Shia casualties and demands. ${ }^{1160}$ At Qadar's insistence, however, SAVAK and Ministry of Foreign Affairs pressed Ayatollah Shariatmadari to force them to return. ${ }^{1161}$ Shortly after that, when a group of Lebanese Shia clerics entered Iran to gather money for the Shia in Lebanon, Qadar warned Foreign Minister Khalatbari of Sadr's "hypocrisy" and pushed him to prevent their activities. ${ }^{1162}$

\footnotetext{
${ }^{1157}$ Seyyed Ahmad Vahedi 213/7 to SAVAK, 16 September 1978.

1158 It seems that Saddam Hussein ordered assassinating him. See Khalid Abdul-Ghaffar's, Saddam's personal aide, interview with Islamic Revolution Newspaper.

${ }^{1159}$ SAVAK Documents, No. 849, 25 August 1977.

${ }^{1160}$ Including Sheikh Mojtaba Araqi, Sheikh Reza Golsorkhi, and Seyed Younes Araghi.

${ }^{1161}$ SAVAK Documents, No. 213/19707, 2 March 1976.

${ }^{1162}$ SAVAK Documents, No. 99, 10 September 1976.
} 
Surprisingly, Iran's Ministry of Foreign Affairs took another direction and instructed all Iran's embassies "to pursue a policy to attract Sadr [to Iran], especially after his reelection as the head of the SICS."1163 Shapour Bahrami, Iran's ambassador to Cairo, had supported Sadr. In his journey to Cairo, Sadr had reassured Bahrami of his loyalty to Iran and the Shah by writing out his comments in a letter and added that with his religious position he would not accept Qadar's proposal [to be his agent]. Bahrami sent the letter to Tehran, and shortly after that, Nowzar Raz-Ara, SAVAK's Chief of Station in Cairo, reported that Sadr's loyalty to the Shah would be a great help to Iran if Sadr were allowed to operate without any limits. ${ }^{164}$ While Iran's non-state foreign policy had been managed by SAVAK since its very dawn, the Ministry of Foreign Affairs rejected framing Sadr as a threat to Iran's national security. "Other Iranian ambassadors, including Shapour Bahrami, Fereydoun Movassaghi, Abbas Nayyeri and Ahmad-Ali Bahrami, confirmed Sadr's claim [that Ambassador Qadar had a key role in transforming Iran's policy towards the Shia]. Shapour Bahrami prepared a letter to the Shah... However, the Shah never considered other ambassadors' analyses and suggestions. Conversely, he was totally influenced by Qadar. Ardeshir Zahedi, former Foreign Minister, confirmed Qadar's “bad qualities." 1165 According to another report, "Shirazi stated that Sadr has been still financially supported by the Iranian merchants and clerics. Unfortunately, Iran's ambassador to Damascus [Mohammad Pour-Sartip] supports Sadr... He added that Sadr's major financial route passes through Damascus, contending that all problems he had faced

${ }^{1163}$ SAVAK Documents, No. 2288/m/8, 14 May 1975.

${ }^{1164}$ Beigi, Abbas William, The Shah's Lebanon Policy: The Role of SAVAK. (January 1997). Middle Eastern Studies, 33 (1): 83.

1165 Fars News Agency, Interview with Ehsan Naraghi, http://www.farsnews.com/newstext.php?nn=8711240772 
were implicitly backed by Iran's ambassador to Damascus. He added they still keep their secret relations." 1166 Indeed, SAVAK and the Ministry of Foreign Affairs challenged each other over Iran's non-state foreign policy.

With the rising disagreement between the Ministry of Foreign Affairs and SAVAK, the Shah found himself obliged to interfere. Receiving mixed reports from the Ministry of Foreign Affairs, Mandour Qadar, general Hussein Fardust, and Seyyed Musa Sadr, the Shah could not devise a clear strategy towards the Lebanese Shia. With the Shah's permission, ultimately, Parviz Sabeti held the 'Commission on Musa Sadr' to make a final decision over Sadr since "to gather information on Sadr, Qadar needed SAVAK full support; otherwise he would not be able to fight with Sadr." ${ }^{\prime 167}$ The Commission consisted of elements in both SAVAK and Ministry of Foreign Affairs, including Manouchehr Zelli [former Ambassador to Lebanon], Foreign Minister Abbas-Ali Khalatbari, Hamid Nasseri [the first SAVAK Chief of Station in Beirut], and Parviz Sabeti to make the final decision on Sadr. Arguing that the issue concerned Iran's national security, instead of foreign policy, Nasseri whose views on Lebanon were considered by the Shah turned the issue to Sabeti. At this historical juncture, the commission decided that Sadr must work with Qadar. The decision was a stamp of approval of Qadar's long-term goal to have Sadr act as his agent in Lebanon. It was the end of an era in Iran-Lebanese Shia relations.

\section{Radical Sadr}

In June 1977, Ali Shariati, the most influential Iranian intellectual and the ideologue of the Islamic Revolution, died in London. ${ }^{168}$ At Sadr's direct request, President Assad

\footnotetext{
${ }^{1166}$ Beirut 471 to Iran's Ministry of Foreign Affairs, 10 September 1977.

${ }^{1167}$ SAVAK Documents, 334/2205, 7 November 1977.
} 
permitted the Iranian revolutionaries to bury Shariati in the mausoleum of Sayyidah Zaynab. Sadr officiated at Shariati's funeral ceremony of 26 June 1977. Shariati's ceremony turned into a political gathering of the Iranian revolutionaries. ${ }^{1169}$ Though held in peace without any fiery speeches against Tehran, Sadr's key role in managing the ceremony was criticized by Tehran. ${ }^{1170}$ SAVAK officials suggested a revival of Sadr's replacement plan by backing Shirazi. "Sayed Hassan Shirazi, who used to control Zeynabiyye for years, was forced to leave Syria due to Sadr-Assad strong relations. the Shrine of Sayyidah Zaynab has now become the center of several [anti-Iran] gangs, particularly [Mohammad] Montazeri and his gangs. It would be great if there is a way to empower Shirazi in a way that he could return to the Shrine of Sayyidah Zaynab and, in return, foul Montazeri's subversive activities. ${ }^{\prime 171}$ However, the substitution plan was never revived.

The Shariati's $40^{\text {th }}$ Day, held in Ameliya School, grew into an anti-Shah meeting. Despite recent clashes between the PLO and Amal, Arafat participated in the commemoration and publicly proclaimed that "Amal is Fatah and Fatah is Amal; if Amal does not support Fatah there would be no Fatah." ${ }^{1172}$ Additionally, Sadegh Ghotbzadeh and

\footnotetext{
${ }^{1168}$ He was truly an Iranian Fanon who articulated a radical interpretation of Shiism.

${ }^{1169}$ Seyyed Musa Sadr, Ebrahim Yazdi, Mostafa Chamran, Seyed Mahmood Doaei, Sadegh Ghotbzadeh, Sadeq Tabatabai, Mohammad Mofatteh, Fatah's representative and Ehsan Shariati, Ali Shariati's son, participated in the ceremony. SAVAK Documents, No. 12h20/22817, 8 July 1977.

${ }^{1170}$ Interestingly, some pro-Khomeini revolutionaries, like Eshraqi were critical of his participation. See Tabatabai, Mohammad Sadeq, Kahterat-e Siasi Ejtemai, Moassese Tanzim Nashr Asar Emam Khomeini, 1388, vol. 1, p. 141.

${ }^{1171}$ SAVAK Documents, No Number.

1172 Tabatabai, Mohammad Sadeq, Kahterat-e Siasi Ejtemai [Social Diaries] (Moassese Tanzim Nashr Asar Emam Khomeini, 1388) vol. 1, p. 112.
} 
Mostafa Chamran praised Shariati's achievements and lashed out at the regime of Tehran, accusing SAVAK of the assassination of Shariati. While Seyyed Musa moderatetly criticized Tehran, Qadar immediately prepared a report, claiming that Sadr led "inflammatory speeches against Your Majesty" in the ceremony. ${ }^{1173}$ Sadr tried to deescalate tensions with Tehran. On 18 August 1977, he sent a letter to Ambassador PourSartip, ${ }^{1174}$ stating that “since Qadar's appointment to [Iran's embassy in] Lebanon, he has been causing trouble, urging mercenaries and the Maronites against me. He has distorted and falsified reports about me because he has a personal problem with me. Thus, I have no option but to attack him and not anyone else. You know that I cannot put up with this situation anymore," Sadr bitterly complained of Qadar. ${ }^{1175}$ Sadr's earnest request fell on deaf ears. Conversely, when Qadar's report reached Tehran, the Shah ordered that Sadr be stripped off his Iranian passport on 27 August $1977 .{ }^{1176}$ It was the last nail in the coffin of Iran's non-state foreign policy in Lebanon.

Made highly-overconfident by the Shah's decision, Qadar convinced Nasiri to launch an anti-Sadr propaganda in Iranian newspapers. They distributed anti-Sadr reports, documents, and articles against Sadr, highlighting his "weaknesses, like Teymour Bakhtiar's direct intervention in dispatching Sadr to Lebanon as Abd al-Husayn Sharaf al-

${ }^{1173}$ Beirut 213/447, SAVAK Documents, 20 August 1977.

${ }^{1174}$ Qadar did not have a good relation with Pour-Sartip. "While Iran's ambassador was Pour-Sartip, it was me who handled the security issues and personal relations with Assad with Damascus," Qadar claimed. See Interview with Major General Mansour Qadar, Oral History, Foundations for Iranian History.

${ }^{1175}$ SAVAK Documents, No. 213/16427, 28 September 1977.

${ }^{1176}$ SAVAK Documents, No. 8/3610-320-2, 28 August 1977. The withdrawal from citizenship or suspension of passports was a common SAVAK method for dealing with expatriate Iranian opponents. For more discussion, see the interview with Hassan Alavi-Kia by H. Ladjevardi for the Harvard Iranian Oral History Project (1 March 1983, Paris) 
Din's substitute, having Marxist attitudes, connecting with Islamist-Marxist forces like Shariati's followers, siding with Leftists in Lebanon, urging the Shia to participate in the bloody Civil War of Lebanon, misusing financial aid mainly coming from Iran and dedicating them to establishing the communist Amal militia led by Chamran and building a center for his regalement in Paris by Ghotbzadeh, smoking opium, cooperating with radical leftist Palestinians that urged the Christians [Maronites], and finally his lack of fluency in speaking Arabic." ${ }^{1177}$ When religious clerics asked for the mediation, Tehran did not show any flexibility. In response to Jordanian Sheikh Talib, the Shah contended that "Sadr's policies in Lebanon have resulted in killing and wandering many Shias.",1178 On 27 September 1977, Sheikh Abdel Amir Qablan, then Vice-President of the SICS, sent a letter to the Shah and asked him to "save the rest of the miserable Shia people of the south of Lebanon from the Israeli bombardment." ${ }^{1179}$ The Shah, however, responded "the path the Shia are now taking is against Iran's policy." 1180 It was the Shah's final decision.

Deeply disheartened, Sadr blamed Qadar for the transformation of Iran's policy towards the Shia. In an interview with al-Hawadeth, Sadr rejected any tension with the regime of Tehran and, in return, blamed "SAVAK and Qadar for building a network of both Shia and non-Shia elements" against him. Sadr pointed out that this network had caused trouble for him in order to weaken his influence among the Shia and Lebanese. ${ }^{1181}$

\footnotetext{
${ }^{1177}$ SAVAK Documents, No. 213/466, 10 September 1977.

${ }^{1178}$ SAVAK Documents, No. 5318-p.6.

${ }^{1179}$ SAVAK Documents, No. 1168, 28 September 1977.

${ }^{1180}$ SAVAK Documents, No. 8/320-2/4750-8/320, 10 October 1977.

${ }^{1181}$ SAVAK Documents, No. 473, 1 September 1977.
} 
Interestingly, Qadar dispatched a different report to Tehran. He claimed that in his interview, Sadr had mentioned that “Iran's ambassador, supported by some of the Lebanese politicians, has been trying to politically connect the Shia with Tehran which I do not accept since it is against both national and religious interests... The Shia are Muslims and any relations with a non-Arab state [i.e., Iran] would be wrong and dangerous."1182 Qadar still insisted on framing Sadr as the Shah's enemy in the Levant.

Meanwhile, Qadar tried to antagonize Sadr and Iranian clerics. Earlier, the Shia Marja'iyyah had financially supported Sadr. According to SAVAK, Ayatollah Ashtiani had donated 1.7 million Lebanese Lire to Sadr. SAVAK also reported that despite Sadr's recently weakened status in Lebanon, the Iranian Ayatollahs had donated 271 million Lire to Sadr. ${ }^{1183}$ The Shah instructed SAVAK to see who supported Sadr. Parviz Sabeti, head of the SAVAK Third Office, prepared a list of pro-Sadr Ayatollahs. ${ }^{1184}$ Qadar's plan aimed at weakening these connections by painting Sadr as a political demagogue. Sabeti added to the report that "We should frame Sadr among the Iranian clerics as the main reason of the Shia backwardness in Lebanon." ${ }^{1185}$ In doing so, Qadar proposed that Tehran invite Ja'far Sharaf al-Din and his allies to Iran to "reveal Sadr's hypocrisy" and to prove to Iranians how Sadr had been wasting Iran's financial aid by providing weapons for Amal. ${ }^{1186}$ Prime

\footnotetext{
${ }^{1182}$ SAVAK Documents, No. (P. 307), 5 November 1977.

${ }^{1183}$ SAVAK Documents, No. (46)

${ }^{1184}$ Including Ayatollah Mohammad-Bagher Ashtiani, Ayatollah Seyed Reza Shirazi, Ayatollah AbdolKarim Mousavi Ardabili, Ayatollah Seyyed Morteza Asgari, Ayatollah Sheikh Yahya Nouri, Ayatollah Seyed Reza Sadr (Seyyed Musa's older brother), Ayatollah Seyed Abdol-Qaffar Sajadi, and Ayatollah Seyed Morteza Mostajabi.

${ }^{1185}$ SAVAK Documents, No. 134/3283, 9 January 1977.

${ }^{1186}$ SAVAK Documents, No. 1182, 30 September 1977.
} 
Minister Jamshid Amouzegar agreed with the plan. ${ }^{1187}$ Upon their arrival to Tehran, Sharaf al-Din and his fellows claimed that Sadr had not dedicated financial aid, gathered from Iranian clerics, to proper goals. ${ }^{1188}$ Qadar-Sabeti's core plan was to frame Sadr as a corrupt leader who had stolen money provided by Tehran and collected by senior Iranian clerics, but the Shah did not support Sharaf al-Din's financial request. ${ }^{1189}$ The second group of Shia clerics, headed by Sheikh Ali Faqihi, visited Iran. They focused on riling Ayatollahs Shariatmadari, Golpayegani, and Khansari against Sadr. Tehran then ordered the Lion and Sun to support the Lebanese people injured in the South by providing financial assistance via anti-Sadr clerics. ${ }^{190}$ Later, Sheikh Hussein Dabouq, an anti-Sadr Shia cleric, ${ }^{1191}$ criticized Sadr's leadership and accused him of wasting 60 million Lire donated by the Shia Marja to the SICS. ${ }^{1192}$ He called Sadr a "demagogue" and called Amal "a group of bandits" in Lebanon. ${ }^{1193}$

Qadar's anti-Sadr policy also consisted of distributing a few books against him in Iran. SAVAK had reacted to an article on Sadr published in the Rastakhiz Newspaper in Tehran. ${ }^{1194}$ In early 1978 , a book and a pamphlet, written in Farsi, were widely distributed

${ }^{1187}$ SAVAK Documents, No. m1-/600-1-20, 6 October 1977.

${ }^{1188}$ Major among them were Sheikh Salman Yahfoofi (Mufti of Baalbek), Ahmad Shoqi al-Din (the judge of Bent Jabil), Sheikh Yousef Asaad Abdel-Satter and Mohammad-Ali Seyyed Abdel-Saheb. SAVAK Documents, No. 1274, 17 October 1977.

${ }^{1189}$ SAVAK Documents, No. 213/16592, 26 November 1977.

${ }^{1190}$ SAVAK Documents, No. 5250-3/5114, 12 December 1977.

${ }^{1191}$ He had connections with Sayed Hassan Shirazi, Ja'far Sharaf al-Din and Kamel Asaad and supported by Iran's embassy in Beirut SAVAK, 213/16665, 17 January 1978.

${ }^{1192}$ Beirut 213/605, SAVAK Documents 16 January 1978.

${ }^{1193}$ SAVAK Documents, No. 592, 5 December 1977.

${ }^{1194}$ The article was originally published in a French weekly magazine, Le Nouvel Observateur. See SAVAK Documents, No. 213/895, 11 March 1978. 
among Iranians living in Beirut. In these books, Sadr was introduced as "a foreigners' agent and the Christian's collaborator." ${ }^{\prime 195}$ The book and the pamphlet were submitted to the Pahlavi monarch. He instructed, "the book and pamphlet should be distributed here [in Iran], too." ${ }^{, 196}$ With the Shah's direct intervention, Qadar prepared a sufficient number of books and pamphlets and distributed them in Qom, Tehran, and other cities of Iran. ${ }^{1197}$ It was a blow to Sadr's image.

The worst was yet to come. On 14 March 1978, Israel launched Operation Litani, occupying the area south of the Litani River, excepting Tyre. Nevertheless, the Israeli Defense Forces (IDF) were not able to crush the PLO conclusively as the Palestinians withdrew to the North and avoided engaging with the Israelis. The major victims of the invasion were the civilian Shia. After a week, the IDF agreed to withdraw from the South. Nonetheless, Tel-Aviv turned over the occupied territory to its new ally, the South Lebanon Army (SLA), led by Major Saad Haddad. In the rest of the country, the UN Interim Force in Lebanon (UNIFIL) set its bases. Part of the UNIFIL was constituted by Iranian soldiers. While Iran did not dispatch its troops to Lebanon at Sadr's request, Sadr welcomed it. He told his followers "My long-term goals had been finally accomplished." ${ }^{1198}$ It was too late, though.

\footnotetext{
${ }^{1195}$ SAVAK Documents, No. 8/270-2/316, 18 April 1978.

${ }^{1196}$ Ministry of Foreign Affairs DB/5254 to SAVAK, 13 November 1977; SAVAK Documents, No. DB/5254, 13 December 1977.

${ }^{1197}$ Ibid.

${ }^{1198}$ SAVAK Documents, No. 8/270-2/316, 18 April 1978.
} 


\section{Chapter 7}

\section{Resurrection: Iran's Non-State Foreign Policy in 1977-1979}

With the termination of Iran's support for the Iraqi Kurds and the Lebanese Shia, Iran's non-state foreign policy apparently came to an end. Nevertheless, Pahlavi Iran unsuccessfully tried to revive its connections with the both Kurdish and Shia non-state actors. Convinced by SAVAK and the Israelis, the Shah planned to contain the rising Iraq by reallocating supplies to the Iraqi Kurds. At the same time, he tried to revive his relations with Sadr. Nonetheless, the waves of the Islamic Revolution forced the Shah to abort these plans. 


\section{Resurrection-The Iraqi Kurds}

"Have the Kurdish people committed such crimes that every nation in the world should be against them?" Mullah Mustafa Barzani told the American media.

\section{The Shah's Strategic Misstep?}

The Algiers Agreement of 1975 was Mohammad Reza Shah's victory in the Middle East. For the Shah, it was a testament to his wise policies. On 15 March 1975, Iranian and Iraqi foreign ministers met in Tehran to talk about the final terms of the Agreement. Later, Prime Minister Hoveyda visited Baghdad, and in return, Saddam met the Shah in Tehran. These visits finally led to signing the Baghdad Treaty of 13 June 1975 that reaffirmed the Thalweg principle and gave Iran the east half of Arvand Rud. Iraq's concession in Arvand Rud was a major step in establishing an Iranian hegemony in the Persian Gulf. By pressing Baghdad to sign the Agreement, the Shah thought, he could restrict the Baath in the Persian Gulf and cut off Baghdad's covert support for the separatist parties in Iran as well as Marxist rebels in Dhofar in Oman.

Nevertheless, the region lacked a strong collective security institution to legitimize Iran's hegemony. In doing so, the Shah initially established the Persian Gulf Collective Security System to embody his idea of the regional leadership. He knew that to the extent that he "pushes for a reduction of [the] Soviet influence in Iraq, he will come under pressure to demonstrate to Baghdad and other Arabs that Iran is not a tool of U.S. policy in the region... Therefore, insisting that Persian Gulf security is the responsibility of littoral states" would be the best strategy for the embodiment of his regional primacy. ${ }^{1199}$ Even Saddam in his press interviews had referred to the possibility of a collective security

${ }^{1199}$ The implication of the Iran-Iraq Agreement- DCI/NIO 1039-75, 1 May 1975. 
arrangement in the Persian Gulf. According to Saddam, the Algiers Agreement ushered in a new-founded Iran-Iraq security cooperation in the Persian Gulf. ${ }^{1200}$ In this situation, there would be neither an Iranian-Iraqi nor an Arab-Persian clash. Earlier, in the Rabat summit of October 1974, Saddam had told Prince Fahd that "Iraq's major concern is to preserve the Arab identity of the Persian Gulf and is ready to cooperate with other Arab regimes to determine a legal framework for Iran's role, not to deter Tehran's threat since Iran is a legitimate power in the Persian Gulf." ${ }^{\prime 201}$ The 1978 Persian Gulf Security Conference in Masqat was the main manifestation of the post-1975 regional power arrangement. ${ }^{1202}$ The Saudis feared that Iraq, whose leaders had considered them "as inimical to Arab solidarity," would "be able to turn its attention to Persian Gulf affairs." 1203 As the Shah correctly predicted, competition among Arabs popped up over the number-two position in regional matters. The establishment of a collective security system would be based on the withdrawal of both the Russian and the American naval forces from the Persian Gulf that, in turn, could leave Iran as the only significant naval force in the Persian Gulf. A final communique issued following Hoveyda's visit to Baghdad in late March 1975 stated that the "Persian Gulf should be spared all foreign interference." ${ }^{204}$ The U.S. was, in fact, worried that "the Shah might be willing to state public opposition to the U.S. naval role in the [Persian] Gulf more forcefully in exchange for greater regional cooperation on security

\footnotetext{
${ }^{1200}$ The implication of the Iran-Iraq Agreement- DCI/NIO 1039-75, 1 May 1975.

${ }^{1201}$ Beirut 1014 to Iran's Ministry of Foreign Affairs, 14 June 1975.

${ }^{1202}$ Parsi, Trita, Treacherous Alliance: The Secret Dealings of Israel, Iran, and the United States (Yale University Press, 2007) p.57.

${ }^{1203}$ The implication of the Iran-Iraq Agreement- DCI/NIO 1039-75, 1 May 1975.

${ }^{1204}$ Ibid.
} 
matters or for concrete examples of a lessened Soviet influence in Iraq." ${ }^{1205}$ It seemed that the Shah had finally reached his long-term ambition to lead the Middle East.

Despite the Shah's efforts, the Agreement never alleviated the Arab suspicion of Iran's regional policy. Right after the announcement of the Algiers Agreement, the Americans were skeptical about a "lasting reconciliation." 1206 They saw Iran and Iraq as "natural competitors in the Persian Gulf," "the most populous states," and "rich in natural resources" with "large well-equipped army." More substantially, "both the Shah and Saddam Husain have widely differing views of how the region should evolve politically and both aspire to regional leadership and dominance." ${ }^{1207}$ Besides, in the minds of some conservative Arab leaders, especially the Omani Sultanate and the Iraqi Shia, Iran's abandonment of the Kurds raised doubts about the Shah's potential to keep the region secure from the revolutionary movements. ${ }^{1208}$ After the Agreement, Sultan Qaboos of Oman was worried about the Shah's steadfastness to support the Muscat regime against the Iraqi-backed rebels in the Dhofar. Although the Shah did not withdraw Iran's Army from Oman until the complete suppression of the Dhofari rebels, his pragmatism was framed among his allies'as Iran's selfishness.

The Shah achieved his symbolic victory in the Algiers Agreement. As time wore on, though, doubts about the consequences of the Agreement raised. Although the Agreement forced Baghdad to concede in Arvand Rud, it destroyed Iran's non-state foreign

\footnotetext{
1205 Ibid.

1206 The implication of the Iran-Iraq Agreement- DCI/NIO 1039-75, 1 May 1975.

1207 Ibid.

${ }^{1208}$ Bonnin, Richard, Arrows of the Night: Ahmed Chalabi and the Selling of the Iraq War (Anchor; Reprint edition, November 13, 2012) p. 58.
} 
policy in Iraqi Kurdistan and stripped the country of its Kurdish lever over Iraq. The Shah "in effect, traded performance for promises in Algiers, and there were few assurances that Iraq would want to honor all those promises once it had mastered its Kurdish problem." ${ }^{1209}$ According to the U.S., Iran would not be able to revive an effective Kurdish uprising inside Iraq if the Baath regime chose to back away from of the Agreement. Indeed, by pulling the rug from under Iraqi Kurds, the Shah made Iran's western border more vulnerable. On the contrary, the Agreement won time for the Bath regime. In the post-Algiers Agreement, Baghdad's resources were all channeled to economic development and military armament, enabling Iraq to increase the size of its Army and double its military spending between 1975 and 1980. The Agreement also enabled Saddam to consolidate his position in Baghdad. In spite of conceding to the Shah in Arvand Rud and partially damaging Iraq's national pride, the Agreement allowed Saddam to unchain Iraq from its Kurdish cause and to lessen the danger of war with Iran. In the aftermath of the Agreement, Saddam initiated an anti-communist campaign and suppressed the ICP. Even President al-Bakr's power was limited. ${ }^{1210}$

Besides, the terms of the Algiers Agreement were mainly perceived to be at the expense of Baghdad. With the Kurdish threat gone and empowered by a rapid growth of Iraqi oil income, Baghdad could now attempt to subvert the Persian Gulf states. Although Arab moderate leaders, particularly Anwar Sadat, had argued that the Agreement would lead to a more moderate Iraq, the Arab conservative sheikhdoms were worried about Iraqi

\footnotetext{
${ }^{1209}$ The implication of the Iran-Iraq Agreement- DCI/NIO 1039-75, 1 May 1975

${ }^{1210}$ Al-Bakr's power was limited especially after the 1977 rise of Iraqi Shia in the south of Iraq when al-Bakr lost his control over the Ministry of Defense and Adnan Khairalla Tulfah, Saddam's brother-in-law, became the new minister. Though al-Bakr remained as president, Baath Party leader, and Revolutionary Command Council chairman, he had little control over Iraq.
} 
capability in sponsoring subversion and Arab radicalism. The U.S. State Department also argued that "the Iraqi Baathist leadership remains revolutionary in outlook and committed to trying to overturn conservative and moderate regimes in the [Arab] Peninsula and the [Persian] Gulf." In the U.S. view, Baghdad had "adopted a two-tiered policy. It actively courts its neighbors on the diplomatic level, while it continues to interfere in their affairs." 1211 In other words, the Agreement provided Baghdad an opportunity to "build its clandestine assets by quietly expanding Baathist cells in the small [Persian] Gulf countries and increasing support for local dissidents. ${ }^{1212}$ In short, Saddam could enter the Arab world stage under the banner of pan-Arabism without any fear of a Kurdish uprising.

As the Shah himself pointed out, Iraq remained a threat to Iran. He feared that Baghdad would attack Iran with the full support of the Arab states of the region and Moscow. According to the Iranian Ministry of Foreign Affairs, "The volume of Iraqi armaments with regards to its population and territory are much more than Iran's." ${ }^{1213}$ The Shah himself witnessed the increasing Russian sales of Scud missiles with offensive capabilities to Baghdad. In his interview with Newsweek in the November 1977, the Shah revealed Iran's apprehension towards Iraq: "We have settled our differences with Iraq, but their military buildup continues. And I wonder how many of your editorial writers and congressmen realize that Iraq has more planes, tanks, and guns than we do-[even] groundto-ground SCUD missiles." ${ }^{\text {214 }}$ The Shah was right that Saddam merely considered the

\footnotetext{
${ }^{1211}$ The implication of the Iran-Iraq Agreement- DCI/NIO 1039-75, 1 May 1975.

1212 The implication of the Iran-Iraq Agreement- DCI/NIO 1039-75, 1 May 1975.

${ }^{1213}$ Iran's Ministry of Foreign Affairs 21810/25, 6 February 1975.

1214 Parsi, Trita, Treacherous Alliance: The Secret Dealings of Israel, Iran, and the United States (Yale University Press, 2007) p.55.
} 
Algiers Agreement to be a truce, rather than a definite settlement, and waited for an opportunity to contest it. The opportunity for Iraq came just five years after the Agreement. However, it was too late for the Shah to take an effective alternative strategy towards Iraq. More significantly, the Agreement damaged Iran's image among the Kurds. Earlier, in the middle of Tehran's heavy support for the Iraqi Kurds, the Kurds saw the Shah as an Aryan King and supporter of Kurds who would help them to gain their independence. However, the Shah's brutal decision in Algiers killed their dream. Initially, some die-hard Peshmerga were hopeful of Iran's change of heart to resume its military support for the Kurds. As the dust settled on the battlefields of Iraqi Kurdistan, the harsh reality set in. Besides, what fueled the Kurds' anger was the way the Shah treated them after signing the Agreement. Amid Tehran's pressure to either surrender to Baghdad or flee to Iran, the Kurds were attacked by a sudden Iraqi offensive. It seemed that the Iraqi had crossed the border with Iran and launched their invasion from Mehran, a western city in Iran. Pejman claimed that the Shah had not permitted Iraqi army to use Iran's territory to crack down the fighting Peshmerga; rather, it was Nasiri who had not informed the Shah of the Iraqis' transgression of Iran's territory. ${ }^{1215}$ Nonetheless, Barzani and the Kurds blamed the Shah for Iran's brutal decision against the Kurds. He claimed that "Isa Pejman sold us out to the Shah and the Shah sold us out to the U.S." 1216 The Kurds could not digest why the Shah cooperated with an Arab leader whose lifelong hatred of Iran and the Kurds was evident.

\footnotetext{
${ }^{1215}$ Qaneifard, Erfan, Tondbad-e Havades: Goftogooi ba Isa Pejman [Hurricane of Events: A Dialogue with Isa Pejman] (Elm Publication, Tehran, 2011) p.201.

${ }^{1216}$ Ibid. p.191.
} 
The Algiers Agreement also brought up what the Shah had been worried about since 1946--it revived the Kurdish question in Iran. In the aftermath of the Agreement, Iraqi Kurdish refugees had become the main source of insecurity in western Iran. Although Iran's Army had disarmed the Peshmerga and isolated them from the civilian refugees, Baghdad knew that the Kurdish refugees would pose a greater potential national security threat to Iran than to Iraq. Besides, the majority of Iran's own Kurds expressed dismay at Tehran's abandonment of support for the Iraqi Kurds. Shortly after the Algiers Agreement, anti-Shah declarations were secretly disseminated in major Kurdish cities, particularly Mahabad. ${ }^{1217}$ The Shah himself was sensitive to the Iranian Kurds' reactions to the Agreement. "It seems that the Kurds expected us to ignore our national interests just because of them," the Shah reacted to SAVAK report on the Kurds' dissatisfaction of the agreement. ${ }^{1218}$ In the meantime, the young urbane Kurds joined radical, leftist, and separatist Kurdish parties. The Marxist Tudeh Party also revived its influence in Iranian Kurdistan. The growing formation of these groups revived a separatist threat to Iran's national security and unity. The debacle of the Pahlavi monarchy gave the Kurds a fertile ground to challenge the revolutionary Iran.

\section{The Last Efforts in the Last Days}

The Algiers Agreement divided the Iraqi Kurds for almost a quarter of a century. Although there had been deep internal tensions between the Kurdish factions since 1964, the Agreement deepened an unbridgeable conflict within the Kurdish leadership. The

\footnotetext{
${ }^{1217}$ SAVAK Document, No number, No Date.

${ }^{1218}$ Qaneifard, Erfan, Tondbad-e Havades: Goftogooi ba Isa Pejman [Hurricane of Events: A Dialogue with Isa Pejman] (Elm Publication, Tehran, 2011) p.191.
} 
Agreement damaged Barzani's prestige and authority and left the Kurds without an effective rebel commander. As Barzani bitterly accepted terms of the Agreement and fled to Iran with his sons, Idris and Masoud, Talabani and Ahmad objected to his decision and chose to keep fighting. ${ }^{1219}$ They criticized Barzani for poor leadership and blamed him for a naïve trust in the Shah. When Iraq launched its last offensive, the rest of the KDP elites left the north of Iraq to Syria and joined Talabani who had left Beirut where he had been posted as the KDP representative since the early 70s. Backed by Hafiz Assad, whose Baath regime had been questioning Saddam's leadership of the Arab people in the post-Nasser era, Talabani and his friends founded the Patriotic Union of Kurdistan (PUK) on 1 June 1975. The PUK guerrillas launched their attacks on Iraqi positions in late 1975 and continued through 1976. In spite of moderate Syrian support, the PUK Peshmerga were only able to operate in the highest regions of the south Kurdistan Mountains. ${ }^{1220}$ When the clashes between the Iraqi Army and the PUK escalated, Saddam invited both Ahmad and Talabani to settle the crisis. However, their request for autonomy was immediately rejected by Baghdad. Despite its initial successes, the Iraqi air force heavy bombardment of their strongholds and a rising tension with the Barzanis weakened the PUK operations. In August 1976, Idris and Masoud Barzani, together with Sami (Muhammad Mahmud) Abd al-Rahman, formed the KDP-Provisional Leadership (KDP—PL). In July 1976, a longrunning feud between two groups was rekindled as Barzani's Peshmerga ambushed and assassinated several PUK guerrillas. ${ }^{1221}$ Talabani vowed revenge and thus minor

\footnotetext{
${ }^{1219}$ Other major figures were Ibrahim Ahmad, Omar Dababeh and Ali Asgari.

${ }^{1220}$ The major bases of the insurrection were between Nawkan, in Iranian Kurdistan, and Kandil, in South Iraqi Kurdistan.

${ }^{1221}$ McDowall, David. A Modern History of the Kurds (London: I.B. Tauris, 2007 ed) p. 344.
} 
skirmishes took place in winter 1977. However, a full-blown war erupted in the Baradust area in April 1978, when Talbani's allies, Askari and Khaled Saeed, were killed by Barzani's Peshmerga. Other PUK leaders, like Bab Sheikh Yazidi, were also killed by Barzani's Peshmerga who were recently supported by Turkish MIT and Iraqi Istikhbarat. The Iranian SAVAK's position was still confused.

The Algiers Agreement formed a détente between Iran and Iraq and temporarily calmed their long-term rivalry. Tehran-Baghdad relations improved in 1978 to the point that SAVAK agents in Iraq informed Iraqi Istikhbarat of a pro-Moscow plot against the Baath regime. Saddam immediately executed dozens of Iraqi Army officers. As a sign of total reconciliation, he expelled Ayatollah Ruhollah Khomeini, the Shah's major exiled leader, from Iraq to Paris ${ }^{1222}$--a decision that accelerated the emergence of the Islamic Revolution. In the aftermath of the Baghdad Treaty, the Shah initially took a counterrevolutionary stance against the Iraqi Kurds. SAVAK participated in the suppression of the PUK whose leader, Talabani, spelled out that "Iraq, Iran, and the KDP-PL are all our enemies." ${ }^{1223}$ As time wore on, though, Iran's strategy changed. With the rising Iraqi threat, the Shah was worried that the U.S. would see the upcoming war with Iraq as a local, remote crisis and leave Tehran to fight alone the Soviet-backed Iraq. By 1978, SAVAK officials asked the Shah to shift his strategy towards the Iraqi Kurds. Indeed, SAVAK's request was a quiet admission of Tel-Aviv's argument that the Algiers Agreement had lifted a heavy burden from Baghdad. The Mossad had already sensed the Shah's suspicions of Baghdad's rearmament. With both SAVAK and the Mossad's insistence, the Shah planned to revive

\footnotetext{
${ }^{1222}$ Farrokh, Kaveh. Iran at War: 1500-1988 (Oxford: Osprey Publishing) p. 46.

${ }^{1223}$ Talabani to PUK HQ (Damascus), Nawkan, 20 June 1978.
} 
Iran's non-state foreign policy in Iraqi Kurdistan. The cooperation between Israel, Iran, and the Barzanis renewed, though gradually, in 1978. SAVAK also held secret negotiations with the PUK. Although SAVAK tried to convince both the KDP-PL and the PUK to cooperate against Baghdad, Talabani approved Iran's offer of support only if SAVAK broke with Idris Barzani and the KDP-PL. ${ }^{1224}$ However, SAVAK took a neutral stance on the issue and stayed away from the Kurdish competition. Only four SAVAK agents, including Colonel Pejman, were aware of and involved in the operation to reopen the Kurdish corridor. "When the Shah asked me how to revive the connection with the Kurds, I offered him to put emphasis on a long-term propaganda to change their hearts and minds towards Iran. I also argued that the plan should not be implemented by SAVAK since the Kurds hate SAVAK after the Agreement ... the Shah asked me to write a detailed plan and submit it to Director Pakravan. I did it; however, the plan was never implemented." 1225 Although Tehran considered the proposal, the Iranians never offered a definite reply, according to the Israelis. ${ }^{1226}$ Indeed, the Shah had been concerned by the consecutive demonstrations in Tehran and Iran's major cities. In the meantime, Barzani, who had been diagnosed with lung cancer, travelled to the U.S. He died on 1 March 1979, and was then buried in Eshnavieh in Western Azarbaijan, Iran's North Western province. ${ }^{1227}$ By this time the Islamic Revolution had occurred in Iran.

\footnotetext{
${ }^{1224}$ McDowall, David. A Modern History of the Kurds (London: I.B. Tauris, 2007 ed) p. 345.

${ }^{1225}$ Qaneifard, Erfan, Tondbad-e Havades: Goftogooi ba Isa Pejman [Hurricane of Events: A Dialogue with Isa Pejman] (Elm Publication, Tehran, 2011) p.202.

${ }^{1226}$ Parsi, Trita, Treacherous Alliance: The Secret Dealings of Israel, Iran, and the United States (Yale University Press, 2007) p. 77.

${ }^{1227}$ Karim Sanjabi, head of the National Front and the first Foreign Minister after the Islamic Revolution, convinced Ayatollah Khomeini to permit Barzani's burial in Iran.
} 


\section{Resurrection--The Lebanese Shia}

"The thought that the Imam Moussa had gone into concealment to re-emerge transcendent had also occurred to us," ${ }^{2228}$ Richard Parker, U.S. Ambassador to Lebanon reported.

\section{Waves of the Islamic Revolution}

In late 1977, the situation was bleak for the Lebanese Shia. Syria had occupied the heartland of the Shia in Lebanon, Beqaa Valley, while the PLO were fighting against Israelis in the south of Lebanon. Although Tel-Aviv had forced the PLO and LNM guerrillas to withdraw from the South, many Shia civilians were savagely killed by Israeli shelling and air strikes. Despite his Amal militia, Sadr was not a warlord. Sadr pleaded the Arab leaders of Algeria, Saudi Arabia, Jordan, and Syria to support the Shia. However, anti-Sadr resentment had been growing. The Civil War had already shakened Sadr's reputation in the region. According to Qadar, "Amir Turki, ${ }^{1229}$ the deputy Defense Minister, criticized all Lebanese leaders, including Sadr. He contended "this man [Sadr] has a fallacious appearance, talking rightly while acting in contrast to what he said. He is fickle, joining new gangs every day." ${ }^{1230}$ On top of that, major Lebanese groups, as well as the PLO, were against him. Tehran had clearly cut off its connections with the Shia. Even Iranian revolutionaries, i.e., pro-Ayatollah Khomeini, the Mojahedin, and the Fadaiyan were lashing out at his stance in the middle of the Civil War. Sadr was alone.

\footnotetext{
${ }^{1228}$ Beirut 05430_d to the U.S. State Department, 19 September 1978, Wikileaks.

1229 Turki bin Abdulaziz Al Saud also known as "the second" (because he is the second son born to King Abdulaziz named Turki), was a deputy defense minister from July 1969 to 1978 . He was forced to resign due to his controversial marriage. His nephew, Turki bin Faisal Al Saud also known as Turki al-Faisal, is the chairman of the King Faisal Center for Research and Islamic Studies. He was the powerful director general of Al-Mukhabarat al-A'ammah, Saudi Arabia's intelligence agency, from 1977 to 1 September 2001, ten days before the September 11 attacks, when he controversially and mysteriously resigned the position.

${ }^{1230}$ Iran's Ministry of Foreign Affairs, No Number, No Date.
} 
Amidst these dark days, an event two thousand kilometers further from Lebanon transformed the fate of the Lebanese Shia: The Islamic Revolution of 1979. "Iran, because of the great leadership of the Shah, is an island of stability in one of the more troubled areas of the world," President Carter raised a toast to the Shah at a state dinner in the Niavaran Palace on 31 December 1977 and praised him as a great leader who had won "the respect and the admiration and love" of his people. However, Iran's stability did not last long. Within weeks of Carter's visit, massive waves of demonstrations broke out in the religious city of Qom and then Tehran and other cities of Iran. The growing waves of demonstrations, the Shah's apparently inflexible policy towards the Lebanese Shia, and his friends' key roles in leading the Revolution convinced Sadr to take a more radical policy towards Tehran. ${ }^{1231}$ In his interview of 4 March 1978, Sadr pointed out that the Shah was supporting the U.S. policy in the region stirring the Muslims against the Palestinians. ${ }^{1232}$ Sadr's pro-Revolution policy was followed with his efforts to assuage the Arab conservative regimes' suspicion over the rise of a Shia-Islamic revolution in Iran. He told Prince Abdollah that "there is an imminent revolution in Iran, led by Ayatollah Khomeini. The Revolution is neither Shia nor Iranian. This is a pure Islamic Revolution. I want you not fall in an American trap and instead, have a good relation with the Revolution.. ${ }^{, 233}$ On 23 August 1978, Sadr wrote an anti-Shah article, 'the Call of the Prophet', published in Le Monde, arguing that "Iran's revolution is different than all other movements in the world." He pointed that this movement was related to neither right nor left, adding that "the Iranian

\footnotetext{
${ }^{1231}$ Sadr's friends, including Mehdi Bazargan, Yadollah Sahabi, Ebrahim Yazdi, Ayatollah Seyyed Mohammad-Hussein Beheshti and Sadegh Ghotbzadeh, were chief elements who played key roles in leading the Islamic Revolution.

${ }^{1232}$ SAVAK Documents, No Number, No Date.

${ }^{1233}$ SAVAK Documents, No Number, No Date.
} 
revolutionaries are not representative of a specific social class ... The motive of this movement is Faith ... that reminds the call of the Prophet." ${ }^{\text {1234 }}$ Less than a week later, he traveled to Libya to a mysterious fate.

\section{A Mysterious Journey}

On 25 August 1978, Sadr traveled to Tripoli at Gaddafi's invitation with two members of the SICS, Sheikh Muhammad Yaacoub and journalist Abbas Badreddine. Though scheduled to leave Tripoli on an Italian Alitalia flight, Sadr and his companions never arrived at Rome. Despite facts to the contrary, Tripoli insisted that Sadr and his companions had departed Tripoli bound for Italy. The Libyan claimed that "the imam [Sadr] and his two companions departed Tripoli on Alitalia flt 881 for Rome august 31. The Italians, however, maintain that the persons traveling under the names of the three Shi'a personalities did not meet the description of the imam and his companions." "1235 According to Qadar, "Sadr never entered to Rome. Somebody else entered Rome with Sadr's passport." "236 Sadr's supporters argued that his baggage was found in a hotel in Tripoli without any sufficient evidence for his trip to Italy. It was the beginning of Sadr's disappearance.

Although Richard Parker, the U.S. Ambassador to Beirut, claimed that "few people will mourn him, even if he has disappeared permanently" since "the Imam is notoriously corrupt even by Lebanese standards,"

\footnotetext{
${ }^{1234}$ Tabatabai, Mohammad Sadeq, Kahterat-e Siasi Ejtemai [Social Diaries] (Moassese Tanzim Nashr Asar Emam Khomeini, 1388) vol. 1, p. 174.

1235 Tripoli 01335_d to the U.S. Department of State, WikiLeaks, 24 September 1978.

${ }^{1236}$ Interview of General Mansour Qadar with Gholam-Reza Afkhami in the Oral History of Iran Program, Foundation for Iranian Studies, Bethesda, MD, US, 1986.

${ }^{1237}$ Beirut 05339_d to the U.S. Department of State, WikiLeaks, 13 September 1978.
} 
September 14 to discuss his disappearance after the SICS pressed Prime Minister Selim Ahmad al-Hoss. Al-Hoss told the press that "the information obtained so far had been 'negative' and added that an official delegation, including Omar Musayki, the secretary general of the Prime Minister's office, would be sent to Libya and other countries to search for Sadr. ${ }^{, 238}$ Rumors soon spread. Initially, many guessed Sadr's return would be likely. According to Lebanese officials in Tripoli, "Imam left Tripoli on September 2 for 'quiet week in Paris." ${ }^{1239}$ In the middle of "Sadr's followers' hunger strike," "the Italian interior ministry was reportedly asking authorities on Malta to search for the imam to see if he had flown there from Rome." ${ }^{1240}$ According to another report, it was believed that Sadr "was alive and well and was either in Malta or near Lake Como. He was being kept under house arrest by Gadhafi agents who were teaching him a lesson." ${ }^{1241}$ However, nobody found him.

The immediate suspect in Sadr's abduction was Colonel Muammar Gaddafi. Tripoli's relation with Sadr was ambiguous. Right after the outbreak of the Civil War, Gaddafi launched an anti-Sadr campaign in May 1975. In Gaddafi's view, Sadr's Movement of the Deprived had weakened the leftist position among the Shia in the south of Lebanon. ${ }^{1242}$ After the formation of Amal, however, Sadr traveled to Libya in September 1975 and, according to SAVAK, was promised by Gaddafi to support his policies in

\footnotetext{
${ }^{1238}$ Beirut 05339_d to the U.S. Department of State, WikiLeaks, 13 September 1978.

${ }^{1239}$ Tripoli 01265_d to the U.S. Department of State, WikiLeaks, 13 September 1978.

${ }^{1240}$ Beirut 05640_d d to the U.S. Department of State, WikiLeaks, 27 September 1978.

${ }^{1241}$ Beirut 05714_d d to the U.S. Department of State, WikiLeaks, 30 September 1978.

${ }^{1242}$ Beirut 213/303, SAVAK Documents, 2 June 1975.
} 
Lebanon. ${ }^{1243}$ Their relations went again downhill as Sadr sided with the Syrian Army and the Maronites in cracking down on the PLO. Besides, it seems that Sadr had refused to follow Gaddafi's demands. There were accounts that the money Gaddafi had donated to Sadr was missing. Rifaat al-Assad, the head of Syrian security and Hafiz Assad's brother, told Brigadier-General Ali Motazed, Iran's Ambassador to Syria and former Deputy of SAVAK, ${ }^{1244}$ that Gaddafi had been planning to kill Șadr. Qadar claimed that "Gaddafi had donated about 12 million dollars to Sadr to organize Amal forces and the Palestinian guerrillas under the name of Amal. Initially, both Amal and Palestinian ran two or three successful terrorist operations. Shortly after that, Sadr unexpectedly refused to follow the plan... When the word reached Gaddafi, he asked for the payback, but Sadr objected to Libyan's intervention in Lebanon internal politics. Since then, Gaddafi was looking for a proper moment to punish him." ${ }^{1245}$ SAVAK also prepared a report based on the Syrian sources, arguing that "Colonel Gaddafi had disagreed to Sadr's policy in the south of Lebanon and his strong opposition to the Palestinian groups. Gaddafi also considered Sadr as a fanatical, religious, and dependent on the right wings [of Lebanese parties]. It also seems that Sadr has spent money donated by Gaddafi on the Shia, instead of Gaddafi's political goals. Therefore, Gaddafi intended to punish him by arresting him." 1246

\footnotetext{
${ }^{1243}$ Beirut 213/1022, SAVAK Documents, 30 August 1975.

${ }^{1244}$ His real name was Ali Nakhjiri-Esfahani.

${ }^{1245}$ Interview of General Mansour Qadar with Gholam-Reza Afkhami in the Oral History of Iran Program, Foundation for Iranian Studies, Bethesda, MD, US, 1986.

${ }^{1246}$ SAVAK Documents, No 618/213, 1 November 1978.
} 
Whether true or not, it was obvious that Gaddafi expected Sadr's full obedience. Additionally, the Libyan leader's anti-Shia attitude might have driven Gaddafi to kill Sadr. Colonel Joloud, the second strongest man in Tripoli, had claimed that the Shia were all Iran's spies when he was in the UAE. ${ }^{1247}$ According to SAVAK, Gaddafi had "become pessimistic about Shiism." ${ }^{1248}$ Additionally, Sadr's disappearance might have to do with his criticism of Gaddafi over Libyan dictator's superficial knowledge of Islam. According to Abdel Rahman Shalgham, Algerian President Houari Boumediene had convinced Sadr to travel to Tripoli. At the time, Gaddafi had announced his strange view towards Quran and Islam. Upon Sadr's arrival to Tripoli, the Shia leader criticized Gaddafi and told him, "You know nothing of Islam. You insult Islam and the Prophet." Sadr's points made Gaddafi very angry. ${ }^{1249}$ Mostafa Chamran also pointed to a discussion over Islam between Sadr and Gaddafi. According to Chamran, Sadr told Gaddafi that "if you transgress the sacred Islamic Sharia, your wife would be religiously prohibited for you since your marriage was based on Islamic Sharia. It would be a catastrophe if you transgress the sacred Islamic Sharia." ${ }^{250}$ According to Qadar, "after giving a speech in a religious institution, Sadr met with Gaddafi. In the meeting, Gaddafi insulted him and then gave orders to kill Sadr and his two companions in a barrack $30 \mathrm{kms}$ South-West from Tripoli. A Libyan diplomat handed this information to the Lebanese ambassador to UN." ${ }^{\text {"1251 }}$ Succinctly put,

\footnotetext{
${ }^{1247}$ Al-Havadeth, No. 144, 13 October 78.

${ }^{1248}$ SAVAK Documents, No 618/213, 1 November 1978.

${ }^{1249}$ Shalgham, Abdel Rahman, Sabz va Siah [Green and Black], translated by Ali Mousavi Khalkhali (Ozam Publisher, Tehran, 1392).

${ }^{1250}$ See http://www.mashreghnews.ir/fa/news/459203.

${ }^{1251}$ Interview of General Mansour Qadar with Gholam-Reza Afkhami in the Oral History of Iran Program, Foundation for Iranian Studies, Bethesda, MD, US, 1986.
} 
Sadr's refusal to enter agent-officer relations with anti-Shia Gaddafi who had already provided Sadr a huge amount of money and his discussion about Gaddafi's Islamic knowledge had paved the way to his disappearance or death.

The American officials were also suspicious of Gaddafi's claim. According to both Beirut and Tehran offices, Nizar Farhat, the Lebanese charge', "suddenly left Tripoli on sept $19 \ldots$ We suspect he knows more than he has told anyone locally... Embassy Beirut might find that Farhat has left behind in Lebanon additional information on the increasingly mysterious case of the missing imam." ${ }^{1252}$ The American officials also approached the Lebanese Foreign Minister Boutros. "Boutros said he had summoned Farhat to hear what he had to say. He would be returning to Tripoli. From what he and others reported, it appeared imam had not gone to Rome as Libyans claimed. He did not understand what Gadhafi had in mind." ${ }^{\prime 253}$ The Lebanese Shia were still unconvinced by these arguments. "Shia deputy Abdul Latif Zein told me later that Shi'a are convinced Libyans are lying. Leaders of the massive procession ... were received by Gadhafi who gave them some reassurance, but not enough. Muammar told them he was very disturbed that his official guest, Imam Moussa, had left without being able to call on him because he had been busy with September 1 festivities... Facts were, however, that Libyan story full of holes. For instance, imam's effects, and those of his companions, had been left at hotel in Tripoli. They would not willingly have left them behind. Hotel was still claiming they were there three days after they were supposed to have left. Imam was compulsive telephoner and if he was at liberty he would have been on telephone long before this. He was either prisoner

\footnotetext{
1252 Tripoli 01335_d to the U.S. Department of State, WikiLeaks, 24 September 1978.

${ }^{1253}$ Beirut 05614_d o the U.S. Department of State, WikiLeaks, 26 September 1978.
} 
or dead, and deed had been done in Libya. Zein said one reason Shi'a had taken conform from Gadhafi's remarks was that latter had said he had intended help imam Moussa with his projects for south Lebanon but had never given him a cent. Alleged motive for Gadhafi's doing away with him was that imam had embezzled $\$ 150,000,000$ given him by Libyans. That rationale, at least, seems ill-founded." ${ }^{1254}$

The Palestinian groups were also among the suspects. Immediately, some allegations emerged that Sadr was killed by Libya over Sadr's relations with the PLO. Shia deputy Abdul Latif Zein suspected Palestinians might have done him in. ${ }^{1255}$ It was obvious that the PLO leaders, even Arafat, criticized Sadr's opposition to the PLO military bases in Southern Lebanon. Right after Sadr's disappearance, the Lebanese leftists and the Palestinians launched an anti-Sadr campaign. As Chamran wrote in his letter to Yazdi, "They spread rumors every day. On a wall of Sour (Ture), they wrote, "Sadr embezzled and [then] escaped." 1256 Another stronger rumor was related to George Habash's role in killing Sadr. Habash had begun challenging Sadr's position since Sadr was against a plan to demilitarize the Palestinian guerrillas in the south of Lebanon that could have deteriorated the Shia socio-economic situation. ${ }^{1257}$ It seems that Gaddafi had killed Sadr at the request of the Palestinians.

Interestingly, some rumors highlighted the role of Damascus in Sadr's disappearance. These accounts argue that Hafez Assad had increasingly considered Sadr's

\footnotetext{
${ }^{1254}$ Beirut 05614_d o the U.S. Department of State, WikiLeaks, 26 September 1978.

${ }^{1255}$ Ibid.

${ }^{1256}$ Yazdi, Ebrahim, Shast Sal Sabouri va Shakouri [60 Years of Patience and Gracefulness] (Tehran, Fall 1390, Nashr-e Majazi) Vol III, pp. 624-25.

${ }^{1257}$ SAVAK Documents, No. 289, 32 July 1978.
} 
influence, though diminished after the Civil War, as an obstacle to its leverage over Lebanon, in general, and the Shia, in particular. According to Qadar, Syria played a direct, decisive role in Sadr's disappearance. "In early 1978, Rifaat Assad asked me to come over to Damascus. In the meeting with him and President Assad, they stressed Syrian enmity of Iraq and their plan to overthrow the Baath regime of Baghdad. They emphasized that only the Shah could help them to accomplish the mission. They said, "we know that you Iranians have agents and networks in Karbala and Najaf. We also know that you are still supporting the Iraqi Kurds. We are going to join you in the support for the Kurds. However, Syria has no border with the rebel-controlled territory in the North of Iraq. So, we want you to permit us to load armament in Khorramshahr and then deliver it to the Iraqi Kurds [Jalal Talabani's PKK]. By intensifying the support for the Kurds and pinning down the Iraqi Army in Kurdistan, we can lead a coup to overthrow the Baath regime with your agents' support in Najaf and Karbala. We, in return, can compensate your favor." I reminded them of IranIraq détente in the Algiers Agreement of 1975. But they insisted on the cooperation with Iran and promised to close the Hawza Zainabiyya and to arrest the [anti-Shah] clerics. More interestingly, they clearly claimed that "Musa Sadr would not be in the Lebanese politics by summer 1978." Shocked by their claim, I asked them, "What do you mean by Sadr's issue?" They responded, "the Shah himself knows." Due to the urgency and significance of the issue, I did not return to Beirut and left Damascus to Tehran with the British Airways. When I met the Shah and explained him the details of the meeting, he strongly rejected Syria's offer and stated, "We have already settled down the issue of the Kurdish rebels and the border disagreements with Iraqis." But when I raised Sadr's issue, he immediately interrupted me and said, "well, they [the Syrian regime] wants to kill Seyyed Musa." After 
a short period of silence, the Shah told me, "let them know that we can close our eyes at loading the weapons in Khorramshahr. We will not interfere." Right before leaving the Palace, the Shah added, "Inform this foolish Seyyed [of the Syrian plan]." Despite all troubles Sadr had caused [for Iran], the Shah was an emotional man who did not want to hurt anybody. Upon my arrival to Damascus, I informed Rifaat Assad of the Shah's response. In the wake of demonstrations in Iran, they quickly sent weapons to Khorramshahr. Nevertheless, the Syrian armament was surprisingly seized by the Iranian officials. The Syrian leaders strongly reacted. I told them that it had been a mistake since the Shah had already instructed." In the meantime, Sadr was planning to visit Libya. Right before his trip, I asked Ja'far, an Iraqi businessman who often connected me with Sadr, to set a meeting. I had intended to make him aware of Damascus plan, but, in the wake of the Revolution, Sadr did not accept to see me. While I insisted to Ja'far to convince him to meet me, Ja'far responded, "Seyyed can not see you since he leaves Beirut to Damascus and then to Tripoli tomorrow." ${ }^{1258}$ According to Qadar, Syrian leaders planned to kill Sadr and, at the same time, intended to make Tehran agreed to this move by facilitating the support for the Kurds. Damascus thought that Sadr's removal would be rewarded by the Shah. As Qadar claimed, "It was Damascus plan to kill Sadr, but due to Sadr's leverage among the Syrian Alawite, they let the Libyan kill him." 1259 "Assad," he added, "used the rising tension between Sadr and Gaddafi by framing Seyyed Musa as a traitor who had connections with the Americans. Assad pushed Sadr to travel to Tripoli to reconcile his

\footnotetext{
${ }^{1258}$ Interview of General Mansour Qadar with Gholam-Reza Afkhami in the Oral History of Iran Program, Foundation for Iranian Studies, Bethesda, MD, US, 1986.

${ }^{1259}$ Ibid.
} 
relations with Gaddafi, but in reality to be killed by Gaddafi." ${ }^{1260}$ Thirty years later, after a bloody debacle of Gaddafi's regime, Hannibal Gaddafi ambiguously claimed that Hafez Assad had played a key role in Sadr's disappearance. ${ }^{1261}$ More interestingly, Qadar claimed that the Shah had asked him to inform Sadr of the Syrian plot. Was it because of the Shah's emotion or did he have his own plan with Sadr?

\section{The Shah-Sadr Secret Deal?}

The Pahlavi regime of Tehran was gradually blamed by the Shia community for Sadr's disappearance. The Maronites Kataeb claimed that Sadr had entered Najaf to see Ayatollah Khomeini to increase their cooperation against the Shah. ${ }^{1262}$ According to Ambassador Parker, Tehran had denounced Sadr for embezzling funds donated to Lebanon for the benefit of the Shia community. ${ }^{1263}$ A-Safir, a major leftist Lebanese newspaper, claimed that the Shah had been behind Sadr's disappearance, asserting that Sadr was kidnapped by the Iranian security services because of his support for Ayatollah Khomeini and the Iranian revolutionaries. ${ }^{1264}$ Another rumor was that it was Tel-Aviv or the CIA that kidnapped Sadr and surrendered him to Tehran. ${ }^{1265}$ Sadr's mysterious disappearance was extensively framed as an Israeli "plot to split the ranks of Lebanese Muslims." 1266 The CIA

\footnotetext{
${ }^{1260}$ Ibid.

${ }^{1261} \mathrm{http}: / /$ www.parsine.com/fa/news/267142.

1262 SAVAK Documents, No. 5921, 14 July 1978.

${ }^{1263}$ Beirut 05339_d to the U.S. Department of State, WikiLeaks, 13 September 1978.

${ }^{1264}$ Beirut 05339_d to the U.S. Department of State, WikiLeaks, 13 September 1978; Tripoli 01290_d to the U.S. Department of State, WikiLeaks, 15 September 1978.

1265 SAVAK Documents, No. 211/287, 21 July 1978.

${ }^{1266}$ Beirut 05476_d to the U.S. Department of State, WikiLeaks, 20 September 1978.
} 
was also accused of kidnapping Sadr. Parker reported that "this affair grows mysteriouser and mysteriouser. To date, we have not been blamed, but that will not last. we will shortly be hearing [a] story that only an intelligence service like CIA could have done such a neat job... On September 25, Shia mufti of Baalbek told reporters that "the disappearance of the imam was arranged in cooperation with U.S. intelligence." ${ }^{1267}$ According to Ambassador Parker, "Most Muslims to whom we have talked believe he is still in Libya or has been kidnapped by Iranians, CIA, or someone else." ${ }^{1268}$ In fact, blaming Iran and his allies of Israel and the U.S. for Sadr's disappearance fit a growing Anti-Shah sentiment in the late 70s. "When Sadr was disappeared, the Lebanese Shia attacked to Iran's embassy in Beirut since they thought Sadr's major enemy was Iran's embassy. But Sadr's son pacified the angry people and asked them to leave the place and instead gathered around Libyan embassy," Qadar stated. ${ }^{1269}$ As time wore on, though, the theory of Iran's participation in Sadr's disappearance was downgraded. As Zein stated, "Had he [Sadr] gone to Iraq or Iran, as alleged by some, he would have surfaced by now."1270

In reality, however, both the Shah and SAVAK had been shocked by Sadr's disappearance. Despite rising tension between Sadr and SAVAK, it seems that unrelenting waves of demonstrations had prompted Tehran to reconsider its policy towards the Shia ulama. Although the Shah had tightened the political domain for both Marxists and Nationalists since the coup of 1953, his main opposition emerged from the Shia clerics. As

\footnotetext{
${ }^{1267}$ Beirut 05614_d to the U.S. Department of State, WikiLeaks, 26 September 1978.

${ }^{1268}$ Beirut 05430_d to the U.S. Department of State, WikiLeaks, 19 September 1978.

${ }^{1269}$ Interview of General Mansour Qadar with Gholam-Reza Afkhami in the Oral History of Iran Program, Foundation for Iranian Studies, Bethesda, MD, US, 1986.

${ }^{1270}$ Beirut 05614_d to the U.S. Department of State, WikiLeaks, 26 September 1978.
} 
demonstrations spread across the Iranian cities other than Tehran, the necessity of approaching more moderate ulamas, including Sadr, became more apparent. In contrast to Qadar's reports, SAVAK had considered Sadr's gradual closeness to Ayatollah Khomeini and his radical followers due to his urgent need for the financial support. ${ }^{1271}$ SAVAK was, in fact, well aware of tensions between powerful pro-Ayatollah Khomeini elements and Sadr. In addition to their disagreement over the Palestine cause, Ayatollah Khomeini's Marja'iyya, and dealings with the Shah, Sadr's view towards Velayat-e Faqih (the Guardianship of the Islamic Jurist) was also a controversial issue. It seems Sadr did not believe in Ayatollah Khomeini's doctrine of Velayat-e Faqih. With the escalation of crisis in Iran, Tehran instructed Qadar to abandon his animosity to Sadr. SAVAK officials suggested that it would be better to approach Sadr by sending him a Quran. The suggestion was immediately rejected by Qadar. ${ }^{1272}$ However, Qadar was not as powerful enough anymore to prevent an unexpected shift in Iran's policy towards Sadr. In a surprising report, less than three weeks before Sadr's mysterious disappearance, Ambassador Qadar finally changed, or was forced to change, his mind and reported to Tehran that "it would be better to work with Sadr, in spite of fighting against him."1273 It seems there had been a grand deal between Tehran and Sadr in the middle of demonstrations in Iran.

In a meeting of 2 October 1978 with William H. Sulivan, the last U.S. ambassador to Tehran, and Anthony Parsons, the UK ambassador to Tehran, Iranian Prime Minister Ja'far Sharif-Emami claimed that "his government had been in contact with Imam Musa

${ }^{1271}$ SAVAK Documents, No. 334, 12 November 1977.

${ }^{1272}$ SAVAK Documents, No. 213/13264, 3 August 1978.

${ }^{1273}$ SAVAK Documents, No. 213/13227, 20 July 1978. 
Sadr shortly before latter's disappearance in Libya. He claimed that Musa Sadr had agreed to break with Ayatollah Khomeini and announce his support for the Shah. At one point, he used the phrase "we had brought him off." Sulivan added, "If the wily imam had indeed made a deal with the GOI [Government of Iran], while at the same time allegedly acting as a channel for Libyan funds being sent to Khomeini, this fact could be a contributing element in his disappearance. I would imagine that colonel Gaddafi does not appreciate being double-crossed." 1274 There have been narratives of Sadr's efforts aiming at diverting Ayatollah Khomeini's “momentum." ${ }^{1275}$ Despite the fact that he had been stripped of his passport, Sadr had been seen by several religious figures, including Jafar Shahidi, as a major scholar in Persian literature and historian of Islam, a month before his disappearance. Whether there was a secret deal between the Shah and Sadr, neither Tehran nor Seyyed Musa revealed it. Indeed, SAVAK and Tehran were optimistic that they might make an effective breach among the revolutionaries by the revival of Iran's non-state foreign policy in Lebanon.

\section{Sadr's Disappearance and the Iranian Revolutionaries}

Sadr's long-running tension with several Iranian revolutionaries endangered his life. Interestingly, most of the anti-Sadr's revolutionaries had been heavily supported by Gaddafi. Mehdi Firouzan, Sadr's nephew and his son-in-law, accused Gaddafi's supporters, particularly Jalal ad-Din Farsi, of playing a key role in Sadr's disappearance. "Some of Gaddafi-allied Iranians during the Revolution still have key information on

\footnotetext{
${ }^{1274}$ Tehran 09565_d to the U.S. Department of State, WikiLeaks, 3 October 1978.

${ }^{1275}$ See "The Shah of Iran, the Islamic Revolution and the Mystery of the Missing Imam," New York Times, January 15, 2016.
} 
Imam's Sadr's disappearance." 1276 Firouzan believes that what happened to Sadr was related to Tripoli's plan to gain leverage in revolutionary Iran. "Mummer Gaddafi tried to gain leverage among high-ranked positions [among the revolutionaries] to usurp the Revolution. However, he could not penetrate the Council of the Revolution. His allies belonged to the second generation of the Revolution, rather than popular figures, like Mottahari and Beheshti. Threfore, Gadhafi-backed Jalal ad-Din Farsi ran for the presidency [after the establishment of the Islamic Republic] but he was later disqualified by the Council of the Revolution and Gaddafi's plot was thwarted."1277 According to Firouzan, "Farsi is one of the closest Gadhafi's allies. He is proud of this relationship." ${ }^{1278}$ As Sadegh Tabatabaie stated, “in response to Sadr's fate, Jaloud himself had said, 'Go and ask Jalal ad-Din Farsi'. " 1279 It seemed Sadr's disappearance was intertwined with the power struggle among the revolutionaries.

In addition to the Libyan plot, pro-Sadr Iranian revolutionaries argued that Sadr was kidnapped or killed for his possible role in the Islamic Revolution of Iran. According to Chamran, "Regarding Mr. Khomeini and Iran's Revolution, I should say that all the Arabs, the leftists, and the Palestinians are all frightened of Iran's Revolution and we hear they are insulting Khomeini and Iran's Revolution. Some believe that Algieria, Syria, and Palestine are all united with Libya over Sadr... They are all frightened of Iran's Revolution. They all know that Sadr is the active instigator of the Shia in Arab states and with

\footnotetext{
${ }^{1276}$ Interview with Mehdi Firouzan, Imam Musa Sadr's son-in-law, See http://fararu.com/fa/news/88120.

${ }^{1277}$ Interview with Mehdi Firouzan, Imam Musa Sadr's son-in-law, See http://fararu.com/fa/news/88120. ${ }^{1278}$ Ibid.

1279 Interview with Imam Musa Sadr's nephew, Sadegh Tabatabaie, See http://www.mashreghnews.ir/fa/news/65884.
} 
Khomeini's victory, the Shia victory would be impending. That is why they prefer not to have Sadr and prevent the spillover of Iran's Revolution into Arab countries. Thus, they would remove Sadr if they could." ${ }^{, 280}$ Al-Osboa al-Arabi newspaper also argued that “Among many reasons, Sadr's kidnapping is because of his possible, predictable position in the [Iran's] Revolution after victory... Imam Sadr's connection [with the Islamic Revolution of Iran] was strong, deep, and almost spontaneous. That is why he had become a guide for leaders of the Revolution as such that Iran's first deputy of prime minister was Dr Sadegh Tabatabaie, Imam Sadr's nephew... With a victorious revolution, Sadr's position and status would be more dynamic and effective since he could be Iran's major channel with Arab states and nations. He could be also a mediator between Islamist liberals and Imam Khomeini's movement. This role would enable him as a leader (a role that could be taken by Sadr) to make consolidate the cooperation among forces and prevent the crisis formation." ${ }^{1281}$ In short, Sadr's possible key role in the new-founded revolutionary Iran played a decisive role in his disappearance.

More significantly, it seems that Sadr's fate was intertwined with Ayatollah Khomeini's succession. "Before the Islamic Revolution, Imam Khomeini was an old man. There were several discussions on Imam's substitution among the revolutionaries in 197778 , wondering how to continue their Islamic movement after him. Some revolutionaries backed Ayatollah Montazeri, the other group believed in Ayatollah Beheshti, and the third group supported Imam Sadr. Nevertheless, none of these candidates themselves were aware

\footnotetext{
${ }^{1280}$ Yazdi, Ebrahim, Shast Sal Sabouri va Shakouri [60 Years of Patience and Gracefulness] (Tehran, Fall 2011, Nashr-e Majazi) Vol III, pp. 624-25.

${ }^{1281}$ Al-Osboa al-Arabi, 19 August 1978.
} 
of these discussions. Sadegh Tabatabaie pointed to the fourth group that backed Ayatollah Muhammad-Baqir Sadr to lead the Islamic movement after Ayatollah Khoemini. He stated that the issue of Ayatollah Khomeini's substitution had been raised in Beheshti-Sadr's talks. "Imam Musa respected his cousin, Ayatollah Muhammad-Baqir Sadr, as such that he named him as the best Ayatollah Khomeini's substitute in a conversation with Ayatollah Seyyed Mohammad-Hussein Beheshti." ${ }^{1282}$

Even before the formation of the Islamic Republic, tensions among these groups had erupted. In fact, Sadr had been challenged by the Gaddafi-backed, pro-Montazeri group over several issues. Some pro-Montazeri elements, like Mohammad Montazeri, Jalal adDin Farsi, Abu Hanif, Abu Sharif, and Ahmad Movahhedi, Iran's first representative in Lebanon after the Revolution, argued that CIA was behind Sadr's disappearance, claiming that CIA agents, i.e., Ahmad Khomeini, Ayatollah Beheshti, Ebrahim Yazdi, Sadegh Ghotbzadeh, and Mostafa Chamran, ran the operation [of Sadr's disappearance]." ${ }^{1283}$ In an interview with an-Nahar, Mohammad Montazeri strongly rejected Libyan intervention in Sadr's disappearance, accused Zionist and American mercenaries of kidnapping Sadr in Italy, and claimed that "if Libyan had intended to kill Sadr, they could have done that in Beirut, Sour or Seida."1284 Abou-Hanif also claimed that "Mr. Musa Sadr left Libya for Rome to see his wife who had been in a hospital in Paris. Mossad spies then kidnapped him in a hotel [in Rome] and sent him to a prison in Israel. Seyyed Musa Sadr was then

\footnotetext{
${ }^{1282}$ Tabatabai, Mohammad Sadeq, Kahterat-e Siasi Ejtemai [Social Diaries] (Moassese Tanzim Nashr Asar Emam Khomeini, 1388) vol. 1, p. 174.

${ }^{1283}$ Interview with Mehdi Firouzan, Imam Musa Sadr's son-in-law, See: http://fararu.com/fa/news/88120.

${ }^{1284} \mathrm{http} / / /$ tarikhirani.ir/Modules/files/Phtml/files.PrintVersion.Html.php?Lang=fa\&TypeId=3\&filesId=137.
} 
martyred by Israelis after heavy tortures. ${ }^{, 1285}$ In the meantime, Ayatollah Hossein-Ali Montazeri, then-Ayatollah Khomeini’s deputy, claimed that "within this context, raising Sadr's issue would be in the U.S. favor!" 1286

Indeed, pro-Sadr revolutionaries, mainly stationed in the Interim Government of the Revolution, were shocked of Ayatollah Montazeri's support of the pro-Gaddafi group, including his son, and Ayatollah Khomeini's meeting with Jaloud. As Chamran stated, "I do not know why the leader of the Islamic Revolution of Iran [i.e., Ayatollah Khomeini] put his hands in the criminal' hands. Did not we revolt because of God? How do not we want to tarnish the Revolution with the criminal' dirt?" Interestingly, Pro-Gaddafi revolutionaries were inexplicably certain of Sadr's fate. There have been also controversial claims over Ayatollah Beheshti's ambiguous role in killing Sadr. ${ }^{1287}$ All in all, Ayatollah Khomeini's substitution played a major role in determining Sadr's fate.

\section{The Iranian Search}

With Sadr's mysterious disappearance, religious clerics and revolutionary leaders of Iran began searching for him. From his exile, Ayatollah Khomeini made efforts to find Sadr. Ayatollah Khomeini wrote letters to both Yasser Arafat and Hafez Assad, ${ }^{1288}$

\footnotetext{
${ }^{1285}$ Ibid.

${ }^{1286}$ Ibid.

${ }^{1287}$ According to the book, Good Spy, a biography of Robert Ames, the C.I.A. station chief in Beirut at the time, it was Ayatollah Beheshti who convinced Gaddafi to kill Sadr. See Bird, Kai, The Good Spy: The Life and Death of Robert Ames (2015) pp. 541-544.

${ }^{1288}$ Khomeini, Seyed Ruhollah, Sahifeh Emam (Moassese Tanzim Nashr Asar Emam Khomeini) Vol. 3. P. 456; Khomeini, Seyed Ruhollah, Sahifeh Emam (Moassese Tanzim Nashr Asar Emam Khomeini) Vol. 3. P. 479; Khomeini, Seyed Ruhollah, Sahifeh Emam (Moassese Tanzim Nashr Asar Emam Khomeini) Vol. 4. P. 45.
} 
requesting Tripoli to reveal the mystery on 18 October $1978 .{ }^{1289}$ Ayatollah himself never trusted the Libyan dictator. As Ali Jannati, then-Minister of Culture and Guidance, narrated, "We offered Imam [Khomeini] to travel to Libya after the termination of his exile in Paris. We thought he would accept the offer but Imam did not accept it. He told us that Gaddafi was not trustworthy." ${ }^{1290}$ In a meeting with Jaloud, Ayatollah pressed him to "follow up Sadr's fate" after his arrival to Libya. ${ }^{1291}$ He told Jaloud that "the Tragedy of Mr. Sadr" would destroy relations between two nations and states. ${ }^{1292}$ "Imam was under heavy pressure to accept Gaddafi. Had he not asked Jaloud to bring Imam Musa Sadr back, Libya's allies [in Iran] would have gained high-ranked positions," Firouzan claimed. ${ }^{1293}$ "Very upset at his disappearance, which is generally regarded as a mark of disrespect to the community," 1294 the Lebanese Shia community also asked Ayatollah Khomeini to support efforts to search for Sadr. In meetings with Mohammad-Mehdi Shamseddin, the vice-president and then-president of the SICS, as well as Sadr's family and Amal's members, Ayatollah Khomeini stressed that, "Mr Sadr is a man whom I raised" and "He is one of my respected children." ${ }^{1295}$

\footnotetext{
${ }^{1289}$ Khomeini, Seyed Ruhollah, Sahifeh Emam (Moassese Tanzim Nashr Asar Emam Khomeini) Vol. 3, p. 347.

${ }^{1290}$ Jannati, Ali, Khaterat [Diaries] (Tehran, Markaz-e Asnad-e Enghelab-e Eslami) p. 43.

${ }^{1291}$ Khomeini, Seyed Ruhollah, Sahifeh Emam (Moassese Tanzim Nashr Asar Emam Khomeini) Vol. 6. P. 357.

${ }^{1292}$ Khomeini, Seyed Ruhollah, Sahifeh Emam (Moassese Tanzim Nashr Asar Emam Khomeini) Vol. 7. P. 118.

${ }^{1293}$ Interview with Mehdi Firouzan, Imam Musa Sadr’s son-in-law, See: http://fararu.com/fa/news/88120.

${ }^{1294}$ From Tehran, 1978BEIRUT05614_d, 26 September 1978.

${ }^{1295}$ Khomeini, Seyed Ruhollah, Sahifeh Emam (Moassese Tanzim Nashr Asar Emam Khomeini) Vol. 3. P. 456; Khomeini, Seyed Ruhollah, Sahifeh Emam (Moassese Tanzim Nashr Asar Emam Khomeini) Vol. 13. P. 166; Khomeini, Seyed Ruhollah, Sahifeh Emam (Moassese Tanzim Nashr Asar Emam Khomeini) Vol. 15. P. 5.
} 
Beyond Ayatollah, other religious ulama, including Ayatollah Marashi Njafi, Ayatollah Tabatabai Qomi, Ayatollah Golpayegni, Ayatollah Abdullah Shirazi, Ayatollah Shariatdmadari, and Ayatollah Taleqani were seeking Sadr. A body, consisted of three clergies, Sheikh Abdol-Qasem Rouhani, Haj Seyed Fazel Milani, and Sheikh Abdol-Hasan Asadi, was sent to Jordan and Syria on behalf of Ayatollah Seyed Abdullah Shirazi to negotiate with the Jordanian and Syrian leaders. "three clergymen reportedly flew to Damascus September 26 to seek [an] audience with president Assad and ask for assistance. They also planned to visit Amman and appeal to King Hussein. Iranian Shiite spokesman said no government has yet responded positively to hierarchy's request for aid in locating Sadr. ${ }^{, 296}$ From the city of Qom, Ayatollah Muhammad Kazem Shariatmadari also sent Gaddafi a telegram that "People in all lands know that Imam al Sadr was invited to your country and had gone there... Thus all Muslims ask the Libyan government, whom they consider responsible for this disappearance, for information about the health and wellbeing of the Imam." ${ }^{1297}$ A Shia leader in Europe Seyed Mehdi Rouhani asked President Giscard D'estaing "to order a thorough investigation of Sadr's disappearance.,"1298 Furthermore, Iranian government Pars Broadcasting reported that Sefoddin Nabavi, the speaker of Islamic Liberalizers Party (Hezb-e Azidik-Khahan-e Eslami), claimed that Sadr was probably alive. ${ }^{1299}$ "According to both actions taken by [the] Islamic Liberalizers Party

\footnotetext{
${ }^{1296}$ Tehran 09307_d to the U.S. Department of State, WikiLeaks, 26 September 1978.

${ }^{1297}$ A Summary of Initiatives and Efforts Connected with the Disappearance of Imam al Sadr," published by the Higher Shia Council.

1298 Tehran 09526_d to the U.S. Department of State, WikiLeaks, 2 October 1978.

1299 The Islamic Liberalizers Party was a new established group based on Islamic Sharia. Nabavi introduced himself as Marja's physician.
} 
and specific telegrams received by President Carter, and Abdul-Salam Joloud, the prime minister of Libya, Imam Sadr has been controlled under Libyan security service", Nabavi claimed. ${ }^{1300} \mathrm{He}$ added that Sadr had been living on the floor of an apartment in Tripoli, under the restricted control.

Along with the Iranian revolutionaries and religious figures, some nonrevolutionary groups and parties were concerned with Sadr's fate. Chief among them was Mohsen Pezeshpour, the leader of the Pan-Iranist Party and a member National Parliament (Majles-e Melli). ${ }^{1301}$ Though non-religious, Pezeshpour made a well-publicized appeal to Prime Minister Sharif-Emami's cabinet on 24 September 1978 to take all possible steps to find Sadr. ${ }^{1302}$ "Iran should fight with such anti-human actions since it has signed the declaration of the UN. More importantly, becuase Iran is the only Shia country and Shia Islam is the legal religion of this country, Iran has legal and ethical responsibilities to defend the Shia interests in each part of the world. Additionally, since Imam Musa Sadr was an Iranian born-leader of the Lebanese Shia, the Iran government must struggle to solve this problem by communicating with the regional states and international associations," Pezeskpour emphasized Iran's both religious and patriotic duty to find Sadr. In Tehran, the anti-Shah Association for Defense of Freedom and Human Rights, associated with the National Front, asked the International Association of Human Rights in New York to set up a committee to inquire into Sadr's disappearance. ${ }^{1303}$ None of these efforts were fruitful.

\footnotetext{
${ }^{1300}$ SAVAK Documents, No number, No Date.

${ }^{1301}$ Tehran 09307_d to the U.S. Department of State, WikiLeaks, 26 September 1978.

1302 Ibid.

${ }^{1303}$ Ibid.
} 
Interestingly, the main person who was looking for Sadr was neither his supporter nor an Iranian revolutionary. Rather, it was Mohammad-Reza Shah. As the word of Sadr's disappearance reached Iran, the Shah immediately instructed both SAVAK and Ministry of Foreign Affairs to pursue Sadr's fate. Eleven days after Sadr's disappearance, SAVAK reported that "Seyyed Musa Sadr, the leader of Lebanese Shia, was kidnapped by unknown men during his visit to Libya." ${ }^{1304}$ Another secret SAVAK document, sent from Israel to the SAVAK Second Office, reflected dominant theories proposed by the Lebanese newspapers. ${ }^{1305}$ The document put forward that "in addition to his travel to Libya and receiving necessary financial support, Imam Sadr might be secretly sent to Iraq to instigate a revolution in Iran." 1306 Two days after SAVAK's theory on Sadr's secret travel to Iraq, Baserinia, SAVAK chief in Qom, sent a telegram to the SAVAK Third Office, reporting a call between Reza Sadr, Seyyed Musa's older brother, and Ayatollah Shariatmadari. ${ }^{1307}$ The telegram showed that Musa Sadr had not left Libya. It also illuminated that the interference of Iran, Israel, and the Christian Lebanese in the Sadr's disappearance was not true and added that "it is possible that Libya has kidnapped Imam since a terrorist group cannot abduct him." According to the telegram, Reza Sadr had asked top Iranian officers to contact foreign security services and even the Russians in pursuing Sadr's strange case. He also added that [Ayatollah] Khomeini sent a "cold" and "spiritless" telegram to Arafat on Sadr's issue. Conversely, Arafat sent a "warm" response, calling Sadr "his brother."

\footnotetext{
${ }^{1304}$ SAVAK Documents, No Number, No Date.

${ }^{1305}$ SAVAK Document, No Number, 23 September 1978.

${ }^{1306}$ Ibid.

${ }^{1307}$ SAVAK Document, 1634/21 H, 17 October 1978.
} 
The telegram finally concluded that "Iran's crucial moves to free a Shia leader like Sadr [from Libya's prison] would have good impact on Tehran's ties with the Shia." ${ }^{, 1308}$ In the following days, SAVAK monitored the Middle Eastern leaders as well as Iranian and Lebanese religious figures, especially Ayatollah Khomeini's conveys. In the meantime, Tehran began accusing Ayatollah Khomeini and his supporters, though indirectly, of Sadr's disappearance. In addition to SAVAK, an Iranian special emissary and former ambassador to Amman, Fereydoun Movassaghi, was dispatched by the Shah to Jordan in late September 1978. He informed King Hussein of the Shah's anxiety over Sadr's fate. Shortly after, Iran's embassy in Amman issued a statement on 29 September 1978, stating that "Iran was increasingly worried about Sadr's fate. Iran had a right to interfere in this issue since Sadr is an Iranian-born and the leader of one million Shia in Lebanon." ${ }^{1309}$ King Hussein of Jordan then sent a private letter to Gaddafi. Calling Sadr as a "luminary of the Muslim world," King Hussein warned Tripoli of "sectarian dimensions" of the issue if Shia Sadr was arrested or killed by a Sunni Leader. Pointing to the interconnection of Sadr's mystery with the Palestinian situation, King Hussein stated in the letter that the issue had made "sensitive and difficult times" for the Palestinians and all Lebanese and proposed that Gaddafi "Help us so we can help you, with God's permission." ${ }^{1310}$ When Gaddafi traveled to Amman, King Hussein asked him again to cooperate on Sadr's issue. He also added that "the Shah has been worried about Sadr's situation."1311 Gaddafi, in response,

\footnotetext{
${ }^{1308}$ SAVAK Document, 1634/21 H, 17 October 1978.

${ }^{1309}$ SAVAK Document, 1634/21 H, 17 October 1978.

${ }^{1310}$ Ajami, Fuad, The Vanished Imam: Musa al-Sadr and the Shia of Lebanon (Cornell University Press, 1986) p. 187.

${ }^{1311}$ SAVAK Documents, No. 213/13369, 2 October 1978.
} 
assured King of Jordan that Sadr had already left Libya. Despite his claim that Libya Tripoli respected Iran as one of the main Islamic countries in the East of Islamic World and Libya, Gaddafi strongly denied Sadr's presence in Libya after his disapperance. After submitting the Shah's message to King Hussein, Movassaghi went to Damascus and delivered the Shah's private message to Hafiz Assad. He claimed that "Libya, Syria, and a third country have attempted to find Imam Musa Sadr and I am happy to say that Sadr's hiding place will be soon discovered." ${ }^{\prime 312}$ It seemed Movassaghi was not at liberty to disclose the third country. ${ }^{1313}$ After talking with Hafiz Assad, Movassaghi stated that Sadr was not in Libya anymore; a claim soon rejected by diplomatic and security reports of both SAVAK and the Ministry of Foreign Affairs. "Assad told me that in spite of some misunderstandings between the Shah and Imam Sadr, Imam Sadr had a permanently positive attitude towards the Shah and Iran. Assad believed that some politicians' negative interference [i.e., Ambassador Qadar], as well as the withdrawal of Sadr's citizenship, had widened a tension between Sadr and the Shah. Assad added that Sadr had looked at Iran as the Shia harbor and sanctuary. General Assad, finally, promised me to redouble his efforts to lessen tension between the Shah and Imam Sadr after Sadr's return to Iran." ${ }^{\prime 1314}$ It was all a mirage, though. The Shah had privately dispatched his personal emissary to inquire about Sadr's fate. Ali-Naghi Kani, former general secretary of the Mardom [People] Party, Alam's close friend, and Sadr's childhood friend, ${ }^{1315}$ was summoned to the Court. "I was surprisingly

\footnotetext{
${ }^{1312}$ Etelaat newspaper, Interview with Fereydoun Movasaqi, 3 October 1978.

${ }^{1313}$ Beirut 09739_d to the U.S. Department of State, WikiLeaks, 5 October 1978.

${ }^{1314}$ Etelaat Newspaper, 3 October 1978.

${ }^{1315}$ Kani had recently resigned from politics due to his objection to the Shah's domestic policy. For more information, see Ayandeh newspaper, 2011. Ayande, a reformist website, interviewed with Dr Kani. It did not point to his exact duty.
} 
called by Shah," Kani said. "He respected me unbelievably. Due to my relations with Shia clergies and Arab countries, the Shah asked me to travel to Saudi Arabia, Jordan, and Egypt, as his special emissary and to ask those rulers to "find and then safely turn" Sadr to Lebanon. I went then to Saudi Arabia and Jordan. Unfortunately, none of their kings helped me. However, President Sadat gave me a shocking information.” Kani claimed that Sadat had told him that "Seyyed Musa Sadr was executed by Gaddafi and his corpse was thrown into the Mediterranean." When Kani told the Shah of Sadr's fate, the Pahalvi monarch became "very, very upset. He sat in his chair for 10 minutes.",1316

\section{The End}

Sadr's disappearance was a fiasco for the Lebanese Shia. There had been several Shia influential figures to lead the community after Sadr, including Ayatollah MohammadMehdi Shamseddin, Seyyed Mohammad Hussein Fadlallah, pro-Baath Soleyman Yahfoufi, and Sayed Hasan Shirazi. Although Shamseddin, Sadr's deputy in the Majlis Aala and a moderate cleric without major connection to Ayatollah Khomeini's followers, ${ }^{1317}$ became the head of the SICS, neither he nor other Shia figures could fill Sadr's shoes. Other Lebanese Shia also warned of devastating consequences of Sadr's disappearance for Lebanon and the region. Hussein Quwatli, the personal representative of the Sunni mufti, said that Sadr's disappearance was "a link in the chain of conspiracies aimed at drowning Lebanon and the region in the terror of mystery." ${ }^{1318}$ The Shia mufti of Baalbek, Sulayman Yahfufi, said that the Shia had concluded that behind the Imam's

\footnotetext{
${ }^{1316}$ See The Shah of Iran, the Islamic Revolution and the Mystery of the Missing Imam, New York Times, January 15, 2016.

${ }^{1317}$ SAVAK Documents, 213/1101, 28 October 1978.

${ }^{1318}$ Beirut 05476_d to the U.S. Department of State, WikiLeaks, 20 September 1978.
} 
disappearance was "a conspiracy aimed at pushing through the capitulationist settlements which are being proposed in the Arab arena." Yahfufi said that Sadr's disappearance had "diverted Lebanese attention in particular and Arab attention in general...from what was happening at Camp David." ${ }^{, 1319}$ Indeed, Sadr's mysterious disappearance increased his reputation, making him a disappeared Imam to the Shia. His followers saw him as a martyr. Ambassador Richard Parker brought up a theory, arguing that "the thought that the Imam Moussa had gone into concealment to re-emerge transcendent had also occurred to us. Indeed, that was an early theory, i.e., that he had stage-managed a disappearance. Local opinion is divided on the subject." ${ }^{1320}$ In the same line of thought, William Eagleton, the U.S. ambassador to Tripoli, noted that "Though we have no evidence on which to base additional speculation, is it possible that, as provided for by Shi'a tradition, the Imam Musa Sadr might have been "taken into concealment"; and, if so, should we await his Parousia?" ${ }^{1321}$ By the late 70s, Syyed Musa Sadr's disappearance had revived the belief of the 'Hidden Imam' for the Shia. More significantly, Sadr's disappearance caused a drastic, yet late, shift in Iran's non-state foreign policy in Lebanon. On 8 October 1978, Ambassador Qadar was finally replaced with Sharaf whose relations with the Lebanese Shia and Arabs were much better. It seemed that the Shah had blamed Qadar for the destruction of Iran's connection with the Lebanese Shia. After his return to Tehran, and in the middle of Sadr's mysterious disappearance, Qadar was called by the Shah. In response to Shah's question on Sadr's fate, Qadar stated, "as Your Majesty found out well,

\footnotetext{
${ }^{1319}$ Beirut 05476_d to the U.S. Department of State, WikiLeaks, 20 September 1978.

${ }^{1320}$ Beirut 05430_d to the U.S. Department of State, WikiLeaks, 19 September 1978.

${ }^{1321}$ Tripoli 01290_d to the U.S. Department of State, WikiLeaks, 15 September 1978.
} 
Sadr was executed. In fact, Sadr's issue has finished." ${ }^{, 1322}$ Qadar was then sent to London. Interestingly, Pahlavi officials were still optimistic of finding Sadr. In early October, Ahmad Bani-Ahmad, Iran's former Parliament member, claimed "from Rome that he had "learned Sadr was safe and well in Libya. According to Bani-Ahmad, Sadr's eldest son, Sadreddin Sadr, had confirmed "his father's whereabouts." ${ }^{, 1323}$ In early November, SAVAK reported that Sadr would be released soon following Elias Serkis, Hafiz Assad, and Yasser Arafat's efforts to convince Gaddafi. "Sadr", the report claimed, "will go to Malta and then to Beirut with a prestigious welcoming ceremony. However, it should be taken into account that Colonel Gaddafi is not reliable." ${ }^{1324}$ SAVAK Director Pakravan, had a positive view towards the report since "1. According to the source of this news, we can trust to the content of news. 2. With regards to our previous information, this information should be acceptable, and Sadr is still in Gaddafi's prison." ${ }^{\prime 325}$ The highranked decision-makers in Iran still believed that Sadr was alive, yet under Gaddafi's control. When Tripoli proposed to send a representative to Iran on Sadr's case, Tehran eagerly accepted the idea. SAVAK was still looking for Sadr's miraculous reappearance. By the time, however, unrelenting waves of the Islamic Revolution had shakened the Pahlavi monarchy. At the end, SAVAK provided its last report, claiming that "Seyyed Musa Sadr is still alive."1326

\footnotetext{
${ }^{1322}$ Interview of General Mansour Qadar with Gholam-Reza Afkhami in the Oral History of Iran Program, Foundation for Iranian Studies, Bethesda, MD, US, 1986.

${ }^{1323}$ Tehran 09474_d to the U.S. Department of State, WikiLeaks, 1 October 1978.

${ }^{1324}$ SAVAK Documents, No. 213/642, 5 November 1978.

${ }^{1325}$ Tehran 09526_d to the U.S. Department of State, WikiLeaks, 2 October 1978.

${ }^{1326}$ SAVAK Documents, No. 224/958, 23 December 1978.
} 


\section{Conclusion:}

\section{Iran's Non-State Foreign Policy and the Shah's Legacy}

"We are in a really terrible situation since Moscow's twin pincers coming down through Kabul and Baghdad surround us," The Shah shared his concern with Alam. ${ }^{1327}$

In the early $16^{\text {th }}$ century Shah Ismail I (1501-1524) established the Safavid Empire (1501-1736 BC) and reunited Iran for the first time after the Arab conquest of Iran. More substantially, he reasserted the Iranian identity based on the Twelver Shia Islam. It was his crucial decision to inject Shiism onto the Iranian plateau that retooled Iran for the modern era. The formation of a Shia empire in the Middle East had a tremendous repercussion on other Shia communities in the region, particularly the Shia Turks in Minor Asia. Shah Ismail Safavi had been framed as both their Shah and Morshed-e Kamel (Complete Sufi Master) for the Middle Eastern Shia. Harshly persecuted by the Ottoman Sultans, the Shia Turk welcomed the Safavi shah's sequential victories. Led by Shahkulu (Servant of the Shah in Persian), ${ }^{1328}$ the Anatolian Shia launched a widespread insurgency in Spring 1510. The Safavi Shah was aware of the power of his Shia supporters; however, he was preoccupied with fighting with the Sunni Uzbek Khans in Khorasan, North-Eastern Iran, at the time. Furthermore, he did not want to have Iran surrounded by two Sunni powers of the Uzbek and the Ottoman; therefore, he refrained from inciting Ottoman Sultan, Bayezid II (1481-1512), by siding with the Shia rebellion. After on-and-off skirmishes, Shahkulu decided to cross Euphrates River--the Ottoman-Safavid border at the time- - in order to join his spiritual leader, Shah Ismail. However, Shahkulu and his 3,000 followers were killed

${ }^{1327}$ Alam, Assadollah. Yad'dashtha-ye 'Alam: Virayesh va Muqaddamah az Alinaqi Alikhani [The Alam Diaries: Edited by Alinaqi Alikhani], Vol. II: 1970-1971 (Bethesda, MD: Iranbook, 1995), p. 259.

${ }^{1328}$ Shahkulu's real name was Karabiyikolu. He became the religious leader of the Anatolian Shia after his father, Baba Khalife Hasan who had a close relation with Sheikh Heydar, Shah Ismail's father. 
in a decisive battle on 2 July 1511 . Although Shahkulu was later praised as a holy figure among the Shia Alevi in Anatolia and modern Turkey, the Ottoman Sultans had successfully suppressed the Shia Turks. ${ }^{1329}$ In the wake of Shahkulu Rebellion, the Shah Ismail had defeated the Sunni Uzbek and killed their leader, Muhammad Shaybani Khan, in the Battle of Marv. However, the other Ottoman Sunni leader, Sultan Selim I, attacked Iran in less than three years after the suppression of the Shahkulu Rebellion. Selim defeated Ismail in the Battle of Chaldiran on 23 August 1514 and Tabriz, Iran's capital at the time, was temporarily captured and then destroyed by the Ottoman Jeni Seri forces. Indeed, Shah Ismail's lack of ability and intention in the support for a non-state entity of the Shia Shahkulu Rebellion led to the defeat of Iran's army and the permanent loss of Eastern Kurdistan—modern Turkey’s Kurdistan.

More than four centuries later, the Islamic Revolution of 1979, led by Ayatollah Ruhollah Khomeini, overthrew the Pahlavi regime and established a Shia regime in Iran. The formation of the Islamic Republic was a watershed in the region, prompting other Shia communities, particularly the Iraqi Shia, to challenge their Sunni, autocratic regimes. Mainly led by Ayatollah Muhammad-Baqir al-Sadr, the Iraqi Shia gradually organized anti-Baath activities. Though rhetorically backing the Iraqi Shia, the newly-founded Iranian Republic was not able to effectively support them due to domestic power struggles and civil war in Iranian Kurdistan and Turkmen Sahra, in the north-east of Iran. Al-Sadr was brutally executed by the Baath regime and the Shia dissidents were suppressed. Only less than a year later, Saddam Hussein attacked Iran and temporarily occupied

\footnotetext{
${ }^{1329}$ Sultan Selim I killed more than 40,000 Shia in the Anatolia. See Bitlisi, Idris, Hasht Behesht [Eight Paradises].
} 
Khorramshahr in 1981. One more time, Iran's lack of ability and intention in the support for a non-state entity of the Iraqi Shia movement ended with a defeat in a bloody war.

In the period between the formation of the Shia Safavid and the Shia Islamic Republic, it was Mohammad-Reza Shah Pahlavi who effectively crafted a non-state foreign policy in the south of Lebanon and, particularly, in the north of Iraq and successfully stopped an Iraqi-backed by Egyptians and Russians--threat. A cursory historical survey of Pahlavi Iran's ties with the Iraqi Kurds and the Lebanese Shia shows the continuity and durability of Iran's non-state foreign policy.

Iran's non-state foreign policy under the Shah's reign was part of Tehran's broader strategy of Containment. Designed to stop adversaries' expansions in the region, Iran's non-state foreign policy targeted a set of threats, i.e., the Red, the Arab, the Kurd, the Black, and the Palestinian. Iran's support of the Kurdish Peshmerga prevented Iraq from possibly launching invasion of Khuzestan and halted its ambitions in the Persian Gulf. Tehran effectively used "the Kurdish issue" as pressure on "the [Iraqi] domestic stability and the Arab Unity,"1330 to keep Iraq "weak, divided, and separate from Nasser," 1331 and to "pin down two-thirds of the Iraqi army and deprive the Baath of a secure base from which to launch sabotage and assassination teams against Iran." ${ }^{\prime 332}$ Iran's support for the Iraqi Kurds also contained Kurdish separatism. As Tehran's support for the Iraqi Kurds grew, Kurdish nationalism in Iranian Kurdistan slowed down and, in return, pushed Barzani to abandon the idea of siding with the Iranian Kurds against Tehran since he did not want to lose Iran's

\footnotetext{
${ }^{1330}$ London 1305 to Iran's Ministry of Foreign Affairs, 2 August 1963.

1331 Baghdad A-424 to U.S. Department of State, enclosure: "Kurds - Iraq," no date (NARA/RG59/CFPF/1964-66/Box2339/POL 13-3-Ethnic Minorities), p.2.

1332 White House, Memorandum, Kissinger to the President, "Progress Report on the Kurdish Support Operations," October 5, 1972 (FRUS/1969-76/E-4/doc.325), p.1.-103
} 
strategic support. ${ }^{1333} \mathrm{He}$ warned both Iranian and Syrian Kurds not to take any step against their central regimes, ${ }^{1334}$ and his Peshmerga kept the border with Iran safe. ${ }^{1335}$ According to SAVAK, the KDP stopped following its propaganda against Iran's national unity. ${ }^{1336}$ This shift finally led to ousting the radical Iranian Kurd leaders of the PDKI, including Ahmad Towfiq. ${ }^{1337}$ The Shah was also careful not to perturb the Iranian Kurds. In a meeting with the U.S. Ambassador Armin Meyer, the Shah revealed his strategy not to antagonize Iran's Kurds by colluding with Iraq against Barzani. ${ }^{1338}$ In the same line, Iran's support for the Lebanese Shia targeted the rising Nasserism on the far east coast of the Mediterranean. While never provided with Iran's military aid, the Lebanese Shia functioned as an antiPan-Arab bulwark through dismantling pro-Nasser elements' plans to join the UAR or another larger Arab entity.

Iran's non-state foreign policy was not primarily shaped for territorial annexation. Interestingly, Iran's regional opponents, as well as the U.S. State Department, highlighted Iran's intention to annex Iraqi Kurdistan. Iraqi Foreign Minister Shathel Taqa had warned: "if the Shah or anyone else has [an] idea of a new Bangladesh in Iraq he is very mistaken." 1339 The U.S. State Department had also reported that "Barzani had approached the Shah on a number of occasions to seek assistance against Iraq. He made grand promises

${ }^{1333}$ SAVAK Documents, 2/490, 8 June, 1964.

${ }^{1334}$ SAVAK Documents, 2/453, 12 January, 1964.

${ }^{1335}$ SAVAK Documents, h/5/3102, 20 September, 1965.

${ }^{1336}$ SAVAK Documents, 13/2933, 25 June, 1963.

${ }^{1337}$ SAVAK Documents, $42 / 89$.

1338 Tehran A-1044 to State, “Iran-Iraq Relations,” January 20, 1966 (FRUS/1964-68/XXI/doc.179).

${ }^{1339}$ Baghdad 564 to the U.S. Department of State State, August 29, 1974, NSA, PCFMESA, Box 14, GRFL. 
of incorporating Iraqi Kurdistan into Iran in return. ${ }^{, 1340}$ In another report, the State Department framed Iran's interference in Iraqi Kurdistan as “comparable to that of Indian involvement with the Bengalese rebels in East Pakistan just prior to the 1971 war."1341 According to the Americans, Tehran might be "tempted [to] support [the] Kurdish rebels in [an] effort [to] divert hostile Kurdish action from its territory." ${ }^{1342}$ Contrary to these claims, the Shah never supported the territorial annexation policy. His primary goals were to contain Iraq and then to force the Iraqi leaders to concede in Arvand Rud. The Shah gradually related the Kurdish and Arvand Rud issues. According to Qadar, it was SAVAK Director Pakravan who first suggested that the Shah use the Kurds in order to gain the concession in Arvand Rud. ${ }^{1343}$ In the mid-60s, Iran's Ministry of Foreign Affairs had argued there were "three issues that escalated tensions between Iran and Iraq: Arvand Rud, the Kurdish War, and the Iranian minority in Iraq ... Tehran cannot be indifferent towards the Kurds ... However, Iran has interestingly intertwined these issues in a way that none of which can be mutually settled down between Iran and Iraq." ${ }^{, 1344}$ Since the late 60 s, the Shah had revealed his preparation to abandon the Kurds to gain the concession in Arvand Rud. $^{1345}$

\footnotetext{
${ }^{1340}$ Tehran 136 to the U.S. Department of State, August 2, 1962 (NARA/RG59/R2/787.00/8-162), PP. 1-2.

${ }^{1341}$ Intelligence Note prepared in the Bureau of Intelligence and Research, November 18, 1974, FRUS 19691976, XXVII, 267, Tab B.

${ }^{1342}$ White House, Memorandum, Saunders to Bundy, April 2, 1963 (JKF/NSF/RKF/Box426/Iraq-1961-63White House Memoranda, p.1.

${ }^{1343}$ Interview with Major General Mansour Qadar, Oral History, Foundations for Iranian History.

${ }^{1344}$ Cologne to Iran's Ministry of Foreign Affairs. No number, no date.

${ }^{1345}$ Tehran A-607 to the U.S. Department of State, "The Iran-Iraq Crisis of December/January: An Analysis," March 5, 1966 (NARA/RG59/CFPF/1964-66/Box2339/POL 13-3-Ethnic Minorities), p.3.
} 
Pahlavi Iran's non-state foreign policy demonstrated Tehran's willingness and desire to accept the regional status quo. Despite support for the Iraqi Kurds, Iran refrained from supporting the disintegration of Iraq and the creation of an independent Kurdish state. The Sjaj had pressed Barzani to "adhere to the line that they consider themselves a part of Iraq." ${ }^{\prime 346}$ In an interview with the Kuwaiti newspaper a-Siasat, the Shah clearly contended

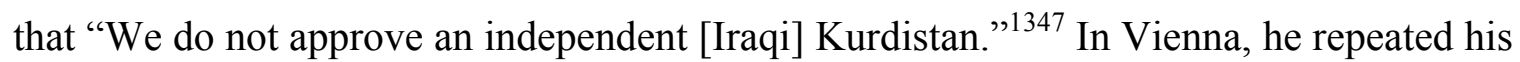
argument that "the autonomy for Kurdistan should be authorized under Iraq's sovereignty." ${ }^{1348}$ For the Shah, the state disintegration policy in the region would lay a fertile ground for Russian infiltration that would, in turn, endanger Iran's state survival. The Shah himself was, in general, against the disintegration of regional states. "The era of territory occupation has passed, and it is not acceptable anymore," he objected to state collapse in the region. ${ }^{1349}$ He was also against the disintegration of Pakistan as well as Israeli occupation of the Sinai Peninsula and Golan Heights. "Any territory occupation by force of arms shall not be recognized," the Shah stated in an interview with a Yugoslavian newspaper in $1967 .^{1350}$

Iran's non-state foreign policy was Tehran's major tool to legitimize its regional role and stability. The Shah was well aware that a state's role was the currency of power,

\footnotetext{
${ }^{1346}$ Helms to Kissinger, May 21, 1974, CIA-Helms.

${ }^{1347}$ Iran's Ministry of Foreign Affairs, No number, no date.

${ }^{1348}$ Iran's Ministry of Foreign Affairs, No number, no date.

${ }^{1349}$ Iran's Ministry of Foreign Affairs, February 1971.

${ }^{1350}$ Borba (Yugoslavia), November 1967.
} 
granted to a state by its neighbors by recognizing the legitimacy of the state's interests. ${ }^{1351}$ Although the Saad-Abad summit of 1972 granted Iran a role as the gendarme of the Persian Gulf, it was the Algiers Agreement of 1975 that legitimized it among states of the region. Given the fact that Iran's support for the Kurds ultimately coerced Baghdad to accept the Algiers Agreement, Iran's non-state foreign policy played a critical role in granting the leading role in the region to Iran. On top of that, the Shah considered Iran's non-state foreign policy as a tool to keep Iran's and the Middle East's stability. As he claimed, Iran was the "only nation capable of maintaining peace and stability in the Mideast." 1352 Pahlavi Iran secured its stability by limiting the threat of Pan-Arab, Moscow-backed regimes of the region by supporting the Iraqi Kurds and to some degree, the Lebanese Shia. It was Iran's 'special stability', a combination of Iran's power and role, that convinced the White House to see Iran as its key ally in the Middle East.

Iran's non-state foreign policy under the Shah's reign was a manifestation of Iran's efforts to disentangle itself from super power politics. Since the coup of 1953, the Shah had been seeking to show his independence from external powers. By the mid-70s, Tehran's growing military and economic power transformed Iran from an underdeveloped, weak state to a major power in the region. As Iran's petrodollar income increased, the Shah's self-confidence grew and that in turn, changed the nature of its relation with the U.S. from a client-master one to a regional partner in the Cold War. He implicitly supported Egypt

\footnotetext{
${ }^{1351}$ Parsi, Trita, Treacherous Alliance: The Secret Dealings of Israel, Iran, and the United States (Yale University Press, 2007) p.291. For more discussion, see Charles Doran, The Politics of Assimilation: Hegemony and Its Aftermath (Baltimore: Johns Hopkins University Press, 1971).

1352 Pahlavi, Mohammad Rezai, Answer to History (New York: Stein and Day, 1980) p. 142.
} 
and Syria in the Yum Kippur of $1973,{ }^{1353}$ and followed a moderate détente policy with Moscow in the 1960s. More substantially, he challenged his American ally with Iran's nonstate foreign policy in Iraqi Kurdistan. In a period between September 1961 and May 1972, his policy towards the Iraqi Kurds stood in sharp contrast with the U.S. strategy in Iraq and the region. It was only after the Saad-Abad summit of 1972 that the U.S. was dragged into the Kurdish War and sided with Iran and Israel in support of Barzani. Furthermore, the Shah tried to control and manage the triangular cooperation of SAVAK-CIA-Mossad in Iraqi Kurdistan. "I told His Imperial Majesty that the Americans and the British are separately working there [Iraqi Kurdistan]. Is not it better to make them work together? The Shah replied back: 'It is better they work separately'."1354 Finally, Iran's unilateral decision to sign the Algiers Agreement, without informing Israel and the U.S., demonstrated Iran's independence. The Shah pulled the rug from under the Americans' and Israelis' feet. "When he got an offer, he grabbed it, completed it, came back, gave the orders and let the United States and Israel know that the game was over."1355

The Shah employed Cold War language to justify Iran's non-state foreign policy, particularly in Iraqi Kurdistan. Cold War language was designed to exaggerate the Soviet

\footnotetext{
${ }^{1353}$ In the meeting with Anwar Sadat, Kamal Jumbalat praised Iran's support for the Arab regimes in the October War and criticized the Iraqi role. According to Jumbalat, the Shah had informed the U.S. that Iran would join Egypt and Iraq if the War had lasted three more days. Iran clearly supported the Arabs. See Beirut 12358 to Iran's Ministry of Foreign Affairs, 27 April 1974. Yasser Arafat put that he was totally impressed by the Shah's statement that "Iran would support the Arabs in the next coming war." See Beirut 3432 to Iran's Ministry of Foreign Affairs, 6 January 1975. Earlier before, it seemed Iran declared an ultimatum to Tel-Aviv not to interfere in Jordan domestic politics through the U.S. embassy. With Iran's Air Force total readiness, Prime Minister Golda Meir withdrew from General Moshe Dayan's threat to cross the Jordan River and promised not to intervene in Jordan. See Istanbul 790 to Iran's Ministry of Foreign Affairs, 11 July 1971.

${ }^{1354}$ Alam, Assadollah. Yad'dashtha-ye 'Alam: Virayesh va Muqaddamah az Alinaqi Alikhani [The Alam Diaries: Edited by Alinaqi Alikhani], Vol. II: 1970-1972 (Bethesda, MD: Iranbook, 1995), p. 348.

${ }^{1355}$ Parsi, Trita, Treacherous Alliance: The Secret Dealings of Israel, Iran, and the United States (Yale University Press, 2007) p.55.
} 
plan in the region by portraying the Iraqi regime as a Kremlin partner and interconnecting major sensitive issues in the region for the U.S., i.e., the security of the Persian Gulf oilfields and Israel and the national integrity of the U.S. regional allies. The Shah's prudent use of this language was mainly rooted in the fact that the U.S. viewed regional conflicts through a Cold War lens. From this analytical angle, the geopolitical contest with the Kremlin covered the globe and, therefore, there was no room for regional-local conflicts per se. It was within this context that the Shah relentlessly employed the Cold War language and painted the Kurdish conflict as a significant Cold War front, rather than a regional competition between Tehran and Baghdad or local fighting between Baghdad and the KDP. In the Saad-Abad meeting of May 1972, his well-designed Cold War language successfully transformed the Kurdish War from a hardly-noticed regional crisis in the distant Zagros Mountains to a war between the Soviet camp and the West and ultimately dragged the U.S. into the Kurdish War.

Pahlavi Iran lacked specific discourse or ideology to articulate its non-state foreign policy. Under the Shah's reign, official propaganda partially highlighted a vague 'Aryanism' or 'Pan-Iranism', demonstrating his ambition to revive the Persian Empire. In the aftermath of the Iraqi coup of 1958, the core of Iran's hearts-and-minds campaign towards the Iraqi Kurds was premised on the view that the Kurds were, in the Shah's words, "the purest Persians, pure Aryans, from their tradition, their language and their history.","1356 When he was asked if there was any 'Kurdish question' in Iran, he quickly responded back, "Absolutely not. It may be in other countries, but not in Iran. The Kurds are 'pure Aryan',

\footnotetext{
${ }^{1356}$ Memcon, April 13, 1962, FRUS 1961-1963, XVII, 247; Tehran 1044 to State, January 20, 1966, FRUS 1964-1968, XXI, 179.
} 
like us." ${ }^{1357}$ The Iraqi Kurds had also tried to consolidate their ties with Iran by emphasizing the discourse of Aryanism. In the middle of the war with Baghdad, Barzani wrote a letter to Mohsen Pezeshkpour, the head of the pro-Kurds Pan-Iranist Party, and expressed his gratitude to the Party for its support for the Kurdish movement. He also stated that "The superficial division among branches of a race [the Iranians] cannot remove their inseparable links... You [the Pan-Iranist Party] has [rightly] introduced the Kurds as a true heir of the Median Empire... Indeed, when all branches of our race had been united together, our World, especially our Arian [World], was prospering and creating.",1358

In the same line, yet in a less significant view, the Shah tried to frame himself as the guardian of the Shia communities. Indeed, several elements in SAVAK and Ministry of Foreign Affairs considered the Shia communities in the region as Iran's 'natural' allies. After the Iraqi coup of 1958, the Iraqi Shia became SAVAK's initial targets for plotting against Baghdad. Throughout the 60s and 70s, SAVAK kept its ties with the Iraqi Shia elites. In his speech in front of President Abdul-Salam Arif, Mehdi Pirasteh, Iran's ambassador to Baghdad, had recklessly stated that Iran, as the major Shia country of the region, would support all the Shia and must keep this policy in the world. Pirasteh's speech infuriated Arif so much that he left the meeting. ${ }^{1359}$ When the Iraqi Army killed 40 Iranian border guards in Badrah in early 1974, Iran intensified its support, yet inconsequentially, for the Shia dissidents in the south of Iraq. ${ }^{1360}$ In Lebanon, the SAVAK Green Plan was

\footnotetext{
${ }^{1357}$ Iran’s Ministry of Foreign Affairs, No Number.

1358 Barzani wrote this letter for the fifth annual meeting of the Pan-Iranist Party, Hakemiyyat-e Mellat (Nation's Sovereignty), No. 96-97.

${ }^{1359}$ SAVAK Documents, 215/36967-m/6/8609, 22 February, 1965.

${ }^{1360}$ Al-Samarrai, Wafiq, Hottam al-Bawabat al-Sharqi [The Destruction of the Eastern Gate], translated in Farsi (Tehran, Markaz Asnad va Tahghighat-e Defa-e Moghaddas) p. 56.
} 
primarily framed around Tehran-Lebanese Shia ties. Even after growing tension between Tehran and Sadr, the Shah refrained from expressing direct enmity towards Sadr. Amid the Civil War, "Bachir Gemayel ${ }^{1361}$ who was in close relations with the Shah came to Tehran three times and pleaded with the Shah for military support. Although the Shah had promised him to support his Phalange forces in all three meetings, he changed his mind at the last minute. When I asked the reason, he replied: 'Imagine if one of these weapons received by the Lebanese Christians, would not they say that the only Shia king in the world pays money to the Christian to kill the Shia?' I answered: 'Your Majesty, the ShiaChristianity division is not important anymore. What is important is ideology. If the Christian forces are defeated by the Shia and the Palestinians, Iran will face an enemy in Lebanon.' But the Shah strongly rejected and said, 'We cannot treat the Lebanese Shia in this way.' The Shah then rejected Gemayel's financial request. There was a 'hidden' factor within the Shah's behaviors. I think he might be influenced by some of his aides," Ambassador Qadar recalled his talk with the Shah. ${ }^{1362}$ In reality, though, the Shah's 'hidden factor' refers to his view towards the Shia people and Iran's central status--as the 'Shia Hub'-for the Shia communities since the rise of the Safavid Empire.

The ideas of a 'greater Iran' and 'the Shia hub' could have provided ideational bases for Iran's non-state foreign policy. However, both narratives were vague and remained disarticulated. While he was fully aware of the threatening ideologies of Communism and Pan-Arabism--and to a less significant degree, Kurdish separatism and Islamism--he could not articulate a strong ideology to justify, expand, and consolidate his rule as well as Iran's

\footnotetext{
${ }^{1361}$ A senior member of the Phalange Party and then-supreme commander of the Lebanese Force militia in the Second Civil War 1975-90.

${ }^{1362}$ Interview with Major General Mansour Qadar, Oral History, Foundations for Iranian History.
} 
non-state foreign policy. In fact, the Shah's realist views devalued the significance of ideational forces in Iran's non-state foreign policy.

Iran's non-state foreign policy was primarily handled by its security apparatus. It was SAVAK, rather than Iran's Ministry of Foreign Affairs, that managed connections with the Iraqi Kurds and the Lebanese Shia. SAVAK elements, particularly Colonel Pejman, played a decisive role in convincing the Shah to side with the Iraqi Kurds against Baghdad. SAVAK also played a critical role in making connections and then terminating Iran's ties with the Lebanese Shia. Ambassador Mansour Qadar was mostly connected to SAVAK, instead of the Ministry of Foreign Affairs. According to Nraghi, "Qadar had attracted the Shah and other top country officials' attentions with jugglery. I believe after 1964, the Shah left all matters relating to Shia clerics to SAVAK. In addition, all matters relating to Egypt, Syria, Iraq, Jordan, and Lebanon were managed by SAVAK. All reports relating to these countries and prepared by the Ministry of Foreign Affairs had to be monitored by Qadar and SAVAK." "1363 Sadr had called SAVAK the main obstacle to improving relations between the Arabs and Tehran. ${ }^{1364}$

Contrary to popular perceptions, Iran's non-state foreign policy was not framed by the Shah's megalomaniac perception of Iran's status as not only the hegemon of the region but also a major power on the world stage. In reality, the Shah's megalomania and aspiration for regional suzerainty emerged with the termination of Iran's non-state foreign policy. In a period between 1974-76, the Shah changed the trajectory of Iran's non-state foreign policy, cutting off his support for Barzani and framing Sadr as an enemy. It was

\begin{tabular}{l}
\hline $1363 \quad$ Fars $\quad$ News \\
http://www.farsnews.com/newstext.php?nn=8711240772.
\end{tabular}


within this context that his megalomania reached an absurd level as he turned his attention to areas beyond the Persian Gulf. He insisted on Iran's necessary presence to keep sea roads open in the Indian Ocean. In doing so, he planned to build a military base in Mauritius and engaged in the crisis in the Horn of Africa by supporting Somalia against Soviet-backed Ethiopia. "My policy is honest and straightforward, and I have no hidden agenda. I say quite openly that I wish Iran to play a role in the Indian Ocean. I have no objection to America being present; indeed I shall actively defend your interests," the Shah told the U.S. Vice President Nelson Rockefeller on 24 March $1976 .{ }^{1365}$ When Americans increased the cost of a military navy supposed to be purchased by Iran, the Shah instructed Alam to tell the U.S. ambassador that "In this situation, we cannot buy these ships. [Tell the Americas that] within this situation a [power] vacuum would emerge in the Indian Ocean and you would be left with Diego Garcia Island. Without Iran's rise, there will be no navy force, except the Indian force, other than the Russian force in the Indian Ocean. You do not want to trust India. Pakistan has no power to purchase them. With a limited power of our navy force, we will not be able to come out of the Persian Gulf. Therefore, you will be alone against the Russians there." ${ }^{\prime 366}$ Although the Western powers reminded him of their sufficient power to secure the Indian Ocean, the Shah never considered their points. Indeed, the termination of Iran's non-state foreign policy coincided with the Shah's rising megalomania.

\footnotetext{
${ }^{1365}$ Alam, Asadollah, The Shah and I, ed. Alinaghi Alikhani (New York: St. Martin's, 1991), p. 152.

${ }^{1366}$ Alam, Assadollah. Yad'dashtha-ye 'Alam: Virayesh va Muqaddamah az Alinaqi Alikhani [The Alam Diaries: Edited by Alinaqi Alikhani], Vol. III: 1973-1974 (Bethesda, MD: Iranbook, 1995), p. 328.
} 
More substantially, the Shah terminated Iran's non-state foreign policy when he abandoned the idea of the balance of power in the region to lead the Middle East. Although he knew that the collapse of the Kurdish resistance would release Baghdad from a longterm crisis and would then enable the Baath leaders to deploy its army in the Persian Gulf and threaten Khuzestan, he abandoned backing the Iraqi Kurds. The Shah's main idea was to abandon the classic regional balance of power and to take up instead a policy of "winning Arab recognition for Iran's regional leadership." ${ }^{, 1367}$ Elements in the Ministry of Foreign Affairs, particularly Foreign Minister Abbas Aram, as well as Prime Minister Hoveyda, had suggested that the Shah approach Arabs to lead the region. ${ }^{1368}$ After building close friendship with Sadat, the last step for the Shah to receive the Arab acceptance of Iran's regional hegemony in the Persian Gulf and the Middle East was to turn Baghdad, Iran's sole remaining foe with an aspiration to lead the region, docile. In his interview of April 1975 with Muhammad Hassanein Haykal, the Shah stated clearly his idea of leading the Middle East, pointing that "We followed the principle 'my enemy's enemy is my friend,' and our relations with Israel began to develop. But now the situation has changed ... I occasionally think of a new equilibrium in the region ... Perhaps [it] can be integrated into an Islamic framework." ${ }^{1369}$ Iraq's concession in Arvand Rud was interpreted by regional states as the recognition of Iran's paramount power. According to Iran's Ministry of Foreign Affairs, the Algiers Agreement had ushered in "the Arabic-Islamic Unity." ${ }^{1370}$ In

\footnotetext{
${ }^{1367}$ Parsi, Trita, Treacherous Alliance: The Secret Dealings of Israel, Iran, and the United States (Yale University Press, 2007) p.80.

${ }^{1368}$ Interview with Major General Mansour Qadar, Oral History, Foundations for Iranian History.

1369 Joseph Alpher, "Israel and the Iraq-Iran War," in The Iraq-Iran War: Impact and Implications, Efraim Karsh (New York: St. Martin's, 1989), 157.

${ }^{1370}$ Beirut 4264 to Ministry of Foreign Affairs, 9 March 1975.
} 
the Shah's view, the Agreement would eliminate the image of Iran as an implacable foe of the Arabs. The U.S. Department of the State reported that "Iran perceives the accord with Iraq as contributing to its effort to draw closer to the Arab states. The Shah, who aspires to regional leadership, does not wish to be classified as hostile to Arabs and a supporter of Israel. Moreover, it may be his perception that the power balance has shifted in favor of the Arabs. He might also anticipate an eventual modification of U.S. policy toward Israel. The Shah does not want to be caught short." ${ }^{\text {1371 }}$ In short, the termination of Iran's non-state foreign policy was rooted in the Shah's plan to keep Iran's bid for regional leadership safe.

Iran's non-state foreign policy under the Shah's reign left a huge legacy for the post-Revolution era. Since the Islamic Revolution of 1979, Iran's connections with nonstate entities in the region intensified. In reality, however, when the revolutionaries came to power, Iran's connections with the Iraqi Kurds were still there. Despite the Algiers Agreement of 1975, the Barzanis kept fighting with Talabani and the PUK. Right after the Islamic Revolution, they sided with the revolutionaries. Baghdad's long-standing enmity towards Iran, as well as Tehran's new revolutionary tones, put Baath Iraq as a major threat to the Islamic Republic and thus, facilitated the revival of Tehran-Iraqi Kurds connections. Tehran later attracted Talabani's PUK and established a potent Kurdish front in the middle of war with Iraq. In fact, the extension of Tehran-Kurdish connections was durable enough to outlive the transformative events of the Algiers Agreement of 1975 and the Islamic Revolution of 1979.

Tehran-Lebanese Shia connections had a tremendous impact on Iran's non-state foreign policy. When the Iranian revolutionaries came to power, there was already a

${ }^{1371}$ The implication of the Iran-Iraq Agreement- DCI/NIO 1039-75, 1 May 1975. 
history, though a weak one, of Tehran's connections with the Lebanese Shia. Contrary to popular perceptions, Pahlavi Iran's connections with the Lebanese Shia were potent enough that one could counterfactually argue that without the decline of Nasserism and Ambassador Qadar's destructive interventions, the Shah might have built a stronger relation with the Lebanese Shia the Islamic Republic has built with Hezbollah and Amal.

Moreover, the presence of the Iranian revolutionaries in Southern Lebanon prepared fertile ground for the Islamic Republic to expand its connections with the Shia Lebanese. Mohammad Montazeri, Seyed Ali-Akbar Mohtashamipour, and particularly Mostafa Chamran were the three key revolutionaries who solidified Iran's commitment to Lebanese Shia. According to Amal deputy, Ali Kharis, "Musa Sadr and Chamran were the backbone of the Iranian revolution and one cannot speak of the Iranian revolution without mentioning these two person."1372

Furthermore, Sadr's support for Assad's Syria and his fatwa in favor of the Alawites planted the seeds of a broader strategic triangular alliance among Tehran, Damascus, and the Lebanese Shia. After the Revolution, the Baath regime of Syria sided with the Islamic Republic of Iran and became the only Arab state-along with Libya--that supported Tehran against the Baghdad Baath. More significantly, Damascus eased Iran's presence in Lebanon and empowered Tehran's connections with Hezbollah. In return, Tehran turned down Syrian Sunni Muslim Brotherhood's pleas against secular Hafiz Assad. Recently, it was Tehran who sided with Bashar Assad's regime against ISIS, alNusra, and the militant rebels backed by the Turks, Saudis, Qataris, and Americans.

\footnotetext{
1372 Shaery-Eisenlohr, Roschanack. Shi'its Lebanon: Transnational Religion and the Making of National Identities (Columbia University Press. Retrieved 2 July 2016).
} 
Iranian-born Sadr's message of modern Islam and his efforts to revive the Shia identity was followed in Iran and then emulated in other Shia communities in Iraq, Bahrain, and Yemen. As Sayyed Hassan Nasrallah stated, "Imam Sadr established the Moqawama [Resistance]. He also founded major institutions on behalf of Lebanese, in general, and the Lebanese Shia, in particular...Whatever Imam Sadr emphasized is now implemented in Hezbollah. He believed in support for Palestine and in resistance as the only way to free Palestine and Lebanon [from Israeli occupation] ... I have been impressed by four major figures: Imam Khomeini, Ayatollah Khamenei, Imam Sadr and Ayatollah [MohammadBagher] Sadr." ${ }^{1373}$ Along with Ayatollah Khomeini, Sadr has been a seminal figure who initiated the revival of the Shia in the region.

On top of that, deep conflict among the Iranian Revolutionaries over Sadr's leadership in Lebanon soon emerged in Iran's domestic power struggle after the Islamic Revolution. On one side, the pro-Sadr revolutionaries, including Mostafa Chamran, Sadegh Ghotbzadeh, and Sadegh Tabatabaie, established the interim government, led by Mehdi Bazargan. On the other side, the anti-Sadr revolutionaries, including Jalal al-Din Farsi, AliAkbar Mohtashamipour, Mohammad Montazeri, and Mohammad Gharazi, gathered in the Islamic Republic Party, SATJA, and the IRGC. Within this context, supporting and criticizing Sadr became a major, though indirect, fault line among the revolutionaries. The pro-Sadr group criticized the isolation of Iran after the Revolution while anti-Sadr forces intended to radicalize Iran's foreign and domestic policy. Indeed, the clash between these two groups over Sadr's policies in the late-70s continued in the 80s and the 90s and shaped the trajectory of both domestic and foreign policy of revolutionary Iran. The issue of siding

\footnotetext{
${ }^{1373}$ http://asreiran.mihanblog.com/post/73.
} 
with or criticizing Sadr was, in fact, as determinant as an ideological split within the Mojahedin of 1975 in forming the trajectory of foreign and domestic policies of newfounded Islamic Republic. ${ }^{1374}$ Sadr's presence in Iranian politics is still strongly felt. ${ }^{1375}$

Iran's non-state foreign policy in the Middle East is a sensitive subject which makes it difficult to propose a theory as a unifying framework. More significantly, it offers something different from, but complementary to, the current crop of textbooks related to Iran's foreign policy and the geopolitics of the Middle East. My hope is to embolden others to study Iran's foreign policy, in particular, and the geopolitics of the Middle East, in general, that have been ignored by scholars for generations by opening up new questions and new areas of research. The present study is also a research project which has to continue. The next project could be on the Islamic Republic's non-state foreign policy which was much broader than what I elaborated here. It could be also extended to the Shah's 'counter-insurgency foreign policy' in Dhofar, Oman, and North Yemen. Above all, I hope I have inspired those who read this study to look at history in a different way.

${ }^{1374}$ In October 1975, the MEK experienced an ideological split between Marxist and Islamist members. While the remaining primary members of MEK, including Masoud Rajavi, were imprisoned, some of the early members of MEK, like Bahram Aram, Torab Hghshenas, Taghi Sharam and Foad Rohani, formed a new Marxist organization. They declared this ideological split in a book entitled Manifesto on Ideological Issues, arguing that "that after ten years of secret existence, four years of armed struggle, and two years of intense ideological rethinking, they had reached the conclusion that Marxism, not Islam, was the true revolutionary philosophy." Most of the Iranian clerical revolutionaries, including Ali-Akbar Hashemi Rafsanjani, felt deep sympathy with the Islamist Mojahedin. They were frustrated with this split. This event had a huge impact on the power struggle and then bloody civil war after the Islamic Revolution.

1375 Sadr maintained strong family relations with political leaders in Iran, Lebanon, and Iraq. Sadegh Tabatabaie, Sadr's nephew, Sadegh Tabatabaie, became the first spokesman of the government after the Revolution. Ahmad Khomeini, Ayatollah Khomeini's second son, married with Fatemeh Soltani Tabatabaie, Seyyed Musa's niece. Yaser Khomeini, Ahmad's second son, also married with Houra Sadr, Seyyed Mohammad Sadr's daughter. Seyyed Mohammad was Musa Sadr's nephew. Former President Mohammad Khatami's wife, Zohreh Sadeghi, is Sadr's niece. Sadreddin, Sadr's son, was also married to Ayatollah Khomeini's granddaughter. In Iraq, Seyyed Musa's cousin, Ayatollah Seyed Muhammad-Baqir Sadr was a major political leader of the Shia. His son-in-law, Muqtada al-Sadr, the leader of the Sadrist Movement, still claims to lead the Shia in Iraq. In the after math of his mystic disappearance, Sadr's family has been a prestigious semi-royal family within the larger Shia community. 


\section{Bibliography}

\section{Archival collections}

\section{a. Iran:}

Markaz-e Amouzesh va Pajooheshhay-e Beynolmelali-e Vezarat-e Omour-e Kharejeh [Center of International Research and Education of the Ministry of Foreign Affairs]

Markaz-e Asnad- Enghelab-e Eslami [Islamic Revolution Document Center]

Sazman-e asnad va Ketabkhane Melli-e Jomouhori Eslami [National Library and Archives of Islamic Republic of Iran]

\section{Published Government Documents:}

Imam Musa Sadr be Ravayat-e Asnad-e SAVAK, Jeld-e Aval, Markaz-e Barrasi-e Asnade Tarikhi-e Vezarat-e Etela'at [Musa Sadr according to SAVAK Documents, Vol I, Center of Survey of the Ministry of Intelligence]

Imam Musa Sadr be Ravayat-e Asnad-e SAVAK, Jeld-e Dovom, Markaz-e Barrasi-e Asnad-e Tarikhi-e Vezarat-e Etela'at [Musa Sadr according to SAVAK Documents, Vol II, Center of Survey of the Ministry of Intelligence]

Imam Musa Sadr be Ravayat-e Asnad-e SAVAK, Jeld-e Sevom, Markaz-e Barrasi-e Asnad-e Tarikhi-e Vezarat-e Etela'at [Musa Sadr according to SAVAK Documents, Vol III, Center of Survey of the Ministry of Intelligence]

Hezb-e Democrat-e Kurdestan-e Araq be Ravayet-e SAVAK [Iraqi Kurdistan Democratic Party according to SAVAK]

Ravabet-e Iran va Araq be Ravayat-e SAVAK [Iran-Iraq Relations According to SAVAK]

\section{b. United States of America:}

US National Archives and Records Administration (NARAI), College Park, Maryland

Central Intelligence Agency Records Search Tool (Crest)

General Records of the Department of State, Record Group 59 (RG59)

Central Foreign Policy Files (CFP), 1967-69

Central Foreign Policy Files (CFP), 1973-76, Access to Archival Databases (AAD), available at: http://aad.archives.gov/aad/

Records Relating to Iran, 1965-1975, LOT 77D400 


\section{Library of Congress}

Papers of Archibald B. Roosevelt, Jr.

Richard M. Nixon Presidential Library (RMNL), Yorba Linda, California Available at: https://www.nixonlibrary.gov/

Gerald R. Ford Presidential Library (GRFL), Ann Arbor, Michigan

Available at: https://www.fordlibrarymuseum.gov/collections-digital.aspx

Published Government Documents:

United States Congress, House Select Committee on Intelligence, CIA: The Pike Report. With an Introduction by Philip Agee, (Nottingham, England: Spokesman Books, 1977).

Keesing's Record of World Events (formerly Keesing's Contemporary Archives), Volume XVII, February, 1970 Iraq.

Congressional Record

Foreign Relations of the United States (FRUS) (Washington, DC: US Government Printing Office)

1946

VII: The Near East and Africa (1969)

1949

VI: The Near East, South Asia, and Africa (1977)

1952-1954

X: Iran, 1952-1954

$1958-1960$

XII: Near East Region; Iraq; Iran; Arabian Peninsula (1992)

1961-1963

XVII: Near East, 1961-1962 (1994)

XVIII: Near East, 1962-1963 (1995)

1964-1968

XXI: Near East Region; Arabian Peninsula (2000)

XXII: Iran (1999)

1969-1976

I: Foundations of Foreign Policy, 1969-1972 (2003)

XI: South Asia Crisis, 1971 (2005)

XXIV: Middle East Region and Arabian Peninsula, 1969-1972

XXVII: Iran; Iraq, 1973-1976 (2012)

XXXVIII: Foundations of Foreign Policy, 1973-1976 (2012)

E-3: Documents on Global Issues, 1973-1976 (2000)

E-4: Documents on Iran and Iraq, 1969-1972 (2006) 
Public Papers of the Presidents: Dwight D. Eisenhower, 1953. Washington, DC: US Government Printing Office, 1960.

Public Papers of the Presidents: Gerald R. Ford, 1976-77, Book III. Washington, DC: US Government Printing Office, 1979.

Online Document Collections:

Cold War International History Project (CWIHP), Woodrow Wilson International Center for Scholars, Washington, DC

"New Evidence on the Iran Crisis 1945-46: From the Baku Archives," Cold War International History Project Bulletin 12/13 (2001):309-314. Available at: http://www.wilsoncenter.org/publication/bulletin-no-1213-fallwinter-2001

Yegorova, Natalia I., The "Iran Crisis" of 1945-46: A View from the Russian Archives, Working Paper 15. Washington, DC: CWIHP, 1996. Available at: http://www.wilsoncenter.org/publication/the-iran-crisis-1945-46-view-the-russianarchives

National Security Archive, George Washington University (NSA-GWU), Washington, dc Digital National Security Archive (DNSA), available: http://nsarchive.chadwyck.com/ Electronic Briefing Book (EBB) 265, available at: http://www2.gwu.edu/ nsarchiv/NSAEBB265/

Henry Kissinger Telephone Transcript (State-Kissinger), U.S. Department of State Electronic Reading Room, available at:

http://foia.state.gov/Search/Collections.aspx

Israel State Archives, On-Line Collection: Prime Minister Golda Meir and the Shah of Iran in 1972, available at: http://www.archive.gov.il/ArchiveGov/pirsumyginzach/TeudaBareshet/GoldShah/

Special Collection: A Life in Intelligence-The Richard Helms Collections (CIA-Helms), US Central Intelligence Agency Electronic Reading Room, available at: http://www.foia.cia.gov/collection/life-intelligence-richard-helms-collection

\section{Author's Correspondence}

Foundation for Iranian Studies Oral History Collection (FISOHC) Gen. Mansur Qadar Harold Saunders

Harvard Iranian Oral History Project (HIOHP) Col. Isa Pejman 


\section{Books:}

Abdulghani, Jasim M. Iraq and Iran: The Years of Crisis. (The Johns Hopkins University Press, October 1, 1984).

Adib-Moghaddam, Arshin, Iran in World Politics: The Question of the Islamic Republic, (Oxford University Press, November 9, 2010).

Afkhami, Ghoma Reza, The Life and Times of the Shah (Berkeley, CA, 2009).

Agwani, M.S. The Lebanese Crisis: 1958: A Documentary Study. (Bombay, Asia pub. House. 1965).

Ajami, Fuad, The Vanished Imam: Musa al-Sadr and the Shia of Lebanon (Cornell University Press, 1986)

Alagha, Joseph, Hezbullah's Documents: From the 1985 open letter to the 2009 Manifesto (Amsterdam University Press, April 15, 2011).

Alam, Assadollah. Yad'dashtha-ye 'Alam: Virayesh va Muqaddamah az Alinaqi Alikhani [The Alam Diaries: Edited by Alinaqi Alikhani], Vol. II: 1973-1974 (Bethesda, MD: Iranbook, 1995).

Alamuti, M. Iran dar Asr-i Pahlavi [Iran in the Pahlavi Era] Vol.II, Jang-i Qodrat dar Iran [Power Struggle in Iran] (London, 1992).

Alpher, Joseph, "Israel and the Iraq-Iran War," in The Iraq-Iran War: Impact and Implications, Efraim Karsh (New York: St. Martin's, 1989).

Al-Samarrai, Wafiq, Hottam al-Bawabat al-Sharqi [The Destruction of the Eastern Gate]. translated in Farsi. (Markaz Asnad va Tahghighat-e Defa-e Moghaddas).

Amir Arjomand, Saeed, The Shadow of God and the Hidden Imam: Religion, Political Order, and Societal Change in Shi'ite Iran from the Beginning to 1890. (Chicago, 1984).

Amir Arjomand, Saeed, Authority and Political Culture in Shi'ism. (Albany, 1988).

Axworthy, Michael, The Sword of Persia: Nader Shah, from Tribal Warrior to Conquering Tyrant. (I.B. Tauris, 2006).

Azani, Eitan, Hezbollah: The Story of the Party of God, From Revolution to Institutionalization (Palgrave-Mcmillan, 2009).

Barnett, Michael N. Dialogues in Arab Politics. (Columbia University Press, October 15, 1998). 
Bayat, Kaveh, Vaghayeh-e Ararat: Khaterat-e Ehsan Nuri Pasha [Ararat Events: Ihsan Nuri Pasha's Memories]. (Tehran, 1999).

Beeman, William, The Great Satan vs. the Mad Mullahs (University of Chicago Press, April 15, 2008).

Beigi, Abbas William, The Shah's Lebanon Policy: The Role of SAVAK. (January 1997). Middle Eastern Studies, 33 (1).

Bill, James, The Eagle and Lion (Yale University Press, Reprint edition, September 10, 1989).

Bird, Kai, The Good Spy: The Life and Death of Robert Ames (Broadway Books, May 26, 2015).

Bitlisi, Idris, Hasht Behesht [Eight Paradises]

Bonnin, Richard, Arrows of the Night: Ahmed Chalabi and the Selling of the Iraq War (Anchor; Reprint edition, November 13, 2012).

Bulloch, John, No Friends but the Mountains: The Tragic History of the Kurds (Oxford University Press, January 7, 1993).

Buzan, Barry and Ole Waver, Regions and Powers: The Structure of International Security (Cambridge University Press, 4 Dec 2003).

Buzan, Barry, Ole Wæver and Jaap deWilde. Security: A New Framework for Analysis, (Boulder: Lynne Rienner, 1998).

Chaliand, Gerard, A People Without a Country: The Kurds and Kurdistan (Interlink Pub Group Inc, 1993).

Cobban, H. The Making of Modern Lebanon (Westview Press, London, November 7, 1985).

Doran, Charles, The Politics of Assimilation: Hegemony and Its Aftermath (Baltimore: Johns Hopkins University Press, 1971)

Ehteshami, Anoushirvan, After Khomeini: The Iranian Second Republic (Routledge, March 10, 1995).

Fardoust, Hossein, Khaterat-e Arteshbod-e Baznesheshteh Hossein Fardoust: Zohour va Soqout-e Saltanat-e Pahlavi [The Memoirs of Retired General Hossein Fardoust: The Rise and Fall of Pahlavi Dynasty]. (Moasese-e Etelaat va Pajouhesh-ha-ye Siasi, 1990).

Farrokh, Kaveh. Iran at War: 1500-1988 (Oxford: Osprey Publishing, May 24, 2011). 
George, Alexander L. and Andrew Bennett. Case Studies and Theory Development in the Social Sciences. (Cambridge, MA: The MIT Press, 2005).

Hahn, Peter, Missions Accomplished? The United States and Iraq Since World War I (Oxford University Press, 2011).

Hall, Peter and Rosemary C. R. T Taylor, Political Science and the Three New Institutionalism, (1996), Political Studies, 44, pp. 936-957.

Harris, G. S. Ethnic Conflict and the Kurds (1977) Annals of the American Academy of Political and Social Science, 433 (1).

Hegel, George Wilhelm Fredrich, The Philosophy of History (New York, 1956).

Jannati, Ali, Khaterat [Diaries] (Tehran, Markaz-e Asnad-e Enghelab-e Eslami, March 2015)

Jawad, Sa'ad, Iraq and the Kurdish Question: 1958-1970. (London 1981).

Johnson, M. Factional Politics in Lebanon: The Case of the Islamic Society of Benevolent Intentions (Al-Maqasid) in Beirut (January 1978) Middle Eastern Studies, 14 (1): 74, n.31.

Kamalian, Mohsen and Ali-Akbar, Ranjbar-Kermani, Ezat-e Shia, (winter 1377, Sahife Kherad press, Qom)

Kaplan, Robert D. The Revenge of Geography: What the Map Tells Us About Coming Conflicts and the Battle Against Fate (Random House; First Edition, September 11, 2012).

Karsh, Efraim. The Iran-Iraq War: 1980-1988. (Osprey Publishing, 25 April 2002).

Khomeini, Seyed Ruhollah, Sahifeh Emam (Moassese Tanzim Nashr Asar Emam Khomeini) Vol. III. IV, VI, VII.

Kimche, David, The Last Option, (New York: Maxwell Macmillan International, 1991).

Kissinger, Henry, The White House Years. (Little Brown \& Co, Boston, Massachusetts, 1979).

Kissinger, Henry. Years of Renewal (New York: Simon \& Schuster, 1999).

Khosrowshahi, Seyyed Hadi, Yad-Nameh Emam Musa Sadr [Imam Musa Sadr's Memoirs] 1387

Korn, David. "The Last Years of Mullah Mustafa Barzani," 1/2 (1994). Middle East Quarterly, P. 22. 
Kramer, Martin Shi'ism, Resistance, and Revolution, ed. Martin Kramer (Boulder, Colorado: Westview Press, 1987).

Laclau, Ernesto. New Reflections on the Revolution of Our Time, Cambridge: Cambridge University Press, 1990.

Laclau, Ernesto. The Making of Political Identities, Cambridge: Cambridge University Press, 1993.

Laclau, Ernesto, and Chantal Mouffe, Hegemony and Socialist Strategy: towards a Radical Democratic politics, Verso, 1985.

Lawrence, Quil, Invisible Nation: How the Kurds' Questfor Statehood Is Shaping Iraq and the Middle East (Walker Books, July 7, 2009).

Levitt, Matthew, Hezbollah: The Global Footprint of Lebanon's Party of God (Georgetown University Press, April 9, 2015).

Little, D. Cold War and Covert Action: The United States and Syria, 1945-1958 (Winter 1990) Middle East Journal, 44 (1).

Louer, Laurence, Shiism and Politics in the Middle East (Columbia University Press, October 30, 2012).

Maleki, Abbas, and Kaveh Afrasiabi, Reading in Iran Foreign Policy After September11 (BookSurge Publishing, October 23, 2008).

Marvin, Sabrina, The Shi'a Worlds and Iran (Saqi Books, June 21, 2011).

McDowall, David. A Modern History of the Kurds. (London: I.B. Tauris, 2007 ed).

Mckiernan, Kevin, The Kurds: A People in Search of Their Homeland (St. Martin's Press, 2006).

Melucci, Alberto, Challenging Codes: Collective action in the information age (Cambridge University Press, 1996).

Mesbahi, Mohiaddin, Free and Confined: Iran and the International System. (Spring 2011). Iranian Review of Foreign Affairs, 5 (2): 9-34.

Milton-Edwards, Beveley and Stephen Farrell, Hamas (Polity, April 26, 2010).

Mohtashamipour, Ali-Akbar, Khaterat-e Siasi [Political Dieries] (Kahneh-e Andisheh-e Javan) Vol II. 
Nasr, Vali, The Shia Revival: How Conflicts within Islam Will Shape the Future. (W. W. Norton \& Company, Apr 17, 2007).

Norton, Augustus R. Amal and The Shia: Struggle for the Soul of Lebanon (Austin, TX: 1987)

Norton, Augustus R. Hezbollah: A Short History. (Princeton University Press, 2007).

O’balance, Edgar. The Kurdish Revolt, 1961---1970 (London: Faber and Faber Ltd., 1973).

Ostrovsky V. By Way of Deception: The Making of a Mossad Officer. (Toronto: Staddart, 1990).

Pahlavi, Mohammad-Reza Shah, The Shah's Story, Published by Michael Joseph. (London, September 29, 1980).

Pahlavi, Mohammad Reza, Answer to History (New York: Stein and Day, 1980).

Parsi, Trita. Treacherous Alliance: The Secret Dealings of Israel, Iran, and the U.S. (Yale University Press, 2007).

Pollack, Kenneth, The Persian Puzzle (Random House Trade Paperbacks, August 9, 2005).

Pollack, Kenneth. Arabs at War: Military Effectiveness, 1948-1991 (University of Nebraska Press, 2002).

Qaffari Qazvini, Qazi Ahmad, Tarikh-e Jahan-Ara. (Hafez press, 1343).

Qaneifard, Erfan, Pas az Shast Sal: Zendegi va Khaterat-e Jalal Talabani [After Sixty Years: The Life and Memories of Jalal Talabani]. (Elm Publication, Tehran, October, 2011).

Qaneifard, Tondbad-e Havades: Goftogooi ba Isa Pejman [Hurricane of Events: A Dialogue with Isa Pejman] (Elm Publication, Tehran, 2011)

Qassem, Naim, Hezbollah (Saqi Books, April 1, 2010).

Rajaiee, Farhang, The Iran-Iraq War: The Politics of Aggression, University Press of Florida (April 20, 1993).

Ramazani, Rouhollah, Reflections on Iran's Foreign Policy (Spring 2010) Iranian Review of Foreign Affairs, 1 (1).

Ramazani, Rouhollah, Iran's Foreign Policy 1941-1973 (Charlottesville: University Press of Virginia, 1975). 
Ramazani, Rouhollah K. Ideology and Pragmatism in Iran's Foreign Policy (Fall 2004) The Middle East Journal, 58 (4).

Ramazani, Rouhollah K. The Persian Gulf: Iran's Role (University Press of Virginia, 1972).

Rubin, Avshalom H. Abd al-Karim Qasim and the Kurds of Iraq: Centralization, Resistance, and Revolt: 1958-63. (2007). Middle Eastern Studies. 43 (3)

Samii, Abbas William, The Shah's Lebanon Policy: The Role of SAVAK. (Jan 1997) Middle Eastern Studies. 33 (1)

Stakelbeck, Erick, The Brotherhood: America's Next Great Enemy (Regnery Publishing, July 15, 2013).

Randal, Jonathan. After Such Knowledge, What Forgiveness? My Encounters with Kurdistan (London: Westview Press, 1999).

Sayigh, Y. Turning Defeat into Opportunity: The Palestinian Guerrillas after the June 1967 War, (Spring 1992) Middle East Journal, 46 (2).

Sayyid, Bobby S. A Fundamental Fear: Eurocentrism and the Emergence of Islamism. (Zed Books; Revised edition, February 7, 2004).

Schelling, Thomas C. Arms and Influence (Yale University Press, 1966).

Schonmann, Noa, Israel's Phantom Pact: Foreign Policy on the Periphery of the Middle East: Foreign Policy in the Periphery of the Middle East (I.B. Tauris \& Co Ltd, 2015)

Shaery-Eisenlohr, Roschanack. Shi'its Lebanon: Transnational Religion and the Making of National Identities. Columbia University Press. Retrieved 2 July 2016.

Shalgham, Abdel Rahman, Sabz va Siah [Green and Black], translated by Ali Mousavi Khalkhali (Ozam Publisher, Tehran, 1392).

Sobhani, Sohrab, The Pragmatic Entente: Israeli-Iranian Relations, 1948-1988 (New York: Praeger, 1989).

Stoakes, F. The Supervigilantes: The Lebanese Kataeb Party as a Builder, Surrogate and Defender of the State, (January 1975), Middle Eastern Studies, 11 (1).

Tabatabai, Mohammad Sadeq, Kahterat-e Siasi Ejtemai [Social Diaries] (Moassese Tanzim Nashr Asar Emam Khomeini, 1388) vol. 1, II, III

Tafreshian, Aboulhasan, Qiam-e Afsaran-e Khorasan (The Revolt of Khorasan Officers). (Atlas, Tehran, 1988). 
Tripp, Charles. A History of Iraq (Cambridge University Press, 2010).

Torfing, Jacob. Poststructuralist Discourse Theory: Foucault, Laclau, Mouffe, and Zizek, Cambridge: Cambridge University Press, 2005.

Vanly, I.S. "Kurdistan in Iraq" in People Without a Country; The Kurds and Kurdistan, edited by G. Chaliand. (London, 1980).

Zabih, Sepehr, Aspects of Terrorism in Iran, (September 1982). Annals of the American Academy of Political and Social Science. International Terrorism (Sage Publications) 463: 84-94.

Zaher, Yaqoub, Masira al-Imam al-Seyyed Msa al-Sadr [Seyyed Musa Sadr's Journey], Vol III (Beirut, Second Edition, 2000). 


\title{
VITA
}

\section{ARASH REISINEZHAD}

Born, Boushehr, Iran

B.A. Chemical Engineering, Sharif University of Technology

Tehran, Iran

\author{
M.A. Political Science \\ University of Tehran \\ Tehran, Iran
}

Visiting Researcher

Paris Institute of Political Studies (Sciences Po)

Paris, France

Ph.D. Political Science

Florida International University

Miami, Florida

\section{PUBLICATIONS AND PRESENTATIONS}

Reisinezhad, Arash, (2014). The Iranian Green Movement: Fragmented Collective Action and Fragile Collective Identity. Iranian Studies, 48 (2):1-30.

Reisinezhad, Arash, (2016). Cultural Opportunity and Social Movements: The Green Movement and the Arab Spring. Sociology of Islam, 4 (3): 236-260.

Reisinezhad, Arash, (April, 2017). Iran and Its Regional Proxies. Paper presented at Annual Convention of International Studies Association, Baltimore, Meryland.

Reisinezhad, Arash, (April, 2017). Weapon of the Oppressed: Media and Informal Spaces in Iran, Paper presented at Annual Convention of International Studies Association, Baltimore, Meryland.

Reisinezhad, Arash, (April, 2017). ISIS: Power, Violence, and the State of Exception, Paper presented at Annual Convention of International Studies Association, Baltimore, Meryland.

Reisinezhad, Arash, (November, 2016). Pre-Revolutionary Iran and the Shia Lebanese, Paper presented at Annual Meeting of Middle East Studies Association, Boston, Massachuset. 
Reisinezhad, Arash, (August, 2016). Ambiguous Connections: Iran and Yemeni Houthi, Paper presented at $7^{\text {th }}$ Annual Gulf Research Meeting, London, Cambridge.

Reisinezhad, Arash, (April, 2013). Social Movements and Their Regional Diffusion: The Green Movement and the Arab Spring, Annual Convention of International Studies Association, San Francisco, California.

Reisinezhad, Arash, (November, 2012). Islam and Social Movement: Religious Opportunities and Constrains, Annual Meeting of Middle East Studies Association, Denver, Colorado.

Reisinezhad, Arash, (September, 2012). Cultural Opportunity and the Arab Spring, Workshop Rethinking the Monarchy-Republic Gap in the Middle East, Marburg, Germany.

Reisinezhad, Arash, (August, 2012). The Role of Master Protest Frame in the Emergence of Social Movement: Iran and Egypt, Annual Meeting of American Sociology Association, Denver, Colorado.

Reisinezhad, Arash, (April, 2012). Culture and Social Movement: Iran, Egypt, and Tunisia, Annual National Meeting of Mid-West Political Science Association, Chicago, Illinoise.

Reisinezhad, Arash, (January, 2012). Media and informal spaces in the Iranian Green Movement, Annual Meeting of Southern Political Science Association, New Orleans, Luisinna.

Reisinezhad, Arash, (December, 2011). The Emergence of the Collective Identity in the Green Movement, Annual Meeting of Middle East Studies Association, Washington D.C. 